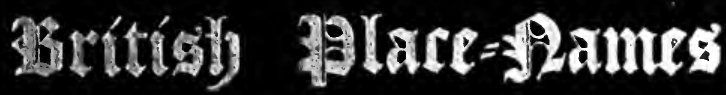

in their

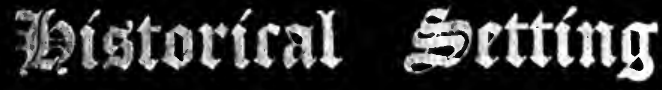

EDMUND MeCLURE, M.A. 
Oniversity of California
Library
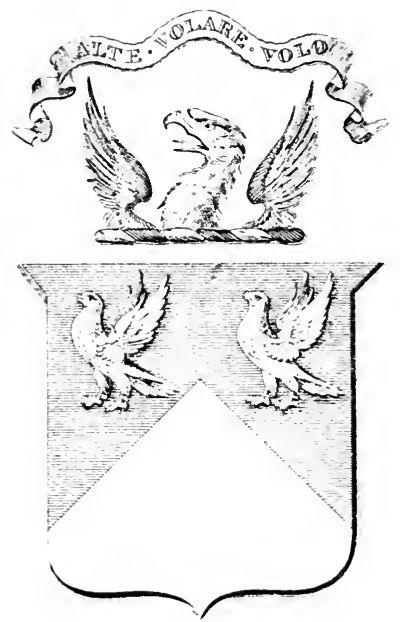

Mo Horse Steptiens. 



\section{BRITISH PLACE-NAMES IN THEIR HISTORICAL SETTING.}

BY

EDMUND MCCLURE, M.A.

LONDON :

SOCIETY FOR PROMOTING CHRISTIAN KNOWLEDGE, Northumberland AVENUE; 43, QUEEN Victoria STREet, E.C. BRIGHTON : I29, NORTH STREET. NEW YORK : E. S. GORHAM. 
[PUBLISHED UNDER THE DIRECTION OF THE GENERAL LITERATURE COMMITTEE]

\author{
MENRY MORSE STEPH RYS
}

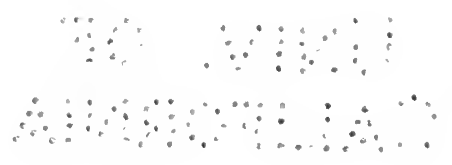




\section{PREFACE}

THE aim of this work is to present and discuss British Place-names as they occur chronologically in authentic historical documents from 54 B.C. till A.D. II 54 . The documents used are for the most part such as exist in critical editions and have been printed from the best texts. In this way the errors of later copyists are excluded, and the changes which time has effected, in such forms as have come down to us, brought under more or less definite laws.

The consecutive narrative which this work presents serves the purpose of a history of Britain during the period under review, thus rendering the discussion of the place-names associated with this historic thread the more instructive and interesting. Such elucidation of these names as the writer ventures to offer is the result of studies in leisure hours extending over some thirty years and more. The nucleus of the work has already appeared in a serial, but the whole would probably never have seen the light in volume form if it had not been for the urgency of friends who were good enough to attach to them more value than they possess in the writer's mind. I have to acknowledge special help from one of these friends, my brother-in-law the Rev. George Herbert, who has been good enough to revise the proofs of the portion of the book dealing with the Roman Itineraries.

Nov. 1909. 
Digitized by the Internet Archive in 2008 with funding from Microsoft Corporation 


\section{CONTENTS}

PAGE

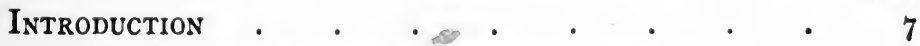

Note A. Methods of linguistic research . . $\quad 13$

I

I. The Roman Occupation a. D. 43-60 . . . 19

Note B. Meaning of Venta . . . . $3^{2}$

II. The Roman Occupation a. D. 60-287 • • $\quad 34$

Note C. British Pedigrees and their historical value . . . . . 54

III. The Roman Occupation A. D. $287-360$. . . 60

IV. The Roman Occupation a. D. 360-410. . . 78

V. The Roman Occupation-Britain as known to the Classical Geographers . . . . . 87

Ptolemy's Description of Albion . . . . 9 I

Note D. The Antonine Itinerary . . . $10_{4}$

The Notitia Dignitatum . . . 1 I 3

The Ravenna Geographer . . II6

Note E. The Legions in Britain . . . 117

Note F. On Tacitus, Annals, xii. $3^{\mathbf{I}} \quad \cdot \quad$ II 7

Note F. 2. Latin words in English place-names before 1066 . . . . 118 


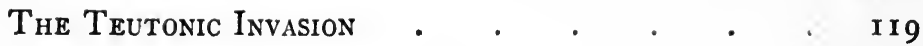

Note G. Glastonbury . . . . . 197

Note H. Topographical Elements in Earliest Anglo-Saxon Documents . 207

(1) Glossaries . . . . . . . 207

(2) Genuine Charters . . . . 213

(3) Ancient List of Territories . . . 220

III

The Coming of the Northmen. Norse Influence on

Topography and Language . • . • . 223

Note I. Words borrowed from Norse . $\quad 230$

IV

The Wars of English and Norsemen and the Noruan Conquest

$\operatorname{INDEX} \cdot \quad \cdot \quad \cdot \quad \cdot \quad \cdot \quad \cdot \quad \cdot \quad \cdot 305$ 


\section{BRITISSH PLACE-NAMES IN THEIR HISTORICAL SETTING}

\section{INTRODUCTION}

IF there were no written histories of our country we should still be able to construct one from things as they are. The present is the inheritor of all the ages, and the whole past is summed up in the state of things of to-day. The language we speak, for instance, involves in it the record of the vicissitudes through which our race has passed throughout the ages. The progress of our civilization is to be traced in the words we now use, the history of the interminglings of our ancestors in past ages is to be found in our present vocabulary, as well as in the physical peculiarities which distinguish us as a nation. But it is especially from the words which are employed as denominations of the towns, villages, and physical features of our country that we may glean a knowledge of our past. All such words are, or were at one time, significant, and if we could determine their original form and meaning we should be able to recover some of the lost pages of our history. In the study of the origin and development of such words we are not left altogether to guesswork. The growth of language, the changes to which syllables, words, and combinations of words are subject in the process of time are not of an arbitrary character, but like everything in nature, the product of gradual evolution. We may not be able to follow always the chain of continuity, and the laws of soundchange may be overridden sometimes by the play of analogy and other influences, but there are principles to guide us in our researches to sound conclusions on the whole (see Note A). 
On a superficial survey, all the names of places recorded in our Ordnance Maps of England would seem to be of English origin. A minute examination of these will show, however, that numerous elements involved in them are not to be traced to an English source. A further investigation of these "foreign" elements will enable us to class them roughly into Celtic, Latin, and Scandinavian. There is, if we take in the rest of Britain, probably also a number of them which belong to a pre-Celtic language; that is to say, designations handed down from a race which was in possession of these islands when the first Celtic invaders entered them. Some of our linguistic experts think that these pre-Celtic peoples were represented by the Picts, who appear to have occupied certain parts of Scotland and of Ireland when our first great English historian-the Venerable Bedewas writing his History, nearly twelve hundred years ago. In his time, Bede says, and the Saxon Chronicle adopts the statement, the following races, as represented by languages, were known in Britain : English, British, Scot-ish (i.e. Irish), Pictish, and Book-Latin (i.e. the language of the Romanized Britons).

The Celtic languages to which Bede here refers under the designations British, Scot-ish, and Pictish, have been scientifically classified of late according to their local survivals into Goidelic, (which embraces Irish, Manx, and Scottish Gaelic), and Brythonic which includes Ancient British (and Gaulish), Cornish, Breton, Cymric (i.e. Welsh), and probably Pictish.

The ancient Continental home of the Celtic-speaking people was, according to latest authorities, the territory lying between the Rhine, the Main, and the Danube, whence according to D'Arbois de Jubainville they spread into North-West Germany, the Goidelic branch about 800 B.c. passing into the British Islands. These were followed, the same writer alleges, about 630 в.с. by a Brythonic (?) people called Belgae, who, driven by Germanic tribes out of the region between the Elbe and the Rhine, occupied North-Eastern Gaul, from whence some passed into Britain. According to Julius Caesar (De Bell. Gal. i) the 
Belgae differed from the Gauls (called Galli, he says, in Latin, Celtae, in their own speech) in language and customs, and were divided from them by the Marne and Seine. Caesar tells us, moreover (ibid. v. I2), that the maritime parts of Britain were occupied by those Belgae who, passing over for booty, had settled there, and that they were there known by the names of the states whence they had sprung. This is confirmed by the names Venta Belgarum (Winchester) and Calleva (or Galleva) Atrebatum (Silchester), the Atrebates ${ }^{1}$ occupying at this period the region round Arras in which their name is still preserved. According to D'Arbois de Jubainville, Celtic invasions of Spain (500 B.c.) and of Bohemia and Italy (400 B.c.) followed. Greece and Galatia in Asia Minor were invaded by the Celts, in the third century B.c.

As to the Belgae being the first Brythonic invaders of Britain, it is clearly against the statement of Caesar, and otherwise not credible.

A tribe called Scots belonging to the Goidels are known to have passed from Ireland into Alban (Scotland) in the fourth century of our era, the latter country being then occupied by Brythons and Picts. ${ }^{2}$ In the fifth and sixth centuries A.D. a southern Brythonic people, under pressure from invading Teutonic tribes, passed over to Armorica in Gaul, in which Gallic speech had then died out, and gave their name to the country-Brittany.

The influence of each of these Celtic peoples is still to be traced in our place-names.

A few native territorial and Celtic tribe-names were familiar to the Romans before our era. Kent, with its white cliffs, was known to Julius Caesar in 54 B.c. by the name Cantium (Cant-io-n), a Latinized form of the native appellation. The

1 Ptolemy (ii. 3. 13) places among the Belgae the towns Iskalis, Hydata Therma (i. e. "Hot Waters" = Bath) and Venta (= Winchester). See later on the Summary of Ptolemy's Geography of Albion.

2 But see later on Sir John Rhŷs's view that Goidels were in Alban much earlier. 
Tămĕses (Tamésa in Ptolemy) was also known to him, and the tribes Belgae and Trinovantes dwelling not far from it, as was also by report Mona (the island of Anglesea) which was captured a little over one hundred years later (A.D. 6I) by the Roman General Suetonius Paulinus, and of which the name still survives in the last syllable of Carnarvon. Julius Caesar received the submission of certain tribes occupying the southern part of Britain; the Cenimagni ${ }^{1}$, the Segontiaci ${ }^{2}$, the Ancalites ${ }^{3}$, the Cassi ${ }^{4}$, and the Bibröci, and the last seems still to survive in our Berk-shire. The early form of the latter is Berruc-scire, Bærruc-scire, Bearruc-scire (in a charter ascribed to A.D. 93I), and Barroc-scire (in a British Museum MS. of A.D. 1050-1065). We shall see, from instances given later on, that an internal " $b$ " in a Latinized Celtic name was pronounced as " $\mathrm{v}$ " and that it tended to disappear altogether. Thus Bivroc would naturally become Birruc with a compen-

1 Gluck (Celtic names in Caesar's de B. G.) sees in this name Ceno= distant, and in magni, the antecedent of Welsh man (Irish magen) $=$ place. Cenno-manni (the tribe who gave their name to Le Mans) is seemingly another form of the same word. For the meaning of Iceni see p. I 10. The tribe Iceni seem to have given origin to the Icenhilderweg (which is mentioned in Cart. Sax. ii, pp. 5I, 255, 259, 377, 557, and in iii. 70, 446. The hilde appears also in Bugg-ilde Stret (now Buckle St.) and in the Rikenild Street (? - Icknield with $\operatorname{Yr}$ def. art. prefixed, cf. Rallt for $\operatorname{Yr}$ Allt). The A.-Sax. Hild meant "War", and its use in these connexions is like that of Here (army in Herepath, Hereweg, \&c., cf. Feger-hildeford (Cart. Sax. i. 47). It is cognate with the Irish cellach = war.

2 This tribe probably dwelt about Silchester, where an inscription seems to preserve the name. It has been conjectured that the tribe-name means "Worshippers of Segontios", a possible name of a "God of Victory". The name occurs in Segontium (Ant. Itin.), now Caer-Seoint near Carnarvon, probably the Cair Segeint of the list appended to Nennius. Siguenza in Spain is the Segontia of Strabo (iii. 4. I2).

3 Anco-Caletes (cf. Vasso-Caletes, where vass $=$ Welsh Grvas $=$ Servant) has been proposed as the correct form, meaning "Servants of the God Caletos". Cf. Ancus Martius = Servant of Mars.

- This has been compared with a corresponding German tribe-name the Chatti, now Hesse, in Hesse Darmstadt, \&c. 
sating lengthening of the first syllable for the elided " $v$ ". 1 The permanence of this ancient Celtic tribe-name in modern "Berkshire" is, in the absence of any probable Anglo-Saxon explanation of "Berruc", not a mere guess. That given in TollerBosworth (A.-Sax. Dict.) on the authority of John de Brompton, Abbot of Jervaulx in the twelfth century, "Bare-oak-shire" is not worth considering. The fact also that at least two names in this county have come down to us with little alteration from Roman times, tends to confirm the view here taken. These are Speen (Latin Spinae=thorns), which appears in the locative case as Spinis $^{2}$ in the Antonine Itinerary, and the river Kennet, the ancient Celtic name of which gave its designation to the Roman station Cunet-io, and to the modern Kintbury (Kenetbury). The tribe-name Bibroci was traced by Dr. Whitley Stokes to the root Bebro-s=Beaver, and he finds the same word in the Gaulish names Bibr-ax, now Beuvray near Autun, and Bibracte, later Augustodunum, now Autun. ${ }^{3}$

Celtic tribe-names on the Continent gave origin to a considerable number of place-names there during the time of the Roman occupation, and these place-names in many instances continue to our own day, notwithstanding the disturbing influences of the Teutonic invasions of the fifth and following centuries. Thus the Belgian A[d]trebates furnish still, as we have said,

1 In words borrowed from the Latin by the English before A. D. 700 it is not uncommon to find " $i$ ", especially in an accented syllable, represented by English $e$, or $x$; thus Signum became Segn (modern sign), Pirus became Peru (modern pear-tree), Missa became Mæsse (modern mass).

2 Spinetum, the Latin for a thorny place, seems to have been adopted early by the English, as we find its equivalent Spinney, in place-names from ancient times, e.g. Spinney in Cambridgeshire: see also Brit. Mus. Facs. ii. 3 .

3 As to the existence of beavers in England and their possibly forming the totem of a tribe, we have in an original charter (Cart. Sax. i. II 7 ) of A. D. 693 the name of Beferith (= Befer rith where rith is stream) now the Beverley River in the district of Battersea. Beaver occurs in other early place-names. Kluge, Et. Wörterbuch, says the Latin Biber is of German origin. It is more probably Celtic, with which the Latin is more closely connected. The Latin has also the normal Fiber. 
a proof of their existence, and of the region they occupied, in the names of the town Arras and of the district Artois. Remembrance of the Remi still survives in Rheims, and of the Senones in Sens, \&c. It is not, therefore, improbable that some of the designations of Celtic tribes in Britain still survive-much disguised perhaps-in certain place-names. It has long been maintained that the name of the Iceni (possibly contained in the Cenimagni of Julius Caesar) is involved in the Icknield Way. In an original charter in the British Museum of A.D. 903 (Cart. Sax. ii, p. 259) the Icenhylt [Icknield] is part of the boundary of land at Princes Risborough, Bucks. It is significant that this charter contains the name "Cynebellinga-gemære", or boundary of the descendants or tribe, as Dr. Birch, late of the British Museum, suggested, of Cunobellinus, the British king, who according to tradition was buried at Great Kimble in Bucks. The name for Kimble in Domesday Book is Chenebella, in Cal. Chart. Rolls, ii. 478 Cunebelle, and in the Taxatio (A.D. 129I) Kenebelle, forms which show that it may not owe its origin to a Saxon Cynebald, such as gave to Kimbolton (Domesday Chenebaltone) its name. ${ }^{1}$

Cunobellinos ${ }^{2}$ was the son of Tasciovanos, also the father of

1 Another explanation, however, is possible. Bede (H. E. iii. 23) gives Cynibillus, or Cynobill (a Celtic name according to Holder), as the name of one of Cedd's brothers-german. He was a priest and monk, and had been educated at Lindisfarne. It is possible that before Lastingham was assigned to him, he ruled some monastery in the South, and that the familia there were called quite naturally Cynebillinga. At any rate we have here a form of name which falls in more satisfactorily than Cunobellin-us with Cynebellingagemare.

2 The name Cunobellinos appears later in a Goidelic form as Conbellini : in early Breton as Convili, later Cynfelin : Plou-gonfelyn (i.e. the plebs or parish of C.), near Brest, preserves the name; and in Cymric (Welsh) as Conbelin and Kynvelyn. The Welsh name Llewelyn is probably from an early similar compound Lugu-belinos, where Lugu, a frequent element in Celtic personal and place-names, represents the designation of a deity surviving in Irish Lug = Elf (Thurneysen, Handbuch des Alt-Irischen, Heidelberg, I909, p. 190). The name is involved in Lugu-Vallium, the wall of Lugu-s, afterwards Caer-(i. e. the later form which the Latin 
Adminius, according to Suetonius (Life of Gaius, 44), and of Caratakos and Togodumnos, according to Dio Cassius (60. 20. I). He died about A.D. 43. His head quarters were at Camulodunum (Colchester). Cunobellinus occurs, together sometimes with the name Camulodunum, on his coins, of which many have been found in the region assigned to the Iceni (e.g. at Leagrave, near Luton, Sandy, Biggleswade, Arlesey, Langford, all in Beds. ; at Baldock, and at Walsworth, near Hitchin, \&c.). These finds are all near the Icknield Way, leading from Streatley, on the Thames, towards Caistor, near Norwich (=Venta Icenorum). Geoffrey of Monmouth (twelfth century) furnishes the fanciful material about Cynebelinus which Shakespeare afterwards worked up into his play of Cymbeline.

The Charter furnishing us with this possible reference to Cunobellinos, if we may trust Dr. Birch, may be a flash of light in the darkness. The assumption that there was no continuity of history from British and Roman to Saxon times is rash. The scantiness of our records may make it difficult to bridge the chasms, but surviving place-names may often serve this purpose: see Note F. 2, p. II8.

The place- and tribe-names of Britain given in Julius Caesar's Gallic War are the earliest Celtic designations furnished to us by history.

\section{NOTE A.}

A short summary of the modern methods employed in linguistic research will at one and the same time illustrate the statement in the text and show the truly scientific character of comparative philology.

F. Schlegel, profiting by the researches of Sir William Jones, published in $\mathbf{1} 808$ his celebrated work on the language and wisdom of the ancient people of India. The

Castra took in British)-Ligualia (Nennius), later Carlued, Welsh C. Lewelidd, now Carlisle. Also in Lugu-dun-um now Lyon, in Lugdunum Batavorum = Leyden, and in Lugdunum Remorum = Laon. 
religious book of this people, the Veda, written in the Sanscrit language, contains elements which go back to perhaps I 500 B.C. (Brugmann's Grundriss, p. 4). Schlegel showed that this language stood in close relationship with ancient Persian, with Classical Greek and Latin, and also with the Teutonic family of languages. This relationship was founded not only on their possessing a large number of common root-words, but also on the intimate structure and grammar of these languages. Later on Slavonic, Celtic, Armenian, and Albanian, were found to belong to the same family and the whole came to be called the Indo-Germanic, Indo-European or Aryan group of languages. As a human family is so called because it proceeds from a common parent, so these related languages were regarded as proceeding from one original speech. The proof is furnished by a comparison of words in these different languages that have a similarity of form and a like significance. Brugmann (Kurze Grammatik, published 1904) shows how from comparison of forms of the same structure and meaning in these languages the original form accounting for all the variations may be reached. The word for "Mother", he instances, is in Ancient Indian Mätár (nominative $M \bar{a} t \hat{a}$ ), in Armenian Mair, in Doric-Greek $\mu a ́ r \eta \rho$, in Latin Mãter, old Irish Mathir, in Old High German Muoter, and in Early Slavonic Mati. These various forms presuppose a prehistoric Indo-European parent form ${ }^{*} M \bar{a} t e^{\frac{1}{r}}$ or ${ }^{*} M \bar{a} t \hat{e}$. The alternative ${ }^{*} M \bar{a} t \bar{t}$ arises from the fact that after a long vowel a nasal or a liquid may drop out. In the singular the vocative was *Mäter, the accusative *Mäterm, the dative *Mätraí, the locative *Mãtéri. The genitive had two forms, depending on whether the nominative ended in a consonant or a vowel. In the former case the genitive ending was, $-o s$, in the latter $-s$, hence Brugmann's two genitive forms of *Mätros and *Mātfs. The foregoing forms are marked with an asterisk to show that they do not actually occur but are more or less necessary grammatical abstractions. The examination of these and of similar forms shows that each contains an element, which may be called the root, and another constituting a formative suffix. Roots may be divided into two classes, (I) Verbal (from which verbs, nouns, adverbs and some prepositions are derived), and (2) Pronominal or Demonstrative, out of which arose probably the case endings of nouns and the inflexions of verbs. The instances cited 
above show that we may gather inductively a hypothetical original form, and, from the laws of sound-change in each of the derived languages, may be able to predict the form that the original would take in any of the latter. The long $\bar{a}$ of the first syllable is, as we see, preserved in all the instances except Old High German, in which it gives $u 0$, arising from an earlier $\bar{o}$ (Brugmann, Grundriss, § 91). The fate of the second vowel and of the consonants may also be inferred, but the stages of evolution in each language can be determined only from a study of the sound-changes operative in that language.

As our researches are chiefly directed to the Celtic and Teutonic elements in British place-names the following bare outline of sound-changes is confined to these languages.

A comparison of the members of the Indo-European family leads to the assumption of the following system (represented as far as possible in our alphabet) as that of the parent speech.

The vowels $a, o, u, e, i$, existed in their long and short forms; $v(w, v)$ and $i(j, y)$ had a consonantal function and formed diphthongs with long or short $a, o, e$. The consonantal liquids $r, l, n, m$, had also syllable-making forms $r, l, n, m$.

The explosives are thus classified.-

$\begin{array}{ccccl}\text { Tenues } & \text { Mediae } & \begin{array}{c}\text { Aspirated } \\ \text { Tenues }\end{array} & \begin{array}{c}\text { Aspirated } \\ \text { Mediae }\end{array} & \\ p & b & p h & b h & \text { Labials. } \\ t & d & t h & d h & \text { Dentals. } \\ k & g & k h & g h & \text { Palatals. } \\ q & g & q h & g h & \text { Velars. }\end{array}$

(See Brugmann's Grundriss, i. § 323.)

[Pedersen (Vergl. Gram. der kelt. Spr., Göttingen, 1908, p. 30) adds the labio-velars $k^{u}, k^{u} h, g^{u}, g^{u} h$, distinguishing them from Brugmann's palatals.] The spirants $(\boldsymbol{\xi}) s(\beta)$ conclude the list.

Pedersen (ibid. p. 3 I) describes thus shortly the modifications to which this system was subjected in Celtic.

The distinction in the first place between long and short vowels is maintained.

The short and long diphthongs are no longer distinguished.

The diphthongs are in part resolved into simple vowels out of which later new diphthongs are formed.

From the syllable-making liquids arise groups of consonantal 
liquids and vowels. " $\mathrm{p}$ " has become a breathing $(h)$ where it has not vanished entirely. The velars and palatals have ceased to be distinguished. The labio-velars have in part become labials $\left(g^{u}\right.$. in all Celtic languages, $k^{u}$ and $k^{u} h$, in Gaulish and British, while, on the other hand, $g^{\text {th }} h$ had lost its labialization in all Celtic languages, and also $k^{u}$ and $k^{u} h$ in Irish after the period of the Ogam-inscriptions).

The tenues had fallen in with the aspirated tenues completely at an early date. The mediae likewise had coincided with the aspirated mediae, but traces of a special articulation of the aspirated mediae were still to be detected. $w(v), s$, the explosives and the consonantal liquids were represented in Celtic in a double manner, that is, besides the normal pronunciation in the beginning of a word, there was a relaxed languid utterance (with wider opening of the mouth), which occurred, among other instances, between vowels. This modification of utterance is called Lenition or aspiration. Pedersen traces, in vol. i. of the work referred to, the modifications of the foregoing sounds in the various branches of Celtic speech.

Short $a$ is preserved, for instance, in Irish Cathir (=a town), and in its Welsh form Cader (=a hill-fortress), both of which are compared with Latin Cater-va (=a troop).

Short $e$ is also preserved, but can become by umlaut $y$. Before a nasal and an explosive it becomes $i$, as instanced in Irish Linn (=Lenda, liquid, and Lind, a pool), Welsh Llyn, the

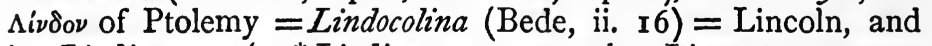
in Lindi-macus ( $=*$ Lindi magos, now the Limmat, a stream running out of Zurich lake). Middle Irish Glend, gen. Glinde (=valley) and Welsh Glynn [together with Welsh Glann (=bank) cognate with Danish Klint (steep-bank) and old Norse Klett-r (rock)] are further instances which enter into placenames in Great Britain.

Short $i$ is preserved in Gaulish but becomes sometimes $y$ or $e$ in later Celtic. Compare Vindo-gladia (Ant. Itin.) now (?) "Badbury-rings", Vindo-bona, now Vienna, with the Gaulish personal name Uuen-brit and the Dorset stream Wenfrith. $\breve{o}$ is preserved, but becomes before certain consonants $\breve{u}$, written $y$ in all syllables before the last. Cf. Welsh mynydd (mountain) and old Breton, -monid, Cornish meneth, the latter with umlaut. Pedersen proceeds to show the fortunes of all the vowels, together with those of the consonants, in the various branches of Celtic speech. As references will be made to this and other 
authorities as each case arises it is not necessary to proceed here further with Celtic sound-changes.

A few illustrations, however, of the changes to which the IndoEuropean vowels and other sounds were subjected in the Teutonic languages may well find a place here (see Brugmann's Grundriss, $\$ 35$ et seq., and Kluge, in Paul's Grundriss, pp. 300 et seq.).

Indo-European $\grave{\imath}$ became Germanic $i$; before $r$ and $h=\breve{e}$

\begin{tabular}{|c|c|c|c|}
\hline $\bar{\imath}$ & , & , & $\bar{\imath}$ \\
\hline 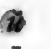 & $"$ & " & $u$; after $a$ in the following \\
\hline $\bar{u}$ & ", & ", & $u \quad[$ syllable $=\check{o}$ \\
\hline$\breve{e}$ & , & , & cos \\
\hline$\breve{e} i$ & $"$ & ", & $\bar{i}$ \\
\hline ěu & $"$ & , & $e t u$ \\
\hline $\bar{e}$ & ", & , & $\bar{e}$ \\
\hline$\breve{o}$ & , & : & $\breve{a}$; this and $\bar{a}$ to $\bar{o}$ are peculiar \\
\hline ŏi & " & $"$ & $a i[$ to Germanic vocalization \\
\hline ŏu & $"$ & , & $a u$ \\
\hline $\bar{o}$ & ", & , & $\bar{o}$ \\
\hline$\breve{a}$ & $"$ & , & $\breve{a}$ \\
\hline$a i$ & , & ", & $a i$ \\
\hline$a u$ & , & $"$ & $a u$ \\
\hline $\bar{a}$ & , & " & $\bar{o}$ \\
\hline
\end{tabular}

The Indo-European explosives $k, t, p$ became respectively $\chi(=\mathrm{h}) t h, f$. The first stage in the $p, k(k v)$ "Shift" according to Brugmann was when they came before $t$ and $s$. $t s$ became $s s$, and $t k$ became $s k$ at about the same time. Then followed the general shift of the tenues, except when preceded immediately by $s$, or when they came under "Verner's Law". The original mediae $g, d, b$, became $k, t, p$.

As a consequence of the shift of original $k, t, p$, it may be assumed, for instance, that historical Teutonic words beginning with any of these letters had originally other initials. Torp's Wortschatz der germanischen Spracheinheit, Göttingen, I 909, gives, for instance, some forty-five early Teutonic stems beginning with $p$, with their equivalents in the various dialects. Most of these are traced to Indo-European originals beginning with $b h(b)$, others are onomatopoetic, others have been borrowed from nonTeutonic languages, and the residuum consists of a few unexplained words, such, to take English examples, as play, plough, 
and path. The last word seems to represent an Indo-European original, instanced in Greek $\pi a$ tros and Irish $A t h=$ ford (=orig. *Päta) and was possibly borrowed, as Schrader (Handelsgeschichte, r3) suggests, from the Celtic, before initial $p$ had disappeared from the latter language. Sufficient instances of Teutonic soundchanges have been given here to show the principles. Further examples will be cited as each case discussed requires. 


\section{THE ROMAN OCCUPATION}

\section{I}

After the departure of Julius Caesar from Britain 54 B.c., the history of this country remains a blank till A.D. 43. It is true that the Roman Emperor Caligula - who had harboured an exiled British chief-wrote to the Senate from Gaul in A.D. 40 , boasting that he had conquered the entire country, but he had never really set foot in Britain. For the progress of the Roman arms in Britain from A. D. 43 to 93 we are indebted in the main to the almost contemporary historian Tacitus. He had exceptional opportunities for acquiring information, as his father-in-law was the famous Roman general Agricola, who reduced almost the whole of Britain to the Roman obedience.

The army sent into Britain by the Emperor Claudius in A.D. 43 was commanded by Aulus Plautius, who brought into subjection the tribes in the neighbourhood of the Thames, and finally captured Camulodunum, the royal residence of the late Chief Cunobellinus. The Emperor Claudius, who spent altogether only some sixteen days in Britain, was present at the capture. In the campaign of this period, the future Emperors Vespasian and Titus (father and son) took part, the latter some twenty-five years later (A.D. 70) becoming associated with a more important historical event in his capture of Jerusalem.

In the year A.D. 49 Ostorius Scapula took the command in Britain, and on finding that the neighbouring tribes had broken into the lands of those who were subject to Rome, prepared to disarm the suspected, and to occupy with camps the whole country to [? between] the Avon and Severn. He was opposed 
by the Iceni, already referred to, but having inflicted defeat upon them, set out against the Ceangi, and reached at length the neighbourhood of the sea facing the island of Hibernia (Tacitus, Annals, ii. 24).

Can we find any traces of these events in surviving placenames? Camulodun-um (Tacitus, Annals, and Ant. Itin.) was the earliest name of Colchester, i. e. Coln-chester, but was supplanted by the term Colonia, a dignity conferred upon it later on. It means the dun or stronghold under the protection of the god Camul-os (see Holder's Sprachschatz, s. v., and Rev. Celt.). The gods of the Britons were sometimes associated with rivers, as we gather from the several streams in Britain called Dee (Deva ${ }^{1}$ ), and from Belisama, the ancient name of the Mersey; and the stream running past this stronghold doubtless involved the name Camul. ${ }^{2}$ The same designation still survives as the name of rivers in Somerset and Cornwall, \&c. As the $m$ in Camul did not become aspirated between vowels in British speech, the first syllable must have been originally Camb (see Pedersen, V. Gramm. $\$ 73$ ) and have involved the idea of "Crooked", an idea preserved also doubtless in the designation of the god; cf. the Irish Idol destroyed by St. Patrick, Cromm-Criaich, in which the same notion of

1 Sir John Rhŷs (Celtic Folklore, p. 448) connects problematically Lydney in Gloucestershire with the Celtic god Nodons (found on an inscription in Lydney Park many years ago), equating it with a Cymric Lūdo. Lydney, however, appears in a Charter of 972 as Lidan-ege, that is, the island of the river Lidan or Litan, a name not uncommon as a Celtic designation of streams, \&c., and meaning in this connexion "broad". Cf. the Gaulish Litanobriga " Broad-burg" according to Pedersen, Gramm. $\S 30)$ of the Antonine Itinerary. It would seem, therefore, to have nothing to do with the Nudd of Tennyson's "Idylls" or with "Lndd of the silver hand ". Torp (Wortschatz, p. 299) traces Nudd or Nuada (stem *Noudent), the name of a Celtic sea-deity, to the root involved in Anglo-Saxon Neotan $=$ to use, to enjoy.

${ }^{2}$ Mr. J.S. S. Glennie, in his Arthurian Localities (E. E. Text Soc., 1869), says, "Cadbury (Somerset) is mentioned in old records under the name Camelot, a name still perpetuated in the adjoining villages of Queen's Camel 
crooked is involved. Was it this Camulodun, or some other place of the same shortened name, to which reference is made in Tennyson's lines?-

"On either side the river lie

Long fields of barley and of rye, That clothe the wold and meet the sky; And through the field the road runs by

To many-tower'd Camelot."

Tennyson (in Elaine) makes London the chief court of Arthur:-

". . Arthur holding there his Court Hard on the river, nigh the place which now Is this world's hugest, let proclaim a joust At Camelot."

Malory places the latter at Winchester, but his geography is not to be trusted. ${ }^{1}$ The name may linger still in that "Camlet way" of which Newcome, in his Hist. of St. Albans, writes, "There is still (1795) visible, beside the Watling Street way, another original Roman road through the forests of Enfield Chace, called at this day Camlet way, which seems to have been the road from Verulam to Camalodunum." There is now no trace of the course of this "Camlet" way, which

and West Camel." He does not give these "old records", so that I am unable to test his statement. There is another river in Somerset involving "Camel". It was called the Camelar, on which are situated Camely and Camerton (anciently Camelarton, Collinson's Hist. of Somerset, iii, p. 329). This place is mentioned in a charter ascribed to the year 961 (Cart. Sax. iii, p. 300). The river runs into the Avon above Bath. Campton, in Bedfordshire, on a tributary of the Ouse, appears, in a British Museum MS. of 1150 , as Camelton, suggesting that the stream flowing by it may then have been known as the Camel. The Hamble river in Hants, Bede's Homelea, may be an early borrowing of Camul, or a cognate word. The element "Camul" is also involved in the ancient form of Chamblay (Camul-oscus, Camblosco), of which name there are several instances, in France. The "Camulos-sesa" of the Ravenna Geographer, which was in North Britain, has not been identified.

1 The Arthurian geography will be dealt with in its place. 
crossed the Watling Street near St. Michael's Church in Verulam, yet it is difficult to believe that it and its direction were an invention of Newcome's, who evidently saw no connexion between its name and the "Camulod" of Camulodunum, of which it would be a possible survival.

The account in the Annals of Tacitus of the design of Ostorius to occupy with camps the whole country to [or between] the Avon and Severn has created difficulties. The manuscript authorities for the Annals give two readings here for the former river. In one it is called the Antona, and in the other the Avon. The seeming impossibility of identifying either of these names with any existing river in this region has led to several conjectures. Dr. Henry Bradley proposed (Academy, April 28, r883) a most ingenious reading of the passagepreviously (?) advanced by Müller, Ptol. Geogr., Paris, I 883, i, p. 87 n.-making castris (by forts) into cis Tris, and prefixing the latter syllable to Antona-m, thus rendering the rivername Trisantona. Sir John Rhŷs is prepared to accept this conjecture, and thinks that this may be the early form of the Tre(h)anta, Trenta, now the Trent; but see p. Ir 8.

The geographer Ptolemy, who about A. D. 120 furnished in his Geography a list of localities in Britain, places the river Trisantona in the neighbourhood of what is now Southampton, and reasons for the correctness of this position will be given later on. The form Trahannon occurs, it is true, in Nennius (ninth century), but it seems to refer to the Trisantona of Ptolemy.

Ostorius had in his advance the Iceni on his front and right. He wanted a river of some importance to protect his right flank in his advance. The Trent seems too far north, but the Nene might have served his purpose. Previous investigators had accepted, without etymological considerations, this river as the Avon of Tacitus. This river, for a certain part of its course at least, has been known, from the middle of the tenth century at latest, as the Nyn or Nen. But there is good 
reason to think that for some part of its course, possibly as far as Peterborough, it was known from early times as the Avon ${ }^{1}$. Leland, in his Itinerary, written about $\mathbf{5} 542$, calls it, over and over again, the Avon. He says in one passage : "The ryver of Avon so windeth about Oundale Town that it almost insulatethe it, savyng a litle by west-north-west." Oundale (Oundle) is suggestive. In the Eccl. Hist. of Bede (died A. D. 735) we have "in the province Undalum" ", but in a charter (now in possession of the Society of Antiquaries) ascribed to the tenth century, it is called in the accusative case Undalan. Dæl (neut.) is a valley, and appears often in the charters as dell, which Sweet considers to be a weak form of dæl, and thus to form its accusative in -an. Dæl was, like its Scandinavian equivalent dal-r in the north of England, generally coupled with rivernames, e.g. Dover-dæl, Worcester (in a ninth-century charter), and the familiar Teesdale, Wharfdale, \&c. Oundle would therefore be a worn form of Avon-dæl, and thus at once confirm Leland's name of the river, and the accuracy of the text of Tacitus which reads Avonam. In Speed's Theatrum Britanniae (16ro), moreover, Avon-well is given as in Rothwell Hundred, and is doubtless the well or source of the stream that, running by Kettering, falls into the Nene. Drayton in his Polyolbion (1613) says of the Nen: "... Avon, which of long, the Britons called her," "whom by Aufona's name the Roman did renown."

1 Dr. Henry Bradley thinks that "Avon" was a generic term applied to British rivers, and that there was in all cases a specific name added to it. The Avon-Nyn would, therefore, be a transitional form, leaving either "Avon" or "Nyn", as one or other form fell out in the course of time. "S. Cett resteth on Undola near the river Nen," says The Saints of Eng. land, a work drawn up shortly before A. D. 1000 (Die Heilig. Eng., Liebermann, Hanover, I889), showing the truth of Dr. Bradley's view.

2 It is right to add that the latter element in this word may be $-d \overline{\bar{l}} l$ (masc.), meaning "portion or division". Numerous instances of this $-d \bar{c} l$ occur in place-name compounds in the North and in such forms as Ferndel or Ferthingdel = a fourth part. The A.-Sax. dal (= valley) is traced (Torp) to a stem meaning to bend. 
As to the Severn, the Romans probably learned the name Sabrina from the Goidels (or Gaels, i. e. the Irish branch of the Celts, who are known to have occupied in the Roman period the greater part of what came afterwards to be designated Wales) and not from the Britons, who knew the river in historic times by the name Hafren. It would be difficult to say when the Britons began to use $\mathrm{H}$ for an initial $\mathrm{S}$. The parallel between the Greek initial aspirate and the Latin $S$ tends to show that the change must have been very ancient.

Sir John Rhŷs (Celtic Britain) would read for Ceangi, "Deceangli," who, he thinks, probably inhabited Flintshire and Cheshire, as the abbreviations Decea, Deceang, Deceangl, appear on pigs of lead ${ }^{1}$ found in the latter county, and in Staffordshire. It has been conjectured, with some degree of probability, that this name is perpetuated in the Deanery of Tegingel (now Holywell, and in the Taxatio, "Englefild"). The Deaneries often involve in their designations very ancient district names. Powel's Hist. of Cambria, published in 1584 , says (p. 10), "the feft Cantref (of North Wales) is Tegengl, and is now a part of Flintshire, having these Comots, Counsylht (now corrupted to Coleshill, Arch. Camb. Suppl., April, 1909, p. 71), Prestatyn and Ruthlan." Ptolemy locates in this region the Promontory of the Cæanganoi ${ }^{2}$, a form which seems to confirm the "Ceangi" of Tacitus. Ostorius had, therefore, probably proceeded to, and beyond, the Dee, to what is now Chester, as a funerary inscription found in the walls there shows, according to Dr. Haver-

1 The excavations at Charterhouse-on-Mendip (Times, Aug. 24, I909) seem to show that the smelting of lead was an industry even before the artival of the Romans in this country. The pigs of lead found there with emperors' names on them are associated with silver coins, of which two are British and two are Republican. The silver of the British coins was probably procured from the lead ore. It is not without significance that the name Mendip seems to preserve in its first element the Breton Men $=$ ore, crude-metal. The Irish form is Mein and the Welsh Mwyn, representing an earlier *Men.

${ }^{2}$ For variants of this form and for further discussion of the place-names occurring in Ptolemy's Geography see p. 9I. 
field (Catalogue Chester Museum, No. 54), that Roman troops were possibly in this locality about A. D. $5^{\circ}$.

The Roman General Ostorius, Tacitus tells us, was recalled from his Western campaign by the outbreak of disorders among the Brigantes. He had not mentioned these people before, but his language implies a previous contact between them and the Roman troops. Indeed, their name was seemingly well known in Rome at an early date, for there is a passing reference to them in lines of Seneca (Apocol. 12. 13-17), who died A. D. 65, not to speak of the allusion in the later (A. D. 90) writer Juvenal (Sat. xiv), who probably was prefect of a cohort in Britain.

Tacitus seems to indicate that the outbreak of disorders among the Brigantes was a concern to Ostorius, because he had previously established some kind of order among them. He was not long, moreover, in bringing them into subjection again. Could these, we might naturally ask, be the Brigantes of the north, or were they some tribe of a similar designation nearer the centre of Roman dominion at this time? The name, in an original charter of A. D. 705 now in British Museum ("Brigunt ford ", Cart. Sax. i, p. 169), of the Brent river, which flows into the Thames below Brentford, might favour the latter hypothesis, as furnishing a possible source of the tribe-name, but the continued employment by the Roman historians of "Brigantes" to designate the tribe or tribes occupying the region north of the Humber, and stretching to the Forth, seems decisive as to the locality.

1 The application of a tribe-designation, as well as a river-name, to a ford is not unusual; cf. Wallingford, Britford, and on the Continent, Frankfort. Ptolemy (A. D. 150) places the Brigantes between the Selgovoi (that is the tribes who gave their names to the Solway Firth) and the Otadinoi, and makes them extend from sea to sea. He includes the following places in their territory: Vinovium $=$ Binchester, Cataractonium = Catterick, Isurium (elsewhere Isu-brigantum) = Ald-borough, Eboracum $=$ York, Olicana $=$ Ilkley, and a certain Camnlodnnum (elsewhere Cambodunum), which has not been identified, but which was probably near Slack; but see note on Ptolemy's Geography, pp. 9I et seq. 
Ostorius probably proceeded from Deva (Chester) via Mancunium (Manchester), into the region of the Brigantes, by a route which was, or afterwards became, the Roman road connecting these two places. From the fact that the early form "Brigunt" has passed into the "Brent" of Brentford, one might expect that a modern survival of the ancient tribe-name "Brigantes" would exhibit a similar modification. We find in an early charter (Cart. Sax. i, p. I77) a "Brente" hill, but even if this could be proved to represent an earlier "Brigantia", it is in Somerset, and therefore, not at all in the locality occupied by the Brigantes. Sir John Rhyss thinks that the kingdom of the Bernicii mentioned by Bede represents an Anglicized form of Brigantes. Starting from a stem which has become in modern Welsh "bri" (=renown), he follows the possible changes of the name until he reaches a form (Brenneich) which might well be represented by Anglo-Saxon lips as Barnicas, from which would naturally arise Bede's Bernicii. Dr. Whitley Stokes would connect the "Brig" in Brigantes with Irish Bri, accusative Brigh (Glossed tulach, i. e. hill), the modern Welsh bre (a hill), which appears in such place-names as "Penbre", "Moel-fre", " hill-top", and "bald hill" respectively. "Bre" and "Brī" may possibly come from a common root meaning "high", but it seems more natural to regard the Brigantes as thus denominated because of their dwelling in mountain fastnesses, than because they were renowned or privileged, and this for the following considerations.

In attempting an explanation of the origin of tribe-names it is well to keep in mind two things: (i) that the forms of such names come to us generally through a neighbouring people, and not from the tribes themselves. Thus, the name "Welsh" (Wealas), which means simply "foreigners", comes to us not from the people so designated, but from the English, who were their neighbours. The Welsh call themselves "Cymry". The Highlanders were so called bv neighbouring Englishspeaking people, and never use in their own speech this de- 
signation of themselves. Gaul and Gauls were applied to the country and people of the land now called France, by Celtic tribes on the borders with whom "Galli" would mean simply (like the English word "Welsh") foreigners; and the name German is also, according to Grimm, a Celtic designation, and is not used in their vernacular speech by any Teutonic people on the Continent in speaking of themselves. ${ }^{1}$

(ii) That tribe-names yield generally on analysis certain distinctions which would naturally be used by one people speaking of another. Thus the Saxons were so called from the "seax" or sword they used in warfare. The Franks were thus designated from the javelin they carried, which was called "franca" by the Anglo-Saxons, and not from a boast of their being a frank or "free" people. The Longobards (after whom Lombardy is called) took in the same manner their name from their long "bards" or spears, and not from their beards.

In a similar manner the nature of the locality, or mode of dwelling, of a tribe furnished to their neighbours an obvious name for them. Thus the Burgundiones, who invaded in the early fifth century that part of Gaul which is now called Burgundy, were so called because they dwelt in a hilly country. Professor Fick associates, in this connexion, the "Burg" in their name with the ancient Irish Brig, which is represented in modern Welsh by the Bre, already mentioned, and thus shows the equivalence of Burgundiones and Brigantes. The Brigantes mentioned by Tacitus derive their name naturally, therefore, from the hills, or rather hill-forts, wherein they dwelt. This is confirmed somewhat by Juvenal's reference to them (Sat. xiv), "Break down ... the Castles of the Brigantes."

The ultimate connexion of Brig and Burg is further

1 The "Insi-Gall" applied to the Northmen of the islands of the West of Scotland means simply "Island foreigners", and the same meaning is also perpetuated in Dugall (generally written Dugald), "the black stranger," or Dane, and in Fingal, "the fair stranger," or Norseman. Gall chnu in Gaelic, like its cognate form in English (wal-nut), means "foreign nut". 
strengthened by the fact that Briga, an extended form of Brig, * Brig-s, was in use by the Celts of Spain from a time long before our era to designate what the Teutonic nations call Burg; for instance, Julio-briga, that is, the "Burg of Julius", which (Not. Dig. 42) was previously called Brigantia.

To return to "Bernicia" - the alleged later form of the tribe of the Brigantes-Bede speaks of the people as Bernicii, and assigns them a place in the present region of Northumberland. The boundaries of the Anglian kingdom thus designated are given in the twelfth-century Life of Oswald, and embrace the country between the Tyne and the Firth of Forth-Deira ${ }^{1}$, another Anglican kingdom, occupying the region between the Tyne and the Humber. Richard, Prior of Hexham, writing about II54, makes the Tees the southern boundary of Bernicia, and the Tweed its northern limit. There is apparently no surviving place-name in all this region preserving the designation Bernicia. If such a form does exist, it is too much obscured to be easily recognized. I have gone carefully through the charters of the Monastic houses in these districts, but can find nothing at all representative of Bernicia. Such forms as Branx-holm or Brance-path, which might suggest a survival, are to be otherwise explained. The numerous Birrens Camps or Burrins Camps, on the Scotch border, are to be interpreted by a passage, p. I7 I, of Burton's Monasticon Eboracense in which he translates Barganes lapidum by "Sheep-fold[s] of Stone $[\mathrm{s}]$ ". This word may be of Celtic origin, for Adamnan's Life of Columba, p. I I 3, gives Bairind as a "great rock", and Burren is the common Irish designation of a stony district. (But see note, p. 272 , and Dialect Dict. sub Burren.)

Having established order among the Brigantes, Ostorius, as Tacitus tells us, began a campaign against the Silures, who

${ }^{1}$ It was from Deira, as we remember, the young Anglian slaves were taken who called forth Pope Gregory's pity in the Roman Forum. The name Deira is seemingly preserved in the Deorstrete, Dere-street, of Sim. Dunelm, 70, and of the Melrose Charters. It was Watling Street north of the Wall. 
had offered a strenuous resistance to the Roman arms, and who were neither amenable to kindness nor severity.

Tacitus describes the Silures as having swarthy complexions (using the same colour adjective as Virgil applies to the Indians) and curly hair. $\mathrm{He}$ is inclined to think, for this reason and because they lie over against Spain, that they came from the latter country and were an Iberic people.

This tribe occupied the region to the west of the lower Severn and to the north of the Bristol Channel. Ptolemy (A.D. I 20) places them to the east of the Demetae, whose territory extended from St. David's Head as far, at least, as Carmarthen (Maridunum), which he makes one of the strongholds of the latter. Ptolemy gives Bullaeum as one of the towns of the Silures, and this place has been identified by some with the Burrium (cf. Din-birrion of the Book of Llan Dav) of the Antonine Itinerary, which, according to the distances there given, would be near Usk, but no distinctively Roman remains, nor a Roman road, have been found here, as far as I know; The Book of Llan Dav (printed from a MS. of the twelfth century) gives among the boundaries of the See of Llandaff, "Buell" on the Wye, now printed Builth, but in the sixteenth century Byellt. This is a place of some strategical importance, and may represent Ptolemy's Bullcum. It is celebrated as the spot where the Prince Llewellyn, the last native ruler of Wales, met his death at the hands of the English in A.D. 1282 .

It would appear, therefore, that the region occupied by the Silures was roughly co-extensive with the ancient Diocese of Llandaff, and included Monmouth and Glamorgan, besides parts of Herefordshire and Brecknock.

The Silures placed themselves under the command of Caratacus, who had won, among the Britons, a high reputation as a general. He succeeded, by drawing the Roman legions after him, in involving the latter in war with the Ordovices, who were a British tribe occupying the country to the north and west of the Silures. Notwithstanding this strategical move of Cara- 
tacus, the combined forces under him were defeated, and his wife and daughter captured by the Romans. Caratacus having taken refuge with Cartismandua, the Queen of the Brigantes, was handed over by her, bound in fetters, to the victors, and was sent to Rome to grace the triumph of the conqueror.

Ostorius had not, however, done with the Silures, who fell upon certain cohorts engaged in constructing camps in Silurian territory, and succeeded in killing many, including the prefect of the camp, and putting the rest to flight. Their attacks were such, indeed, that Ostorius, worn out by the arduous and anxious character of the campaign, at length succumbed, and died about the year A. D. 53 .

Ostorius was succeeded by Aulus Didius, of whom the chief exploit recorded is his saving Cartismandua, the Queen of the Brigantes, from the attacks of her husband, Venutius, a native, Tacitus tells us, of the State of the Jugantes ${ }^{1}$. Veranius, who succeeded Didius A. D. 57, died in the following year, after having ravaged the territory of the Silures.

Suetonius Paulinus, who was sent by Nero to succeed Veranius, led the Roman legions to the Menai Straits, and, crossing to Mona (Anglesea) in flat-bottomed boats, reduced the island to subjection. Mona was the chief seat of Druidism, and Tacitus describes the Druids as pouring forth, from among the hosts drawn up on the shore to oppose the Romans, dire imprecations upon the latter. The Romans established a garrison on the

1 The MSS, read Jugantes or Evigantes, the latter reading appearing in the Editio Princeps. Camden, on the ground that no such people as the Jugantes were known and that the "State of the Brigantes" appeared elsewhere in Tacitus (Agricola), substituted Brigantes here, and he has been followed by all subsequent editors. This is a dangerous method and tends to stop further research. We have several instances (Anscombe's Welsh Genealogies in Archiv für Celtische Philologie) of $J u$ or Giu being read by transcribers as Evi, but no transition from Bri to Evi, and we may therefore assume that Jugantes or Evigantes is the right reading. If Venutius had been, like Cartismandua, one of the Brigantes, there would have been no need to specify the fact. 
island, and strove, by destroying the Sacred Groves, to put an end to the sanguinary rites performed within them.

This brings us down to the year 60 of our era. Have we any memorials of these events, we may ask, in the existing topographical nomenclature of the country? Solinus, writing about A. D. 80, tells us of an island Silura lying off the coast held by the Dumnonii (that is, the Devonians, meaning the coast of Devon and Cornwall). Sir John Rhŷs thinks that the name of this island is of the same origin as that of the Silures, whether Solinus meant by it the Scilly Isles, or the region on the north of the Bristol Channel. The quantity of the " $u$ " in Silures is doubtful. In Holder's Sprachschatz it is given as short (Silŭres), but in Scheller's Lexicon it is Silüres. If the vowel were short it would facilitate the contraction of the word, and Sir John Rhŷs's conjecture that the name of the chief man connected with the temple of Nodons discovered at Lydney Park (in the region of the Silures)-Silulanus-involves a term which may be equated with Silur, seems very probable. The name appears also in the Antonine Itinerary in conjunction with "Venta", i. e. Venta Silurum, now Caer Went in Monmouthshire, and in an inscription found here lately. The word "Venta", like the term "Silures", is somewhat obscure. The note on the next page is an attempt to explain it.

The island Silura, mentioned by Solinus, is probably the same as Susura, an island in the British seas, found in the list of the Ravenna Geographer. No explanation of the meaning of the term "Silures" has yet been offered. It does not seem even to be a Celtic word, and the probability of its survival in any modern form is remote. Jornandes, who wrote about A. D. 552, read in the passage he quotes from Tacitus, "Sylorum" in place of Silurum, but this was a mistake. Perhaps he confused the name with that of the Silura referred to by Solinus, possibly now a little island off the coast of Glamorgan, called in Speed's map (A.D. I610) Sylye, now Sully. The "stormy strait" which, according to Solinus, 
separated Silura from the coast of the Devonians, might mean the Bristol Channel and not the sea between Scilly (Sorlinga in the earliest maps given by Nordenskjöld and still les Sorlingues of French navigators) and Land's End. Sully Castle and the parish of Sully on the adjoining mainland would seem to indicate that the name covered a region sufficiently large to form a designation for a tribe. The origin and meaning of this name are, however, not clear, and I know of no earlier form than that preserved in the Taxatio of Pope Nicholas (late thirteenth century) "Sulleye".

As to the Ordovices mentioned by Tacitus, Sir John Rhŷs considers them to have been a Brythonic and not a Goidelic tribe. He places them in what was later called Powys, a region which interposed between North and South Wales, both at this time inhabited by a Goidelic people. The name survives, he thinks, in Rhyd Orddivy (or the "ford of the Ordovi"), near Rhyl, and in Din-orwig (formerly Dinorddwig), in the neighbourhood of Carnarvon, meaning the fortress of the Ordovices. The district between the Dovey and Gwynedd (=North Wales) is called in the Iolo MSS. Cantref Orddwyf, or "Hundred of the Ordovi", and this, Sir John Rhŷs thinks, is a further survival of the term.

\section{NOTE B.}

The meaning of "Venta" in the British place-names, Venta Silurum, Venta Belgarum, Venta Icenorum:-

I. It is evident from the forms of these names that they were imposed, and intended to be understood, by a Latin-speaking and not by a Celtic-speaking people.

2. Putting aside place-names in regions occupied by the Romans, the word "Venta" does not occur in Celtic literature, either in the form "Venta", or in its equivalents "Guent" or "Went". There is, moreover, no Goidelic equivalent with any topographical meaning.

3. The word "Ventum" or "Venta", however, occurs in place-designations in Romanized regions on the Continent. We 
have, for instance, "Beneventum" 1 in South Italy (now "Benevento "). In Northern Italy, "Mutatio Beneventum" (Anton. Itin., 558, 14), between Brescia and Verona. In Spain we have "Et oppidum nobilissimum Beneventum" (L. Marin. Siculus, De Rebus Hispaniae, Book III), now "Benaventa", south of Astorga. There are also in Spain and Portugal several places of this name, e.g. "Benavent," north of Lerida in Catalonia; "Benaventa," on a tributary of the Tagus, not far from its mouth; and "Benaventa", west of Oviedo in Galicia. The Abbey of Benevent (Creuse) is a French survival of the name and the word also occurs in Germany, e.g., "Beneventenreut" (Oesterley, Geog. Wörterbuch), where reut (OHG. riuti) is the equivalent of our North Country royd = clearing. There are, besides, dozens of places called "Venta" in Spain, such as "Venta la Reina", "Venta del Marquis", "Venta Moral", "Venta la Vadera ", "Las Ventas", \&c. "Venta" in Spanish means now an "inn", or a place where food and drink are sold. The original meaning was probably "market", the word being possibly derived from "Venum-eo", contracted to "veneo"="I go for sale": its past participle in the neuter singular would be "vēnitum", and the neuter plural "vēnita".

4. Ducange confirms this import of the word in a passage where, sub voce "Venta", it is said that it means "a place where goods are exposed for sale, or where tribute is received from things sold ", and a quotation is given from the obituary notices of the Church of Langres (France), "John de St. Sequano gave to the Church of Langres sixty shillings (soldi) of 'Touraine in the 'Venta' or 'Hall' ('aula '= here 'market', cf. 'les Halles', the Paris 'Covent Garden') of Montissalio."

5. The word "Beneventum" meant probably "a good market place", for in the Ravenna Geographer (p. 280, 5) "forum novum", or "new market", is said to adjoin Bene-

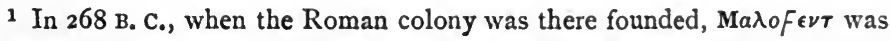
changed to Beneventum. The name occurs on a bronze coin as an abl. sing. Benuentod (in Samnite, which was subject to Oscan influence, according to Conway, Italic Dialects, i. p. 17r). Keller, Lat. Volksetym. p. 14, records Benuuent: as in Oscan the Ven in Venio becomes Ben, Ventum cannot well be from Venio. It was Malovent, moreover, before it was colonized by the Romans. Pliny, iii. 12. 107 gives Terventum, Tereventum, as a Samnite place-name now Trivento, and Livy cites a Carventana Arx (xxii. 15. 16) as a place-designation of the Latini. 
ventum, that is presumably the "old market"; and Pliny (Hist. Nat. iii. I r), speaking about the southern Beneventum, says thus more auspiciously named now, but formerly called "Maleventum".

In the Life of St. Cadoc (Cambro-British Saints, Rees, pp. 70 et seq.) already referred to, it is related that the saint was carried on a cloud from Llancarvan (i. e. the Church of St. Carfan, the later Welsh form of Corbagni-genitive) to "Beneventana Civitas", where he was made bishop; but as no bishop of Beneventum of that name is to be found in Ughello's Italia Sacra, the place must be sought elsewhere. It seems clear that Beneventum was not far from Llancarvan, for, in the same Life, it is said that St. Elli, Cadoc's successor at the latter place, "was accustomed to go very often with his disciples to the City of Beneventum," a practicable thing if the locality were in Britain, but not so if it were in Italy. One is tempted to think of the "Bannaventa" (given in MSS. A and F as Bennavento) of the Antonine Itinerary which has been identified by some with "Daventry", but there were possibly more places than one of this name in Britain : cf. also the Glannibenta of the Not. Dig., given as Clanoventa in the Ant. Itin. The "Venta" of the Silures, however, may have been meant, or rather, that of the Belgae.

From the foregoing it seems clear that the "Venta" of the tribes named was the locality where they sold and bought what they needed or where they paid tribute. As far as Venta Silurum is concerned, it is not without significance that its near neighbour was called Chepstow (that is, "Céapstow" = market), in earlier times "Emricor va" (Lib. Land.), where there may possibly exist an echo of "Emporium" coupled with $m a(v a=$ place $)$, the later form of mag-os.

\section{THE ROMAN OCCUPATION}

II

Tacitus goes on to tell us of the great disasters which the Romans experienced in Britain in the following five years. The Iceni under their King Prasutagus and their Queen Boudicca had become friends of the Romans, thinking to purchase by 
submission freedom from further attack. They found, however, that they were treated by the Roman centurions as a conquered people. The queen and her daughters were subjected to all manner of indignities, and the people were exposed to robbery and oppression on every hand. Owing to this state of things and the fear of worse the Iceni took up arms. They were joined by the Trinovantes and other tribes who had not yet had their spirit broken by servitude, and who were actuated by bitter hatred of the veterans recently planted as colonists at Camulodunum (Colchester). The latter had been driving the natives from their lands and treating them as captives or slaves.

Paulinus Suetonius, who had succeeded to the command of the Roman troops in Britain, was away at this time on an expedition to some other part of the country. Camulodunum, which had not been fortified, was taken by the allied British tribes, and the temple therein (erected under the Emperor Claudius), to which the Romans retired as to their citadel, was carried by storm. Suetonius hastened to the rescue of the colony and was able to make his way to Londinium (London), which, although it had not been raised to the dignity of a colony, was then celebrated as the greatest mercantile centre in the island. Suetonius, finding that with his comparatively small body of troops he could not defend the place, left it to its fatenotwithstanding the prayers and tears of the inhabitantsjudging it preferable to lose one city rather than endanger the whole region occupied by the Romans. Accompanied by the able-bodied men of the place he hastened to take up a position in which he could defend himself. The Municipium of Verulamium (close to St. Albans, where there are extensive Roman ruins, and where, according to tradition, St. Alban was martyred in A.D. 286), which had then a large number of inhabitants, was also left at the mercy of the enemy. Both London and Verulamium were captured by the Britons, and, as Tacitus tells us, some 70,000 Romans and their allies were slain. The hopes of the Britons were naturally excited by their success, and they 
hastened to crush by superior numbers the Roman troops drawn up in an advantageous position under Suetonius, but numbering not more than 10,000 men. The generalship of the Roman leader and the strategical position he had chosen enabled the Romans to win a decisive victory, in which fell some 80,000 Britons. Boudicca, who with her daughters, had passed in her chariot from tribe to tribe to fire them with her wrongs, could not endure defeat, and put an end to her existence by poison. The generalship of Suetonius was not, however, fully appreciated at Rome, and he was ordered by the Emperor Nero to hand over his command to Petronius Turpilianus (A.D. 62).

Of the tribe named Trinovantes we seem to have no survival in our topographical nomenclature. Their capital was, as we have seen, Camulodunum (Colchester), and the area occupied by them embraced all Essex and Hertfordshire. The name itself seems to involve the numeral Tri- (three), whatever "novantes" (cf. Ptolemy's Novantoi) may mean. A similar use of this numeral appears in the names of ancient tribes of Gaul, e.g. Tri-cori (Pliny: to be compared with Petor-corii ${ }^{\mathbf{1}}$, that is, "four hosts," now Perigord), Tricassi, now Troyes, Triboci, Tri-castini, \&c. We have also the same numeral in the Gaulish Trinanto (which is glossed Tres-Valles=Three Valleys), and in the Nant tri neint ( $=$ Valley of the three Valleys), which appears in the Book of Llandaff of the twelfth century. "Nant tri neint" survives in "Turnant brook".

"Londinium" still appears but slightly altered as "London" and continues, as in the days of Nero, to be the greatest mercantile centre in the island. There has been evidently a continuity of civil life here since Roman times, and this fact furnishes a comment on the theory that in Britain the Roman centres, which preserve relics of their ancient names to our own day, were not continuously occupied.

Is there a modern representative of the name Verulamium?

1 Korio = A.-Sax. Here, see Stokes (Wortschatz d. kelt. Sprach.), and later, p. 155 . 
The answer to this question depends upon several considerations. We cannot, for instance, predict from purely philological grounds the form a place-name will assume in passing into use among people speaking an alien language. The law of attraction, by which the unfamiliar place-name is drawn into the orbit of the familiar, has produced some strange metamorphoses in our nomenclature beyond explanation by linguistic laws.

It began to exercise its influence in Britain at the very beginning of the Teutonic invasion. Eburācum ${ }^{1}$, or rather Eburac, for the um was Latin and evanescent, was not long in passing into Eoforwic, which would mean in English "Boarshelter or house", and became finally "York".

Regulbium could not long be preserved by Teutonic lips in this uncouth form, and soon found an intelligible equivalent in civitas Recuulf, also Racuulfe (Bede), and Raculf-cestre [also Raculfs Cestre], which finally became the modern form Reculver or "the Reculvers", as we find it in the seventeenth century, from the two towers of its Church serving as landmarks to fishing vessels.

Ritupice also was made to have some kind of meaning by taking on Bede's form Repta caester, which finally degenerated, through the Rales-burgh of Leland's Itinerary (vii. 137), into the present Rich borough.

But these changes are nothing to the modifications which the ancient name of Rochester suffered. The form by which this place was recorded in the Roman Itinerary was Duro-brivis, which means "the Stronghold at the Bridges".2 In the Peutinger Tafel it appears as Roribis, showing that by this time the

1 Dr. Henry Bradley would regard Eborācum as representing a Celtic accusative Eburacon.

2 Duro as a prefix is most probably the same as durum-a suffix in such names as Augusto-durum, \&c., and meant stronghold. Sir John Rhŷs sees in it a word cognate with our "door" and with the "for" in the Latin Fores and Forum. In Durobrivis as in Durócasses the accent was probably on the 0 , facilitating the reduction of the Duro to Dr-in Drenx, and to Hro- in Hrofibrevi : see Pedersen, V. Gramm. § 163 . 
Duro- had become $R o$-. In some unaccountable way the name came to be made in Kentish lips Hrofibrevi (In civitate Hrofibrevi, in a charter ascribed to A.D. 604-Textus Roffensis, fol. I 19). Cf. also the Hrofes-breta, Text. Roff, fol. 127, which like the preceding distinctly connects Hrofe's with a distorted form of -briva. The next step was to reduce it to Hrofi, as " in civitate Hrof " (charter ascribed to A.D. 762-Text. Roff. f. I22), whence arose, owing to the prevailing fashion of Teutonic peoples to call their " tuns ", "steads", \&c., after their possessors, the form in the possessive case, found in Bede (Hist. Eccl. iv. 5), "Hrofes-cæstir," and his assignment of the first part of this name to a certain person called Hrofe.

If Duro-bernia (Duro-vernum), the ancient name of Canterbury, had not been supplanted at an early date by Cantwaraburg, meaning "the stronghold of the men of Kent", it bade fair to become as much disguised in its modern form as Durobrivis. In the Anglo-Saxon Chronicle, under A.D. 604, it appears as Dorwit, the "wit" representing the zeer or wern; "Hrofesceaster is xxiiii mîla fram Dorwit-ceastre.' This appellation seems to have survived long enough to give a designation to the road leading to Dorobernia, which appears (in a charter ascribed to A. D. 605) as Drutingstræt, that is probably * Dorwitinga Strat, Dorwit $=$ Drut.

I add one more instance, which serves not only to illustrate the principle of attraction of the known for the unknown, but also shows how the desire for intelligibility led to the creation of purely imaginary designations for rivers and other natural features. In the Antonine Itinerary a station is mentioned as being to the west of $[L]$ Eto-cet-um (in Ravennas $L e(c) t o-c e t-u m$, later Luit-coet, afterwards Luyc-cit, Lic-cit, then finally Lich in its modern name Lichfield), called Pennocrucium ${ }^{1}$ (or, as in

1 This word involves a common British term, Cruc. Modern Welsh Crag $=$ tumulus. As the initial $k$ in Tentonic languages had, before the beginnings of history, become guttural $c h$, then $h$, and finally disappeared, we must look for the English equivalent of Cruc to a word beginning with 
several MSS., Pennocrutium), that is, "place of the head-, or chief-, tumulus." This appears in early Saxon times as Pen-cric, but has finally assumed the name of Penk-ridge (Staffordshire), and not only has a "ridge" been thus created which has no counterpart either in nature or in the original word, but the name of "Penk" has been imposed upon a brook, which had no other title to this designation but the fancy of the imposer.

After these preliminary illustrations of the fate on the lips of the Teutonic invaders of early Celto-Roman place-names, let us turn to Verulamium. The Venerable Bede, who was a Latin scholar, knew the ancient form Verulamium, which, he says (Hist. Eccl. I. vii), is now called by the English people Verlamacastir, or Vaetlinga-castir (Vaeclinga-Castir, Plummer's Bede). The Anglo-Saxon version of Bede's Hislory, which was made according to Plummer (Bede, vol. ii. ro9) more than a hundred years later, gives these names respectively as "Werlameceaster or Wæclingaceaster". These names were regarded then, therefore, as equivalent. The former is the source whence the name

$h r$ or finally $r$. We find this in Anglo-Saxon hréac (= "heap of corn "), also in Corn-hrycce with the same meaning. The modern English form rick, in hay-rick, is the same word. The Irish equivalent, entering into many place-names, is Cruach. The British word appears in Welsh place-names, e. g. Crick-howel, \&c., and has been anglicized in western English counties into Creech. We have, for instance, in a charter ascribed to A. D. 682, now at Longleat (Cart. Sax. i, p. 97), a grant to Glastonbury of lands at an island in the Tan (=Tone) (which gave its name to Taunton) "near the hill which is called in British speech Cructan, but by us (English) Crycbeorh". This is Creech Michael, Somerset, where there are several other places of this designation. The district preserves other indications of the previous Celtic inhabitants, one of them appearing in this same charter; Weala-ford where Weala is the genitive plural of Wealh (= Welshman or oreigner). The charter, although not of the date ascribed to it, preserves early forms. As to the Penn-o in Pennocrucium, it is the modern Welsh $\operatorname{Pen}$ (= head, top) which enters into many place-names in the Principality. It occurred also in Roman times on the Continent, e. g. Penne-locos (= top of the lake) given in the Antonine Itinerary as nine miles from Vibisco (now Vevay on the Lake of Geneva). The ium of Pennocrucium is a Latin termination of a quasi-adjectival character. 
of the river Wærlame (Die Heilig. Englands, p. 9), or "Verlam", which is given as "Ver" in Drayton (Polyolbion, 245), is drawn. In Chauncey's Hist. of Herts we have several similar forms of this river-name. The first element is equated by Dr. Whitley Stokes with the Greek euru- = broad, and is not a river-name : but cf. Umbrian Veru (= Gate), Latin Ap-erio, and Greek єै $\rho v \mu \alpha$, protection: and Anglo-Sax. werian, to ward off, wer, waru = weir, dam: all from an Indo-European root $=$ "to shut in": see Torp (Wortschatz, p. 394).

Why, we may well ask, should there be two designations, both involving the Roman Castra, for one place? Have we not here an instance (of which Pogatscher (Lautlehre) gives us many) of a learned and a vulgar survival of a common original? Werlame-ceaster is the form preserved by the bookmen. The vulgar, trusting to their only available source, the sound, made it Wætlinga ceaster.

Is it possible that, owing to the principle of attraction, the unintelligible Werlam was gradually brought by the unlearned folk into the intelligible Watling or Wacling? It would seem so. The combination of a British " $r$ " and " $l$ " must have presented then, as it does now, an unusual difficulty to Teutonic lips. The British "l" in the beginning of a syllable had even at this early period, according to Sir John Rhyss (Welsh Philology), a sound which was expressed later on in Welsh by "lth" (cf. Buell and Builth given above), and afterwards by "ll". "Werlam," as pronounced by natives, would, therefore, sound in English ears something like Werthlam. But this form was combined with Caster, and the lam, as an unaccented syllable, would be ready to take on the familiar unaccented ending, -ing, as in Abingdon, which, as is well known, was originally Abbandun. Watting, or Watlinga, a customary genitive plural, had a possible meaning for English people and was sufficiently near to this assumed Werthlam or Werthling to be suggested by it.

A Continental instance of a similar attraction from the unintelligible to the intelligible is furnished in the Vituduro of the Ant. 
Itin. $\left(25^{1}\right)$ which was made into the present "Winterthur", both elements of which are easily comprehensible = "Winter Door".

Something more is involved in this question than the English form of Verulamium. Wætlingacæster was a Municipium in Roman times and evidently a great executive centre. The road from Canterbury ran to it originally by what is now Westminster, without passing through London. It was known as Wætling Street, because, to judge by analogy, it ran to Watling-Caster, the place giving the name to the road, and not the contrary, as Mr. Plummer assumes (Bede, ii. 20). The road beyond it to the north took on the same name in later developments. In a Charter of A.D. I 337 (Bodleian Charters, Coxe ed.) Watlingstreet at Wellington (Shrop.) is called Erlamstret, an undoubted reminiscence of Werlame Stræt, and a further proof that the road was so called from its objective, Werlame-Ceaster. Akemann Street was so called, as we know, because its objective was Ake-mann Caster (now Bath), and the modern designations "London Road ", "York Road", "Bath Road", named after their objectives, perpetuate merely a very ancient practice. Some regard the oldest form to have been "Wæcling Street", but in Sweet's Oldest English Texts, the form is Waetling Street. The variant "Waecling" in the MSS. is an additional proof of the uncertainty as to the sound of the middle consonants.

This suggestion as to the origin of Wetling Street or Walling Street is, in the absence of any other satisfactory solution, worthy of serious consideration. It is based on the principle followed in the name given to the Bath Road, that is the Akeman Street ${ }^{1}$, in which the Aquae (Baths) of Aquae Sulis,

1 The Akeman Street can be traced through Cirencester from Bath to Tring. It probably ran from thence to Verulamium. Acemannesceaster occurs in the Anglo-Saxon Chronicle, under A.D. 973. Its Latin form is given in a Charter ascribed to A.D. 972 (Cart. Sax., No. 1278) as Aquamania. Mann in Welsh=locus (Davies, Dict. Britt.), which suggests a satisfactory origin for the name. It is possible, however, that Ace-man may simply mean Bath-man or Bather, bence the Akeman-Street would be Bather's Street, and Akemanes Ceaster, Bather's Chester. The 
the ancient name of Bath, still survives. It is also in keeping with the name of the road Drutingstræt in the Kent Charter, if the conjecture about it be correct.

Suetonius was recalled by the Emperor Nero from the supreme command in Britain in the year A.D. 62. St. ''aul was an obscure prisoner at Rome at this time, and no one then anticipated that the cause with which he was identified would one day hold sway over a wider realm than that of the Emperor Nero, under whom the apostle was put to death some five years later. Even then Britain was being prepared for the Gospel seed which already was being sown everywhere by Christian soldiers in Rome's ubiquitous legions. As commander of one of these legions-"the twentieth"-Julius Agricola entered Britain in A.D. 69, two years after the apostle's death. He doubtless assisted in the campaigns undertaken against the Brigantes at this time, and had probably a hand in the attempted reduction of the Silures; but nothing of note was effected until he was appointed to the supreme command in Britain in the summer of A.D. 78. From that date until his recall in A.D. 86 he was indefatigable in his efforts to make Britain as stable a part of the Empire as Gaul had at length become. His sonin-law, Tacitus, was, as has been previously pointed out, the historian of his campaigns. Hitherto warfare had been restricted to the favourable seasons of the year, but Agricola waited not upon either time or opportunity and began in the winter months an attack upon the Ordovices, who had again become troublesome. Reducing them to obedience, he marched forward to recover the island of Mona (Anglesea), which had been relinquished when Paulinus had been recalled by Queen Boudicca's rebellion. Having no boats, he availed himself of the services of his light-armed auxiliaries, who were expert swimmers, and re-established Roman authority in the island almost without

Old English compounds Hundredmann, Sochemann, \&c. are parallel instances of names from occupations. 
striking a blow. The ubiquitous activity of the Roman General left the natives neither time nor opportunity to make concerted attacks, and his wise selection of sites for his camps enabled him to overawe the tribes on every side. Many of them submitted and allowed camps and garrisons to be established in their midst. This was an opportunity, of which Agricola quickly availed himself, for introducing amongst the British tribes Roman manners and customs, which, as he knew, would make for peace and settled government. He urged and encouraged the natives to build temples and construct houses and marketplaces. And already the sons of native chiefs began to devote themselves to the liberal arts. By extolling the natural ability of the people beyond that of the Gauls, Agricola induced those who were shrinking from the use of the Latin speech not only to apply themselves to its acquirement, but to strive after eloquence in the use of it. Thereupon, Tacitus adds (Agricola), came the adoption of the Roman costume, and, with the not unfrequent Roman toga, a yielding to the blandishments of a vicious life, with its baths, its public concourse, and the elegancies of human converse-in a word, with that which is called humanity by superficial observers, but which is in reality an element in servitude.

This policy, justified by its results, was no doubt persisted in, and Southern Britain, at least, must have become at an early period as settled as the adjacent Roman possessions in Gaul. The Legions are henceforward to be found mainly in the north and the west, that is, on the borderland of wild and turbulent tribes yet untouched by Roman civilization. In the south there had arisen many populous towns, and the great roads which began to traverse the island in every direction brought them into close relation with each other, and, after the passage of the Channel, with a similar network on the Continent, all converging towards Rome, the Seat of Empire.

In the second year of his command (A.D. 80) Agricola proceeded northwards, and conquered several tribes (whose names 
have not come down to us), among whom he placed the usual forts to secure his conquests. The ninth legion, which was in Lincoln before 75 (Haverfield, Linc. $N$. and Queries, July, 1909), was probably at York at this time: see note, p. I17. In five further campaigns during the ensuing six years before his recall (A.D. 86), he succeeded, by combining naval and military expeditions, in reducing for a time practically the whole country. In his third campaign, as Tacitus tells us, Agricola found himself face to face with new peoples, whom he terrified by his raids as far as the Tay (ad Taum = the Tava Estuary of Ptolemy), a name then applied to an estuary or firth in what is now Perthshirea region settled, as we subsequently learn, by the Picts.

The fourth year was consumed in securing the territories through which he had passed. The narrow space of land between the Firths of Clyde and Forth (Clota et Bodotria, the Boderia, with a variant Bogderia, of Ptolemy) he fortified with forts, so that the enemy should be, as it were, removed into another island. In Agricola's fifth campaign he reached the western coast of Scotland facing Ireland, a country which he had hopes of eventually conquering, and with this aim had received under his protection one of the kinglets of the country who had been exiled on account of some home trouble.

The last campaign of Agricola in Britain was directed against the people inhabiting Caledonia (that is, the region north of the Forth), who had almost cut to pieces the ninth legion, but upon whom he now inflicted a severe defeat at the Graupian Mount, slaying some ten thousand of them with the loss of only three hundred and sixty of his own troops. As the summer was far spent, Agricola retired into the territory of the Boresti, where he received hostages from the enemy. Here he ordered his fleet to circumnavigate the island, while he himself led his troops by slow marches, in order to make a deeper impression on the enemy, into winter quarters. The fleet at the same time, favoured by the weather, reached with glory the port which Tacitus calls Trucculensis (variant Trutulensis), whence it 
returned by coasting along the nearest side of Britain. The Emperor Domitian, becoming now jealous of Agricola's successes, and fearful of their consequences, recalled him from the island.

The topographical names involved in this part of the record of the Conquest of Britain are few in number, and some seem to have left no survivals. The Tay still perpetuates the name of the estuary (ad Taum) which Agricola reached in his third campaign. The name seems at this time to have been restricted to the tidal waters, and to have been extended afterwards to the river, which flows through Perthshire. This was a Pictish region at this time, and the interpretation must be sought in that language. Skene (Four Anc. Books of Wales) states that the Cymri called this river the "Tawi". The best MS. of the Agricola, the Vatican, reads "Tanaus", which is probably for Tavaus. Ptolemy's form is Tava. The firth of "Clyde" represents the Clota, and the "Forth" may be the lineal descendant of the Bodotria of Tacitus, although, as the transition stages are lacking, the guess is hazardous. In Bodotria the initial " $\mathrm{B}$ " was doubtless, as in similar latinized words, pronounced as "V", and would thus make the transition to "Forth" more natural. The Brythonic form of the name, "Werid," in which an initial "V" has become "W" $(=G u)$, may be an intermediate form.

Caledonia is a somewhat mysterious word, and Sir John Rhŷs thinks that "the Celtic etymologies usually proposed for it will not bear examination" (Celt. Brit., p. 285). Although Ptolemy and the Latin poets make the " $\mathrm{e}$ " in it long, Sir John Rhŷs says there is no ground for this in any of the extant Celtic forms of the name. The modern representative of the genitive of Caledo, shown in the second syllable of Dun-keld (earlier Dunchailden: see p. I53), would seem to bear this out. Sir John Rhŷs would make "Caledonia" a designation derived from the national name "Caledo", which was found a few years ago on a bronze tablet at Colchester. The wood of Caledon of Geoffrey of Monmouth, and the site of King Arthur's victorythe wood of Celyddon (Nennius)-contain the same "Caledo". 
Stokes, assuming a long " $\overline{\mathrm{e}}$ " in the word, cannot connect Caledonia and Caldet $=$ wood. Professor Windisch, however, is inclined to accept the connexion.

The prevalence in Britain of place-names containing more modern forms of this Caldet, meaning forest or grove, is in favour of this connexion. ${ }^{1}$ Whether we have a connected word in Calat, in the early form (Glasgow Charter, A.D. I I $3^{6}$ ), Calat-ria, later Kalentyre, and now Callender, the district between the Avon and Carron Rivers, it is difficult to say. In the annals of Ulster under A.D. 735 we have Calat-ros as the name apparently of this district. Skene identifies Calat-ria and Calat-ros, and finds the common form represented in the Cymric Galt-reath, otherwise Catraeth (Four Anc. Books of Wales). The "Calat-" would thus have become on Cymric lips "Galt", ${ }^{2}$ and hence it would be easy to see the origin of the Galt-res (also given early in the form "Calt-res") forest in Yorkshire, a name identical with Calat-ros, (ros=moor). The "Galt-weid" (now Galt-way in Galloway) of the Holyrood Charter, and the Galt-hanin in Abernethy district (Reg. of Aberbrothoc, A.D. I214), and the Gal[ $t]$ klint Wood of the Bodleian Charter (thirteenth century), supposed to be in Northamptonshire, and Galt-klint Castle, which has not been identified, all involve, seemingly, the same element.

Here begins a difficulty. The Welsh Gallt is given as the equivalent of Alt (of which the plural form, Gelltydd or Elltydd, are probably represented in Bagillt and Counsylht, now Coleshill, Flint), a height, and is used to designate "Cliff" (cf.

1 See Pedersen (V.Gramm. $\$ 69$ ), who shows that in the Irish Caill, Welsh Celli, Corn. Kelli, the $l l$ represents an earlier $l d$. Stokes traces (Wortschatz) these back to Kaldat, of which the Norse and English Holt is a cognate form.

2 "Alt" in Gaelic has come to mean a stream. If, as is somewhat improbable, Catraeth (the place, according to Nash, where Penda was slain by Oswy in 654) =Calatros, i. e. Galtres, then it was in Bede's Loidis and not in Scotland. Some of the places cited above, involving Galt, may contain the Old Norse Galti (=boar) which appears in Scandinavian placenames and in English districts occupied by the Northmen. Galt-Klint would thus be pure Danish (Danish Klint=cliff, high bank). 
Gold-cliff on the Bristol Channel, which seems to give in its first element this Galt). Pedersen (Gramm. $\$ 88$ ) traces Alt to the same stem as the Latin alt-us=high). As far as origin or meaning goes the Welsh Gall cannot thus be connected with Caldet. Caled is, however, possibly the first element in Calleva (i.e. Caled-va ?), now Silchester, the Sil probably standing for the Latin word silva, the equivalent of Caled. Calat and Caled may, therefore, be different forms with the same meaning.

Of the Graupian Mount (Mons Graupius of the Vatican MS.) nothing is known, and the "Grampian" Hills are an antiquary's invention of the sixteenth century. The "Boresti" seems to Sir John Rhŷs to contain a Brythonic form of the low Latin Foresta $=$ Forest, but as the initial was doubtless pronounced "V", we may have here possibly the early form of the place called Forays in A.D. $\mathbf{1 3 3 2}^{2}$, and now Forres in Elgin. This is, at any rate, somewhere in the neighbourhood of where Agricola was campaigning. It would be, then, from this point that the fleet was ordered to circumnavigate the island. Where the Trucculensis Portus was is a matter of conjecture. Sir John Rhŷs thinks that the Taizaloi of Ptolemy and the Truccul in this word had a common origin, and that the site of this was somewhere near Peterhead. But is there any need that the Trucculensis Portus should be in Scotland at all? It might be miles away "whence [unde] the whole fleet returned coasting along the nearest side of Britain ".

When Agricola handed over the administration of Britain (A.D. 86) to his successor the country was, as Tacitus describes it, quiet and secure. It is a matter of conjecture who this successor was, but Suetonius, who compiled the lives of the twelve Caesars about A.D. I 20, mentions, as Governor of Britain at this time, a certain Sallustius Lucullus, who was subsequently

1 "The Texel," an island off North Holland, of which we have early similar forms, may have been furnished to Ptolemy by navigators in the North Sea, and been placed by him in Eastern Scotland as "Taizaloi", but see the discussion of Ptolemy's Geography further on, pp. 91 et seq. 
put to death by Domitian. The Emperor Domitian died in A.D. 96 at the age of forty-five, and was succeeded by Nerva, who ruled only two years. On his death he was followed by his adopted son Trajan. Of affairs in Britain we know little or nothing until the accession of Hadrian, the successor of Trajan, in A.D. 117. Spartianus, who wrote, about the beginning of the fourth century, the Lives of the later emperors, tells us in his biography of Hadrian that the Britons at the outset of his reign could not be maintained under Roman authority. Julius Severus was at this time (A.D. 120) in command in Britain, but the Emperor Hadrian thought it wise to appear there (A.D. I23) in person. He set things in order there, and was the first, as Spartianus says, to construct a wall, of some eighty miles in length, which was to serve as a boundary between the barbarians and the Romans, that is, those who accepted Roman rule. The length of this wall, corresponding as it does with that which runs from Wallsend on the Tyne to Bowness in Cumberland, compels one to identify it with the latter. The inscriptions found in the neighbourhood of this wall-which consisted of a stone wall with large and small forts, together with a ditch-date, as Dr. Haverfield says, "mainly if not wholly from Hadrian's reign." South of this wall, and separated from it by an interval varying from 30 to 1,300 yards, is a vallum consisting of three ramparts and a ditch. Mommsen thinks this was thrown up in connexion with Hadrian's wall, but other authorities look upon it as an earlier structure.

Hadrian died in A.D. 139, and was buried by his successor in that magnificent mausoleum which is now known as the Castle of St. Angelo at Rome. Antoninus Pius was his successor. Julius Capitolinus, who wrote about the beginning of the fourth century, tells us that during the reign of Antoninus the Britons were reduced to order by Lollius Urbicus, who had been sent to Britain as Governor in A.D. I39. He constructed a second wall of sods between the Clyde and Forth, after he had driven away the barbarians. This wall was not apparently 
intended to supersede Hadrian's wall, but to relieve pressure on the latter. Dr. Haverfield infers that it was soon abandoned. The inscriptions found along its course show that the legions employed in constructing it (the twentieth, the second, and the sixth) finished the work in the time of Antoninus Pius. Pausanias, a Greek writer of about the middle of the second century, incidentally mentions that the Emperor Antoninus deprived the Brigantes of much of their lands because they had begun to overrun the Genunian territory or patrimony (Moira), of which the inhabitants were subject to the Romans.

The construction of the second wall by Lollius Urbicus seems to have been connected with his efforts to punish the Brigantes, whom we find in previous records to have been included in the region now called Northumberland, and to have extended to the Forth. The territory taken from the Brigantes was, therefore, in that region; and the Genunian land, which was open to their attacks, may have been either north or south of the 'TyneBowness wall. Sir John Rhŷs would make the Brigantes here mentioned the northern section extending to the Forth, and he would look for the Genunian possessions somewhere in that quarter.

In the absence of any inscriptions near the Clyde-Forth wall later than Antonine, Dr. Haverfield's conjecture that it was quickly abandoned seems very probable, and, as the Romans appear to have been hard pressed in this region all the time, it is not likely that the Genunian territory, occupied by a people subject to Rome, should be found in this part of the country. Where then was this Genunian (or as some editors would read, Venunian or Venuvian) territory? The late Dr. Reeves and Sir John Rhŷs were disposed to see a connexion between it and a certain Geona Cohort mentioned by Adamnan in his Life of Columba. Columba, the Irish apostle of the Picts of North Britain, died within not many days after the arrival of St. Augustine in the island of Thanet (A.D. 597). His biography was written by Adamnan about one hundred years 
later, and the earliest MS. containing his biography is of the first quarter of the eighth century, that is, it was extant before the death of the Venerable Bede (A.D. 735). Adamnan tells us that when Columba was in the Isle of Skye, an old man, a commander (Primarius) of the "Geona Cohort", landed on the island and was converted through an interpreter by Columba. His name is given as Artbrannan, a thoroughly Celtic appellation, and yet Columba required an interpreter to talk with him. It is therefore argued that he was a Pict and spoke Pictish, which presumably was a non-Celtic speech-but this would leave his Celtic name unexplained.

Of the Geona cohort, Dr. Reeves wrote (Adamnan's Life of Columba, p. 62) that it was "probably a Pictish corps deriving this name from the district to which it belonged". Sir John Rhys is inclined to think that Geona "is a defective spelling of Genona", and that it referred to the Genunian territory of Pausanias. This he would locate in the Pictish mainland opposite Skye, but it is hard to believe that Roman institutions could survive so late, as the words "Primarius" and "Cohort" imply, in this wild and rather inaccessible country, and it is still more difficult to believe that this could be the Genunian territory which was occupied by a tribe subject to Rome in A.D. I 40, and exposed to attacks from the Brigantes at this time.

The editorial conjecture of "Venunia" for "Genunia" suggests the place called in the best MSS. of the Antonine Itinerary Vinonia, and now known as Binchester. This is sufficiently near the Brigantes, whether these were within or without the Tyne-Solway wall, to account for their attack on Vinunian or Genunian territory. The Greek word used by Pausanias, Moira, was employed, it is true, by Xenophon to denote a division of an army, and suggests thus the Latin Cohort, but it is far more frequently used for patrimony, share, or portion.

We learn from Julius Capitolinus, before mentioned, that the Britons gave trouble again about A.D. 16r, and that Calphur- 
nius Agricola was sent against them by the Emperor Marcus Antoninus, better known as the Philosopher Marcus Aurelius (A.D. I6I-9).

In the year A.D. I8I also, as the same author tells us, the Northern tribes broke through the wall, but were worsted by Marcellus Ulpius, who had been sent against them by the Emperor Commodus (A.D. 176-92). But it was to the Emperor Septimius Severus $\left(\mathbf{I} 93^{-2}\right.$ II $)$ was due the actual pacification of the northern part of the country. He made a wall across the island, $3^{2}$ (or $\mathbf{r}^{2} \mathbf{2}^{2}$ ) miles in length, says Eutropius ${ }^{1}$ (writing in A.D. 370), and the same statement is made by Spartianus, who adds that it was fortified at each end where it met the sea. Aurelius Victor (a writer of A.D. 360 (?)) repeats the statement, which appears also in the Chronicon of St. Jerome (who died A.D. 420), in Orosius (born in Spain about A.D. 390), in Cassiodorus (died A.D. 573), in the so-called Nennius (eighth century), and in Bede (died A.D. 735). This is a statement which it is difficult to reconcile with evidence from other sources. In the epitome of Dio Cassius, which we owe to Xiphilinus, who compiled it about A.D. 107r, we find no reference to a wall constructed by Severus, though mention is made of some earlier fortification. No inscriptions, moreover, connected with Severus have been found on either of the walls. Until some further discovery is made one may assume, with Mommsen, that Severus merely reconstructed the Clyde-Forth wall during his northern campaign.

He doubtless found it a difficult matter to subjugate the northern tribes, and provided some sort of bulwark against them, but it is difficult to connect him with either wall. The tribes which gave him most trouble were, as we find in the

1 In the extension of Entropius ascribed to Paulus Diaconus (died 782 ) and in other writers, Severus is said to have fully secured the regions obtained in this war by a great ditch and a strong Vallum with towers at long intervals, stretching 132 miles from sea to sea. The mention of the ditch, Vallum and Towers, appears first in a MS. of the tenth century. 
epitome of Dio Cassius, the Caledonians and Maeatae, and he proceeded against them in person, almost reaching the northern limit of the island in his march. $\mathrm{He}$ was old and sickly, and had to be carried in a litter all the way. At length, on returning from that campaign, he succumbed to his malady, and died at York in the year A.D. 2Ir. His body was cremated there, and the remains carried to Rome. He was succeeded by his son Antoninus, known better as Caracalla (A.D. I 98-2 I 7).

Archbishop Ussher was the first to see a connexion between the Maeatae of Dio and the Miathi (De Bello Miathorum) of Adamnan's Life of Columba. The battle here referred to, according to Dr. Reeves (Adamnan, p. 35), is that called in the Annals of Tighernach Chirchind, which Dr. Reeves would identify with Kirkintulloch on the Clyde-Forth wall. ${ }^{1}$ Sir John Rhys has no hesitation in placing the Maeatae immediately north of the wall (where Dio locates them), and finds in Dunmyat (alias Dalmyot and Demyat), a few miles north-east of Stirling, a stronghold of these people, preserving their name, as Dunkeld preserves that of the Caledonians, and Dumbarton (Dun-bretane) that of the Britons. He also connects the two rivers and the island called May with the Maeatae also, to which might be added Dunmay in Fife.

From the death of the Emperor Septimius Severus in 2 I I to the year A. D. 287 , that is for seventy-six years, there is practically nothing known of affairs in Britain. Lampridius, a writer of about the end of the third century, tells us, it is true, that the Emperor Alexander Severus was killed (in A.D. 235) by his own troops in a town called Sicila (or Sicilia), in Britain, but adds that others assign the place to Gaul. Aurelius Victor, a later author, definitely asserts that Sicila was in Britain, but all other writers agree in describing the death of Alexander Severus as having taken place in the neighbourhood of Mainz on the Rhine (Bretzenheim, as some conjecture) whither he had been called

${ }^{1}$ But compare Circinn and Magh-girginn referred to later on, p. 77. 
from the East to repel the Germanic tribes which were then threatening the Empire.

Severus was succeeded by Maximinus, who was declared an outlaw by the Senate in $23^{8}$, and was followed in rapid succession within that year by four Emperors, whose names hardly require to be mentioned. Gordianus III ruled from 238 to 244 and had as his successor Philippus (244-9), Decius $(249-5 \mathbf{I})$, Trebonianus Gallus $\left(25^{1-3}\right)$, Valerianus $(253-60)$, Gallienus $(253-68)$.

Postumus, who ruled, with Victorinus, in Gaul only, was Emperor from $25^{8}$ to 267 . Claudius II and Tetricus ruled from 268 to 270 , and were followed by Aurelian (270-5), Tacitus (275-6), and Probus (276-82). Diocletian and Maximianus were Emperors from 284 to 305 , and it was during their rule (A. D. 287) that Britain again came within the horizon of history.

This period of seventy-six years, although almost a blank ${ }^{1}$ as far as written history is concerned, is not without other indications of the persistence of Roman rule and activity in the island.

Contemporary inscriptions on stone monuments discovered at various places show that the jurisdiction of Rome was maintained in the region south of the Tyne-Bowness Wall. There have been found, for instance, inscriptions of the time of Elagabalus (A.D. 218) at Riechester, Northumberland, and of the time of the Emperor Alexander Severus at Old Penrith, as well as on the Roman wall. Of the time of the Emperor Gordian III inscriptions have been discovered at Lanchester (Durham), at Bittern near Southampton and at Old Carlisle.

1 The historian Zosimus, writing in Greek about the beginning of the fifth century, tells us that the Emperor Probus sent into Britain (A.D. 280?) a number of Burgundians and Vandals to sustain Roman authority there. This is significant as showing that Teutonic tribes were in Britain before the time of Zosimus, and throws light, possibly, on Geoffrey of Monmouth's "Africans". 
Inscriptions of the reign of Philip have been found at Old Penrith, and others of the time of the Emperor Gallus and Volusianus at Bowness (Cumberland) and at Bittern, Southampton. Of the reigns of Valerianus and Gallienus there has been found an inscription at Caerleon (Monmouthshire), and other inscriptions have been discovered at Pyle, near Neath, Glamorgan, at Bittern, at Castor (Northampton), and at Kenchester (Hereford), representing respectively the reigns of Victorinus, Tetricus, Florianus (276), and Numerianus (284).

There is possibly further indirect testimony to the Roman occupation of Britain at this time in the Ancient Welsh Genealogies, if we could disentangle from them the historical elements which they seem to contain. The Bards, who are referred to by classical writers from 200 B.c. onwards, are uniformly represented as the annalists and genealogists of the Celtic chiefs. Giraldus Cambrensis, writing in the twelfth century, says (Descr. Cambriae, cap. iii) "I ought to record that the Welsh Bards or reciters have in certain ancient and authentic books of theirs the genealogies of the aforesaid Princes, but written in Cymric, and the same they know by heart". The genealogies of Cymric (Welsh) notables which have come down to us, contain besides native names, many of Latin origin. See Note C.

\section{NOTE C.}

The early British Pedigrees which have come down to us have been probably preserved by the Bards. These pedigrees are not consistent with each other, and there are indications that they were edited from time to time in the interest of certain families. They contain names, however, which go back apparently to Roman times and could not well have been introduced at a later date. Some of these names seem to have come into use at the period with which I am dealing and to have persisted as appellations for a long time after. Hence a difficulty arises of identifying the personages who bore them. These pedigrees are found, with one exception, in MSS. from the eleventh century onwards (see Mr. E. Phillimore's transcript of the earliest-Harleian MS. $3^{859}$-in the Cymmrodorion Mag. vol. ix, 
for 1888 , pp. I 4 I et seq.). The exception, which is inscribed on stone, dates from not later than the middle of the ninth century, and may, therefore, be dealt with here first, as it seems to refer to matters of the end of the fourth century. This inscription in memory of an ancestor called Eliseg (Elized, according to Mr. Phillimore) was carved at the instance of a certain chief called Conchenn ${ }^{1}$ on a stone cross which gave the name to, and still stands at, Valle Crucis near Llangollen. The monument, according to experts, belongs to a period some four hundred years after the Roman troops had left Britain, but there are indications on it which would lead one to assign some of the sources of it to the end of the fourth century. Only a portion of the inscription was made out in the seventeenth century by Mr. E. Lhuyd, whose MS. was copied by Westwood and Hübner. Professor Sayce (Arch.Cambrensis, Jan. I 909) has advanced a most ingenious restoration. At the end there is a pedigree containing three Roman names, Pascen, Maximus, and $\operatorname{Sev}[i] \mathrm{ra}(?)$, and of these Maximus has been identified with Maximinus who was a companion in arms with Theodosius in Britain, and in A. D. 367 , according to Bede [epit.], was made Emperor. Sev[i]ra is given as his daughter. Bede also tells us that Maximus went into Gaul and slew there the Emperor Gratian, who was then $\left(3^{89}\right)$ at Lyons. $^{2}$ The end of the

1 This is the same name as Conchend (Doghead) occurring in the Irish annals. See the Filire of Oengus (published in a revised edition by the Henry Bradshaw Society) sub voce "Conchenn". The name is undoubtedly Irish in this form, but it took on afterwards a Cymric shape, Cyngen, which disguises its origin but is otherwise instructive, as it suggests that the Celtic prefix cuno-, Welsh Cyn, involves "hound". Conchenn is represented on the stone [Haddan and Stubbs, Councils, i. 626] as King of Powys, and the Annals of Cambria at A. D. 814 calls his father Catell, who died in 808. Sir John Rhŷs has shown (Epigraphic Notes in Archrologia Camb., Jan., 1907) that in the ancient Celtic personal names involving cuno, such as Cuno-maglus, Magli-cunas, Cunotamos, Cunovalos, \&c., the element Cun-o means "hound ", and has nothing to do with a supposed Cwn $=$ high .

${ }^{2}$ Maximianus (or Maximinus) was of British origin according to Socrates the ecclesiastical historian, and in Sigebert's Chronicon he is made to be of imperial descent, and a kinsman of Constantine the Great. All this falls in with the traditions (taken from Geoffrey of Monmouth) preserved by Matthew of Westminster (Chron. Majora, under A. D. 376). 
inscription refers evidently to this fact, although Gratian's name does not appear. "Pascen $(\mathrm{t})$ " and "Eliseg" are names that occur several times in the Welsh pedigrees, and Nennius (Hist. Brit., 70) applies the Latin name Pascent to the son of Vortigern, the British king at the time of the Teutonic invasion, and the Irish version of Nennius makes the latter the son of Guital (? Vitalis).

The transcript of the Genealogies edited by Mr. E. Phillimore was originally compiled, according to the late Henry Bradshaw, by an Anglo-Norman scribe, in the eleventh century, from older documents of varying age. It furnishes a considerable number of Roman, and possibly historic, names associated with those of the families of British notables, among the latter being Eliseg (Elized). The Roman names are somewhat disguised, but their classical forms can be readily restored. In "Aircol son of Trephun", for instance, the former represents, according to Sir John Rhys, Agricola, and the latter is apparently the British equivalent of Tribonianus, a name appearing in 235 as a designation of the Emperor Gallus. Tribon- becomes quite normally Trifun- in Welsh: cf. Tafarn and Taberna. In the sequence of "Atern, the son of Patern pesrut (that is, of the red tunic-Peis from Low-Latin Pexa-i.e. Chlamys purpurea) son of Tacit" we have possibly a reminiscence of the Emperor Tacitus $\left(275^{-6}\right)$ and of Ovinius Paternus, a consul of his time. Anthun, which occurs more than once in connexion with Maxim Guletec (that is, Emperor), represents perhaps M. Antonius Gordianus, Emperor A. D. 238. The Maxim referred to in the pedigrees, as well as on the pillar, is given as he "who slew Gratian King of the Romans", i.e. the Maximus who, elected Emperor in Britain, was killed afterwards by Theodosius (A. D. 388), but possibly Caius Julius Verus Maximinus is meant, who was Emperor from A.D. 235 to 238 . In another sequence, "Dimet son of Maxim Guletic son of Protec," we have probably the latter Maximus associated with the Emperor Domitius Aurelianus (270). The short 0 of Domitius would give normally a Welsh 0 , but we have instances where, like long 0 , it becomes $u=\bar{\imath}$ (Pedersen, Gramm. i, p. 195). Iouanaul (cf. Juvenal, Haddan and Stubbs, Councils, i, p. I66), Grat ${ }^{1}$, and Urban ${ }^{2}$ also occur.

1 Gratus was Emperor in A. D. 222. Cf. also Annius Gratus, Emperor in A. D. $25 \mathrm{I}$.

${ }^{2}$ Urbanus was the colleague of Maximus in $236 \mathrm{~A} . \mathrm{D}$. 
Another name, Serguil, occurring in the pedigrees, is the British form of Servilius, which is the name of a consul under the Emperor Trajan. "Pappo Post Priten" is the mysterious designation of an important personage, "son of Ceneu," occurring in the genealogies, and is perhaps a reminiscence of Pappus, a consul under Gordianus, who may have been a Praepositus (Post?) in Britain at the time. Praepositus, which was applied to an Admiral of the Fleet, as well as to other officers, gives the modern Welsh Prawbst. The name of the Emperor Postumus might be compared here, but he ruled only in Gaul.

Several other Latin names of civil and military functionaries, many of them not such as would occur to a later compiler, appear in these genealogies, and thus reflect the days of the Roman occupation. For instance, we have more than once "Protector" (and the shortened form Protec) meaning one of the imperial life guards, and applied in this sense by Spartianus in his Life of Caracalla to a certain Marcellus. "Stater" ${ }^{1 "}$ is another official designation, meaning one who attends on the Provincial magistrate. There occurs also a mysterious designation "Pincr misser", a term which seems to have baffled all commentators; but may it not be for Pincerna mensarius, a butler? Lampridius uses, in his Life of Alexander Severus, "Pincerna" in this sense, and the term Pincerna was applied also to a subordinate officer of the Frankish Court: Brunner, Rechtsgeschichte, ii. 102 ; cf. Stevenson's Asser, p. I64 n.; and Duddan Pincerni (sic, for genitive) in a Worcester Charter ascribed to 779, Cart. Sax. i, p. 325.

"Peretur" (later, according to Sir John Rhŷs, Pryderi) is another name occurring in the genealogies as one of the sons of Eleuther [Eleutherius ?] of " the great retinue", [i.e. cascord = gosgordd], and, as far as I know, has not been explained. May it not be an attempted transliteration of Praetor, all the more readily retained because of its seeming resemblance to the British pryderus = "solicitous", "caring about"? These are only a few of the probable Roman names in these genealogies, which are supposed to preserve some survivals of the oldest materials of British history. List xvi is instructive in this respect. It gives the chronological sequence of the Roman Emperors down to 337 , with some omissions, and makes each

1 The form Stalor Praetorius or Praetorian Stator occurs. 
emperor the son of the preceding one. The forms given to the classical names are instructive. I place the list in one column and the actual succession in another.

List "Harleian MS." 3859.

Map ( = Son of) Constantis

Map Constantine the Great

Map Constantine

Map Galerii

Map Diocletiani

"In his time suffered the blessed martyrs in Brittannia, Alban, Julian, Aron,with many others"

Map Caroci (glossed in later hand Map Probi " i imperatoris")

Map Titti

Map Auriliani

Map Antun dv. and Cleopatre. Map Valeriani Map Galli

Map Decius. mus

Map Philippus (sic)

Map Gordianus

Map Alaximus ${ }^{1}$

Map Alaxander

Map Aurelianus

Map Mapmau cannus (= Maucannus)

Map Antonius

Map Severus

Map Moebus (? for Marcus Antoninus)

Map Commodius

Map Antonius

Map Adinuand us (= Adrianus?)

Map Troianus

Map Nero: under whom suffered the blessed Apostles of our Lord Jesus Christ, Peter and Paul.

Map Domitianus
Actual Succession.

Constantine, 306-337

Constantius and Gallerius, 294-306.

Diocletian, 286.

Carus, 282, and his sons Carinus and Numerianus, 283.

Probus, 276.

Tacitus, 275 ; Florianus, 276.

Aurelianus, 270.

Aurelius, Quintillus, and Aurelianus, $268,270$.

Galienus, 253 ; Postumus, 258.

Amilianus and Valerianus, 253.

Trebonianus, Gallus, and Volusianus, $25 \mathrm{I}$.

Decius, 249.

Philippus, 244.

Gordianus, 238.

Maximinus, 235 .

Alexander Severus, 222.

Elagabalus, 218.

Macrinus, $21 \%$.

Antoninus (Caracalla), 198.

Pertinax, Julianus, and Severus, 193.

Commodus, 176 .

Marcus Antoninus and Lucius Verus, 161.

Antoninus Pius, 138.

Hadrianus, I I 7 .

Traianus, 99.

Nerva, 98.

Domitianus, $8 \mathrm{r}$.

1 Mr. Phillimore rightly read $A l$ as a mistake for $M$. 
List "Harleian MS." 3859.

Map Titus

Map Vespassianus

Map Claudius

Map Tiberins : under whom suffered our Lord Jesus Christ.

Octavianus Angusti Cessarus.

In his time our Lord Jesus Christ was born.
Actual Succession.

Titus, 79.

Vespasianus, 69 .

Galba, Otho, and Vitellius, 68.

Nero, 54 .

Claudins, $4 \mathrm{I}$.

Caligula, 37 .

Tiberius, 14.

Octavianus Augustus, 23 B. C.

The foregoing list is instructive in showing how these genealogies were made up, as well as in its transcription of names, even when these are manifest blunders. The misplacing of Antony and Cleopatra and of Nero is curious. The scribe had apparently Nerva before him and, making it Nero, added the Latin account of the martyrdom of SS. Peter and Paul. The omission of all notice of Carausius and Allectus tends to suggest that all the information about the emperors was acquired from continental information derived through foreign ecclesiastics or books. It has not certainly the air of home tradition.

The list will serve to explain also why imperial names were foisted into the previous pedigrees. It is not, therefore, too rash to connect, as I have done, the names of known Latin rulers with the indigenous appellations appearing in the genealogies, seeing that commentators assign several of these Latin forms to British saints who lived at a much later date, and of whom inscriptions still survive. For instance (see Haddan and Stubbs, Councils, vol. i, pp. 162 et seq.), an inscribed stone bearing the name "Pascent" exists at Tywyn in Merionethshire and is not earlier than the sixth century. The conjecture about Pappo Post Priten may also seem rather ridiculous in face of the fact that at Llanbabo (i.e. the church of Pabo) in Anglesea, there exists a tombstone with this inscription, Hic iacet Pabo Post Prud, \&c., that is, 'Here lies Pabo Post Prud." Unfortunately, however, this tombstone, while it evidently preserves, in the figure upon it of a sceptred king, older traditions, belongs to the thirteenth or fourteenth century only, and is probably an instance of how pious ecclesiastics made use of early names to found upon them claims for the antiquity of sacred sites. The Lives of the British saints contain many such associations, but they were all written centuries after the saints lived. It ought to be 
here noted that certain ancient place-names are found in the Genealogies, e. g. in List v dimor meton (i. e. "from mor meton" = ? the Middle Sea, Mediterranean. In xxv Glastenic (Glastonbury) and Loyt Coyt (Lichfield). In xxxii manau Guodoton, i. e. Manau of the Votadinoi (see p. 67).

\section{THE ROMAN OCCUPATION}

III

With the year 287 Britain not only comes again into the light of direct history but also appears then, and for some eight or nine years afterwards, as independent of Roman authority. This is the alleged year of the martyrdom of St. Alban at Verulamium, and the baptism of the land by Christian blood was a prelude to British independence. It was, however, but an independence in name. The new ruler, Carausius, assumed the Roman purple, and took up the position of an emperor.

The story of Carausius is invested with all the elements of romance. Eutropius the historian, who died about A.D. 370, tells us (ix. 2I), that Carausius sprang from the vilest of the people, and we learn from Victor (A.D. 360) that he was a citizen of Menapia, that is, roughly, of the region extending between the river Meuse and the sea. The Menapii, who gave their name to this district, extended in the time of Julius Caesar even to the Rhine, and gave him no little trouble in his Gallic wars, but by A.D. 287 they had become Romanized. The position of Menapia, with its numerous islands in the estuaries of the Rhine and Meuse, was favourable to the development of a seafaring population, and the Romans would naturally avail themselves in manning their fleet of this aptitude of the people. Carausius was a seaman, having exercised, as Victor tells us, the calling of a pilot from his youth upwards. For this reason, and because he had already obtained celebrity for his prowess in war, he was placed in command of the Roman fleet, which had been got together at Boulogne 
(Bononia), to drive from the seas the Germans who were then infesting them. Eutropius is more specific and gives us the nationalities of those German raiders, and defines the coast also upon which they were making their descents. They were Franks and Saxons, and it was to act against them that Carausius had his commission given him (Eutropius iv. 2 r), to maintain Roman authority on the seas which washed the coasts of Belgium and Brittany (Armorica). ${ }^{1}$

These Teutonic pirates infested not only the Belgic and Armorican coasts but also those of south-eastern Britain, and a special official, with the designation of "Count of the Saxon Shore ", ${ }^{2}$ had to be appointed to keep them in check. The Saxons were, therefore, pirates in the Channel long before they made a permanent settlement in Britain, and this fact, coupled with the notice by Ammianus Marcellinus of the combined attack of Saxons and Scots upon the Britons, tends to explain why the Celtic peoples of Ireland, Scotland, and Wales have no other name for the Teutonic invaders of Britain than Saxons (Sassenach, Saisnec).

Carausius, making good use of his old skill as a pilot, succeeded in following up the Teutonic pirates, and in wresting from them no inconsiderable booty. He was accused of having appropriated this booty to himself instead of sending it into the provincial or imperial treasury, and as a suspicion then arose that he was enriching himself by compounding with the enemy,

1 The loss in the Celtic language at an early date of the original initial $\mathrm{P}$ disguises the cognate forms of certain native words. Armorica or Aremorica is an adjectival form from "Are"=(p)arei " upon" and "Mori" = the sea. "Are" is thus cognate with the Greek Para=" beside" and (P)areimorica is thus the equivalent of the Greek Parathalassios or Para-alos. Po-mer-ania, on the Baltic, is a similar form in Slavonic (but with the preposition Po, of a similar meaning to $P a r a)=$ sea coast .

2 This term appears first in the Notitia Dignitatum, drawn up about A. D. 420, but the Comes Maritimae Tractus occurs in Ammianus Marcellinus (writing about A.D. 390) who tells of Saxons, together with Scots and Attacotts, attacking the Britons in A. D. 368 . 
an order was given by Maximianus for his destruction. On this, Carausius boldly assumed the purple and took possession of Britain. Here he maintained his rule for some seven years, and forced the Roman emperors finally to come to terms with him and to acknowledge his authority. Numbers of coins of his reign have been found on which he designates himself as emperor, but none in which he limits his authority to Britain. One of the later coins has the inscription "Carausius and his brothers", that is, as has been surmised, the emperors Diocletian and Maximianus. A few-some of them found at Rouen-have a Roman Galley on the reverse. Eutropius goes on to tell us that Carausius was at length (293) slain by his companion Allectus, who, after a reign of three years, was overthrown by the praetorian prefect, Asclepiodotus, and Britain was restored shortly afterwards, by the capture of London, to the Roman dominion, after an independence of ten years.

Some further details of the career and fate of Carausius, and of his successor Allectus, are to be found in a panegyric, pronounced upon the Emperor Constantius Chlorus by Eumenius, who was born, of Greek origin, at Autun (Augustodunum) in Gaul, and who became a kind of private secretary to Constantius. Constantius had been sent by Aurelian into Britain in A.D. $27 \mathrm{I}$, where he is said to have married his first wife Helena, whom legend makes to have been the daughter of a British chief, Coel, and the mother of Constantine the Great. ${ }^{1}$ When Constantius was associated with Diocletian and Maximianus in the Empire in A. D. 29r, Maximianus bound him still closer to his interests by giving him his step-daughter, Theodora, in

1 Sozomen (writing about 400) and Theodoret (about 4.50) describe Helena's finding of the Cross at Jerusalem, but they say nothing about her parentage. It is not until the ninth century (Life of St. Helena by Altmann, who died 882) that we have any information on this point: some early records of her birth make her a native of Treves, and others of a place in the present Bosnia, \&c., but Geoffrey of Monmouth and those who followed him make her a Briton and the daughter of "King Coel". See Dict. of Christ. Biography, sub Helena. 
marriage, Helena ${ }^{1}$ having been repudiated. Constantius, having been sent by Maximianus into Britain to overthrow Carausius, moved with such rapidity that his arrival in Gaul anticipated any announcement of his coming. Carausius had strongly fortified Boulogne (called Gesoriacum ${ }^{2}$ as well as Bononia), to which Constantius laid siege, and, to prevent the fleet of Carausius coming to its succour, blocked up the entrance to the harbour with large rocks and beams. Eumenius tells us that his prosecution of the campaign (A.D. 292) was delayed by the necessity of building ships for his transit into Britain. Although his panegyrist makes the best of it, it is clear that Constantius was unable for a time to make any headway. 'The Roman fleet appropriated to protect the coasts of Gaul had followed the fortunes of Carausius. Increased by new vessels built after

${ }^{1}$ She is called concubine by Orosius and Sozomen.

2 The oldest MS. (eighth century) of the Itinerarium Anton. gives in two places a various reading of this word, which seems to be the right one, viz. Gesorigensi and Gessorigiaco. Celtic place-names ending in -acum, as D'Arbois de Jubainville has shown, contain in the majority of instances the personal name of the owner of the locality, but it is often attached to common nouns, giving them the significance of "belonging to" as in Taverniacum, now Taverny. Gaisorix is such a name and actually occurs, according to the reading of Zeuss, in Orosius, v. 16, 20. Gaiso-n meant spear in Celtic and was borrowed by the Latins in the form Gaesum, which is used by Vergil and also in the Vulgate (Joshua viii. 18). The Greeks also had the word, and cognate forms are found in Teutonic personal names, e. g. Hario-gaiso-s, Laniogaiso (a Frank and a Roman tribune, A. D. 354). The Teutons obtained their first knowledge of iron from the Celtic tribes, and borrowed the name for spear from them also, that is, at a time when intervocalic $s$ was still retained in Celtic. How early this was is shown by the employment of the stem gaiso in Teutonic proper names, Schrader, Aryans, p. 235. The Early English equivalent is Gar, which also appears in personal names, e.g. Wulfgar and Garwulf. The form Coisis of the Todi bilingual stone is read by Sir John Rhŷs (Proc. of British Acaldemy, vol. ii.) as Goisi(o), which he is inclined to connect with the Gaulish Gaiso-n, Gaiso-s; Irish, Gale="spear", Gaide, "armed with a spear"=Gāisid-ios. Góidel or Gáidel he regards as probably parallel to Gáde = Gaesatus. Bononia (Boulogne), by which "several places were known, is a late Celtic word, as it displaces an early form here, and in the case of Bologna (Bononia), where it replaces the older Felsina. 
the Roman model, manned, moreover, not only by Roman troops, but also by foreign soldiers-a motley assembly of Gaulish merchants and barbarian mercenaries-all under the command of such a skilled nautical strategist as Carausius, the opposing Roman forces, new to maritime matters, had, as Eumenius says, little chance of immediate success. It was probably owing to this condition of things that a temporary peace was patched up with Carausius, of which we have an indication in the coin referred to above.

The murder of Carausius by Allectus furnished a new opportunity for the recovery of the island, and Constantius, taking advantage of it, set sail from Boulogne (Gesoriacum) for Britain, and, evading in a thick fog the enemy's fleet which was stationed in favourable positions in the Isle of Wight (Vectis), reached the coast. Having burned their ships, and successfully engaged the enemy on the way, ${ }^{1}$ the Roman forces marched on

1 The Praetorian Prefect, Asclepiodotus, seems to have landed at a different place, and, preceding Constantius in the march on London, to have had an engagement on the way, in which Allectus was slain. Some of the Roman fleet, having evaded that of Allectus, probably put into a port on Southampton Water, from which Clausentum (in the neighbourhood of Southampton) could be reached. The Roman road thence to London passed by Silchester, into which place Allectus may have thrown himself, for, as Eumenius says, he left his fleet to keep his enemy in view. This place seems from the narrowing of its gates at a date subsequent to its foundation, and from other indications, to lave been held, before its final desertion, by a force inadequate for its defence. That the enemy outside was Roman and not British may be inferred from the discovery of a Roman Eagle there, amid other signs of a conflict. Silchester seems from this time forward to have been left waste, for no indication has so far been found there of an occupation by the Teutonic invaders. The final engagement must have been outside the place. Eumenius states that Allectus preferred to come to blows with the generals of Constantius rather than with the Emperor himself, and that after the engagement the enemy's dead strewed the fields and hills (Campos atque Colles), their barbaric garments and long golden (rutilantia) hair defiled with dust and blood. Among the dead lay Allectus himself, the ensigns of his dignity thrown away, and only distinguishable by a single garment, showing that he was determined (as Eumenius says) when he saw the approach of death not to be recognized amongst the slain. Skene 
London and put to the sword its garrison, which had been strengthened by the Franks and other barbarians who had taken refuge there from Asclepiodotus.

It may be interesting to compare the account of Carausius and Allectus as given by the Latin historians, just summarized, with that furnished by Geoffrey of Monmouth in his Historia Britonum. Such comparison may throw light also on the sources of the latter, and at the same time show how Geoffrey handled these sources. The date of Geoffrey's history is fixed by its dedication to Robert, Earl of Gloucester, a natural son of Henry I, who died in A.D. II47. Geoffrey was made Bishop of St. Asaph in $I_{1} I_{I}$, and died in $I_{54}$. He says in the dedication of his history that it is a translation into Latin from a very ancient MS. in the British language, placed in his hands by Walter, Archdeacon of Oxford. A Welsh "version" of the Historia Brilonum was in existence in the first half of the thirteenth century. The MS. of that date is described by Mr. G. Evans in the Hist. MSS. Commission Report on Welsh MSS., vol. i, Pt. II, Peniarth, p. 378 . Mr. Evans calls it the oldest MS. known of the Llevely's Version. There were three Archdeacons of Oxford in the twelfth century called Walter, but Walter of Wallingford (or Calne), who was in possession of the Archdeaconry (according to Le Neve's Fasti, vol. ii, p. 64) in $\mathrm{IIO}_{4}$ and also in II 5 I, is the only one contemporaneous with Geoffrey. ${ }^{1}$ Geoffrey's history is generally regarded as a wild romance in which what little there is of

(Celtic Scotland, i, p. 94) would make the barbarians under Allectus to be Caledonians, because Tacitus (Agricola, ii) describes the latter as having golden (rutila) hair, but Tacitus uses this colour-adjective as an indication of the Germanic origin of the Caledonians. The barbarians with Allectus were certainly Franks and possibly also Saxons, who were a seafaring people at this time.

1 Walter Map (map is Welsh for son or boy) was not made Archdeacon of Oxford till 1196 . He calls himself Welsh, and his De Nugis Curialium shows that he was acquainted with Welsh lore. His date is inconsistent with Geoffrey's. 
historical material is worked up to satisfy the taste of an age devoted to the marvellous and romantic. Yet, strange to say, it was regarded for a long time almost universally as trustworthy history. As has been well said, " it is hardly going beyond bounds to say that there is scarcely a European tale of chivalry down to the sixteenth century that is not derived directly or indirectly from Geoffrey of Monmouth" (Thomas D. Hardy, Materials relating to the History of Great Britain, \&c., vol. i, Pt. I, p. 349). We all know the use made of Geoffrey, or rather, of Holinshead's excerpts, by Shakespeare in his Cymbeline and King Lear, and by Lord Buckhurst in his Ferrex and Porrex.

Geoffrey's account of Carausius shows that his material was not altogether false, and it is possible that many other episodes in his history which appear to us incredible may have had an historic base. He knows, probably from Bede (H. E. i. 6), who followed Eutropius, that Carausius was " of mean birth", and that he had given proof of his prowess in warlike engagements. He does not imply that he was other than a Briton, and makes him proceed from Britain to Rome to get leave to defend with a fleet the coasts of Britain. Carausius procures this permission, deluding the Roman Senate, and then gets a fleet together which he mans with adventurous youths and dissolute characters, who flock to him in the hope of plunder. He invades the adjacent islands and plunders countries, cities, and towns. At length he proposes himself to the Britons as their king, and is accepted, he engaging to drive the Romans out of the island. Geoffrey makes him kill the son of Septimius Severus, Bassianus (that is the Emperor Caracalla, who died in A. D. 217 ), then (i. e. in A. D. 287), according to him, ruling in Britain. Allectus, according to Geoffrey, was sent by the Roman Senate to kill the tyrant, which he did, and then assumed the government. The Britons, however, resenting the injuries he inflicted on them for taking the side of Carausius, made, says Geoffrey, Asclepiodotus, Duke of Cornwall (Dux Cornubiae), their king. 
Allectus was then in London, but on the approach of Asclepiodotus went out to meet him, and was slain together with many thousands of his men. London was then prepared for defence against Asclepiodotus by a certain Livius Gallus, who, seeing the futility of resisting, surrendered, on the condition that he and his men should be allowed to depart. But no quarter was given, for a body of Venedotians (that is, of Northern Welsh) "cut off all their heads on the same day upon a brook within the City which was known afterwards from the name of the leader, in British speech, as Nantgallim, and in Saxon as Gallemborne ", that is the well-known Wal(l)brook, taking its name from London Wall!! This is a fair specimen of Geoffrey's unscrupulous mode of falsifying history while preserving one or two names to give his story countenance.

The name Menapia is fraught with interest. I have taken it, as is generally assumed, to mean a region in the Low Countries, where Cassel still preserves the first part of the name of its chief fortress Castellum Menapiorum, but it is fair to add that there are other views about it. There were several places thus designated. Pliny calls the Isle of Man "Monapia", which Orosius resolves into Menavia." Some such form as Monapia was thus apparently the antecedent of the Welsh Manaw ("manau" in Nennius), for the latter name was applied by the Welsh, as "Sir John Rhŷs says, not only to the Isle of Man (Monapia), but also to two districts in Scotland, one on the southern side of the Firth of Forth, called in Welsh "Manau or Manaw of the Gododin " (i. e. of the people called Otadinoi by Ptolemy or better Votadini, see p. 100), " and another Manaw to the north of the Forth" (Celtic Britain ${ }^{3}$, p. II2). The genitive is Manann, represented in Clackmannan, i. e. "the Stone

1 Bede, H.E. ii. 5, calls both Man and Anglesea Mevania=Menavia, and the name Menevia (St. Davids) had a probable Menapia as its original. It is curious to note that there was a Mevania on the Via Flaminiana (Ant. Itin. 311) now called Bevagna. Cf. also Moerheb of the Worcester Charter and the early name Murief, the Scotch Moray, referred to further on, which may have originally ended in -apa. See p. 260. 
of Manau". The name Manapia is given by Ptolemy, moreover, to a city in Ireland which has been placed somewhere on the Wexford coast. ${ }^{1}$ This is the city from which Sir John Rhŷs (Arch. Cambr. 1888, pp. 143, 274) is inclined to believe Carausius came. Carausius he is "tempted", he says (Celt. Brit." p. 286), "to identify with the Irish Cú-Roi, which seems to have meant the "Hound of the Plain'." He thinks it represents an early Kuo-rovesi-es, ${ }^{2}$ from which Carausius might naturally arise. Sir John Rhŷs considers he was one of those Irish Goidels (invaders or early settlers) who have left monuments of their presence in Wales in the numerous inscribed stones, with or without Ogams, of the fifth or sixth century A. D. found there. One of these inscriptions discovered at Penmachno contains this same name:-Carausius hic iacet in hoc congeries (sic) lapidum (Here lies in this Cairn of Stones, Carausius), see Haddan and Stubbs, Councils, i. 166.

The monument is too late for the Carausius of A.D. 287 , but it shows that this name was not uncommon among the Celtic peoples. The Menapii on the Meuse were most probably a Celtic people at this time, and their name is capable of being explained from that form of speech.

W. Stokes (Urkeltischer Sprachschatz, p. 3) regards the ending " $a p a$ " in Gaulish place-names as cognate with the Latin $a q u a$, and with the Old German $a h a$, Anglo-Saxon $\bar{e} a=$ river, the latter appearing in numerous English river and place-names (e.g. Fulney, Linc.; anciently Fulan-ea : Ea-ton= river-town, as well as Ea-land, that is, waterland or island). He thinks

1 Ptolemy's name for the Isle of Man is Monáoida (variant Monarina). Ravennas in one place (v. 3o) calls it Evania (for ? the Mevania of Jordanes), and in another (v. 32) Manna.

${ }^{2}$ But $C u$ was most probably then represented by Cun or Con (genitive) in compounds, such as Cunoglas, which Gildas interprets in Latin as Lanio. fulvus, i.e. Tawny Tearer or Hound. In Conchenn cited above, $C u$, "hound," is in the genitive. The Teutonic equivalent is Hun $[a]$-entering into many personal names. See Celtic Britain, iii, p. 294, and also Sir John Rhŷs's Paper in Arch. Cambr. already quoted. 
that it has left no survivals in modern Celtic speech except perhaps in the Irish Oiche=Uisge, i. e. (whiskey) "water". River-names with the suffix apa are numerous in that region of Flanders which was designated Menapia (the -ia termination being Latin). In Germanic districts there it takes the form of -eff and -aff, and in others -ep or -eppe, e.g. Erlaff, Honaff, (Hunapa), Sombreffe (earlier Sumar-afa), Oteppe (earlier Altapia), Jemeppe, Gempe (ancient form Gemapia). Transitions similar to that of Manapia and Manau may be traced in the forms of Hunapa, which appears A. D. $9 \mathrm{I}_{4}$ as Honav-i and in 1229 as Honeffe. ${ }^{1}$ Alberti, Descrittione d' Italia, makes, p. 344 b, the early name of Milan (Mediolanum) to have been Messappia, but this is probably connected with the Messapioi of the South and not with any Celtic word.

The martyrdom of St. Alban has been ascribed previously to a period preceding the accession of Carausius (A.D. 287). Tradition refers it to the Diocletian persecution which began in A. D. $3 \circ 3$. It is very doubtful, however, whether the latter persecution extended to Britain. Constantius, who then ruled in the west, was on the testimony of Sozomen (about 440) well-disposed to Christians, of whom there seem to have been many at his court. Sozomen gives an instance (Hist. Eccl. i. 6) of this, saying that he himself had ascertained it and deemed it worthy of record for its remarkable character. Wishing to inquire into the disposition of the Christians in his palace Constantius called them together and told them that those who were willing with him to worship the gods should be retained in their offices, but that those who refused would have to leave the palace, thankful that they were not otherwise punished. Those who assented to worship the gods and those who refused were separated, and Constantius, deeming that the latter, having shown their fidelity to God, would be faithful to him, were enrolled by him among his friends and counsellors, while the others, being ready to betray

${ }^{1}$ For further instances see $\mathrm{La}$ Frontiere linguistique en Belgique, by Kurth, 1896 . 
their Deity and therefore likely to be untrue to their temporal lord, he excluded altogether from his presence.

This event Haddan and Stubbs (Councils, i. 6) conjecture to have occurred in Gaul shortly before the death of Constantius, which took place at York in A.D. 306. Eusebius, however, writing about 326 (Hist. Eccl. viii. 13), gives a long list of Christians martyred in the East at this time, and Lactantius (writing about A. D. $3^{\mathrm{r}} 3$ ) describes the Emperors Diocletian and Maximian as raging everywhere like cruel beasts against the Christians, except in Gaul (praeter Gallias), which included Britain. St. Alban could hardly, therefore, have been martyred at this time. The Anglo-Saxon Chronicle and the Liber Landavensis attribute his martyrdom to a more likely period, namely, to A. D. 286. We know that St. German, Bishop of Auxerre, in France, visited Britain in A.D. 429, and his biographer, Constantius, a priest, of Lyons, ${ }^{1}$ who was alive in 448 when St. German died, describes the visit of the latter to the tomb of St. Alban at Verulamium and his carrying away some of the dust. One cannot make oneself heard in a vacuum, and it is therefore more difficult to deny the martyrdom of St. Alban than to accept the tradition. If we accept the later date there is a further difficulty. Within ten years of his martyrdom we find three British bishops, [also a presbyter and a deacon,] representing at the Council of Arles seemingly the four Provinces into which Britain had then been divided. The names as given by Mansi (Councils, ii. 466, 467) are:-Eborius, Bishop of York, Restitutus, Bishop of the City of London, Adelfius, Bishop of the City Colonia Londinensium, the latter word conjectured by Haddan and Stubbs (Councils, i. 7) to be for Legionensium, that is, Caerleon-upon-Usk.

1 The discovery not long ago of the MS. of another Life of St. German, by Constantius, shorter than that given in the Acta Sanctorum, dating from an earlier period than the other MSS., shows that the latter have interpolations, but this does not affect the above. 
The Presbyter was called Sacerdos, that is Priest, and the Deacon was named Arminius.

The four Provinces of Britain at this time are given by Rufus Festus in his Breviarium (written after A. D. 369):Maxima Caesariensis, Flavia, Britannia Prima, and Britannia Secunda; Flavia is omitted in some MSS. Silvius Polemius (who was a friend of Hilary of Arles and wrote about 449) gives in his Laterculus the same Provinces, with the addition of Valentiniana, but in the order Britt. Prima, B. Secunda, Flavia, Maxima and Valentiniana (Mon. Germaniae Hist., vol. ix, p. $\left.5^{1} 3\right)$. In the absence of definite information as to the positions of these divisions we are left in a great measure to conjecture, but it is generally agreed that Britannia Prima contained London as its chief place, and Britannia Secunda, Caerleon, ${ }^{1}$ while York $^{2}$ was the centre of administration for Maxima Caesariensis. Flavia and Valentia formed probably the western side of Britain, extending from the Dee, and the region south of the Clyde and Forth. The British Bishops at Arles represented, therefore, three of the Provinces, and the other ecclesiastics may have come from Flavia, of which Lugu-Vallum ${ }^{3}$

${ }^{1}$ Caer-leon, Castra Legionum, means the camp of the Legions. It was called in the Antonine Itinerary Isca of the $2 n d$ Legion, Augusta, from its situation on the Isca or Usk.

${ }^{2}$ York was called Eburäcum in the Antonine Itinerary, and was possibly, like Ebriācus (now Yvré-le-Polin) and Eburiācus (now Evry nẹr Melun), derived from a man's name Eburos, but Gluck (Names in J. Caesar's de B. G.) would associate it with Irish Ebrach = "muddy". The name of the river at York, "the Eure," may preserve an early Ebur, with such a meaning; cf. the English Ouse of similar significance. Ěburrŏs is given by Holder, AltCelt. Sprachschatz, as = Yew ; Irish 1bar (which enters into " Newry", =" the Yews", Co. Down); Welsh Effur for earlier Ebur. The word entered into numerous early place-names, e.g. $\mathrm{Eb}$ (ur)odouron (Ptolemy), now Ivorne in Switzerland; Eburo-Caslum (Rav.) in Britain, not identified; Eburomagus (mentioned by Ausonius); Eburodunum, now Yverdon, \&c.

${ }^{3}$ Lugu-vallum or Luguvallium is probably made up of Vallum $=$ rampart, and "Lugu", a designation of a Celtic deity-Lugos: compare Lugudunum, \&c., see p. 12 n. In late British times it became luel as in Caerluel, now Carlisle. Dr. Whitley Stokes is inclined (Urkeltischer Sprach- 
(Carlisle) was probably the chief place, for there are several Provinces in the list given by Mansi which were represented at Arles by lower dignitaries than Bishops.

Constantius is represented by Eusebius (Life of Constantine, xv) as having died at York in the bosom of his family, his son Constantine having arrived just in time to receive his last embrace. His impressive funeral at the same place is described by the same author (c. xiv). ${ }^{1}$

In the Panegyric pronounced upon Constantius by the Eumenius already referred to, delivered about A.D. 297, the first mention is made of two peoples who were afterwards to bring great troubles upon the Britons. These were the Picts and Irish (Hiberni), with which enemies alone, Eumenius says, the Britons had been accustomed to deal until Julius Caesar entered Britain (54 B.c.). The inference is natural that these peoples had been foes of the Britons for a long time before the days of Constantius, and the mention of the Hiberni ${ }^{2}$ in this con-

schatz, 276) to regard Vallium as derived from a Celtic stem Välo= "wall,' and cognate with the Latin Vallum. This stem is also, according to him, the source of the Pictish fahel in the Peanfahel of Bede (H.E., i. 12)= "Caput Valli," and of the Welsh Gwál="Murus," given by Davies (Dict. Camb. Lat.). The Ravenna Geographer gives a Banno-vallum after Lincoln, apparently on the route to the North (for the succeeding names are seemingly all in that region).

${ }^{1}$ Nennius, or the author of the Historia Britonum which is ascribed to him, and was edited in its present form in the eighth or ninth century, says that Constantius was buried at Segontium (of which he gives another name, Mirmantum), and that his tomb was to be seen in his time. The river "Seint" or "Seoint", near Carnarvon, is alleged to preserve the name and site of Segontium, which is located by the Antonine Itinerary in this neighbourhood, but even if Nennius had any foundation for the statement, which directly contradicts Eusebius, the place may have been Silchester, which was in the region of Caesar's Segontiaci, and possibly bore the name of Segontiacnm before the Belgic Attrebates gave it the name of Calleva.

2 The earliest form of the term "Hiberni" as applied by the Romans to the inhabitants of Ireland, is involved in Juvenal's designation of the country, "Iuuerna," written by the Latins usually as "Hibernia". The early form was preserved until lately in a graffito in the Palace of the 
nexion throws light upon the ancient Goidelic (i.e. Irish) monuments in North and South Wales referred to above, and suggests a conquest by them of that part of the country in early times. Sir John Rhys thinks the Irish were used largely by the Romans as mercenaries and that they composed chiefly the garrisons of their cities. He conjectures that these cities fell consequently an easy prey to "Picts and Scots", the garrison being akin to and friendly to the latter.

In a Panegyric pronounced on Constantine by an unknown orator (but ascribed to Eumenius), Constantius is described as having made, shortly before his death, his last expedition to the North, where among the woods and marshes of the Caledones and of the other Picts, he accomplished many and great exploits.

From the physical description of the Picts given by the poet Claudian ( $D e$ Consulatu Honorii, written about A. D. 400) it would be natural to assume that the name given to this people by the Romans, "Picti," was Latin, and that it is the equivalent of the term " marked by the iron" employed by Claudian (i.e., from another passage of Claudian, "tattooed," as it would appear, on the cheeks), who represents the Roman legion as having "put a check upon the atrocious Scot, and as having read on the dying Picts the characters marked on them by the iron, made more visible by the ebbing of the life blood".

The historian Herodian states that the Picts did not wear clothes lest they should conceal the pictures, and this implies that the tattooing was not confined to their faces. An Irish

Caesars, at Rome. It was read by the present Bishop of Salisbury, before its effacement, as Iverna, indicating the country of a certain Concessus. It is curious in this connexion that the traditional name of St. Patrick's mother was Conchess, representing the feminine form Concessa. Ptolemy's form is Ivernia. These forms would, like the Evernili Patria of Adamnan, go back, according to Dr. Stokes, to a stem ever. The Irish name of Ireland Eriu, genitive Erinn, and the Welsh form Irverddon, throw us back on an earlier Iverijo; or (P)iverjo, as Dr. Stokes gives it, which accounts for the Iver in Iverna. 
writer (Duald Mac Firbis, early seventeenth-century author of Chronicum Scotorum) explains the Irish word for Picts (Cruthni) as meaning a people who painted the forms (Crotha, plural of Cruth=the Welsh Pryd="form") of beasts, birds, and fishes on their faces and bodies. The English invaders of Britain turned Picti into Peoht-as, and this form appears in several personal names current in the seventh and eighth centuries among them, e.g. Pioht-helm, Peoht-wine, \&c. The Scotch still use the word in the form Pechts, which they apply also to fairies (Pixies), and it is from a late Norse form (Petta) we have the name of the Pent-land Firth, that is, "the sea of Pictland": see Rhyss (Celtic Britain", p. $3^{1} 3$ ), who gives, however, another origin to the Pentland in the "Pentland Hills".

Notwithstanding the fact that Latin is the obvious language of the term, some Celtic philologists consider "Pict" to be a British word, equating it with the Irish Cicht, which Cormac's Glossary renders by a term meaning "to engrave", "to carve ". ${ }^{1}$ But the Britons when they used the word Pict adopted it, as the Saxons did, from the Romans, for the British designation of the Picts and Pictland was Prydyn, or earlier Priten. The Welsh name for Great Britain, inis Prydain, still preserves this word, which is cognate with the term Cruthni or Cruithnech by which the Irish always named these people. One of the oldest designations of the British Isles is the Greek Pretanikai Nésoi, that is Pretan-ik islands, which contains the

1 The early name of the people who gave their name (Pictavi or Pictones) to Poiton and Poitiers has led French philologists to this conclusion, but, although Pictones was applied also (Tigernach's Annals, Annals of Ulster under A. D. 749, and Reeves' Adamnan, pp. 385,386 ) to a people of North Britain, it is possibly merely an arbitrary extension of Caesar's term for the Gaulish tribe (Pictones) to the Picts of that region. The initial " $\mathrm{P}$ ", if original, would disappear in all the Celtic dialects and leave the stem as $I c t$, a form which, strange to say, seems to be preserved in the name of the port from which Caesar embarked for Britain, Portus Itius, or, as Sir John Rhŷs, owing to the fact that Muir-n-Icht (or sea of Icht) was the Irish name for the English Channel, would read it, Ictius. Ptolemy's Ition promontory (now Cape Grisnez) has a variant Ikion. 
antecedent of both Cruithenech and Prydain. ${ }^{1} \quad$ It has nothing to do etymologically, strange as it may seem, with the Greek term for the British, Brettanoi, or with the modern word "Britain" which, owing to similarity of sound, gradually displaced the original form.

The Picts about the time of Constantine (A.D. $3^{2} 5$ ) occupied probably all Scotland north of the Forth and Clyde, and the district to the south-west, which is now called Galloway. They also possessed a large portion of Ulster, and some other districts in the east of Ireland. As Bede assigns to these a language distinct from that of the Britons (now represented by the Welsh), and from that of the Scots (which was the same as the Irish) there has been much discussion as to its nature. The few words which have been handed down as Pictish belong seemingly to the Celtic family of Speech, differing but slightly from the British, ${ }^{2}$ and this fact has induced some historians to regard them as Celts. The matter is not, however, so easily decided.

1 The common form under Prydain and Cruthni would be, as Sir John Rhŷs has shown, Qrtania, of which the adjective was Qrtaniko-s, the Welsh initial " $\mathrm{P}$ " being the equivalent of an early " $\mathrm{Qv}$ " represented in late Irish by "C"; compare the Welsh Penn $(=$ Pend $)$ and the Irish Cend (=Cenn, " head"). The original Aryan initial "P" had disappeared from Welsh and Irish and all the other Celtic dialects before historic times.

2 Cormac's Glossary, written in the ninth century, alludes to the Iarn or Iron language (which Sir John Rhŷs would equate with Ivern, although the word also represents the early Celtic form for iron, i. e. Isarn, from which the Teutonic peoples have got their Eisen and (ron) and cites two words from it, viz., fern, anything good, and Ond, a stone. These seem non-Celtic (although Dr. Whitley Stokes would equate fern with the Latin Supernus) and may belong to the Ivernian or original language of Ireland. The term Ond enters possibly into Ondemone, the name of a place where, according to Adamnan (Life of Columba), the Irish Picts were beaten by the Goidels in the year A. D. 563. Sir John Rhŷs thinks it was near the river Bann in Ulster. Adamnan, who wrote a little before the end of the seventh century (the earliest MS. of his Columba is of the eighth century), represents Columba as needing an interpreter on two occasions in speaking to Picts. No mere dialectic difference will satisfactorily explain this necessity. 
The Picts had been in contact in Scotland with a Brythonic people for centuries, and for as long in Ireland with a Goidelicspeaking race. It is not unnatural to assume that in the long run their own language, whatever that may have been, should have been displaced by a Celtic tongue, and that they should disappear as a distinct people. This had become the case before the twelfth century, for Henry of Huntingdon (Hist. Ang., i) says, " the Picts seem to be so completely wiped out and their language so completely annihilated, that what is told of them in the writings of the ancients, appears now to be a fable." Sir John Rhŷs regards the Pictish language as not only non-Celtic, but possibly non-Aryan, that is, as having nothing in common with the great Indo-European family of speech. According to him the Picts represent the ancient inhabitants of these islands before the coming of the Celts, and it is to their influence he assigns several abnormal characteristics of the early Celtic inhabitants, such as the existence of Druidism among them. The place-names in the regions occupied by the Picts ought to throw a decisive light on the question, but these have been so influenced by subsequent occupiers that it is not easy to get at original forms, and even if this could be done, it would be not less difficult to compare such forms with those which may still exist in other parts of Europe. The Irish version of Nennius in the Book of Ballymote compiled in the fourteenth century (a fragment of Nennius also exists in the MS. "The Book of the Dun [Cow]" written before A.D. I I06) tells us that the sons of Cruithne, the Eponymus of the Picts, "divided the land (Alban or Scotland) into seven divisions as Columcille says :-

Seven Children of Cruithne

Divided Alban into seven divisions :

Cait, Ce, Cirig, a warlike clan;

Fib, Fidach, Fotla, Fortrenn,

and the name of each man is given to their territories." Cait

1 Fortren in the Felire of Engus, Jan. 31, = mighty. Tren in Irish = strong. 
appears in the Pictish Chronicle as Got, and Cirig as Circinn. Skene (Celtic Scotland, vol. i, p. I 86) identifies five of these divisions as follows: Fib is Fife, Fotla is Athfoitle (now Atholl), Fortrenn is the district between the Forth and Tay, Circinn is Maghgirginn, which he thinks is corrupted into Mearns (but in 1106 the form is Mairne, see below) and Cait is Caithness. Although this is one of the usual attempts to explain territorial names by designations of assumed rulers, it is valuable as giving the early forms of these land divisions, and may help in deciding the linguistic question. In a Charter dated A.D. I1 28 (Early Scottish Charters, Lowrie, p. 65) "Fif and Fothrif" represent Fife and Kinross, and it is possible we have in the Fothr of Fothrif (? locative plural) a dialectic equivalent of the Irish Fid, gen. Feda, =Wood. Fid (=Tree) is in Gaulish Vidu, as in Viducasses (now Vieux, Calvados), in early Welsh by Guid later Gwydd, in English by Wood, in Norse by Vith-r, with, which occurs in place-names in the North of England. Fidh is compounded in Irish with other words, as Feenish (Fidhinis, that is "wood-island", R. I. Ac. Proceed., 1909, p. 281, "Wood of Fiodh-hail" (ibid. 275); Fiod-fail, Annals of Four Masters). Perhaps Fother, or Fethar is for *Fiodh-thir = "Wood-land". The forms Fetter (as in Fetteresso, \&c.), Feither, Fother, suggest that the first syllable may represent Fiodh. "Foth" and "Fothur", "Feather" or "Futher" occur often in Scotch and North English place-names, and always seemingly as indicating Wood, for which significance we have the evidence of the Irish Fothribh (? loc. pl.) and Foithre, given as meaning "Woods". Fothur has been frequently contracted into For as in Forteviot, formerly Fothuir-tabhaicht, and Fordun, anciently, Skene says, Fothurdun, but in "The Book of the Dun Cow" (compiled I ro6), p. 4, col. I, R. I. Ac. facsimile, it is " $\tilde{F}$ dun (i.e. Fordun) in Mairne". This is the place of the death of Palladius as given in the Irish version of Nennius. In the Latin Nennius it is simply "in terra Pictorum". The modern Finhaven was in early times Fothenaven, representing 
presumably Fothan-amhain or "Riverwood". Furness, anciently Futher-ness, seems to preserve Fothur or Fudir, and "Foodra Castle" on the point there contains presumably the same word. names of these territories are thus probably in the last analysis Goidelic, and describe physical features.

\section{THE ROMAN OCCUPATION}

IV

From the death of the father of Constantine the Great in A.D. 306 we hear nothing further of Roman Rule in Britain for over fifty years. Ammianus Marcellinus, who wrote about A.D. 390 , is our next historical authority. He says (xx. r) that " when the Emperor Constantius was Consul for the tenth time and Julian for the third (that is in A.D. 360), the fierce tribes of Scots and Picts were invading and devastating the country near the frontier, and that terror had laid hold of the province, already worn out by a number of previous calamities". When this news was brought to Constantius, who was then at Paris, he shrank, in face of the threatenings of the Germans, from leaving Gaul without a ruler, and therefore sent a deputy in the person of a certain Lupicinius to arrest the trouble, either by arrangement or by force. Lupicinius having assembled light-armed auxiliaries-Germanic Mercenaries-proceeded to Bononia (Boulogne), whence, with favouring gales, he promptly reached Rutupia, that is Rich-borough, near Sandwich in Kent. He thence set out for Lundinium (London), in order that, having taken needful counsel, he might hasten to the seat of war. We know nothing of the result of this expedition, but it cannot have been altogether satisfactory, for five years later (A.D. $3^{6} 5$ ) the Romano-Britons "were being plagued, as Ammianus tells us (xxvi. 4) by continuous calamities at the hands of Picts and Saxons, Scots and Attacotts ". Three years later the grave news 
was brought to the Emperor, who was on his way from Ambiani (Amiens) to Treviri (Treves), (Ammian, xxvii. 8. r) that "Britain was brought by a conspiracy of the barbarians to the greatest straits, that Nectaridus the Count of the Saxon Shore had been slain, and that Fullofaudes, ${ }^{1}$ the Roman General, had been overthrown by the stratagems of the enemy ". These foes were the Picts-now divided into Dicalydones and Verturionesthe warlike tribe of the Atecotts, and the Scots.

Theodosius, the father of the Emperor Theodosius the Great (who seems from a reference in Zosimus to have been present in the campaign) was sent to restore order. He set out from the accustomed place, Bononia, and quickly reached Rutupia. Joined here by the levies, he set out for London, "an ancient city, which was later called Augusta." The enemy had evidently reached this neighbourhood, for the Roman General, "distributing his body of men into several divisions, attacked the marauding bands of the enemy, embarrassed as they were by their booty, and speedily put them to flight. The recovered prey of bound captives and cattle, taken from the miserable tributaries, he restored to them, reserving only a small part of the booty. for his wearied soldiers. Thereupon he entered joyfully as if in triumph into the city, previously overwhelmed with calamities but now quickly renewed with hope by his deliverance." Theodosius did not immediately pursue his advantage, but confined himself for the present to putting forth edicts, offering pardon to returning deserters, and calling back others who were on furlough.

Some time after, when he had skilfully collected his troops, Theodosius set out (A.D. 396) from London, as Ammianus goes

1 The appellation of this General is Frankish and henceforward we find many high officials of the Empire bearing foreign names-showing the increase of "barbaric" influence, and heralding the breaking up of the Empire. The fact that London was besieged by various Celtic tribes at this time, when Theodosius met them in the neighbourhood, may account for the finding of a pillar stone with an Ogam (Goidelic) inscription at Silchester, hitherto an inexplicable find. 
on to tell us, and brought powerful help to the agitated and plagued Britons. Having scattered and put to flight the many tribes which an unpunished arrogance had incited to attack the Roman administration, he repaired the cities, and the damaged strongholds, adapted only for a long time of peace. Having done this and "provided for the security of the frontier by vigilant garrisons and advanced guards, he restored to its former condition that province which had submitted to the sway of the enemy-thenceforth to be known as Valencia by the decision of the Emperor Valens, as if he had been decreed a triumph".

Our next authority for a record of affairs in Britain is Zosimus (a Greek writer of the beginning of the fifth century).

During the time of the Emperor Gratian, ${ }^{1}$ to whom was assigned the rule of Britain in A.D. 379, the soldiers in that country-surpassing, as Zosimus says, all others in boldness and turbulence-elected Maximus Emperor, a former companionin-arms of Theodosius. The Picts and Scots again (in A.D. $3^{84}$ ) invading the province, Maximus (as Prosper of Aquitania, a papal notary who died in A.D. $46 \mathrm{I}$, tells us) promptly vanquished them, and thereupon, ambitious of extending his sway, proceeded to Gaul. Securing the obedience of the troops there, he encountered and defeated Gratian at Paris, who, flying to Lyons, was there put to death. Maximus in his turn was slain at Aquileia, near Venice, by the Emperor Theodosius in A.D. $3^{88}$.

The incursions of their enemies continuing, the Britons applied for help to Stilicho, the Minister of Honorius, and a legion was sent to their aid (396). The poet Claudian (about A.D. 400) tells us that thereupon the Romans vanquished the Picts and "following the Scot with flying sword moved with audacious oars the hyperborean sea". This legion, according to Paulus Diaconus, was withdrawn in 402 , but further appeals

${ }^{1} \mathrm{He}$ was son of Valentinian, and the friend and correspondent of St. Ambrose. 
were made, and in 406 we find, from the Notitza Dignitatum, ${ }^{1}$ that there was a strong force again in Britain, consisting of the second and sixth legions, and, according to Skene, the twentieth, although it is not mentioned therein by name. The paralysis which was beginning to steal over the heart of the Empire was manifested first in its outlying parts, and the soldiers in Britain in the period between 407 and 409 had, as Zosimus tells us, chosen as Emperors, first Marcus, then Gratian, whom they killed after four months, and finally a soldier called Constantine. The latter, leaving as generals in Britain Justinian and Neviogastes (a Teutonic name), passed into Gaul, where he succeeded in maintaining his ground at Valens on the Rhone against Sarus, sent by Stilicho to attack him. Constantine finally succeeded in persuading Honorius to make him an associate in the Empire. The Alani and Suevi had begun in 406 to make their attacks on the Empire, and Rome was captured by Alaric in 4 IO. Honorius was thus forced to withdraw from Britain the Roman legions, which left (shortly before A.D. 4 10), ${ }^{2}$ never to return: see note, p. II 7 .

We encountered in the period previously dealt with the tribal names Picts (divided into Dicalydones and Verturiones), Saxons, Scots, and Atecotts. ${ }^{3}$ Who were these tribes and where were their settlements in Britain? The Picts have

1 This is the title or a work drawn up early in the fifth century showing the officials and the seats of administration of the various provinces of the Empire, together with the disposition of the troops.

2 The Britons, according to Gildas (Mommsen's edit. p. 36), appealed again to the Romans for help when Agitius (i. e. Aetius) was Consul for the third time, i. e. about 446.

${ }^{3}$ St. Jerome, $a d v$. Iov. 2. 7 , when a young man (c. A. D. 360), saw in Gaul a British tribe, the Atticots, feeding on human flesh! These were probably Atecotts, enrolled in the Roman army and stationed in Gaul (see Not. Dig. Or. 9. 8. $29 ;$ Occ. 5. 48). In the time of Honorius (c. A. D. 400) there were three or four divisions of them in the army in Ganl (see Not.Dig.). We know not their place of origin, and their name, considered by Sir John Rhŷs as involving "Coth"=old, and meaning ancient inhabitants, is obscure. 
already been touched upon, but owing to the important position occupied by them in the early history of these islands it is necessary to revert to them here. There are two distinct views as to their race and origin. First, Sir John Rhŷs maintains, as I have said, that they were the indigenous inhabitants of these islands, and non-Aryan, that is, they did not belong to the great Indo-European family which includes, as far as language determines them, the Latins, Greeks, Teutons, Slavs, Celts, \&c. ${ }^{1}$ Sir John Rhŷs bases his contention mainly on certain personal names which appear in ancient records of the Celtic peoples of these islands, and which, both as regards their structure and meaning, seem to him non-Celtic. An instance will suffice to show his position. A common personal designation in early Celtic documents, including Ogam inscriptions of the fifth or sixth century, is made up of $\mathrm{Cu}=$ hound and a determinative, such as $\mathrm{Cu}-\mathrm{Ulaid}=$ the hound of Ulster, $\mathrm{Cu}$-neit (Conu-Nett in Ogam) = the hound of Neit, probably an ancient deity; Mael-con, ${ }^{2}$ a Pictish monarch in the time of

1 The question or race and language of the pre-historic, non-Aryan people of Western Europe is a very difficult one. Kluge (in Paul's Germanische Philologie, i, p. 323) offers some conjectures. The preTeutonic people of North Germany, as M. Rieger, whom he quotes, suggests, may have been called Hūnōz; the Hünengräber there still preserving the name. Certain words common to German and Celtic, such as apple, Irish uball, A.-Sax. appel, may, he thinks, have belonged originally to a non-Aryan language. Silver, hemp, cat, rat, finch, pink, all seem non-IndoEuropean, but their provenance has not been traced; to which might be

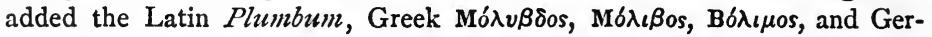
manic Blei (=lead), which Torp (Wortschatz, p. 287) is inclined to trace to a common (?) Iberic root.

2 The use in Goidelic of Mael, Giolla, \&rc., and of the Welsh Grwas (meaning servant) before personal designations, as in Mael-Coluim (Malcolm = servant of Columba), Giolla-Christ (servant of Christ, now Gilchrist), Giolla-Josa (= servant of Jesus, which with Mac prefixed becomes Mac Leish), Gwas-Patrick (= Gospatrick, servant of Patrick, the name of an ancient family in Cumberland, and occurring also in Wales, e.g. Flynnon Gwas Patrig ( = the well of the servant of Patrick), in Denbighshire (Arch. Camb. Suppl., April, I909, p. II6); marks, according to Sir John Rhŷs 
St. Columba (sixth century) = the tonsured servant of the hound : Sir John Rhŷs sees in these and similar compounds evidence of a totemistic and non-Aryan nomenclature. He finds also, in the Pictish parts of Scotland, districts, such as Fife (Fib), which to him bear non-Aryan designations. The Picts (Cruthni) are referred to in Irish records as occupying not only the northern half and some other parts of Scotland, but also Northeast Ulster (the county Down and the southern half of county Antrim), Meath and districts about the Shannon river.

The main difficulty in regard to this theory is that in all these districts we have seemingly no early place-names but those which bear an unmistakably Celtic character. From an examination of the earliest place-names found in these parts I would pronounce them to be Celtic. Goidelic (that is, Gaelic) placenames, too, are largely scattered over all Scotland. Sir John Rhŷs would explain the diffusion of such Goidelic names by the gradual extension of the conquests of the Goidelic Colony, founded in Argyll in the fifth century. In a letter to the writer (dated Sept. 10, 1904) he says: "It is by no means certain that the Calgacos or Galgacos of Tacitus was Celtic, but it was not too early for Celtic names to have reached the North. I have also supposed that there were Goidels in the Tay valley from before the time when the history of the North begins : their language and nomenclature may have begun to spread early." It is clear from Ammianus also that Scots were in North Britain from at latest A.D. 360 onwards, and the usual view as to the origin of the Scots in Alba (the name by which the Goidels designated it, still surviving in the title of the Duke of Albany) has to be reconsidered.

Bede $(H . E$. $)$ preserves the early Irish traditions about the

non-Aryan usage; but how would he explain the Teutonic Gottes-scalc, Mara-scalc (now Marshall), and Senescalc (now Seneschal), in which scalc = servant ? Cf. also Cnop or Cnap, in Here-cnap, made up of Cnap, originally "boy", "servant" (Eng. knave), and here =host, army : $c f$. Cnobhere also, in the Cnob-heresburg of Bede (H.E. iii. I9). 
Goidelic settlement in Alban of circa A. D. 500. Reuda (Bede's name for Cairbre Righfada or Riada) came, according to Bede, from Ireland, and made a settlement among the Picts. His followers were called Dalreudini, from $D a l=a$ part and Reuda, as Bede rightly says. Dalriada, the home of the Scots in Ireland, was the northern half of the county Antrim (the name being still preserved there in a district called "the Route"), and the colonists transferred the name to their Scotch colony, which was also designated-by Goidels evidently and not by the inhabitants - as Airer-Gaedhel (Argyll), that is, the border of the Goidels or Gaels, for thus it is translated in early documents. From this district the conquest of all Scotland was, according to the usual view, gradually effected, being consummated by the Scottish King Kenneth MacAlpin in A. D. 844; some time after which Scot-ia, previously applied to Ireland only, came gradually to be the recognized designation of Scot-land. The non-Scotic parts of Scotland were at first distributed between the Picts and Britons-the Picts occupying the country north of the Clyde and Forth and also Galloway, the Britons the southern part, with their capitals at Ailcluit (that is, the Clyde Rocknow Dumbarton, earlier Dun-Brettan, or fortress of the Britons) and in Fortrenn, the district between the Tay and the Forth, which preserves, according to Sir John Rhŷs, the name of the earlier Pictish possessors-the Verturiones mentioned by Ammianus. Sir John sees also in the Verteris in the Not. Dig. (a name reflected, according to Dr. Stokes, in Arthuret, Westmoreland) a word of the same origin as Verturio-nes-the signification being preserved in the Welsh Gwerthyr = fortification.

From an examination of the place-names of Scotland as found in the "Retours", \&c., of the fifteenth, sixteenth, and seventeenth centuries, it is clear that Brythonic influences were exercised not only upon the part of the country ascribed to the Britons but also within what were considered Pictish districts; Scottish place-names, however, except those of English and Norse origin, are now overwhelmingly Goidelic throughout the country. 
There are a few seeming exceptions, and these may prove the rule, and show that the Picts, although they had lost their own language at a very early date, as tradition asserts, imposed some Pictish place-names. The exceptions are words beginning with a "P", a crucial letter, since normally no Celtic language, nor Teutonic either, has preserved an original initial " $\mathrm{P}$ ". In the Teutonic it becomes " $F$ " or " $V$ " ; in the Celtic it disappears. Now there are hundreds of place-names in Scotland of which the first syllable is Pet or Pit, an element represented in Pictish districts as far back as the twelfth century (The Book of Deer, in which Goidelic place-names also abound). Some think it is a non-Aryan Pictish word, others that it is an abnormal instance of the preservation of an initial " $\mathrm{P}$ " in Celtic, and others, as in the Oxford English Dictionary (sub "Peat"), that it is a British word and cognate with the Welsh $P$ eth, meaning a portion, of which the Goidelic equivalent $C$ uit is given with the same meaning in the Wiirzburg Glosses; the original qv sound being represented by $P$ in British and $C^{\prime \prime}$ in Goidelic. If this be the origin of "Pett" in Scottish place-names (which is supported by Dr. W. Stokes), it shows the former widespread influence of the Britons in that country.

Bede tells us that the Pictish word for the eastern end of the Northern Wall was Peanfahel, ${ }^{2}$ a manifestly British form. And Sir John Rhŷs can see no sign of a Goidelic origin in the names, given by Ptolemy and Tacitus, of the tribes and places in North Britain before the coming of the Scots. "As for any direct proof of the existence of Goidelic there in the time of Agricola or Ptolemy, there is", he says, "absolutely none that I know of" (Rhind Lectures, 1889, p. 82). The natural

1 Of two or three English words, with a " $\mathrm{P}$ " initial, referred to (p. 17), such as Path, Play, Plight, Torp (Wortschatz, Göttingen, 1909, p. 219) would connect Path with an Indo-European root, Beit. For the other two, he says, no corresponding Indo.European root has been found.

${ }^{2} \mathrm{Mr}$. Nicholson wonld make this word to be a Goidelic pronunciation of a Latin (?) "Pennaevalli". 
inference is that Alban was originally inhabited by a homogeneous race, similar in language to the people of South Britain. A further examination of Scottish " $P$ " place-names given in note below renders this more probable. ${ }^{1}$

1 Pen, a distinctly British word, corresponding to the Gaelic Ceann or $K e n$, anciently $C e n d=$ head, seems to be represented widely in Scotland, and even in regions occupied by the Scots. The Chartulary of Newbottle (A.D. 1145 ) gives us the early form of Pencaitland, namely, Pen-cet-let, in which, besides the British Pen, we have the early form Cet $=$ the Welsh Coed =wood, which appears also (Holyrood Charters) in Dal-chet, now Dalkeith, and in Bat-chet, now Bathgate, and in Rothket (Lindores Chart. 103), and in Penket, Lancs. (Cal. Chart. Rolls, ii, 326); cf. Ros-uc-chet in the Retours. Cnlquith in Cumberland is in its early form Cul-chet; cf. also Hesketh, formerly Hesket. The aspiration of the "c" by which cet becomes chet shows that these forms have been transmitted to us by Goidels. The Briton would have turned the " $c$ " into a " $g$ ". The "Keiths" in Scotland are thus seemingly representatives of Cet $=$ wood, given to us in the Le(c)to-cetum of Ravennas, and (L)Etocetum of the Ant. Itin. The word does not seem to occur in Goidelic, but it appears in Old Cornish as Cuit, in later Cornish as Coys, Cos, in Breton as Koat,

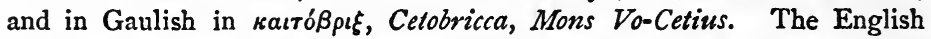
equivalent is Heath. See Pedersen, V. Gramm. § 38. Pen appears even in Argyll of the Scots; the Retours give therein Pencalmer, Pend-lachna, Pen-in-inver, \&c.

Poll, English Pool and Welsh Proll, is found all over Scotland, in its variants Pol-, Pil-, Pal-, Pow-, Po-, Pa-, prefixed as usual to the name of a brook. As it appears in the Pictish Dalaradia of Ireland (Poleglasswhere occurs also Pit Meave, i. e. portion of ? Queen Maobh $=$ ? Queen Mab), and is also common in Teutonic countries, its wide prevalence suggests a borrowing from a non-Celtic and non-Teutonic speech.

Perth $=$ bush-land, a distinctly British word, occurs in several Scotch counties, some of them eminently Pictish. Peebles, Peeble, Pebble, Poppel, Poffil, \&cc., are all, like Spanish Pueblo and Welsh Plruyf, borrowed from the Latin Populus, or Plebs, in the sense of Parish. Compounds containing Pron, Prene, Pryn, Parn, found even in the north, seem to be representatives of the British word for tree $=$ the Welsh Prenn, the Gaelic Crann. Thus Barnbougle was earlier Parnbougal and Prenbougal $=$ Cowherd's-tree. The Monastic Annals of Teviotdale gives also an instance showing at the same time how names get distorted. The place given as Prenwensete (p. 269) = white-tree-seat, has now become Primside.

Dunpeleder is by tradition the place in Scotland where St. Monenna founded one of he five churches. Dr. Skene made it Pender-law in 
There is no more trustworthy source of information concerning the early forms of a language than contemporary inscriptions. Of these we possess a considerable number in Scotland, including Orkney and Shetland. Fifteen of these are cut in Ogam characters on the edges of monumental stones, and are in some cases accompanied by inscriptions in the Roman alphabet. Nothing of scientific value has yet been deduced from them. The occurrence of words in them assumed to contain " $\mathrm{P}$ " has given Mr. Nicholson, Bodley's Librarian, ample room for ingenious conjectures, for which the inscriptions in bronze found at Coligny, in Ain (France), 1897 , others at Todi, and others in two lead tablets discovered at Rom (district of Poitiers), in $\mathbf{1} 88_{5}$, have contributed further material. These conjectures, however, until we receive further light, are guesses, and nothing more.

\section{THE ROMAN OCCUPATION.}

\section{$\mathrm{V}$ \\ The British Isles as known to the Classical GeOgraphers}

Sir John Rhŷs (Celtic Britain ${ }^{3}$, p. 204) would ascribe the earliest mention of the British Isles by name to the episode in

Haddington, but the Chartulary of Nerwbottle preserves the site. It was known in A. D. I 203 as Dnnpeleder, but passed into the modern name Drumpellier. It is in Clydesdale, and is known for its collieries. Pelydur is the plural of the Welsh Paladr=a spear, and the connexion seems obvious.

If we take other names than those beginning with " $\mathrm{P}$ ", the case is strengthened-for instance, those involving the British $\operatorname{treb}=\mathrm{dwelling}$, such as Trev-er-nant (i.e. "dwelling on the valley", now Trannant), Traver-er-lin (dwelling on the lake, now Crailing), Trav-er-flat (now Trail-flat), Trevecoer (now Traqubair), Nu-dreff (now Nidrie). Another characteristic British word, blaen (= point, source), occurs in Blantyre, Blanerne, \&c.

The evidence of the Pictish inscriptions is not yet convincing as to the existence of a non-Aryan language in North Britain, and the attempt made by Mr. Nicholson, Bodley's Librarian, to prove them all Gaelic (Keltic Studies, 1904) is unsatisfactory. 
the labours of Hercules preserved by Pomponius Mela (Bk. ii. 5). In a fragment of the lost tragedy of "Prometheus Bound", Prometheus shows to Hercules the way to the garden of the Hesperides, and tells him that when he arrives among the Ligures he will find himself without offensive weapons, but that Jupiter will take pity on him and send him from heaven a shower of stones with which he will defeat the Ligurian army (cf. Joshua x. $7,8,9)$. The scene of this battle was anciently known as the Campus Lapideus sive Herculeus, now called La Crau du Rhone, where great boulders are scattered broadcast over the plain. Mela, after alluding to the classical name of the place, says it is where Hercules fought against Albiona and Bergiona, the sons of Neptune. ${ }^{1}$ Sir John Rhŷs sees in these names Albion and Iberion, ${ }^{2}$ that is Britain and Ireland. This is a most brilliant conjecture, and has been, in a sense, borne out by the subsequent history of these islands, which may be considered in a special manner as "the sons of Neptune".

The word Britannia employed by classical authors, both Greek

1 As showing the early association of Celtic and Greek ideas concerning the sea, it is not without significance that the early Irish word for seaTriath, genitive Trethan (Cormac's Glossary) - has been equated with the

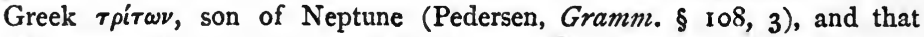
Manannan Mac Lir is the Celtic Poseidōn. The Celtic Alba, genitive Alban, although restricted eventually to Scotland, had been applied to the whole country as far as the English Channel, and included even Glastonbury (Cormac's Glossary-compiled in the ninth century, edited by W. Stokes, Calcutta, 1868, p. I II ; cf. also The Book of Leinster, fo. $29^{2}$, line 43).

2 Sir John Rhŷs says (Rhind Lectures, December, 1889) that Albion and Iverion are non-Aryan names. It may not be necessary to assume a mistaken reading in regard to Bergiona. A British island which Pliny (Nat. Hist. iv, c. 16) calls Bergos (possibly the Burehu in Leland's Itinerary, now Burhou, north-west of Alderney), may be the Bergiona in question. Pliny, in the same chapter, gives Albion as another name for Britannia. Pliny mentions another large British island, from whence the voyage to Thule was made, under the name Berricen (Holder, Sprachschatz) with various reading Nerigon, perhaps for Berigon. Cf. the Vergirios Ocean of Ptolemy which seems to preserve the modern Irish Fearge $=$ ocean $:$ ferg $=$ fierce. 
and Latin, is exhaustively dealt with by Sir John Rhŷs in his Celtic Britain ${ }^{3}, 207$ et seq. He traces the word to the term with which one branch of the Celtic family designated themselves, that is, Brŭttones (in modern Welsh, Brython). The traders who visited South-West Britain for tin (from a Celtic term, according to Torp) brought this word back to the nations lying eastward, where it took the form Britanni, from which they made eventually their Britannia. The latter has no closer connexion with $Y$ nis Prydain than an accidental resemblance. Pryten is dealt with on p. 74 .

Diodorus the Sicilian, writing in Greek about 45 B.c., furnishes one or two early British place-names. Besides the promontory Kantion (Kent), he mentions two others, Belerion and Horca or Orca. He notices that the people of the country war with chariots, and that they cut off the ears of corn and store them in places underground. The people about Belerion, he tells us, are excessively fond of strangers and, owing to intercourse with foreign traders, civilized in their habits. (Cf. Strabo, below.) He describes also how they procure the metal tin, and how, carrying it in wagons at low water to the island called Ictis (? the Vectis-i.e. Wight-of the Roman writers), trade with it to merchants, who take it to Gaul, and through that country to the mouth of the Rhone.

He uses the word Kattiteros, a dialectic form of the classical Kassiteros, for tin, and hence from, at latest, the time ( $45^{\circ}$ в.c.) of Herodotus (Book III. I I $_{5}$ ) onwards, the British Islands were also called Kassiterides, or "tin-islands",- a name given also by Diodorus to islands off Portugal. Belerion, given by Ptolemy (Geog. ii. 3I) C. A.D. I50 as Bolerion, is identified with Landsend, and Horca (the Okrion-point of Ptolemy) with the Lizard.

Diodorus had also heard of savage British tribes inhabiting a region called Iris (Irin, accusative), of which nothing is known. Connexion with Claudian's Ierne (the Iverna of Mela) = Ireland, is possible.

Strabo mentions the latter country as occupied by savages, 
and as barely inhabitable on account of the cold. Strabo calls Thule the northernmost of the British Isles, and in describing the inhabitants of the Cassiterides pictures them as clad in black tunics reaching to their feet, and girt about the breast, walking with staves, and bearded like goats-and tells us that they barter to traders (of whom the first comers were Phenicians) tin, lead, and skins, for earthenware, salt, and brazen vessels.

Writing about the river-estuaries on the continent, from which the voyage to Britain was made, Strabo says that the Rhine port was not at the river-mouth, "but among the Morini (who border on the Menapioi), to whom belongs Ition (Iction, see p. 74), which Julius Caesar used as a naval station when he passed over to Britain."

Mela mentions an island called Sena opposite the Ossismi, where nine virgins, devoted to a Gallic oracular deity, perpetuated the cult; they could unchain the sea and winds at pleasure.

Pliny mentions, besides the places already noticed, the British localities Mona (modern Anglesea), Camalduno, Sylva Caledoniae, Silures, Hybernia, Orcades (Orkneys), Acmodae (Aebudes Islands = Hebrides), Monapia (Isle of Man), Ricina (? Rachry, or Rathlin Island), Vectis (Wight), Limnus (Lympney, Liminge), Andros (also Adros), and nearer the continent the islands Siambis et Axantos (Strabo's Uxiama=Ushant, cf. Ossismi), and in the German Ocean the scattered Glessariae (involving the Teutonic word Gleza = Amber, the English glass) called by the Greeks Electrides, that is, bearing electron (=amber).

Pliny also mentions the island Mictis (? Vectis, above) as that in which tin is produced. Cherries, he says, were not known in Italy before the Mithridatic victory of L. Lucullus. In the year of the city 680 ( 73 в.с.) they had been brought first from Asia Minor, and in 120 years they had reached Britain where they were favoured by the cold of the north. This accounts for the early occurrence of place-names involving Cherry (cf. Cheriton) 
He tells also of different kinds of marl found in Britain, and of the different ways of using them.

Woad (called in Gaulish Glastum) is also mentioned by him, and its employment in staining the bodies of married women and maidens when taking part in certain religious rites.

Solinus, who wrote about A.D. 80 , repeats what seems to have struck all the classical authors who described Britain, that the natives used boats made of a framework of twigs covered with hides (that is, Coracles).

To early British place-names he contributes "Silura" island - separated, he says, from the Dumnonii by a turbulent straitwhose inhabitants knew not the use of money; and Ad-Tanatos (Thanet, whose soil kills snakes even when exported).

In the foregoing notices of Britain we have only incidental mention of the names of localities there. (I) The Geographical descriptions of Ptolemy (A.D. C. I 50), (2) the Itinerary of Antonine, compiled in its present form towards the end of the fourth century, (3) the Peutinger Tafel, drawn up about the end of the fourth century, (4) the Notitia Dignitatum, made as recently, it is thought, as the beginning of the fifth century, and (5) the anonymous Ravenna Geographer, who flourished in the seventh century - these, with the exception of the Peutinger Tafel, furnish us with more or less complete designations of the rivers, promontories, towns, regions, roads, \&c., of Britain during the Roman occupation.

\section{Ptolemy's Geographical Description of Albion}

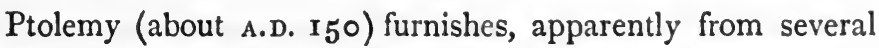
distinct sources, a geographical description of Great Britain. One source seems to have been an account by navigators, engaged probably in trading, of the chief landmarks and river estuaries on the coast-line. Ptolemy starts with this coast-line, and locates the various places mentioned, by giving their longitude east of the meridian passing through the Canary Islands 
(Makaroi nessi) and their latitude as conjectured north from the equator. The island of Thule (celebrated, as Mela says, by the Greek and our own poets) he takes as the northern limit of the known world in this quarter, and places it, following the Periplus of the geographer Marcian, in $63^{\circ} \mathrm{N}$. Beginning with Aibouda (supposed to be Uist), the most eastern of the Aiboudai (Hebudes, misread by $\mathrm{H}$. Boethius Hebrides), which he places in $15^{\circ}$ east of the Canaries, and in $62^{\circ}$ north latitude, he assigns positions for other islands of the group :-Rikina, Malaios (? Mull), and Epidion, ${ }^{1}$ and, east of Ireland, monaoida (= Man), Mona (= Anglesea), and two desert islands. Ptolemy then proceeds with the description of the coast-line of the "Prettanic" island of Alvion (Albion), beginning with the peninsula of the Novantoi (Galloway) stretching out into the Duêcalëdonian Sea. This he places in longitude $2 \mathrm{I}^{\circ} \mathrm{E}$. of Canaries and in latitude $6 \mathrm{I}^{\circ} 4^{\prime}$. The Rerigonian bay (?Lough Ryan) follows (in long. $20^{\circ} 30^{\prime}$ : lat. $60^{\circ} 50^{\prime}$ ) and then the Vindogara bay, by longitude and latitude further east and a little to the south, but as the sequence of places seems uniformly towards the east (i. e. to the north, for Ptolemy's Scotland lies nearly east and west) the latter bay is probably that on which is the port of Ayr. The estuary of Klota (that is, the Clyde) follows, with the Lemannonion bay still further east (i.e. north), identified by some with Loch Fine and by others with Loch Linhe. The Epidion Promontory occurs a degree further to the westward and has been identified with the Mull of Cantire. The mouth of the river Longos is placed east (i. e. north) of the Lemannonion bay, and has been identified with Loch Linhe, into which Loch Lochie by a river of the same name discharges. The Itios river-mouth, which follows,

1 Pomponius Mela (Lib. iii) writing shortly before the beginning of our era, mentions the Hebudes (Hemodes) as well as the Orchades, and states that Britain so long a closed country had been lately opened up by the greatest of chiefs (Julius Caesar). His description of the inhabitants, and especially of their mode of warring in chariots (Covinos, acc. plurr.) armed with scythes, shows his indebtedness to Caesar's De Bello Gallico. 
lying nearly three degrees of longitude away to the east (i.e. north), cannot well be Loch Etive as assumed by some, but may be the Sound of Sleat conjectured by others. Volas bay is placed two degrees east of the Itios river, and has been identified with Loch Broom, into which a river at Ulla-pool discharges. The Nabar-os river follows one degree further east (i.e. north) and has been identified with Loch Naver and a stream of that name.

Ptolemy places next at the extreme northern point, which is given as longitude $30^{\circ} \mathrm{E}$. of the Canaries, the promontory of Tarved-um or Orkas, which is thought to be Dunnet Head. There is a doubt whether the -dum in Tarvedum belonged to the original word or whether it contained the Latin termination and was borrowed by Ptolemy from a Roman source. The reading Tarvaidunos in the Marcian Codex (p. 56r. 22) as given by Müller (Ptolem. Geographia, i, p. 83) settles the question. It is clear we have here an instance of the combination of Celtic -dun (stronghold) with some such form as the Goidelic Tarbh (= bull, used possibly as a personal name: Gaulish Tarvos, Welsh Tarw, Old Breton Taruu). de Jubainville makes the word *Tarvosedo- $n=$ "Place of bulls". Tarv occurs in several Celtic piace-names, e.g. Tarv-anna, now Thérou-anne. Tarv was possibly a Bull-deity. Tar-vedum might otherwise be translated as "beyond the Vedu-m", but this form is excluded here. Tar = trans, occurs in Tar-bert, Tar-Crich, \&c.

Ptolemy then proceeds with the description of the western side of the island, facing the Hibernic and Vergivios Ocean, beginning again with the peninsula of the Novantoi. He places in a sequence, in which each place is west (i. e. south) of that which precedes it, the following localities:-Abravann-os rivermouth; estuary of the Iena; river-mouths of the Deva and Novi-os; estuaries of the Ituna and of Morikambe; the port of the Setantioi; the estuaries of the Belisama and Seteia; the promontory of the Kaianganoi; the mouths of the rivers Toisobi-os, Stukkia, Touerobi-os; the Oktapitaron promontory; the mouths of the 
rivers Tobi-os and Ratostabi-os; the estuaries of the Sabrina and Uxella; the promontories of Herculis, Antivestaion or Bolerion, and Damnonion or Okrion.

The Vergivios Ocean, for this seems the correct reading, recalls the Old Irish Foirrce (= sea) into which Ferg (violence) seems to enter (Stokes, Wortschatz der keltischen Spracheinheit, p. 273). As to the tribe of the Novantoi, Sir John Rhŷs thinks they may have got their name from the Novios river above referred to. Novios is supposed to have been the name of the river Nith in Ptolemy's time, but the earliest form we have of the latter stream is that given in Bede who, in his sketch of the life of Wilfrid, states that he was restored to his bishopric at a Synod, held under Osred King of the Northumbrians (A.D. 709), at the river Nidd (juxta fuvium Nidd). There can be no linguistic connexion between Nidd and Novios. Novant-oi from the form of the word seems to be allied to the Brythonic branch of Celtic. The termination is the same as in Brigant-es here, with a Latin instead of a Greek plural-ending. Cf. also Ptolemy's Decantai and the early Welsh Arx-Decant-orum, now Deganwy which, in The Welsh People, Rhŷs Jones, p. 88, is connected with the Irish Ogam-form Deccetes found in (?) sixth-century inscriptions in Devon, Anglesea, and Ireland.

The combination $-n t$ in Celtic words had lost the $n$ in Goidelic, seemingly before historic times. See Pedersen, Vergl. Gram. d. kelt. Sprachen, pp. I 37 et seq., where a large number of instances are given such as Irish Det (= tooth), Welsh Dant, \&c.: cf. Brigit, female personal name, and that of the goddess Brigantia : also Gabro-senti (Not. Dig.) = "goat-path", and Old Irish Set = way (see Thurneysen, Handbuch d. AltIrischen, Heidelberg, 1909, i, p. 120). Ptolemy says, moreover, later that the Novantoi had two towns (Poleis) called Loukopibia and Rerigonion (of which we may possibly have still an echo in Luce-bay, Luce-river, and in Cairn-Ryan, Lough-Ryan). With regard to Loukopibia the $p$ flanked by 
vowels would in Goidelic have disappeared (Thurneysen, i, p. $3^{6}$ ), and the name must have belonged to another dialect.

Abravannos was supposed by Horsley (Brit. Rom. 364) to contain the Welsh Aber (= river-mouth), and Müller would identify Avannus with the river Annan that flows past Dumfries, but this is pure conjecture.

The Iena is supposed to represent the modern Wigton-bay.

The Deva here might seem to have been misplaced and to represent the Dee passing Chester, but Ptolemy places Deva (Chester) in a different locality, and there were doubtless other rivers of this name. The Novios may be the Novia or Novitia of Ravennas, but its position alone and not its form connects it with the Nith.

The Ituna may be the river Eden, as name and site seem to correspond, and Morikambē corresponds with Morecambe Bay, but there is no evidence, I think, of the early occurrence in English documents of the latter name, and it may have been first given by some antiquary attempting to follow Ptolemy. The name means "sea-bend". There is another Moricambe Bay given in the maps of the Solway Firth, which seems to indicate the claims of a rival antiquary.

The Setantioi (which may be compared with Setanta, the youthful name of the hero Cú-chullain-possibly the name of a deity) appears in the variant Segantioi, suggesting Segontium (now Caer Seiont near Carnarvon), but the position north of the Mersey-Belisama-does not fit in. The latter name appears in continental inscriptions as a by-name of Minerva, and is one of several instances of the association of Celtic deities with river-names. The Seteia estuary has not been identified. Ganganoi is another reading for Kaianganoi, and is a name also given by Ptolemy to a people in Ireland. The reading in the Annals (xi. $3 \mathrm{r}$ ) of Tacitus, Ductus inde Ceangos, has been made in De Ceangos, and the latter word identified with the abbreviation on Roman pigs of lead found in Cheshire, \&c., Deceang, Deceangl, which Sir John Rhŷs would 
identify with Tegeingl, the Welsh name of Englefield, in this locality. ${ }^{1}$

The river Toisobi-os (the vowel-flanked $s$ would probably have vanished early: cf. the Gaulish personal name Esugen-us, and Welsh Owen, Irish Eogan) and would have taken the later Welsh form of Toibi, which would be represented by the river Dovey, initial $t$ becoming naturally $d$. But the Tobi-os is as likely an antecedent, if the latter be not the modern Teifi flowing into the sea at Cardigan.

The rivers Stukkia, Touerobios, and Ratostabios have not been identified, but the Towy, Tawe, and Taff are not far from the places assigned to them. Rato occurs in Ratu-magos, now Rouen, and seems to be also the Ratas of the Ant. Itin., now Leicester (see p. 264). The promontory Oktapitaron (St. David's Head) Sir John Rhŷs regards as non-Celtic (Celt. Brit. ${ }^{3}$, p. 23 r). The Sabrina is of course the Severn, and the Uxella may be the Axium of the Ravenna Geographer = (?) the Axe in Axebridge which corresponds as far as position goes with Ptolemy's Uxella Domnonion, but Uxella means "high". Antivestaion or Bolërion is Land's End, but neither name has left a relict.

Ptolemy then follows the coast-line of the south of Britain facing the "Pretannic Ocean" from the Damnonion (Devonian) promontory Okrion (= ? the Lizard). The mouth of the Kenion (= ? Fowey) river is placed two degrees to the east (i. e. north) of the Okrion promontory and more than half-way from the latter towards the mouth of the Tamar-os (the Tamar). The Iskamouth follows two degrees further east (north), and is doubtless the Exe at Exmouth, from which the next place, the mouth of the Alaun-os, is not far removed (= ? the Axe, upon which lies Seaton, identified with Moridunum, the place preceding the Alauna Silva of Ravennas). The Megas Limen or Great Port (? Poole Harbour) is placed next, and beyond it to the east the mouth of the river Trisanton (=? the Test, which rising near

${ }^{1}$ In the Triads we have (99) Tegeingl yn Rhyfoniog, i.e. (?) in Roman territory. 
Andover [? Antondover], flows into the sea at Southampton). Beyond this at some distance is placed Kainos Limen (i. e. New Port, doubtless Portsmouth). The Kantion (variant Noukantion) promontory follows about a degree to the north-east and is possibly Beachy Head.

Ptolemy then proceeds to describe (beginning at Tarvedum) the coast-line facing the Germanic Ocean. The next place to this is the Virveddr-um promontory (guessed to be Duncansby Head) which seems to preserve the Irish Druim, Welsh Trum (= mountain ridge), but it may be for Virvedr-um; cf. the river Vedra, below. This is followed to the west (i. e. south) by the Verubium promontory (? the "Noss", near Wick), and further west by the mouth of the Ila (cf. the Ellos, a headwater of the river flowing by Helmsdale). The high shore (Ochthé $H_{y}$ psèlē) following one degree further west (i. e. south), perhaps is the high land at Tain): two degrees further west (i.e. south) is the Varar estuary (=? the Moray Firth), then east of this a short distance is placed the mouth of the Loxa river, to which Lossiemouth fairly well responds. The estuary of the Tuessis which follows closely is probably that of the Spey, and the immediately succeeding place, the mouth of the Kaili-os, is possibly the river at Port Gordon. The place lying half a degree to the east, called the promontory of the Taizaloi, has been identified, although the distance does not agree, with Kinnaird's Head near Fraserburgh; and the mouth of the Deva which follows half a degree to the west (i. e. south) is doubtless the Dee which joins the Don at Aberdeen. The Tava estuary which follows at one degree to the west (south) is the Firth of Tay, and at a degree further west the mouth of the Tina ( $?=$ the Tyne at Tyningham), followed at a distance of $I^{\circ} 3^{\prime} \mathrm{W}$. and $0^{\circ} 30^{\prime}$ N. by Boderia estuary, which is undoubtedly the Firth of Forth, called by Tacitus (Agricola, xxiii. 25) Bodotria. Following the coast-line we have next, at nearly a degree distance, the Alaun-os, which has been identified with the Alne at Alnwick, and, at a further degree distance, the mouth of the Vedra 
(= Wear-mouth), followed by the Dounon gulf ( $=$ ? the mouth of the Tees). The "favourably situated Gulf-port of the Gabrant(o)vikoi " follows at a distance of less than a degree, and, although the actual mileage is short of that required, the estuary of the Humber, of which the Gabrant may have been an earlier name, ${ }^{1}$ seems to be meant. The Okelon ${ }^{2}$ promontory would in this case find its proper site in Spurn-Head, and the mouth of the river $A b$-os or $A b o u b$-os would then be fitly placed at the exit of the river which passes through Louth to the sea. Some make it the Ouse. The Metaris estuary, about a degree distant, is probably "the Wash", and the Gariennos mouth would be, according to distance, Lynn, but it has been generally assumed that the river is that which gave its name to Garianno, placed in the Notitia Dignitatum (vol. ii, occid., p. 80) on the "Saxon shore", and occupied like Branodunum (Branchester) by Roman cavalry to guard the coast from the ubiquitous attacks of the Saxon pirates. This place is regarded, and probably rightly, as Burgh Castle, at the junction of the Waveney and the Yare, the latter river preserving a relic of the name.

The promontory (Exoche) following would then be that near Lowestoft, the extreme eastern point of England. The mouth of the Sidumanios river would then fall in naturally with the river flowing past Ipswich, upon which, at a distance of thirty-two miles from Caistor near Norwich, two Roman roads converge on a place which may have been the Sitomagus (= ? "corn-plain"), possibly reflecting Sidumanios, of the Antonine Itinerary (480), although the distance from Colchester is too short. The estuary of the Tamésa (the Thames) and the Kantion promontory finish Ptolemy's coast-line of Albion.

He now proceeds with the various tribes(with their cities) inhabit-

1 Cf. the Gamber, Hereford, formerly Humir : Lib. Lana.

2 The "Mars" stone (A.D. I52) lately found at Caerwent gives Ocelo(s) as one of the Celtic names of the War-god. See also Proceed. Soc. Antiq. 1894 , p. II 8, for another inscription to Deo Marti Ocelo found at Carlisle, and cf. Ocelum-duri and Ocelo of Caesar's De Bell. Gall. i. 10. 3 ; cf. also Tunnocelo of the Not. Dig. 
ing the country, beginning with the Novantai and their towns Loucopibia and Rerigonion already referred to ; below which he places the Selgovai, with the variant Elgovai (=? "Hunters," from Irish Selg (= chase); cf. Old Welsh in-helcha glossed in renando: the name is preserved in the Solway Firth), with their four towns (I) Carbantorigon (="the royal chariot place". The Latin Carpentum, = carriage, and our Carpent-er, come from a Celtic *Carbantion, which appears in several place-names. This is probably the Carbantium of Ravennas); (2) Uxellon (cf. the Uxela of Ravennas, preceding Lucotion and Corda and the same writer's Uxelludamo, placed near the Roman Wall after Esica (Great Chesters) and Banna, and before Avalana; ?= Aballaba of the Notitia; cf. also the Axelodumum of the Notitia, placed by some at Hexham and by others at Ellenborough); (3) Corda (unidentified); and (4) Trimontium, which, from its occurring also in Ravennas next to Eburocaslum, was probably in Yorkshire, and may be the Triberg of Domesday. North-east from these Ptolemy places the Damnonioi (Dumnonii), with the following towns: Kolanika (Colanica in Ravennas), Vandogara (? = Vindogaro previously mentioned), Koria, Alauna, Lindon, and Viktoria. Sir John Rhŷs connects the Damnonii here, and the tribe of the same name which gave its designation to Devon, with an ancient goddess Domnu (genitive Domnann, in Inber Domnann, the old name of Malahide Bay in Ireland, Celt. Brit.', p. 299), their eponymus ancestor. There is not sufficient material to attempt the identification of their towns, which were somewhere south of the Clyde probably. The Otadinoi are placed by Ptolemy further to the south, and had the following towns: Koria, Alauna (these two are given also as towns of the Damnonii), and Bremenium, a sequence which resembles that of Ravennas, viz. Bremenium, Cocuneda, Alauna. Bremenium (Bremenium also in Ant. Itin.) has been satisfactorily identified with Riechester on a branch of the North Tyne; Alauna is a place probably on the Alne (? = Alnwick); Koria, which occurs elsewhere, may be an extension of the prefix 
which occurs in Corstopitum, now Corbridge (see p. 155); and the Cocuneda (cf. Fano Cocidi of Ravennas, Vat. MS.) is probably now represented in the name of the river Coquet. The locality of the Otadinoi (read by Rhŷs, Celt. Brit. ${ }^{3}$, p. I56, Votadini) is thus fixed, and, as the name has been (ibid., pp. II 4 and 156 ) identified with the Gododen of Welsh literature and with the "Manaw of the Gododen", this fact gives us also a southern limit of the Manau or Manann still surviving in "Sla-mannan Moor" and Clack-mannan. The fact is historically important. On the east (north) of the Damnonioi Ptolemy places the Epidioi, and further east (north) the Kerones (variants Kreones, Karnŏnes, Karnŏnakai), and still further east at the extreme limit the Kornavioi, all of which seem to involve the Indo-European root $K$ er (= horn, or corner, represented in Corn-wall), and to indicate that this tribe inhabited a projection of land, perhaps Cantire, which means "the head, or end, of the land". It must be kept in mind that Ptolemy's Scotland is placed nearly east and west, and that his east consequently represents nearly north. The Kalédonioi (called Picts in the Panegyric of Eumenius) he places between the Lemannonion gulf and the Varar estuary (see above), and beyond these the Kalédonian forest (mentioned by Pliny, iv. 102, and Solinus 22); and still further to the east (i.e. north) the Dekantai, beyond whom come the Lougoi, joining on to the Kornavioi; and beyond the Lougoi the Smertai. It is somewhat difficult to reconcile this account with what Ptolemy states elsewhere. The Kalédonioi and Maiatai are said by $\operatorname{Dio}(76, \mathbf{1} 2)$ to be the two greatest tribes of the Britons (Brettanoi), the latter inhabiting the region "in which the island is cut in two" (i. e. between the Forth and Clyde), and "the Kalédonioi beyond them". Ptolemy does not mention the Maiatai, unless Mertai, the reading of several MSS. in place of Smertai, is meant for them. The Ravenna Geographer gives (433) this sequence as on the line between sea and sea (Tyne-Bowness): Banna, Uxelludamo (? Ellenborough or Hexham), Avalana (= Aballaba = ? Papcastle), Maia, Fanum 
Coczdi, and on p. 230 another sequence Maro, Olerio a, Deriventione (the Derwent in Cumberland), and Ravonia. An inscription on a patera found at Rudge (Wilts) (Corp. Inscr. vii. I29I) gives $A$ Mais, Aballava, Uxelodu[no]. Amboglanis (for Amboglanna), Banna. We learn something of the locality of the latter from an inscription found at Burdoswald (Corp. Inscr. vii, No. 830), in which the Venatores Bannies[es] dedicate an altar to Silvanus, and from another inscription found at Carrawburgh : ibid. vii. 62 a.

The Maiatai, with which Maia is associated, were somewhat to the north of the Roman Wall, and the Kaledonioi joined them on the north, and the Dekantai and Lougoi, with the latter of whom the Kornavioi marched, were to the east (i. e. north) of them. The Smertai (or Mertai) are placed beyond the Kaledonioi, and below the latter the Vakomagoi, among whom, Ptolemy adds, are the following towns: Bannatia, Tamia, Pteröton Stratópedon (= "Winged Camp"), Tuesis. The Ravenna Geographer has a sequence (p. 435) which seems to reflect that just given: Ugrulentum (cf. ?Trutulensis Portus: Tac. Agric. iii. 8), Iberran, Pinnatis (cf. Pleröton), Tuessis. The Tuessis estuary, as stated above, is probably that of the Spey, and the other places are to be looked for in that neighbourhood, but there is nothing to guide the investigation.

Ptolemy places the Venicones (variant Vernikomes) to the west (south) of the Vakomagoi, and assigns one town-Orrea-to them, probably the Latin word (Horrea) for grain stores. The place was probably in Forfarshire. Venic-o occurs in an inscrip-

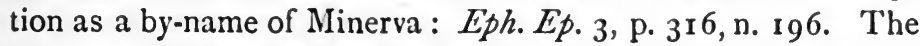
Taizaloi follow to the east (north), and one town-Devana-is given to them, which may possibly be the town on the Deva (= Aberdeen).

Ptolemy goes back then to the Selgovar and Oladinor, placing below them (to the south) the Brigantes, stretching from sea to sea. These towns are given as theirs, Epiakon, Vinovion, Katouraktonion, Kalagon, Isourion, Rigodounon, Olicana, Eborakon, and 
Kanioulocounton. Of.Epiaton nothing further is known. Vinovion (Vinovia in Ravennas and in Ant. Itin.) is Bin-chester; Catterick (Cataractone of the Ant. Itin.) clearly represents Katouraktonion; Kalagon is evidently the Calacum of the Ant. Itin., and, according to the mileage on the road from Ribchester (? Bremetonacum) to the north, would be Casterton on the Lune; Isourion (cf. Isurium and Isubrigantum of the Ant. Itin.) is Aldborough. Rigodounon ( $=R i$, genitive $R i g$ (= king), and $-d u n=$ stronghold) has not been identified, but it lay to the west of Olicana (considered to be Ilkley), whence there ran to Bremetonacum a Roman road, upon which Rigodunon probably lay. Eborakon (Eburacum in Ravennas and Ant. Itin.) is York; Kamoulodounon (Camulodonum in Ravennas and Cambodunum in Ant. Itin.) is the Campodonum (Bede, H.E. ii. 14) where Paulinus erected a basilica, afterwards burnt down with all the township by the Pagans. The Anglo-Saxon version of Bede calls it Donafeld. It was probably the modern Slack.

Near the Brigantes, "on the favourably situated Gulf-port" [of the Gabrant(o)vikoi, see above], come the Parisoi and their town Petouaria (? Decuaria of Ravennas, cf. Numerus Petueriensis, Not. Dig.). The Humber mouth is meant, and relics of these names, if they exist, must be sought there. Patrington, from its early forms, cannot be adduced. Matthew of Paris is said to have been so called from Paris, a district round Horncastle. A long way to the west and south of these Ptolemy places the Ordovikes (Ordovices, Tac. Agric. xii. $3^{8}$ ), with their towns Mediolanion and Bramnogenion. Sir John Rhŷs (Celt. Brit. ${ }^{3}$, p. 308) finds traces of the Ordovices in Rhyd Orddrey near Rhyl, in Dinorwig (earlier Dinorddwig) near Carnarvon, and in the Cantref Orddwyf, "Hundred of the Ordovi," of the Iolo MSS. He traces the first syllable to Welsh gordd, in Old Welsh ord $=$ hammer. Ravennas gives the following sequence; Seguntio (Caer Seiont), Canubio (Conway river); Mediolano, Saudonio, Deva (Chester), and the Itinerary gives Mancunio (Manchester), Condate (= Northwich : cf. Kind-street, the modern name of the 
Roman road here), and Mediolano (nineteen miles from Condate). On another route the Ant. Itin. gives, after Manchester, Condate, and, at twenty miles, Deva, Bovio (ten miles from Chester, ? =Beeston Castle, Bui-stane in Domesday), Mediolano (twenty miles from Bovio), Rutunio(? on river Roden), Urioconio (Wroxeter). If there be not two places called Mediolanum, that of Ravennas seems misplaced. The identification with Whitchurch also will not well square with the mileage. Brannogenion (Branogenium of Ravennas, ? = Bravinnio of the oldest MS. of Ant. Itin., where it is placed twenty-seven miles from Wroxeter-Viroconium) is probably Brandon, Herefordshire. Ptolemy makes Dẽva (Chester) and Virokonion towns of the Kornavioi, and Lindon (Lincoln) and Ratai (Leicester) towns of the Koritavoi, or Koritanoi. The towns of the Katvellaunoi (mentioned by Dio Cass. 60. 20, under the same name, but the correct form as on an inscription found at the Roman Wall (Corp. Inscr. vii. 863 ) is Catu-Vellauni) are Salinai and Ourolanion (=Virulamion). The Salinai, or salt-pans, were some forty or fifty miles east by north of St. Albans, and were probably on the Essex coasts, where there are yet "Salterns". Beyond this tribe Ptolemy places the Ikenoi with one town, called Venta (Caistor near Norwich), and then more to the east, on the estuary of the Tamesa, the Trinovantes with their town $\mathrm{Ka}$ moulodunum (mentioned by Tacitus, Dio, Pliny, and in the Itin. and Peut. Taf., $=$ Colchester). Ptolemy then goes to the extreme west where are the Démétai $($ Dimet $=$ Dyfed $=$ South Wales) with their towns Louentinon and Maridunon (Carmarthen), and east of these the Silures with their town Boullaion (? Builth, in Irish version of Nennius Boguelt), and after these the Dobounnoi with their town Corinion (?Cironium, Ravennas; Durocornovium, Ant. Itin. = Cirencester). The Atrebatioi with one town Caleva (Silchester) follow, after which, a long way to the east, Ptolemy places the Kantioi (Kent) with their towns Londinion (London), Darvernon (Durovernum in the Itin., and in the Peut. Taf., Duroaverus = Canterbury), Routoupiai 
(Ratupis in Peut. Taf.; Ritupium in Itin.; Rutupinove edita fundo Ostrea, Juvenal, Sat. iv. 14 ; Rutubiportus in H.E. i. I of Bede, following Orosius, i. 2 ; now Richborough). Below the Atrebatioi and Kantioi Ptolemy places the Regnoi (cf. Regnum of the Ant. Itin., ninety-six miles south of London, $=$ Chichester) with their town Noiomagos (Navimagio, Ravennas; Ptolemy, in his Prolegomena, cites authority for its being fifty-nine miles south of London; thus it was possibly near Shoreham). Next the Dobounoi are placed the Belgai with their towns Iskalis (which is further west than the mouth of the Axe and must be sought probably on the south shore of the Bristol Channel), Hydata therma (i.e. Hot waters, = the Aquis Solis of the Ant. Itin., to which Solinus, xxi, refers; now Bath), Venta (Venta Belgarum of the Itin. = Winchester). To the west and south of the Belgai are placed the Durotriges (Dorset, i.e. Dor-sata) with their town Dunion (= ? the Muridunum of the Ant. Itin., thirty-six miles from Dorchester and fifteen from Exeter; in Peut. Taf., Ridumo=? Sidmouth, or Seaton). Then far to the west Ptolemy places the Dumnonioi (Devon) with their towns Voliba, Uxella, Tamare (the two former in the neighbourhood of the latter, which was on the Tamar), and then at a considerable distance to the east Iska (Isca Dumnuniorum of the Ant. Itin., now Exeter).

Ptolemy concludes his account of Albion by mentioning the islands near the Orcada promontory (the most northern point of Scotland), viz. Skêtis and Doumna (=? the Scandias and Dumna of Pliny, iv. 104), which have not been identified.

Of the names given in the Antonine Itinerary some have been already dealt with. The whole is now appended to this Note.

NOTE D.

British Place-names in the Antonine Itinerary, the Notitia Dignitatum, AND the Ravenna Geographer.

The Antonine Itinerary was finally edited some time in the end of the fourth century and is preserved to us in three MSS. of the eighth century, as well as in many later. 
It furnishes a series of routes, with the chief stations upon them, traversing the country up to "the limit", i. e. to the ClydeForth Wall.

Route I is from " the limit", i. e. the Wall (Vallum), to Pretorio, a distance as given of 156 miles.

Bremenio (High Riechester) is the starting-point, after which follow Corstopitum (Corbridge), 20 miles; Vindomora (Ebchester), 9 miles; Vinovia (Binchester), 19 miles; Cataractoni (Catterick), 22 miles; Isurium (Aldborough), 24 miles; Eburacum (York), 17 miles; Derventione (? Stamford Bridge), 7 miles; Delgovicia (unknown), I 3 miles; and Pretorio (unknown), 25 miles. $^{1}$

Route II. From the northern Wall ad Portum Ritupis (Richborough), 481 miles.

It starts from Blato-bulgio (somewhere near Middlebie Kirk in Dumfriesshire), and then follow Castra Exploratorum, I 2

1 The names of stations throughout are given here in the oblique cases in which they are recorded in the Itinerary: the Bre in Bremenio (Bremenion, Ptol.) seems to be the same as that in Bremetannaco in the Not. Dig.; and also possibly the Bra in Braboniaco (Not. Dig.) (= Brovonacis of the Itinerary) and in Bravonio of the Itinerary: cf. Brocavo in Route V. It would be hazardous to connect it with the Celtic stem Mrog ( $=$ brog in Allo-broges, \&c., because the final "g" would probably not have disappeared so early. Welsh Bro now = country: the scholiast to Juvenal viii. 234 says, "the Gauls call land Broge").

As there was a bridge over the Troutback at Brovonacis (Arch. Acliana, vol. iv), Briv, = Bridge, may be involved, which from recent excavations there was in existence in the first century. Corstopitum has left a relic in the Cor of Corbridge. The Gaulish name Epostero-vidus shows that "st" was preserved in early Celtic, and therefore Corstopitum may be a British word, although its meaning is very obscure: see p. 155 . In Vindamora we have the Celtic adjective Vind = white: Mara (from Mari = sea) seems out of the question, although the place was on a river which might have spread out into a lake here. Vinovia is preserved in the Bin of Binchester. Cataractoni does not imply the existence of a waterfall, as cataracta is used by Livy for a portcullis. Isurium is given in Route $\mathrm{V}$ as Isubrigantum, and may involve the Celtic $I s=$ low : from Aryan Ped-su = "at the feet". For Eburacum see p. 37. Derventione still survives in the river Derwent which runs under Stamford Bridge. Delg in Delgo-vicia seems to be "thorn". Pretorium = the General's head quarters. 
miles; Luguvallo (Carlisle), I 2 miles; Verada (variant Vereda, which Sir John Rhŷs prefers, = Castle-steads near Old Penrith), I 4 miles; Brovonacis (Kirkby Thore), I3 miles; Verteris (Brough Castle), 13 miles; Lavatris (near Bowes), I 4 miles; Cataractone, 16 miles; Isurium, 24 miles; Eburacum, 17 miles; Calcaria (Tadcaster), 9 miles; Camboduno (? Slack), 20 miles; Mamucio (Mancunio in Route VIII, Manchester), 18 miles; Condate (near Northwich), 18 miles; Deva, leg. xx Vict. (Chester), 20 miles; Bovio (= ? Bee-ston, Bui-stane), ro miles ; Mediolano (? Whitchurch), 20 miles; Rutunio (? on river Roden) I 2 miles; Urioconio (Wroxeter), I I miles; Uxacona (? Oakengates), I I miles; Penno-Crucio (two miles south of Penkridge), I 2 miles; (L)Etoceto(near Lichfield), I 2 miles; Manduesedo(Mancetter), 16 miles; Venonio (High Cross), I 2 miles; Bannaventa (near Daventry), I 7 miles; Lactodoro (Towcester), I 2 miles; Magiovento (Fenny Stratford), I7 miles; Durocobrivis (? Dunstable), 12 miles; Verolamio (near St. Albans), I 2 miles; Sulloniacis (? Brockley Hill), 9 miles; Londinio (London), 12 miles; Noviomago (unknown), ro miles; Vagniacis (? Springhead), I 8 miles; Durobrivis (Rochester), 9 miles; Durolevo (? near Sittingbourne), I3 miles; Duroverno (Canterbury), I 2 miles; Ritupis (Richborough), 12 miles. ${ }^{1}$

1 Blato-bulgio has a parallel in Blabo near St. Andrews in Fife, which was earlier Blathbolg, and Sir John Rhŷs thinks it may be non-Celtic. The not unfrequent place-names (e.g. Dun-bulg) in Scotland and Ireland seem to imply that butg is Celtic, but probably with a meaning other than "bag": cf. the Irish form of Arthur's sword Caladbolg=" hard in making notches" (Strachan's Gram. of Old Welsh, s.v. Bolg = therefore "notch", pass, Welsh brolch): cf. English use of Corfe as in Corfe, Castle. Blato bulgium was north of Hadrian's Wall. This explains Prof. T. Mommsen's view that " a limite id est a Vallo" meant the wall of Severus between the Clyde and Forth, at which the Roman imperial roads terminated. Provinces of Roman Empire from Caesar to Diocletian, London, 1909, vol. i, p. $187 n$.

The exploratores were scouts who removed their Castra from place to place. Luguvallo is explained elsewhere. Vereda Sir John Rhŷs would connect with the Verēda in Paravereda (English Palfrey) and make it a place for Cavalry. For Brovonacis see previous note. For Verteris see Pedersen ( V. Gramm., § 30), who gives a stem Vert, = "turn". The Swindale beck makes a rapid turn near the spot. Calcaria seems to involve Calx $=$ lime, a necessary material for Roman buildings. I know not if chalk be found near. Camboduno would be "the fort at the bend". Mancunio is obscure. Condate $=\mathrm{a}$ river confluence, and the name seems preserved in Kind 
Route III. From Londinio ad Portum Dubris, 66 miles.

Durobrivis is the first station given, 27 miles; Duroverno follows, 25 miles; and Dubris (Dover), 14 miles. ${ }^{1}$

Street there. Mediolan-o = "middle of plain". The river Roden seems to preserve Rutunio. Urioconio (in Route XI Viroconium) is preserved in the Wroc of *Wroc-cester (= Wroxeter) and in "the Wrekin". Sir John Rhŷs does not explain the name, but in discussing the British Coins of Commios (Celtic Britain ${ }^{3}$, p. 23) he refers to the territory ruled over by his son Verica as extending "as far north as Aldchester", and it is just possible it extended farther, and that we have this personal name in Viroconium. Cf. Ariconium and the name on the lead plate found at Bath as read by Bodley's Librarian, Mr. Nicholson, also the inscription to Deo Arciacon. The place was destroyed in some catastrophe at an early date. Uxacona (variants Usoccona and Uscocona, which suggests Usk (= Water)) is obscure. It seems to survive in Oakengates near which the roads (Northern Gates) forked, one going to Mediolano and the other to Pennocrucio. For (L) Etoceto, see p. 86. The Sedo in Manduesedo is cognate with English "seat". Mandu appears in other British personal names, e.g. Cartismandu-a (see p. 30) and also in Gaulish Viromandui, \&c. The contraction of full personal names to the first element in them was as common among the Celts as among the Greeks and Teutons (see p. 133). So we have in Mandne-sedo the seat, perhaps, of a Chief called e. g. Mandubratios, who was son of the King of the Trinovantes (Celtic Britain ${ }^{3}$, p. 17). Venonis is obscure. Banna-venta seems to involve the British Bann = High, and Venta $=$ Market. See note on Venta. Lactodoro (variants Lacto-duro and Lactodrodo) seems to contain -duron (stronghold). Magio-vinto contains seemingly Mag-os = plain, place. Duroco-brivis seems to contain an adjective formed from Duro (stronghold) and brivis, an oblique case of Briv= bridge. The site may have been on the low ground below Dunstable, as no bridge could well be on the height there. Sir John Rhyss draws attention to Dvorico, in a Gaulish Inscription, meaning some kind of portico (Celtic Britain ${ }^{3}$, p. 301 ). For Verolamio see p. 39. Sulloniacis seems to be the oblique case of a place called after its proprietor, Sullon-i. It is somewhat striking that Brockley Hill is called in Cart. Sax. iii. 605, "The old Tunsteall," i. e. "Town site". Names ending in -acus, although made thus simply adjectival, seem to be generally used for patronymics corresponding to English names in -ing, -ingas. The meaning of "Londin-ium" cannot be satisfactorily explained with our present knowledge. Novio-mago means "new-place". Vagniacis (variant Vagnacis) is probably an oblique case of a patronymic from a personal name, *Vagn-o, cf. Vaco in Vacomagi. Durobrivis, see p. 37. Duro-levo is obscure. For Duroverno see p. 38. For Ritupis see p. 37 .

"Dubris is in the locative plural, meaning "at the Waters", i. e. the two 


\section{Route IV. From Londinio ad Portum Lemanis (Lympne),} 68 miles.

This is the same as the preceding Route as far as Dubris; whence to Portum Lemanis is 16 miles. ${ }^{1}$

\section{Route V. From Londinio to Luguvalio-to the Wall, 443 miles.}

The first station is Caesaromago (? near Widford, south-west of Chelmsford), 28 miles; after which follow Colonia (called Camoloduno in Route IX = Colchester), 24 miles; Villa Faustini (? Woolpit), 35 miles; Icinos (? Ickworth near Bury St. Edmunds), 18 miles: Camborico (unknown), 35 miles; Duroliponte (? Godmanchester on the Ouse), 25 miles; Durobrivas (? Castor on the Nene), 35 miles; Causennis (? Ancaster), 30 miles; Lindo (Lincoln), 26 miles; Segeloci (Ageloco in Route VIII = Littleborough), 14 miles; Dano (Doncaster), 21 miles; Legeolio (Lagecio in Route VIII=Castleford), 16 miles ; Eburaco (York), 2 I miles; Isubrigantum (=Isurium of Route II, = Aldborough), I 7 miles; Cataractone (Catterick), 24 miles; Levatris (Lavatris Route II, Lavatres Not. Dig. near Bowes), 18 miles (I 6 in Route II); Verteris (Brough), 14 miles; Brocavo (near Brougham Castle), 20 miles; Luguvalio (Carlisle), 22 miles. ${ }^{2}$

small streams which found their exit here. Dubron is the earliest Celtic form for Water. The French Donvres still preserves the plural.

1 Lemanis has been dealt with else here.

2 The identification of the places on this route after Colchester is a bewildering work. Assuming the Villa of Faustinus to have been at a place where the Peddar's Way forked, this might be Woolpit, in Domesday Wlfpeta $=$ Wolfpit. Although no trace of a Roman road is found between Woolpit and Bury St. Edmunds or Lackford, it is probable, from the discovery of Roman remains at Ickworth (? involving Icinos, cf. the Icenan river of the Cod. Dip. iii. 316, which gave the name to Itchington), that a route lay in this direction. The road is plain onwards toward Newmarket and Great Chesterford. The latter place may be Camborico which involves $C a m b=a$ bend. Prof. Skeat has shown that Cambridge arises from Grantabrycge, and hence Camborico cannot be identified with it. The next station, Duroliponte, is 'given as twenty-five miles from Camborico. Sir John Rhŷs (Celtic Britain ${ }^{3}$, p. 300) thinks that -lipons may be a Celtic termination and have nothing to do with Latin Pons, but if Godmanchester on the Ouse represents the site, the idea of a bridge is natural. Duroli might thus represent the genitive of the early name of the Ouse. Durobrivas seems to be Castor, where Mr. Codrington (Roman 
Route VI. From Londinio to Lindo, I 56 miles.

The first stage given is Verolami (St. Albans), 2 I miles; then follow Durocobrivis (Dunstable), I 2 miles; Magiovinio (Magiovinto in Route II =Fenny Stratford), 12 miles; Lactodoro (Towcester), I 6 miles; Isannavantia (the oldest MS. reads Isannantia. This is the Bannaventa of Route II, and the Bannavento of Route VIII = ? near Daventry), 12 miles; Tripontio (? where Watling Street crosses the Avon), I 2 miles; Venonio (High Cross), 8 miles; Ratas (Leicester), I 2 miles; Verometo (Vernemeto, evidently the correct form, in Route VIII = Willoughby), 13 miles; Margiduno (Castle Hill), 12 miles; Ad Pontem (? E. Stoke-on-Trent), 7 miles; Crococalana (near where the Devon joins the Trent, ? Brough), 7 miles; Lindo, I 2 miles. ${ }^{1}$

Roads ${ }^{2}$, p. I40) says the Nene here "was crossed by a timber bridge on stone piers, the remains of which were removed when the river was made navigable". The briv.as is thus explained and the extensive Roman remains (including a mile-stone with M.P. L (or LI), i. e. 50 or $5 \mathrm{I}$ miles, possibly the distance from Lincoln) show the importance of the place. Cansennis is at the correct distance for An-Caster, where the an-may still preserve a relic of the former name. Lindum has been explained. Segeloci or Ageloci probably involves the antecedent of the Welsh llwch (= lake), which Dr. W. Stokes would trace to a stem (P)loug ( $=$ to fly): the Penne-locos (= "Lakehead") on the Lake of Geneva involves the same word (Thurneysen, Handbuch 47). Dano involves probably the old name of the river Don. Legeolio is obscure. The remaining names on this route have been already explained, except Lavatres (which may be allied with the Ancient Irish Lothur, glossed Canalis (Pedersen, V.Gramm. $\S 42$ ), and Breton Laouer, trough. Cf. the river Lowther) and Brocavo, where we have probably the same termination as in Ande-gav-ia (Angers), the Ande- here representing an intensive prefix or the early form of the definite article (Thurneysen, Handbuch des alt. Irischen, p. 471).

1 Magio-vinto seems to involve $M a g=0=$ plain, place. Lacto-doro: the variants give -duro, hence this is the stronghold possibly on a river *Lact-o, now the Tove, which gave its name to Tovecester, Towcester. Isannantia of the oldest MS. can hardly be a misreading of Banna-venta (= ? "chief market"), but seems to be a synonym composed of $I s a$ (= Low, at foot of) and nant-ia, possibly "valley". Tripont-io = "Three Bridges", cf. Tri muntium of Ravennas and the numerous other compounds with Tre = three. Venonio is obscure. Ratas seems to be related to the Modern Irish Rath, an earthwork, found also in Pembrokeshire. Ver-nemeton is the correct reading doubtless, and means "Chief Temple" as it stands: see 
Route VII. From Regno (Chichester) to Londinio, 96 miles. The first station is Clausentum (? Bittern), 20 miles; then follow Venta Belgarum (Winchester), ro miles; Calleva Atrebatum (Silchester), 22 miles; Pontibus (Staines), 22 miles; Londinio, 22 miles. $^{1}$

Route VIII. From Eburaco to Londinium, 27 miles.

The first station is Legecio (Legeolio, Route V), 2 I miles; Dano, 16 miles; Ageloco (Segeloci, Route V), 21 miles; Lindo, 14 miles; Crococalana, I4 miles; Margiduno, I4 miles; Vernemeto, I 2 miles ( 13 in Route VI) ; Ratis, I 2 miles ( 13 in Route VI); Venonio, 12 miles; Bannavento, 18 miles (20 in Route VI, via Tripontium); Magiovinio, 28 miles; Durocobrivis, 12 miles; Verolamo, 12 miles; Londinio, 2 I miles. $^{2}$

Route IX. From Venta Icinorum (Caistor near Norwich) to Londinio, 128 miles.

First station, Sitomago (? where Roman road from Caistor reaches the river now called Gipping), 32 miles; followed by Combretonio, 22 miles; Ad Ansam (? Stratford), I5 miles; Camoloduno (Colonia in Route V), 6 miles ; Canonio (? Kelvedon), 9 miles ; Caesaromago, 12 miles ; Durolito (? at Writolaburna, original Charter of $692-3$ in B. M., now Writtle), 16 miles ; Londinio, I 5 miles. ${ }^{3}$

p. I3o on Nemet. The Margi in Margi-duno is obscure. Croc-o-calana seems to involve $C r u c=$ tumulus.

1 Regno: cf. Regina, now Regensburg; it possibly involves Rig = King. The famous Chichester inscription gives the name of Cogidubn-i (Phil. Trans., 31 Oct., 1723), and this was doubtless his residence as king of the "royal" people of the district. Clausentum is obscure. Venta Belgarum and Calleva have been explained elsewhere. Pontibus means at the Bridges, the ruins of which probably gave origin to the Saxon Staines $=$ Stones.

2 The names in this route have been already dealt with.

3 Venta-Icenorum. Sir John Rhŷs thinks Eceni was probably the correct name of the Iceni who occupièd the Norfolk and Suffolk district. He equates the name with the Welsh egin = bladed, which possibly comes from the root $a k=$ sharp. The Welsh word is cognate thus with A.-Saxon Eginu = English Awns, as in the awns of barley. Sir John thinks these people, like the Saxons, were called from the weapons they bore (see p. 27), probably swords. 
Route X. From Clanoventa (Glannibanta Not. Dig.) to Mediolano (? Whitchurch), 150 miles.

The first station is Galava (unknown), 18 miles; then follow Alona (unknown), 12 miles; Calacum (? Overtown on Lune), I 9 miles; Bremetonaci (Ribchester), 27 miles; Coccio (Wigan), 20 miles; Mancunio (Manchester), 17 miles; Condate (Northwich), 18 miles ; Mediolano, I 9 miles. ${ }^{1}$

Route XI. From Segontio (Caer Seiont, near Carnarvon) to Devam (Chester), 74 miles.

Conovio (Conway), first station, 24 miles ; then Varis (? Bodfari, Flint), 18 miles; Deva, 32 miles. 2

Sitomago seems to mean Corn-plain. The initial "s" has vanished in the modern Irish $I t h=$ corn, as in Ithtige = cornhouses (Thurneysen, Handbuch, p. 83), cf. Mag-ith.

Combretonio appears to involve Com-ber $=\mathrm{a}$ bearing together, a confluence, as in numerous place-names in Ireland and Wales, Commer, Cumber, plur. in Cumrew, Cumberland. This might lead to the identification.

Ad Ansam is Latin for "at the Bay". The French Anse preserves the signification. Stratford would satisfy the conditions, as the tidal waters came np thus far.

Canonio is an obscnre word. Caesaro Mago = "Imperial place" and must have been of importance as the seat, probably, of authority. Zaragoza for "Caesar Augusta" indicates the disguised form in which this name, if it survived, would now appear.

Durolito may be represented in a degenerate form in the Writola burna. An intrenchment and other remains have been found at Writtle, which is about a mile from the Roman road to Colchester and seemingly on that which converges on it from Braintree. The Itinerary may deal with both these routes, and hence the difficulty about the mileage. The fate of Duro in Durobrivis prepares one for such a transformation.

1 This route is full of difficulties. We do not know where Clano-venta (or Glannibanta) was. If Clan-represent Glan, as the Not. Dig. indicates, it would mean "market on the bank" of some river, ? the Lune, of which the early name seems preserved in Alone (cf. the Aenona of Ravennas, now Nona). Calacum has been placed at (?) Overtown on the Lune, and Bremetonaci at Ribchester. Coccio is supposed to be Wigan, but these are pure conjectures. From Mancunio the places are clear.

2 Caer Seiont and the river Seiont "Seintes" in Cal. Chart. Rolls, ii. 280), near Carnarvon, preserve a relic of Segontium ( $=$ ? the place of the God of Victory). Conovio is obscure, as is also Varis, of which a reminiscence may be preserved in Bod-fari, Bod = dwelling. 
Route XII. From Muriduno (? an error for Ptolemy's Maridunon $=$ Car-Marthen) to Veroconium (Wroxeter), 186 miles. (The aggregate makes up only 166 miles.)

The first eight stations are a repetition of those in Route $\mathrm{XV}$, and do not belong here. The first station of this route is Leucaro (? Loghor), I 5 miles from Maridunum; then follow Nido (? Neath), I 5 miles; Bomio (? Cowbridge), I 5 miles; Isca Leg. II. Augusta (Caerleon), 27 miles; Burrio (? Usk, but cf. Din birrion of Lib. Land.), 9 miles; Gobannio (Abergavenny), I 2 miles; Magnis (? Kenchester), 22 miles; Bravonio (Brandon), 24 miles; Virocono, 27 miles. ${ }^{1}$

Route XIII. From Isca (Caerleon) to Calleva (Silchester), rog miles.

Burrio, the first station, 9 miles; then follow Blestio (Monmouth), II miles; Areconio (cf. Deanery of Erchenfield), I I miles; Clevo (Gloucester), I 5 miles; Durocornovio (Cirencester), I 4 miles; Spinis (Speen), I 5 miles; Calleva, 5 miles. $^{2}$

Route XIV. Another route from Isca to Calleva.

The first station is Venta Silurum (Caerwent), 9 miles; Abone (Mr. Codrington makes this Sea Mills), 14 miles; Trajectus (Mr.

1 Maridunum is another form of Muridunum, Mari = the Sea : early Irish Muir. Leucaro is obscure. Nido, = Neath, has its parallel in the German Nied, which is the survival of the Nida of the Itinerary.

Bomio would become later Bovio and may have suggested the Cow (as a translation) in Cowbridge. Isca, of the second legion called Augusta, i.e. Isca Legionis or Caer (= Castra) Legionis. Burrio is obscure but cf. the Din birrion of the Lib. Land.

Gobannio ( = ? Smithy) is doubtless from Gobann, genitive of Goibniu = Smith, perhaps, an Irish Vulcan; cf. Gaulish Gobannitio (Caesar, De Bell. Gall.). Goibniu is an Irish proper name = Smith: Mac Gowan (i.e. Goibnenn, genitive) $=$ Smith's son.

Magnis would seem to be Latin, but it is possibly an ablative plural of Magen = Old Irish for "place", which is the equivalent of Welsh Maen = stone, the common significance being " earth surface"; cf. Magos (Pedersen, V. Gramm. § 59). Bravonio is obscure.

2 Blestio is obscure. Areconium preserved in Erchen seems to involve a personal name. See previons note, p. 107. Clevum alias Glevum is preserved in the Glou of Glon-cester. Durocornovium is seemingly the stronghold of the Cornovii. Spinis is the locative plural of Spinae $=$ thorns. 
Codrington makes this Bitton), 9 miles; Aquis Solis (variant Aquis Sulis = Bath), 6 miles; Verlucione (Wans), I 5 miles; Cunetione (near Marlborough on Kennet), 20 miles; Spinis, I5 miles ; Calleva, I 5 miles. ${ }^{1}$

Route XV. From Calleva to Isca Dumnuniorum (that is Isca of the Devonians $=$ Exeter), 136 miles.

The first station is Vindomi (? unknown), I 5 miles; then follow Venta Belgarum (Winchester), 2 I miles; Brige (variant Brigae; position unknown, but between Winchester and Salisbury), I I miles; Sorbiodoni (in the misplaced stations placed before Route XII it is Sorvioduni = Old Saresbury), 8 miles; Vindogladia (Badbury Rings), I 2 miles; Durnonovaria (Dorchester), 8 miles; Muriduno (somewhere near the Otter river), 36 miles ; Isca Dumnuniorum, 15 miles. ${ }^{2}$

\section{Place-names in the Notitia Dignitatum.}

Chapter XXV gives the following places on the Saxon shore (Litus Saxonicus), that is on the coast exposed to the raids of Saxon and other pirates:-

Othona (the Ythancaster of Bede, discussed p. 179), Dubris (Dover : p. 107), Lemannis (Lympne, p. 215), Branoduno (Brancaster : so called probably from a personal name Bran. Cf. Bran, son of Lir (Llyr), in the Mabinogion), Garriano (Burgh: see p. 176), Regulbi (Reculver, see p. 37), Rutupis (Richborough, p. 37), Anderitos (Anderida and Andredes Wald: p. I 43 . Cf. Andereton of Ravennas, p. 238, and Anderitum of the Peut.

1 Venta Silurnm is the "Market of the Silures". Abone is the locative case of Abon = river : it would seem to mean the Severn, but 14 miles can hardly be accounted for, except the route was along the shore as far as the Trajectus (i. e. the Ferry), which would be at Aust Passage (Anst possibly from the Legio Augusta), see p. 203 ; but then this is too far from Bath (Aquae Sulis, i.e. "The Waters of the God Sul-"). Verlncio contains the intensive $V e r$ and possibly the loco-s mentioned above =lake, probably the spreading out of a river. Is there such a thing at Wans? Cunetio involves the river-name, now the Kennet.

2 Vindomi is obscure, but seems to involve Vindo $=$ White. Brige is evidently Briga $=$ Burg or Stronghold. Sorbio-dnnum, see p. 146, ? from Irish Soirb = easy, perhaps earlier "level". Vindo-gladia = White ditches, i. e. fosses cut in the chalk. Cf. Cladid = to dig, in Old Irish, and Welsh Clawd $=$ trench, grave. Durnovaria is dealt with elsewhere, see p. 138 . 
Taf.), Portum Adurni (position unknown: probably west of Brighton. The river "Adour" has seemingly been coined from Camden's identification).

Chapter XXXVIII furnishes the names of the stations of troops under the command of the Dux Britanniarum - a dignity which Böcking thinks (Not. Dig. II, pt. 2, Occid. p. $85^{*}$ ) was first instituted by Constantine.

Sextae, the first on the list, is the station of the Sixth Legion and probably means York, the station of this legion according to Ptolemy. Böcking (ibid. $853^{*}$ ) shows that York was called a Colonia on coins and inscriptions, a Municipium by Aurelius Victor, a Civitas by Spartianus, and an Oppidum by Bede.

Praesidium, where was stationed the Prefect of the Dalmatian cavalry, is unknown, but cf. Sir John Rhŷs's Celtic Britain ${ }^{3}$, pp. 229, 302, where he shows that the Epiacon of Ptolemy and the Vereda of the Ant. Itin. may mean places for horses or cavalry.

Dano (near Doncaster, p. 108). Morbio (site unknown, but cf. Moerheb, p. 2 I 6, and Murief, i. e. Moray, which in the "Story of Arthur" (Red Book of Hergest) is said to be another name for Reged). Arbeia, the station of the Tigris boatmen, was probably South Shields, where an inscribed stone was found with the designation of these boatmen, who were doubtless required to carry supplies by the North Tyne to the garrisons on the Wall. The attempted identifications of these last two places with Moresby and Ireby on account of similarity of terminations is baseless, because the -by is Scandinavian.

Dictim, the station of a Numerus of the Dictensian Nervii, is unidentified.

Concangios (see p. 95). Lavatres (see s. v. in Ant. Itin.). Verteris (see p. 106). Braboniaco (this is the Brovonacis of the Ant. Itin. It is supposed to be Kirkby Thore, Cumberland; cf. the Ravonia of Ravennas). Maglone (not mentioned elsewhere, site unknown. If the name involved $\mathrm{Mag}$, plain, place, there would be a thematic vowel following it). Magis (locative plural $=$ at the plains, but where these were is not known, but cf. Maes, p. ror). Longo-vicio (variant Longovico $=(?)$ "Long row of houses." Camden identified this, and afterwards relinquished the identification, with Lanchester on the Lune. The site is unknown. It may have been the Lanchester north of Binchester). Derventione, where were stationed troops called Petueriensis, ? from the Petuaria of 
Ptolemy. There were several rivers in Britain called Derventio. This may have been that mentioned by Bede, $H$. $E$. ii. 9, "Close to the river Derventio where was then a royal vill."

Stations along the Wall according to the Notitia Dignitatum.

Segeduno (the Serduno, probably, of Ravennas: it has been identified with Wall's End).

Ponte Aelii (Newcastle), called after Aelius Hadrianus.

Conderco (Condecor, Ravennas $=$ ? Benwell Hill).

Vindobala (Vindovala, Ravennas $=$ ? White-wall, identified with Rutchester, but the site is unknown).

Hunno (Onno in Ravennas-near Halton).

Cilurno (Celunno, Ravennas. This was at Chesters near Chollerford, which, with Chollerton, both on the North Tyne, seems to preserve the early name of that river, "Cilurn"so-called, probably, as suggested by Sir John Rhys, from the Cavities in the rocky river-bed here. Welsh Cilwrn $=$ Chaldron).

Procolitia (Brocoliti in Ravennas = Carrawburgh. Broco-lili, from a comparison with such forms as Broco-mago (now Brumat) in the Ant. Itin., seems the correct form. Broco- may be associated with Welsh $B r o g=$ country, and the lit-i may involve the stem lit $=$ broad).

Borcovicio (= House-steads). It is possible that we have in Borco a case of metathesis of Broco. Vic-io is from the Latin Vicus.

Vindolana (=Chesterholm: here we seem to have lan-a, plain, or land, and Vindo = white).

Asica (Great Chesters).

Magnis (Magnis in Ravennas. This is placed at Carvoran). Ambo-Glanna (= Burdoswald, ? the Gaba Glanda of Ravennas. The name contains $A m b=$ about. Anglo-Saxon $Y m b$-, preserved in "Emb-er days", and Glann = shore, bank).

Petrianis (unknown).

Aballaba (Avalana of Ravennas, unknown site) seems to involve the Celtic Aball, Uball=apple: Appleby is a Scandinavian name.

Congavata (Chester-le-Street was called by Richard of Hexham "Kunka-Cester" and may preserve this Congavata. It lies about 8 miles south of the Wall).

Axeloduno (= Uxelludamo of Ravennas. It is placed by some at Hexham and by others as far away from the Wall as Ellenborough. The Hex in Hexham is a relict of Hagustaldif we accept the Earliest English form-but it is possible that 
the latter intelligible word may represent the unintelligible Axelo-dun, or rather Uxellodun = "high fort ").

Gabrosente (Gabrocentes of Ravennas, supposed to be Gateshead. Gabr- = Goat, and sent, Irish set, with the usual loss of $n$ in $n t=$ path, $=$ Gothic Sinths).

Tunnocelo (supposed to be the Fano-Cocidi of Ravennas. Cf. the inscription (Camden-Gough) to the God Cocidius found in Cumberland. Mommsen makes Cocidius a by-name of Mars (Prov. Rom. Empire, i. 193). Watling Street crosses the Coquet, which may be a deified river).

Glannibanta (this is seemingly the Clanoventa of the Ant. Itin., which see. It is placed by some at Cockermouth, but the site is unknown).

Alione (this is the Alone of the Ant. Itin., which see).

Bremetennaco (probably the Bresnetenace Veteranorum of Ravennas. It has been identified with Ribchester).

Olenaco (this can hardly be the Olikana of Ptolemy, one of the cities of the Brigantes, which has been identified with Ilkley, but this is far from the Wall).

Virosido (site unknown. For the significance of Viro see Vero-lam-ium: and cf. Viro-dun-um (Ant. Itin.) now Verdun and Viro-viacum (ibid.) now Werwick. Sido probably represents Irish Suide, Welsh Sedd = seat).

The Ravenna Geographer furnishes longer lists of British place-names in Roman times, but it is difficult to identify many of them owing to a seeming lack of method in their arrangement. Instances have been given above which tend to show that he had one or more Itineraries before him, but he is not consistent in following these. In his list of names he seems to associate together sometimes those which are more or less near to each other, but he often departs from this practice. An article on the Roman place-names of Derbyshire by W. B. Anderson, M.A., in Melandra Castle (Manchester University Press, 1906), raises this question: the sequence of rivers Dorvantium (Derwent), Anava, and Bdora seem to belong to Derbyshire, so do the places Nanione (or Navione), and Aquis = Buxton. There are several Derwents, it is true, but a mile-stone, discovered in 1862 near the Silverlands of Higher Buxton (now in Buxton Museum), furnishes, as we see from the article, the name Anavione. A fragment, moreover, of a sepulchral inscription found at Foligno in Italy records 
(1102 in Eph. Ep. vii) a Censitor Brittonum Anavion[ensium]. Mr. Anderson, from the facts (I) that the river Noe joins the Derwent about one and a half miles below Brough, and (2) that there was a Roman fort at Brough, to which the Roman road (now Batham Gate) leads, (3) that Brough is about the right distance from Buxton, viz. ten or eleven miles according to the miliary, infers that Brough represents Anavio, so called from the Anava now the Noe. The third name Bdora, although it has been placed far afield, may have its reflex in the Derbyshire Dore, otherwise (see p. 239) hard to explain. There is a stream at Dore, but it is now called "the Sheaf".

\section{NOTE E.}

\section{The Legions in Britain, see p. $8 \mathrm{r}$, ante.}

Mommsen (Prov. Rom. Empire, i. 174, London, 1909) says that for the subjugation of Britain three of the Rhine Legions and one from the Danube were destined thither, and adds:-

"The three legions of the Rhine were the and Augusta, the I $4^{\text {th, }}$ and the 2oth ; from Pannonia came the $9^{\text {th }}$ Spanish. The same four legions were still stationed there at the beginning of the government of Vespasian; the latter called away the I $4^{\text {th }}$ for the war against Civilis, and it did not return to Britain, but, in its stead, probably the 2nd Adiutrix. This was presumably transferred under Domitian to Pannonia; under Hadrian the $9^{\text {th }}$ was broken up and replaced by the 6th Victrix. The two other legions, the 2nd Augusta and the 2oth, were stationed in England from the beginning to the end of the Roman rule." B. W. Henderson (Life of Nero, pp. 202 et seq., and Eng. Hist. Review, Jan., I 903, states that in A.D. 49 the $9^{\text {th }}$ legion was at Lincoln, the $14^{\text {th }}$ and 20 th at Wroxeter, the 2 nd at Gloucester. The 2 nd was shortly afterwards pushed forward to Caerleon and the $14^{\text {th }}$ and 20 th to Chester. After Nero's death, in A. D. 68, the I 4 th was withdrawn from Britain and the 9 th removed to York.

\section{NOTE F.}

Tacitus, Ann. xii. 31, see p. 22, ante.

Mommsen, Prov. Rom. Empire, i, p. I 78 , reads, "Ostorius makes ready to secure all by camps (extending) to the . . ntona 
and Sabrina rivers," and places the camp for the 14 th legion at the confluence of the Tern with the Severn near Viroconium (Wroxeter).

NOTE F. 2.

Some Latin words which had entered into place-names before the Norman Conquest :-

Calx, as "Cealc" in Cealchythe.

Castra, as Castor, Chester.

Castellum, as "on tha Cæstello", Cart. Sax. iii. $33^{8 .}$

Castelletum, as Cistelet.

Chors (Cohors), as in "Dovor-Cortæ", Cart. Sax. iii. 603.

Cerasus, in numerous Cheritons.

Fons, as in "Ceadeles funtan", now Chalfont, Cart. Sax. iii. 40; "Teofunten", now Teffont, Wilts., ibid. 385 ; "Funtines burnan," ibid. 588, cf. also "Fobbefunte", now Fovant, Wilts., ibid. ii. $23^{2}$; Funtgéall", now Fonthill, Wilts., ibid. ii. 234 ; "Hamanfunta", now Havant, \&c.

Fossa, as "fossa", cf. Foss-way.

Palantium, as in "the Palant" at Chichester. See Index.

Palus, ? as in "Plash".

Pirus, as "Pere" and "Pirige" in Pirigtún, now Purton.

Populus, as in "Populfinig", Cod. Dip. $65_{2}$.

Portus, as in Portsmouth.

Porta, as in "Port stræt", \&c.

Prunus, as in "Plumstede", now Plumstead, Cod. Dip. 562.

Puteus, as in "hwytan pyt", Cart. Sax. ii. 81.

Silva, as in "Monks' silver". See Index.

Spinae, as in "Spene", now Speen, Cart. Sax. i. 506.

Spinetum, as in Spinny.

Strata (via), as in "Stræt", passim.

Sulcus, as (?) in "Sulhford", Crawford Charters, i. Ir.

Vicus = row of houses, dwelling, or market in the "Wich" of place-names.

Latin topographical survivals in Celtic districts are naturally more numerous; some of them, like Cornish pras, prat (for pratum), are incidentally dealt with as they occur in this work.

It is but right to add that the Teutonic invaders may have imported a few of the Latin terms here given. See Pogatscher (Lautlehre).

Ecclesiastical elements in early English topography are excluded from this list, as they could not well be survivals from Roman times. 


\section{THE TEUTONIC INVASION}

IT is commonly believed that the Teutonic tribes-Saxons, Angles, \&c.-invaded Britain about the year A. D. 449. It is clear, however, that some of them had entered this country long before. Apart from the Saxon and Frankish pirates who were making continuous expeditions against the "Saxon shore" from as early at least as A.D. 297, and who also took service in Britain under Carausius, there were, according to Ammianus Marcellinus (writing about A.D. 378), Saxons, ${ }^{1}$ in alliance with Picts and Scots, fighting against the Romano-Britons in 365. Alliances, begun so early, seem to have established a precedent, for Bede tells us of two subsequent occasions when the Teutonic invaders had Picts as their allies, one which, although it is ascribed by Bede to 449 (Bede, $H$. E. i. I 5), is relegated by Plummer (ii. 33) to possibly the fourth century, the other in 430, the occasion of St. German's" "Hallelujah victory", which shall be dealt with later. The entente cordiale between the Northumbrian English and the Southern Picts was later on cemented by marriage. Eanfrid, who was a greatgrandson of Ida (King of Bernicia, A. D. 547), was, according to Skene, the father of Talorg Mac Anfrith, King of the Picts, who, following the Pictish custom, inherited the kingdom from his mother's side. The personal names (involving Peoht) of distinguished Northumbrians about this time, to which refer-

1 "Picts, Saxons, Scots, and Atacotti harassed the Britons with continuous calamities." (Bk. xxxvi. 4.)

2 Bede's account of the "Hallelujah Victory" is taken almost word for word from the Life of St. German, ascribed to Constantius, a presbyter of Lyons : see later note, p. I 25. 
ence was previously made, testify to friendly relations. Peohthelm, for instance, who was Bishop of Whitern in the eighth century, means the helmet, or protector of the Pict.

The easy conquest of Galloway (the region of the "Niduarian Picts " or Picts west of the river Nid, or Nith ${ }^{1}$ ) by Oswy, and the subsequent strong Anglicizing influence exercised over this region, are thus explained. Here, at least, the Teutonic invaders were not "exterminators". The first Teutonic settlements on the East coast, south of the Forth and north of the Humber, were made probably as early as the fourth century. They consisted to some extent presumably of Frisians, whom Procopius, writing about A.D. 560 ( $D e$ Bello Goth. iv. 20), associates with Angles as invaders of Britain; and Dumfries, i. e. the Dun or stronghold of the Frisians on the Nith, is considered still to preserve their name. The German Ocean is called in the Historia Britonum of Nennius (c. $3^{8}$ ) the Frisian (Fresicum) Sea, and (c. 37) the Tythica Valley. In Jocelyn's Life of St. Kentigern Litus Fresicum ("Frisian Shore") is applied to the district of Culross (see Sir H. Maxwell's Scottish Land-names, p. 73, who also makes the Caer Pheris of Nennius to be Dumfries). The Lowland Scotch has some points of resemblance to the Frisian dialect, and certain old Frisian place-names seem to find an echo in the Lowlands. Leith on the Forth finds, for instance, its satisfactory signification in the Frisian Leith $^{2}=$ passage or ferry, which corresponds to the southern "Lode" (compare the Lodes on the Severn) representing the Anglo-Saxon " $L \bar{a} d$, Gelād", and still surviving in the present Yenlet (for Bede's Genlade) in the Thames-mouth, and

1 Ptolemy places the river Novios about fifteen miles to the west of the estuary of the Ituna, which has been identified with the Eden, the river flowing past Carlisle into the Solway Firth. The Novitia of the Ravenna Geographer is supposed to be the same river and to represent the early form of the Nith. But Novios could not become Nith, and it is pure conjecture that it is the Novitia of Ravennas. The origin of "Neath" given in a note further on suggests another source.

2 See Outzen, Friesisches Glossarium, p. 186. 
also in Inlet. In the last syllable of Prendergast (Berwickshire) ${ }^{1}$ there is possibly a representative of the Frisian Gaast=morass, but as the remainder of the word is presumably Celtic, it is also possible that Gast or Gest may be a corruption of some Celtic form. Although Gast is of early occurrence (Prene-gest, Coldingham Charter, A. D. I roo), it seems, like - Wyndes, mentioned in note below, of Teutonic origin, but it may be a corrupt form of the termination -gask (= Casach, Gaelic for "outlet of a lake", or ford), which appears, for instance, in composition with Teutonic words, as in (Buttergask) "Butter-gask", where "Butter" probably means Bittern, cf. the Lincolnshire "Butterbump" as a name for that bird, and the English Buttermere. 'The difficulty of finding topographical evidence of the existence of Frieslanders in the Lowlands of Scotland is increased by the fact that this region, originally the home of Picts and Britons, was successively overrun by Goidels and Norsemen, the existing place-names furnishing abundant testimony to the influence of both these peoples.

The earliest direct notice of the invasion of Britain by Teutonic tribes is in The Destruction of Britain, a Latin work written about A. D. 537 by a Briton called Gildas. The Britons, fearing a return of their troublesome enemies the Picts and Scots, invited the help, as Gildas bitterly says, of a "most ferocious people of the execrable name of Saxons, hateful alike to God and man". "Then," he continues, "bursting forth from the lair of the barbarous lioness, a flock of whelps, with favouring gales and omens ... set forth, at the instance of the

1 Plenderleith in Roxburghshire was earlier ( $\mathrm{I}_{5} 87$ ) Premderleith. Plenderguest and Prandergaist occur also as equivalents; cf Pranderwyndes. The word Premder is suggestive. The early Irish word for priest was Cruimther, which appears even in an Ogam inscription, Rhŷs, Lectures ${ }^{2}$, 349 et seq., and is from Presbiter, through Prebiter. Cormac, writing in the ninth century, gives in his Glossary an Old Welsh form Premter (see Pedersen, V. Gramm. § I 24. 6). Premderleith would be thus "Priests'ferry", and Pranderwyndes, "Priests'-lanes." "Priest" enters into many English place-names. For English words having exclusive parallels in Frisian and Dutch see Kluge in Germanische Philologie, vol. i, p. 793 ; Siebs, ibid., pp. 724-9, treats of Frisian and Northumbrian. 
unfortunate Tyrant (? Vor-tigern = Over-Lord) in three Cyulas, as expressed in their language, in our ${ }^{1}$ language, Longae Naves (i. e. long ships), and fixed their terrible claws at first upon the eastern part of the island, ostensibly as if to fight for the country, but in reality to assail it." Supported by further arrivals from the Continent the Saxons gradually encroached upon the Britons, and in a few years overran the country, probably only at first in marauding bands, "the eastern fire, heaped up moreover by sacrilegious hands, laying waste," as Gildas says, "the adjoining towns and country-an unceasing kindling-until consuming at length almost the whole face of the country from sea to sea, the flaming and fierce tongue was licking up the western ocean." Some of the natives, he says, were slain, or perished from hunger-while others gave themselves up to slavery or passed beyond the sea. ${ }^{2}$ At length the miserable remainder taking heart, and with Ambrosius Aurelianus, a man of Roman race, at their head, gave the invaders battle and obtained a victory over them. This was, as we gather, in 466 . "From that time," Gildas says, "sometimes the natives (Cives) and sometimes the enemy were the victors, until the year of the siege of the Badonic Mount [which was near the Severn mouth], the year of the latest and not the least slaughter of the Gallows-rogues; and the year which is now beginning, its first month having already elapsed, is, as

1 This is one of the proofs that the Britons had become in the main Latin-speaking under the Roman occupation of 400 years; "Nennius" also uses the Teutonic word Chiulas not only for the ships of the Saxons, but also for those of the Roman fleet. The Old English form was ceol, still used on the Tyne for a flat-bottomed boat (keel). Bede.(i. 25) employs the Latin term Longae Naves. The Welsh Llong, Irish Long = ship, was derived at an early date from the adjective. It gave rise in Irish to Longeas, a voyage, and Loingseach=voyager, sailor, now "Lynch", a personal name. Loingseach Ile ocus Arann in Chron. Picts and Scots, p. 99, is rightly translated by Skene, " mariner of Mlay and Aran."

2 This doubtless refers to the British emigration in the early sixth century to the Continental district called then Armorica; see later on where this subject is dealt with. 
I have discovered, the forty-fourth from that year, the year also of my birth." I Mons Badonicus has been placed by conjectures in various localities. All we know is that it was presumably east of the Severn mouth and high land. If the name survives I would suggest that it is preserved in Bown Hill. Badon would naturally become Bown, and the neighbouring Frocester and Woodchester indicate Roman ways accessible to the invaders.

Prosper of Aquitaine (A. D. 403-63) tells us, under the year 4 I3 (Mon. Germ. Hist., Chron. Min., p. 467), that "Pelagius Britto (that is, a Briton) ${ }^{2}$ put forth at this time the doctrine called after him (Pelagianism) against the grace of Christ, and that, aided by Caelestius and Julian, led many into his error. It was this Pelagius and his teaching which were the occasion of Britain's coming again into the light of history. ${ }^{3}$ For, as the same

1 This is my translation of Plummer's reading of the original (see his Bede). Some critics (Mommsen, for instance) regard as a later gloss the words "which was near the Severn month", but the passage represents in any case ancient tradition. Bownhill is one of a range bristling with formidable earthworks which seem to have owed their existence to the need of commanding the passages across the Severn mouth. Woodchester, which is close to Bownhill, is possibly the Kaer zudei of the Y'storya Brenhined, pp. 184, 204, 234 of Red Book of Hergest, vol. ii. Meugant was made Bishop of Caer Vudei, see excerpt from The Story of Arthur in Introduction to Early Welsh, p. 165, but although Dr. Strachan identified the other Caers mentioned therein this is not explained. Mommsen (Chronica III, Mon. Germ. Hist., p. 8) gives the date of the Epistola of Gildas as a few years before 547. The date of his birth and of the battle of Mons Badonicus is, according to both Mommsen and Zimmer, a few years before 504. Bede's date works ont about 499. The Annales Cambriae place the battle at 516 , The A.-Sax. Chron. records a battle between Wulfhere, King of Mercia, son of Penda, and Fscwine, King of the West Saxons, at Biedan Heafde in 675. This may refer to a second battle at Mons Badonicus given in Annales Cambriae under 665. Mr. Plummer makes Biedan Heafde to be Bedwin, Wilts., Bedvinde in Domesday, and seemingly Celtic.

2 Orosius (writing about A.D. $4^{\mathrm{I}} 5$ ) and St. Augustine (about A.D. $4^{\mathrm{I}} \boldsymbol{7}^{\text {) }}$ call him also a Briton.

${ }^{3}$ Earlier references to British affairs are to be found in the notices of St. Ninian (died A. D. 432), of Palladius (to whom Prosper of Aquitaine 
writer tells us, under A. D. 429, "Agricola, a Pelagian, the son moreover of a Pelagian Bishop called Severianus, corrupted the

refers under $43 \mathrm{I}$ ), and of St. Patrick, whose mission to Ireland is assigned to A. D. 43 2. Bede ( $H . E$. iii. 4 ), writing in A. D. 731 , states that "a long time ago, as it is maintained, the Southern Picts, having given up their idolatry, had received the true faith by the preaching of the Word through the most reverend Bishop Nynias, a most holy man of the British race, who had been fully instructed in the faith and in the mysteries of the truth at Rome; whose episcopal See and Church were distinguished by the name of St. Martin the Bishop, and in the place, which now the English hold, his body and those of many saints rest,- which place belonging to the Bernician province is now commonly called Candida Casa (Whitehorn-in Galloway), becanse he had there built in a manner foreign to the British, a church of stone." Alcuin (born at York A.D. 735, died Abbot of Tours A. D. 804), tutor of Charles the Great, also mentions Ninian in his epistles, and asks the intercession of St. Nyniga, and that of the monks, at Candida Casa, to whom he sends a silk veil for covering the relics of the saint (Usher, De Primord. Britt. Eccl., p. 669, and Haddan and Stubbs, Concilia, ii. 8). Alcuin mentions also, in his letter to the nobles of Kent (Haddan and Stubbs, Concilia, iii. p. 5I0), Gyldum Brettonum Sapientissimum. The life of St. Ninian, written by Ailred of Rievaulx (died I 166) is too late to be of historical value, but the traditional association of Ninian with St. Martin, who died about 400, helps to fix his date. The Anglo-Saxon Whitern (Whithorn) is a translation of Candida Casa=white house. In the Martyrology of Oengus it is "Futerna in the "Rinns of Galloway" (p. 2I2). "Futerna" is an instance of the difficulty to Gaelic lips of pronouncing the $w h$ (or $H w$ ) in Whitern. The substitution of initial " $\mathrm{F}$ " for " $W$ " was not nncommon also, after the eleventh century, in the dialect of Kent (Grund. Germ. Phil. i. 857). The "Rinns" are points of land jutting out into the sea. The ancient Irish form is Rind (masc.)=point, Rind (fem.) = Star (Pedersen, $V$. Gramm. p. 37). There is a further reference in the Martyrology of Oengus (compiled about A. D. 800) to a place in this neighbourhood called Dun-rechet, now probably Dunragit in Galloway, which may contain the name of the region of "Reged" referred to in Welsh tradition as imposed upon the district of Gower after having been presumably used elsewhere (in the North). Reged has been located (Celtic Scotland, i. I53) in the country near the mouth of the Clyde. The Welsh version of Geoffrey says Reget is another name for Murief (=Moray). Whithorn was also known according to Skene (Celtic Scotland, ii. 47), as Rosnat or Alba (white) and Magnum Monasterium. The evidence of this is strong, but not convincing. Roseneath in the estuary of the Clyde has an outward resemblance to Rosnat, and tradition assigns to it an ancient ecclesiastical importance (New Statistical Account, vol. viii), but it was, however, in 
British churches by the introduction among them of his teaching, and that, at the suggestion of Palladius, a deacon, Pope Caelestine sent German, Bishop of Autissiodorum (Auxerre in France), in his stead and guided the Britons, perplexed by heresies, into the Catholic faith" (Mon. Germ. Hist. ix, p. 472). In the Life of St. German (Surius, July 30 ), which was written by Constantius, a priest of Lyons, about A. D. 480 , this event is alluded to in different words. The Britons, according to Constantius, sent delegates to St. German, asking him to come to their aid, and after a Synod had been called, it was agreed that St. German, accompanied by Lupus, Bishop of the Tricassini (that is, Troyes in France) should go to Britain. They travelled through the Parisii (Paris), where St. German persuaded St. Genevieve, ${ }^{1}$ afterwards the Patron Saint of Paris, to dedicate herselt to God, and, setting sail from some port on "the Gallic Gulf", made for Britain. A violent tempest arising on the way, he calmed the waves, after invoking the Holy Trinity, "by pouring oil upon them," and reached safely the British coast. The heretical teachers, who are depicted as conspicuous by their wealth and splendidly robed, appeared, with great multitudes of the people, including women and children, before St. German, who proposed an open discussion, which was accepted. The heretics were beaten, and St. German, proceeding on his way back, stopped at Verulamium (as we have already said) to return thanks to God at the tomb of the Martyr St. Alban. The place of meeting was, it would thus appear, not very far from St. Albans.

a district called in early charters Nevet, and was doubtless originally Ros-nevet or the promontory of Nevet (representing possibly an older Nemet = sacred), which would become quite normally Neath.

1 From the fact that an early MS. of the Life of St. German, discovered at Paris a short time ago, does not contain this episode about St. Geneviève, it is inferred that the biography, as we have it, was edited in the sixth century, but it is reasonable to think that Constantius himself must have put together the details about St. German's visit to Britain in the absence of any motive for their later insertion. 
St. German was delayed on his return by a sprained foot. In the meantime news was brought that the Saxons and Picts were making attacks upon the Britons. St. German offered to lead the latter, and promptly assumed the command. It was the season of Lent, as Constantius tells us, and many were being prepared for Baptism at Easter. On the Feast of the Resurrection, after the celebration of the Holy Mysteries, and when many of the soldiers were still wet with the waters of Baptism, St. German guided them to victory. At the sound of the trumpet the whole army was by his orders to repeat thrice as with one voice, "Hallelujah!" the refrain, probably, of the Easter gradual. The effect was miraculous. The enemy, drawn up on the high ground preparing for the assault, were thrown into dismay by the unfamiliar sound reverberating among the hills; casting down their weapons, they fled naked away, many being drowned in attempting to cross a river in the neighbourhood. This was the celebrated Hallelujah Victory, which, recorded by Bede (i. 2), almost in the words of Constantius, occurred about A.D. 429. It is clear that the Britons whom St. German encountered were Romanized. Their ecclesiastical representatives at the great meeting are conspicuous by their riches, and splendid in their dress! There is no need, it would seem, of an interpreter. St. German can discuss the subject of prevenient grace in a language known to the witnessing thousands. The locality is in no remote corner of the island, but in the centre of its civilization. Welsh historians are sometimes inclined to appropriate to themselves all historic references to the insular Britons, and they have

1 The editor of the Monumenta Historica Brittaniae, p. 127 n., quotes from St. Gregory the Great a passage in his Commentary on Job (Lib. xxvii. 6 [should be 8]), which seems to refer to the incident, "Behold," says Gregory, " the tongue of Britain which had known only to gnash (frendere) barbarously has now for a long time begun to sound forth in divine praise the Hebrew Alleluia." Loth (L'Émigration Éretonne, p. 43) cites a passage from the Acts of S. Melanus, edited about the time of Gregory (died 606), echoing Gregory's expression-"frendentium ... Britonum". 
even placed the scene of the Hallelujah Victory in the Welsh hills, at a place near Mold, called Maes Garmon, which they would translate "German's Plain". Picts and Saxons, however, were not accustomed to seek for booty in barren mountains, and, as we have seen, had some sixty years before got as far south as London and invested it.

Constantius tells us of a second visit to Britain made by St. German about the year 447, accompanied this time by Severus Bishop of the Treviri (that is Treves). This was the year before St. German's death, who passed away at Ravenna in the year 448 .

The year after the death of St. German brings us to the traditional date (A.D. 449) of the beginning of the settlement of Teutonic tribes in Britain. The date is very uncertain, but Bede, calculating from the time (the third Consulate of Aetius= A. D. 445) when the Britons made their last appeal for help to Rome, makes the date of their arrival 449. "In the year", he says, "from the Incarnation of Our Lord 449 ... people of the Angles and Saxons, invited by the fore-mentioned king (Vortigern) were borne to Britain in three long ships, and had assigned to them by the same king a settlement in the eastern part of the island"1 (Hist. Eccl. i. r5). The main fact is

1 This settlement is more definitely described in the Historia Britonum of Nennius, which records the arrival in Britain of three Ciulae, with Horsa and Hengist on board (using the same Tentonic word ( $\mathrm{CeOl}$ ) as Gildasa word not found in Bede or in the Anglo-Saxon version of his Historia Ecclesiastica). The writer adds that Guorthigern received them with kindness and that he handed over to them the island, "which in their language is called Tanet, but in British speech 'Ruoihm'." The variations of this name in the MSS. suggest a form "Ru-oichim", which seems to contain the same $R u$ we find in Ru-tupia (Richborongh), representing possibly an early Pro (Umbrian Prue) as in Pro-montorium of which the North Foreland preserves the idea; see later note on Regulbium. Tanet (Thanet), which appears in a charter A. D. 679 as Tenid (Sweet's Oldest Eng. Texts, p. 427), is associated by Holder with the Celtic word for fire, in Irish Tene, genitive Tened, Welsh and Cornish Tan. It may, however, involve the term Tann = in British "oak" (cf. Welsh Glastan=oak, and the early forms of the name for Glastonbury, Glastenec, according to 
borrowed from Gildas, but the name of the British king, Vortigern, and the mention of the Angles seem to be an addition. ${ }^{1}$ Bede goes on to say that the assignment of a place of settlement for the new-comers, together with the payment of stipend for military service, was conditional on their fighting against the adversaries of the Britons, that is, the Picts and Scots. The new-comers, Bede says, belonged to three of the stronger peoples of Germany, namely, Saxons, Angles, and Jutes, of

Mr. E. Phillimore, Ann. Camb., from an eleventh century MS. in Cymmrodorion Mag. vol. ix). A Tannetum appears in Gaul (eighth century) and is now represented by Tannois on the Meuse. Tannenbaum in German = Fir-tree. The word survives in the English, Tanner, Tan-yard, \&c.

1 Mommsen, the latest editor of Gildas (Mon. Germ. Hist., 1894), does not give the name of Vortigern in the text which he adopts. As he is aware that this name occurs in the oldest MS. of Gildas (Avranches MS. of twelfth century) and also in the Cambridge MS. of the thirteenth century, it is clear that he regards its appearance therein as the result of interpolation. $\mathrm{He}$ is, in fact, inclined to believe, as against Zimmer in his Nennius Vindicatus, that Bede took the names of "Vortigern", "Hengist, and Horsa", and other items from the original form of the Historia Britonum, known later under the name of Nennius. Mommsen is disposed further to ascribe this original form to an unknown author writing in the seventh or the beginning of the eighth century. (See Mommsen's edit. of the Historia Britonum, pp. II5, I 7, I32.) Zimmer, whose Nennius Vindicatus (Berlin, 1893) is a masterpiece of scientific criticism, thinks that Nennius was the real author of the Historia Britonum, and that he compiled it in South Wales in A. D. 796, from several sources, and that it was afterwards edited by another writer in North Wales, about 810 (see $n$. p. 152). He thinks that Bede did not borrow from it, nor that it was indebted to Bede. As it has been shown by Dr. Whitley Stokes in The Tripartite Life of St. Patrick (Rolls Series) that excerpts from the Book of Armagh-a work copied by a scribe in the year 807 , from MSS. that were then faded from age-appear in the Historia of Nennius, one would natnrally assume that the latter was compiled subsequent to that date: but some of the ancient sources of the Book of Armagh may have been accessible to the writer of the Historia Britonum at an earlier time. Zimmer shows, indeed, that other Irish originals furnished material for Nennins. The earliest MS. of the Historia Britonum is that of Chartres, in France. It was made from an imperfect copy in the ninth or tenth century. There are also several MSS. of an Irish version-one of them, containing a fragment only, which seems to have been written about A. D. IO72. Nennius, following Prosper of Aquitaine, mentions the mission 
which the first, subdivided later into East Saxons (Essex), South Saxons (Sussex), and West Saxons (Wessex), took their origin from the Old Saxons on the Continent.

The historical events connected with the landing of the

of Palladius to the Scots; and Bede, i. $\mathrm{I}_{3}$, states the fact (from the same source) that Palladius was sent (abont A. D. 43I) by Pope Caelestine to the Scots believing in Christ. Bede seems to know nothing of St. Patrick (whose mission to Ireland is ascribed to $43^{2}$ ), and as Nennius furnishes in the Historia considerable biographical details borrowed from Irish sources as to the Apostle of Ireland, it seems clear that Bede had not this part of the Historia Britonum before him. St. Patrick, as we learn from the Book of Armagh and other early sources, was a Briton, born at a place called Nemthnr, which an eleventh-century annotator (the scholiast on St. Fiech's Hymn in the Liber Hymnorum, Henry Bradshaw Soc.) makes to be the same as Ail-Cluade (Dumbarton); this is the Alcluith of Bede, $H$. E. i. I, which he properly translates Petram Cluithe or "the rock of Clyde". His father Calpurnius, who was a Deacon and a Roman official, belonged to a place called "Bannavem Taberniae", not far from "our" (that is, the Irish) Sea, which is confidently identified by one of St. Patrick's ancient biographers with Nentre (or Ventre, as the Brussels MS. has it), a name appearing in the Life of St. Patrick by Probns (tenth century) as Nentria, and seemingly a reflection of Nemthur. Mr. Nicholson (Bodley's Librarian) from these particulars assigns the British home of St. Patrick to Daventry-which beside being close to the Bannaventa of the Itinerary of Antonine (which he equates with Bannavem) has "Ventry" still in its construction. This is an ingenious speculation, but lacking in probability. We have records of more than one Bannaventa. In the Life of St. Cadoc given in Capgrave's Nova Legenda Angliae (London, 1516, or Oxford Press Reprint), that saint is said to have been transported on a clond from his monastery at Llancarvan ("three miles from Cowbridge," says the Life), to the city of Beneventa. In the Life of this saint current in Wales (Cambro-British Saints, by Rees), Elli, the successor of Cadoc at Llancarvan, is said to have made frequent jonrneys to Beneventa, which could not have been far away; but see previous note on Venta. Professor Bury, in his St. Patrick, is inclined to look for Bannavem Taberniae somewhere near the Bristol Channel.

"The foot of the River Severn" might be expressed and pronounced in modern Irish as Bun-an-Taberna, or Bnn-aven-an Tabern-a. The initial S of Sabern would be eclipsed after the $a n$ by T. This eclipsing is as old at least as the Book of Armagh (A.D. 80\%), where we find in the Life of St. Patrick don T(s)aball=" to the Saball" or Barn, now Saul in the County Down (see p. 254). The familiar names MacIntyre and MacTaggart 
Teutonic tribes in Britain in the fifth century had been thrown, long before Bede's time, into a Saga-like form, so that, as Professor Kluge ${ }^{1}$ says, it is not possible to obtain a trustworthy picture of them. The names of the two leaders as given in Bede, as well as in the Saxon Chronicle and Nennius, cannot well be regarded as historic. They belong rather to the mythical period reflected in the earliest poetry of the Continental Germans. In the Anglo-Saxon epic of Beowulf ${ }^{2}$-which,

are for Mac-an T(s)air (of which we have the form Mac-in T(s)air = "son of the Carpenter (Sair)" in the Martyrology of Oengus, ninth centnry), and Macan T(s)acerd = son of the Sacerdos or priest. Bun (genitive Bona) is cognate with the German Boden, English Bottom (for Botten), and Latin Fund$u s$, and is frequently used in Irish with the names of rivers to signify their issue into the sea, e.g. Bun-doran, Bun-drowes (the Bun-drobhais of the Book of Armagh), Bun-an-dall, cf. Bunchrere, Inverness. If we adopt Bannavem = Bannaventa (i. e. "chief market", cf. Ban-Chor=Bangor), the term Tabernae seems likewise to come from Sabern (Sabrina), which in Welsh is and has seemingly always been Hafren, or Habern. Thurneysen shows (Handbuch des Alt-Irischen, p. 139) that eclipse of an initial consonant, as here (" $t$ " eclipsing " $s$ "), occurred after all words terminating in $-n$ (=Indo-European $-m)$. The same is the case after the definite article int. "Bannaven(ta) Taberna" would in early Irish represent the Bannaventa of the Severn, or principal Chepstow, thereon. Glastonbury (called, Lib. Hymn., H. Bradshaw Soc., i, p. 103, in the ninth century "Glastimber of the Goidels," i. e. of the Irish) is not far away from the Severn estnary, and St. Michael's Tor, as far as signification goes, may represent Nemthur $(=$ Heaven-Tor or Temple Tor $(N e m=$ heaven : Nemet $=$ holy : and Nemeton =temple), St. Patrick's birthplace. In Die Heiligen Englands, p. I7, there is the entry in AngloSaxon, "there rest S. Aidanus and S. Patrick in Glastingabyrg, and many other Saints," see Note G. on Glastonbury. We have thus a site satisfying Professor Bury's requirements and, as the Bristol Channel was an early harrying place for Irish pirates, a locality whence Patrick might have been carried off. The transfer of the second legion from Caerleon to Rutupiae about the end of the fourth century would enconrage these piratical expeditions in the Bristol Channel. There were certainly no Roman legions in Dumbarton in the early years of the fifth century.

1 Geschichte der englischen Sprache in Paul's Germanische Philologie, vol. i, p. 782 .

2 The poem of Beowulf is contained in an unique MS. in the British Musenm. It suffered some damage from the fire at Ashburnham Honse in 1731 , but was photographed in 1883 by the Early Eng. Text Soc. The story is mainly taken up with the exploits of the legendary hero 
according to B. Symons, belongs in its earliest shape to the seventh century - a certain Hengist is mentioned who plays also an important part in the poetic fragment known as The Battle of Finnsburg. But this warrior met his death on the Continent, presumably at the hands of the Frisians, to whom he was opposed. Bede's genealogy of the brothers Hengist and Horsa goes back, like those of the early English kings generally, to Woden, but Nennius traces the genealogy higher than Woden, and enumerates earlier ancestors, some of whose names appear in Beowulf. Folcrvald, one of these, is given by Nennius, and it is remarkable that it is found associated with a certain Hengest in Beowulf, and that it occurs also in the Anglo-Saxon poem of Widsith (that is, Wide-wandered), which Symons regards as the oldest and most important monument of early Germanic epic poetry. ${ }^{1}$ It seems clear, therefore, that Hengist and Horsa were

Beowulf, who destroys a devastating demon called Grendel, and also slays a fiery dragon at the cost of his own life. Beowulf was one of the Geatas, whom Symons identifies with the Jutes (Germ. Philol. ii. 2I), from which people he thinks the poem found its way into England, where, with many additions, it was sung, according to him, as early as the sixth or seventh century. Symons sees in place-names of the tenth century, such as Grendeles mere (Wiltshire), Grendles bec and Grindelespytt (Worcestershire), evidence of the popularity of the Saga in this country; but may some, if not all of these involve Grundleas = bottomless? The episode of the death of Hygelac is historic, Chochilaicns (Hygelac) being slain by Theodebert, King of the Franks, on the Lower Rhine, somewhere about A. D. 520 , of which event Gregory of Tours (Hist. Franc. iii. 3) gives us an account.

1 Bishop Leofric, after the removal of his See from Crediton to Exeter, placed in the keeping of the Cathedral Chapter there, about A.D. 1050, a mycel Englisc boc (a large English book), which still remains in the custody of that body. It contains the Widsith (called also "the Traveller's Song "), besides some other pieces of Anglo-Saxon poetry. The Wídsith is, as Ten Brink calls it (Paul's Germ. Philol., ii, p. 538), the earliest English poem, and its importance both in regard to the names and distribution of Continental peoples in the epic period, and to our knowledge of the sources of the Sagas, has been accentuated by several recent scholars. The lists of the kings renowned in Saga and of the nations which the Wanderer visited carry us back to a period not later than the sixth century, and possibly in several instances to a much earlier time. Nennius makes 
not real personages, but names imported most probably from Sagas current in the ancestral home of the invaders. Such place-names as Hinksey in Berkshire and Henstridge in Somerset, which appear in the Charters respectively as Hengestes-ige and Hengestes-ricg, can have nothing, therefore, to do with the mythical leader, but are formed from Hengest (in Anglo-Saxon, Stallion); and the numerous compounds of Hors (neuter nominative for "horse", genitive plural, Horsa), such as Horsham, Sussex, Horsley (Horsaleah), Surrey, Horsfall (for Horsafald= Horse-fold, compare Studfall=A.-Sax. stódfald, that is, a fold of horses, \&c., \&c.), need no further explanation.

The place of landing of the invaders, according to the Saxon Chronicle, was Yproines fleot. It is manifest that this name belongs to a later period, when some Jutish settler had succeeded in imposing his own personal name upon the fleet or creek that served his homestead. There were, in early times, many similar associations of fleet with personal names in England, such as Hudan-flét (=the fleet of Huda) in Kent, and Wilbaldes-fleot in (?) North Hants. The first syllable of Yp-wine is connected by Ettmüller (Lex. A.-Sax. 35, 39) with the Eop in Eoppa (compare Eormenlaf and Yrminlaf in Beowulf), a name of which we have many examples in Anglo-Saxon documents. Eoppa is, indeed, a contracted representative of some such full name as Eop-wine, ${ }^{1}$ and is found also written Eobba (Searle's

Hengist and Horsa the fourth in descent from Woden, from whom the ascending line of ancestry proceeds as follows:-Frealaf, Fredulf, Finn, Folcwald, Geta. Henry of Huntingdon follows Nennius here and in many other places. The Saxon genealogies-see the list given in Grimm's Teutonic Mythology (Stallybrass's ed.), vol. iv, pp. I 709 et seq., and also Plummer's Saxon Chron., ii, pp. I-6, substitute for Folcwald throughout Godwulf. It is suggestive of the origin of these names that they are given in the alliterative way of $A$.-Saxon poetry, e.g. Hengist and Horsa, Frealaf and Fredulf, Finn and Folcwald, \&c.

1 Professor Fick has shown (Die Griechischen Personennamen) that the normal form of personal name among early Aryan peoples (with the exception of the Latins and one or two others) is made up of two significant words joined together, according to the rules of composition. As we are 
Onomasticon, p. 228 ), which, as far as form goes, might well be the antecedent of the Ebbe in Ebbsfleet in the Isle of Thanet, the locality regarded traditionally as the landing-place of Hengist and Horsa and of Augustine.

The possibility of Ebbs-fleet being a survival of Ypwines fleót is not an altogether convincing argument as to their identity. An assumed intervening form preserved in the Life of St. Mildred (Capgrave's Nova Legenda Angliae), Ypples fleet (in

concerned here with only the Tentonic branch it will be sufficient to cite such familiar instances as Ethel-beorht, Ethel-wine, Ethil-zvald, Ethelfred, Ead-bald, Ead-mund, Hyge-bald, Sige-zuulf, \&c. These names, subject to ordinary wear, became in certain instances shortened; thus, to take English instances, Ethelfred became EElfred and finally Alfred. But there was another process at work upon them which led to forms departing considerably from the originals. It was customary in familiar speech to condense the compound name by omitting one or other of its elements, doubling sometimes the final consonant if there be one, and appending the vowel $e$ or $a$. The contraction sometimes preserved the final consonant of the second element, as Ceolf for Ceolwulf. Thus an Eithel-fred might become Ell-a, or Allfwine might also become Ella, as we see in the instance of Alfwine, Bishop of Lichfield in the tenth century, who was also called Elle, and Edwin called Eda by Simeon of Durham, and Ead-bald, Ead-a or Eadda (the Frankish equivalent being Aud-o, of which Odo (Otho, Otto) is another Continental form). Hygebald would naturally become Hygge or Hngga (still represented in the genitive form as Huggs, Hucks and Hicks). Of Sigeborht the diminntive wonld be Sigge or Sigga (Sigge still existing in the genitive as the surname Sykes, variant Six). The first historic account of this shortening of the personal name is found in a Latin writer of the beginning of the fourth century, Flavius Vopiscus, who, in his Life of the Emperor Aurelian, gives the name of a leader of the Goths as Cannaba for Cannabaud, i.e. Cannabald. The process is seen exemplified clearly in the Anglo-Saxon charters, where the signatures are sometimes made with the full name and sometimes with the shortened form. It is important to keep this shortening in mind when dealing with Anglo-Saxon place-names, numbers of which involve personal designations in their contracted form, as, for instance, in the Hutan flebt cited above, where Huda is a shortened personal name (cf. Huda, the leader of the Surrey men in A.D. 853: A.-Sax. Chron. under this year). On this principle Eoprwines flebt would naturally become Eobbes-fleet, Ebbes-fleet. An instance of a contracted name formed from the second element in the full name is given in "Bugga", the pet appellation of St. Eadburga. 
Thorp's Diplom., p. 34I, Hyppelesfleote), does not clear away the difficulty. It was the port in the Isle of Thanet at which St. Mildred landed from France, and presumably not far from her Monastery, "Minster," but its form suggests another origin than Yp-reines-fleot. The contracted personal name involved in it ought to have contained, in its original form, an " 1 " in its second element, such as -laf, -roulf, -wald.

But, we may ask, where did the scribe of the A.-Sax. Chronicle get his Yproines fleot? Bede does not mention it, but simply repeats the words of Gildas that the three long ships came to the eastern part of the island. Nennius gives no further particulars except the statement that the Island of Thanet was assigned by Vortigern to the new-comers. When we come to think that the earliest scribe employed on the most ancient existing MS. of the Saxon Chronicle (for there were several) ended his work some 250 years after the time of Bede, the chance of the survival of the name of the landing-place in popular tradition is very remote. And when we further consider that the new-comers did not land as enemies, but were received as guests by the British king, it seems more natural that they should have landed at the recognized port of the region, Rutupia, ${ }^{1}$ within whose strong walls Vortigern had presumably taken up his position. The Romans had made this for years, as we have seen, their British landing-place, and there is no evident cause why another port should have been chosen. It was an island on the Wantsum, ${ }^{2}$ and was probably regarded as a part of

1 Rutupia by metathesis had become, by the time of Bede, as has been shown, Repta or Reptuceaster, as if contracted from Rupitia, and in the time of Thorn, a monk of Canterbury (fourteenth century) had been further degraded into Rates in Ratesborough, which finally became Richborough.

2 The river Wantsumu of Bede is evidently a Teutonic name, and, as he says, it was fordable or passable in two places, it is natural to assume that it took its name from this circumstance. That is, while the northern branch of the Stour was not fordable, this was Want-sum; made up of Want, or its modem dialectic equivalent $W e n t=W a y$ (cf. the "Four Wents "), and sum having the same qualifying force as it has in winsome, 
Thanet. The whole region has been so much altered physically by the upheaval of the littoral and the blocking up of the river by sands that, as Professor McKenny Hughes, writing on the assumed landing-place of Augustine, suggests, it is impossible to obtain an accurate mental picture of what it was in the fifth century. All we can say with any approach to accuracy is that Thanet or its immediate neighbourhood was the place of landing. The Chronicle adds, under the year 449, that the new-comers were called upon to fulfil their engagement by contending with the invading Picts and Scots, over whom they gained a victory. Henry of Huntingdon tells us, preserving as Mr. Plummer thinks (A.-Sax. Chron. ii) a bit of local tradition, that the enemy had come as far south as Stamford.

Trustworthy materials for the history of the early stages of the Teutonic invasion of Britain are not to be found anywhere. The period between A.D. 449, the alleged date of the arrival of the invaders, and 597, when St. Augustine landed in Kent, is, so far as recorded events are concerned, covered by uncertain traditions only. Bede furnishes, as we have seen, no other information than is to be found in Gildas, and we have to look to Nennius's History of the Britons and to the Anglo-Saxon Chronicle for any further information on this period.

In Nennius we find an absurd story about Vortigern's movements. The British king, under pressure of the enemy, is represented as having consulted his magicians (Druids in the Irish version), who advised him to proceed to the extreme limits of his kingdom in search of a stronghold where he might defy his foes. After devious wanderings Vortigern arrived at length in Guened ${ }^{1}$ (i.e. Venedotia or North Wales), and there discovered

that is, equivalent to -able in lovable. The stem $V a n d$ is represented in all the Teutonic languages. A tributary of the Yar near Norwich is still called the Wen(t)sum: -sumu, the form of the termination in Bede, occurs as an oblique case of sum in the Blickling Homilies.

1 This word (now Groynedd) is connected by Pedersen (Vergleich. Gramm. der keltischen Sprachen, i, p. 106) with Irish Fine = relationship. He cites the Old Breton co-sruenou glossed indigena and connects it with 
on one of the hills of the Snowdon group (montes Heriri=Eryri =snow) a site for his citadel. In his attempt to build this, as Nennius tells us, the materials were supernaturally removed as fast as they were accumulated. Vortigern, inquiring of the magicians the reason of this, learned that he would never succeed in his endeavour until he had found a youth without a father and, slaying him, had sprinkled the foundation with his blood. This youth, according to the narrative, was "found at the field of Elleti (cf. Maes-Aleth of Myvyrian Arch.) which is in Gleguissing", and turned out to be Ambrosius, the successful leader of the Britons against the Teutonic invaders, of whom Gildas gives the account already furnished.

Ambrosius (who afterwards became the Myrdin (Merlin) of Geoffrey of Monmouth) was brought to the king, and convicted his magicians of ignorance, by showing that under the proposed foundations of the stronghold there were a lake and, at the bottom of the lake, two vessels (dishes are probably meant) with a folded-up tent between them. The tent contained a red and a white worm asleep, which began a contest, ending, after seeming defeat of the red worm, in the expulsion of the white worm into the lake and the disappearance of the tent. This is made by Ambrosius a picture of the result of the conflict between the British and the Teutonic invaders. The red worm, he tells the Old High German Wini, Anglo-Saxon Wine=friend, and Latin venia = indulgence, Venus and English wont. Groynedd would mean, therefore, "Related people" just as Combroges (= Cymry) means "fellow countrymen".

1 Gleguissing, or Glegwisic, embraced Glamorgan, Monmouth, and part of Hereford, all of which territory was at the time, as we learn from contemporary inscribed stones (Ogams), in the hands of the Goidels or Irish Celts. Sir John Rhŷs (Journ. R. Soc. Antiquaries, Ireland, 1902) tells us that there are over thirty Ogam stones in South Wales, one in North Wales, and five in Devon and Cornwall. These are ascribed to the fifth or sixth century. A large portion of Wales was occupied by Goidels until the arrival of "Cunedda and his sons" from Strathclyde about the fifth or sixth century. The latter were the Cymry $=$ Cum-broges, or fellow countrymen, that is, the linguistic ancestors of the Welsh people of the present day. 
king, represents the Dragon ${ }^{1}$ of the British and the white worm the Dragon of the foreign people, who having already occupied the greater part of Britain, will hold it almost from sea to sea, but that afterwards the Britons will drive the Angles across the ocean. Vortigern thereupon gave Ambrose a citadel, together with all the kingdoms of the western side of Britain, while he himself with his magicians proceeded to the north to a region called Gunnesse, where he built a city called, after himself, Caer Guorthigirn. ${ }^{2}$

1 The purple Dragon, as we learn from Ammianus Marcellinus, was the Roman Imperial Standard. He describes (Bk. xvi. 39) how Caesar was recognized in the battle by the purple standard of the dragon which, fixed to the top of a long spear, fluttered in a state ragged with age. The legendary father of Arthur is called Uthr (? = Victor) Pen-dragon, that is, "chief dragon." Geoffrey of Monmouth represents Uthr and Aurelius Ambrosius (Merlin) to be sons of Constantine, the usurper of imperial authority in Britain about 407 , previously referred to. The symbol of Roman Imperialism thus lived on after the Romans had left Britain, and survives to-day as the title of the Tudor Pursuivant, "Rouge Dragon": compare the Griffins in the Tudor arms. In Barbour's Bruce (vol. ii, 205, Eyre-Todd's edition) "raise the Dragoun" is made to mean raise the devil, but it is evidently the Dragon-Standard. At the battle of Lewes (1264) the king's troops, according to Reshanger, marched to battle "Expansisque vexillis, una cum signo regis indicem mortis praecedente, quod draconam vocant, progrediuntur".

2 One or two later MSS. add, "built there the city Guasmoric near Lngubalia (Carlisle), called in English Palme Castre. We have here probably the source of a name occurring in Welsh history; "After Meuric had gained the victory (over Rodric, King of the Picts) he set up a great stone as a token of it in the country called from his name Westymar, but in Welsh Gwysmeuric." This is taken from the Welsh of the Historia Regum Britanniae of Geoffrey of Monmouth. In an early form of this history the stone is said to have been put up at "Westymer, that is in Cymric Gwys Veuruc" (Red Book of Hergest, a MS. of the fourteenth century, ed. by Rhŷs and Evans, vol. ii, p. 99). The Brut of Layamon (thirteenth century) repeats in verse the same incident :-

"Up he sette thæne stan . . .

And hehte (called) thene stan Westmering."

Geoffrey of Monmouth makes Meuric into Marius, calling him the son of a certain Arviragus, a contemporary of the Roman Emperor Vespasian (A.D. 69-79), and names the province where the stone was set up "West- 
Guorthemir the son of Guorthigirn fought valiantly in the meantime, Nennius goes on to tell us, against Hengist and Horsa, and drove them and their people into the island of

moreland". All this shows how history has been eked out by fanciful etymologies. West-more-land, or rather West-mere-land, means what the several components of it signify, that is, the "west lake-land": Gwas-moric or Gwys-menruc may possibly represent in British speech the original name of the district, a name similar in import to lake-land or lake-settlement (Celtic mor, cognate with mere = sea). "Gweis" is given in Davies's Dict. Brit. Lat. (1632) as an obscure word with the doubtful signification of "tent". Some light is thrown upon its meaning by its occurrence in Asser's Life of Alfred in the Welsh designation of Dorset. "In the district which is called in British Durngueis but in Saxon Thornsæta", thus the sixteenth-century transcript of the lost MS. reads. Mr. Stevenson's effort (Asser, 49, 7) to make gueis a misreading for gueir, which he would equate with the varia in Durno-varia (the name of Dorchester in Roman times: Dornwarana Cester in Cart. Sax. ii. II9), is not satisfactory, inasmuch as the Roman name of the district was Duro-triges and not Durno-varia. Is this to be read "Durot-riges" or "Duro-triges"? In favour of the former we have (Pedersen, § 26. 4) Old Cornish Darat $(=$ ? Dorot $)=$ Door. Sir J. Rhŷs adopts the latter (Celt. Brit. $^{3}$, 301). Gueis is probably the British equivalent of the Irish feiss, which Stokes (Worlschatz der keltischen Spracheinheit) derives from a Celtic stem vest $i=$ settlement or residence, cognate with Sanscrit vastu or Greek astu, cf. OHG. Wist = Mansio. The change of $-s t$ final into $-s$ is normal, Welsh Rhos ( = Moor) had originally a final $-t$, as had Glas (= Green) Pedersen, Vergl. Gram. $\S 49.5$. It would thus have the same meaning as the Anglo-Saxon sata and the Celtic -triges. Durn-o varia, as will be explained later, may possibly have been the native name for the Roman amphitheatre-Durn $=$ Fist, and Varia $=$ theatrical plays. The form of the latter word (in this sense) was in late Cornish guare (as in Plain an Guare Cornwall) and not gueir as assumed by Mr. Stevenson.

This throws light on the passage in Asser (i. I8) in which from an assumed Saxon Gewis "the Britons name all that people Gegunis". In the eleventh-century MS. of the Annales Cambriae this word is given as Givoys, and in the Brut Tywyssogyon as Iroys. In the district Gleguissing (Glegwisic in previous note) in Nennius (which embraced that part of Herefordshire called Ewyas) we seem to have the same designation, coupled with a prefix serving the same purpose possibly as Gwlat in Gla-morgan = Grolat (or dominion of) Morgan. Ewyas seems thus a survival of the Giuoys of the Cambrian Annals, having lost its initial " $g$ " in quite a normal manner. Mr. Stevenson says (Asser, p. 16I) of Iroys (in Red Book of Horgest, 260) that this form shows that the name 
Thanet, whence being helped by further troops from Germany, " they afterwards fought against the Kings of our people, sometimes being successful and extending their limits, and sometimes being overcome and expelled." Guorthemir, Nennius tells us, was successful in four battles, of which he records the names of three. The first was at the river Derwent, "the second at a ford which is called in their (that is, the enemy's) language Episford, but in ours Rithergabail, and there fell Horsa, together with the son of Guorthigirn, whose name was Categirn (=Catutigern, battle-lord or general). ${ }^{1}$ The third battle was in the field near the Stone of Inscription (lapis tituli) on the shore of the Gallic sea." The Anglo-Saxon Chronicle, under the years 455,457 , and 465 , records three battles in which the victory is claimed for the invaders. The first of these, which is seemingly identical with the second of Nennius (Episford), is thus given: "Hengest and Horsa fought against Wýrtgeorn, the King, at the place which is called Egelesthrep and his brother Horsa was slain, and Hengest after this obtained the

was of English origin, for the OE. $\delta$ was a spirant, and hence could be written $i$ when followed by a palatal vowel as in this case, whereas later Welsh $g$ was a stop (like $g$ in God) in such a position. It is significant, in confirmation of my assumption, that Geoffrey's "Octavius dux Wisseorum" is in the Welsh Ystoria Brenhined "Eudaf Earl of Erging and Ewyas", where Erging represents the Erchen in Erchenfield, and the Areconium of the Ant. Itin. The "Gewissi" wonld thus mean in the British tongue simply "settlers", as opposed to the indigenous inhabitants, and there is no need to seek a Teutonic etymon for the name, or to connect it with a certain mythical Gewis of the Anglo-Saxon genealogies or a similar eponymus form in Welsh. The Gunnnesse of the text looks like a mis-reading of some such form as Gervisse, reflected in the Gwas of Gwas-Moric. The twelfthcentury Irish version reads Gunnis, and $u$ is easily mistaken for $n$ in transcribing.

${ }^{1}$ Holder cites an old Cymric Cato-tigirni (= Catu-tigernos). The Cadegyr of the Welsh Triads is probably the Categern of the text. The Middle Irish Ceitern, which survives in Shakespeare's "Kernes and Gallowglasses" (Macbeth, I. ii-cf. 2 Hen. VI, Iv. ix and Rich. II, II, i), is a cognate word. Catu ( = battle = Anglo-Saxon headu) occurs in many Celtic names, e.g. Cat-walader, Duno-Catus (now Duncan) $=$ "fortress warrior", \&c. 
Kingdom, and Æsc his son.” Ægelsthrep has been identified by common consent with Aylesford.

Egels-threp is made of some such personal name as Ægelwulf contracted into Ægel (Ail) and -threp, which is probably a dialectical form of $t h r o p=$ thorp. There is no need to adduce an Icelandic form to explain it, as Mr. Plummer does (A.-Sax. Chron. ii. ro), for Thorp is found in the Continental home of the Jutes (see Outzen, Friesisches Glossarium, 352) as Terp, which by normal metathesis or transposing of the " $r$ " becomes trep or threp. The battle which Nennius calls Episford looks like a reminiscence of Ypwines or Eopwins fleet, but from its British equivalent is evidently a reminiscence of another and later fight, as we shall see.

Bede had possibly Aylesford in his mind when he wrote (Hist. Eccl. i. xv) that Horsa, who fell in the battle, had his monument "in the Eastern part of Kent". Mr. Plummer is inclined to think that the flint-heap at Horstead is this monument, and that Kits Cotty-house, which is in the neighbourhood, marks the resting-place of Categirn, also slain, according to Nennius, in the fight. Both these guesses are unsupported by satisfactory evidence, for Horstead is capable of another and natural interpretation which has nothing to do with any hero of the Sagas, and Kits Cotty-house is clearly a cromlech belonging to a much earlier age.

The British name of Episford, "Rithergabail" according to the best text of Nennius, is suggestive. It seems to be made up of the British Rith ${ }^{1}$ (possibly a dialectic form of Rit as in Augusto-ritum $=$ ford), and er-gabail, representing possibly a Cymric form of a river called Gabail with the definite article ir or the preposition $a r(=$ upon) prefixed. The variants,

1 Rit would normally become Rhyd in later British. The rith here, evidently intended to be a translation of the -ford in Episford, is, therefore, possibly a dialectic form, or incorrect. Rither is still more probably the equivalent of the Ancient Welsh Reatir glossed "Torrents". This is in Modern Welsh Rhaiadr = Waterfall. It is cognate with A.-Sax. Rith $=$ Stream (Pedersen, V. Gramm., §46). For Gabail see next page. 
some of which mistake the initial $R$ of the "Rith" for an $S$ (a common nistake owing to similarity of form in the writing of the time), give Sith en- or ena-gabail, showing that the Southern British definite article an may have been in the original word. Gabail is probably a British form from the stem Gabalu = fork, of which the A.-Saxon equivalent was Geafl or $G a f o l$, and was seemingly applied to the fork of a river. There were several British rivers so called (probably from a "fork" or confluence), e. g. that at Biggleswade, where North-hill and South-hill parishes preserve, in their second syllable, the early Ivel or Gevil. ${ }^{1}$ The Il of Ilchester, formerly Ivel-Chester, represents an earlier Gevil (= earlier Gabal) which appears also in Yeovilton (Gavylton, Cal. Chart. Rolls, ii. 404) and it was this river, and not the Camel, as is generally assumed, that gave its name to Gafol-ford, where a battle took place in A.D. 825 (A.-Saxon Chron. under 823) between the English and the Cornish Britons. The Rith-er-gabail may be, as far as the meaning is concerned, identical with Gafol-ford, and thus a reminiscence of this battle and not of that at Aylesford.

Two years after, that is, in 457, according to the Saxon Chronicle, occurred the battle of Crecganford in which Hengest and his son Asc (= Ash, or, metaphorically, "ship") "fought against the Britons ... and there slew four thousand men: and the Britons then forsook Kent, and fled with great terror to Lunden byrg" (London). As the river Cray (Crecga) falls into the Darent (Derwent) close to Crayford (Crecganford) this battle is evidently that called by Nennius the battle of the Derwent.

The third battle, according to the A.-Saxon Chron., was fought in 465 at Wippedsfleet, which, as the Britons had been driven out of Kent, could not have been in that county.

1 The district called Gifla (genitive plural in the tenth- or eleventhcentury list of Anglo-Saxon territorial names, Cart. Sax. i, No. 297) seems to preserve this Gifl. 
Wipped would be quite a normally contracted form of Wigbed, made up of Wig, victory, and beadu= battle. An inverted combination of this name appears as "Bedwig" in the genealogy of Woden (A.-Saxon Chron., A.D. 855), which is, as would appear from the variant Beowi, identical with the original hero of the poem of Beowulf. The third battle of Nennius at the "stone of inscription on the Gallic sea", has no seeming connexion with that at Wippedsfleet. Some identify it with Folkestone.

The battle of Wippedsfleet, according to the Saxon Chronicle, was followed by another in 473 , where the Britons (Walas) ${ }^{1}$ were again defeated and "fled before the Angles like fire". Four years later (477) the Chronicle announces the arrival in "Bretenland" of Ælle and his three sons, Cymen, Wlencing, and $\mathrm{Cissa}^{2}$ in three ships, "which came to land" at the place

1 The Anglo-Saxon Wealh, plural Wealas (Walas), was doubtless used by the Teutonic invaders, as it was used on the Continent, to denominate those who lived under Roman jurisdiction and spoke the Latin language. Welschland is the German word for Italy, and Welschnuss, like our English Walnnt, is the nut growing on Romance Soil. Fick thinks it was anciently the term applied to the Volcae, a Celtic people on the French shore of the Mediterranean, but in historic times it meant Roman pure and simple. As Professor Kurth says (La Frontière Linguistique, vol. i, p. 396), the word is applied by the German peoples to those who speak a neo-Latin tongue. The English limit its present use to "Wales" and "Welsh", the modern equivalents. Breten-land and Brettas represent native designations which were known to the Romans and used by them, as in Brit-annia, \&c. The hybrid Bretwalas combines both names.

2 The designations of the alleged three sons of Alle are assumed to exist in the place-names Cymenesora, Lancing, and Cissecester (Chichester), an assumption which places alternative considerations before us. Either these localities were called after the actual persons, or the designations of these persons were evolved from the pre-existing place-names. The abstraction of the invader Port from Portesmutha (Portsmouth), a name involving the Roman designation Portus, a harbour, is in favour of the latter hypothesis. The fact that the personal names Cymen, Wlanc, and Cissa are found elsewhere as in Cymenes-denu (Cart. Sax. No. 225; Brit. Mus. facsimile), Wlanc-heard (a moneyer, Grueber) and Cissan-Anstige, Cissan beorh, \&c. (Cod. Dip. 1235 and ro94) would fall in with either hypothesis. Cumenesora 
which is named Cymenes-ora. There, the Chronicle says, many Britons (Wealas) were slain " and some driven to flight into the wood that is named Andredesleage". We hear nothing further of Elle's movements until three years afterwards, where, it is stated by the Chronicle, he fought against the Britons near the bank (Stath still common in Norfolk and Lancashire placenames) of Maercrædes-burn. Six years later, according to the Chronicle, Elle was still fighting in this region, for in the year $49 \mathrm{I}$ he besieged and captured Andredes Cester ${ }^{1}$ and slew "all that dwelt therein, so that there was not a single Briton (Bret) left". Four years later (495) the Chronicle relates the arrival of two new leaders (aldormen), Cerdic and his son Cynric, with five ships, at the stead that is called Cerdices-ora, " "where they fought against the Britons (Walas) on the same day."

exists in a Spurious Charter (Cart. Sax. No. 64) and is placed in Sussex near (West) Wittering (Unidringa-muth, Cart. Sax. No. 60), and, as there is no reason to suppose that the scribe invented the name, it may well be the place meant by the Chronicle, and may also be, as Camden suggested, Keynor, in Selsey, but the absence of intermediate forms besides the inherent linguistic difficulty would exclude the identification. Coonore appears in Domesday, but it seems to be in the Pevensey Hundred. Lancing still preserves its early form, and Chichester (the Roman Regnum or Regentium) is not much modified.

1 Andredes-Cester has been identified by some with Pevensey (Pevenisel in the Charters and in Domesday Book) in Sussex. It represents the name Anderida given by the Romans to a garrisoned place somewhere in this neighbourhood (Notitia Dignitatum). The forest of Andred stretched from Kent (Saltwood, which gave its name to Saltwood Castle, was in it, see Cart. Sax., i, p. 574) into Sussex and perhaps beyond, as we find an Andret in Hampshire recorded in Domesday. Pevenisel is clearly a British word, and probably contains $P e n$ in its first syllable, the $n$ coalescing with the consonant following, as in Perrin for Pen-rhyn. It probably preserves a name as early as Anderida, and conld thus hardly have replaced the latter. The neighbourhood of Saltwood Castle is a more likely site.

${ }^{2}$ Cerdices-ora is suggestive. Cerdic has a distinctively British look, and the name is given by Bede $(H . E$. iv, 23) as that of a British king (Cerdic) to whose territory Hereric, the husband of Breguswith, mother of the Abbess Hild, was exiled. Nennius also refers to this British Cerdic (Certic) as having been expelled from Elmet (Yorkshire) by Ædwine (Eoguin). Ceretic is also the name of Hengist's interpreter, according 
Six years later (50r) a certain Port and his two sons, Bieda and Mægla, are represented by the Chronicle as coming in two ships to the place which is called Portes-mouth (Portes mutha), where they killed a young British man of high rank. The Chronicle under 508 relates the death at the hands of Cerdic and Cynric, of a "British King whose name was Natan-leod", after whom the land as far as Cerdices-ford was named Natanleaga. ${ }^{1}$ Cerdices-ora is also the name of the place where the

to Nennius, and there is a Ceretic in the Book of St. Chad (Lib. Land., pp. 199, 220, \&c.). There seems to be no representative of such a personal name among the Continental Tentons (see Förstemann). It would seem, therefore, that Ceretic is the same name as Corotic (the vowel changes being perfectly normal from the $i$-umlaut), to whom St. Patrick wrote, and that it is cognate with Caratacus who opposed the Romans, and was adopted as a personal name owing to alliance or kinship, by the early invaders of Southern England. It is curious that Geoffrey of Monmouth makes one of Arthur's opponents to be Chledric (variant Cheldric). The permanence of Celtic place-names in the region first occupied by the West Saxons tends to show something more than warlike relations with the natives. For instance, An-dever (Andover), representing probably an earlier *Anton-dover, of which the former element seems to be still preserved in Annport, Abbots Anne (Domesday Anne), not to speak of the Anton River given in the Ordnance Survey Maps, which, like the Rivers Penk, Chess, Adur, \&c., is possibly an antiquary's guess for the Trisanton of Ptolemy : compare also the Mutu-Antonis of the Ravenna Geographer. Mitchel (that is "muckle" or "great" Dever), and Candover (Cart. Sax. Cen-dever), which are in this neighbourhood, involve the same word Dever (Dubron) $=$ water. The modern Welsh form is Dufr, but it appears as Duur in the thirteenth-century (Gir. Camb. Itin. Kambriae, i. 8), and as Duuir and Duur in Lib. Land. (Evans and Rhŷs ed. from twelfth-century MS.). Wendover, Bucks (Wandofron, Cod. Dip. 593), and the rivers Conder and Calder (Cumberland) and other Calders in the north, together with Caldour (earlier Caledofre, Monast. Annals of Teviotdale, which, p. 3, gives Tefeged as the early name of the Teviot) near Kelso, involve the same word.

Cerdices-ora (ora $=$ shore) according to Ethelwerd (Chron. A. D. 519), was on the Avon, and Mr. Plummer would place it at Char-ford below Salisbury (Sax. Chron. ii. I3), but this is a long way to bring five ships up from the sea. As Cerdices-ora is also the landing-place of the West Saxons from three ships in A.D. 514, the place, if it ever existed, was probably somewhere else.

1 Natan-leaga, derived by the Chronicler from Natan-leod, seems to 
West Saxons landed in Britain in $\mathbf{5} \mathbf{1 4}$, who, according to the Chronicle, came thither in three ships, and, with Stuf and Wihtgar at their head, put the Britons (Brittas) to flight. The Chronicle makes Cerdic and Cynric to have obtained the kingdom [of the West Saxons added by a later hand] in 519 , and to have fought against the Britons at what in the writer's time was called Cerdices-ford. Eight years after $\left(5^{2} 7\right)$ Cerdic and Cynric are still contending with the Britons in this neighbourhood, to judge by the name given in the Chronicle to the battlefield-Cerdices-leaga. Three years after $\left(53^{\circ}\right)$ they are alleged to have conquered the Isle of Wight and to have slain a few ( fea) men at Wiht garæsbyrg. ${ }^{1}$ In 534 , when Cerdic dies, the

have been in the region (called Jutish by Bede) between the rivers Hamble (Homel-ea, Bede iv. 16) and the Itchen. Leaga is plural. The singular leáh meant originally, from the cognate form 100 in Waterloo and Lat. Lucus, "wood." The several "netleys" seen to still preserve there the name. Natan has a resemblance to Nectan, the name of several Pictish chiefs, not to be expected so far south. The leod Sir John Rhŷs cannot explain.

1 "Wiht garresbyrg" is thus written in the best MS. of the Chronicle, "Wihtgarabyrg" being the form a few lines later. There was evidently a doubt in the Chronicler's mind as to the assumed personal name's being in the genitive singular or genitive plural. To support the supposed derivation it should be, of course, in the genitive singular. Other considerations had their weight with him. He knew that Wiht was the name of the Island (now Wight) and he was probably aware that "Wihtgara" was a plural form, and meant seemingly, as in the early list of territorial names given in the Cart. Sax. (vol. i, p. 4I4), "Of the people of Wight." The form Wihtgarabyrg recalls the Wint-gara (which Mr. Stevenson thinks a mistake for Wiht-gaga, but gaga is even more obscure) of the "territorial list": see p. 220. The leader "Wihtgar" was evolved probably from such a form, a thing easy to do owing to the existence of similar compounds of Wiht (= modern Wight, a being, a sprite), such as Wihtred. Mr. Stevenson's (Eng. Hist. Rev. xiv. 32) argument that -gara is a genitive singular of garn, an archaic form, is not in keeping with the fact that the genitive is -es in all early personal names containing -gar: e.g. Hrothgares in Beowulf 668, Athelgares in Battle of Maldon 605. "Stuf," a name equated with the Scandinavian Stufr, has probably no stronger base. As to the survival of Wihtgaresbyrg in Carisbrook, after reading Mr. Stevenson's account of the matter in his Asser's Life of Alfred I feel that the idea must be given up. 
Isle of Wight (Wieht) is given to his nephews, Stuf and Wihtgar, the latter of whom is related by the Chronicle to have died in $\mathbf{5 4 4}$ and to have been buried at Wihtgarabyrg.

The Chronicle then suddenly shifts the record to the north, telling us that Ida, from whom descended the royal race of Northumbria, began to reign in 547 , and built Bebban-burh (Bamborough: in British, according to Nennius, Dinguoaroy).

The next entry belongs to $\mathbf{5 5 ^ { 2 }}$, and relates Cynric's victory over the Britons (Brittas) at the place which is called "æt Searobyrg", where he put the Bretwalas to flight. In $55^{6}$, Cynric and Ceawlin fight against the Britons (Brittas) "æt Beranburg".2 In 560, Ceawlin succeeded to the kingdom of the West Saxons, and in the same year Elle received the kingdom of Northumbria. Under $5^{6} 5$ the Chronicle announces the arrival, from the Scots, of a presbyter, Columba, ${ }^{3}$ among the Britons (Bryttas), to teach the Picts (Peohtas), and adds that he built a Minster on the island of Hii (that is Iona). The Chronicle goes on to say that in 568 Ceaulin and Cutha fought against Æthelberht at Wibbandûn, in Kent, and put him

1 Searo-burh is old Salisbury. The Roman name was Sorbio-dunum. The Saxon tongue got searo out of sorbio, and, from a practice which seems universal among Teutons, made this into a personal name, and adding the genitive termination -es arrived at Searis-bury, then Saris-bury, and at length Salisbury. These stages can be exemplified. There is no satisfactory evidence that the place was ever called Sarum. The forms in Norman times were Sarisberie Domesday Survey; Sarresbere 1232, Calendar of Charter Rolls, vol. i; Saresberia I268, Saresbury 1270, Saresbury 1294, Henry de Sarr 1 298, Calendar of Charter Rolls, vol. ii. The Cathedral was removed to its present site in 1219 . We have Nova Sâr. 1364 (Ch. and Rolls, Brit. Mus.), and the sign of contraction has been taken falsely as implying um, hence the creation of a "ghost-word" and its assumption by post-Reformation bishops.

2 " At Beran byrg" was placed by the late Professor Earle at Barbury Camp, between Swindon and Marlborough.

${ }^{3}$ We have fortunately a Life of Columba written by his disciple Adamnan about the middle of the eighth century. The earliest MS., penned by Adamnan's disciple during the latter's life-time or shortly after, is in existence, and was published by the late Bishop Reeves. 
to flight, killing two leaders (Aldormen), called Olaf (note the Scandinavian form of the name) and Cnebba. Three years after (57 I), according to the Chronicle, Cuthwulf fought against the Bret-walas at Bedcanforda ${ }^{1}$ (on the authority of Henry of Huntingdon, identified with Bedford), and took four towns (tunas), Lygeanburg (represented in the name of the farm, woods, and hamlet of Len-borough, near Buckingham), Egelesburg (Aylesbury, Bucks.), Bænesingtun (Benson, Oxfordshire), and Egonesham (Eynsham, Oxfordshire), and died the same year. Six years after this (in 577), Cuthwine and Ceawlin, the Chronicle tells us, fought against the Britons (Brettas) and slew three kings, Coinmael, Condidan, and Farinmael, ${ }^{2}$ in the place which is called Deorham (Dyrham, Glouc.), and took three chesters (Caestra), Gleawan Ceaster (Gloucester ${ }^{3}$ ), Ciren-

I It is somewhat difficnlt to see how a battle at Bedford, which is not near any Roman road, could have led to the capture of "towns", most of them fifty miles off. Tun = originally hedge round the house, and later a farm or village. The arrangement is purely Teutonic, and the tunas here must refer to a later settlement of the conntry. It is on the authority of Henry of Huntingdon (twelfth century) that Bedcan-forda has been made Bedean-ford, "which is now," he says, "called Bedeford." From the analogy of Bakewell, which in the Saxon Chronicle is called BadecanWiella (A.D. 924), one would expect Bedcan-ford to become Beke-ford. This renders the identification doubtful; besides, the name did not exist before the battle, but, like those of the towns captured, was imposed by the Teutonic settlers in after times. Bedford is called in Die Heil. Eng., p. 13, Bydanford, "where are the relics of Æthelbyrht".

2 "Deorham is identified with Dyrham on the turnpike road between Bath and Gloncester," Earle. Condidan has been identified with the Kynddylan of the Welsh, whose rule extended southward from Shropshire. Nothing is known of the other two kings except that their names, as presented in the later MSS. of the Chronicle, are in an earlier form than in the older, e.g. Con mægl, Farin-mægl-magl = Prince.

s Gloucester was, according to Nennius, called "Cair Glovi", from its builder, Gloiu, or Glou, who has been identified by some with Claudius Caesar, but its form in the Antonine Itinerary is Clev-um. Nennius makes Vortigern (Gnorthigern) son of Guitaul, son of Guitolin (Vitalinus), son of Glouvi : and states that "Bonus, Paul, and Mauron, sons of Glovi, built Caer-Glovi, in English Gloecester". A Mawron, Bishop, signs one of the Grants to Glastonbury (W. of Malmesbury, De Ant. Glast.). 
ceaster, and Bathan ceaster (Bath). Seven years after (584), the Chronicle goes on to say, Ceawlin and Cutha fought against the Britons (Brettas) in the stead that is named Fethanleag (not identified, but on linguistic grounds not Faddiley in Cheshire), where Cutha was slain and Ceawlin took many towns (tunas). Under $5^{88}$ the Chronicle places the death of King Flle and the beginning of the reign of his successor, Æthelric, who ruled five years. Ceol (variant Ceolric) is stated, under 59 I, to have reigned [in Wessex] five years, and in the following year the Chronicle records a great slaughter "æt Woddesbeorg ${ }^{1}$ " and the expulsion of Ceawlin, whose death, together with that of Cwichelm and Creda, is given in the following year (592), in which Athelfrith succeeded to the kingdom ("of Northumbria" is added by a later scribe).

The next entry is under 597 , when Ceolwulf is said to have begun his reign over the West Saxons and to have successfully fought against Angles, Walas, Picts, and Scots. This brings us to the arrival of St. Augustine in Thanet in the year 597, which is placed, however, by the Chronicle under 6or.

The period covered by these entries, which represent the readings of the earliest existing MS. of the Saxon Chronicle, covers some $\mathbf{1}^{2}$ years.

We should naturally expect that the events recorded during this long period would find some echo in other documents covering the same time. But this is not the case to any appreciable extent. The Ecclesiastical History of Bede-

1 This has been made by Green and others into Wanborongh near Swindon. The latter is Wemberge in Domesday, and on linguistic grounds could never have been Woddesbeorg. In the Welsh version of Geoffrey of Monmonth, Caer Vudei is given in one place as the equivalent of Silchester and in another of Cirencester. Woodchester (which in Cart. Sax. i, p. 238, is given as a place qui vetusto vocabulo nuncupatur Uuduceaster) may really be meant, and this was near Caer Badon (Mons Badonicus), where, according to Geoffrey, Arthur carried the Image of the Virgin in the battle, or, according to the Annales Cambriae, the Cross, if its identification with Bown Hill, near the estuary of the Severn, be correct. 
possibly because it is ecclesiastical-furnishes, for instance, little that corresponds with the Chronicle. On the other hand, it contains, in common with the histories ascribed to Gildas and Nennius, some incidents to which there is no reference in the Chronicle. The account of the defeat of the Teutonic invaders by Ambrosius Aurelius in 466, and of other victories, including that at the Badonic Mount in 537, recorded both in Bede and Gildas, finds no echo in the Chronicle, except perhaps in the defeat of Ceawlin in the battle at Woddesbeorg, a fact that seems to confirm the placing of Mons Badonicus at the neighbouring Bown-hill (i. e. Badon hill).

A promise was previously given that the place-names in connexion with the legendary King Arthur should be dealt with later on. The occasion has now arrived to refer to some of them, for the events just summarized cover the period to which Arthur's victories are ascribed.

The earliest mention of Arthur is in Nennius. "On Hengist's death," says this author, "Ochta, his son, passed from the northern part of Britain "- whither he and Ebissa had previously proceeded, as Nennius mentions - "to the Kingdom of the people of Kent, and from Ochta have sprung the Kings of that country. Arthur was combating against them-that is the Saxons-in these days, together with the Kings of the Britons, but he himself was the general (dux bellorum $=\mathrm{G}$ weledig of the British) in the wars, in all of which he came out the victor." Nennius calls him Mab (=son of) Uter (?=the Latin Victor) and goes on to give a list of his twelve battles. "The first was at the mouth of the river called Glein, the second, third, fourth, and fifth upon another river called Dubglas, ${ }^{1}$ which is in the

1 Glas is a common river designation among the Celtic people in Great Britain and Ireland, and even in Brittany. Dub (now Dubh) in Irish means black, and coupled with glas = "black stream". The second element has no direct connexion with the colour adjective glas (= green, blue, or grey) with which it has been confounded. As instances of its meaning we have the following existing river-names: Wen-las, made up of Gruy'n (ancient Vind) and glas = white stream : Cam-las = crooked stream : Du-las 
region of Linnuis : the sixth battle was on a river called Bassas, the seventh in the Wood of Celidon, that is Cat- (=battle) Coit(=wood) Celidon. The eighth battle was in the Castle Guinnion, in which Arthur bore on his shoulders the image of Holy Mary ever Virgin, and the Pagans were put to flight in that day. ${ }^{1}$ The ninth battle took place in the City of the

and Duglas $=D u b$ glas. The Welsh form of the ancient $D u b$ is now $D u$. Cynlas, another Welsh brook, has as its prefix the equivalent of the Latin Con, and the whole would mean confluence. This prefix takes the form $C y d$ before a $d$, and $C y d d z u f r$ (which would now be Cyddwr, and possibly exists in the Kidder of Kidderminster) would mean confluence also, cf. Kiddermore Green in Ordnance Map of Wolverhampton district. Another prefix to glas in Welsh river-names is dau=" two", which is applied to the junction of streams, as in the modern Dowles, a river joining the Severn below Bewdley and in several Welsh confluences called Dowlais; similar instances occur all over Wales, and in Brittany, and we have in Scotland and Ireland like forms, such as Finglas (Fin = Welsh Gwyn), but retaining the $g$ of glas which is normally lost in compounds in Welsh. Parallel applications of these prefixes to words meaning streams are found broadcast in Wales. Wendwr, made up of Groyn and $D w f r,=$ white water: Can-dwr = crooked water: Deuddwr $=$ two waters: $D a$ Usque $=$ two waters, appears in Davoren's Glossary, and explains the place-name Desk in Scotland. Wen-frut, made up of Groyn and frrvdd, = white stream, a name which appears, as we see by the Charters, in the modern Winfrith, Dorset, and elsewhere. The rivers Winster in Derbyshire and Westmorland preserve, besides $G w y n n=$ white, probably an ancient river-name Ster, of which there are many instances in Brittany, and of which the numerous "Stours" in this country may be a dialectic form. The old Breton form was staer, probably for an earlier stagr, cognate with the Latin stag-n-ıım. *Dubnoglas = deep stream, Dubglas and Daulas in English-speaking districts have assumed such forms as Dofiisc (Charters), Dawlish, Devilis, Dewlis, Dewlish, Devil's Water, \&c. Glas occurs as a prefix in the sense of stream in the Irish Glas-Nevin (Glas-Naoidhen), and the English Glazebrook possibly preserves an echo of the name. Glas = stream does not occur in Celtic Vocabularies, although it appears in the Book of Armagh (1 za 2) in lagslais, which Thurneysen translates (Handb. d. alt. Irischen, p. 151) "along the streams". No cognate Aryan form has been ascertained. There is some doubt about the genders of many Welsh substantives, and glas is among the number. If feminine the prefix Groyn would become Gwen.

1 Geoffrey of Monmonth refers this incident to the battle at Caer Badon (Mons Badonicus), and the Cambrian Annals make Arthur carry the Cross on his shoulder at the latter victory. 
Legion (in Urbe Legionis=Chester). The tenth battle occurred on the shore of the river called Tribruit (variants Trah-treuroit, Robroit). The eleventh battle was on the mount called Agned. The twelfth battle was on Mount Badon, in which fell in one day nine hundred and sixty men in a single attack by Arthur, and he himself and none other brought them down."

Gildas, as we have seen (p. 122), mentions the last-named battle; and Bede follows him word for word, although there is no reference to Arthur by either writer. Has the large and widely extended literature connected with King Arthur no other base, it may be asked, than this short record given by Nennius? Professor Zimmer (in his Nennius Vindicalus, pp. 283 et seq.) adduces evidence to show that there was not only an Arthurlegend in existence in Wales about the end of the eighth century, when Nennius wrote, but that it was known in South Wales even in the seventh century, and he infers from the oldest of the British heroic poems that Arthur was a real personage, and a leader of the Britons at the end of the fifth and the beginning of the sixth centuries, in their battles against the Angles and Saxons. In the name of the Dubglas, on which river four of these battles were fought, he sees an archaic form, which, like those of some other proper names used by Nennius, goes back to the seventh century (679).

The most of the Welsh historic poems ascribed to the early bards, Aneurin, Taliessin, ${ }^{1} \&$ c., have a distinct characteristic. Their scenery and events, as Skene (Four Ancient Books of Wales, i, p. 242) has pointed out, "lie in the north:

1 These poets are referred to by Nennius in connexion with the time when Ida, King of Northumbria, joined to Bernicia (c. A.D. 550) Dinguaoroy (Bamborough, that is Bebbanborough, the stronghold of Bebba, but anciently possibly Duno Varia, cf. Durnono-varia (Dorchester), and Argento Varia, now Horburg, not far from Strasburg, = Argento-rato of Peut. Tafel). "Then, in that time," he says, "Du-tigirn (= ? Tut-tigern=Lord of the people) fought vigorously against the Angles. Then Talhaern, Tataguen, were distinguished in poetry: and Aneurin (et neirin in the MS.) and Taliessin, and Bluchbard, and Cian, who is called Gueinthguaut, flourished at the same time together in British Poetry." 
the warriors whose deeds they celebrate were Groyr $y$ Gogledd, or men of the North." Sir Walter Scott (note to Vision of Don Roderick) had previously arrived at the same conclusion. It was natural, therefore, that Skene should attempt to identify the battles named by Nennius with sites in Scotland. He finds the site of the first battle on the Glen in Ayrshire, and that of the second, third, fourth and fifth on the river Douglas in the Lennox. ${ }^{1}$ The battle on the Bassas was fought, according to him, at Dunipace on the River Bonny; the "Wood of Celidon" he identifies with the Tweeddale region, and the Castle of Guinnion he places on the Gala Water in Wedale. The Urbs Legionis he would make to be Dumbarton, and the river Tribruit, which he calls the Tratheu (that is, "shores") Trywerid, he identifies with the Carse of Stirling, equating the werid in the latter word with the British name of the Forth, the Bodotria of Ptolemy. Mount Agned is with him Edinburgh, and the Badon Mount is "Bouden Hill", between Stirling and Edinburgh (Four Anc. Books, i, p. 53).

Mr. Skene's identifications, plausible as they may seem, are guesses, and sometimes guesses against etymological laws. There are certain considerations, moreover, which seem to indicate that

1 The genesis of Nennius's History of the Britons, as it has come down to us in the eleventh-century Harleian MS., is thus summed up by Zimmer (Nennius Vindicatus, pp. 105, 208, \&c.). (I) In the year 679, a Briton of the North, a subject of the Angles, took in hand (in order to bring up to his own time the Historia written by Gildas of Alclut-Dumbartonabout A. D. 540) a history of the Angles and Britons from the time of Ida of Bernicia, and of the Britons, Du-tigirn, and Mailcun of Venedotia (North Wales); (2) This work, including the Historia of Gildas, with some additions made between 737 and 758 , came at the end of the eighth century into the hands of a Southern Welshman (Nennius), living on the Mercian border, and became the foundation of his new edition in 796 ; (3) Nennius made use of three supplementary sources-(I) an Irish one, (2) the Chronicle of Eusebius-Jerome, together with the continuation of it by Prosper Tyro, and (3) the South Cymric Liber beati Germani, in putting together his work, which, with slight additions by the North Welsh editor of A. D. 810, is in the main that of the Harleian MS. 
Arthur's sphere of action was not confined to the country north of the Tweed. Mr. Pearson, for instance (E. E. T. Society's Merlin, part iii, pp. cxlix et seq.), assuming that the battle of Mount Badon was fought in A.D. $5^{20}$ (Annales Cambriae has $5^{1}$, but see note, p. I 23), concluded that this conflict was with the West Saxons, who were pressing on the Southern Britons, and not with Angles in the north, whose first king, Ida, is ascribed to 547 . He refers also to the twelfth-century Life of Gildas, by Caradoc of Llancarvan, as proving that Arthur was at war with a certain King Melvas at Glastonbury. Among other considerations, he dwells on the fact that the Arthur legend was widespread from an early date in Brittany, and that the most likely channel by which it had been conveyed thither would be the Britons who there took refuge when driven out of Southern Britain in the sixth century.

Nennius, in giving the list of Arthur's battles, had traditional sites handed down to him by his preceding North-British editor of 679 , and this may account for such names as the Glein, a river still retaining that designation in Northumberland, and for the Dubglas, of which there are numerous instances in North Britain. The wood of Celidon is also to be placed there, an echo of the name existing in Dun-Chailden (Dunkeld) and in Schiehallion ("Schechalzean alias Uchel hills," I642, Inquis. Speciales), which Sir John Rhŷs (Celtic Britain", 165) would make with reason to stand for Sith-Chaillinn, that is, the Sidh (pronounced "Shee") or residence of the Caledones.

The Urbs Legionis (City of the Legion) can be nothing else than Chester or Caerleon, and Skene's attempt, owing to the form given to it in the Irish version, to make it into Kairlium, and thence into Dumbarton, is quite unsatisfactory.

Boudenhill ${ }^{1}$, moreover, could hardly have preserved its $d$

1 The "barony of Bowne" in the county of Berwick, cited in 1409 (Registrum Magni Sigilli, p. 240), would have suggested a more satisfactory origin, but "Bown hill" in Gloucestershire better meets the requirements (see p. I23). 
flanked by vowels all these centuries, and must have had a different origin.

The poems of Aneurin, Taliessin, \&c., to which Nennius refers (see note) would, if we had them in their authentic form, doubtless throw light upon the obscure period of the foundation of the Anglian kingdom of Northumberland, but until we have critical texts they afford merely a wide field for conjecture.

At the close of the sixth century, the Teutonic invaders had made themselves masters of a great part of South Britain, and had also established themselves strongly in the region north of the Humber. The victory over the Britons at a place called in later times Deorham (Dyrham) had, as the Chronicle tells us (A.D. 577), enabled the West Saxons to occupy Gloucester, Cirencester, and Bath, and had opened up to them the Severn Valley. It was probably in an advance in this direction that Ceawlin (592) was checked at Woddesbeorh, and, after great loss (micel walfill = muckle slaughter), was driven out (was ut adrifen). His successor, Ceolwulf, who began to reign over the West Saxons in the year 597, seems, however, to have made up for this loss, as the Chronicle represents him as having fought constantly and successfully against Angles, British (Walas), Picts, and Scots, although it gives no information as to the localities of his victories.

One result of the westward advance of the invaders was the enforced emigration, in the fifth and sixth centuries, of a large number of the native British to what was then called Armoricathe modern Brittany-effecting a transformation of the latter country. ${ }^{1}$ We know from authoritative writers of early date the state of Armorica before the Britons arrived-the names of its peoples and chief centres of population down to the end of the fourth century. These names are naturally Celtic, but they

1 Wurdesten, who died Abbot of Landevenec in Brittany in A. D. 884, wrote a Life of St. Winwaloe (Guenole), in which he speaks of the Britons leaving their ancestral land when the Saxons occupied it; see Bollandist Edition of the Life, 1888, p. 9. 
belong to a substratum differing considerably from that of the great mass of place-names which we find in Brittany to-day. The older topographical nomenclature has persisted to some extent, ${ }^{1}$ but it has been overwhelmed by names introduced through the immigrants from South Britain.

1 Nantes, for instance, still preserves the name of the people called the Namnetes by Polybius, Caesar, and other ancient writers. Vannes also contains a representative of the Veneti who are represented by Caesar (De Bell. Gall. iii. 9. 10) as having sent to that part of Britain lying opposite for aid for themselves and their allies in their contest with the Romans. The Coriosolites and Redones, who are numbered by Caesar ( $D e$ Bell. Gall. vii. 75. 4) among the thirty states (civitates) constituting Armorica, gave their designations respectively to the modern towns Corseul (near Dinan) and Rennes. The Coriosopites of the Gallican Notitia (drawn up at the end of the fourth century and existing in a sixth-century copy), reminding one of the Corstopitum (now Corbridge) of the Antonine Itinerary, after holding its own for a century or two yielded to its modern equivalent Quimper (kemper, from conber=confluence, see p. 186), a name found in all Celtic districts under the forms of Cummer, Cumber, and probably in such hybrids as Quemer-ford near Calne. Corsept near Paimbœut on the Loire seems still to preserve the name of the Coriosopites. Pedersen, $V$. Gramm. $\$ 49.5$, shows that st becomes $s$ in Brythonic, which thus connects Corio-sopites and Cor-stopitum. Auray (river), Port Slocan, Arguenon (river), Orne, earlier Olina (river), represent respectively, Ptolemy's Hērio-s, Port Saliocan-os, Aregenua (=Reginea [the Reginca of the Peut. Taf.], the genua probably being for Gaulish Genava = "Mouth", Cornish Genau; cf. Geneva), and Olina; see Müller's Ptolemy. The Corio in Coriosolites and Corio-sopites (and the Cor of the British Corstopitum if the original form was Corios $(t)$ opitum $)$ represents the Celtic stem Korio $=$ Host or Army, which appears also in the Tri-corii and Petru-corii (= respectively, the Three and Four Hosts) of the Gallican Notitia, the latter part of the word being still preserved in Perigord. Compare the Quatuon Signani of Tarbeli (chief town Dax, that is, De Aquis) mentioned by Pliny ( $N . H$. iv. 19), which, as the Signum was the standard of a Cohort as distinguished from the Aquila of a Legion, meant seemingly, "Four Cohorts," and was thus equivalent to Petru-corii; Petru="four", Old Welsh, Petwar, now Pedwar. Corio is cognate with Modern German Heer, OHG. Harjo, Anglo-Saxon Here=Army, preserved in Herpath and in Harbour (= Hereberge = "Army refuge"), and not, as in the Oxford English Dict., in Market Harborough, for in the thirteenth century this was Haverberg. The Corio-vallum of the Ant. Itin. has the 
Dr. Loth (L'Émigration Bretonne en Armorique) thus summarizes the changes effected:- "In the fifth century the Armorican Peninsula was entirely Roman in language and culture. Its soil was traversed by Roman roads connecting its important towns, which were situated for the most part on the coast. The centre of the country, sparsely inhabited, was covered with forests. The population was mostly Christian. ${ }^{1}$ In the sixth century the same region-with the exception of certain portions of the territories of the Redones, Namnetes and Veneti-had taken an entirely different aspect-its name, its language, its culture had become transformed." 2 There had same prefix, and is now represented (Kurth, Frontière Ling.) by its Teutonic equivalent "Heer-le" (= Army-place) in Belgium.

1 Mgre. Duchesne shows that there were at this time four Episcopal Sees in the peninsula.

2 The name Britannia is applied to Armorica by Gregory of Tours; and Britannia Minor or "Lesser Britain" is the usual appellation in the early Lives of Breton Saints. The designation itself is a confirmation of the immigration. The same designation, Brytaen Vechan, is used in the Welsh version of Geoffrey of Monmouth's History.

If we look at a large scale map of Brittany, such as that of Cassini, published in the eighteenth century, we cannot but be struck by the similarity of the place-names there to those of Cornwall. In order, however, to account critically for that resemblance we must see the names in their earliest accessible forms. Fortunately we have specimens of the topographical nomenclature of both countries from the ninth or tenth century onwards. Certain original charters, of the tenth century, in the possession of the Dean and Chapter of Exeter, together with the later list in Domesday Book, furnish material for comparison with the rich examples of placenames in the Chartulary of Redon, containing charters from the ninth century onwards.

It may be well to ask, before comparing these materials, whether the language of Armorica before the British immigration was like the modern Breton. In the Chronica minora, edited by Mommsen, vol. i, p. 6r3, we have a list (fifth century according to the editor) of seventeen Gallic names with their Latin equivalents; some of these, such as nant $[0]$ (=valley), Prenn $[e]$ (=Great tree) and treid $[e]$ (=foot) are common to Britain and the Continent, but others, like Brio $[=$ Briv-o = bridge] and Onno (=river), seem to belong to an earlier Celtic period, and to have left little or no remains in Britain (but compare Duro brivis = Rochester and the Onno of the Not. Dig.). The resemblance between Cornish and Breton forms is too 
been previous immigrations from Britain. Not to speak of the intercourse between the Gaulish and British tribes referred to

close to think of them as parallel developments only. There are, also, some crucial words which, now current in Brittany, may have originated in Britain; for example, the word strkat=road, which appears also in placenames (e. g. Ker -stret, Ker -strat=our Stratton). But we have to take into account here an old Cornish stret, glossed latex, and a middle Cornish streyth $=$ stream, probably $=$ Irish strath and Cymric Ystrad (Pedersen, $V . G$. \$5. 3). The word Prat from Latin Pratum occurs in Breton place-names and (as Pras) in Cornish also. The former must, I think, have been borrowed by the British from the Via strata of the Romans, and handed on by them to the Teutonic invaders of Britain on the one hand, and to the Bretons on the other. Prat was probably a British borrowing also. Pogatscher (Zur Lautlehre der Romanischen Lehnworte im Altenglischen) found some diffculty about the vowel-change of Strat and other words, such as Cealc, in passing into Old English, because he seems not to have considered the possibility of a British transition stage. The British-borrowed forms of strata and Calx were stréat and Calc, the latter taking the form, if correctly printed, of -Colc in the British Museum original Charter of A. D. 847 [Cart. Sax. ii, p. 34], where Odencolc $(=$ Odyngalc $=$ Limekyln, Pennarth MSS., I, pt. iii, p. 1078) appears as a boundary in Dorset, near(?) Durlstone Head (= perforated rock, from A.-Saxon Thyrel=hole), where the Tillywhim Caves seem to preserve a reminiscence of the Cornish (Breton) Touleu $=$ holes, and veyn (=plural of maen) =rocks-this being the exact equivalent of "Đurlston". In the Suppl. to Camb. Arch. J. for April, 1909, we have, p. 49, Karreg Tylhvaen = "the stone of the Hole-rocks". Oden seems, by the way, to have also been borrowed from the British by the Saxons, but, if the dictionaries are right, by a change in meaning. Somner's Dictionary gives on odene Cylne macian where the word is made= "threshing floor", but, as there seems no Tentonic etymon for the term, its association with Cyln (Kiln) suggests its being the same vocable as the Cymric Odyn: tha olde oden missene (Cart. Sax. ii, p. 476) is obscure if it does not involve the Latin messis $=$ harvest.

Celchyth (British Museum Charter of A. D. $78_{5}$ almost contemporary) or Cealchyth (" "Chalk-port") contains Calx also, but the best equipped English philologist could not have predicted, from phonetic laws alone, the form which it ultimately assumed, namely, "Chelsea." If the historic stages had not been accessible this result would have been repudiated. Phonetic laws have nevertheless their value-of which we have special instances in the British names common to Britain and Brittany. Thus, if we were to seek for the normal representative of the Welsh mynydd (="mountain", anciently minid, Lib. Land., cf. the Devon Peon Mynet, Cart. Sax. ii. 432) in Breton, we know that $d d$ final in Welsh is $z$ in late 


\section{by Caesar, and of the British troops who accompanied Maximus to Gaul in the fourth century, there is an instance of a large in-}

Breton, and we therefore look for and find menez (as in Trarmenez = Tra ar menez = "beyond the mountains") later mene - "mountain " in Breton. In Cornish place-names this word, formerly menedh, now also appears as mene. In England the word survives in Longmind (Shrop.), Minton and Mindton beside it, in Stadment (Heref.), and probably in the minn of Bosley Minn near Macclesfield. Testa de Nevill, p. 59, Foresta de Longe Munede: cf. Munet in Clun (Salop), ibid. p. 60; cf. Dorments Farm near Minety, and Jackments Bottom near Kemble and other Jackments, Mintridge (Heref.), Okment Hill, Devon (=Uchmynydd ; cf. Ugmennith, Radnor, Cal. Chart. Rolls, ii, p. 7), and the many meends (in Shrop. and Heref., and in Forest of Dean). As th final in Welsh $=s$ in Breton we expect to find Cos in the latter dialect representing the Coth (=Old) of the former-witness the numerous instances of Cosquer in Brittany $=$ Coscaer $=$ Old town, for caer has become ker in Breton and means now simply "village" or "town" Mazor is "great" in Welsh, but aw in Welsh in a middle syllable is $e u$ in late Breton, we find therefore meur="great" as in "Tremenr" = great habitation or hamlet (the $m$ remaining unchanged, although the noun is feminine). The Cornish form is Trevear. Bian or Bihan=little, appears as vean in "Trevean" both in Cornish and Breton. The definite article in both Breton and Cornish is an (as in Irish) in contradistinction to the Welsh $y, y r$.

The following elements entering into place-names are common to Cornish and Breton:-Als (C), Aot (B) =shore =Welsh Allt cliff; Chen (C), Quin $(\mathrm{B})=$ Welsh $C$ ef $n=$ ridge [cf. Chevenage near Avening, which seems to involve Cefn and English edge]; Celli and Gelly (C), Guilly (B)=grove as in Pengelly and Penguilly; Crach (C), Creach (B) =hill, as in Creach am bleiz (Welsh Blaidd) $=$ wolf-hill. Ancient Cornish Cuit, later Coit, and finally coos (goos in composition, as in Hew Goose, Cornwall (B. M. Charters, $\left.{ }_{15} 16\right)=U c h$-goed, "above the wood," and Fynten Goys (B. M. Charters, 1410$)=$ Fountain wood) is coet in Breton. Ti (as in old Cornish "Ti coith" = old house) becomes in modern Cornish Chy, but retains its old form in Breton. Bod (C), Bod $(B)=$ habitation, enters into frequent combination with personal names in both conntries, but it has also come to signify a clump of brushwood in Breton; Pont $(\mathrm{C}$ and $\mathrm{B})=$ Bridge, Pren $(\mathrm{C}$ and B) $=$ tree, $\operatorname{Run}(\mathrm{C}$ and B) =low hill, $\operatorname{Ard}(\mathrm{C}), \operatorname{Arz}(\mathrm{B})=$ high, Pen (C and B) =head, Poul (C and B) = pool (Breton Poull-pry and Cornish Polpry=marlpit). Towvan (C) (Welsh Tyreyn), Tevenn $(\mathrm{B})=$ seashore; Lis $(\mathrm{C}$ and $\mathrm{B})=$ court ; $\operatorname{Ros}(\mathrm{C}$ and $\mathrm{B})=$ moor $; \operatorname{Carn}(\mathrm{C}$ and $\mathrm{B})=\operatorname{rock}=$ cairn; Treath (C), Treiz (B) = strand; Aber $(\mathrm{B})=$ estuary, is not found, I believe, in Cornwall. Port (C), Porz $(\mathrm{B})=$ Port; Ster and Steir $(\mathrm{B})=$ river, is represented probably in Britain by Stour (Stuur in early Charters). 
trusion of insular Celts in the fifth century. In the year $470,{ }^{1}$ as Iornandes tells us (De Reb. Goth., c. 45), "Anthemius, the Roman emperor, on discovering that the Visigothic king, Euric, meant to occupy Gaul, solicited the help of the Britons, and twelve thousand of the latter, under their king, Riothimus, crossed the sea, and were received by the emperor in the city of the

The Ordnance map gives as a tributary to the Worcester Stour a river called Smestow; a few miles up this river from its junction with the Stour is Sme-ster and Sme-ster-mill. Have we not here a Ster (=Stour) differentiated from the arm passing Stourbridge by an adjective Sme $=$ Small ? Cf. also the Stergavale and Stergaule of the Cart. du Redon with Streguil (Straguil), the earlier name of Chepstow, which seems also to involve the Gabail=fork, already referred to ; cf. the Breton "Pennaster" and "Bannaster" =(?)respectively the head and foot of a river. Glas (B) appears in Daoulas (=two streams), and is represented, I believe, in South Britain by the lis $[c]$ in Doflisc (Cart. Sax. iii. 667) = Dwfn-las, deep stream, now Dawlish; Divlisc (now Dewlish) of the Charter is probably Dubglas = black stream; Pontulas in Brittany is to be compared with the Welsh Pont dulas; also with the Hereford Pon-tri-las, where the bridge still spans the three streams. Dourdu $(\mathrm{B})=$ black water; Gouver $(\mathrm{B})$ and Gover $(\mathrm{C})=$ rivulet ; Geun (B), Cornish goon, Welsh Gwaun = marsh or moorland; Garz (B) Cornish Gard, gerd (as in Pengerd now Pennard) = hedge; Lin (B as in Linhalec), British Lin=lake; Vern (B), British wern $($ Gwern $)=$ alders or swamps, as in Breton Pen-en-vern. The Breton particles huel (Welsh uchel), Isel=" higher" and "lower" respectively, and eys $(=$ Welsh $I s)=$ below (as in Porz is quin = the Port-below-the-ridge, Cefn) enter largely into both Cornish and Breton place-names. Cf. Breton Minard (=narrow height) with Cornish Min-ard near St. Germans, and Miniard, Worcestershire.

1 In an early addition to Nennius the Armoricans are described as the Britons who crossed from Britain to the Continent under the Emperor Maximus and who were called Letezvicion, a name of which the writer gives a fanciful derivation. It is the same word we find in the Saxon Chronicle (A.D. 885 and 9 I $_{5}$ ) for Armorica, and was evidently borrowed, like many other words, from the British. It represents the old Cymric Letewic (now Lledewic) plural Letewicion, an adjectival form applied to the coast of Armorica. Litau (old Cymric di litau is glossed for Latio in the Oxford Ovid, eighth century) was applied to Latium, or Latin territory, bnt, according to Dr. W. Stokes, its original meaning was "coast", preserved in its cognates, the Latin litus, and Lituwva=Lithuania. Sir John Rhŷs thinks it means a land reached by boats. 
Bituriges (Bourges)." 1 Greg. of Tours (Hist. Franc., ii. 18) mentions that the Britons were driven out of Bourges by the Goths, and that many of them were slain at Dol in Brittany, where they seem to have taken refuge. These expeditions, however, were transient in their effects. The invasion of the sixth century was almost a national movement. The battle of Old Salisbury (552), and of Beran burh (556) were possibly its immediate cause. The immigration thus begun continued into the seventh century, and in the ninth century the people had become so powerful that they were able, under their king, Nominoe, to defeat the Franks in a decisive battle and to make Brittany an independent kingdom.

The British emigrants embraced, seemingly, a large religious element. Paul Aurelian, one of their ecclesiastical chiefs, with his three disciples, Iahœvius, Tigerno-maglus and Ceto-merin, as we learn from his ninth-century biographer, arrived at a place in the west of "Domnonia", a name which Mgr. Duchesne thinks to have been brought from Paul's ancestral home, the region of the Dumnon-ii=Devon. St. Malo, St. Samson, St. Winwaloe, were all from the island of Britain, and we see from the number of monasteries which soon began to rise in their new home how great a part monasticism played in the conquest.

About $35^{\circ}$ years after their arrival it is noteworthy that a similar cause compelled many of the descendants of these British exiles to take refuge in their ancestral home. In Merlet's edition of the Chronicle of Nantes (Paris, 1896) we find the following entry: "At this time" (that is, when the Northmen were ravaging Brittany), "Mathuedoi, Count of Poher, took flight to the English king Athelstan (Adelstan), with a great multitude of Britons, together with his son Alain-afterwards called Twistedbeard (Barba-torta) - to whom the same English King Æthelstan had been sponsor at the font, and whom, on account of the association and friendship of this new birth he held in great

${ }^{1}$ Sidonius Apollinaris (died 479) testifies (Epist. i. 7) to the presence of Britons on the Loire in his time. 
trust." This occurred in the year $93 \mathrm{I}$, six years before \&thelstan gained his great victory at Brunanburh over the Danes and their allies. There is, in my opinion, an unexpected light thrown on this record by certain ancient inscribed stones preserved in the church of St. Mary at Wareham (Dorset), where some of the exiles may have found a refuge. I have made careful copies of these fragmentary inscriptions, all seemingly of the tenth century, and put them together here for reference.

Built into the east wall of the north aisle are two inscribed slabs, the first reading catgug $[\cdot]$ c Filivs Gideo, and the second GONGDRIE. A pillar, of which the top is broken off, now in a side chapel, has the remains of two names-ENIEL'F.-UPRIT'I; and, on a fragment of a column, IUDs[or]-Tcrvi. There is also in the porch a fragment of a slab with the following inscription of a much earlier form: - viscv-FiLivs vi-. It is difficult to believe that a colony of native British Christians could have been living peaceably at Wareham at this period, a place which had in Alfred the Great's time (877), been a great stronghold of the Northmen. Coupling the date of the form of the letters in the inscriptions with the entry in the Nantes Chronicle these records seem to point to Wareham as one of the refuges of the exiles from Brittany mentioned by the chronicler. ${ }^{1}$

${ }^{1}$ Comparing the Wareham inscriptions with forms of personal names current in Brittany in the tenth century the agreement is striking. The Chartulary of the Abbey of Redon, edited by De Courson (Paris, 1863), furnishes numerous Charters, dated from the beginning of the ninth century onwards, containing many personal names. Here we find forms similar to Catgug[u]c, e.g. Catuucocon for Catguc-on (A.D. 821). Gedeon (probably an assimilation of a Breton Gedeo or Gideo to the Biblical name) occurs in several Charters, one of them A.D. 9r3. Catguc and Gedeon appear also in the Book of Llandaff, a twelfth-century MS. Compare Catuntic of the Bodmin manumissions (Rev. Celt. i. 337, a MS. of the tenth or eleventh century now in the British Museum). Gongdrie looks like a Frankish female name with a Latin genitive ending. There are many Frankish names in the Redon Cartulary. A Gundric Presbyter, for instance, witnesses along with a Gedeon to a Charter of $87 \mathrm{I}$. The missing letter in -eniel was probably $D$, since a Deniel, son of the Count Gurmhailon, witnesses to a Charter of $9^{1} 3$ which Matuedoi (the exile named 
The seventh century opens in the Saxon Chronicle with the record of a battle between Æthelfrith, King of Northumberland, and Aedan, King of the Dalriadic Scots, ${ }^{1}$ at a place not named in the oldest MS., but called Egesan-stan or Dægstan in later MSS. of the Chronicle. The form in Bede [H.E. i. 34] is Degsastan, which he describes as a celebrated place. Aedan was defeated and took to flight with the small remnant of his forces. Theodbald, the brother of Æthelfrith, who seems to have encountered another leader of the Scots, was, as Bede tells us, slain and his army destroyed. A twelfth-century MS. of the Chronicle adds that "Hering son of Hussa led the army

above) drew up (grafavit) and signed. A Juneprit who witnesses a Charter of 820 (Chartulary of Redon, p. 201) has the same final syllable as the - Uprit of the inscription. The Iudn of the next inscription has a final letter (or letters) which looks like $o$ with an $i$ above it, making thus a form like Judnoe which occurs in the book of Llandaff; the last element may, however, have been -imet, makingJudnimet, a witness to a Redon Charter of 879, and also found in the form Iutnimet (modern Edyfed) in the Welsh Genealogies (Cymmrod. Soc. vol. ix, p. I78. Genealogies from Harleian MS. 3859 , tenth century, E. Phillimore). Compare Jud-hent of the Bodmin manumissions. It is a somewhat singular coincidence that the Salisbury Cathedral Library has a Psalter of the tenth century containing a Litany with numerous invocations of Breton saints, and this may well have been brought by the exiles. A thirteenth-century reference to "the Breton's lands" (Cal. Ch. Rolls) in Hampshire may preserve the tradition. Ethelstan's friendliness to British people is further witnessed in his grant of lands to the Church of St. Buryan near the Land's-end. The Charter though wrongly dated is probably a copy of a genuine document (Cart. Sax. ii, p. 527). There is an inscribed stone at Lustleigh of the same character and probable origin. See my article on the whole subject in the English Historical Review, October, 1907. Reference may here be added to the letter (Cart. Sax. ii. 319) in which the Prior of St. Samson sends relics to Ethelstan, and offers the prayers of his community for the King's welfare. Cf. also Mr. Edmund Bishop's remarks on the subject in The Bosworth Psalter. In Die Heiligen Englands, Hanover, 1889, p. 19, we have: "There is at Middletune (Milton Abbas, Dorset) the head of S. Brangwalator and the Arm of S. Samson, Bishop, and his Cricc" (Crozier).

1 That is, of the people who migrated in the sixth century to Argyll from Dalriada in Ulster, where the name is still preserved in the district of the co. Antrim called "the Route". 
of the Scots thither; and afterwards no King of the Scots dared to lead a host against this (that is the Anglian) people ". Hussa is made in the Annals of Lindisfarne to have been a son and a successor of Ida, who founded the Kingdom of Bernicia in 547. Hering, therefore, as Mr. Plummer points out (Saxon Chron. ii, p. 19), was probably endeavouring, with the aid of the Scots, to supplant his cousin Æthelfrith. The site of this battle is unknown. Skene's conjecture, that it is represented by Dawston in Liddesdale, has nothing but the name to support it. The fastnesses of this region could hardly then have been in the hands of the Angles, but were probably within the Brythonic Kingdom of Strathclyde, which maintained its independence up to the tenth century. Mr. Bates (Hist. of Northumberland, p. 53) says that it was "most probably Dissington, the Digentum of the Hexham Chroniclers", but here not even the form of the name supports the hypothesis. The place was clearly in Bernicia, where numerous place-names ending in $-\operatorname{stan}^{1}$ are located in the early monastic charters, but nothing like "Dxgsa-stan", after a careful search, is to be found among them.

Hitherto Ethelfrith and his predecessors had to contend with the Brythonic people of Bernicia. Now he is brought into conflict with the Dalriadic Scots under Aedan. Aedan is an historical personage. In Adamnan's Life of Columba, written about a hundred years after Columba's death in 597, Columba is represented (Reeves's ed., p. 35) as praying in Iona for Aedan's success in a previous conflict (596), called by Adamnan the battle of the Miathi, that is, of the Maeatae. (For the site of this battle see p. $5^{2}$.) These Miathi were Picts, who were accustomed to make alliances with the Angles, and Aedan probably pressed his advantage over them by subsequently attacking Ethelfrith. This was in 600 (603 Sax. Chront) according to the Annals of Tighernagh, which does not mention Aedan's

1 For example, "Halistan" (Brinckburn Chart., p. I 28), Rudemanstan or Kydmanstan (ibid., 208). 
defeat, but records the slaying of Æthelfrith's brother, here called "Eanfraith". The entry is- "Battle of the Saxons by Aedan where Eanfraith brother of Æthelfrith (Etalfraich) was slain by Maeluma MacBaedain, who was the Victor".

The year 603 is also memorable for the meeting of St. Augustine and the British Bishops. "Augustine," says Bede, " with the help of King Æthelbert, invited the Bishops and the learned Britons of the neighbouring province to a conference with him at a place, on the confines of the Huiccii ${ }^{1}$ and West Saxons, which up to this day is called in the language of the English 'Augustine's Oak'."

The place of the meeting was not, therefore, in any town or settlement, and its site was somewhere on the border, in Bede's time, of the West Saxons and Huiccii. ${ }^{1}$ The extent of the

1 The Ecclesiastical History of Bede (ii. 2) furnishes us with the earliest form of this word, viz. Huiccii. The Moore MS., in which it occurs, was written, according to Sweet, about A.D. 737. In a charter of $77^{\circ}$ (see Sweet's Oldest English Texts, p. 43I) the form is the same (Huiccii), but in a subsequent charter (ibid., 791-6) the spelling is Huuiccii. The Anglo-Saxon version of Bede's Hist. Eccl. ii. 2 (ninth century), renders in Confinio Huicciorum by Hwicna Gemare, and Huicciorum Vilfrid Episcopus (v. 23) by Wilfrid is Hzvicna biscop, where Hzvicna is the genitive plural in-na (-ena), suggesting a nominative plural Hwica ( $\mathrm{fem}$.). The best MSS. of Nennius [H. K.] read Huich. The name occurs in the Wonders of Britain at the end of the following passage (translated): "The third miracle is the hot pool which is in the Huich region, and it is surrounded with a wall made of brick and stone, and men go into it at all times to bathe, and every one can have a bath according as he wishes; cold, if he wishes cold, and hot, if he wishes hot." This has been assumed naturally to mean the Roman hot baths at Bath. The reading of several other MSS. of Nennius-Huiccorum-would seem to leave no doubt about the locality.

Some connexion between Hricna and the Wigera in Wigera-ceaster has been assumed by some English antiquaries, but this is by no means clear. The Statute of the Council of Clofesho (Oct. 12, 803), of which we have a contemporary MS., furnishes us with the earliest form, as far as I know, of Worcester-Wegoranensis civitatis Episcopus. This suggests that the form Wigornia owes its $n$ to the Latin termination -nensis: thus the original form was Wigora or Wigera, probably the genitive plural of Wig or Wigge. This Wigera seems to survive in the name 
West Saxon Kingdom in Bede's time may be gathered from the latter's account $[H . E$. v. I 8$]$ of the division of the Bishopric

of the great forest which at one time appears to have covered a large part of Worcestershire, that is the Wyre forest. Wirecestre (1274), the mediaeval form of Worcester, exhibits a parallel of the process by which Wigera becomes Wyre.

The continuation of the Brut y Tyzuysogion (MS. Commission Report on Welsh MSS., vol. i, pt. ii, Pennarth), p. 346, gives Caerwrangon as Worcester (thus identifying the latter place with the Caer Guiragon (variants Guoranegon, Guairangon) of Nennius) and at p. 357 there is a reference to Saint Wlsdan (Wulstan) yn ghayr wrangon. The Guirag in Guirag-on suggests a connexion with Wigora $(G u=w)$ as if the latter represented *Wiragora. The Welsh Gwig given by Davies (Dict. Brit. Lat., 1630) as meaning Nemus would furnish a satisfactory origin for Wigera-ceaster, its signification being thus the "chester" of the Forest-men. Strabo's (30 B.C.) statement ( $L i b$. iv) bears on this. The cities of the British are, he says, forests (drumoi) wherein they construct with felled trees an enclosure for their huts.

If there be any connexion between Guvig and Huic, it is not clear. Guig would represent an earlier Vig or Vicc, and Huic, if English, an Indo-European Kivig, but this stem does not appear in Torp's Wortschatz, and may therefore be set aside. Guig seems to appear in such place-names as Wygemore (1214, B. M. Charters), now Wigmore, in Wygezude (1270, Cal. Chart. Rolls, ii. I35), both in Herefordshire, in Whychewode, variant Whucchewode (1284, ibid. ii. 275), in Cart. Sax. ii. 6, Huicceundu, Oxfordshire, and Wiggebeare (1408, B. M. Charters), now Wigborough, Somerset. At p. 68, under St. Asaph, in Eivd Llwyd's Itinerary of Norlh Wales (suppl. to Arch. Cambr., April, 1909) occurs Gwic-Wern ( = alder grove). Llwyd adds that it is commonly called Wickware, a name occurring in English place-names, but representing generally there Wic-zuara $=$ "of the village people"; cf. Burh-zvara, Crester wara. The Wizarazvic or the original Charter of $85^{8}$ (Cart. Sax. ii, p. 100) seems to contain the Latin Vivarium. Warwick represents Warincguvica of Cart. Sax. i. 22\%. Compare for Guic the Viro-ziacum, now Werwick, of the Antonine Itinerary (IVirouino, Peut. Taf.) and the ancient name of Nantes, Condivicno, in the Peut. Tafel. The association of Wig in the sense of "wood" with English -beare (Anglo-Saxon Bearo = wood) and with -rvood seems to be one of the many instances of the coupling of synonyms belonging to different languages, e.g. Chetwood, Chute (earlier Chet) Forest, involving Cet, Welsh coed ( $=$ wood) in its later Anglicized form, Ceat. That the Whyche of "Whychewood", assumed by some to contain the Huic of Huiccii, is related to Grvig, seems suggested by the early name of [Child's] Wickham, which appears in a $97^{2}$ Charter as "Uuiguuennan". The wich 
of the province in A.D. 705. It was then divided into two parochiae, one being assigned to Danihel, previously a Bishop in the Isle of Wight, and the other to Aldhelm, formerly Abbot of Malmesbury. The Bishop of Bristol (St. Aldhelm, his Life and Times, p. r39) makes Aldhelm's See to have "comprised Berkshire, Wilts., Dorset, and part or even the whole of Somerset, if not still more of the south-west :- the two pagi of Hants and Surrey went to the other Bishop, Daniel ", who had his See at Winchester and is elsewhere mentioned by Bede as one of his informants in the south.

The territory of the Huiccii can be but vaguely determined. In the Appendix to Florence of Worcester (twelfth century), it is given as a reason why Worcester was erected into an Episcopal See, "that the City of Wigornia in the time when the Britons or Romans were ruling in Britain, then as now, was distinguished as the celebrated metropolis of Hwiccia or Magesitania." Magesitania is a territorial name formed most probably from the term Magonsete, ${ }^{1}$ which is employed in a contemporary charter of A.D. $8 \mathrm{r}$, to designate the settlers in what is now part of Herefordshire. We may assume from this and other passages that the Huiccii occupied the country now embraced in Hereford, Worcester, and Gloucestershire. A point of contact between the limits of this region and Wessex must therefore be sought somewhere to the north" of Gloucester-

in Droit-wich, \&cc., has nothing to do with either Huiccii or Groig, but represents the Latin Vicus, which was used to designate a row of houses in classical times, but in English place-names chiefly means "dwelling", "shed" (as in Hardwick and Rotherwick = cattle-sheds), \&c. In the Droitwich district it meant, as in Saltwich, the sheds where the salt was stored for sale. The "Vicus emptorius" of the Salt-wich Charter implies this. The Latin Vicus is also represented in Irish Fich (glossed Municipium), in Cornish Gweek and Breton Gwig = town. Pedersen, V.G. § 130 .

${ }_{1}$ This word probably represents Magenas $\hat{x} t e=$ the settlement of the people of the Mag or plain. The Gaulish and British form of $M a g=$ (Plain) was Magos (Latin magus, as in Argentomagus and Noviomagus). The modern Welsh is $M a$ ( $=v a$ in compound names as Morva = Seaplace) with a cognate form Maes, pl. meusydd $=$ field. 
then, as after the battle of Dyrham, probably a Wessex Centre.

The claim of Aust, on the estuary of the Severn, may be thus dismissed, especially as this name is probably, as Mr. Plummer has pointed out, a relic of the Traiectus [Augustae, that is, Legio ii], the name in the Antonine Itinerary of the passage to the north side of the Channel.

The "Oak" may have been near Cricklade or, indeed, anywhere in that district, and the British Bishops may have come from any place as far north as Chester, which was British until some thirteen years after. That they did come from the north is somewhat confirmed by Bede's account of the second meeting with Augustine, at which there were "seven British Bishops, and many most learned men, especially from their most distinguished Monastery of Bangor' ('Bancornaburg', that is, Bangor-is-coed) over which Dinoot was then ruling as Abbot". Augustine on the failure of this Synod is made to say, "if they (the British) were unwilling to accept peace with the English as brothers, they would have to accept war from them as

1 Bishop Reeves (Eccl. Ant. of Down, \&c., p. 199), who was followed by Dr. Joyce (Irish Place-names), derived Bangor from the Irish word Beanna $=$ horns, and identified the name with the numerous places in Ireland called "Bannagher", that is, Peak-district. But this origin will neither (I) satisfy the physical configuration of the ground, nor (2) account for the similarity of the form of the name in other Celtic dialects. There are several (see Myvyrian Arch.), Bangors in Wales, two in Brittany, and one, in its diminutive Benchoryn (twelfth century, now Banchory), a foundation of St. Ternan, in Scotland. We want a meaning for Ban, therefore, which will satisfy the requirements of not only Irish but Welsh and Breton Dr. W. Stokes (Wortschatz d. Celt. Sprach.) shows that the Irish Benn "point" = Cymric Bann "high" = Breton Ban "Eminence". The meaning in common seems to be "high" as applied to Bendchor (in Down, Bk. of Leinster), Ban-cor, later Bangor in Wales, and Bangor in Belle Ile, Brittany. The application of Cor (Chor) to a band or company (as in the term "Ban-chor" = a band of women $[\mathrm{Ban}]$ in the Book of Leinster) shows that the traditional meaning of Bangor, as the "Exalted band" (that is, of monks), is fully borne out, and that Bishop Reeves, who is very rarely wrong, fell short of the full meaning in this instance. For the application of "Bangor" to Glastonbury, see Note on the latter. 
enemies," which prediction, Bede adds, was fulfilled when Æthelfrith, with a great army, came in 6r6 to Chester (Carlegion=City of Legions) and defeated Brocmail its defender, slaughtering some twelve hundred monks of Bangor who had come to pray for the success of the British. The number of monks in this monastery, Bede tells us, was estimated at 3,100, all living by the work of their hands. "The Apostle's Oak" on the Abberley Hills, Worcester, which has been claimed as the site of the meeting, was not on the Wessex border at this time.

The Chronicle, following Bede (H. E. ii. 9), records under the year 625 the appointment of Paulinus as Bishop of the Northumbrians, and under Easter, 627, the baptism at York of their King, Eadwin. Bede tells us that following the baptism of the King and his nobles great multitudes became desirous of the "laver of salvation", and Paulinus spent thirty-six days catechizing and baptizing at the royal vill called "Adgefrin", now commemorated by "Yevering Bell", a hill rising above the Glen river in which the baptisms, as Bede tells us, took place. This vill was deserted, Bede continues, by subsequent kings, and another substituted for it at a place called "Maelmin"1 (variants Melmin, Melmun). This name has not been found in subsequent documents, but Kirknewton ${ }^{2}$ in all probability

1 This would probably pass through the stage of Melvin to Melvie, but I know of no such name in this neighbourhood. Min is given by Davies as "lip" or "edge" (from stem *Makno), and in Breton it means "a point of land", cf. " the Point of Minard" (minard=high promontory), to the east of Paimpol in Brittany, and the Minard and Minalto of Bannister's Cornish names, also Minard in Wales, \&c., see p. 159. Mael means "bald", that is "having no trees". Mael-ros (now Melrose) means the tree-less moor or promontory.

2 The present church here dates no further back than the time of Charles II, but it was then rebuilt on an old site, its dedication to St. Gregory the Great being preserved. In the restoration of the church some years ago there was found, under the chancel floor, what appears to be the side of a small sarcophagus, on which is deeply carved the subject of the Visitation of the Three Kings. This is now built into 
occupies its site. It was a new-town in contradistinction to an older, and the dedication of the Church there to St. Gregory suggests a connexion with the mission of Paulinus, tradition pointing out Pallins-burn, which is but a short way off, as a further memorial of the Bishop.

The conversion of the people north of the Tees was followed by that of the region, called Deira, to the south of it. Bede (H.E. ii. I 4) tells us of the baptisms administered by Paulinus in the River Swale (Sualua), "which flows," he says, "by the town of Catterick (Calaracta), for as yet," he adds, " no oratories or baptisteries could have been built in the first beginning of the Church there." There had been, however, he informs us, a palace erected in the royal vill at Campodonum, ${ }^{2}$ but this had

the east wall. The treatment, even to the short-kilted tunics of the kings, is purely Roman, and the work has no parallel in Britain, its exact analogues being found in the fourth- and fifth-century sarcophagi in the Lateran Museum. The size of the slab indicates that it was for a young person, probably one of the scions of the house of Northumbria whom Paulinus had baptized. Abbot Gasquet, who visited the place after my description of it to him, fully substantiates the Roman character of the work, and the probable period of its execution. This serves to confirm the identification with Malmin the new royal vill.

1 There is in Britain more than one river called Swale. The East and West Swale, and the stream which gave its name to Swale-cliff, all in Kent, are other instances. The name may be Teutonic and connected with the Anglo-Saxon verb Swell-an, to swell. Its frequent appearance in Germany would seem to bear ont this hypothesis, e. g., the river Swala (A.D. 882), Swala-feldt (A.D. 793), on the Schwale, and the numerous Schwal-bachs (Oesterley, Hist.-Geog. Wörterbuch). Cataracta (in the Anglo-Saxon version Cetrehtun, and Cetrehtan) represents the Cataractone (locative case) of the Antonine Itinerary. It was probably imposed by the Romans on account of a portcullis, in which sense Cataracta appears in Livy, xxvii. 28 ; Vegetius, De Re Mil. iv. 4 ; Pliny, Ep. x. 69.

2 Campodonum is given in the Anglo-Saxon version of Bede as Donafeld. It is doubtless the Cambodunum of the Ant. Itin., and was some twenty miles south-west of Tadcaster (Calcaria). It has been placed at Slack, but there seems to be no relic of the name in that neighbourhood. The Roman road from Tadcaster to Manchester (Mancunio var. Mamuci-o) did not go direct, and hence the difference of the actual mileage from that of the Itinerary. It ran to what is now called Adel, near which on a comparatively modern 
been burnt down, together with the whole vill, by the pagans who slew Eadwin, the stone forming the altar, which alone escaped destruction, being removed to Thryduulf's monastery in the Wood of Elmet. "Later kings", Bede adds, "had in lieu of this built for themselves another vill in the region which is called Leeds (Loidis)."

The conversion of the people of the province of Lindissi ${ }^{1}$

map there is a place called Camp-town. I have not been able to find an earlier form of this.

Thryduulf's monastery was presumably not far away, but it has not been identified. It was in Elmet; compare Barwick-in-Elmet. Elmet is a British word applied to the district to the east of Leeds (Loidis, a district and also a British word). The stem Loid is possibly the same as that involved in the Lothians (Lodonia), and in the Lincolnshire Louth, but its meaning is obscure. Elmet, in a later form where the $m$ has been aspirated, occurs in the thirteenth century list of Cantreds and Commotes of Wales in Red Book of Hergest, vol. ii, p. 4II, and also in a later list (Cymmrodor. Mag., vol. ix). It is placed in Emlyn by the latter and in Cantref wartha by the former, both in South Wales. The first syllable of Elmet occurs in several Welsh place-names, e.g., El-vel or Elvael. Dr. Stokes finds a representative of the Greek "Poll-os" and the German "Viel" in an old Irish "Ol" [also hil] = great. This is possibly the equivalent of the Welsh $e l$ in these compounds.

1 Lindissa (Anglo-Saxon on Lindesse, and now represented by the district of Lindsay) involves the Lind-um of the Ant. Itin. The stem Lind, from earlier Lend, meant "water", "lake"; it occurs in Irish as Lind, in Old Welsh as Linn, modern Llynn, in Breton as Lin = marsh. Lindissa was thus probably "fenland", and its inhabitants in the genitive plural were called "Lindis-farorum". The last element may be from Fara cited by Torp (Wortschatz, p. 229) as representing "race", "family", in Lombardic. It is the same word as A.-Sax. Faru = journey, MHG. Var = "way", "track", but cf. Veri, p. 2I3. The $-i s$ in Lindis seems not to be of British origin, but is probably Tentonic-see Pedersen, V. Gramm. $\$ \mathbf{I}_{5} \mathbf{I}$, on Indo-European final.-s, $-s t$, -sk, in late Celtic. The final syllables, however, may have been -issa in Celtic, recalling isam, isaf (=lowest), of which the stem is identified by Pedersen ( $\$ 34$ ) with *Ped-su ( $=$ at the foot); cf. Pevenissel. It is not the same word as Lindisfarn, of which the last syllable is probably the Celtic ferann (ancient stem verann, according to Dr. Stokes), mod. Irish fearran $=$ land (sometimes losing its initial $t$, as the Welsh loses the 
followed-the baptism of Blaecca, the prefect of the City of Lincoln (Lindocolina), and of his whole household being the first-fruits of the preaching of Paulinus, who afterwards (A.D. 633) was made Bishop of Rochester-he having left in York Jacob, a deacon, who gave his name, Bede adds, to the vicus where he dwelt (conjectured to be Akeburg). Bede acknowledges his indebtedness for his history of the beginnings of Christianity in this region to a certain Deda, Abbot of Peartaneu, ${ }^{1}$ who had

equivalent gu, and becoming Arran, as in the several islands of that name and in the designations of "land" in the West of Ireland; cf. Joyce, Irish Place-Names, ii. 360). Lindisfarn (also called Medcaut, and in Tigernagh's Annals under A. D. 632, Inis Metgoit. In the Felire of Oengus it is Inis Medcot) is therefore of the same significance as the Anglo-Saxon Ea-land, that is water-land, island. Farne is the name of an island close to Lindisfarne. The Guern in Guern-s-ey, and "the Warne", although no longer above water, may possibly belong to the same stem. Simon of Durham, i. 51, derives the Lindis of Lindisfarn from the name of a river flowing into the sea opposite it; Leland calls the Witham (early form Widma) river flowing past Lincoln the "Lindis", and also the Rhee, a generic word ( = also Ree, $R e y, R e i$ ) for stream in late English, representing Anglo-Saxon Rith cognate with Irish Riathor (= torrent), Old Welsh Reatir now Rhaiadr ( = waterfall), Latin $R i$-vus, Pedersen, v. 9, §45. The transition from rith to rey is shown in the Berkshire Child-rey from the form Cilla-rith of the early Charters (Cod. Dip. 746, 1133, \&c.). In Holinshed's Chronicle, Rhee is said to be a general word for stream. The New English Dictionary pronounces the word of obscure origin, and the Eng. Dialect Dict. has no light to throw upon it. (1) The frequent occurrence of Rith in Anglo-Saxon place-bonndaries implies that it must have a modern representative. (2) If Ree be not that representative there seems no other to hand. (3) The instance given above shows that it has become rey, and the conclusion that rith $=$ ree seems fully justified. Rye, which occurs in place-names, is quite a different word. On the Welsh border it represents $R h i w=$ slope, as in Rhiw-las (= green slope) in Hereford, which is represented a few miles away (near Dymock) by Rye-lass. Lind-Colina (Anglo-Saxon Lind-Cylene) contains "Colonia", although the existence of an Anglo-Saxon Lind-Cylne in Kent, where Lind = Limetree, makes the connexion obscure.

1 The fact that Peartanen (now Partney, not far from Spilsby) begins with a $P$, and has an ending (eu) of which the significance is not clear, suggests that it is not an English word. Parthenay (earlier Partenacum) too, occurs in France, and is derived by Holder (Sprachschatz) from a personal name Parthenus, 
had from the lips of an old man an account of the latter's baptism and that of a great multitude by Paulinus in the River Trent (Treanta) near the city called in the language of the Angles Tiouulfingacæstir,' King Eadwin himself being present on the occasion.

Eadwin seems to have owed his advancement to Christian influence. For it was while he was a fugitive from Athelfrith's persecution at the Court of Redwald, King of the East Angles, that he secured, as Bede tells us (H.E. ii. I2), by divine interposition, the help of the latter, who, in a battle on the east bank of the river $\mathrm{Idla}^{2}$ (A.D. 627), slew Ethelfrith and helped to place Eadwin on the throne of Northumbria. Eadwin's influence with Redwald led afterwards to that King's conversion and to a temporary spread of Christianity in East Anglia. But it was to Sigeberht, who had been baptized when an exile in Burgundy, that the conversion of the people was mainly due. He succeeded in

a Latin form of the Greek word for Virgin. Most or our words connected with the cloister are derived from the Greek, viz., "monastery," "coenobium," "monk," "nun," "anchorite," \&c., and it is not quite impossible that the Greek Parthenōn, which is used for a nunnery (Life of Anthony in the Lausiac of Palladius), should also have passed to the west. The form in the Anglo-Saxon of Bede's History is, in this respect, suggestive. Peortan-ea tham ham $=$ of the ham or home of Peortanea. The en termination is here made into $e a$, which would indicate "river". The oldest Anglo-Saxon form, however, of the latter word, as far as I can find, is $\bar{e} a$, as in Bede's "Homel-ea" (now the Hamble river), and $e u$ does not become ea, but eo, as in Bede's Hreutford for Hreodford (Redford or Redbridge, Hants). The $e u$ represents, therefore, a different and probably a foreign element. All this is pure speculation, and the name in a Sussex charter Peartinga-wyrth (identified by Mr. Birch with Petworth) leads to further surmises.

1 Tiounlfingacæstir has not left any relic of its name, but it has been identified with "Little borough" (the Roman Segelocum or Agelocum) where the Roman road crosses the Trent. It has nothing to do with Torksey, which in 873 was Turcesig.

2 Idla is the Idle river in Notts.; as the form in I 200 was Yddil (B. Mus. Index of Charters) it looks as if the $a$ termination is for $\bar{e} a$, river (Old Frisian $a$ ). In any case the origin and menning of the word are obscure. 
A.D. $63 \mathrm{I}$, and made Felix, who was born and ordained in the same region, to be bishop of his kingdom, assigning to him Dunwich (Dommoc or Domnoc) ${ }^{1}$ as his See.

The battle of Haethfelth ${ }^{2}$ (Oct. 12, 633) in which Caedualla, the King of the Britons-Penda of the royal house of Mercia assisting him-overcame and slew Eadwin, put a temporary check to Christianity in Northumbria. Paulinus, who had been a missionary in this region for some years, then took ship and sailed, with Eadwin's widow, to Kent. A kinsman of Eadwin, Osric, who had been converted by Paulinus, succeeded to the southern part of Northumberland (Deira) and Eanfrid, son of Ethelfrith, who, having been an exile with the Scots and Picts, had been brought up as a Christian among them, succeeded to the northern portion called Bernicia. Both these kings, however, returned to idolatry, and Caedualla, who slew them, was regarded by Bede as an instrument of divine vengeance $(H . E$. iii. I). Oswald, the brother of Eanfrid, who had been in exile with him among the Scots, succeeded to the Kingdom of Northumbria and slew Caedualla at a place called, in the language of the Angles, Denisesburna, ${ }^{3}$ that is, the "Stream of

1 Dumnoc is Celtic and involves a term which means "deep" (Dumnos or Dumno-s = the modern Welsh $D w f n$ ). It probably signified a port with a deep-water approach as distinguished from shallows with shifting sands. The $o c$ is an adjectival termination. The use of the cognate Dutch (Frankish) word Diep in Nienwe Diep, and Dieppe, is a parallel instance of the employment of such a word to designate a port.

${ }^{2}$ Haethfelth is supposed to be Hatfield Chase near Doncaster. Nennius and the Annales Cambriae call this the battle of Meicen. The Welsh and Irish Chronicles are two or three years behind, and place the battle in A.D. 630. Caed-ualla is represented in Welsh history as having been King of North Wales (Gwenedd), but if this were the case this territory probably reached further north at that time. Chester lay waste (hence West Chester) after Ethelfrith's victory, and Eadwin's writ hardly ran there. The point of contact between Caedualla's and Eadwin's territories was probably to the north-west of Chester.

3 The site of this battle is now well known. In a thirteenth-century charter we find the Archbishop granting " $\mathrm{xx}$ acras terrae ... in Ruleystal 
Denisus". This battle began at a place a little north of the Roman Wall called by Bede Hefenfelth, which he places not far from Hexham (Hagustaldensis Ecclesia), but ended in the victory over Caedualla at Denises-burn (A.D. 634). Christianity was restored in Northumbria by Aedan, sent, at Oswald's request, by the Scots, to whom Oswald assigned the island of Lindisfarne as his See. After reigning nine years Oswald was slain at Maserfelth ${ }^{1}$ by Penda $\left(6_{42}\right)$, and was succeeded by Oswiu. His relics, Bede tells, were taken to the monastery of Bardney (Bardaneu). ${ }^{2}$

... inter Denisesburne et Devilis", that is, twenty acres of land-in Ruleystal between Denises-burne and Devilis. Denises-burn is now Rowley Water, and Devilis, which is one of the many forms into which Dubglas (= black or peaty stream) has come, is now, by a natural attraction, Devil's Water (Speed's Map, 1610, was Dovols $f$.), and gives its name also to Dilston (see previons reference to Dubglas). The battle began at Hefenfelth seven or eight miles north of Hexham beyond the wall, where a chapel existed for centuries after, built, as alleged, on the site of the cross which Oswald raised there. Leland identified the spot with Halidene, now Hallington. Hexham is the modern form of Hagustaldesham. Hagosteald meant a young soldier, or a bachelor. The modern German Hagestolz = old bachelor, preserves the latter meaning of the word. It gave name also to a place, Hægstaldes-cumb in Somerset (Cart. Sax. i. 97). It is possible, however, that we have here a case of attraction, and that the original word was Romano-Celtic, perhaps some compound of Uxello = high, as in the Axeloduno of the Not. Dig. (Uxelludamo of Ravennas) with which Hexham had been identified, although there are difficulties with the surmise. Nennius calls this battle Cat-scaul, "Cat" = battle, and "scaul" may be for is (g)uaul = beneath the wall.

${ }^{1}$ Maserfelth is commonly assumed to be Oswestry, which in Welsh is Croes-oswald, or Oswald's Cross. Nennius and Ann. Cambriae call it Bellum Cochboy. And Simon of Durham places it at "Waneloc" (? Wenloc) which he makes $=$ Croes-Oswalt.

${ }^{2}$ Bardaneu is distinct from Partaneu, but owes, seemingly, its form to the same original influence. What that influence was is not easy to say. In Die Heiligen Englands, p. II, the name is "Bardanege, where rest near the river Withma, St. Ethered, the king, and St. Ostryth, sister of King Oswald". The termination $e u$ is here made $e g e=$ island. The Withma is now the Witham river, the earlier name suggesting an obscure Celtic original. 
Oswiu fought and slew Penda at Winwidfeld ${ }^{1}$ in 654 (at the river Uinuaed, according to Bede). Mercia had been Christianized, according to the Saxon Chronicle, in $6_{52}$, and Penda was therefore nominally a Christian at the time of his death. Wessex during these years had been extending to the westward, the Chronicle recording a victory over the Britons (Walas) at Beandune [somewhere probably on the high lands north of Bath, and not at Bampton (Oxf.) or Bindon (Dorset)] in A.D. 614, but Mercia was coming into conflict with Wessex, for in 628 the Kings of Wessex, Cynegils and Cuichelm, fought with Penda at Cirencester (Cirenceastre), the battle ending, however, in a truce. Pope Honorius sent Bishop Birinus in 634 to evangelize the West Saxons, and Cynegils was baptized in the following year at Dorchester (Dorcic or Dorcic-ceastre) ${ }^{2}$ in Oxfordshire, and Cuichelm in 636 at the same place. Cenwalh, according to the Chronicle, succeeded to Wessex in 643 , but was driven out by Penda two years after. He was not baptized until 646. Birinus was succeeded in $65^{\circ}$ by Æigelbeorht (Egelbiryth), a Frankish Bishop, who had been educated in Ireland. In $65^{2}$ Cenwalh is represented in the Chronicle as fighting at Bradford-on-Avon (Bradan forda be Afne), and six years later he overcame the Britons (Walas) at the Penns (Peonnum = Penselwood), and drove them as far as the Parret (to the Pedridan). ${ }^{3}$ The extension of Christianity in East

1 Uinuaed is supposed to be the river Broad Aire which flows by Leeds. The form suggests some Celtic river-name, beginning with Vind-o (= clear, white, as opposed to Dub-o, "dark"), of which there were numerous instances, some of them coming down to our own day, e.g., Winfrith Win-ster.

${ }^{2}$ Dorcic-ceastre appears in the Chronicle also as Dorces-ceastre, illustrating the tendency of the Teutonic settlers to make the Celtic prefix in a name they did not understand into the genitive case of an imaginary holder, cf. Rofes-ceastre and Raculfs-ceastre. Dorcic here may represent the Durcinate of the Ravenna geographer, but the latter seems from the sequence in which it appears to be in East Anglia.

Penn is here, as often elsewhere, made Peon. It represents an early Pond (which in late Cornish becomes Pedn) meaning "head". It is 
Anglia at this time is shown by the entry in the Chronicle under ${ }^{6} \mathbf{5 4}_{4}$, "Botulf began to build the minster at Icanho," which was afterwards, it is assumed, called Botulfston, that is, Boston, in Lincolnshire. ${ }^{1}$

In the records of the spread of Christianity in Britain, during the seventh century, numerous localities of an interesting character are mentioned. Bishop Felix, who came from Burgundy, then but lately brought by Irish monks to a knowledge of Christianity, laboured in East Anglia, where he was assisted later on (A.D. 633) by a small band of Religious from Ireland. Fursey, the leader of these, erected a monastery within a Roman fortress, probably that of Garianno [Not. Dig.], then known, according to Bede, as Cnobheresburg, ${ }^{2}$ and now identified with

here in the English dative or locative plural ending in -um. The Pedrid-an river is Celtic, but comes to us through Teutonic sources. It may mean the "chief ford" -river, that is, Pen-rit, which would pass naturally into *Perrit, the Parret-but this is purely speculative.

1 Ican-ho is made up seemingly of the genitive of some shortened personal name, Ica, and $h o(h \hat{o} h)$, a promontory, but the Ican may preserve a reminiscence of the people called Iceni, whose chief centre was at Venta Icinorum, near Norwich. St. Botulf is said in Die Heiligen Englands (p. II) to have been buried at Medeshamstede near the river Nen: and to rest (p. 15) at Thornige (Thorney Abbey) with several other saints. The battle at Bradford-on-Avon seems to be that described by William of Malmesbury (i. 23) as "in a place called Wirtgernesburg". William lived sufficiently near to be acquainted with any local tradition, but nothing is known of a citadel of Vortigern in this locality. Nennius makes the Citadel $(A r x)$ of Vortigern to be "beside the river Teibi in Demetia", that is apparently Cardigan, which is by the Tivy in South Wales. "Caer Guorthigirn," in his list of Civitates, is elsewhere possibly Tintern for Dinthigirn or Dindeyrn, or fort of the chief. Vortigern $=$ Over-lord.

2 The personal name Cnobhere involved in this name is seemingly made up of Cnapa = boy, servant (now English "knave") and Here = Army, host. Cf. Marah-Scalc ( $=$ Marshall $=$ horse-boy) Gottes-scalc, Sene-scalc (=Seneschal), \&c. Cenapa occurs as a moneyer in the time of Ethelstan (Grueber, A.-Sax. Coins), and Cenepes-moor appears in a charter (Cod. Dipl. 120). The name Cnofwealh (Cnobwalch) is in the Durham Liber Vitae. There are, as far as I can discover, no continental forms similar to Cnobhere, and it is quite possible that we have here a pre-Anglian name attracted into a form intelligible to Tentonic ears. The monastery 
Burgh Castle close to the junction of the Yare and Waveney rivers. In the life of Fursey (Capgrave, Nova Legenda Angliae) - of which some form was used by Bede-he is said to have worked twelve years in Britain, after which, in his desire for a more secluded life, he left his monastery to his brother Foillan and to two Presbyters, Gobban and Dicul, and proceeded to Gaul. Here he founded a monastery called Latiniacum (now Lagny) not far from Paris, and died about $65^{\circ}$, his relics being afterwards enshrined in a newly built church at Perrona (Péronne) in Picardy.

According to a MS. [E] of the Saxon Chronicle, written in the first half of the thirteenth century, the King of Northumberland and the King of Mercia erected in East Anglia a minster in $66 \mathrm{r}$, to which " the name of Medeshamstede was given, because [as the MS. says] there is a well there called Medes-wæl ".." This was known afterwards as Peterboro. The same MS. alleges that a grant of lands and privileges was then made to the minster, but it is clear from the names of the places cited, \&c., that no such grant could have been made at this time. Bishop Tuda, who was present at the consecration of this minster, died the same year, and according to this MS. was buried at Wagele, ${ }^{2}$ but according to Bede at Pægnalaech. Peada, King of Mercia,

was built within the "Chester" (on Sumre Ceastre, A.-Sax. version), which possibly had then a name-perhaps the "Garian" of Gariannum, now preserved in the river "Yare".

${ }^{1}$ Medes-wal suggests the personal name Math, a contracted form for some such appellation as Mrthhelm, which occurs in the Iib. Vitae.

2 It is clear that the early form in Bede, "Pægnalaech," is the correct one, and that the twelfth-century chronicler has made, owing to a common mistake, the $P$ into a $W$, which it resembles in the A.-Sax. character. Pxgna is in form a genitive plural of Pæg, and probably represents a British tribal name. Laech $=$ Leah in A.-Sax., which came to mean field, meadow, but was originally "wood "; see Stevenson's Asser's Life of Alfred, p. 272, and Kurths (Frontiere Linguistique, i, p. $3^{6} 5$ ), who cites the examples of Belgian place-names ending in -loo (e.g., Waterloo), earlier -log. The place has not been identified, but Paull in Yorkshire, in Domesday Book Paghal, and in later documents Pagula (see Poulson's Holderness', may represent the name. It has nothing to do with Whalley. 
and his following were baptized, according to Bede, by Bishop Finan (one of the Irish Clergy from Lindisfarne) at the royal vill called Ad Murum (Walton) where, Bede tells us, Sigebert also was baptized by Finan. 'The conversion of all Mercia by the Lindisfarne missionaries followed. Diuma, one of these missionaries, was made by Finan Bishop of the Southern Angles and Mercians, but died shortly after $\left(6_{5}^{8}\right)$ in a region called In $F_{\text {eppingum, }}{ }^{1}$ being succeeded by another Irish Bishop called Ceollach (now Kelly), who, shortly afterwards returning to Iona (Hy), was followed in the See by Trumher, an Englishman, ordained by the Irish of Lindisfarne. He had been abbot, as Bede tells us (H.E. iii. 24), of a monastery called Ingetlingum [the place where Osuiu was slain, now Gilling, Yorkshire].

After the death of Felix, Bishop of Dunwich, in 647, Honorius, Archbishop of Canterbury, appointed Thomas, of the province of the Gyrvii, ${ }^{2}$ to succeed him among the East Angles. Mission work in this region, however, passed soon to the Lindisfarne

1 This has not been identified. "Fobbinges" occurs (but in Essex), and the word here is a similar form in the locative plural. The resting-place of Diuma is given in Die Heil. Eng., p. II, as Ceorlingcburh near the river Wenrisc, that is, Charlbury near the Windrush, Oxon. This river-name is doubtless Celtic and involves probably $-i s c=$ water.

${ }^{2}$ Gyrvii means "fen-dwellers," "Gyrwe-fenn" is glossed "marsh", and Yarrow is given by Bede as In gyruum, at the mouth of the Wear river, that is the marshy land at Wearmouth. For the land boundaries given in Cart. Sax. iii, p. 203, we have " on Gyruwan fen that eft (thence directly) on Bugla fen". Cf. also the "Gyrwa river" in the Chronicle of Melrose. Kluge (Gesch. der Eng. Sprache, p. 78I, in Paul's Germanische Philologie) would make the Gyrwe, as well as the Hwicce, Teutonic tribe-names, possibly of continental origin, although they have not been identified in the ancestral home of the Teutonic invaders. Of the continental Rugii (cf. Holm-ryge in Widsith) Kluge finds a representative in Sath-ryge (now Surrey), and in East-ryge (now Eastry in Kent). For the former Bede has "in regione sudergeona", in the Anglo-Saxon version Suthrigna-lande, both in genitive plural. In an original charter of 780 (Cart. Sax. i. 353) occurs " in regione Eastrgena" (= Eastry). Croyland (Crúland) is placed by Die Heil. Eng., p. II, on middan Girwanfônne, i. e. in the middle of the Girwanfenn. The same anthority records from a MS. written before 1000, that Thunor, who had at the command of King 
clergy, one of whom, Cedd, who had founded a monastery at Lastingaeu ${ }^{1}$ (Lastingham near Whitby), was ordained Bishop by Finan, and became most successful in the conversion of the people, especially in the City (civitas) of Ythanceastir, ${ }^{2}$ which,

Egbert slain the brothers of Eormenburg (Domneva), had buried them at Eastrege under the king's "high setl" in his Healle (Hall).

1 The termination $e u$ in Lastinga-en, Hernt-eu, \&c., is of obscure origin and meaning. In Bede's time the ending in the latter word had come to be identified in meaning with $i g=$ island, but when the A.-Sax. version of Bede's History was made, Herut-eu became Herot-ēa, that is, Hartwater, or, as it is now, Hartlepool. $E a$ (=water) and ig (= island) are both traceable to a common Gothic stem ahwa (cognate with Latin Aqua), which became Old German $a h a$, and later $a$, as in Fuld-a, but an A.-Sax. form $e u$ for the normal $\bar{e} a$ is not found. It is possible that we have in this termination a remnant of a Celtic ending, and that the first part of the combination is of similar origin, but attracted into intelligible Teutonic forms. Compare Lastinga-eu and Lastingham with Incuneningum and Concha-ceastre; Coldingham, and Bede's Coludi urbs-in the Chron., Coludes-burh. It was in this "Town of Coludi" that Edilthryda, daughter of Anna, king of the East Angles, became a nun. The abbess at the time was Abba, whose name survives in St. Abb's Head, near Coldingham Adilthryda was subsequently made abbess in a region called Elge (Eligabirig, Die Heil. Eng. 7)-now Ely. This name was given to the place, Bede says $(H . E$. iv. 19), becanse of the abundance of eels in the marshes surrounding it. Kluge (Etymol. Wörterbuch, sub Gau) thinks that the ge in the name represents the German Gau = district, and that the complete word means Eel-district. The A.-Sax. Chron. [E] variant Helige is late, or one might think of the British Helig = willows.

${ }^{2}$ Ythan-ceastir has been identified, and rightly, with the Othona of the Notitia Dignitatum. It is now marked by St. Peter's Chapel in Bradwell, Essex, which is called St. Peter's ad murum. This is referred to in Die Heil. Eng., where on p. 13 it is said, there resteth $\mathrm{S}^{\text {ta }}$ Osgith (Osyth) in Cicc (Chich) near the sea at St. Peter's Minster. There is a wall there, but whether of Roman origin is not certain, but the ancient Chapel, now a barn, has Roman bricks built into it. The Blackwater, on which the place is, forms the lower reaches of the Pant. I suggested some years ago (see Plummer's Two Sax. Chron. ii. 149) that this is the Iudan-byrig of the Chron. under $95^{2}$ [D], where King Eadred imprisoned Wulstan, Archbishop of York. The mention immediately afterwards of Thetford suggests that the place was in East Anglia, not at Ged-burgh (Jedburgh), where the King's writ did not run. A similar form, Geotha-, occurs among the A.-Sax. mints (Grueber, A.-Sax. Coins). The form in Fl. of Worc. is Juthan birig. 
Bede adds, is on the shore of the river Pent [Penta], and at Tilaburg (Tilbury). Siudhelm, who had just succeeded to the throne of East Anglia (660), was baptized also by Cedd at a place called, according to Bede (H. $E$. iii. 29), "Rendlaesham, that is the dwelling of Rendili." Cedd died in 664, and was succeeded by his brother Ceadda, then abbot of Lastingham.

Finan, Bishop of Lindisfarne, died in $66 \mathrm{r}$, and was succeeded in the See by Colman, another Irishman, who became the champion of the Celtic mode of keeping Easter as against the Roman. A synod was summoned to settle this question, Bede tells us (iii. 25), " in the monastery which is called Strenaeshalch, which means the bay of the watch tower [Sinus Fari]".1 Bede makes the Pharos of Alexandria the second of the seven wonders of the world, the Capitol being the first. So he was familiar with the word. Hild, who had formerly ruled the monastery at Heruteu ("the Isle of the Hart", according to Bede), was the abbess of this place, and took the part of the Irish in the controversy, Bishop Cedd, who acted as interpreter, maintaining, as Bede says, a most watchful attitude on both sides. Wilfrid was the most powerful advocate of the Roman position, and through him an agreement was arrived at, but Colman would have no part in it, and went with his followers (some thirty monks) to an island in Ireland called, says Bede, Inisboufind, that is, "the island of the white cow." He afterwards found a more suitable place called Mageo, where he built a monastery which was known for centuries after as "Mayo of the Saxons", now Mayo.

When Theodorus (like St. Paul, a native of Tarsus) became Archbishop of Canterbury in 668 he set about reforming

1 Halc (preserved in halec, haugh in Scotland) = Healh, which Sweet renders hiding-place, bay, but its modern form means "low lands by a river". Streon = treasure, gain, wealth, and it is not easy to see how it could mean "watch-tower" (Pharus). Mr. Mayhew makes the meaning " the rock of gain". It is possible that Bede's fari may represent a Teutonic word, such as far, which is given by Outzen as Frisian for boundary, or it may be the same fari we find in Lindisfarona, see p. I jo, note. 
irregularities, and finding that Ceadda had not been rightly consecrated Bishop [he had been consecrated by a Bishop of Wessex, assisted by two British Bishops (Bede, H.E. iii. 28)], he consummated the act after the Roman manner. Ceadda erected a monastery at a place called, by Bede, Ad Baruae, that is, "at the wood," but his See was at Lyccidfelth ${ }^{1}$ (Lichfield), where he died and was buried (A.D. $67^{2}$ ).

1 Among the Civitates Britanniae of Nennius we have Cair Luit Coyt, that is, "the stronghold of the Greywood." Luit coyt represents, as Dr. Bradley pointed out, the earlier Leto-cetum (Lecto-cetum of Ravennas; cf. [L] Etocetum of the Ant. Itin.) of which Bede gives the shortened form Lyccid in his Lyccidfelth. In an original charter of A.D. 803, now in the British Museum, the form is Liccidfeld, for possibly *Litcidfeld. This has become Lichficld, which has nothing to do with Lic (body or corpse), with which it is usually associated. The Let may also mean "broad" and the name would thus = English "Broadwood", but Llweyd coed occurs in Wales to-day. The origin of the Litchfield in Hants seems to be from an early Ludeshulfe ("Church of Lydeschulv" in temp. I7 Edw. II. Hist. MSS. R'eport XV. App. x. p. I73).

The oldest form of Coed is preserved in the Continental place-names, Kaıтó $\beta \rho \iota \xi$ (in Portugal), Ptolemy ii. 5. 2, given by the Ravenna Geographer as Ceto-bricca. In the Brythonic districts of Scotland we find it modified, probably by Goidelic lips, into Chet or Keith. The early form, as already stated, of modern Bathgate is "Bat chet" (Holyrood Charters), and the early antecedents of -Keith take the same form, see note, p. 86. Several modern English place-names, involving chet, chute, such as Chet-wood, Chute Forrest, appear early with $\mathrm{Cet}$ in the compound. For example, we have in the Calendar of Charter Rolls, "Forest of Chett" (1248), "In Bosco de Cett," I270, where Chute is the modern form; "Chetwod," Bucks. (1 290), and "The wood of Cett-red", Dorset (1242); cf. Lasket grove (Monmouth), Lasket in Cumberland (where probably the originally prefixed definite article has caused the dropping of the initial $g$ ), and Glascoed; Kesteven in Lincoln appears (B. Mus. Charters) in twelfth century as Ket-stefena (Chetsteven: Domesday), in which the latter element is seemingly an Anglian genitive plural of Stemn or Stefn = stem, and the whole may represent "the wood of trees large enough to be used in ship-building". Another origin is, however, possible. The A.-Sax. Stefn means also "period", and dialectically in Steven " appointed time or place of meeting". Cett appears also in an early Charter as tumulus. We have thus " the district of the people who assembled at the Cett; cf. names of Hundreds. The form Ceoftefne in Ethelwerd's Chronicon is evidently a mistake of the Copyist. In a copy of a Westminster charter of 1067 (B.M.Charters) 
Sussex and the Isle of Wight were not converted till the close of the seventh century. Wilfrid, who, when he was a Presbyter, was sent by Alchfrid, son of Oswiu, to Gaul, to be consecrated Bishop, received Episcopal Orders at Compiègne (Compendio) at the hands of Agelberct (Agelbeorht), then Bishop of Paris, but formerly of Wessex. Wilfrid was Bishop of York from 669 to 678 , when, as Bede says (H.E. iv. 13), "driven from his Bishopric, and having wandered about for a long time through many places, he went to Rome." On his return he set about converting the South Saxons. The king of these people (ÆEdilwalch) had been recently baptized in Mercia-Wulfhere, the king, being his sponsor, from whom Edilwalch received as a gift the Isle of Wight and the Province of the Meanuari ${ }^{1}$ (Meanwara, Anglo-Saxon version), that is, of the region of which East and West Meon and Meonstoke preserve the name. At this time, A.D. 68I, Sussex, as Bede says, was ignorant of the Divine Name and of the faith, but a certain Irish monk named Dicul (probably the companion of Fursey) had a very small monastery in a place called Bosan-hamm, ${ }^{2}$ where, surrounded by woods and the sea, he, with five or six others, lived a life of meekness and poverty. Wilfrid's success was great, and King Ædilwalch

we have "Penceat Wood in Battersea Manor", which seems to be the same as "se wude the hatte Pœnge", i.e. the wood called Penge belonging to Battersea according to an almost contemporary charter of 957 . (Cart. Sax. iii. 189). In a charter of I 308 we have "Penge in parochia de Badricheseye". It is probable, therefore, that Penge is the worn equivalent of Penceat $=$ chief wood, the ceat as in the Letcet of Lichfield being softened to $c h e=g e$ : cf. Pen-cet, Lancs., p. 86. The Westminster Charter of 693 does not include Penceat. This derivation which explains an early obscure form is both startling and suggestive. In Die Heil. Eng., p. I I, we have the entry "There rest St. Ceada and St. Cedde, and St. Ceatta in the minster named Licetfeld near the river called Tamer (Tame)".

${ }^{1}$ Mean represents the district, and may have taken its name from a river; wara $=$ "of the people". The Moenus, now the Main (-Germany), and numerous rivers called Main in Ireland, show that a Celtic etymon is possible.

${ }^{2}$ Now Bosham. The diocese of Selsey, afterwards Chichester, took its beginning from this small monastery. 
gave to him Selaes-eu, ${ }^{1}$ in the $A .-S a x$. Chron., Seoles igge, which, Bede says, means Seal's-island.

A new authority now appears on the scene. Caedualla, "a most vigorous youth of the royal race of the Gewissi," after having raided Kent, according to the A.-Sax. Chron. in 685, invaded Sussex, slew Ædilwalch, and ravaged the whole country. $\mathrm{He}$ also took possession of the Isle of Wight, and put two brothers of the King Arualdi to death, the youths having taken flight to the mainland, where they had hidden themselves at a place called Ad Lapidem, but were discovered. The abbot of a monastery called Hreutford" (that is, "the ford of the Reed," says Bede), obtained permission to baptize them before their execution, and they were thus the last martyrs of early Britain.

Caedualla went to Rome three years afterwards (689) and was baptized by Pope Sergius, and there he died, furnishing material for Welsh legend. The names "Caedualla" and "Gewissi" (see previous note) suggest alliances, if nothing closer, between the Welsh and the West Saxons. It is noteworthy that his predecessor, Kentwine, is recorded as having driven the Welsh (Brit-wealas) to the sea (A.-Sax. Chron. 682). The Wessex kings for some time had been extending their sway over the whole West country. In 66r (A.-Sax. Chron.) Cenwalh won a battle over Wulfhere, King of Mercia, at Posentes byrg (now

${ }^{1}$ Selsey is the modern name. Here Bede again understands $e u$ to be the same as $i g=$ island. He makes a similar assumption (H.E. iv. 6$)$ in regard to Chertsey, which he says " is called Cerotaes-ei, that is, Cerot'sisland". The A.-Sax. Chron. under 964 makes it "of Ceortes ige". Cerot may be a donblet of Herot = Hart, as in Herut-eu; or Cerot may be a personal name. The root Ker (= born) involved in Hart (= horned deer) is the same as that found in Hrother (=horned cattle)-the initial $h$ in both cases representing an Indo-European $k$ which appears in the Latin cervus and the Welsh carw ( $=$ stag) cognate forms. Rother appears in several English place-names, e.g. Rotherhithe (the earliest form contains Rether), Rotherfield, Rutherford, \&c.

'Ad Lapidem bas been identified with Stoneham on the Itchen: Hreutford is Redbridge near Southampton. 
considered to be Pontesbury, south-west of Shrewsbury; but compare Poscetene tune in Hereford Domesday, in which seems to be involved a genitive plural of $C e t$ ), and drove him as far as Æscesdun, that is, as Mr. Plummer has shown (Two Sax. Chronicles, ii, p. 23), the Berkshire downs. Ina, Caedualla's successor, according to a contemporary note to the Chronicle, "built (? repaired) the minster at Glastonbury," which had probably ceased to be British about this time : see Note G, p. 197 .

Wilfrid returned to York in 686, where he remained till 692, when he went to Leicester. From Leicester he went to Hexham in 705, where he died in 709. All England was now Christian, and up to 686 even the Picts of Galloway received Bishops from the English.

The last years of the seventh century are marked by some interesting events, among them being the consecration of St. Cuthbert as Bishop of Lindisfarne. As a youth he had entered the Monastery of Mailros, of which the abbot, as Bede tells us, was then Eata, afterwards Bishop of Hexham, but Cuthbert spent many years afterwards as a recluse on the Farne Island, about nine miles from Lindisfarne, now Holy Island. ${ }^{1}$ Cuthbert's teacher was the famous St. Boisil, "a priest of great virtue and of a prophetic spirit," whose name is still preserved in St. Boswell's-on-the-Tweed. Boisil, and another Bosil, Bishop of the Hwiccas, seem to be Celtic and not Teutonic names. Indeed, according to the Libellus (Hardy, Materials, i. 310-13), Cuthbert himself was also Irish, although bearing an A.-Saxon name. ${ }^{2}$ King Ecgfrid, who had caused Cuthbert to be consecrated bishop, was, however, no friend to the Irish, for in the year A.D. 684 , a year before Cuthbert's consecration, he had sent an

${ }^{1}$ Mailros and Hexham have been already explained. Bede, by coupling Hexham with Lindisfarne in designating the Bishopric of Eata ("afterwards Bishop of Hagustaldensis or Lindisfarnensis Church"), seems to indicate that Hexham was then the bishop's see.

2 Cüth is A.-Saxon for known, clear (still preserved in uncouth), and Berct $($ later Beorht $)=$ distinguished, now bright. Ireland was called Scotia and the people Scots in Bede's lime and much later. 
army into Ireland (Hiberma in the text; "on scotta ealonde" in the A.-Saxon version) under a leader called here Berct, but afterwards "Berctred", who, according to the A.-Sax. Chron., was slain by the Picts in 699 (698 Bede). The Northumbrian host under Berct devastated the country of the Irish, whom Bede designates " as a harmless race and always most friendly to the nation of the Angles". Neither churches nor monasteries were spared in this invasion. The Irish defended themselves with their weapons, but also trusted to their continuous prayers for heavenly help. The divine vengeance was not long delayed, for in the following year, as Bede tells us, Ecgfrid, having set out on an expedition to devastate the Pictish province-against the protests of his friends, Cuthbert included-and having been led by a simulated flight of the enemy into the fastnesses of the mountains, was there, together with the greater part of his army, slain (May 20, A.D. 685). Bede adds, "Because in the previous year he had turned a deaf ear to the most reverend Father Ecgberct, enjoining him not to attack Ireland (Scotia), which was not injuring him, he had now to suffer the penalty of that sin, by not hearkening to those who were anxious to recall him from his own destruction." 1

The Picts, and some portion of the Britons in the North,

1 The Annals of Ulster calls the place of the battle Duin Necthan, and states that Ecgfrid was buried at Iona, a somewhat surprising statement from his known enmity to the Irish. The place of the fight was Dunnichen in Forfarshire (called in a charter of William the Lion, Dunnechtyn), also marked now by Dunnichen Moss, the equivalent of Nechtanesmere, the name of the battle in Simeon of Durham, who lived in the early part of the twelfth century. The MS. is of the same century. The A.-Sax. Chron. [E] says that Ecgfrid was slain "be northan Sx", that is "to the north of the Sea of Forth" (Plummer, A.-S. Chron., ii, p. 32). Nennius calls the battle "the action of Linn Garan". Nechtan was the name of several Pictish leaders, and the appellation still survives in the families of MacNachten or McNaughten. Holder derives Nechtan from *Nect-a'g)nos = Neit-anus, which he connects with old Irish Necht glossed glan, that is "pure", "clean", but Nét (also Neid) was, according to Cormac's Glossary (ninth century), the Celtic God of War. Cf. Mog-Nét = Slave of Nét. See Celtic Britain ${ }^{3}, 26_{5}$. 
recovered after this victory their territory (which had been previously subject to Angles and Scots), and were still in possession of it in Bede's time. Trumwine, who was bishop in this locality, had to retire from it with his following, "who were in the monastery of Abbercurnig, ${ }^{1}$ situate, indeed, in the region of the Angles, but close to the strait which divides the lands of the Angles and Picts (that is, the Forth)." He took refuge at Whitby (Strenaeshalch) where he afterwards died (Bede, H. E. iv. 26). Cuthbert died in the Island of Farne in the year 687, but his body was removed afterwards to Lindisfarne, and thence, after many wanderings during the Danish invasion, to Durham where it still remains.

Bede tells us that a certain Presbyter named Herberct, who led the life of a solitary "in an island of that great lake out of which the Derwent (Derventio) river flows" (now known as St. Herbert's Isle in Derwentwater), was accustomed to visit Cuthbert, and on one occasion, coming to Carlisle (Lugubalia) to see him, obtained from him the promise that he and St. Cuthbert should die on the same day, which came to pass on March 20 in the year mentioned. ${ }^{2}$ Bede ascribes several cures

1 This is now Abercorn. The first part of the compound (Aber) is made up of the Celtic preposition $a d$ (Latin $=a d$ ) and bero-s, cognate with Latin fero and its English equivalent, "I bear." It means a junction of streams, and contains the same element we find in Irish Commar (Kom-bero-s), Welsh Cymmer, Breton Kemper (giving its name to Quimper), meaning "a coming together of valleys, streams, or ways". The word Inver, of similar meaning, is made up of the same element with the prefix Eni $=$ in; ${ }^{*}$ Eni-bero-s becoming the Irish Inber and the Welsh Ynfer. 'The Welsh Gofer (= stream), Cornish Guver (plural Goverou), Breton Gouer are made up of the preposition $V o$ (now Welsh Guo) = (under) and the same bero-s. (See Dr. W. Stokes, Wortschatz d. Keltischen Spracheinheit). The Corn in "Abercorn" represents the name of a river, possibly the Carron, involved apparently in the Linn-garan or "CarronWater" referred to in preceding note.

${ }^{2}$ An anonymous life of Herbert speaks of him as coming to visit Cuthbert "from the Islands of the Western Sea" (Maris), which Mr. Plummer makes to mean "West Mere", that is, Westmoreland. See previous note on this region on p. I37, and Geoffrey of Monmouth's 
of various diseases to the relics of St. Cuthbert, the accounts of some of which he himself had heard from witnesses. Among these cures he mentions that of a young man suffering from a tumour, who dwelt "in the monastery of Dacore, so called after the river on which it was built".

fanciful origin of the name. Derwent was the name of several rivers, one of them giving designation to the Roman station Derventio, supposed to be Stamford Bridge, near York. Dervent-io contains, seemingly, the stem Derv-a or Darv-ac, represented in old Irish Daur (Gen. Daro) $=$ oak, Welsh Derw, and in the Anglian Trẽow = tree. The form Dor, in Mapuldor (also Mapnldre and Mappowdre) $=$ Maple-tree, and in Appeldor (Appuldre) $=$ Appletree, making English place-names like Appledore, Appuldrecombe, Mapuldre-ham (pronounced now as Maple-durham), is an old termination, but has no linguistic connexion seemingly with "tree". Derv occurs also in Derven-tnm, now Drev-ant in France, and also "In foreste Dervo", now la forit de Der in Haute-Marne, France. See Pertz, Dipl., n. 31 (A.D. 673), p. 30. Dr. W. Stokes thinks Daruernon to be, as Ptolemy gives it, the early form of what is called in the Ant. Itin. Durovernum (Canterbury), and ascribes the first part of it to Danu = oak, the Old Irish Daur. The form Durovernum, besides being better established, is more easily explicable: Dur-o (in old Gaulish Duron) = citadel, as in the place-names Augusto-durum, Brivodurum, \&c., and $V e r n-u m=$ alder tree, or originally rather "Swamp", since the Welsh adjective formed from its modern equivalent, Grvern-og = swampy, boggy: the Breton Guernog has the same signification. Compare Verno-dubrum, now Verdouble in France. Sir John Rhyss sees in Duron a cognate form of Irish Dorus, Old Cornish Dor = door, gate; cf. Darat already referred to. River-names may take their form from any accidental circumstances, such as the trees upon their banks, of which we have familiar instances in Ash-brook, Asche-burn (twelfth century), now Ashbourne, but the Celtic Esk (= water) may in some cases be the antecedent as already stated, compare the Welsh Onn=ashes, and the Onn-ey (=Onn-ea river), Shropshire. "Lngu-vallium" referred to in the text is the form in the Ant. Itin., and means the "wall of the God Lugus" (Dr. Stokes). The British forms were Caer Ligualid, Liwellid. Simeon of Durham calls it Luel, and applies to a certain Eadred (A.D. 867) the designation Lulisc because he had been educated in a monastery founded by Cuthbert at Luel. The God Lugus and derivations from it are referred to p. I 2.

1 This small stream is called Dacre, near Penrith. The early form was possibly Dacara, which contains the suffix $\bar{a} r \bar{a}$, a frequent ending of Celtic river-names, such as Isara, Iscara, Oscara, Samara, Tamara. 
Miracles ascribed to the virtues or the relics of early English saints abound in Bede and later writers. St. John of Beverley (died $72 \mathrm{I}$ ) is a noteworthy miracle-worker of whom Bede heard many wonderful things (Bk. v. 2) from one of his deacons called Berct-hun, afterwards abbot of the monastery In-dera-uuda (= Beverley), that is "in the wood of the Deri" (Deira province). St. John's favourite resort in Lent, when he was Bishop of Hexham, was a retired dwelling not far off, to which the cemetery of St. Michael the Archangel belonged, and where he performed some miracles. This was identified by Richard of Hexham (Decem Scriptores, col. 291) with Herneshaw, that is probably Earnes-Scaga or Eagles-Copse, and now thought to be St. John's Lee near Hexham. Berct-hun informs Bede of another miracle of St. John, performed (A.D. 686) at a nunnery in a place called Vetadun of which Heriburg was the abbess. Folcard, who wrote the life of St. John of Beverley before ro84, makes the name Betendune, with a variant Yatadini. Smith, in his Bede's H.E., identifies the place, correctly, it would seem, with Watton, between Driffield and Beverley. There seems to be in this name a reminiscence of the people called Otadinoi (or Votadinoi) of Ptolemy, who places the Brigantes between them and the Selgovoi, a name still preserved in the Solway Firth. ${ }^{1}$ Bede tells us $(H . E$. v. I 2$)$ of another wonderful occurrence which took place in the region of the Northumbrians called Incunenigum, where a certain Drycthelm having been raised from the dead, gave afterwards his experience of hell, purgatory, and heaven, in language which has a certain resemblance to that of the great trilogy of Dante. ${ }^{2}$

1 For the Votadinoi, see back, p. 100. The name is represented in early Welsh literature as Gododin and Guotodin. The locality is defined by the fact that Bremenion (now Riechester) was in it (see Ptolemy).

${ }^{2}$ Mr. Moberly identifies "In Cuneng-um", which is a locative plural, with Cununga-Chester, called also Cuncha-Chester (in Simeon of Durham and in R. of Hexham), and known now as Chester-le-Street. Congavata of the Notitia Dignitatum may be the locality, although it has been identified with Moresby. Congangios of the Not. Dig. has been identified by Holder, following Sir J. Rhŷs, with Ceangi, a people of North Wales mentioned by Tacitus. 
The great Archbishop of Canterbury, Theodore, died in 692 , and was succeeded, as Bede says (H.E. v. 8), by Berctuald, abbot of a monastery at Reculver (in Racuulfe) "which lies on the northern mouth of the river Genlada". In what Mr. Plummer calls "the oldest extant native charter of which we possess the original (dated A.D. 679)", a grant is made by Hlothari, King of Kent, to this Berctuald, and "in civitate Recuulf" is given as the place at which it was executed, that is the Regulbium of the Notitia Dignitatum. ${ }^{1} \quad$ The Genlade has already been explained-Gen $=G e g n$, opposite, and lada (Gelad) =passage, way; the modern name is Yenlet, which is given to two or three places in the Thames mouth; it is the antecedent of Inlet (see Oxford Dict., sub "Inlet"). The numerous lodes on the Severn, "Saxon-lode," \&c., preserve the word in its sense of "passage, and it also appears with the sense of "way" in place-names ending in -let. Cf. gelêt $=$ a junction of roads.

The Teutonic tribes of Britain had not only become all Christian towards the end of the seventh century, but efforts were made by some of them to convert their kinsfolk on the Continent. The priest Ecgberct, previously mentioned, who had been leading the life of a pilgrim in Ireland, proposed that the word of God should be made known to the natives from whom the Angles and Saxons had sprung-that is, to those "who were corruptedly called by the neighbouring people of the Britons, Garmani, namely, the Fresones, Rugini, Danai, Hunni, Old Saxons, Boructuari" (Bede, H. E. v. 9). ${ }^{2}$ Ecgberct was twice

1 This word seems to contain the Celtic Gulb (Old Irish Gulba) = beak, point, and a prefixed preposition cognate with the Latin Prae, represented here by $R e$ : compare $R a k$ (= ? Prae-ek) in Rac-ynys = "insula prae-jacens" (Dr. W. Stokes), and the Irish Island of Rachrie. $R u=$ point [it occurs in a list of places in Myvyrian Archaeology], so frequent in place-names on west coast of Scotland, is possibly of kin.

2 The Frisians, as we have seen, formed a section of the invaders or Britain, and their name is probably preserved in Dun-fries (Dumfries), For the Rngini, who gave their name to the Island of Rugen, in the Baltic, see previous note on Snth ryge and East-ryge = Surrey and Eastry respectively. 
warned, it is alleged, by an appearance in a vision of Boisil, former Abbot of Melrose, to desist from his enterprise until he had received instruction at the Monastery of Columba in Hii (Iona), the founder of which was now called, as Bede says, "Columcelli, that is Columba of the Cella (=Cell)", represented by the Celtic prefix "Kil" in names of churches, as in Kilpatrick, \&c., and in the parts of the Continent where Irish missionaries worked by $-Z$ ell, as in Appenzell, \&c. Notwithstanding the repetition of the vision, Ecgberct persisted, and was about to sail forth when a tempest destroyed his ships and cargo, Ecgberct and his companions being, however, saved. One of these companions, named Victberct, who had spent many years in Ireland (Hibernia) as an anchorite, managed to set sail for Fresia (Friesland), whence, after preaching fruitlessly for two years to King Rathbod and his people, he returned to the contemplative life. Vilbrord and twelve companions then took up the work, and having been received favourably by Pippin, King of the Franks, who had conquered Fresia and expelled Rathbod, he was rewarded with success. ${ }^{1}$ Following his example two English Presbyters named Heuuald (one called Black Heuuald and the other White Heuuald), who had spent much time in Ireland, set out on a similar mission, but were slain by the Pagans and thrown into the Rhine (A.D. 675). Their bodies were afterwards recovered and enshrined in the church of Cologne. Vilbrord was consecrated by the Pope and made Bishop of Fresia, and Pippin gave to him a place for his cathedral in his celebrated castle, known in the language of the inhabitants as Viltaburg, i. e. "the City of the Wilts", but in Gallic speech as Trajectum. ${ }^{2}$

1 Bede says nothing about the mission of Boniface (Winifrith) to the Frisians. He was martyred at Doccum in Friesland. Willibald, in his Life, says Winifrith was educated at Adescancastre, that is at Exanceastre, Exeter, which seems to have been under English dominion at the time, that is before the end of the seventh century.

${ }^{2}$ The A.-Sax. version of Bede says Wiltenburg and Et-Treocum, that is Utrecht. 
Bede's ecclesiastical history extends to the year $73 \mathrm{r}$. He died in 735 in his monastery at Wearmouth (Viurae-muda) in Yarrow (Ingyruum), where he was buried; his relics were afterwards removed to Durham, but they and the rich reliquary which contained them were carried off from the cathedral in I54 I. He chronicles comparatively few events during the last thirty years of his life. We have among these the record of a visit to Aldfrid, King of the Angles, paid by Adamnan, ${ }^{1}$ abbot of the monastery of Hii (Iona), who, after a sojourn of some time in Northumbria, became persuaded that the Roman method of keeping Easter was the right one. Endeavouring in vain, however, to convert to his opinion the monks of Hii and those who looked to them for guidance, he took ship to Ireland, where he was more successful, and died within a year after his return to Iona. Bede mentions also that Adamnan presented to King Aldfrid an important work on the Holy Places, the matter of which he had obtained from a Gaulish bishop named Arcuulf, who, after visiting the Holy Land, Damascus, Constantinople, Alexandria, and many islands of the Sea (Mediterranean), at length was wrecked on the western shores of Britain, whence he made his way to Adamnan's monastery at Hii. This work, from which Bede gives some extracts, has come down to us, and is important for its description of the holy sites in Jerusalem in the seventh century.

Bede chronicles also the death of Wilfrid in 709 at Oundle (In Undalum), ${ }^{2}$ and his burial in his own first monastery at Ripon (Inhrypum) after a stormy life, of which Bede gives a summary (H.E. v. I9).

1 Upon Adamnan see p. 49.

2For "Oundle" see p. 23. It may be well to point out here that In Un-dalum may contain in its final element the locative plural of dal, meaning shares or divisions. "In Hrypum" is also in the locative plural. Its origin is obscure. There is no Saxon word that seems near to it, but it is possible that the Norse place-name Ripar (= Crags), dative plur. Ripum, may have had an English equivalent with initial $H$. The Latin $R i p a=$ " river bank" wonld be far-fetched. This place is now Ripon 
We have also his account $(H . E$. v. $2 \mathrm{I})$ of the conversion of Naiton (Nechtan), King of the Picts, to the Roman observance of Easter and to the Roman mode of tonsuring (A. D. 7 ro). Naiton, he tells us, wrote to the abbot of Bede's own monastery at Jarrow to obtain architects to build future churches, after the Roman custom, for his people, a request which was granted.

These peaceful relations with the Picts did not continue long, for in the following year ( $7 \mathrm{I} \mathrm{r})$ Bede records (Epit.) that "Berctfrid fought with the Picts", a statement repeated by the A.-S. Chron. (under 710) with the addition that the battle took place between Hæfe and Cære, and that Ine, and Nun his kinsman, fought against Gerent, Wala-king (king of the Welsh). The Irish annals (Tighernagh and Ulster) record the defeat of the Picts by the Saxons in $7 \mathbf{I}$ I at the field of Manann. ${ }^{\mathbf{1}}$

Although Adamnan had not been successful in Romanizing his monastery, Ecgberct, who has been just referred to, had, according to Bede, convinced the monks of Hii of their insular errors and persuaded them to follow Roman customs (A.D. 7 I 6 ), so that, eighty years after they had sent Bishop Aedan to Northumberland, they accepted, under their abbot Dunchad, ${ }^{2}$

${ }^{1}$ Mr. Plummer (Two Sax. Chron. ii, p. 36) surmises, and I think rightly, that "between Hæfe and Cære" means "between the rivers Avon and Carron", which include the plain of Manann, corresponding with the site of the battle in Campo Manand given by Tighernach. Gerent, if it is not a British name, is for Gerontius, a name derived from the Greek, but in use among the Romans. He was seemingly king of the Welsh (that is Latinized Britons) in Cornwall. The Liber Landav (pp. 108-I I4, ed. Evans-Rhŷs) says St. Teilo, when he crossed rom Armorica to visit King Gerennius on his death-bed, landed at Din-Gerein, i. e. the Castle of Geraint, now Garrans, Cornwall. Haddan and Stubbs conjecture that this is the Dinnurrin mentioned in the Canterbury Scribe's record of the Profession of Kenstey the Bishop of Dinnurrin, H. and S. Councils, i, p. 674 n. H. and S. add cf. "Din-sol", the Cornish name for St. Michaels Mount (Camb., Brit. SS. 65).

2 Dunchad: this, in its early form (as on the Ogam Stone at Glan Usk near Crickhowel) was Duno-Catus, meaning "the fortress warrior". It became Anglicized to Duncan, but its derivative Mac Dhuncadh, now pronounced MacConkey or Maconochie, preserves the original sound of the ending. 
the Catholic traditions. Ecgberct, after spending thirteen years among them, died in Hii on April 24, 729.

Bede ends with a description of the English Church in $73 \mathrm{I}$. Tatwini, who had been a monk in the monastery of Bredon (Briudun), ${ }^{1}$ was now Archbishop of Canterbury, Inguald was Bishop of Essex, Aldberct and Hadulac were Bishops of the East Angles, Daniel and Fortheri Bishops of Wessex, Aldwini Bishop of Mercia, and Walchstod Bishop of the people west of the Severn (that is, of Hereford), Wilfrid Bishop of the Huiccii, and Cyniberct Bishop of the Lindisfari ${ }^{2}$ (that is, of the people of Lindissi, or Lindsay in Lincoln). "Four bishops ruled in Northumbria: Vilfred in the Church of York, Edilwald in Lindisfarne, Acca in Hexham, and Pecthelm in Candida Casa (Whitern, now Whithorn), which latter, owing to the increase of the faithful, lately made into a bishoprick, has now as its first bishop the same" (i. e. Pecthelm). The Picts, Bede adds, were now allies of the Angles not only by treaty, but by the tie of Catholic peace and truth, and as rejoicing in belonging to the universal Church. The Irish (Scot/2) inhabiting Britain were also content with their boundaries and meditated no evil designs against the Anglian people. The Britons alone, by their opposition to the Angles and to the Catholic Church, remained unsatisfied. "This," says Bede, "is the state of Britain in this year, the $285^{\text {th }}$ after the coming of the Angles into the country."

We have now to go to the Saxon Chronicle and later sources for the course of events in subsequent times. A few events, however, in the early part of the eighth century which are not

1 This is Bredon (Worc.). A charter of A.D. 780 (Brit. Museum, Facs. i. I1) gives "Breodun". There are several hills of this name in England. The first part seems to represent the Welsh Bre (plural Breon)=hill, appearing in many compounds, such as Penbre (giving Pembrey, Pemberton, and possibly the Pepper in early place-names), Moelfre = bald hill. The early form was Brig. Holder (Alt Celt. Sprachschatz) says that "Brigden" in Belgium represents an early Brigo-duno-n, and is thus of the same origin as Bredon.

2 For Lindisfari as distinct from Lindisfarne see note, p. I 70. 
found in Bede are to be found in the Chronicle. We have, for instance, the death of St. Guthlac recorded under 7 I 4 , and under the year $7 \times 5$ we have the entry that Ine (King of Wessex) and Ceolbred (King of Mercia) fought at Woddesbeorg ${ }^{1}$ (variant Wodnesbeorg). The death of Ceolred, who was buried at Licetfelda (Lichfield), and of Æthelræd, who was buried at Beardanig (on Beardan igge), ${ }^{2}$ are recorded under the following year. Under 718 a religious community at Winburna (Wimborne) ${ }^{3}$ is referred to. The overturning of the defences of Tantun (Taunton) is mentioned under 722. The Chronicle records also under 733 the occupation of Sumertun by Æthelbold, King of Mercia. The Chronicle [F] under $74^{2}$ says, "There was a great synod gathered together at Cloveshou, at which were present Æthelbold, King of Mercia,

1 Woddesbeorg. Mr. Plummer (op. cit. ii. $3^{8}$ ) makes this to be Wanborough, presumably on Kemble's identification (Cod. Dipl., Index) of Wodnesbeorg with "Wanborough, Hants" (? Surrey), but Wanborough, Surrey, was, in I I47, Wenebergia, and Wanborough, Wilts., was, in I 245, Wamberge, both forms excluding an original Woddes or Wodnes-beorg. Wodnesborough (Wodnesberge in thirteenth century) in Kent agrees so far as form is concerned, but it does not suit the locality, which was somewhere on the confines of Wessex and Mercia. William of Malmesbury gives Wodnesdic, now "the Wansdyke", but see previous note, p. 148 .

${ }^{2}$ It will be observed that the Beardan-eu of Bede has here become Beardan-ige, where Beardan is treated as the genitive of a personal name.

${ }^{3}$ The Win in Winburna (that is Wimborne) is the same word as the Celtic Win in Winfrith (Dorset) that is Win (or Wen) frut (= white stream), and means white or clear. The burna is of course English. Tantun takes its origin from the Celtic name of the river flowing through it, the Tan, possibly for an earlier Tam, of which the meaning is obscure, but from the number of river-names in which it occurs it seems to have been almost a generic word for a stream, e.g., Tam-eses, Thame, Temede (now the Teme), \&c. A river Thame in Durham has a Tanton upon its bank.

${ }^{4}$ This is given in Bede as Clofes-höh or hoch. The first element is seemingly a personal name in the genitive, and Höh means promontory. Cliffe at Hoo is linguistically impossible. Cloves or Clofes could not become cliff. The early form of Closeworth (Somerset) was in $125^{2}$ Cloves-wurthe (Cal. Chart. Rolls, i. 408), and in 1270 Cloves-uude (ibid. vol. ii, p. I36). See p. 23 I. 
Cuthbert, Archbishop, and many other wise men." Ethelbald, together with Cuthred, King of Wessex, fought against the British (Walas) in 743, but Cuthred nine years later turned his arms against Æthelbald, defeating him at Beorg-ford ${ }^{1}$ (752), and the year after we find him again engaged in a conflict with the Walas. Cuthred died the following year and was succeeded by Sigebryht, who was deprived of his throne by Cynewulfhis Witan, owing to his wicked deeds, consenting-and driven by him into Andred (that is, Andred's Wood), where he remained until he was slain at Pryfetes ${ }^{2}$ floda. Cynewulf, who, we are told, had fought many battles with the British (Bretwalas), received his death, after a long reign (A. D. 784), at the hands of Sigebryht's brother, Cyneheard, at a place called Merantun. The account in the Chronicle of Cyneheard's attack on Cynewulf is interesting (as Mr. Plummer has shownTwo Sax. Chron. ii. 45), for its illustration of the arrangements of a Saxon residence. The chief building was the hall (Heall) with the other apartments around it, the whole surrounded by a rampart of earth (weall) constituting a burg (burh). The gate (geat) was an opening in the weall, but the entrance to any of the buildings within it was called a door (duru). Cyneheard captured first the "bur " or ladies' chamber, at the door of which Cynewulf was slain, and in the fight which followed the king's supporters were all slain, "with the exception of a British hostage (Gisl, which enters into many Teutonic personal names, e.g. Gislbert, Gilbert, but, according to Pedersen, was originally borrowed from the Celtic, see p. 200), who was

1 Kemble gives Berg-ford as the early charter form of Burford (Oxford).

${ }^{2}$ Pryfetes floda is now Privet, Hants, where are two places of this name. The first element seems a personal name in the genitive case, and the second is the plural of Flod, meaning, according to H. Sweet, "water"; thus "Pryfetas Water" or Creek. Pryfet as a personal name is non-English, and a British original is equally hopeless, except we may see in it Pryvet, the Old Welsh plural of Pryf = worm (Strachan's Early Welsh, p. 24). Cf. Kerrig y Pryved in Suppl. Camb. Arch. Journal, A pril, 1909, p. 31, but see p. 210 where Prifeta $=$ a young steer, and cf. Privetes Moreshed (C. Sax, ii. 422). 
severely wounded." Cyneheard was shortly afterwards slain by Cynewulf's thanes and was buried at Ascan-mynster (Axminster), the king's body being entombed at Wintanceastre (Winchester).

Beorhtric, who succeeded Cynewulf as King of Wessex in 784, died, after reigning sixteen years, and was buried at Werham (Wareham). In the same year (784), says the Chronicle, Æthelbald, King of Mercia, was slain at Seccan-dun and buried at Hreopa-dun. ${ }^{1}$

Under 76I the Chronicle [E] records the slaying of Oswiu by Moll, King of Northumbria, at Ædwines-clif, ${ }^{2}$ and under 762 the death of Frithewald, Bishop of Witern (who had been consecrated at Ceastrum, locative plural $=$ York) and the consecration of Pyhtwin, his successor, at Ælfetee. ${ }^{3}$

In 733 the Mercians and the men of Kent fought at Ottanford (Otford, Kent), and in 777 Cynewulf and Offa fought around Benesingtun (that is Benson, Oxford), of which Offa succeeded in getting possession.

Seletun (now Silton, York) is mentioned under 779 as where Beorn Alderman was burnt, and Soccabyrig under 780 as the place of consecration of Higbald to Lindisfarna ee. A synod was held at Aclea in 782 and another at Cealc-hythe in $785^{4}$

${ }^{1}$ Seccandun is now Seckington, Warwickshire, and Hreopa-dun is now Repton.

2 Edwines-clif is in Simeon of Durham "Eldunum near Melrose", now Eildon (Eildon hills). Ail is Celtic for "rock", from an early [P]alek. It occurs in Ail-Clud = Clyde Rock, now Dumbarton, and in this Eildon $=$ "Ail-dun", rock fortress. Cognate forms in other languages are fels (from [P]allos) in German $=$ rock ; French falaise $=$ cliff. Fjall in Norse ("Fell" in North of England) = hill.

3 Elfetee. This seems to contain the British El-vet, and ee another form of $\bar{e} a=$ river or for $i g e=$ island, but the first part may be A.-Sax. Elfetu (Norse $A l f t)=$ Swan, and the whole "Swan-river". An Elvet forms part of Durham, but the name occurs in this, and in an earlier form, Elmet, elsewhere. See p. I 70 .

- Soccabyrig is now possibly Sockbridge on the Eamont ( $\bar{e} a=$ river and mont for mund = mouth, see note, p. 269. Mr. Plummer suggests Sockburn on the Tees. In Lindisfarna ee the last syllable seems to represent island. 


\section{NOTE G.}

\section{Glastonbury.}

There is no place in these islands which can boast of a longer continuance of religious life than Glastonbury. Although it does not figure among the Civitates Britanniae appended to the Historia Brittonum of Nennius, its antiquity is unquestionable. In William of Malmesbury's (twelfth century) De Antiquitate Glastoniensis Ecclesiae, we have an attempt to trace the origin of Christianity there to the time of Pope Eleutherus (Pope from I 77-92). This writer knows of the legend in Bede (H.E. i. 4 ; v. 24), who, following the entry in the Liber Pontificalis (drawn up according to Duchesne in 530), relates how the British King Lucius asked Pope Eleutherus for missionaries to convert his people, and that the Pope sent them. William of Malmesbury gives the names of these missionaries as Phaganus and Deruvianus, using as his authority the forged Charter of St. Patrick hereafter referred to. The question of King Lucius and the mission of Eleutherus has been dealt with fully by Zimmer (Nennius Vindicatus, pp. 140 et seq.), and by Haddan and Stubbs, Councils, vol. i, pp. 25, 26), and may be relegated to the region of pure fable. The Apostles St. Philip and Joseph of Arimathea are also brought in by William of Malmesbury, the latter being made the leader of an earlier mission.

The forged Charter, ascribed to Ireland's Apostle, gives besides the names of the assumed founders, Fagan and Deruvian, a list of their early successors. This list is an instance of a pious fraud unsupported by knowledge. Some of the assumed personal names therein are designations of

The Norse $e y$ is to be excluded, as the form here was in use before the Northmen came. There are numerous Acleys, but this was presumably in the south. It may be Ockley in Surrey. Cealchythe can be traced through Chalchithe (1465), Chellsaye (sixteenth century) to Chelsea. (See B. M. Charters and Rolls and cf. the form in the Taxatio of Pope Nicholas, wherein its position establishes its identity beyond doubt.) Challock in Kent was, in the ninth century, Cealf-loca or calf-enclosure, and Mr. Plummer's mention of Mr. Karslake's view is, therefore, superfluous. The term loke still survives in East Anglia. A further instance of this use of loca is given in Hist. MSS. Report XV, App. x. 148, "Recourse with cattle to the Pynloke" (i.e. Pound-enclosure). 
localities (e.g. Wellias, Breden, and Swelwes, where we have most probably a reminiscence of Wells, Bredon, and the Swelle common in English place-names, from Srvelg = swallow, indicating the disappearance of a stream underground). Some of the other names, as Adelwolred, are Anglo-Saxon compounds and impossible in this region at the date. Hin-Locrinus (thus in William of Malmesbury: Gale's MS., thirteenth century, now in Trin. Coll. Camb., reads hin loernius) seems borrowed from Geoffrey of Monmouth's Locrinus-formed from the Welsh word for England Lloegr - with hin, i.e. hèn (= old) prefixed. Glastonbury is called in this Charter Ynsgitrin (in Gale's MS. Insgytrin) that is, Inis (= island) and gytrin for veytrin (i. e. Vitrinus = "of glass"), which quasi translation the composer of the name uses, assuming that the Glas in Glastonbury represented the English word Glass. The Welsh Triads calls also the place "Bangor Wydrin in the island of Afallen (Avallon)". St. Patrick's Charter is ascribed to $43^{\circ}$ (Cart. Sax. i, p. 1), and it did not strike the scribe as anything extraordinary that an English place-name should be found there at so early a date. Professor Freeman, if I mistake not, also made Glastonbury a pure English name. The names Fagan and Deruvian (variants Dyfan, Devinianus) are late forms - the latter probably corrupt - of possible Irish names. Arnulf and Ogmar, which also appear in the document as Irish brethren, seem to be Scandinavian forms. There is a mention in the Annales Cambriae of Glastonbury, and it is alluded to in the Scholiast to Fiech's Hymn (see p. I 30 , Irish Liber Hymnorum, H. Bradshaw Soc. and vol. i, p. 103), where a Sen Patraic (i.e. Old Patrick) is associated with the place. This is not the Irish Apostle, but, according to the editor of the Annals of Ulster (Rolls Series), p. I 7 , the Founder of Armagh, who was followed there by S. Benignus (Beonna); also associated with Glastonbury by William of Malmesbury who makes him Abbot there immediately after St. Patrick.

There are numbers of Charters of Grants to this place, many of doubtful authenticity, in the Cart. Sax. and in William of Malmesbury's work already cited. Some of these throw some light on place-names in the locality.

Among the charters of Grants by English kings, bishops, \&c., we have one ascribed, but with doubtful foundation, to A.D. 680 (Cart.Sax. i, p. 74), in which a piece of land called Lantocal and a marsh called Ferramere (now Meare) are alleged to have been given to the Abbot Hemgisl by the Bishop of Winchester. 
Ferramere is clearly an English form and suggests English occupation of the district, which could not have been earlier than about A. D. 658 .

Another charter ascribed to 681 (Cart. Sax. i, p. 96: Ord. Survey facsimile) records a grant by Baldred King of Mercia of land on the top of the hill called Pengerd (Pennard, Somerset) to the same Hemgisl (Hemgils) for the completion (supplementum) of the Church [at Glastonbury] of the Blessed Mary and St. Patrick. The bounds of the land-which are given in Anglo-Saxon-are all English, except the name of the river Brue (Briuu), implying that the West Saxons had then settled in the region about the Church and had given names to localities there. To Cullanbyrg, to Stangedelfe (stone quarry), and to Stanenanbrycge (stone-bridge) occur among them.

Another charter ascribed to 682 is a grant by Centwin King of the Saxons (Cart. Sax. i, p. 97) to the same Hemgisl (Hamegils) of twenty-three measures of land (Mansiones) in a "place close to the celebrated wood called Cantuc-uudu (the Quantocks), bounded on the south by the Tan (the Tone river) ... with other boundaries as far as the ford called Wealaford" (Weala, gen. pl. of Wealh=Welshman). A HagstaldesCumb (see p. 116) occurs among the boundaries, and also in Cart. Sax. ii, p. 77 .

We now come to a charter (Cart. Sax. i, p. 165) ascribed to Ini, King of Wessex, who is stated in the Chronicle to have rebuilt the monastery there (before 680). The charter which is ascribed to 702 (for 705) grants a piece of land on both sides of the Doulting stream to the Abbot of Glastonbury. Among the boundaries is a Crich hulle (now Creech-hill, see note, p. 23).

This is followed (Cart. Sax. i, p. I66, Ord. Survey facsimile) by a grant of land near the Tan (Tone) at a place called Pouelt (now Pawlet) and of land on the Doulting stream-here called Dulut-ing. Pou seems to be the British form of the Latin Pagus, universally so used in Brittany, and the -elt seems to be the same as the -ulut in Duluting, representing possibly the remains of some Celtic land designation.

A further grant of Ini appears in a charter (Cart. Sax. i, p. 177) ascribed to $66_{3}$ (Dr. Birch suggests for 693 or 708 ) in which land in and about the mount called Brente (now Brent Knoll) is given to the same Abbot Hemgisl (here Hengisl). The bounds are the Sabrina (Severn estuary), the Axa (Axe), 
the Termic, and the Siger. The name Ternuc occurs in another Charter, and it is doubtlessthis Termic. The "Tarnock Common" (Tornoch in 1533 ) near Biddenham on Ordn. Survey Map preserves the name. Another river called Torric (which seems to be the same) appears in the boundaries. The Axa (Exa in a charter of A.D. 944, Cart. Sax. ii, p. 553) is probably for Isca, which appears in Charters also as Esce, as in the early forms of the Berks and Derby Ashfords (AEscford). Hengisl here may be the correct form and the equivalent of the Cornish Hen-gwystl = Old hostage. The names of the notables Tangisil and the $d u x$ Hamgisil of the Kent Charter ascribed to A.D. 605 (Cart. Sax. i, p. 10) have the same termination and there are numerous similar names in the Liber Vitae. Gísl (= hostage) is also used as a prefix in names, e.g. Gîslhere Gíslbeorht (= Gilbert), \&c. The similarity of Hengisl and Hengwystl suggests that the abbot may have been British, and it is significant in this connexion that a grant by the King of Devon is referred to in William of Malmesbury (De Antiq. Eccl. Glast.) of the land called Ineswertrin to Worgret Abbot of " the old Church," and that Abbot Bregored followed him after one interval. Worgret is a manifest Celtic name with many parallels in Breton nomenclature, e.g. Uuoruuoret, see Cartulaire de Redon, passim. The possible identification is not strengthened, however, by Pedersen's opinion ( $V$. Gramm. $\S 87$ ) that the Old High German Gisal and A.-Sax. Gísl are borrowed from the Celtic, for this borrowing must have taken place in pre-historic times.

A grant by Fortere, Bishop [of Sherborne] to the Abbot [of Glastonbury] is given in Dr. Birch's Cart. Sax. i, p. 189, in which the river Aesce (the Axe referred to above) and a "port" called Bledenithe (i.e. *Bleden-hithe; hithe = port) and also the Church of the Blessed Martin Confessor are mentioned. This charter is ascribed to 7r2. The A.-Sax. blèd, meaning "branch", may be used in Bledenithe for an inlet of the Axe. Dr. Birch makes the Bledone granted to Winchester (?) 975 (Cart. Sax. iii, p. 647) to be Bleadon on the Axe; Bleden-ithe is more likely to be the modern Bladney standing on rocky ground and communicating with the Axe seemingly by one of the "Rhines". The association of St. Martin as well as St. Patrick with Glastonbury district is a note of antiquity in itself.

Another charter of Ini (here Ina) granting lands to Glastonbury, ascribed to $\mathbf{7 2 5}$, appears in Cart. Sax. i. 207. It is very corrupt and the place-names are much distorted, possibly by 
successive copyists. Budecalech (now Butley, which may be for Budecan-legh, which, though English in form, may be Celtic) appears among them in probably its correct form. Sowvie is for Sow-ige (cf. the variant of the next charter), i. e. ? Sü-ige or Sug-ige = "Sow island", now "Zoy". William of Malmesbury gives a legend to account for the name stating, on the authority of ancient British history, that a certain Glasteing (the Welsh eponymus of Glastonbury) following his sow with eight legs through Escebtiorne (? Iveythorn in Street) and Wells by the Sugewege (Sow's way) found her at an apple-tree near the old church, and gave to the island hence the name of Avallonia. Lantocai also occurs for the Lantocal previously mentioned involving the Celtic Lan = "enclosure" = finally "church".

The next charter (ibid. 2 ro) is ascribed to the same date and furnishes an early form of the river Parret (i.e. Pedredi-strem), and gives the river Kari (Cary) as a boundary. Pouell has become here Poholte, but it is Pouholt in a subsequent charter (Cart. Sax. i, p. 213 ) which gives us also Cengisl (variant Hemgisl, but it is Coengils in a later charter) as the Abbot in 729. The latter charter is alleged to have been signed at Pen-crik, hardly the Pencric (now Penkridge) in Staffordshire, for the writ of the King of Wessex would not avail at this time so far north. It was probably one of the Somerset "Creeches".

A certain Hilla makes a grant in 744 with the permission of Ethelbald (called by a shortened form Elbald in the same charter, Cart. Sax. i, p. 242) of Balteresberghe (Balsboro in Speed's Map of 16ro, now Baltonesboro) and Scobbanwirth to Glastonbury. Among the boundaries, which are very corrupt, occur Nimet and the river Olan or Olitane, which seems to have given its name to the Leden ford occurring in the same charter, Litana (= broad). The Nimet here is suggestive. It still occurs in the names of several localities in Devon (Cart. Sax. iii, p. 624, gives the early form), and we find it in the Nemeto-briga in Spain, and the Nemetacum Atrebatum in Belgium (recorded in the Itinerary of Antonine) and in the early name of Nanterre-Nemeto-duiron. Its meaning is given by W. Stokes (Wortschatz d. kelt. Spracheinheit, p. 192) as "noble", "holy", who cites the Irish; in bratha nemed " the judgements of the nobles"): it occurs in the Old Welsh personal names Gornivet, Eidnivet, \&c., and in the early Breton Catnimet, Iudnimet, \&c. Compare the old Cornish Carn-nivet = "heaven-bow", that is, rainbow. There was probably a religious shrine at the spot 
before the foundation of Christian Glastonbury. The place may be the St. Michael's Tor, close to Glastonbury (and near enough to Baltonesboro to be a boundary) which elsewhere I have connected with the Nen-thur (i. e. (?) Nemet-tor) of St. Patrick's birthplace. There is a Nempnet north of the Mendips, but this is out of the question. The charter mentions further that the Glastonbury monks (who are called there Hengisling, i.e. followers of Hengisl) had chosen a wooden Church at Glastonbury as a resting-place for the sarcophagus of Hengisl. William of Malmesbury describes all the churches here ( $D_{e}$ Antiq. Glast.). A letter of Pope Leo III (A.D. 798) confirming the monastery of Glastonbury to Kenelm, King of Wessex, is given in the Cart. Sax. i, p. 392 .

There is a charter of King Edbert ascribed to 801 (Cart. Sax. i, p. 418) granting a portion of land at Bodecaleie (the Butley previously mentioned) to a certain Eadgils, and among the boundaries the following names occur:-Bregedes-were (i.e. (?) the weir of a man named Breged: could this be the Abbot Bregored? A Brudenewere appears in Sock Dennis in 1280 , B. M. Chart. and Rolls), Lang-Echer (=Acre) and Ucking Echer (cf. Ucingford, B. M. Chart.), Swelle, Lancher pille (? = modern Lancherly : for Lancher, see p. 298) and Stan-pille (pille is here, from its association with "stone", most probably a boundary pillar and not pill= stream : cf. "on thone Stenenan Stapol "= stone pillar, Cart. Sax. i. 47), Olde-lake, Hoctan- (h)yth, the Old yo (not, I think, $\bar{e} 0 h=$ poetical for yew, but the $Y e o$ river, a possible dialectical form of éa, éo, cf. old- Lake), self(h)ith cf. Shuthelve Hill, Axebridge), Weles(h)ith and "from the (h)ythe", \&c. This charter was confided to the church of Glastonbury.

A charter ascribed to 842 (Cart. Sax. ii, p. I3) mentions some localities near the Brue river, among others the river Alum (upon which is Dicheford: there is a Ditcheate, i. e. Ditch-gate, two miles north of the Brue) which has its confluence (Gemido = Gemiythe) with the former river. The name occurs in another grant of lands near Glastonbury (Cart. Sax. ii. 47x) along with a curious place-name (near Batcombe) "at Austien on than put" i. e. puteus = well. Here is another possible claimant for "Augustine's Oak" or rather "Austin's Well", but the Wessex boundary was not so far west in A.D. 604. A Worcester Charter (Cart. Sax. i. 109) has at Austin, of which we may still have an echo in "Austins rick" of the Ord. Map. The Penryn Awstin 
in Kernwy of the Welsh Triads (ii. I83) seems to contain the same word, and if it was meant to designate "Aust Cliff" (Penrhyn = Promontory) on the Severn mouth it shows that Kernwy (Cornwall) extended further north than is assumed. Alum may be a form of the common Celtic river-name, Alauna, now generally Alne (Aluuinn-as in Cart. Sax. i. 227Warwickshire) as in Alnwick, Alne-Chester (now Alcester, Warw.). Nimet appears in the same charter, attracted into the intelligible form Nymede, as if "new meadow". The charter is alleged to have been written at Andredes-eme, which suggests the Andred in Andreds-wood-a more correct ending is given below-but William of Malmesbury explains it as St. Andrew's (Chapel).

The charter dated 904 (Cart. Sax. ii. 263) is alleged to have replaced a lost charter showing the lands which Athelstan Dux, son of Etheredi (for Æthelredi) had given to Glastonbury when he became a monk there. It contains the boundaries of Wrington, Somerset, but the names are very corrupt. The Wring is a river which gives its name to Wrington and Wringford. Preosteselwe, with which the boundaries begin, is not intelligible: it may be for Priests leah, now Priestleigh, Somerset. The remaining names are not instructive.

King Edmund granted to St. Dunstan, Abbot of Glastonbury, certain lands at Christian-Mal-ford, Wilts. ( = Cristemal = "Christs Cross"). "On tha olde oden missenne" occurs in the boundaries, which is an obscure sentence; Oden may be for the Welsh Odyn=kiln, although it is given as Anglo-Saxon for "threshing-floor" (see Oden Colc, p. 157). The last term suggests a borrowing from the Latin messis (= a reaping) either by the British or English. The Welsh and Cornish Mesen (= acorns) can hardly apply.

In Cart. Sax. ii, p. 544, there is a grant of privilege to Glastonbury by King Edmund in A.D. 944, and also a grant of land at Wootton, Somerset, by King Edmund in 946, to the thane Athelnod (Cart. Sax. ii. 578) which land is liable to charges on behalf of Glastonbury. The boundaries are in corrupt and late English. Ashbury (in which is Ashdown, Berks.) is granted in another charter to Glastonbury by Edricsee Cart. Sax. ii, p. 594 .

The Dean and Chapter of Wells were formerly in possession of a charter, now lost, of King Eadred, granting in A.D. $95^{\circ}$ land at Pucklechurch (Pucelancyrca) to Glastonbury. A copy exists 
in the Record Office from which (Cart. Sax. iii, p. 44) I extract the more important boundaries:-Stanford, Hennamere (henna $=$ fowl, i. e. perhaps here "wild-fowl mere ") - Gosamere (Gos = "goose", gives an irregular plural Gēs, but here we find a regular genitive plural Gosa), Stanora (ora=bank); Hlypget (hliep = leap, geat = gate, "? a gate that can be leaped one way only." The place-name Lipyate is not uncommon).

Further boundaries are:-Hamma (gen. pl. of hamm= meadow or enclosure) on Kynges Rode (= to King's Cross or possibly "clearing"). Byd in the boundaries seems a river-name, but it may be for byht (masc. $=$ a bend, bight: neut. $=$ a dwelling). It appears here in Bydincel (wincel = corner), in Bydewyllon (Byd-well), and in "tha hamm on Byd". "Of Loddera-wyllon" (Loddere= beggar: Wiella = well). On Loddra-wellun occurs in a grant to Pershore, Cart. Sax. iii, p. 589; cf. Beggares-thorne in charter granting land at Bledon, Somerset, Cart. Sax. iii, p. 648. Hreod-mor wyllon ("Reed-moor springs "), "Where the wyrtwala runs to Fearn beorhg" (i.e. Fern hill). Wyrtwala appears in the dictionaries as "root", i.e. as the equivalent of German Wurzel, but this cannot be its significance here or in the many other cases where it appears as a boundary. Weall-wala (= (?) "Wall foundation") occurs only in poetry, but the Wala here may mean "foundation" and Wyrt-wala thus = "rootfoundation", or the ground base perhaps of old structures. The compound, however, may mean simply vegetable (wyrt) garden. See Craweford Charters (Napier and Stevenson), p. 68, on a parallel use of Wyrtrum. On tha eggce = "on to the edge," a common element in place-names. On thone graf $=$ " on to that one grove". On haran stan = " on to the hoar (gray) rock". On hric weg = "on to the ridge way". On oxna healas = "on to the oxen shelters" (healh, pl. healas = "corner, shelter"). On Hegestaldes setl $=$ to the residence of Hægestald (see Hexham, p. I 74), and lang Fromes along the Frome river. On Cweorn Cleof $u="$ to the quern-cliff", i. e. the cliff from whence querns or stone handmills were obtained. On Befer pyttas = "to the Beaver holes". On Escburhg = "to Ashbury". On Sinder ford = (?) a ford where "slag" is used for stepping-stones.

The obscurity of the name Puckle Church has been referred to elsewhere (see p. 275). To the explanation there advanced may be added the hypothesis that the latter element (Cyrca) may not be for Church at all, but a modified form of the British Cruc (= tumulus), in which case the term Pucel would be 
a natural determinative, the whole meaning possibly "fairy mound"; cf. Pukelonde, B. M. Ch. and Rolls. The names in this charter have been analysed at some length because they afford fair instances of Saxon name-giving.

In Cart. Sax. iii, p. 89, we have a confirmation by King Edwith (var. Eadwig) of the grant in 956 of a vineyard at Pathenebergh'e to Glastonbury. Dr. Birch places this, I know not upon what authority, at Mere in Wilts., and says the vineyard is noticed in Domesday. I should be inclined to look for it closer to Glastonbury, and if the name Mere is implied anywhere it might more fitly be Meare close to the monastery and on the $E a$ (= river) mentioned in the boundaries, that is the Brue. This is confirmed by the fact (see below) that Patheneberga is placed "in insulis" in King Edgar's grant of privilege to the abbey. Pathene seems to be for Pathena, a genitive plural of a word which is not seemingly English; cf. Peatanige now Patney, Wilts., Cart. Sax. iii, p. 354. Pamborough, the modern surviving form, shows that the place was some four miles north-west of Glastonbury. Oslakes-leag, in the boundary, may still survive, but I have not found it on the map.

In Cart. Sax. iii, p. $45^{2}$, is another Glastonbury charter in which the Cari stream is mentioned, and in another charter of Edgar dated 968 (Cart. Sax. iii, p. 493) a grant is made to Glastonbury of land on the Dorset Stour, in which Dewlish (Develisch) is mentioned (see p. $\mathbf{r}_{50}^{\circ}$ ).

King Edgar granted again certain privileges to Glastonbury in $97 \mathrm{I}$ according to Cart. Sax. iii, p. 574, in which certain places in the islands (in insulis, i. e. in the low insulated lands near the Abbey) are mentioned, among them "Bekeria, which is called parva Ybernia (little Ireland)". It is somewhat striking that we have in this word, not only a link connecting Glastonbury with Ireland, but in the term itself a form but slightly modified of the Irish Bec-eriu (= Little-Erin : erinn being the genitive of Eriu). The term occurs also in the Felire of Oengus (Henry Bradshaw Soc., p. I I 8), with the same significance, as the designation of a little island off the Wexford coast which is now known as Beggary-island. The Glastonbury form is preserved still in the name of a village not far from the Abbey, called Bickery in the new Ordnance Survey Map, replacing a misnomer in the older maps, where, doubtless by the influence of some local antiquary, the surveyors set it down wrongly as Bickworthy. William of Malmesbury says that St. Bridget 
spent some time on this island, and that certain relics of her and of St. Indracht were preserved in the church. Ind-recht = "the Just"; the modern form in Ireland is Hanratty. Patheneberga also occurs here as in insulis, and also Adredes-eya for the form given above as Andredeseme. The eya termination is the usual Latinized form of the Anglo-Saxon ige = island. King Edgar grants privileges here to Glastonbury at the instance of St. Dunstan Archbishop of Canterbury, Oswald Archbishop of York, Brictellinus (Beorhtholm) Bishop of Wells, and others, for the soul of his father whose body rests there, and for the souls of his ancestors. Among the signatures-at London it is said in one of the MSS.-appear the names of Keneth (Kinadius rex Albanie) King of Scotland, and Mascusius, "High Admiral" or "Wicing Chief" (Archipirata), the latter name probably a distorted form of the name Magnus common among the Scandinavians.

Æthelflæd (Cart. Sax.iii. 600), second wife of King Edmund I, she gives for the souls of Ædmund and of King ÆAdgar and for her own soul, land at Domerham to Glastonbury.

A charter of King Edgar (Cart. Sax. iii. 608), ascribed to 973, exchanges land at Brancminstre, elsewhere Branuc minstre involving a Celtic personal name (? St. Branoc, diminutive of St. Brandan, associated with Bristol and with Braunton, Devon), for land at Hamme. Branuc Minstre recalls "Branok hyalf hiwisce" (Thorp, Dipl. p. 107), belonging to Glastonbury.

In this charter we have as bounds Wernan ford and Wernanstrem and the river Wern; also a Stanwei (stone-way, perhaps a Roman road) and the river Peret (Parret). The names are corrupt, showing the results possibly of frequent copying. There are several other charters given in William of Malmesbury's De Antig. Glaston. Some of these contain seemingly early forms of place-names in the locality, e. g. Ceddren (Cheddar, where a grant of Elleanboro is situate); Godenice (now Godney) which is said to be so called from the Holy Trinity; Martenesie (from a chapel of St. Martin on the island); Badecumbe juxta Montem Munidop (Mendip, Mened-ipp in 1290 ( Cal. Ch. Rolls, ii, p. 363), see note, p. 24); Bedul, Branuc Dunhead (= Downhead, where probably Branuc Minstre may have been, cf. Branch Huish (Huish $=$ Hiwisc $=$ familia and also a land measure : see above), N.E. of Downhead); Lemucerine (probably a corruption of some Celtic name); Eatumberg = ? Emborough, Eteneberga in 1270 Cal. Ch. Rolls, ii. 137 (cf. Eotas = Jutes 
and Eoten = giant. See Asser, Life of Alfred, Stevenson); Occemund (? Oakhampton); Occenefeld (? Okenhede of B. M. Ch. and Rolls); Peasucmere (Peasuc $=$ ? a personal name); Lidenege (cf. Lidenford above); Ieholt, Attaholt, Lupreite (? Lopen); Loffelagethe (?=Lovehill); Hochye (= Hoctanhythe); Hornblawerton (now Hornblotton, appears to contain the name of Horn-blower); Wiarepath, Ymerwivel, Munekeneleghe, ultra Montem usque ad Cuniessam ( $=$ ? Combeshed near Marden Bradley), ad la Brittasche "which is at the head of the south bridge of Strete", i. e. Street.

\section{Note $H$.}

Topographical Elements in the earliest Anglo-Saxon Documents.

\section{Glossaries.}

Among the earliest, not directly historical, English documents furnishing words which are found in ancient place-names, the Epinal and other glossaries (edited in H. Sweet's Oldest English $T e x t s)$ occupy an important position. These glossaries belong to a period extending from the seventh to the ninth centuries.

In the citations which follow, E. = Epinal-Erfurt MSS., "written any time between 600-700," Sweet ; C. = Corpus MS. later than Epinal; and L. = Leiden MS., ninth century.

Bodan (C.) = bottom, as in Botham-ley, Ramsbotham, \&c.

Haegu-thorn (E.) = hedge-thorn, white thorn.

Mapuldur (C.) = maple tree, as in Mapledurham.

Holegn (C. $)=$ holly, as in Holenhyrst, now Holnhurst, Glouc. (Cod. Dip. $3^{8} 5$ ).

Holt-hona $(\mathrm{C})=$. woodcock.

Aler (E.) = alder-tree ; aler-holt (C.) = alderwood, as in Alercumb (Cod. Dip. 193), \&c.

Boece $\left(C_{.}\right)=$beech, as in Buckliurst.

Gors (C.) $=$ furze.

Scald-thyflas (E.) is given as a gloss on Latin Alg $(a) e,=$ ? sea-weed, here, water-weeds: cf. Thyfel $=$ thicket. $^{1}$

1 In (C.) Sond-hyllas (? for *Sondthyflas) is given as an equivalent, and seems to indicate that scald = sand or sea-shore; but scald hulas is given in (C.) for Papyrus, for which eo-risc (= river-rush) is alike given. 
Faag (E.) $=$ spotted. $^{1}$

Faestin (C.) = stronghold: gives fast in place-names, as in Buckfast. Fastenes in Napier's Glosses to Aldhelm = municipii.

Laam $($ C. $)=$ loam, as in Lamhythe (Lambeth : hythe = harbour); Lampyttas = loam-pits.

Fleotas (E.) = estuaries, as in Benfleet.

Haesl (E.) = hazel, as in Hasler.

Falaed (E.) = cowstall, fold, as in Stodfold.

Berc (E.) = birch, as in Birchover.

$\operatorname{Edisc}(\mathrm{C})=$. "deor-tuun", i. e. deer-inclosure, deer-park, as in Hídes-Edisc (Cod. Dip. 355).

Edisc-ueard (E.) = game-keeper.

Dael (C. $)=$ Deep-pit, as in Doverdale.

Hrith-hiorde (C.) $=$ cattle-herd. ${ }^{2}$

Ambrones (C.), a word applied by Nennius to the Saxons, is here glossed Gredge $(\mathrm{C})=$. Grâdig $=$ Greedy. For the origin of the term see Holder (who derives it from a Celtic stem meaning "hateful"), Sprachschatz sub voce.

Waeter-thruh (C.), Waeterthrum (C.) (abl. pl.) = canal, waterpipe, and also used (C.) for cataract.

Cisten-beam (C.) = chestnut-tree, from Latin Castanea.

Beber (C. $)=$ beaver, as in Beverley.

Wase (C.) $=$ mud, mire, as in Wase, Wasan, Berks. (Cod. Dip. $546)$.

Gloed (C.) = coal, charcoal ; cf. Welsh Glo.

Steort (C.) = tail ; as in Start-point and red-start.

Elh (C. $)=$ elk.

Holu (C.) pl. = caverns.

Pearroc (C.) = "grating", gloss for clathrum: cf. German Pferch and Pearrocas in place-names: modern "paddock" and "Park".

Cisirbeam $\left(\mathrm{E}_{0}\right)=$ cherry-tree.

Gebuur (C.) = husbandman.

Ceapstou (C.) and Gestrio (C.), both used to gloss Commercium $=$ trading.

${ }^{1} \mathrm{Cf}$. the Celtic Breac, of the same meaning, used largely in place-names. Cf. Egelis Brich, translated Varia Capella in Holyrood Charters, p. 9. Cf. Falkirk. Breac is connected by Thurneysen (Handbuch d. Alt.-Irischen, § 2I9) with the Gaulish personal name Briccus, and with the Greek Preknos (= spotted deer) and the Old High Germ. Forhana (=trout).

${ }^{2}$ Cf. Hrither = cattle, cognate with German Rind and Rinder. Cf. Rinderpool. 
Tuun (C.) (= town) and throp (C.) (and thorp) are used to gloss compitum $=$ a meeting-place, a cross-road.

$\operatorname{Hreod}(\mathrm{E})=$. reed.

Hyrthil (C.) $=$ hurdle.

Gaec (C.) = cuckoo.

Lepeuuince $\left(\mathrm{C}_{0}\right)=$ lapwing.

Saex (C.) = knife.

Sules reost $\left(C_{.}\right)=$plough-rest. $^{1}$

Hyðae (C.) $a b l .=$ station, refuge, i. e. harbour, as in Celchyth, Chelsea.

(H)oruaeg stiig (E.) = a bye-path ; or = "out of ", orweg = " out of the way".)

Thyrne (C.) $=$ thorn.

Walcyrge $(\mathrm{C})=$. the Fates.

Walh-habuc (C.) = falcon. Walh here $=$ foreign.

Worhona $(\mathrm{C})=$. pheasant.

We $[$ a]rg-rod $(\mathrm{E})=$. Felon's Cross = gallows, which appears in place-names.

Suamm (E.) = fungus.

Cisil (E.) = gravel.

Secg (E.) = sedge.

Risc-thyfil (E.) = bed of rushes. ${ }^{2}$

Yppe (E.) = a summer room, abl.

Gyte (C.) = a flooding.

Sondgewearp (C.) = sandbank.

Huuer $(\mathrm{E})=$. caldron, as in Wherwell.

Egisi grima (E.) $=$ ghost. $^{\text {s }}$

$\mathrm{Cnol}(\mathrm{C})=$. hill top, as in Knowle.

Haerg (C.) (= Hearg = heathen temple), employed to gloss "Lupercal", the cavern sacred to Pan."

1 Sulh = plough is regarded by English etymologists as an English word, but it seems borrowed from the Latin Sulc-us, for I can find no Tentonic connexions, and as Sulh-lung, Sulung, is a synonym of Furh-lung, i. e. Furlong, the Sulh = Furh = Latin Sulc-.

${ }^{2}$ Cf. Eo-risc (= river rush) and Leber, used in (C.) to gloss Scirpea. The form $e o$ here for the later $e a=a$ river, may serve to explain the form Yeo, for stream in Devon, Somerset, \&c. Leber becomes Liver, Lever, and Ler, in place-names: e.g. Liverpool, Livermere, \&c. The effort to connect the Liver- of Liverpool with the Lither-in Litherland is futile.

${ }^{3}$ Cf. Egisauuda = Ghost or Terror Wood and Fearfulwood in Ordnance Survey map of Bromsgrove district.

- This word appears in several place-names: e.g. Pepper-harrow (Peper 
Obr (C.) = brink. ${ }^{1}$

Byre $(C)=$. shed, cottage. Dr. Sweet makes it the same word as Būr (modern Bower) which appears in Burford on Teme.

Slach-thorn (E.) $=$ sloe-thorn, i. e. blackthorn. ${ }^{2}$

Scytehald (C.) = oblique, steep: hald is given in (C.) for "prone" and haldi for pendulous.

Uuic-ing sceadan (E.) acc. : $=$ piratic-raid. $^{3}$

$\operatorname{Aesc}(\mathrm{E})=$. ash.

Thri uuintri steor (E.) (= a steer of three winters) is the gloss to Prifeta, i. e. Latin Primitius, the aspiration of the $m$ showing that it was borrowed through the Celtic.

Clif hlep (C.) = according to Dr. Sweet, "leap from a cliff", it is the gloss to Pessum (= to the ground).

Cofa (C.) gloss to $P$ istrinum $=$ a pounding-mill. Cof $a$ in the dictionaries $=$ Chamber.

Pirge $\left(\mathrm{C}_{0}\right)=$ pear-tree.

Furh-wudu (C.) = fir-wood. Torf (Wortschatz der Germ. Sprach., p. 234) says "Fir" is from the Danish.

Plum-treu (C.) plum-tree.

Birce (C.) used for poplar as well as birch.

Hlyte $(\mathrm{C})=$. lot, or portion.

Faerh $(\mathrm{E}$.$) = young pig, farrow.$

Unlab (C.) $=$ posthumous $:-l a b .=-l a f$, common in personal names.

Brycg (C.) = bridge.

Sae-geseotu (C.) = sea-shore, a gloss to Promaritima.

$\operatorname{Aac}(\mathrm{E})=$. oak.

Geberg (C.) = refuge.

Harow in I I 47), Harrow-on-the-hill, \&c. The latter locality seems to be referred to as Gumeninga hergae in a Charter of 767 . Guma, modern English in bridegroom $=$ male person. Hence the term means (?) men's harrow.

1 This is the $O$ fer of the Dictionaries = German Ufer. It occurs in numerous place-names, especially with the names of trees prefixed, e.g. Birch-over, Ash-over, Oak-over, Hasel-over, \&c. ; all of which forms are found further shortened to Bircher, Asher, Oaker, Hasler, \&c., in the Shropshire-Hereford district.

${ }^{2}$ Sloh-treo or *Slach-tre is another form which appears in a Charter of 779 as Sloh-tranford (tran is the genitive of treo, treu) now Slaughterford.

3 This shows that unicing was in use before the Norse Wikings made descent on these islands. Sceadan is traced to Scadan = to divide; it seems here to have the force of German Schade $=$ harm. Wicing occurs in place names. 
Heolstras (C. $)=$ nooks, cf. Holster.

Staethsuualwe (C.) = sand-martin-staeth = bank.

Lectha (E.) = bilge of a ship.

Salh $(\mathrm{E})=$. willow, sallow.

Seto (E.) $=$ gloss for Stabula = stalls, abodes, Seotu. (C.) $=$ cattle pasture (Bucetum)

Molde (C.) abl. = sand, earth.

Sinder $($ C. $)=\operatorname{slag}($ Scoria $)$.

Sugu (C.) = sow.

Staeg $(\mathrm{E})=$. pond $($ Stagnum $)$, -stay in place-names.

Lind $(\mathrm{E})=$. lime-tree : Baest is a also given in (E.) and (C.) as the equivalent.

Iuu $(\mathrm{E})=$. yew.

Wond $(\mathrm{C})=$. a mole: also wondeuueorpe.

Win-aern (C.) = wine-house.

Fear (C.) = bull.

Tigule (C.) = tile, an early borrowing from Latin. It appears in place-names as Tilehurst.

Geteld (C. $)=$ tent.

Stream-um (C.) abl. pl. = "by streams".

Aespe (C.) = aspen-tree.

Anstig-a (E.) $=$ a pass. $^{1}$

Cebertuun (E.) caebrtun (C.) = a fore-court. ${ }^{2}$

Cuu (C.) = cow.

Elm (E.) = Latin Ulmus. ${ }^{3}$

Mistel (C.) $=$ mistle-toe, $(t a$. fem. $=$ twig) .

Caelf $\left(\mathrm{C}_{0}\right)=$ calf. $^{4}$

Uar (E.) = sea-wrack.

Bergas (E.) $=$ hills.

Hog (L.) = promontory.

Herst (L.) $(=$ Hyrst $=$ wood $)$ is given as a gloss for Latriuncula $=$ covert.

Ibaei (L.) acc. = ivy.

1 Anstige $f e m$. is used also for a narrow path, that is, a path for one person. It appears in place-names and in personal names borrowed from the latter as "Anstey".

${ }^{2}$ Later $=$ Cafortun, meaning also a mansion. It occurs as Caverton in place-names.

3 Shows that the name was borrowed from the Latin early. The Witch-Elm called Wice, in Anglo-Saxon, was indigenous.

4 Appears in Challock, Kent, in Charter as Caelf-loca- $n=$ enclosed place for calves. 
Firgin-gata, i. e. mountain-goat (L.) $=$ Ibexes. $^{1}$

Beel or Aad $(L)=$. funeral pile.

Loh (L.) = hole, abyss.

Haegtis $\left(\mathrm{L}_{.}\right)=$witch, modern Hag. ${ }^{2}$

Lecas (L.) $=$ leeches.

To these may be added a few similar words from Old English Glosses, Napier, although the glosses, chiefly on Aldhelm's writings, are not earlier than ninth century.

Wæferlice, belonging to theatres (cf. Waverley).

Hyfa $=$ cells.

Scire $=$ parish .

Bure, dat. = seat.

Telgran $=$ thickets

Basincge = Lat. melote (in Vulgate Heb. xi. 37) in " Goatskins". Hedene in same gloss. i. e. Hide-clothed, cf. Basingstoke, Basing-werk.

Cludes $=$ heights, Clûd also $=$ rock.

Sprit $=$ of thickets.

Pleghuses = theatres, cf. Playstowe.

Torra, gen. pl. $=$ rocks.

Stancyslas = gravel, cf. Chesil Beach.

Scræf = cave, as in Shrawley, in Charters Screafleah.

Heahtorra, gen. pl. = mountains, cf. High Tor.

Segel $=$ banner.

Wudefine $=$ wood-heaps, cf. Limfin $=$ lime heap in Cart. Sax. i. 5 18.

Waga, gen. pl. = deep waters. This is the zway in Medway, Weymouth, \&c.

Cyte and Hulce $=$ cells.

Wasa, gen. pl. $=$ sands.

Wylm = boiling, as in Eawylm, i. e. Ewelm = river-spring.

Onedstowe $=$ wrestling-places.

1 Firgen appears in Cart. Sax. i. 366, Firolandes for (?) Firgenlandes (cf. Firle beacon near Seaford) for mountain. It occurs on the whale-bone casket ? 700-800 (Sweet), where the whale is said to have been thrown npon Fergen-berig, i. e. (?) on the main-land (Sweet) or high ground. Torf (Wortschatz der Germ. Spracheinheit, 1909, p. 234) makes the original signification to have been "wooded hill". The Old High German Fergunea is the Hercynia silva. The stem is Ferhu=oak, A.-Sax. Furh, replaced by Danish Fir in Fir tree.

2 Connected by Torp with Anglo-Sax. hage (=hedge, wood, enclosure), a suffix $=$ hate. Cf. Hagu-stald. 
Syla $=$ wallowing-places, $\mathrm{cf}$. Sole in place-names.

Wyla = ? gen. pl. "of Caves", cf. Wygel, gloss. to Cavea in Diefenbach's Glossarium, cf. Wyle-cop, Shrewsbury.

Grundwealle, dat. $=$ foundation.

Pintreow $=$ pine-tree, from Lat. Pinus.

Wilegum, dat. pl. = baskets.

Landgemacena, gen. pl. = of neighbouring lands.

Dimhus and Dimhof = hiding or dark place, cf. Dimchurch.

Warena, gen. pl. = citizens: Old Norse -veri, as in Rûmverjar = Romans. This is the Varii in Chatuarii, \&c., and is the final element in Cantwarena.

Snæda $=$ parts.

Hæthen = heathen.

Healle, gen. $=$ stone $:$ also $=$ palace.

Hweras and $\mathrm{Crocc}=$ pots.

Moldum, dat. pl. = sands.

Cocca, gen. pl. = "chickens, cf. at Scyte Cocce and cock shot", (variant) "Cock shade" in place-names. The Dialect Dict. makes the latter to mean open spaces in woods where woodcocks may be shot.

Edwinde $=$ whirlpools.

Watelum, dat. pl. $=$ tiles.

\section{Gruine Charters.}

Dr. Sweet printed in his Old English Texts (pp. 426 et seq.) the vernacular words occurring in what he considered to be genuine Old English Charters. As some additional genuine charters have come to light since 1885 , when Dr. Sweet's book was published, the following selection of place-names is taken from authentic charters up to A. D. 800, thus excluding any of Scandinavian influence.

In an original charter of 679 now in British Museum we have the following names in Kent:-Tenid (the oldest English form of Thanet): Uuestan-ae (i. e. Westan-èa = river running from the west): Recuulf (= Reculver Regulbium, see p. 37) in Sturia (latinized form of Stúr, or Stur-ēa, now Sturry).

In Essex charter of 692-3 now in British Museum we have: monastery called Beddan-haam (Beddan is here the weak genitive of a man's name Bedda:-the haam is properly the inner bend of the knee, and possibly came like the Celtic Cambus to be applied to land on river-bends and then to pieces of land generally. The East Frisian Hamm meant a piece of 
land drained by dykes. It is not the same word as Hām =home, house); Ricinga-haam (the Ric-inga here is a genitive plural of a family name). In Deccan-haam (now Dagenham) we have the genitive of a personal name Decca. In Angen-lab-es haam we have a personal name made up of $A n g a=$ only, unique, and $l a b$, later laf $=$ left, remaining: thus "only surviving son". Cf. Angen-geot-ing of the Northumbrian genealogies in Sweet, which may mean "the descendant of the only begotten"; cf. be-gietan, \&c., the vulgar use of "get" substantive; but Dr. Sweet makes Geoting = son of Geot. The "field in the wood called Uuidmundes felt" means the field of Widmund. Torp(Wortschatz) traces field "to a stem meaning open, cf. Latin Pal-am=openly". Among the boundaries are Writola-burna (in which Writola seems a genitive plural, but it may be a mangled Celtic word). Centinces treow (= Centing's tree), Hanc-hemstede (the hanc here seems to represent the Teutonic stem hanh = to hang; A.-Sax. later forms Hôn, hêng; cf. Hanger, Ongar, \&c. Hemsted is home-stead). The Tamisa is also given as a boundary. The grant is endorsed "to Bercingon", i. e. the people of Berc $=$ Barking.

An original charter of 704 now in B. M. gives the name of Tuican hom (Twickenham? = Twih-ean-ham, i. e. the dwelling between the rivers Tamisa and Frocesburna, which are mentioned. Twicen = a place where two roads meet, is not involved).

In a letter of $70_{5}$ (original in British Museum) Breguntford, now Brentford, Middlesex, is mentioned (see p. 25).

A Kent charter of 700 or 715 mentions Liming-ae (see below) and Pleghelmestun (i. e. the enclosure of Pleghelm). The boundaries are Bere-weg (i. e. way along which the produce of the land is brought home, Hei-weg = Hay-way), Meguuines paeth (i.e. Megwines path), and Stret leg (i. e. the wood, afterwards meadow, on the Street $=$ the Roman-road. A portion of land called Rumining Seta (see Seto in Epin. Gloss. Rumin-ing, now Romney Marsh, may involve "Romans"). The grant is made to the Church of B. V. M. at Lyminge.

The Dean and Chapter of Chichester have the original charter of the year 725, in which the bounds of Hugabeorg-some unreadable-are given, e. g. on theodweg (theod = people, publicway) (to) the East-end of Lavingtunes dices, i. e. Lavington dyke to Frecce-hlince (Frecce, = bold, is obscure, but hlinc = slope, ridge) to Halignesse beorge (i. e. to the hill of Sanctity) of tham garan (i.e. from the Gore, "a piece of land," cf. Kensington 
Gore) to tham Byrgelsun (= to the burying-places) to Billinga byrig (to the burg (Dat. byrig) of the Billings)-where Scealces burna and Bollan-ea come together (scealcs = servants as in Marah-scalc $=$ marshall) ; - and Isenan æwelm (iron-spring, ēawelm = river source) and Sængelwicos and other names which are not intelligible.

An original charter in Brit. Museum, dated $73^{2}$, grants land near Limin-ae (i. e. the river Limen which appears in Liminge and Lympne, near Hythe, and is ultimately traceable to the portus Lemanis, of the Itin. of Antonine). The names Sand tun (Sandtown) and Hudan fleot (Huda's fleet or estuary) occur in the copy published in Cart. Sax. i. 215, but as Dr. Sweet rejects these, they are not probably of the date of the charter.

Another original charter, dated 740 , grants fishing at the mouth of the Limin-aea river, and "a portion of land in which is situated the oratory of St. Martin, with the dwellings of the fishermen, and another portion near the Marsh called Biscopes uuic (i. e. Bishop's dwelling) as far as the wood called Ripp (unknown and probably not an English name), and to the bounds of Sussex, as formerly possessed by Romanus, priest of the Church of the most blessed Virgin Mary, which (quod (sic)) is in Liminia -eae (Lyminge)".

The oratory of St. Martin at Lyminge-ae, and the name of the presbyter, Romanus, suggest early continental connexions, while two of the signatories Dun-uualhi Pincerni (gen.) and Dunuuallan (gen.) seem to point to the Celtic names Duno-vali and Dunovellaunus, cf. Cassi-vellaunus, Catuuallon, \&c.

A Kent charter of 770 (in B. M.) mentions the monastery of Recuulfi (attracted into this form on account of the common name Rac-uulf see above), Perhamstede (where Per = modern Pear) in the region er (?) of the Caestri-uuara (gen. pl. =" of the Castlemen "), where is the place called Heahhaam (heah = high, Higham).

The Hehham (= Highham) of the original charter of 774 (in B. M.) is possibly the place here mentioned. The boundaries there given are Mædham (i. e. Meadham), Ac-leag (= Oakley), Wæter lea (Waterley), Colling (= Cooling), Eohinga burh (Eoh = steed, Eohinga gen. pl. of patronymic: Burh = burg), Mersctun (Marsh-ton), Mercfleot = "boundary river". All these places are near Rochester.

An original charter of 774 (in B. M.) mentions the Merscuuare (i. e. the marsh-people) of Romney,=here Romenal, among 
whom Hlid (Lydd, Kent ? = litus, shore) is placed. Denge marsh is also mentioned.

The earliest Mercian charter extant seems to be of the year 736. It is now in the B. M. and deals with lands in the "province of Husmerae", that is in the region of the Stour (Stur) above Stourbridge. It gives the ancient Celtic names of two forests, Cynibre and Moerheb, which still survive in Morfe and Kenver forests; see p. 67. Brochyl (i.e. Badger-hill) is mentioned as being "in silva moreb".

The synod of Clofeshos (Cloveshou in later charters) is men. tioned in a Mercian charter (now in possession of Dean and Chapter of Canterbury) of the date $\mathbf{7 4 2}$.

An original charter in B. M. of A. D. 755-7 contains a grant by the King of Mercia to Eanberht, of land near the wood called Toccan-sceaga (i.e. Toccas Shaw or wood) not far from the hillock (tumulus) called Reada-beorg (i. e. Redhill). A Tyccæa abbot signs the charter, probably the Tocca here mentioned. The locality has not been identified.

A Mercian charter of 759 (now in B. M.) grants land in Worcester at Onnan-forda, bounded on the south by Uuisleag (Wisley), on the west by Rind-burna (Rind, which is the OHG. form, is probably a dialectic word here for Hrith (=Hrither $=$ Rother $=$ cattle), on the north by Meosgelegeo (=mossy tracts : Dr. Sweet), and on the east by Onnan duun. The river Oney giving its name to Onibury, Shropshire, is perhaps too far west. Onn is the Welsh for Ash-trees: cf. English "ash" in stream-names.

In a Mercian Charter of 767 we have a grant of land in Middlesex lying between Gumeninga hergae (that is the harrow or pagan temple of the Gumenings $=$ ? Harrow-on-the-hill) and Lidding brook, in exchange for land in Ciltinne (? Chilterne hills or Chiltern All Saints) in a place called Wichama.

A Worcester Charter of 770 (in hands of Dean and Chapter of Worcester) mentions the Huiccii (see p. I64), the river Saluuerp (Salwarpe), Cymedes halh, Huitan stan (= white [pillar] stone), and Readan-Solo. Saluuerp seems to mean, like Sal-gewearp, "Salt-heap," i. e. the river that ran by the Salt, packed ready for transport at the Salt wīc or Salt market-now Droitwichwas thus called from the fact that river-names frequently take their designations from such incidental factors. ${ }^{1}$ Redan solo =

${ }_{1}$ The halh in Cymedeshalh is given by Dr. Sweet as = healh=corner. It is evidently the same word which we find in the North in the forms 
Red cattle-ponds. Sole occurs with this meaning in Kentish place-names, see Syla, pl., in Napier Glossaries.

A Kent Charter of 778 (in B.M.) mentions the following names:-Brom-geheg (Broom-meadow, Dr. Sweet), and a marsh called Scaga (= Shaw), a meadow called Hreod-ham (Hreod $=$ reed), a place east of the bounds of the Clif wara (gen. pl. = "the people of the Cliff," which place, if it existed now, would be called, like Clifwara near Cheddar, Clewer) "and to the south of Tucincg-næs". " To the west of the bounds of the Culinga (the name of this family is still preserved in Cooling Castle) is Mearcfleot. ${ }^{2}$

Another, a Wessex, Charter of 778 gives the names of Bedewind (Bedwin, Wilts.: which looks like a British name involving Celtic Vind = white), Cymenes denu (= Cymen's Valley), ad Peadan-Stigele (= Peada's style), Tatan Edisc (= Tata's deer park). Several words then follow involving gat, geat, get = English gate, e.g. Rames dene geat (= Ram's personal name, ?-den-gate), Holh-ryge-get (= Hollow-ridgegate), \&c. ${ }^{3}$ In Puttan Ealh (= in Putta's (heathen) temple, cf. Alh-mund = Temple Guardian), to Bulcan pytte (Bulca's pit : pit from Latin Puteus). Baldwines Healh (see Halh above), " into the Antient Monuments in a place called at tham Holenstypbum ( $=$ at the Holly Stumps) to Wadbeorge (Woad-hill),

Healc, halec, Halech, Hauch, and Hough. It is always there associated with rivers, and Jamieson in his Scot. Dict. defines it "low-lying flat ground, properily on the border of a river". In the Records of Kinloss, p. I1 2, we have " the third part of the Halech of Dundurcus and the third part of the fishery of the same halech". The old name of Whitby given by Bede (see p. I 80 ) bears out this signification.

1 Tucineg, a patronymic, and næs = nose or point. This name shows that nas, like wicing and Throp, existed in English place-names before the coming of the Scandinavians.

${ }^{2}$ This is the mercfleot of the A. D. 774 charter cited above, which gives also Colling for Culinga. An original charter of 808 , in B. M., also mentions Culingas, with its bounds Cyninges-tun-tih ( $=$ ? Kingstown paddock $=\mathrm{Tih}=\mathrm{Teah}=\mathrm{Teag}$, now $\mathrm{Tye}$ and Tey in place-names, e.g. Marks Tey, Essex, which involves, as Mr. J. H. Round shows, Feudal England, 464, the name of the village of Marck in the Pas-de-Calais, borne by Adelolf de Merk, the owner of Marks Tey district in Domesday 3. Cf. Tigan, now Tey river, Essex, Cart. Sax. iii. 602. The 808 Charter mentions Genlad, Biorn heardes lond (i. e. Bernard's land), and Thorndnn.

${ }^{3}$ These gates were probably entrances to the enclosed Edisc or park. 
thence to the spring which is called Forsca burna (= Frogs' brook)." 1

A Gloucestershire Charter of 779 (in B. M.) gives the following names:-Sulmonnes burg (= Suhl monnes-burg = Ploughman's burg), the stream called Theodningc (=? a patronymic from (?) Theodnoth), the river Uuenrisc (now Windrush: the last element seems Celtic $-i s c=$ water, and the first element Gwen, wen, fem. adj. = white; cf. the rivers Winster where Ster is probably the early form of Stur), Uuithig-ford (= Withyford) a valley called Turca-denu (that is the den on the river Turca; cf. the Welsh Twrch = boar, which is also the name of a river: see Mabinogion story of Twrch Trwyth), Slohtranford ( $=$ ford of the Sloe-trees, now Slaughter-ford). This Charter was signed at Ioratla-forda (Hartleford, Glouc., seems to involve Heorot (= hart, stag): possibly a genitive plural of a form Heorotlu, a species of stag).

An early grant $(785)$ to Westminster Abbey, published by the Ordnance Commission in Photozinc facsimile, gives the name of the island on which the minster was built, Torneia (i. e. Thorn-ige = thorn-island), which is called in the Charter "a terrible place" (perhaps in the sense of holy-dread). The grant is of land at Aldenham (Aldenham, Herts.) of which the bounds are given: among them:-Colen-ea (that is the Colne river), the middle of the street (i. e. Watling Street, which crossed the Thames at Thorney island), Tidulfes treow (= Tidulf's tree; cf. Elstree), Hæsel-hyrst gate (Hasel-wood), Lusebyrge. The names are manifestly late and most of them unintelligible. This is probably why Dr. Sweet does not include them in his early charters.

In Cart. Sax. i, pp. 342, and 344, two charters which Dr. Birch says are almost contemporary (A. D. 785) are published, in which Ioccham (Ickham) and Per-hamstede (mentioned above) are placed in the wood called Andred (see p. 143). Dens for feeding swine in this wood are mentioned; e.g. Dunwal-ing daenn (where we may have a reminiscence of the Dun-walh(i) before mentioned) Suithhelming daenn: a stream called Heorat burna (= Hartbourne), a Snad (= Snæd, a piece of a wood), and fishing in the Pusting uuerae (Wer = Weir). Hroching (now Rocking) also occurs, and Limen wero weald

${ }^{1}$ The Peada and Putta in this Charter are not normal English personal names and imply a foreign connexion. 
(= ? Limen (Liminge), men's wood) and burh waro uuald (i. e. the Burgmen's wood: Sealterna Steallas (the salt houses' steads). The names are late forms and Dr. Sweet rightly does not include these in his early charters.

The charters pp. $35^{\circ}$ and 360 Cart. Sax. i (taken from the ancient Chartulary of St. Denis near Paris) are manifestly late forms, notwithstanding the seal of Offa affixed to the latter. The forms Chichestra, Hastingas, and Successa (for Sussex) amply prove this. Pevenesel may preserve the ancient name of Pevensey, and Lunden uuic may be Sandwich.

An original Charter of 788 (in B. M.) gives the name of a region called Eastrgena (now Eastry; the rgena is supposed to be the genitive plural of the continental tribe the Rugii, who also appear in the early name of Surrey; see p. I 78 ). Duningcland and Celchyth (Chelsea, see p. I57) are also mentioned.

Another original Charter of 793 (in Canterbury Cathedral Library) grants several places in Middlesex :-on Linga Hæse (= Hayes, Middlesex), Geddingas (Yedding, Middlesex), Froces burna and Tuican ham (see above, for the repairs of the Church of the Holy Saviour, Canterbury).

An original Charter (in B. M.) of $793^{-6}$ grants lands in the province of the Huuiccii at Uuestburg near the river Aben (Westbury, Glouc., near the Avon). The Charter is recorded as having been written in the celebrated place called Clobeshoas.

Another original Charter in B. M. dated 799 grants land at Ciornincge (Charing, Kent : another village called Charing gave its name to Charing Cross. "Chère reine" is a survival of days of ignorance), Seleberhtes Cert (perhaps Great Chart). Cert is a mysterious word. It seems to mean "wood", but its origin is probably not Teutonic: Kent was latinized early and the word (cf. numerous wics in Kent) may be from that language: cf. Carectum $=$ reed-land or sedge-land. Bryning lond (called Biringland also), Humbing lond on Bioraham (? = Barham, Kent) æt Burnan (at bourne).

An original Charter of 798 (in B. M.) mentions several places in Kent: Hremping-uuic, called also Hafing seota (see Seota above), south of the Limin-ea (i. e. the river Limin at Liminge): also Bobing-seata. In the contemporary endorsement seota is made of the weak declension genitive singular seotan. 


\section{Ancient List of English Territorial Names.}

There is a list of English territorial names (given in Cart. Sax. vol. i, pp. 4I4-16) copied, presumably from an ancient form, in the tenth or eleventh century. That it is a copy of an earlier document seems clear from the distorted forms of some of the names, which are difficult, if not impossible, to identify.

I append the list with such notes as occur to me.

HIDES

Myrcna landes (i.e. of the land of the Mercians) . 30,000

Wocen Sætna ${ }^{1}$. $. \quad . \quad . \quad . \quad .7,000$

Westerna $^{2}$ (Porcensetene in later Latin form $=$ ? Worcensetene)

Pec Sætna ${ }^{3}$.

Elmed Sætna ${ }^{4}$

Lindes farona ${ }^{5}$

Suth Gyrwa ${ }^{6}$

North Gyrwa

[East Wixna ${ }^{7}$

West Wixna]

Names in brackets from another list, $C . S$. i. 416.

Spalda ${ }^{8}$

1 Satna is a genitive plural and is equivalent to wara, gen. pl. of wer= man. Cf. Ceaster setna (Cart. Sax. ii. 217) and Caestruuara (Cart. Sax. i. 282). It means thus in the connexion here "of the people or settlers of". Wocen is possibly an error of the copyist for Wrocen $=$ the Wrekin district, for the people of which Wreocen Setna actually occurs (Cart.Sax. iii. 355).

2 This seems an error of the copyist. The alternative name Porcensetene is clearly a mistake for Worcensetna, a duplication possibly of the previous name.

3 These are the settlers of the peak district.

- Elmed Sætna would seem to refer to the Elmet district in Yorkshire mentioned by Bede. We have an Elme-setena (Elmley Lovell) in Cart. Sax. i. 502, but this, as the list seems to proceed to the north-east, is too far to the West. An Ylmesaton in Essex (?) appears in Cart. Sax. iii. 6or.

${ }^{s}$ Lindes farona (i. e. Lindsay-farona) seems the gen. pl. of Faru (f.), one of the meanings of which is "troop".

"Gyrwa, Gyrwe fenn is glossed Marsh Gyrwa = of the fens.

7 Wixna is gen. pl., a contraction of Wicsetna, that is, people of the market. There was a Wixenabróc in Worcester (Cod. Dip. 570), now Whitsunbrook.

${ }^{8}$ Spalda is evidently for Spalding district. 
HIDES

Wigesta $^{1}$. $\quad . \quad$. . . . . 900

Herefinna $^{2}$. . . . . . . . $\mathbf{1}, 200$

Sweord ora ${ }^{3}$. . . . . . . . . 300

Gifla [Eyfla in C.S. i. 416$]^{4}$. . . . . 300

Hicca [Wicca in C.S. i. $\left.4 \mathrm{r}^{5}\right]^{5}$. . . . 300

Wiht gara [-gora in C.S. i. 416 $]^{6}$. . . 600

Nox gaga ${ }^{7}$. . . . . . . . 5,000

Oht gaga . . . . . . . . . 2,000

Total $=\overline{66,100}$

That is, says the oldest MS. which does not give East and West Wixna with their 900 hides, sixty-six thousand one hundred hides.

It is clear from this that the copyist of the oldest MS. had omitted East and West Wixna although his total number of hides is only correct with their addition.

The list then proceeds:-

HIDES

Hwinca $^{8}$. . . . . . . . 7,000

Ciltern Sætna $^{9}$. $\quad . \quad$. $\quad . \quad$. . . 4,000

Hendrica [the second list gives hides 3,000] . . 3,500

1 Wigesta might be an error for Wigerna (Worcester), but there was a Wicgestan near Burton-on-Trent (Cod. Dip. 1298).

2 A probable mistake for Hereford.

3 There was a Sueordleag in Dorset (orig. Charter Cart. Sax. ii. 34), and a Sweordestan in Gloucester (Cart. Sax. ii. 174).

4 Gifla may represent (I) the district around Biggleswade where the name of the river Ivel or Givel still survives in North-ill and South-ill parishes; or (2) it may mean the district around Ilchester to which the river Givel $=$ Ivel gave its name.

${ }^{5}$ Hicca, with its variant reading Wicca, could not mean, owing to the small number of hides, the province of the Wiccii.

6 This name may have nothing to do with Wight.

${ }^{7}$ Nox and Oht gaga are inexplicable in these forms.

8 There is no light on Hwinca.

- Ciltern, or the Chiltern bill district. The remaining names down to Widerigga are unintelligible. Widerigga may be the Withering-Sett, Suffolk. East and West Willa seem to refer to the district near the Wiley river (Wilts.). The name in the Charters is Wilig, Unielea. The remaining names explain themselves. 


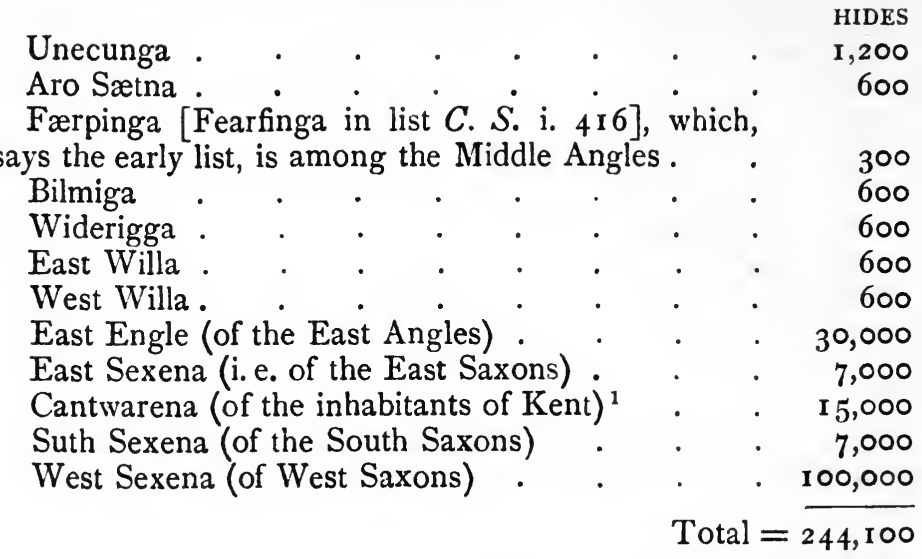

Amounting in all, says the list, to two hundred and forty-two thousand seven hundred hides, falling short of the correct total by $\mathrm{I}, 400$ hides, or, if we estimate Hendrica at 3,000 , by 900 hides.

1 This term involves the Warena in Prof. Napier's Glosses, see p. 213. It is different from the genitive plural (wara) of wer = man. 


\section{THE COMING OF THE NORTHMEN}

\section{Norse Influence on Topographical Nomenclature and Language.}

$\mathrm{T}_{\mathrm{HE}}$ entry in the Chronicle under 787 is remarkable for the announcement that in Beorhtric's days, who, as we have seen, succeeded Cynewulf as King of Wessex in 784, the first ships of Danish men reached the land of the Angles.

The actual year is between 784 and that of his death -800 . The "three" ships, which came from Heretha-land ${ }^{1}$ put into some place on the Dorset coast, according to Ethelwerd's Chronicle, whither, the same authority tells us, the King's Reeve, Beaduheard by name, rode from Dorchester, believing that they were traders and not foes, and was there slain. From this date forward until the eleventh century the British Isles were subject continuously to the raids of these pirates, and large portions of the land were from time to time occupied by them.

Their first appearance in the Irish Seas was, according to the Irish Annals, in the year 795, but they had most probably been making southerly voyages from a much earlier date. The

${ }^{1}$ Heretha-land, "strictly Hörðaland on the Hardangr-fjord in Norway," says Mr. Plummer (Two Sax. Chronicles, ii. 58), "the country of the Hörðar or Hawrds (Charudes, Harndes)." In the Irish Annals it appears as Irruaith, and is there a general term for Norway. It is to be noted, however, that the "Hreth" Goths are placed in Jutland or in S. Sweden (Iceland. Dict., sub Goti and Reið Gotar), and hence the reason possibly why these invaders are referred to as Danes by the Chronicle. The Annals of St. Neot (compiled towards the end of the twelfth century) say that the ships put into the "island called Portland". 
causes of these expeditions are not easy to discover. Dr. Vigfusson was probably right in ascribing the main cause, as far as Norway was concerned, to over-population. ${ }^{1}$ The Danes, although they are thus named in the entry of the A.-S. Chronicle referred to above, and are confused throughout with Norsemen proper, were not among the first invaders. In the Irish Annals, the Norsemen and Danes are distinguished as "FinGall" and "Dubh-Gall", or fair and dark foreigner respectively. This distinction of fair and dark hair was probably of a racial character, for ethnologists tell us that the skull of the average modern Dane is not by any means of Aryan type.

Possibly in pursuit of the whale, the early Norse sailors may have been led to the soutn and west, and made as their first land-fall the Faroe or Shetland Islands. In an age when the compass and the log were unknown, these early navigators -would normally hug the shore, but once they had reached the Shetlands, these, and the Orkneys, would become a base for further explorations. It was from such a base, as we know, that the Norsemen harried the coasts and islands of Scotland and Ireland, and it was here that their sovereignty over Sodor and Man began, which survived until $1470 .^{2}$ Nowhere else in these islands do we find such undisputed evidence of the presence of Norsemen as in the modern place-names of Shetland and Orkney. The previous occupants, as we infer from the existing Pictish "Brughs" and Barrows, were Picts, and the early names

1 "The Northmen," said Dr. Vigfnsson, "were cribbed up in a narrow, overpeopled strip of land: a powerfnl race of men, with vast pent-up strength lacking all outlet, a great human steam-boiler without the requisite safety-valve: till in the Wiking Age the great exodus to west and sonth opened a new field of action to them" (Corp. Poet. Boreale, i. 426).

2 What is known in Norwegian history as "the flight of the Jarls", who emigrated to these islands in 872 , was the beginning of the Kingdom of the Sodor (Sudr-eyjar = sonth islands, or "Sodor islands", applied to the Orkneys [Orig. Iceland, i, p. 253]) and Man. Man and the South isles were made subject by treaty to Scotland in 1266 , but Shetland and the Orkneys were not really handed over till 1470 . 
of these groups of islands ${ }^{1}$ probably preserve a relic of their original language. Irish missionaries, probably from $\mathrm{Hy}$ (Iona), had laboured in these islands from about the end of the sixth century until the arrival of the Norsemen some 200 years later, and indications of their presence there are still preserved by a few Ogam inscriptions, place-names, and dedications of churches. Irish hermits were found also in Iceland when the Norsemen discovered it about A. D. 850 . $^{2}$

An account of the voyages of the Norsemen prior to the time of Alfred the Great (A. D. 849-900) was furnished to that king by the two Scandinavian travellers Wulfstan and Ohthere, and their account was added to Alfred's Description of Europe. No mention of Britain occurs in this account, but it is clear from the whole narrative that Norse seamen went far afield, and that they were acquainted with the White Sea as well as the Baltic. Though they were pagans, and remained so until the eleventh century, they must have been brought into contact, in their eastern wanderings, with Gothic Christianity-that is, Greek and not Latin Christianity. This is evidenced from the word

1 The name of Shetland in the sagas is Hjallt-land. Hjallt and Shialt (the latter preserved in the existing designation of "Shelty" for a Shetlander or a pony from the islands) are evidently the same word, and are paralleled by the Cymric and Goidelic names Hafren and Sabern for the river Severn. The Picts, who in historic times spoke a language more akin to Welsh than Gaelic, would follow the former in using in place of Shialt the form Hialt. The earliest Scandinavian maps (Nordenskjöld Atlas) give Hjialt-land. An analogous instance is the parallel between the Hjalpands-ey of the sagas and the Shapinsay of our maps.

As Orkn in Norse means a Seal, Orkn-eyjar would seem a natural designation for these islands, but the term Orc in Orcades goes back to classical times, long before a Northman had put his foot upon them, and its meaning must be songht in the language of the earliest inhabitants. If these were Celts orc, oircnin (glossed Porcellus) has the meaning of Pig in their language, and is cognate with the Latin Porcous, and the A.-Sax. Fearh = farrow. Compare Latin orca = Grampus, but the word is probably non-Aryan.

2 The Landndima Bbc (that is "Land Settlements Book") shows that there was a considerable Irish element among the early Norse settlers in Iceland. Place-names like Ir-œ = Irishman's river, occur also in this work 
"Papa", which they applied to the Irish priests they encountered in the islands, and also from the term "Kirkja" with which they were conversant as the designation of church." The place-

1 The Goths on the south of the Danube had become Christianized in the fourth century. They had, as their historians tell us, come originally from the Baltic coasts, and probably some connexion with their Norse kinsmen was maintained in later times. There is at any rate no likelier source for the knowledge by the Norsemen of such terms as Papa and Kirkja. Professor Kluge thinks the former is from the vocative Papa of the Greek Papas: the latter is from a Greek adjective formed from Kurios = Lord. The names of some islands in the Shetland and Orkney group perpetuate the former appellation, e.g. Papa Isle (Shetland), Papa Stour (Shetland), Papa Stronsay Isle (Orkney), Papa Westray (Orkney). The Flateyjarbok, ii. 417-18, gives us some of the saga-forms Pap-ey hin litla = "Priest-island the little", and Pap-ey hin Meiri = "Greater Priest island", which are now represented by the two Pabeys of the Hebrides. The name occurs also in Iceland, e.g. Papafjördr. It is possible that we have in the Domesday "Popeselle" or "Popesalle" an echo of the same word. It was in Kent, where one would expect from its Jutish occupiers, a closer connexion with early Scandinavian traditions and language. I ventured to point out some years ago in the Athenaim that there was distinct evidence in the place-names of Kent of a Jutish element therein. I have seen no reason since to change my opinion. The most important evidence is in the early name of Bapchild. Haddan and Stubbs, Councils, iii, p. 244, cite from the Anglo-Saxon Chronicle the account of the "Great Council, at the place which is called Baccan-Celde" held about 694, long before the Norse invasion. The element Celde in this name seems to be the Scandinavian Keld $a=a$ well, of which Outzen (Friesisches Glossarium, p. 159) gives the Jutish form Kild with the same meaning. The only parallel for the term is the Keld of the North (=well), of Scandinavian origin, for undoubtedly Norse is the term St. Kilda, which applies not to a holy person of this name, but to the known Holy Wells on the island; cf. Halikeld, Yorks., Cal. Chart Rolls, ii. 240. It is a strange thing to find in Kent alone-apart from the North-a word closely allied to a Scandinavian form, but the strangeness is explained by the assumption of a Jutish origin. The Baccan in Baccan-Celde is seemingly the genitive of a shortened personal name Bacca. Celd occurs also elsewhere in Kent, as in an original charter of $85^{8}$ (British Museum Facsimiles) in the form Hwyte Celdan ( = white well), it being coupled there with another well Wassingwell, as the site of a water-mill. There is also a "Honey Child" in Romney Marsh (Honi Child 1227), where we have also a "Snargate" which receives its explanation (see p. 232) as a Scandinavian 
names in Iceland referred to in the Landnáma Bóc, of which we have a thirteenth-century MS. (the materials therein going back to the ninth or tenth century), and those in the various sagas, enable us to show, by comparison with the existing placenames in Shetland and Orkney, how completely the Scandinavian tongue had displaced the original language of these islands. ${ }^{1}$ The historical statement that Norwegian was the term. "The Nore" also seems to bear indication of a similar origin. It is noteworthy also that the Scandinavian Gil (see p. ${ }^{2} 3 \mathrm{I}$ ) is used in Kent.

1 The topographical nomenclature of Shetland and Orkney is almost exclusively Scandinavian. As instances we may take the names containing such Norse forms as Voe (elsewhere $-w a y=V a g r=$ creek), Skaw (Skagi = a low headland as opposed to Höjoe = a high headland), ness; wick (=Vik, a bay), firth (= fjördr), Holm (applied to uninhabited islands), Sound (Sund), ey (=ey, island, plural eyjar), exemplified in Lang-ey, Flat-ey, Sand-ey, Ha-ey (that is "high-island", now Hoy), Sker-ey (that is "rock-island"), Hun-ey (for Hafn-ey, i. e. Haven island), Urfas-ey (probably for Örfirisey, from Örfiri = ebbing). Stad-r (stead) which takes the form of ster (plural) and sta, Bústadar (Home steads $=$ Bowster and Bister, as in Isbister, \&c.), eyrr (Danish Öre, Swedish Ör; = air, ayre, a gravelly bank or point running out into the sea, as in Helsingör, Shakespeare's Elsinore), thing (also ting $=$ a meeting of the people, as in Sands-ting, Ting-wall, where wall $=$ Völlr $=$ field, compare Dingwall in Sutherland, Cheshire, \&c.): $B \boldsymbol{u}$ (also By = habitation): Gardr (=garth = enclosure): Sat-r, mountain pastures: Dal-r, a dale : Skáli, a shieling or temporary dwelling in the pastures: Skaill = Skál, a bowl, a hollow : Skogr (also Skew and Shaw = wood-brushwood, Danish Skov): Klettr, Danish klint (Clett, Cleat, an isolated rock): Gnupp (Noup, or Nupe or Nip $=$ a peak, as in Gaitnip = Goat-peak): Hop (a sheltered haven, or spot): Holl, a hill : Borg (Burg), Hus (= house, e.g. Bon-us ? = *Boonhus $=$ Prayer-house, the equivalent of English Bede-hus, Bed-ern. Bettws in Wales is the English Bedhus, which occurs also in Scotland), Lax (= Salmon) in Laxforth : Hamarr, a rock, as in Hamarr-Gnipe in Iceland = Cragpeak. We should not expect to find on these wind-swept islands words meaning wood, such as Lund, Holt, \&c., and they are absent. The parallel names in Iceland show how thoronghly the Norse has prevailed in these islands.

These place-names in their turn have become surnames, as in Foubister, Isbister, Inkster, Cursitter. We find also in these islands other personal names which have a distinctively Scandinavian character, e. g. Swan-son, Man-son, Simon-son, Hender-son, Olla-son, which preserve respectively the well-known Norse personal names, Svein, Magnus, Sigmundr, Heinrekr, 
vernacular there down to the seventeenth century is further confirmed by Brand, who found in Hara in I 701 people who knew only Norse. Caithness and Sutherland-the parts of Scotland lying nearest to Orkney-furnish also indubitable evidence of Norse occupation, ${ }^{1}$ but it is on the chart of the west coast of Scotland and the adjacent islands that the Scandinavian sea-rovers have left their most permanent mark. There is hardly a headland, or a half-sunken rock, or the scrap of an island, or a bay or inlet, in these western waters which had not been charted-although their mode of doing so is unknown to us-by these daring navigators, and handed down to later mapmakers. $^{2}$ It is to the same navigators, too, we owe the names

and Olaf. Many such names have become shortened, as in Gunn (from Gunn-björn, or Gunn-laugr). Oman is from Amundr, which also appears in the western islands, in a Celtic dress, as MacAmond and McCammond, where quite a number of similar Norse appellations are perpetuated, as McCorquodale for MacThor-Ketel, McCorkell for MacThorkell-the Th in Gaelic being silent, MacAlden for Mac-Halfdene; Half-dan (now Haldane $=$ Half-Dane).

There are pitfalls for the philologist in the place-names of this region. What could one make, for instance, of Pomona, a designation of the main. land of Orkney? Although it occurs early it seems the application to this island, by an antiquary, of the Pomona associated by Solinus with Thnle, and it remains there to disturb future investigators.

1 In Caithness and Sutherland the following small selection of placenames supply ample evidence of Norse influence there. Cannis-by, Seaterhill, Wick, Ny-bster (for New Bustadar, plural), Ul-bster, Lybster, Rester, Bilster, Bilbster, Thuster, Achilbster, Scrabster, Halla-dale, Armadale, Torrisdale, Erri-boll (bol $=$ English Botl, Bold = house), Fres-gill, Laxford, \&c., \&c. There appear many other Norse forms, such as Clett $=$ rock; Geo ( $=$ Gjá, a cleft) which becomes Goe, and in the Hebrides is Celticized to Geodha, pronounced Geyo [Giau in Manx], and Gil = stream. These names tend to confirm the assertion of the Saga that "Olaf Feilan (= Irish Faol-an = the Wolf), Thorstan, and Sigurd conquered Katness, Sudrland, Ross, Moray, and more than half Scotland", Landnáma Boc, ii. I4.

2 The Skeirs and Skerries, the Ha-Skeir (High-reef) and Deas-Skeir (Des = shaped like a hay-rick, or Irish Deas $=$ south), all significant as things to be avoided by the navigator, stud the western seas. There, too, we find Shellay with its shell beach, and Sanda, with its sand, Pabbay, 
of Ireland and of three of its four provinces, together with the appellations of many of the isles and bays on its eastern coast and on that of the Isle of Man. ${ }^{1}$ These expeditions were not made, however, for the purpose of acquiring a knowledge of

which marked the lone monastery of world-renouncing Irish monks, Vallay, which promised Vellir, or fields of rich grass behind its rocky shore-every name significant if we could interpret them. In the Western Isles, Skye, Rona, Raasay, Uist, Lewis, Harris, \&c., we have fnller illustrations: e.g. Ose Point (Ass = ridge; Oss, mouth, also occurs as Ois, as in Ois Gillbay), Scara-vay (Skarar = edge: Vagr = bay), Causa-Mul (Míli probably borrowed from the earlier Celtic inhabitants $=$ jutting crag), Sletta-val (=level field), Ha-skeir, Ha-clett (= High reef and rock), Geo (cleft), Valla-rip (ripr $=\mathrm{crag}$ ), Greanascore (Grain $=$ forked valley $=$ Grain in Northumberland, York, and Lincolnshire place-names, and skor $=$ cleft), Husa-bost, Steis-buist, Kirka-bost (bost is the shortened form of Buistad-r), Staffa island (stafar $=$ posts of a building), Stack (stakkr $=$ stock), Bolaval and Bola bratt (= Bull field and Bull hill: Eng. Brant $=$ brattr), Vater-galt (vatr $=$ vatre $=$ water, and Galt $=\mathrm{H} n g=$ Hogsback, ridge, but here the Celtic Galt = cliff may be involved; and countless Sgeirs (=sker $=$ reef $)$.

1 The Ster in Ul-(for Uladh-)ster, Lein-(for Leigin)ster, Mun-(for Mumh)ster, is Norse-so is the termination of the islands, Ireland's eyeas opposed to Angles-ey -and Lamb-ay. Howth Hill, Wicklow (earlier Wiking-low), Wexford, Water-(that is weather)ford, Leixlip, Carling-ford, Strang-ford, \& c., all show Norse impress.

The Isle of Man is full of Norse appellations, including such Icelandic forms as á = river, Brekkr = brink or slope, Dalr, Ey, Eyrr, Fjöı $\varnothing_{-r}$, Garðr, Gil, Hammar, Haugr (Tumulus, How), Hóll, Setr, Vað (a ford), Vik, Vollr, and the surnames there show also a large Norse influence; e.g. Casement (from McAsmundr), Caskell and Gaskell for McAskill, short for McAsketill; Cottar for McOttar, Corlett for McThor-ljotr, Crenill for McRagnild, \&c. In Manx personal names beginning with $c(k)$ we have the last letter of $M a c$ ( $=$ Son), the initial $M$ becoming aspirated in oblique cases and finally vanishing. The Welsh $M a p, A p$, and $P$ initial represents the same change, e.g. MapRichard, ApRichard, and Prichard. The spread of Norse influence in Southern Britain is also marked by Scandinavian place-names, which will be dealt with in due conrse. Great caution is needed here, however, as many English names are similar to the Norse.

The extent to which our Modern English vocabulary is indebted to imported Norse words exhibits further the pervasive character of Scandinavian influence. A short list of familiar words traced to a Norse ancestry is appended (see Note I). 
geography or for peaceful commerce. They were uniformly piratical, and the main objects of their pursuit were the costly shrines, the richly adorned books, and other precious objects of religious art belonging to the churches and monasteries. The Wars of the Gaedhill and the Gaill (i.e. the Irish and the foreigners), and the Annals of Ulster and other Irish Annals published under the direction of the Master of the Rolls, are filled with records of the pillaging of religious houses in Ireland, and the A.-S. Chron. contains records of similar atrocities in England. ${ }^{1}$ The early expeditions were of the nature of summer raids, and the person engaged in them was distinguished by the name of Sumar-lithi (Somer led), that is, Summer-sailor. The Norsemen soon came, however, to make permanent settlements in all parts of Britain, succeeding eventually in asserting their sovereignty in the early years of the eleventh century (ror6) over all England.

\section{NOTE I}

A sHORT List OF Words (abstracted chiefly from Torp's Wortschatz, Göttingen, 1909) BORROWED FROM THE SCANdinavian INvaders of Great Britain.

Norse $A n g-r$ is involved in place-names of the western islands, and a cognate form, Norse eng (grass-land), is the origin of our northern eng and ing = meadow.

Bakki (= bank) is found in northern place-names. Beck (of which the English form Bece gives "beach", and "batch", "bach" = Brook: the early form of the Chester Sandbach was Sandbec); Billow; Bleak; Bloom; Bole (of a tree); Bunker (heaps, $c f$. Bunker-hill or Golf bunkers); Booth; Boon (A.-Sax. form is Bên) are from the Norse, as are also-

1 Mr. Plummer shows (Two Sax. Chronicles, ii. 156) how it had become necessary, owing to the ravages of the Scandinavian pirates, to fortify the monasteries. Peterborough was, as he says, one of the earliest instances, which from being a Home-stead (Medes-hamstede) and exposed to attack, was made a Burh, by being encircled with a wall (an earthwork) with defences. It was henceforth Peter-borough. 
Cake; Car, in northern place-names, Norse Kjarr (= low bushes); Carl (churl); Cast (to throw); Kid ; Crook.

Down (feathers).

Fir (tree); Fors = foss (= waterfall).

Gate (in the sense of way); Gable ${ }^{1}$; Gamel (= old, in personal and place-names); Girth; Gills (of a fish); Guest; Gil (= narrow valley in northern place-names and in Kent).

Hope ( $=$ a bay and river valley); Holm (a sea- or riverisland in the north. It is also English); Haug- $r^{2}$ in northern place-names.

III.

Kindle.

Law ; Lœck-r (= brook : in northern place-names, as Leek : the cognate English Leach, Lech, Letch, and Latch appear in the south and in the Charters as lacu= also "lake"); Loft; Loan.

Meols (Norse Mel-r, a sand-bank, appears in the Wirral district); Muggy; Mire.

The Meoles at Shrewsbury, e.g. Cruck Meole, seem to involve the Welsh $\mathrm{Moel}=$ bald, i. e. treeless.

Nore (= Norse Nór, a bay with narrow entrance). ${ }^{3}$

Ôss (river-mouth: in northern place-names); Orm ("Orm's Head" = Serpent's head).

Raise (to elevate); Royd and Roothings (Norse Rjôj $=a$ clearing : in northern place-names: cf. German Riute, Reute); Root; Râ, Rô (= Corner : in northern place-names).

Set and Sæt-r (= summer grazing places : in northern placenames); Skagi (tongue of land: in northern place-names); Skôg-r (Wood: in northern place-names as Sko and Skov, the latter a Danish form) Skin; Scab; Skirt; Scrape; Skull; Sky; Score (a notch); Scum; Screech; Scrannel; Scraggy; Squatter; Squander; Squall (to cry); Stith (=Anvil) and

1 A.-Sax. Gafol = fork, is derived according to Torp (Wortschatz, 125), from Latino-Celtic Gabalus = Gallows.

${ }^{2}$ The A.-Sax. Hôh, pl. Hōas (= promontory), as in Clobes-hoas, Cloveshoh, may be cognate, but Sweet makes this to be the same word as Höh $=$ heel, which Torp (Wortschatz) traces to a different Teutonic stem. The Hill of Howth involves the Norse $H_{0 j} \gamma_{e}=\mathrm{a}$ high headland; an OHG. form appears in Donners haugk, and suggests that the Clob in Clobes-hoh may be mythological.

3 As "the Nore" in Kent seems the only instance of this term in Britain it is possibly a Jutish word (see p. 226). 
Stithy; Sly; Sleuth (hound); Snap; Snar (= quick: in Snargate [= the Shakespearian "next way"], which being in Kent may be Jutish); Spæ-woman (prophetess); Spike; Spill ; Sling; Swain; Sway.

Tarn; Teig-r (piece of meadow: with ablaut, A.-Sax. Tig, Tih: A.-Sax. Teag (= paddock, = Tey in place-names)) is traced by Torp to a different stem (see p. 2 I 7 ); Take; Wapentake; Thrive; Thrift; Trash.

Wand (a rod); Wath (a ford, in northern place-names: the English form is Wade (A.-Sax. Wæd) in Biggleswade, \&c.); Whin, Whirl. 


\section{IV}

\section{THE WARS OF ENGLISH AND NORSEMEN}

THE events ascribed by the Anglo-Saxon Chronicle and other authorities to the closing years of the eighth century are, for the purpose of this work, comparatively few. Under A.D. 788 we have the record in the Anglo-Saxon Chronicle of the meeting of a Synod at Pincanheal (in Simeon of Durham, according to the Surtees Society Editor, Winchanheal and Wincahala) and of the assembling of another at Aclea in the following year-a year under which the Chronicle notes the slaying of Elfwald, King of Northumbria, Simeon adding that this was "in a place called Scythles Cester, next the Wall ", and that he was buried in the

1 Pincanheal appears in one MS. of the Anglo-Saxon Chronicle as Wincanheal. The confusion between the Saxon $P$ and $W$ has often led to misreading of proper names, and we have no guide here as to the original form, except the assumption of Matthew of Paris (following R. de Wendover), written before 1269 (Rolls, Ed. i. 354), that the place was Finchale, near Durham, in his days a Benedictine Priory, founded about 1196 on the site of the hermitage of St. Goodric, who died about II 70 . From the lives of this saint (Capgrave, Nova Legenda Angliae, and Acta Sanctorum, May 2I) the place was fixed upon by St. Goodric because it was a primitive solitnde, a resort of wolves. It was not, therefore, likely that it would be selected for a Church Conncil some $37^{\circ}$ years before this hermit's time. There is, moreover, as far as I know, no instance of an initial $P$ becoming $F$ among the Teutonic peoples of Britain in historic times. A change of initial $W$ to $F$ is almost without precedent. An initial $T h$ in Early English, it is true, became often $F$; Thelbrig (i.e. plank or deal bridge) is now Felbrig; Thindon (1296) is now Finedon (Northants); Thenglesham (831) is now Fenglesham (Kent). The earliest form of Finchale seems to have been Fink-halh, which became later Fink-halgh, Fink-halugh (Priory of Finchale, Surtees Soc., p. xiii), where fink seems to be the AngloSaxon $f i n c=$ finch, the Anglo-Saxon halh representing, according to $\mathrm{H}$. Sweet, 
Church of St. Andrew, Hexham (Hehstealdes-ige). The death of Jaenbryht, Archbishop of Canterbury, is noted in the Chronicle

"a corner", " a hiding-place", but in its modern equivalent, "haugh" = low lands by a river. The final $h$ in halh is a guttural $=c h$. The latinized form is Halha, which appears in a charter of the exrly thirteenth century, as descriptive of thirteen acres "infra Halha" (= under the Haugh) between the rivers Wear and Gaunlesse (Feod. Prior. Dunelm. p. 7 note). This Halha seems to have been part of Bishop Auckland, of which the earliest form in the Durham Charters and in the "Boldon Book" is Alclet, probably for an earlier Halc-let or Halc-clet, that is Haugh-rock, so that neither "oak" nor "land" seems to enter into the name. For a parallel transformation of Nolt-clet to Noltland see Viking Mag., Jan., 1909. Halugh-ton, near Darlington, a similar componnd of Halc, is now Haughton. The form of the word in Scotch Charters (e. g. Kinloss) is Halech. This form seems to suggest that the word is Celtic, especially as a connexion between English hole and healh (Torp, Wortschatz) is not clear. The Breton place-name Linhalec $=$ salt-lake suggests the connexion. Finchale does not appear in "the Boldon Book" drawn up in 1183 . Simeon of Durham (who died about I1 30 ) gives the name of the place of the Council as Pincanheal and Pincahala, which his Editor (Surtees Soc., Simeon of Durham, i, pp. 22 and 29) has no hesitation in changing to Winchanheal and Wincahala respectively. Whichever form we assume, the locality of the Council is yet to seek. Haddan and Stubbs (Councils, iii, p. 444), after pointing out that Smith (Bede, H. E. iii. 27) identifies Pincahala and Finchale with Pægnalaech (in Anglo-Saxon translation of Bede Peginaleah), are inclined to the reading Wincanheale, and to connect it with Wincle in Cheshire, but this is Winchul in late twelfth century (B. M. Charters and Rolls) and possibly the Winescol of Domesday Book. For the possible modern form of Pægnalaech see the conjecture, p. 177. The element Pag assumed there seems to occur in other northern place-names, e.g. the Domesday Paghenale, later Panhale, and now Pannel, near Harrogate.

As the previous Council of Aclea (782) is not mentioned by Simeon of Durham, Haddan and Stubbs considered it to have been a southern gathering. They add, "In the Durham Ritual published by the Surtees Society there is a note written by a Provost Aldred, at 'Suðan Wudigan gæte (= ? Newdigate, Plummer, Anglo-Saxon Chronicle, ii. 78) æt A'clee on West Sæxum', in the tent of Elfsige the Bishop. The note is of the tenth century, but the place is probably the synodical place of encampment. It is not, however, further identified"; Haddan and Stubbs, Councils, iii. 439 note. The Synod of Aclea or Aclech of 788, Haddan and Stubbs, following Raine (Rich. of Hexham, Surtees Soc., p. 38), would identify with Aycliffe near Darlington, but $a c l e a=$ oak-wood (original meaning of leah), and there would be no temptation to change it. "Scythles cester next 
under 790, and also the appointment of his successor $Æ$ thelheard [Abbot of the Monastery of Hlud, according to one MS.] in the same year. Baldulf was consecrated (at Hearrahalch, says Simeon) Bishop for Hwitern (Whitehorn in Galloway) in 79r, according to the Chronicle, and in the same year, according to Simeon, two sons of Ælfwald were slain by Æthelred, King of Northumbria, at Wonwaldremer.' Under 792 the Chronicle states that Æthelbryht, King of East Anglia, was beheaded by order of Offa, King of Mercia, and that Osred, who had succeeded Elfwald as King of Northumbria (and had returned, according to Simeon, from exile in the Isle of Man (Eufania), whither he had been driven in 790), was slain (at Aynburg, according to Simeon) and buried at Tynemouth. Simeon of Durham, in recording the death (in 796) of Offa, refers to the the wall" (variants Scydescestre, Cithlescester and Scithles-ceastre) has been identified with Chesters, near Chollerton (in 1232 Chelreton, Cal. of Chart. Rolls, i. 1 7 I) on the Wall. Both Chollerton and Chollerford seem to contain the name of the Roman station Cilurnum (Not. Dign.) and to involve a possible early name (Chollern) of the North Tyne. If Scythles-cester be Cilurnum, it has nothing in common with that name, but it may mean and be a corruption of some other station near the wall, such as "Uxellodama", which follows, with one interval, Aesica ("Great Chesters") in the Ravenna Geographer.

'Hludense Monasterium: Haddan and Stubbs (Counc. iii. 468) are inclined, for reasons there given, to place this in Mercia, and to identify it with Louth (L.uda before $1166, B . M$. Charters, p. 487) or with Lydd or Luddesdown in Kent. Louth does not seem to be recorded in Domesday, and Lydd represents an early Lyde and Lide. Luddes-down appears to involve a personal name. The Domesday Lud-cerce (Lud Church) in Notts. is almost an exact equivalent, and was probably close to the modern Lowdham (Ludham in Domesday). It does not, however, appear in the Taxatio, but it answers the term more fully than any other conjecture. Simeon interprets Hearra-halch as "the Place of Lords". The AngloSaxon Hearra certainly meant "Lord", as in the Anglo-Saxon version of Genesis, and in Cadmon, and halch has been explained above. There appear in the Charters of Melrose (Monastic Annals of Teviotdale, 260) a Harehoch and a Harehouden (now Harden in Roxboroughshire), which may possibly contain the name. Mr. Plummer suggests Harraton in Durham. Aynburg has not been identified. Wonwaldremer is Winandermere, now Windermere. 
dyke built by him from sea to sea, that is, from the estuary of the Dee to that of the Severn.

The year 793 is noteworthy in the Chronicle for an attack on the Church of Holy Island (Lindisfarena é) made by the northern heathen pirates who harried Northumberland in the following year, but after despoiling Ecgferthes Minster at Donemuth, 1 were scattered by a storm, some of their ships being dashed to pieces, and the escaping crews killed by the English at the river mouth. Under 794, the Annals of Ulster (Rolls Series, p. 275) records the burning of Rechra ${ }^{2}$ and the pillaging of the Isle of Skye $(S k i)$ by the heathen pirates. The previous year they had devastated all the islands of Britain (ibid., p. 275), and in 797 Peel (Inis Patraicc), in the Isle of Man, and Ireland and Scotland $(A l b a)$ were ravaged by them. In 802 and 806 they devastated Iona (I Columbe Cille), and the head of that community removed to Kells in Ireland-the body of St. Columba being taken about the same time to Saul, ${ }^{3}$

1 Mr. Plummer says, "Yarrow is called 'Donemouth' as being the junction of the Done with the Tyne" (Anglo-Saxon Chronicle, ii. 64). "In Lindisfarena ée" means "in the island ( $\varepsilon$, a Northumbrian form, presumably, for $i g e$ ) of the people of Lindisfarne", as we see from Simeon of Durham. It was the custom of the pirates to attack the islands first. It is curious that in a letter to the clergy and nobles of Kent, dated 797, Alcuin warns them of the extreme danger threatening Britain by hitherto unheard-of ravages of pagan pirates, and of the need, therefore, of giving up their internal dissensions. He recommends them to study Gildas the wise, and to learn from him the causes why the Britons lost the rule of their country.

2 Rathlin Island off the coast of Antrim, or Lam-bay Island, both called in early times Rechriu for (?) Rech-eriu = standing before Erin, gen. of Eriu, cf. Welsh Rach-ynis = island off the coast (Strachan's Middle Welsh Grammar). Bec-eriu = little Ireland, was the early name of "Beggery Island" off the coast of Wexford (Martyrology of Oengus, Henry Bradshaw Soc., p. II8). The same name appears as that of a place belonging to Glastonbury in a Charter ascribed to $97 \mathrm{r}$ (Cart. Sax. iii. 574 ), see p. 205 .

3 The form of this name in The Book of Armagh (A.D. 807) is Saball, and is, as Pedersen has pointed out (Vergl. Gramm., p. 219), the earliest Irish instance of a borrowing from the Latin. The original was Stabulum. 
Co. Down, Ireland, where it was when The Book of Armagh was written in 807 . The attacks of the Norse pirates became more and more frequent, and they established themselves in forts at Dublin and elsewhere. The Danes seem to have appeared first in these raids, according to The Wars of the Gaedhill with the Gaill (Rolls Series, p. 19), about 850, although Mr. Skene (Celtic Scotland) wrongly calls the early invaders uniformly Danes.

Ethelred, King of Northumbria, was slain, according to Simeon of Durham, in 796 [795], at Cobre, ${ }^{1}$ and was succeeded by Osbald, who, obliged within a month to fly, took refuge with the King of the Picts. Eardwulf, having succeeded, was consecrated at St. Peter's, York, in 795, but his claims were questioned, and were only decided by a subsequent battle which was fought in 798, according to the Chronicle, at Hweallæge, in Northumberland, and, according to Simeon, at a place called by the English, Billingahoth, close to Walalege. ${ }^{2}$ Eanbald, Archbishop of York, died in 796 (in a monastery called Etclete, ${ }^{3}$ says Simeon), and was buried at York (Eoforwic). In the same year Ceolwulf, King of Mercia, made himself master of Kent and took thence King Eadbryht Præn prisoner to Mercia. One MS. of the Anglo-Saxon Chronicle relates the death, under 798 [?], at Sudberi (Sudbury, Suffolk) of Althun, Bishop of

The Celtic word for barn is in Irish Skibber, in Welsh Ysgubor, and a Breton form Skiber which seems to have found its way to the Continent. See the German forms in Diefenbach's Glossarium, a supplement to Ducange, where Skubor, Skiber, Sabal, and Sawl are given (under Acervus) as equivalents of Barn.

1 Cohre is regarded as a shortened form of Corbrigge $=$ Corbridge, already explained, but it may be for Cover-ham.

2 Hweallag and Simeon's Walalege have been identified with Whalley in Lancashire. The form in Domesday is Wallei, and the earliest documents of the Coucher Book of Whalley (fourteenth century) give Whalleye. Billingahoth does not occur in the latter, but Bilyngton does.

3 Etclete is so like the early form of Auckland (Alclet) that, in the absence of any other possible identification, it may be regarded as a misreading of that name. 
Dunwich, and of his burial at the latter place [(on) Domuce], and the same MS. records that the body of St. Wihtburg was found at Deorham (Dereham, Norfolk) in the same year, uncorrupted fifty-five years after her burial.

In the last year of the century (800) the Chronicle records the succession of Ecgbryht to the Kingdom of Wessex, adding that on the same day Æthelmund, an alderman from the Hwiccii, rode over Cynemæres ford (Kempsford, Glouc.) and was encountered by the men of Wilts (Wilscete) under their alderman, Weoxtan, and the latter were victorious, both leaders being slain. ${ }^{1}$ Simeon of Durham records in the same year the consecration of Eanbryth at Cettingaham to the bishopric of Hexham.

Under 80I, Simeon of Durham notes the death of a certain Abbot Edwin, "also called Eda," and his burial at Gegen-forda." In the Chronicle from 801 onwards the monotonous record of the succession of kings and bishops is only broken for some years by occasionally a more interesting event, such as, under $81_{3}$, the harrying of Devon and Cornwall (West Walas) from east to west by Ecgbryht, referred to above, or in 816 the burning of the English School at Rome. In 822 the Chronicle records another Synod held at Clofes-hoo (variant Clofes-ho), and under the next year we have an account of further fighting with the Welsh (Wala) and Devon men (Defna) at Gafulford," and of a battle in which Ecgbryht, King of Wessex, defeated at

1 This is the only mention of the Hwiccii in the Chronicle. Cynemæresford was in 1236 Kynemeresford (Cal. Chart. Rolls, i. 222), and in I54I Kamyseford (B.M. Charters). Cettingham is probably Cottingham, Yorks. (Domesday Cotingeham, compare Catingeuuic).

2 This is Gainford-on-Tees, see Simeon of Durham, Surtees Soc., i. 39 note; Gegen, Gegn, or Gean involves the idea of our again, and in composition means "duplicate". The Genlade of Bede, already explained, contains the same idea. Note how Edwin is shortened to Eda. This process has been previously referred to, and we have, as already stated, many instances of these shortened personal designations in place-names.

${ }^{3}$ Clofes-hoo has been previously dealt with. Gafulford is identified (Plummer's Anglo-Saxon Chronicle, Index, ii) with Galford, Devon, but see p. 141 . 
Ellendun ${ }^{1}$ Beornwulf, King of Mercia, with great slaughter. The same year witnessed the extension of Ecgbryht's power over Kent, Surrey, Sussex, Essex, and East Anglia : in 827 he overran all Mercia, together with the country south of the Humber, and led an army to Dore ${ }^{2}$ against the Northumbrians, who were obliged to submit to him. He was also, as the Chronicle says, the eighth Bretwalda (variant Bryten Wealda) since the origin of this title. In 828 Ecgbryht led also an army against the North Welsh (North Walas) and reduced them to obedience. The Annales Cambriae record, under 816 , an invasion by the Saxons of the district of Snowdon (Montes Ereri) and Roweynauc (Rhyfoniog, Denbigh), but this, like the invasion of the latter region (here called Rienuch) by Offa, rccorded in the same Annales under 795, must be ascribed to the Mercians, and not to Ecgbryht. The record in the same Annales, under 822, of the destruction of the citadel of Deganwy (Arx Deganhur) and of the conquest of Powis (Poywis) by the Saxons possibly refers to the campaign of Ecgbryht in 828 . The Scandinavian pirates appeared on the scene again in $83^{2}$, when they ravaged Sheppey in the Thames (Sceap-ige), and in the following year Ecgbryht fought against thirty-five ships' crews at Char-

1 The site of Ellendun is supposed (Plummer's Anglo-Saxon Chronicle, Index) to be Wroughton, Wilts. This is fully confirmed by the fact that Wroughton is still known in ecclesiastical registers as Ellingdon. A paper on this subject, written by Mr. T. S. Maskelyne, sent to me by Canon Codrington, D.D., of Chichester, traces the history of the mistake by which the place was identified by J. R. Green (in his Hist. of the Eng. People, p. 45) with Wilton. Sir R.C. Hoare was the first to identify the site with Wroughton (Keg. Wiltun., pp. 54, 55), which name, he says, was added to Elyngdon.

2 Dore (Derhyshire), south-west of Sheffield, still retains the name, which it bore also in time of Domesday. It is mentioned also in the Chronicle under 942. Mr. Plummer would make it an English word (= door) meaning a mountain pass, but it looks more like the cognate Celtic Dor-um, encountered in many place-names with seemingly the same meaning. It may, however, be a river name. The Bdora of Ravennas seems to be in a sequence with places conjectured to be in Derbyshire, see p. II 7 . 
mouth (at Carrum), but after much slaughter the Danes (Deniscan) held the field. In the following year (835) a large fleet of the pirates, having put into Cornwall, joined forces with the West Welsh (West Walas) and made successful raids into Wessex, of which Ecgbryht having heard, he led an army against them and put to flight both the Cornish (Walas) and Danes (Deniscan) at Hengestdun. ${ }^{1} \quad$ After a glorious reign of thirty-seven years he died in $83^{6}$.

The year 837 witnessed, according to the Chronicle, two fights with the Danes, one at Southampton (Hamtun), in which the Wessex alderman Wulfheard gained a victory over thirtythree ships' crews of Danes, and the other at Portland (Port), ${ }^{2}$ where $\notin$ thelhelm, the leader, and the Dorset men were defeated by the Danes, and Athelhelm slain. In the following year $\left(83^{8}\right)$ the Scandinavian pirates inflicted a defeat on Herebryht, alderman, in the region of the Marsh-dwellers (Merscware), that is of Romney Marsh, and slew many in Lindsay (Lindesse), East Anglia, and Canterbury.

From the middle of the ninth century onwards the attacks of the Scandinavian pirates on the British Isles became more frequent. The year $8_{5} \mathrm{I}$ is distinguished by a victory obtained over them at Wicganbeorg by the men of Devon under Ceorl the Alderman, and also by the slaying of a great number of them and the capture of nine of their ships in a sea-fight at Sandwich $\left(\right.$ Sondwic) ${ }^{3}$ in Kent, by King Ethelstan-under-

${ }^{1}$ Hengest-dun is Hingston Down, Cornwall. Hengst (= stallion, horse generally, but possibly also a personal name) enters into several placenames, e. g. Hingston, Cambridge, and Henstridge, Somerset.

2 Port is used for what is elsewhere in the Chronicle (982) called Portland.

${ }^{3}$ The Scandinavian invaders are generally designated simply as "Heathen" in the Anglo-Saxon Chronicle. This word in one form or another is common to all the Teutonic dialects. Its assumed connexion with Heath in the signification of "men of the heather" is not at all convincing. Professor Kluge would be inclined to look upon the word (Etym. Dict. sub voce), of which a form appears in the Gothic translation of the Scriptures (Haithnó-a feminine noun sing.), as being adopted like "Church" 
king of Kent-and the Alderman Ealchere. The heathen invaders, the Chronicle adds, remained in Thanet this year for the whole winter, a thing they had not done before. The year $85 \mathrm{I}$ did not pass away without reverses elsewhere. Three hundred and fifty of the invaders' ships having entered the Thames,

and "Pfaffe" (the Papa previously referred to) in some way from the Greek. It would seem, therefore, that Dr. Vigfusson's suggestion (Icelandic Dict. sub voce) may be correct that it is adapted from the Greek td éthne, the word in the New Testament for gentiles, see also New Eng. Dict. The Anglo-Saxon Chronicle sometimes specifies them as Danes (Deniscan). In the Irish Annals the Norwegians are called either Fair Gentiles (Find Geinti) or Lochlanns (Lochlannach, i. e. men from the lake or fiord-land). The latter term is preserved in the surnames of McLoughlin and McLachlan. The Irish called the Danes Danar or Dub-geinti (Black Gentiles) or Dubgaill (black foreigners), which still exists in the surnames McDougal or McDugald, McDowall = "son of the Dane" and Doyle. As to Wicganbeorg (=Wicga's hill or tumulus), Mr. Stevenson (Asser's Life of Alfred, p. 175) rightly dismisses the identification with Wembury or with Weekborough, both in Devon. He suggests Wigborough, Somerset, which Mr. Eyton identified with the Wincheberie of Domesday and Winchin-beria of the Exon. Domesday. Bnt it is not probable that the beria termination in Domesday represents $B$ eorg $=$ hill, which appears to be represented apparently therein by berga, representing an oblique case. Beria seems uniformly to represent the dative of Burh $=$ Byrig.

The termination bere or bera in the Exon. Domesday seems to represent the Anglo-Saxon bearu, dative bearwe, = wood, as in Ac beara, Collabera, Eattebera, Lochesbera, Hundesbere, Laurocabera (now Larkbear). It occurs also alone as in "Bere Forest".

In Exon. Domesday, Beorg, dative Beorge, appears seemingly as berga, as in Albretes-berga, Lange berga, \&c., and takes in modern times the form borough. Burh, dative byrig, is represented in Chentis-beria (now Kentisbury), Cungres-beria (now Congresbury), \&c. In these circumstances Winchin-beria cannot well represent Wicganbeorg, which remains thas unidentified.

Sandwich (Sondwic and Sandwic) involves wic in the sense of "bay", and is, therefore, probably Scandinavian $(=V i k)$, although, as we have seen (p. 2 Io), the term Wicing occurs before the arrival of the Norsemen, and the Wic may be English. It was the chief haven on the sonth coast for the assembling of the Danish fleets. It is mentioned in the Sagas (Corpus Poticum Boreale, ii, 262). Sand-vik (sand-bay) is a common place-name in Iceland and Norway. 
the crews took Canterbury (Cantwaraburg) and London (Lundenburg) by storm, and put to flight the King of Mercia (Beorhtwulf) and his army.

Passing over the Thames into Surrey, the invaders were encountered at Ockley (Aclea) by King Athelwulf, and his son Æthelbald, together with the Wessex host, who, after slaughtering an unheard-of number of the heathen, gained the day.

In one of the MSS. of the Anglo-Saxon Chronicle drawn up at Medeshamstede, that is, Peterborough, we have, under $85^{2}$, some local details with regard to the endowment of that monastery. On condition of his assigning Sleaford (Sliowaford) in Lincoln, to Medeshamstede, and paying certain rents in kind, the monks let to Wulfred the land of Sempringham (Sempingaham) for his lifetime. The Charter dealing with this arrangement is in existence. ${ }^{1}$

Under 853 the Anglo-Saxon Chronicle records that the Mercians assisted by the King of Wessex attacked the North Welsh (North Walas) and reduced them to obedience. The Chronicle goes on to state that the men of Kent, under Ealhere (probably the Ealchere referred to above), and the men of Surrey, under Huda, fought in the same year with the heathen

1 This Charter is in possession of the Society of Antiquaries, and is printed in Cart. Sax. (vol. ii, p. 57). Sempingham (which lies to the south of Sleaford) seems to be the correct form. The name occurs also in the Domesday Survey of Norfolk in the hundred of Diss (Dice). It is now Shimpling there. Sempinga is seemingly a genitive plural of a patronymic. Sliowa ford contains apparently a river-name. Compounds with involve generally (1) a personal name in the genitive; or (2) the nature of the river at the point (as Stan-ford, Mud-ford, Sand-ford, \&c.); or (3) the aninials, \&c., which may cross, as Horse-ford, Shef-ford (Sheep), Oxen-ford, Wain-ford (Wagon); (4) the kind of river, and sometimes its name; (5) the aids to steady crossing as Staf-ford, that is, with a guiding rail: Bam-ford (that is, Beam = tree laid across): Trefford (Tree, Treow-ford). "Sliowa-ford" comes under (4), and the brook is there still known as the "Slea", for probably Sleow-ea = Tench-river : compare Trout-beck, a frequent brook name. 
pirates in Thanet (Tenet), but after an initial success were worsted with the loss of both their leaders.

In the year 854 the heathen men remained again, the Chronicle states, over winter, taking up their quarters in Sheppey (Sceap-ige, that is, Sheep-island).

Æthelbald, who had succeeded his father Æthelwulf as King of Wessex, died in 860, and was buried at Sherborne (at Sciraburnan). Ethelbyrht, his brother, now became King of Wessex and Kent, and in his days the heathen men came with a large fleet and stormed Winchester (Wintan Ceastre), ${ }^{1}$ but the Hampshire and Berkshire men put them to flight and held the battlefield.

Under 861 in the Anglo-Saxon Chronicle the record occurs of the death of St. Swithun, Bishop (of Winchester), whose name is not mentioned anywhere else in the Chronicle.

In 865 the men of Kent tried to buy off the heathen army in Thanet, but the latter stole away in the night and ravaged all the east of Kent. Next year a great fleet of pirates arrived, and took up their winter quarters among the East Angles (on East Englum) providing themselves, says the Chronicle, with horses. The East Angles made peace with this army.

Having crossed the Humber in the following year to York (to Eoforwic Ceastre) the heathen army was attacked there by the Northumbrians, ${ }^{2}$ who stormed the town, but were at last defeated with great slaughter and had to make peace with the enemy. The Welsh Annals (Annales Cambriae under 866) refer

1 Scira-burna =Clear brook. Wintan-ceastre (Winchester) is based on the ancient Romano-British name Venta-Belgarum, or the Venta of the Belgae, who, according to Caesar, were Continental Celts. The meaning of Venta has been already dealt with, p. 32 .

2 The Angles attracted Eburacum as I have already said (p. 37) into a familiar compound Eofor-wic, that is, "Boar-lair or shed." This was, like all the adaptations from the Romano-British nomenclature, a great leap, and it took place at the very outset of the occupation. It may be said, indeed, that all the startling changes in place-names took place shortly after the Teutonic settlement. The forms afterwards were fairly well preserved. 
to this battle at York (Urbs Ebrauc) noting that it was devastated by the Danes (Dub gint = black gentiles).

The heathen army moved the next year into Mercia, to Nottingham (Snottingaham ${ }^{1}$ ). The Mercians and the men of Wessex tried to dislodge them, but failed, and had to come to terms with them.

The heathen went again to York in 869 , where they remained a year. In the following year (870), having passed through Mercia to the East Angles, they took up their winter quarters at Thetford (at Theodforda $a^{2}$ ). Here King Edmund fought against them but was defeated and slain, and the Danes (Deniscan) proceeded to subdue the whole country, and to destroy the minsters. The rich abbey of Medeshamstede was reduced by them "to nothing" on the occasion.

Some additional details upon the invaders who arrived in East Anglia in $\mathbf{8 6}_{5}$ are given in the Chronicle of Melrose, a twelfth-century MS. The leaders are there called Iwar (Ivar)

${ }^{1}$ Snottinga-ham is said in Asser's Life of Alfred to have been called by the British Tig guocobauc, which Asser, who, as a Welshman of St. David's, knew Welsh, says means "Honse of Caves" (rather "Cavy-house"), for guocob-auc is an adjective derived from Guocob=cave, modern Guocof. Guocob and Guocov occur in the Book of Landaff.-Wookey and Wookey Hole near Wells, and the early forms are not against the supposition, seem to represent the British word. Compare Vooga (Williams' Cornish Dictionary) which Norden makes Googoo, that is Guocof. Cf. Fogo in the Brythonic districts of Scotland. The Tig is the early British form for honse, modern $T y$. Any one who has seen the caves at Nottingham cut out of the sandstone rock will admit the appropriateness of the name. Snottingham has nothing to do with caves, but is probably, as Mr. Stevenson says, derived from the patronymic Snottinga, descendants or family of a certain Snuot or Snot. Snottar is Anglo-Saxon for Wise, and may be a form of the word. A similar compound exists in Norse names. Another instance of Asser's knowledge of British Place-names is his British equivalent of Thanet = Ruim. This would seem to indicate an acquaintance with Nennius, where this name is also found. See p. 127.

2 Theod-ford made up of Theod=" people", "pnblic" and ford, that is, it was on a public highway. There are several places of this name and similar compounds occur among the Scandinavians, e.g. Theor-braut = Highroad. 
and Hubba, who directed the campaign in Nottingham and York and were in command when King Edmund was slain in East Anglia. In the F. MS. of the Anglo-Saxon Chronicle they are called Ingware and Ubba. The heathen army when it advanced to Reading was, the Melrose Chronicle states, under the leadership of Bagsecg and Halfdene, Ivar having presumably died (Wars of Gadhill and Gaill, p. 270). In the series of battles fought in this part of Wessex, Bægsecg (Bægscecg in Asser) was killed, and Halfdene then proceeded with part of his host into Northumbria, whence (according to the Anglo-Saxon Chronicle under 875) he harried the Picts and Strath-Clyde Britons. Strath-Clyde had been ravaged by Norsemen ("Lochlanns" according to Fragments of Irish Annals, p. 192) a few years before 870, and Alt Clyde (Alt Clut in Welsh Annals = Dumbarton, properly Ail-cluathe, genitive Ailech Cluathe $=$ the rock of Clyde) taken by siege. The year before these Norsemen (according to Fragments of Irish Annals) had ravaged Fortrenn and made the people tributary. ${ }^{1}$

1 The various spellings of Ivarr in the Anglo-Saxon and Celtic annals (Imhar in Irish) are doubtless owing to the early form of this Teutonic name, viz. Ingo-mar. In the Flatey Jarbok, iii. 507, it appears as Ingvar, but generally in Norse as Ivarr, in which form it has passed into the Scotch personal name MacIver (or McKeever)=Ivarson and Iveson, and the Welsh Ivor. The celebrated Archbishop of Reims, Hincmar, bore the same name. The Ingo is obscure, but Förstemann wonld connect it with jung (young) and also identify it with the suffix -ing in Teutonic personal names, e.g. Harding, Heming, Helding, \&cc. Hubba is a name unknown to the Sagas. It is probably a nickname. A similar form Húfa is used as such, meaning "with a helm", and Hubo, a Teutonic name, is made cognate by Förstemann. Brgsecg is evidently, from the variants, a corrupt form. It may be an ekename of which the second element is probably, from the form in Asser, Skegg = beard, as in Kolskegg = Black beard. It could hardly represent Berserkr, which was also used (Iceland. Dict. sub voce) as a nickname = "Bear-coat." Half-dene has been already explained. In the Irish Annals it is Alb-dan.

Ethelwerd's Chronicle states that King Edmund was buried at Beadorices Uurthe, that is, "Beadn-richs farm," the old name of St. Edmundsbury. Beadu-rich (= battle-king) was a common Saxon name and gave origin both to Battersea and Petersham, which in Domesday Survey are "Patri- 
In $87 \mathrm{I}$ the heathen army came to Reading (to Readingum), but they were defeated at Engle-field (on Engla-felda ${ }^{1}$ ). Three days after this, King Æthered, and Ælfred his brother (the future celebrated King Alfred), led an army to Reading against the heathen men, but after great slaughter on both sides the Danes held their ground. About four days later, King Ethered and Elfred fought another battle with the foe at $Æ s c e s d u n e,{ }^{2}$ and cesy" and "Patricesham" respectively. In the original Westminster Charter of 693 (Cart. Sax. i. 116) the former is Batricesege. In 1067 (Brit. Museum Chart. and Rolls: Copy) the former is Batriceseie or Patriceseia, and the latter is in 1266 (Merton Cart.) Petrichesham. It is clear we have to do in both cases with a Saxon magnate called "Beadurich" and not with "St. Peter", who is wrongly assumed by some to be the Petrich in Petrichesham. Initial $\mathrm{P}$ is not an uncommon mutation of $\mathrm{B}$ in English.

As to the Scandinavian raid upon the Picts and Strath-Clyde Britons, it is clear that the aggressors here were Danes, but the siege of Ail-Cluathe ( 870 in the Annales Cambriae) was by Lochlanns, who had also in 865 or 869 invaded Fortrenn under Amlaiph (that is, Amhlaif, pronounced Awlaif $=$ Olaf) and Avisle (Ann. Ult. i, p. $374=$ Háisl) aided by the Scandinavians of Ireland and Scotland, and had plundered all Pictland. These were not Danes, as Dr. Todd (Wars of Gaedhill and Gaill, lxxix) made them out to be, but, according to Fragments of Annals, p. 159, Norsemen. Fortrenn has been dealt with before. It was the Pictish district proper, and contained Dunkeld and Scone. The similarity of the word to Fortren (=mighty, Felire of Oengus, Jan. $3^{1}$ ) probably led to its being considered in the Irish version of Nennius as the eponymus founder of the district.

1 Engla-felda is probably rightly explained by Asser as the "Camp of the English". Readingum is the locative plural of a patronymic, nominative plural Redingas. The Basengum mentioned lower down is of the same nature. Meretune is probably Marten, Wilts., which is "Mertone" in Domesday, and "Meretone" (in Hundred of Kinwarestan) in 1227. Winburna is most probably, as was previously stated, a hybrid word involving the British Winn=white and the English burna.

2 Escesdun is not, as Mr. Stevenson has rightly shown, composed of $A s h$-tree and Down (as Asser states), but involves a personal name $A s c$ in the genitive case, AEsces, contracted from some such original as AEscrvine. The name still exists in Ashdown Park in the manor of Ash-bury (that is, Ascesburh) at the west end of the Berkshire Downs. A Charter ascribed to about 931 (Cart. Sax. ii. 376) gives as a boundary AEscas byries Sulgeate, that is, the south entrance to Ascesbury. Mr. Stevenson (Asser's Life of Alfred, p. 238), though tempted to connect the Nachededorne 
after great slaughter put them to flight. About a fortnight later, however, Æthered and Ælfred were defeated at Basing (at Basengum) and again after a hard fight at Meretune, where the Danes (Deniscan) possessed the battlefield. After this battle there arrived a great body of pirates (Sumor lida $=$ Summer army), and in the same year King Æthered died,- and was buried at Wimborne (at Winburnan), his brother Elfred succeeding to the crown.

Alfred became king, as we saw, in $87 \mathrm{r}$, and all the manuscripts of the Anglo-Saxon Chronicle agree in giving $90 \mathrm{r}$ as the year of his death. His reign of some thirty years was as eventful, perhaps, as that of any English Sovereign, and in his strenuous career during this stormy period he well earned the distinction of "The Great" which posterity conferred upon him.

The record of Elfred's deeds is preserved for the most part in the Anglo-Saxon Chronicle, and in his life by Asser, which supplements the account in the Chronicle by some important particulars. Elfred's biographer was a Welsh Bishop, who says, in his own words (Cap. 79), that "he was brought up, educated, tonsured (as monk), and finally ordained in the holy places of the extreme west of Britain (St. David's)". His learning seems to have given him a certain fame, and he was invited by Ælfred to pay him a visit. Asser relates how he came to the royal vill at Dene ${ }^{1}$ in Sussex, where he saw the King for the first time. The King's efforts to secure Asser's services in his literary labours were not at first attended with success. Asser was unwilling to leave his country and his people without consultation with them, but promised to let the King know his decision. On his way back he fell ill of a fever, and lay ill for (= "barethorne" Hundred, which contained an "Assedone") of Domesday with the anica spinosa arbor of Asser, will not associate this Assedone with the Escesdun of the battle.

1 This is donbtless the Dene mentioned in Elfred's will, and is represented, as Mr. Stevenson suggests, by east and west Dean, near Eastbourne. It is in the dative or locative of the Anglo-Sax. Denu, a dell. 
over a year at a place he calls Wintonia. ${ }^{1}$ Letters from the King finally induced him to agree to his request, a thing he was the more content to do because, as he says, the King's authority had at this time, and long before, extended to all the south part of Britain: "Himeid, for instance, with all the inhabitants of the Demetic region, had submitted to Ælfred. So also had Houil (Higuel, that is modern Howel), son of Ris, King of Gleguising, and Brochmail and Fernmail, sons of Mouric, kings of Guent. Elised, son of Teudubr, King of Brecheniauc, had also submitted to the King. Some of these had been driven, as Asser tells us, by the exactions of Rodri the Great [King of Gweneth $=$ North Wales], and others by the tyranny of the "Aldorman" Eadred (that is Ethelred), and of the Mercians to seek Ælfred's protection. ${ }^{2}$ Asser was honourably received by

1 It is clear this could not be Winchester, Venta Belgarum, and it is probable, therefore, that it was the Venta Silurum, now Caer Went, which was on the Roman Road to the West, and is styled Guentonia by Welshmen in the tenth century when writing Latin. See Liber Landavensis, RhŷsEvans, p. 220.

${ }^{2}$ Himeid's death is recorded in the Annales Cambriae under 892. He was King of Dyfed (Demetia). Maes-yvet (Maes Hyveidd of the Myvyr. Arch.), the Welsh name of Old Radnor before, and in the sixteenth century, possibly preserves his name. Rotri (Rodri), King of North Mid Wales and Cardigan, was slain by the Saxons, according to the Annales Cambriae, in 876 , and Howel's death is placed by the same authority under $885(894$ in the Brut). For Gleguissig (Gleguising) see p. 138. A Fernmail, son of Teudubir, is mentioned by Nennius as the King then reigning (785-8I , according to Zimmer, Nennius Vindicatus, p. $7 \mathrm{I}$ ) in the two regions Buelt and Guortigirniaun. Buelt is now Builth, and embraced that part of Powis lying between the Wye and the Severn; and the lordship of Gwrthrenion (Gzorthernion: Myrv. Arch., Warthrenion, Gerald. Camb. Itin. c. I) in Radnorshire, preserves seemingly Guor-tigirn-iaun, which stands to Guortigern (Vor-tigern =over-lord) as Cereticiaun (Cardigan) does to Ceretic. The Brochmail and Fernmail of the text are seemingly of later date, but the latter was probably King of the Builth region. Brochmail and Fernmail witness a charter in the time of Nud, Bishop of Llandaff (ninth century), Lib. Land, p. 226. A Teudur, son of the Elised referred to on the pillar at Abbey Crucis (see p. 55), is mentioned under 927-9 as King of Brecknock, Lib. Land., p. 237. 
King Elfred at his royal vill of Leonaford, ${ }^{1}$ and we learn from Ælfred's preface to his translation of Gregory's Pastoral Care how he valued Asser's help. The King rewarded him first by granting him the monasteries of Cungresbyri and Banuwille, ${ }^{2}$ and afterwards by the gift of Exanceastre, including the whole diocese (Parochia), which embraced also Cornwall (Cornubia). As the See of Exeter was not yet formed, it is clear that this was an earlier ecclesiastical division of which Sherborne was the Bishop's Stool, for the Annals of St. Neots records his death as Bishop of Sherborne in 909.

Of Asser's Life of Alfred only one manuscript was in existence in the sixteenth century, and this was unfortunately destroyed in the fire at the Cottonian Library in $\mathbf{r} 73 \mathbf{r}$. Prior to this, however, several copies had luckily been made, upon one or other of which the existing printed editions are based. It seems clear from the opinions of experts ${ }^{3}$ who had seen the original MS. that it was written in two or more hands about A. D. 1000. The author seems to have completed his biography in 893 (Cap. 91. 4), when Elfred was forty-five years old. Anything subsequent to this is, therefore, from another hand. Mr. Stevenson's introduction to the latest printed edition of the work (Oxford, 1904) is a marvel of painstaking research, and from this and his numerous valuable notes to the text the reader cannot but arrive at the conviction that Asser's Life of Elfred is a trustworthy historical document. The Annals of St. Neots, which was formerly associated with Asser's Life of Elfred, and

1 Mr. Stevenson conjectures this may be Landford, Wilts.

2 Now Congresbury (Thonne resteth $S$. Congarus on Congresbyrigsee Tha Halgan on Angelcynne, Liebermann, Hanover, 1889) and Banwell (probably from Bēnawille $=$ Prayer-well). Cf. Bonus and Bedhus previously explained. In a "History of the Bishoprick of Somerset till I174" (Camden Society, 1840), Congresburia is made the earliest seat of the Bishop, and Bishop Daniel is there said to have removed it to "Cideston" [Tideston], that is, Wells.

3 Among others by Humphrey Wanley, an early Secretary of S.P.C.K., and afterwards Secretary of the Society of Antiquaries. 
was so called from its having been discovered by Leland at St. Neots in Huntingdonshire, is regarded by Mr. Stevenson as a Post-Conquest compilation, made up chiefly from the AngloSaxon Chronicle and Asser's Life. Its topographical additions will be noted in their proper place.

Within a month of Elfred's accession he had a conflict with the whole army of the Danes at Wilton (Wiltun), and having with his small force seemingly put them to flight, a ruse on the enemy's part, he lost the battle. Asser adds a topographical detail that Wilton was on a hill on the south side of the river Guilou. ${ }^{1}$ The Chronicle and Asser agree in stating that Elfred fought in the same year eight pitched battles with the Danes in the region south of the Thames (Themese), and was day and night on the move owing to incessant attacks of the enemy. A peace was patched up at the end.

In 872, the Chronicle tells us, the Danes withdrew from Reading (Readingum) to. London (Lunden byrig) and remained the winter there, the Mercians making peace with them, which they also did in the following year when the Danes removed to Northumbria (on Northhymbre) and settled for the winter at Torksey (Turicesiege) in Lindsey (on Lindesse). Next year (874), the Danes having made their winter settlement at Repton (Hreopedune), drove King Burgræd over the sea, putting a thane, a creature of their own, in his place.

In 875 part of the Danish army (under Healfdan) went from Repton to the River Tyne, and harried the country, extending their attacks to the Picts (Peohtas) and Strath-Clyde Welsh (Stracled Walas). Three of their leaders (Godrum, Oscytel, and Anwynd) removed from Repton to Cambridge (Grante brycge $)^{2}$ and settled there for one year. In the same year

1 This is presumably the British form of the river Wiley which gives its name to Wil-tun and Wiltunscir, whence Wiltescir, modern Wiltshire. A similar form of river name occurs in Wales, as in the Camguili ( $=$ "winding-Guili") and in Aber-guilly in Carmarthenshire. Welsh $g u=w$.

${ }^{2}$ For the various stages of transition between Granta-brycg and Cam- 
Elfred, having had a naval engagement with the enemy, took one of their ships and put the others to flight. The Danes, having left Cambridge in the following year, proceeded to the Castle of Wareham (Werham), where was a monastery (Asser adds) situated in a most safely protected place between the rivers Frome (Frauu) and Terente [= Trent] in the district (paga) which is called in British Durngueis (Mr. Stevenson reads Durngueir) but in Saxon Thornsata. ${ }^{1}$ Proceeding from hence bridge see Professor Skeat's masterly paper on the subject. The Cam was originally called, it would seem, Granta, which also probably gave its name to Cair Granth (wrongly written Grauth in Nennius's List of Civitates Britanniae) now Grant Chester. The Camborico of the Itinerary, although near, has nothing seemingly to do with Cambridge.

1 Mr. H. Bradley, whom Mr. Stevenson follows, sees in Fraun an evolution of a supposed earlier Främa, of which the river From (given in the Anglo-Saxon Chronicle under 998) preserves the form, a form that would have developed naturally in British lips to Frauv, and later to Fraw, as in Aberffraw. This wonld mean that the Saxons had occupied this district before the British change of $m$ to $v$ had become operative (but see Pedersen, V. Gramm. \$99. I, for a possible instance of an aspirated $m$ in the middle syllable in Ganlish). A similar early occupancy is implied, therefore, wherever we find in Britain a river called Frōme, that is, in Somerset, Gloucester, Hereford, \&ce. As to the reading Durngueir, which Mr. Stevenson assumes to be that of the original MS., it is considered to be a natural development of the name of Dorchester in Roman times, Durno-varia, gueir representing varia according to Welsh phonology. But the British dialect in South Britain was not what we know as Welsh. Moreover, Thornsata (or better Dornsata) is not given by Asser as the equivalent of Dorchester, but of the district (paga) now Dor-set, an almost exact representative of the Durotriges (cf. Allo-triges and Allo-briges) of Ptolemy (see p. 55). A possible derivation of Durnovaria raises a further difficulty. Durn-o can be explained here (as it has been by Dr. Whitley Stokes in the personal name Durnacos) as "fist" (Irish Dorn, Welsh Dwrn), and Varia, as "plays", "theatre". Seeing that there is no evidence of a native stronghold at Dorchester, it was probably founded by the Romans. The amphitheatre they constructed there would furnish to the natives a significant name for the place, and in British would possibly be represented by "Fist-plays" (Dourna in Breton is to fight with the fists). The Cornish word for a theatrical play was Gware, a seeming direct descendant of Varia. Cf. plain an Guare in Cornwall. "The Guare Miracle, in English, a Miracle play.... For representing it they raise an earthen Amphitheatre in some open field," 
to Exeter (Exanceastre-Asser, Cairuisc) ${ }^{1}$ the Danes lost 120 of their ships in a gale off Swanage (at Swanawic, a Norse name = Swain's bay). The mounted army proceeded to Exeter. Ælfred strove to outride them, but although he failed to prevent their getting into this stronghold, yet he compelled them to give him hostages and make peace. The Danes then withdrew to Mercia.

Asser, under the year 878 , relates that the pagan army having left Exeter (Eaxeancestre) came to the royal vill of Chippenham (Cippanham), situated on the east bank of the stream "called in British Abon" (Avon), ${ }^{2}$ where they wintered, having driven

Carew's Survey of Cornwall, 1769, p. 7 I. Cf. the Welsh Guare miragl of the Yolo MSS., p. 86. The Argento-varia (now ? Horburg) near Argentoratum (Strassburg) was probably so called from an amphitheatre. The Anglo-Saxon forms of Dorchester, Dorn-wara Ceaster and Dorn-zvarana Ceaster, seem to preserve guare, and not the genitive plural of wer $=$ wara, men or warena.

${ }^{1} \mathrm{Mr}$. Stevenson regards the uisc in Cair- (=castra) uisc as indicating a Welsh development of Isca or (Esca) later than the time of the Saxon occupations of Exeter (Escanceaster), and that Asser heard the name from the natives of Devon or gave it a Welsh form. The latter is probable. Asser seems to show in one or two places an acquaintance with Nennius, in whose list of Civitates occurs Cair Legeion Guar Usic [Uisc], which the Irish version places at $O$ per-uisc (Aber-uisc). This is now Caerleon. The form uisc is possibly, therefore, Welsh as well as Irish, and, perhaps, an oblique case. Caer Esca occurs in the Welsh Triads as presumably the early name of Exeter.

${ }^{2}$ Cippanham (Chippenham) seems made up of Ciepa (gen. Cicpan) $=$ "trader", and hamm, "meadow." The double $p$ in Cippa suggests, however, a personal name. "The ham at Cippan-hamme" is a legacy in Flfred's will (Cart. Sax. ii. I 78). There seems to have been no Roman road nearer to Chippenham than the Fosse Way by which the pagan army could proceed direct to Cirencester. Asser calls Cirencester Cair Ceri in British. This is another instance of dependency on the Historia of Nennius, where Cair Ceri occurs among the Civitates Britanniae, most of the names of which seem to belong to Wales and the North. The identification is not supported by its ancient designation Korinnion, Ptolemy: Cironium Dobunorum, Ravennas. The Commot of Ceri and the Castle of Cruk-ceri (Crukeri) in Radnorshire possibly preserve the Caer Ceri of Nennius. The form Abon, given by Asser, is almost the same as the Abona of the Ravenna Geographer, about which Sir J. Rhŷs finds a difficulty. 
many of the inhabitants of the region over sea and compelled the rest to submission. But Ællfred with a small host betook himself to the protection of woods and moors, where he maintained his independence with much privation and trouble. In the winter of the same year the brother of Ingwar (InwarAsser) and Healfdan sailed from South Wales (Demetic region), where he had wintered, with twenty-three ships and came to Devon (Domnonia). Here, before the king's stronghold of Cynuit, ${ }^{1}$ which was well protected on every side but the east, Elfred's men, by an unexpected sally at daybreak, gained a complete victory over the pagans, killing their king and over 800 of his men.

In the Eastertide of 879 Alfred and his little host threw up a fortification at Æthelingaeg ${ }^{2}$ (Aethelinga-eigge in the Chronicle $=$ Athelney at the junction of the Tone and Parret).

From this fortress as a centre "Ælfred, with the vassals of Somerset ", Asser says (but the Chronicle gives, "of the part that was nighest of the Sumursæte", Sumurscelna gen. plur.), made frequent successful raids against the pagan army in that region. At length, in the seventh week after Easter, he rode forth to Ecgbryhtes-stan ${ }^{3}$ to the east of Selwood (Seal-zeyda, Chron.:

1 Cynuit. No word has suffered more than this at the hand of guessers. It has been made into the Domesday Comich, now Combwich: and even into Cannington (Candetona in Domesday). It has also been identified with an ancient fortification in the parish of Abbotsham near Bideford, for which the name Kenwith Castle has been assumed. Nothing is known of the place, which was clearly in Devon. The efforts made to fix the site in Somerset (and to include the latter in Devon) are based upon the unsupported opinion that the fleet from Demetia came to co-operate with the pagan army at Chippenham. "Arx Cynuit" would probably be represented in Devon by Dun-cynuit. Domesday gives a Donecheniu (Domnechenif in Exon. D. day) in Cornwall.

2 Ethelinga-eg means not "the island of nobles", but the island of the descendants of some one whose full name was some such form as Ethelbeorht, or Æthel-ræd.

3 The place-names involved in this enterprise of Elfred have been the subject of many conjectures. As to Ecgbrihtes-stan, Mr. Stevenson (Asser's Life of Alfred, p. 268) shows clearly that Brixton Deverill is not the place. 
"Seluudu, that is, Sylva-magna in Latin, Coit maur in British speech," Asser), where he met ["all", Asser] the inhabitants of Sumurtun shire [paga], of Wiltun shire, and of Hamtun shire, all those who had not voyaged beyond sea for fear of the pagans. Alfred's host remained one day in camp here, and starting at daybreak came on to Ecglea [Iglea and AEglea, in the Chronicle] where they camped for the night. On the

All we know is that it was east of Selwood, but the extent of that forest in the ninth century we have no means of ascertaining. In the list of Cities attached to Nennius a Cair Pensa vel Coyt occurs (the reading of the Harleian MS. of the eleventh century : the Vatican MS. of the eleventh century has Pensa vel Coin) which has been identified by Mr. Kerslake with Penselwood (Pen-savel-wood), but no light is forthcoming on Savel. In the fourteenthcentury MS. of the Welsh version of Geoffrey of Monmouth (Red Book of Hergest : Rhŷs-Evans, ii, p. 97) a Pen-hwyl-koet occurs, which is there said to be the name of Exeter. In an earlier MS. this identification does not occur. It is a pity, therefore, that Mr. G. Evans should have reprinted this MS. without the readings of the Dingestow and other earlier MSS. Pen-hwyl-koet was identified by Mr. Kerslake with Pen-savel-coit. It seems probable that it was intended to translate Pen selwood, since hwyl and its cognate Irish form Sebl represent $S e ́ l$ (contracted from Segel=Anglo-Saxon for the modern "sail"). Initial $h$ is not organic in British speech, but represents an $s$ (cf. Hafren and Sabrin-a), and wy is the representativc of the older long $e$. Thus the British scribe in translating Sel-zvood treated it as Sail-wood. Geoffrey has many similar grotesque translations of English names, for instance, his fanciful origins of Walbrook, in the City of London, and of Southampton. If Savel is the correct origin of the Sel or Seal in Selwood it is quite obscure. If the extensive pits in the neighbourhood were meant for granaries, the Irish Sabal derived from the Latin Stabulum (Pedersen, V. G. § 136 .) has that meaning, and was possibly borrowed through the British. Pen-Sabal would mean "Chief Granary". The Pens which gave names to Pen-selwood, Pen-domer, \&c., seem to be grouped in the Anglo-Saxon Chronicle under the term Aet Peonnum. Domesday selvra, and selva, now Monk-silver, seem to show that Latin Silva was in early use for "wood", and is probably the origin of this sel as well as the many "silver" streets (i. e. "Forest roads"), \&c. Mr. Stevenson adopts the reading Iglea [Ig-leah, where leah $=$ wood] of the Chronicle, and identifies it with a place called Ilegh in 1439 near Sowley (that is, South-leigh) wood. An "Iley Oak" stood according to tradition near Lord Heytesbury's lodge at Sowley Wood. A Domesday Illega annexed to Knowles St. Giles was in South Petherton Hundred, but that wonld seemingly shift the locality out of the region of probabilities. 
following morning early the standards were moved and the host came to Ethandun. ${ }^{1}$ Here Elfred's host met the whole pagan army, which after great slaughter was put to flight, the escaping fugitives being pursued right up to their stronghold [Geweorc, which may have been Chippenham], where after a siege of fourteen days they were obliged to submit to Elfred's conditions of peace. The pagans gave hostages, swearing to leave Alfred's kingdom, while their leader, Godrum, promised to receive Baptism, which promise three weeks afterwards he fulfilled, when he and some thirty of the worthiest of his army came to Aller (Alre) over against Athelney. There Alfred received him from the sacred font as an adopted son, and the Chrism-fillet was removed eight days after at the royal vill of Wedmore.

The pagan army removed [879] from Chippenham to Cirencester ["Cirrenceastre, called Cair ceri in British, which is in the south part of the Huiccii ", ${ }^{2}$ Asser] and there remained for a year, and in the same year a band of Wikings assembled at Fulham [Fullanhamm] on the Thames and took up their quarters there.

Under the year 880, the Chronicle tells us, the heathen army which had been for a year at Cirencester proceeded to East Anglia, and occupied and divided the land. ${ }^{3}$ The force which

1 Ethandun. A place of this name was left by Elfred to his wife (Cart. Sax. ii. I78). That this was a royal possession is clear, and as King Edgar granted Edington (Wilts.) to Romsey Abbey in 968, Mr. Stevenson thinks the proof of identity is not seriously questionable [Asser's Life, p. 273]. In a letter to the Athenaum (October 5, 1907) Mr. Stevenson goes anew into the question, and says in regard to Edington (Wilts.), "It cannot by any ordinary process of reasoning be shown to be an impossible site, and its acceptance does not involve any transgressions of the laws of history or philology or logic such as Bishop Clifford and his followers are driven to commit."

2 See note above on Cair-Ceri and compare Celtic Folk-Lore (Sir John Rhys, i. 280, where Ceiri is connected with Cawr (Giants = Picts or Scots).

3 Evidence from place-names of this and subsequent occupations is clear. Scandinavian elements in British place-names will be dealt with later. 
had occupied Fulham proceeded to Ghent (Gent) in Flanders [Fronc-land] and fought with the Franks, proceeding afterwards (882) far up the Meuse (Mase).

In the year 882 Elfred had a sea-fight with the Danes, in which he captured four of their ships. The next two years the heathen army were occupied on the Continent, sailing up the Scheldt as far as Condé (Cundoth) ${ }^{1}$ and the Somme to Amiens (Embenum).

In the year 885 the aforesaid army was split into two divisions, of which one proceeded to the east, and the other began the siege of Rochester (Hrofes ceastre), throwing up a work against it. Elfred coming to the relief of the besieged city, the enemy made for their ships, having been deprived of their horses. Another sea-fight occurred at Sturemouth (Essex) the same year, in which, returning from a victory over one fleet, Ælfred was beaten by another larger one of the Danes (Deniscan). Carl (Charles the Fat), the King of the Franks, is said, by the Chronicle, to have recovered at this time virtually the empire of Charles the Great-except Brittany (Lidwiccium, dative plural of Lidwiccias). ${ }^{2}$

The Chronicle records under 886 that the heathen army proceeded up the Seine (Sigene $=$ Sequăna) and settled for the winter. At the same time Elfred occupied London (Lundenburg), where all the English kin, except those who adhered to the Danes, rendered obedience to him. ${ }^{3}$ After having secured the place (burg) he gave it to his son-in-law Æthered to hold.

The Anglo-Saxon Chronicle records under 887 that the

1 Condoth is the Anglo-Saxon form of Condate, a common Romano-Celtic word for confluence. Ambiani was the ancient name of the people whose capital was Samaro-briva, that is, the bridge on the Samar-a, now the Somme.

2 See p. 159, where the Leterwicion of Nennius is cited as the origin of the Anglo-Saxon form.

3 Asser says that Elfred, after the burning of cities and slaughter of people, restored London City in a worthy manner, and rendered it habitable. 
heathen army proceeded through the bridge at Paris (Paris), up the Seine, across to the Marne, and up the latter river to Chezy (Cariei for Caziei, that is, Asser adds, "royal vill": it appears in an early form as Casiacum), where, and also "within" the Yonne (Iona), they settled for two winters. It was about this time that Elfred (as Asser tells us) constructed two monasteries, one at Athelney (approachable only by boats) and the other, a nunnery beside the East gate, at Shaftesbury (Sceftesburg).'

In 890 the Chronicle records the death of King Godrum, Alfred's godson, who, according to the Annals of St. Neots, had established his rule in East Anglia, after King Edmund-the same authority adding that he was buried at Headlega (Hadley, Suffolk).

Under $89 \mathrm{I}$ we have an account in the Chronicle of the arrival, in a skin-covered coracle without oars, of three Irishmen (Scottas) on the coast of Cornwall (on Cornwallum). They started out with no aim but that of making a pilgrimage, and about the seventh day came to land. Their names are given as Dubslane, Maccbethu, and Maelinmun. They proceeded soon after their arrival to King Elfred. Asser, in dealing with the charitable acts of Elfred, after stating that Ælfred helped monasteries and churches in Mercia, Cornwall, Gaul, Armorica,

1 Sceftesburg appears in the Chronicle and Charters as Sceaftesbirig. The first element is the genitive of a personal name Sceaft, shortened from some such form as Scefthere (Cart. Sax. i, p. II3) or Sceftwine (ibid., p. 164): Sceaft = spear. Shafton, another name for the place, is clearly from the same Sceaft.

In the Latin form of the History of Geoffrey of Monmouth a certain King Hudibras is said to have built Mount Paladur, now Shaftesbury. The Welsh version (in the fourteenth-century MS.) calls the builder Run Palatyr-vras (bras = stout) and the town "Caer-vynyd Paladur (mynyd = mount) which is now called Kaer Septon". Sceptonia is the form given in the Latin version of the Angio-Saxon Chronicle and hence the later Shafton. The town was walled in Asser's time, as he mentions the East Gate. Bin port, for "Binnan Port" (= within the Gate), is still one of the streets there. 
and Northumbria, adds, "and even sometimes in Ireland (Hybernia) also," a fact which may help to explain this voyage.

We have in the Chronicle under 893 an account of the arrival at Limenemouth ${ }^{1}$ from Boulogne (Bunnan representing Bononia, the Roman name for Gesoriacum; see p. 63) of 250 ships of the heathen army. This port, adds the Chronicler, is in the eastern part of Kent, at the east end of the great wood that we call Andred, which is $\mathrm{I} 20$ or more miles long and 30 miles broad. They took their ships four miles up the river from its mouth, the Chronicle adds, and there stormed a badly defended stronghold. Then they threw up a strong fort at Apul-dore (Apuldran, Annals of St. Neots, = Apple-tree).

In the year 891 (in the Chronicle 893) the Annals of St. Neots records the arrival of Hasteng (Hastengus) with eighty ships at the mouth of the Thames, on one bank of which, at Middeltuna (Milton), he threw up a fortress, and on the other bank, at Beamfleot (Ben-fleet, Essex), a similar stronghold. The same annals state under 893 that York was captured by the Northmen, the bishop-named Sebur-escaping.

In the same year, the same authority adds, " Elfred fought with the Northmen in a place called Fearnhamme (Farnham, Surrey) and put them to flight. Pressed by Ælfred they crossed the Thames at the Colne ${ }^{2}$ river to an island and were there

1 This is the "Ad portum Lemanis" (locative plural) of the Ant. Itin. Lemana is given as the name of the river, which became on Saxon lips Limen-ea (ea = river), now Lympne, Kent. The coast has changed much since Roman times.

2 Colne appears frequently as a river name, and especially in districts where Roman settlements are manifest. Although it cannot indicate that such districts were Coloniae, it may preserve some Anglicized form of that Latin word with its generic meaning of "cultivated place", "farm". Colonus (from Colo) is properly a farmer. The earliest form encountered seems to be Colen as in Colenceaster (Cart. Sax. ii, p. 359). Compare Colen-ea (now Colney, Herts., ibid., i, p. 339). The Cylen in Lindcylne (in Kent, Cart. Sax. i, p. 483) cannot well be the same word; nor can Cunugl-ae (Cart. Sax. i, y. 240), which Mr. Birch identifies with the Gloucestershire Colne, contain the origin of the word. Cunugl is the 
beset by Elfred. Eventually they went into Essex. Ethered, who had been left in charge of London, proceeded with his forces to Beamfleot and captured the heathen army's stronghold there, together with much spoil-including the wife and two sons of Hasteng, whom he brought back to London, and presented to Flfred, but was ordered to restore them at once. Hasteng, however, according to the Annals of St. Neots, repaired the fortress at Beamfleot, and threw up another at Shoebury (Sceobyrig), the army, which had been at Apuldore, joining his forces there, and also a large number from East Anglia and Northumbria. The Chronicle then records the ascent of the Thames by the heathen army, and their progress westward until they reached the Severn, up which they proceeded. Ethered, having in the meantime collected an army, pursued them to Buttinga-tun on Severn shore (stathe). Here he besieged the heathen army and, compelling them by hunger to give battle, won the victory, the remnant of the army seeking safety in flight. ${ }^{1}$

Having reached their head quarters in Essex, and placed their women and ships in safety, the heathen set out, with reinforcements, across England, and reached at length a waste Chester in Wirhealum (locative plural of Wirheall, now Wirral), called Lega Ceaster (Chester on the Dee). Hence they proceeded to North Wales.

In the following year (895) they proceeded to Essex, to an antecedent of Knoyle in Dorset (Cart. Sax. iii, p. 16). The origin (Cnoll) given in the New English Dictionary for Knoyle is, therefore, not correct. A river Calne occurs in Scotland.

1 This is the raid recorded in the tenth-century MS. of the Annales Cambriae under 895. "Nordmani venerunt et vastaverunt Loýcr (= Loegria, the Welsh name of Mercia probably, bnt later applied to England) et Bricheniauc (Brecknock) et Guent et Guinn liguiauc." Guinn Liguiauc is in Lib. Land, Gunliviuc and later Gwent loog. Liguiauc seems a personal name, Cymmrodor. Mag. ix. 167 . As the Danes are distinctly said to have gone up the Severn, and as the Brut tells us that in 890 (893) they came a second time to Montgomery, the place is evidently Buttington, opposite Welshpool, and not Buttingtontump at the junction of the Severn and Wye. 
island called Meresig, Mereseg (Mersea, Essex), whence they sailed $(896)$ up the Thames to the Lygan (river Lea), and up this for twenty miles. King Elfred driving them thence they proceeded to Cwat-brycge ${ }^{1}$ on Severn, which they fortified. In 897 they went across the Channel to the Seine.

In 898 Rollo, the founder of the Dukedom of Normandy, besieged Chartres (Civitas Carnotiensis), but had at last to raise the siege.

The Annals of St. Neots under 900 records the death of Flfred and the succession of his son Eadward, also the defection of the latter's cousin Æthelwold, who withdrew to Northumbria and joined the fortunes of the Northmen there.

When the tenth century opens we find Eadward, the son and successor of Ælfred, reigning in Wessex, his sister Æthelfæd and her husband ruling in Mercia, where their authority was limited seriously by the Danes, who bore sway also in East Anglia and Northumbria. Ethelwald, Eadward's cousin, before taking

1 Prof. Earle pointed out that there is still a Quat and Quatford near Bridgenorth. Mr. Eyton (Antiquities of Shropshire, vol. ix, 143-150) derives Quat from Coed (early form Coyt $=$ forest), pointing out that the Wyre, Kinver, and Morf Forests embrace all this district on both sides of the Severn. In an original charter of A.D. 736 [Cart. Sax. i, p. 223) we have the early names of two of these forests, Cynibre (which has become "Kinver", passing through the forms Chenefare [dative, Domesday] and Kinefar, Testa de Nevill) and Moerheb (which has become "Morfe"). Moerheb is interesting as it is probably the same word as the twelfth-century Moref (now Moray, in Scotland: Murief in Geoffrey of Mon.), representing possibly an earlier *morapa, apa (= Lat. aqua, Old High German aha) being, according to Dr. W. Stokes, the Gaulish form of water, giving ep-, ef-, -aff in the later termination of riverand place-names. Compare also the Morbi-o of the Not. Dig. Moravia in Germany also was in the ninth centnry Mor-ava and Mor-aha, implying that * Morapa was the original form. Cynibre is also interesting as showing the possible source of some of our place-endings in -far and -ver, and may represent an early $*$ Cunobriga $=$ high-burgh. Bridgenorth does not appear in Domestay, but its early name Bricge occurs in the Anglo-Saxon Chronicle in A.D. 912. The Norse Bryggja, = a landing-place, may be the origin of the bridge in Bridgenorth-the "north" is obscure if it be not a corruption of Morf. See p. 6r. 
refuge in Northumbria, had, as the Chronicle records under $90 \mathrm{I}$, seized without the King's 'leave the residences at Wimborne (at Winburnan) and at Christchurch (at Tweoxn-eam, that is, "between the rivers", known in the twelfth century as Christe Cerce). King Eadward moved against him and encamped at Badbury Rings (at Baddan-byrig ${ }^{1}$ ). Ethelwald, who had escaped by night to Northumbria, where he was received as king, came back later on with a fleet to Essex.

Under 903 we have the record of the Consecration of the New Minster at Winchester, wherein were placed the relics of St. Judoc, ${ }^{2}$ and wherein Grimbald the priest, who had come over from the Continent to help Alfred, and had died in 903 , was buried.

Under 905 the Chronicle relates how Ethelwald, having induced the Danes of East Anglia to break the peace, ravaged Mercia as far as Cricklade (Crecca-gelade ${ }^{3}$ ), where, crossing the

1 Baddan-byrig, Badbury Rings. This seems to be, according to the mileage, the Vindo-Cladia (variant Vindo-gladia) of the Itin. Ant. Vind-o is represented now by the Welsh Gruynn= White; Irish Finn: cladia (= Klâdiâ?), as Dr. W. Stokes has pointed out (Wortschatz der Keltischen Spracheinheit, p. 82), contains probably the stem Klado (= ditch) preserved in Welsh Cladd (Clawdd), and Irish Clad. The compound would thus mean "White-ditches", a natural term for a stronghold with a series of concentric rings cnt in the chalk. Baddan is the weak genitive of Badda, a name which occurs frequently, and is probably a shortened form of some such name as Beadu win = "war friend". For Winburna, which seems also to contain Vindo, see p. 194. Tweoxn-eam="between the rivers" ( $E a=$ river), is declined irregularly and $e a m$ is the dative or locative plural.

2 St. Jndoc was a Breton saint of the seventh century. The name is a diminutive from some full form such as Jud-gual. It has become, both in Brittany and in Cornwall, Just, as in St. Just, see Les Petits Bollandistes. The new minster was removed to Hyde Abbey in the twelfth century.

- Crecca-gelade is now Cricklade. Gelade (dative) is "a passage", and is a collective form of $\mathrm{Lad}=$ way-preserved in the numerous "Lodes" on the Severn, e.g. "Saxon's Lode". Crecca is possibly connected with Welsh Craig = "rock", or with Cruc = mound.

on Bradene. The name Braden occurs in Domesday in Bradene stock, 
Thames, the heathen army raided in and about Bredon forest (on Bradene), and then set out homeward. Eadward overran all their country between the dikes (dicum) and the Ouse (Wusan) and as far as the fens (fennas) northward. On the king's homeward journey the Kentish men (Kentiscan) lagged behind contrary to orders, and were attacked by the Danes, who gained the victory, after much slaughter on each side. This battle seems to have been that fought at Holme (somewhere in East Anglia), which is recorded in one of the MSS. of the Chronicle under an earlier year.

In 907 the Reeve of Bath died (at Bađum), and in the same year peace was concluded both with the East Angles and Northumbrians at Yttingaforda. For the next three years we have records of the construction or repairs by the English of strongholds at strategic points in connexion with the movements of the Danes. Thus, that at Chester (Ligcester, that is, Castra Legionis) was renewed in 907 . There was a fight between the Angles and Danes at Tattenhall (Teotan-healh ${ }^{1}$ ), and there is also a Domesday Bradene (dat.) in Somerset. Its modern form of Bredon, a name found both in Wales and in the West Country, suggests that it represents possibly an early Brigo-dun-um, that is, "hill fortress."

Between the dikes and the Ouse. "The dikes", some of which seem to have been in existence in Roman times, were evidently a known term in the tenth century. The Wusa is obscure. It may be a modified form of some Celtic word, or it may be connected with Wase (mud), compare $W \bar{o}=$ wet. Early forms occur in Charters, e.g. Usa (Cod. Dip. 480), Use (ibid., 621). Yttingaforda has not been identified. It may be a misreading for Ultingford and be thus represented by Ulting in Essex.

1 Teotan heal contains the weak genitive of a personal name (Teota) contracted from a full form such as Theod-win. Heall is used for a large structure where a chief resided, as well as for "shed" generally.

at Bremes byrig has been identified by Mr. Plummer with Bromesberrow near Ledbury, Hereford. In favour of the identification is the fact that Bromesgrove represents an earlier Bremesgraf, but berrow is not the usual modern equivalent of the dative of burh.

To Scergeate. Mr. Taylor (Danes in Gloucestershire) would make this Shrewsbury, but this is linguistically impossible. The place is most probably the Scrget (Codex Diolomat. 1199, where the editor makes it 
Staffordshire, in 9ro, in which the Angles were victorious, and in the same year Ethelfled built the stronghold (burh) at Bromesberrow (at Bremes byrig) near Ledbury, Herefordshire. In 912 she arrived at Scergeat (to Scergeate) on the eve of the Invention of the Holy Cross, and constructed the burg (burh) there, and in the same year that at Bridgenorth (Bricge). In the next year, 913, she came with all the Mercians to Tamworthy (to Tamaweorđige ${ }^{1}$ ) and built the burg there, and afterwards that at Stafford (at Stafforda). King Eadward in the same year ordered the northern burg at Hertford (at Heorotforda) between the rivers Maran, Beane, and Lee (betweox Memeran Beneficcan and Lygean) to be built. When he was afterwards at Maldon (Maldun) in Essex he constructed the burg at Whitham (Witham), in the same county, whereupon many of the people who had been previously under the Danes $\mathrm{Sc}$ [i]rget). It was near Beenham in Berkshire, and close to the Kennet (Cyneta) river.

1 Tamaweordige appears in the Charters as Toman-worthig, involving probably the genitive of a personal name Toma or Tuma, which occurs. Stafford has been previously explained.

The river Memera (variant Mara) is obscure, as is also Bene ficca. Lygean, now the Lea, from the variant Ligene, looks as if the $n$ were organic and suggests that the word is connected with the common Celtic river-name, Logana.

at Eadesbyrig is identified by Mr. Taylor (Danes in Gloucestershire), probably rightly, with Eddisbury, Cheshire, but the same writer's identification of at Weardbyrig with "at Warburton" in the same county is an unsupported guess. The place is evidently the Weardburh of the Codex Diplomaticus (343,1056, II 48, II 78 ), and is now Warborough, Oxford.

Warinc-wic $=$ Warwick. Waeringa- (a genitive plural) wic would be the correct form, involving probably a patronymic.

Cyric-burh Mr. Taylor would make Chirk (in thirteenth century Cirice), but more proof is needed. Chirk owes its name evidently to the river Ceriog (of which the earlier form would be Cerioc) which passes by it. Cyric suggests "Church", and Cyric-burh may be the place called Cercelle in I 295 (B.M. Charters and Rolls), later Cherchehulle, and now Churchhill, Oxfordshire, i.e. in the same county as the Warborough above.

Rumcofan appears in the twelfth century as Runcofa (B.M. Charters and Rolls), now Runcorn. Côf $a=$ cave, chamber. The vowel-flanked $f$ disappeared, facilitating the transition to Corn. 
submitted to him. Ethelflæd in 914 constructed burgs at Eddisbury (at Eadesbyrig) and at Warwick (at Waringwicum), and in the following year those at Cyric-byrig, Weard-berig and Runcorne (at Rumcofan). The building of these strongholds over a wide area indicates how seriously the authority of the English was encroached upon by the Danes. The entry under 9ro (in another MS. 912) in the Chronicle seems to indicate at first sight that before this time London (Lunden-byrig) and Oxford (Oxnaforda ${ }^{1}$ ) were in possession of the heathen; the words are, "King Eadward took possession of London and Oxford," but they may mean merely that he resumed over them his authority, which had been previously delegated to Æthelflæd.

In 9 I I the Northumbrian Danes broke the peace and, refusing all overtures of Eadward, overran Mercia. The king was then in Kent with a hundred ships, and when he took the field the ships went south-east along the coast to meet him. The enemy, thinking all the king's forces were in the ships, began to harry the country, but Eadward, on hearing this, sent forces after them, both of the West Saxons and of the Mercians, and intercepted them on their return (at Wodnesfield, says Florence of Worcester), and after great slaughter put them to flight.

Ethelflæd in 916, three days after the feast of St. Ciricius and his fellows, sent a force against the Welsh (on Wealas) and stormed Brecenan Mere. In the next year the heathen army rode out from Northampton (of Hamtune) and Leicester (of Ligera Ceastre, ${ }^{2}$ variants Ligora, Ligran, Ligere) and slew

1 Oxnaforda. Oxena is the genitive plural of the A.-Sax. word for Ox. This is the first mention of the place in the Chronicle.

Brecenan-mere was in Wales, but its connexion with Brecon (Brecknoc) is doubtful.

2 Of Ligera Ceastre. Wm. of Malmesbury (Gest. Pont. $\S 176)$ saw in Leger-a the name of a river, but the Soar appears (Sor, 1253, Cal. Chart. Rolls, i. $4^{26}$ ) as the stream running by, and seems to preserve the Sarva of the Ravenna Geographer. In the Welsh version of Geoffrey's story of Lear (Red Book of Hergest) the river is called Sorram. If "Munt Sorel" 
many men at Hocneratun (variant Hocceneratun), but in a subsequent attack on Lygtun (Leighton Buzzard) were put to flight. In the same year Æthelflæd, "the lady of the Mercians," captured Derby (Deoraby), but with the loss of four of her thanes slain within the gates (binnan tham Gatum). In the next year $(918)$ she got possession of Leicester (Legraceaster) by treaty and the greater part of the army belonging to it became subject to her. In the same year a great fleet of the heathen came over sea from Brittany (of Lidwiccum), and, entering the mouth of the Severn, harried the North Welsh (north Wealas) on all points of the coast. In Erchenfield

(Mount Sorrel) which appears in $1_{15}$ I (B. M. Chart. Rolls) is not a Norman imported name it probably preserves the name of the Soar, cf. Sorewella (Sorezvelli), Domesday of Hants. In the Triads (2) the breadth of Britain from Criccyl in Anglesey to Soram (i. e. Sarre in Kent) is given as 500 miles. The latter place is referred to as Serra and Searre in a charter of King Eadbert (Cart. Sax. i, p. 268).

Legra appears in Domesday and in the thirteenth century for Layer Marney, Essex. It is probable, therefore, that we have here the genitive plural of the A.-Saxon Leger (now Lair), used, like the Dutch Leger, for camp. This would connect it, as far as meaning is concerned, with the Romano-Celtic Ratae (by which the place was known to Ptolemy), appearing in the Ant. Itin. as Ratas and Ratis. The latter is in the locative plural, as we see from the milestone discovered at Thurmaston, on which there is inscribed a Ratis II (miles). The Romano-Celtic singular K'atum appears in Argentoratum, now Strassburg, and probably in Ratu-magos, now contracted to Rouen. Rath in Irish place-names (e.g. Moy-rath, now Moira, representing an early *Mago-ratum) is the same word, and Dr. W. Stokes assigns to the stem the meaning "earth-rampart" or "earth-bank". The place, notwithstanding Henry of Huntingdon's identification, has nothing to do with Cair Lerion in the list of cities in Nennius. The Domesday form Ledecestre is difficult to explain. The form Lethecestre also occurs.

Hocneratun is undoubtedly the same as the "manor of Hokenarton" (Calendar of Charter Rolls, i, p. 49), now Hook Norton in Oxfordshire. This is an instance of "attraction", by which the natural development of the word has been diverted.

Lygtun. This is Leighton Buzzard, Beds. In the Cod. Dip. 161 it is Lygetun.

Deoraby $=$ Derby, a name imposed by the Scandinavians. Its Saxon name was North Weorthig. 
(Ircingafeld ${ }^{1}$ ) they captured Bishop Cameleac and carried him to their ships, but Eadward ransomed him afterwards for $£_{4}$. Their plundering expeditions in this region were brought to an end by the opposition of the Gloucester and Hereford men, who put them to flight, slaying Earl Hroald (Harold) and many of the army. After giving hostages they stole away, on one occasion to the east of Watchet (Weced), and on another to Porlock (Port locan), but were beaten each time. Some of those who escaped settled on the island of Bradan Relice, but, being driven thence by hunger, went to Deomidum (Demetia = South Wales) and thence to Ireland. Eadward after this went to Buckingham and erected burgs on either side of the river. Many of the enemy owning obedience to either Bedford (Bedanforda) or Northampton (Hamtun) submitted to him. Athelflæd died at Tamworth (at Tamanweorde) the same year (918) and was buried in St. Peter's, Gloucester. In the year after (919), Eadward captured Bedford and ordered a stronghold to be built there on the south side of the river. In 92 I Eadward had the burg at Towcester (at Tofeceastre ${ }^{2}$ ) constructed, and

1 Ircingafelda is now represented by the Deanery of Archenfield, which probably contains, with the district of Ergin (variants Ergic, Erging), in Monmonthshire, an echo of the Areconium of the Ant. Itin. Arcencale (A. D. 709, B.M. Charters and Rolls), now probably Ercal, seems to involve the same designation, and, as already hinted, may be from a personal name. The Arcunia of Aristotle (Black Forest, stretching to the Danube), = ?*Para Kunia = very high, is ont of the question. Bradan Relice (and Steapan Relice) contains the Irish adaptation of the Latin Reliquiae, = Relig, applied to a graveyard. This is perhaps the "insula Echni qui modo Holma vocatur" = Flatholm or Steepholm at the mouth of the Severn.

Weced $=$ Watchet is seemingly a Celtic form whose original would be some such word as Guocet = earlier vocetum = "under-wood", cf. Mons Vocetius.

Port locan, now Porlock, involves the Latin Portus, which was adopted in all the Celtic regions of Great Britain.

2 Tofeceaster, Towcester, has been identified with the Lactodorum of the Ant. Itin. The river Tove, on which it stands, may be an antiquary's deduction. It does not occur, as far as I can discover, in early documents. For the termination duron, or dorum, see p. 37. The Lact-o is obscure. Weolud, or its modern form Welland, is difficult to explain. 
also another at Wigingamere. The heathen attempted in vain to reoccupy Towcester, but carried off booty from the region between Byrnerwudu (Bernwood Forest, Bucks.) and Aylesbury (Aglesbyrig). The heathen army forsook Huntingdon (Huntandun) the same year, and constructed a stronghold (Geweorc) at Temesford (at Tameseforda). But this was afterwards taken by storm, the heathen king and two of his earls being slain. Colchester (Colneceastre) was also taken from the Danes; the king went afterwards to Passenham (Passanhamm), Northants, and remained there while the burg at Towcester (Tofeceaster) was being encompassed by a stone wall, and after this all the army which owed obedience to Northampton, and those as far north as the Welland (Weolud), chose Eadward as their lord. The king also repaired Colchester and established his rule among those who had previously been under the dominion of the Danes. The heathen army at Cambridge (to Grantan brycge) chose him as their Lord, and in the same year the king built the burg at Clede-mouth (at Cledemuthan).

The Chronicle records under A.D. 922 that "King Eadward went with his forces to Stamford" (Steanford) where, "on the south side of the river, he constructed a burg, and all the folk belonging to the northern burg submitted to him." While he was at this place, his sister Æthelfld died at Tamworthy (the earliest recorded form is Tamanworthig $=$ the farm of Tama, doubtless a personal name), whither the king proceeded, and "all the people of Mercia, who previously had been under Æthelflæd's rule, submitted to him; and also the kings of North Wales, Howel, Cledauc, and Ieothwel (Iudwal), together with their people, sought him as their lord". ${ }^{1}$ Then follows in

Wigingamere Mr. Plummer would identify with Wigmore, Hereford, but the numerous Wigmores in the country have other antecedents.

Clede-mouth cannot well be the Dou Clediv (now Dun-gleddy) of the Lib. Land., as Mr. Plummer would make out.

- ${ }^{1}$ Howel is the well-known Welsh law-giver Hywel Dda. In the Annales Cambriae the death of a King Clitauc is recorded as having occurred two years after that of Ethelfix. He was evidently, therefore, the 
the Chronicle an account of the king's visit to Nottingham (Snotingaham), where he repaired the burg, and garrisoned it with Englishmen and Danes. In the year 923, proceeding to Thelwall (Thelwale) in Cheshire, he constructed a burg there, and ordered a division of his forces to go to Manchester (Mameceaster $)^{1}$ in Northumbria to repair the burg there. The Chronicle records under 924 his construction of a burg at Nottingham on the south side of the river, opposite the other, and his connecting it with the latter by a bridge over the Trent (Treonta). The king thereupon proceeded to the Peak district (Peac-lond), to Bakewell (Badecanwiellan, Badeca = probably a diminutive of a personal name), close to which he formed a burg. It was at this time, the Chronicle adds, that "the king and people of the Scots chose Eadward as father and lord". The Northumbrians also (including Raegnal, who had captured York - Eoforwic-the year before), English, Danish, Northmen, and others, together with the king and Welsh of Strathclyde (Stracled Weala), submitted to him. Eadward died the next year (925) at Faringdon ("Farndun in Mercia"), Berkshire, and was buried at Winchester, his son Æthelstan being crowned at Kingston as his successor the same year.

Ethelstan occupied Northumbria in 926 , after the death of Sihtric, the king of this region, who had married Æthelstan's sister, and whose son Guthfrith was driven out and forced to

king mentioned in the text. Juthwal signs, along with Howel, a charter ascribed to A.D. 928 (Cart. Sax. ii, p. 342).

1 The form in the Ant. Itin. is Manucio or Mancunio, but the former, which is preserved in the Anglo-Saxon name, is probably the correct reading. Mamuc seems an adjectival form, but the meaning is obscure. The Celtic Mam seems to have meant originally the same as Bron (=breast), applied to a round hill. In the Liber Landavensis we have Mam-ilet Forest on the Gamber, in Hereford, and Mam-heilad (now Mam-hilad in Monmouthshire), which is evidently the same word. The heilad has an inorganic $h$, and -ilet therefore represents the original form, which may be a personal name. Mamble in Worcestershire appears in a charter ascribed to the tenth century (Cart. Sax. iii, p. 209) as Momela [gemara] in the genitive plural. The Domesday form is Mamele. 
take refuge with the people of Strathclyde. The Chronicle adds that " Ethelstan reduced to obedience all the kings of this island, first of all Huwal, King of Cornwall (West Wala), and Constantine (Cusstantin), King of Scots, and Owen (Uwen: Uuer, Simeon of Durham), King of Went (Monmouth district), and Ealdred, son of Ealdulf [who had been driven out by the Danes] from Bamborough (Bebbanbyrig), with pledge and oath, who made peace in the place that is called Eamotum ".

Under the year 933 the Chronicle records an expedition by Ethelstan, as well with land forces as with a fleet, into Scotland, where he ravaged the country. $\mathrm{He}$ is said by Simeon of Durham to have proceeded as far as Dunfoeder (by which Fothurdun, ${ }^{2}$

1 Eamotnm is perhaps Emmet in Northumberland, or possibly Dacre on the Eamont river. Ea motum is the locative plural of $E a-(\mathrm{ge})$ mot = "river confluence". This is a Saxon form. Emmet, which is found also in Yorkshire, as in Emmet-roda (Burton's Monasticon Eboracense, p. 101) = "Emmet-clearing", may be its modern representative, but from possible influence of Scandinavian-in which Munn-r is the term for a river-mouth-the form Ea-mont is not to be excluded. We have, for instance, near Snaith, in Yorkshire, the place called Armin or Airmin, which in $\mathrm{I}^{2} \mathrm{I} 4$ was called Hayrminne (British Museum Charters and Rolls, i) where the Scandinavian Munn-r = mouth, is combined with the name of the river, the Aire. Arminni is a common name in the Sagas for "confluence", as is also Ar-mot (the equivalent of English Eamot), where the $A r$ is the genitive case of $\hat{A}=$ river in Norse.

The Early English equivalent of Munn-r is Muth, which gives the modern place-name Mythe (a dative form), as in "the Mythe" at the junction of the Avon and Severn at Tewkesbury.

${ }^{2}$ See p. 77, where the meaning and varions forms of Fother are discussed. Florence of Worcester, who also mentions Dunfoeder, may have had some knowledge of the place-names Fudir (later Futhir and finally Fur in Furness, still preserved in Foodra Castle), and the early form of Westmere-land. Sir Herbert Maxwell (Scottish Land-names, p. 64) is my authority for the early form of Fordun, but $I$ have not been able to find Fothurdun in any documents. Fothuir-tabhaicht was certainly the early form of For-teviot near Perth, a later one being Fether-teviet (Lib. Ecclesiae de Scon, p. 20); cf. Tefeged in Monastic Annals of Teviotdale $=$ the ancient name of the river Teviot, Mount Teviot. Perhaps this-like Reged-is a regional word of which echoes survive in Cheviots and Tweed. The final syllable may have been ced for cet which in Brythonic lips would 
the ancient name of Fordun, may be meant) and Wertermore (conjectured by Mr. Skene to be Kirriemuir). After this we have a blank up to the year 937, in which the famous battle of Brunanburh (ymbi Brunan-burh = about Brunan-burg) took place. The particulars of this fight are given in an Anglo-Saxon poem, inserted in the Chronicle, with which Lord Tennyson's spirited rendering has made us familiar :-

Athelstan King,

Lord among Earls,

Bracelet bestower,

Baron of Barons,

$\mathrm{He}$ with his brother,

Ednund Atheling,

Gaining a lifelong

Glory in battle,

Slew with the Sword-edge,

There by Brunan-burh,

Brake the Shield-wall,

Hew'd the Lindenwood,

Hack'd the battleshield,

Sons of Edward with hammer'd brands, \&c.

The site of this battle has been more disputed, perhaps, than any other event in history. From Somerset (Mr. Birch) to Dumfries (Mr. Hodgkin and Mr. W. H. Stevenson), from Lincoln (Mr. A. Hunt and others) to the Mersey (Dr. Weymouth), various writers have sought for the locality of the battle.

There was leagued on the one side the Danes of Northumbria, Constantine, King of the Scots, the Danes of Dublin under

become ged, and in Goidelic Ceth, Cheth. Cf. We-ced, Litcet, "Hesket forest," now Hesketh, Cumberland. Whitaker's Craven, ed. 1812, p. I3, is the first authority I can find for Further-ness, which reading Raine (Priory of Hexham, i, p. 82) adopts in Richards' Acts of King Stephen. Whitaker adds that the "small castle of the Foodra ... is always called the Peel of Further." At p. 77 I have given reasons for identifying Fother, Further, Fether, and Fetter in place-names with the Irish Foithre given by O'Reilly as "Woods", and found in the dative Fothribh in the Calendar of Donegal, August I, and in the Book of Lecan (fol. I34 bb), for "Forest". 
Anlaf, and, according to Simeon of Durham, the Strathclyde Welsh. On the other side were the forces of Wessex and Mercia under Æthelstan and Edmund Ætheling. The site of the battle must be looked for in some locality which would serve as a meeting-place for Æthelstan's opponents, and which could also be readily reached by Æthelstan, who was presumably, as Mr. Plummer says (Anglo-Saxon Chronicle, ii, p. 140), at York in the year $93^{6}$. The Roman roads of the country have, therefore, an important bearing on the site, for bodies of troops could not be readily moved across country. The name of the battle-place ought also to throw some light on the place. The form in the oldest MS. of the Chronicle-Brunan-burh-involves a personal name Bruna, of which there are several instances (Searle's Onomasticon). It is a shortened form of some wellknown personal designations as Brunheard or Brunwine, and as a patronymic would appear as Brun-ing. The genitive plural of the latter is Bruninga, and this is the form which occurs in an early charter in the British Museum dated 938 . Mr. Birch calls it the "Original Charter", and it is published in the British Museum Facsimiles, a fact which indicates its high antiquity in the eyes of the authorities. - The late Mr. Kemble may have been right in stigmatizing as spurious the grant which it confers, but that does not detract from its witnessing to the currency in the tenth century of Bruningafeld as the name of the battle-site. William of Malmesbury (who died about 1 1 26) gives the form Brunefeld, a natural curtailment of the longer name. In the tenth century MS. of the Annales Cambriae the battle is called merely Brune. Simeon of Durham (i. 76) designates it at Brunanwerc $=$ "at the stronghold of Bruna"; he also calls it Weondune. The name of the battle in the Egils Saga $\left(c .5^{2}\right)$ is, as Mr. Plummer says (Anglo-Saxon Chronicle, ii, p. I4I), too mythical-"Winheath by Winwood". Vîn (= "wine") is here possibly metaphorically used for "blood".

From these facts I venture, with fear and trembling, to 
suggest a new site for the battle, excusing my temerity by a few convergent arguments.

In documents of the time of King John (British Museum Charters and Rolls) the name Brunefeld appears more than once as the designation of a place now called Bromfield (in Speed's 1610 Map, Brumfeild), in Cumberland. It is on a tributary of the Waver river which flows into the Solway Firth, and lies about five miles due west of the Roman Camp, south of Wigton, called "Old Carlisle". The camp at White Hall, on the Roman road from Old Carlisle to "Burrens" 1 at Papcastle, lies four miles to the south-east, and, according to R. S. Ferguson, quoted by Mr. Codrington (Roman Roads p. I9r), there was a Roman road running direct from Old Carlisle to Maryport which must have come even closer to Brunefeld.

Ethelstan, if he were at York, could therefore have proceeded by a Roman road to the vicinity of the locality. The King of Scots could also have come thither by Watling Street and the road south of the Wall, and for the Strathclyde Britons there were roads, traces of which remain, from Dumbarton to Carlisle. The Danes of Dublin could find a ready access to

1 Burrens, with many variants (Birrens, Borrans, Burwens, Burwain, Borrowens), is found frequently in Border place-names. Borwen occurs in 1570 (Levin's Manipulus Vocabulorum) as meaning Cumulus=" heap", " mound", but an earlier form of what seems to be Burrens is in the Register of Fountains Abbey (in the British Museum), which Dr. Burton (Monasticon Eboracense, p. I 71) quotes-Burganes Lapidum-and translates "sheep-fold of stones[s]". Burians in Jamieson's Scottish Dict. is interpreted as "cairns" or "circular enclosures of stones". Burganes is probably the original form of these words, and is seemingly connected with Anglo-Saxon Beorgan, " to protect." The idea of a refuge, for sheep, $\& \mathrm{c}$. , is therefore a fundamental one, but see note, p. 28.

Baregain, a not infrequent farm-name on Ordnance Survey maps of the southern districts, may be connected. Carew (Survey of Cornwall, p. 62) makes it a small holding.

Canon Taylor, Vicar of Bromfield, tells me there is an earthwork close to the Vicarage. Mr. Collingwood has examined this and thinks it later than the tenth century. 
their British and Scottish allies in the mouth of the Solway. Florence of Worcester's (died III8) statement that Anlaf entered the mouth of the Humber with a great fleet cannot well be reconciled with the facts of the case. It is hard to believe that he went all the way from Dublin to the Humber when he could find on the nearer west coast a much more accessible meeting-place with his allies. Florence may refer to the simultaneous advent of the eastern fleet to distract Ethelstan's attention. The most important critics are, in any case, in favour of a west-coast landing-place for Anlaf. Cumberland, that is, the Strathclyde Kingdom, moreover, was subject to Wessex in some sort, for its king had submitted to Eadward in 921 , and in A.D. 926 the Northumbrians, as we have seen, yielded to Ethelstan at Ea-motum, in the present county of Cumberland. We find, furthermore, that this region was given to Malcolm II, King of Scotland, by King Eadmund, in 945, eight years after the battle of Brunanburh, in whose hands it remained, with various fluctuations, until finally made an English possession by William Rufus in 1092. In the Scottish Historical Review for October, 1903, there is reproduced a document of singular interest in this respect, viz. a "writ" of Gospatric belonging to the year 1072 or thereabout. It is written in Anglo-Saxon, and thus shows that this was the official language there at the time. It deals with lands in Alner-dale (Allerdale), and mentions the Waver (Wafyr), of which Crummock brook (that is, Crooked-brook) the stream flowing by Bromfeld, is a tributary. The name given to the Wampool, therein, is interesting-Poll Wadan. The latter element is not easily explained. It would be too rash to connect it, through a possible ${ }^{*}$ Wantdon, with Simeon of Durham's Weondun.

The battle of Brunanburg seems to have brought quiet for some time, and King \&thelstan died in peace some two years after, that is, in 940.

Ethelstan was succeeded in $94^{\circ}$ by Eadmund Etheling. 
Under the year 942 there has been inserted in the oldest manuscript of the Anglo-Saxon Chronicle a short poem describing a campaign in which Eadmund ravaged a part of Mercia bounded by Dor (Dore, near Sheffield, probably a river-name as it is employed for a boundary, see Bdora of Ravennas, p. I I 7), Hwitan Wylles geat, and the river Humber, and how he freed from the yoke of the heathen Northmen "the five burgs", that is, Ligaraceaster (Leicester), Lindcylene (Lincoln), Snotingaham (Nottingham), Stanford, and Deoraby (Derby). Another manuscript of the Chronicle records under 943 that Eadmund entrusted to St. Dunstan, Glastingaberig, where he had been previously Abbot. Eadmund, in the next year, is recorded as having overrun all Northumberland, and as having reduced it to obedience, driving out two kings-Anlaf, son of Sytric, and Rægnald, son of Guthferth. The D. MS. of the Chronicle records under 943 that Anlaf had previously destroyed Tamworth (Tamwurth), and that the Danes had obtained a great victory, carrying off large spoil. Eadmund, it is therein stated, had then besieged Anlaf at Leicester, with the result that the latter became King Eadmund's friend. In the year 945 Eadmund ravaged all Cumberland, and leased it to Malcum (i. e. Malcolm), the King of Scots, on condition that the latter should become his ally both by land and sea.

The D. MS. places in 946 the stabbing of King Eadmund, at Pucklechurch (at Puclan Cyrcan), by Liofa. Eadred his brother succeeded, and his first act was to reduce to obedience the unruly Northumbrians, and to compel the Scots to become his allies-"willing what he willed". In 947 the D. MS. records the coming of King Eadred to Taddenes scylfe (Tanshelf, Yorkshire), where Archbishop Wulstan and the Northumbrians swore fealty to him, only to break their oaths shortly after. The Northumbrians having again revolted and made Yric their king, Eadred ravaged, in 948 , Northumberland, in which pillage the Minster of Ripon (Rypon), which Wilfred had built, was burned down. (The E. MS. postdates this election of Yric.) As Eadred 
was on his way back the heathen army of York overtook the king's forces, which were lagging behind at Ceasterforda, and there was great slaughter. On the king's threatening to ravage the country again, the Northumbrians forsook Yric and made amends.

In 952 Eadred, according to the D. MS., ordered Archbishop Wulstan to be imprisoned in Iudanbyrig, ${ }^{1}$ and in the same year

1 The place-names occurring in these extracts from the Anglo-Saxon Chronicle are identified to some extent in the text, and some have been previously explained, as Dor, Ligeraceaster, Snotingaham, Tamworth, \&c. A few remain to be dealt with. Hwitan Wylles geat is probably "Whitewell's gate", as Mr. Plummer suggests, and is to be identified with Whitewell, not far from Dore. The form of Lincoln here, Lind-Cylene, is pecnliar. The D. and E. MSS. give a more correct(?) form Lind-colne. A Lind-Cylne occurs in Kent (C.Dip. 204), where the lime-tree is probably meant, but Cylne is possibly the genitive of Cylen, a kiln.

Professor Freeman was of opinion that Glestingaberig is purely English, but I fully agree with Mr. Egerton Phillimore (Cymmrodorion Mag., vol. ix, p. 180) that "Glastenic" (which occurs in the twelfth-century MS. of the Annales Cambriae, copied from a tenth-century original) is certainly the native name of Glastonbury, from Cornish and Breton Glasten or Glastan, "Oaks." The element Tan and its cognates have been previously dealt with.

"Pucklechurch" is mysterious. It has no connexion with the French Pucelle, virgin, derived from the Low-Latin Pulicella $=$ a girl. The form in Domesday, Pulcrecerce, has led some to make it a half translation of Pulchra-Ecclesia, = beantifnl church, but this, in face of the earlier form, is impossible. It is better to take the nearest Anglo-Saxon equivalents, Piicel $=$ a goblin, and Circe $=$ church, although this presents (1) the difficnlty of an abnormal designation, and (2) that of the fact that Pucel is masculine and would form its genitive in -es. Perhaps at this time it had fallen into the weak declension, making its genitive in -an. There may also have been a legend about a goblin haunting the place before the erection of the church. See Note G on Glastonbury, p. 204. Puck, =a fairy, is a very obscure word. It is not English, and its Irish form Pookha shows it is not Goidelic. There is, I believe, no Teutonic equivalent in Continental regions.

Taddenes-scylfe was Tanshelf in 1257 (Calendar of Charter Rolls, vol. i, p. 472). The latter element means crag or peak and the former is the genitive of a personal name, but I confess I know none like it in form.

Ceasterforda is identified by Mr. Plummer with Chesterfield in Derbyshire, but the place seems to have been nearer York. Castle-ford, Yorks., would 


\section{Eadred caused a slaughter to be made at Thetford (Theotford), on account of the slaying of the Abbot Eadhelm there.}

The Chronicle records under 954 that Archbishop Wulstan meet the case, and it preserves possibly in the form Castle a previous Castra.

Indanbyrig has been already dealt with, see p. 179. To begin with, the Notitia Dignitatum gives Othona on the Saxon shore as garrisoned by a company (numerus) of the Fortenses. It was, therefore, somewhere on the east coast. Bede, H.E. iii. 22, mentions Ythan-ceaster as being on the river Pant (ripa Pentae Amnis). The Blackwater in Essex still bears in its upper reaches the name of Pant, and Pentelow and Panfield are names of places on its course. The whole river was probably, therefore, called Pent or Pant in Bede's time. At its mouth, in the parish of Bradwell (Bradwall in the thirteenth century) there is a chapel called S. Peter ad Murum, and earlier Capella de la Vel (i. e. of the Wall). P. Holland, the translator of Camden, said there was at this place a thick wall, a huge ruin, where many Roman coins had been found. The present name of the hundred in which the place stands is Dengey, but in Domesday it was called Witbrichtesherna = probably Wigbeorhtshyrn, that is, "Wigbeorths-corner". In this hundred Domesday places Effe-cestre. This place has not yet been identified, but it was apparently on the Blackwater, the northern boundary of the Hundred. Now Indanbyrig, where Wulstan was imprisoned, is called in Florence of Worcester Juthan-birig, and the form, presumably of this place, on a coin of Ethelred II is Geoda, which would be pronounced Ietha or Ytha. The sound of th in place-names is frequently represented later by an $f$, for example, Thelbrigg (plankbridge) appears later as Fel-brigg; Finglesham is for an earlier Thenglesham, and Finedon for older Thingdon. It is possible, therefore, that in the time of Domesday the form Ytha had become Eoffa or Effe, thus giving the form Effecestre for Bede's Ythanceaster. It ought to be added that Wulfmær, the minter of the coin at Geora, minted other coins in East Anglia. It is ridiculous to think that Jedburgh (originally Geddeworth), where Athelred's writ could not have run, was the place.

Dorchester, Frome, Oundle, Ely, Chertsey, Westmorland, Thanet, Acemannes Ceastre, and Wareham have been already explained.

Corfes-geat is an instance of the use of an element, other than a personal name, with the genitive in es to form the designation of a place. Corf is a "cutting" (Ceorfan = to cut) and means here the cut in the long ridge to the south of Wareham. Geat means here practically the same thing $=$ the opening in the hills. The oldest parts of the castle here go back to Saxon times, showing the strategic importance of the place in regard to invasions of the heathen pirates from Swanage, a stronghold 
obtained again a bishopric at Dorchester (on Dorce Ceastre, Oxfordshire), and in the next year we have the entry of Eadred's death at Frome (on Frome), and of his burial at the Oldminster (Ealdminster), Winchester.

Eadwig, son of Eadmund, succeeded Eadred, and in 957 banished Dunstan.

In 957 the death is recorded of Archbishop Wulstan of York, who was buried at Oundle (Undela).

In $95^{8}$ Eadwig died and was succeeded by his brother Eadgar. Eadgar was favourable to the monks, and, sending for Dunstan, gave him the Bishopric of Worcester (Wigarceasire), and afterwards that of London. He made him Archbishop in 961 . In 962 Paul's Minster of London was burned, and rebuilt the same year.

In 963 Æthelwold was made Bishop of Winchester, and having obtained permission from King Eadgar, proceeded to restore the minsters, which had been destroyed by the heathen. He rebuilt Ely (Elig) and placed monks there, and proceeding to Peterboro' (Medeshamsted), found there nothing but old walls

of theirs. Abbandun has become Abingdon, showing the tendency to introduce the patronymic ending -ing in place-names.

Calne, which lies some four miles north-east of the Roman station of Verlucio, bears the same name as it had in the Ang.-Sax. Chron., and is probably Celtic. Cal-ston hill, close by, may involve the same initial element, suggesting an early*Calo-dunam as the origin of both. Seoles-igge is regarded as meaning Seal's island (ige), but one wonld expect the genitive plural in the former element and not the singular. As it is written it seems to contain a personal name in the genitive.

In Lege-ceaster we have an anglicized mode of representing Castra Legionis, or "Camp of the Legion".

Crediton, which was then the seat of the Bishop of Devonshire, appears here for the first time. It is on the Credy river, which, if not evolved from the name of, seems to have given origin to, the Cridian-tun of the Chronicle. Rumes-ige (Ramsey, Hunts.) is, according to its form, "the island (ige) of a certain person called Rum." No such name occurs in Searle's Onomasticon, and it is possible that we have here, as in Hrofes-ceaster, a corruption of some pre-Saxon place-name, the more likely as there are several places so called, cf. Ruim, the British name of Thanet. 
and wild woods. In the walls, the Chronicle [E.] tells us, he discovered a writing, which had been drawn up by a former Abbot, stating that the Minster had been built by King Wulfhere (A. D. 656) and Æthelred his brother. On showing Eadgar the discovered document the king made to the Minster grants of land in various places. ${ }^{1}$ Ethelwold was the first to make a wall about the Minster, and hence gave it the name "Burch" (that is, Peter-burg), and had the relics of St. Kyneburh and St. Keneswith, which lay at Castor (Castre), North Hants, and those of St. Tibba at Ryhall (Rihala), Rutland, transferred hither. Die Heiligen Englands, pp. I I, I 3, says that St. Botulf was buried at Medeshamstede "near the river (éa) Nén". Mention is also made there of the saints above-named, and also of St. Florence, martyr.

Under 964 the Chronicle records that canons were expelled from Winchester (both from the Aldminster and the Newan Minstre) and from Chertsey (Ceortes-ige) and from Milton (Middeltune), and monks set in their place.

In 966 the Chronicle [E.] records the ravaging of Westmoringeland (Westmorland) by Thored, Gunnar's son; and in 969 we find Eadgar ordering Tenetland (Isle of Thanet) to be pillaged.

In $97 \mathrm{r}$ Oskytel, Archbishop, is recorded (Chronicle B.) as having died at Thame, Oxford (at Tame).

In $97 \mathrm{I}$ (970) the death is recorded of Eadmund Ftheling and his burial at Ramsey, Hunts. (at Rumesige). Eadgar, who had succeeded to the Crown in 958 , was solemnly consecrated king, according to the Chronicle, in 973, at the "Ealdanbyrig, Acemannes Ceastre, that was also called Bathan" (Bath).

In 975 Eadgar died and was succeeded by Eadward, who was slain at Corfe Castle (aet Corfes Geat) in 978 and buried at Wareham (Warham), but his body was afterwards removed to

1 These place-names are given in the Chronicle, but seem to be twelfthcentury forms. 
Sherborne. He was succeeded by Ethelred, who was crowned at Kingston (at Cinges-tune) in 979.

In 977 there was a great meeting at Kirtlington, Oxford (Kyrtlingtun), at which died suddenly Sidemann, Bishop of Devonshire (Defnascire), who, although he wished to be buried at his bishop's stool at Crediton (Cridiantun), was, by order of King Eadmund, interred in St. Mary's Minster at Abingdon (Abbandun).

In 978 there is a record of an accident at Calne in Wilts., in which all the chief men of the Wittan ("parliament"), with the exception of Dunstan, fell from an upper story, with the result that some were killed and others injured.

In 980 Athelgar was consecrated Bishop of the See of Selsey (Seolesigge), afterwards transferred to Chichester, and in the same year Southampton was ravaged by the heathen sailors, who killed or took prisoners many of the inhabitants. Thanet was also overrun by the enemy, and Chester (Legeceaster) by a northern band of the same pirates.

In the record of the Anglo-Saxion Chronicle covering the period from the accession of King Ethelred, in 979, until his death, in 1016, we have nothing but a series of calamities suffered by England at the hands of the Danes. Under 98I, we have, as already mentioned, the pillaging of Southampton, upon which followed the ravaging of Sce. Petroces stow ${ }^{1}$ in Cornwall, and attacks upon the coasts of the Devonians and of

1 St. Petrock's stow. Padstow in Cornwall, and Padstow in Devon were originally called Petrockstow. The latter is called Petroches-stow in Domesday. The place here meant, however, is evidently the Benedictine Monastery at Bodmin, which appears in the Bodmin Manumissions (eleventh century), as "æt Petrocys Stowe", see Haddan and Stubbs, Councils, i. 683, where the question is discussed whether this was the seat of the Cornish Bishopric before its removal to St. Germans ("called by the British Llanaledh"). The appearance of Stow (here the place of burial or the shrine of relics of the saint) in Cornwall at this time shows the extent of Early English influence there. Professor Napier and Mr. W. H. Stevenson (Crazuford Charters) would make the place the other Padstow in Cornwall, and not that of Bodmin, against Haddan and Stubbs. 
the Welsh (Cornish) (ge on Devenum ge on Wealum). In the next year, three Wicing ships made a descent upon Dorset and ravaged Portland (on Portlande) ${ }^{1}$

In 984 , the death of Ethelwold, Bishop of Winchester, "the father of monks," is recorded, and under 986 we have the announcement that the king devastated the bishopric of Rochester (Hrofeceastre) and that a great murrain broke out in England the same year.

Under 988 (variant 987 ), we have the record of the ravaging of Watchet (Wecedport) $)^{2}$ by the enemy, and of the death of Archbishop Dunstan (St. Dunstan).

In 993, we have an account in the Chronicle of the arrival at Stane ${ }^{3}$ of 390 ships under Unlaf, which, after going to Sand-

1 Portlande. This shows that the element Port, borrowed from the Latin, and probably through Romano-British, had come to be applied by English to place-names. Port-loc, already referred to, is another instance. Por (as in Porchester and Porlock) seems to be the usual contraction. Whether Pur-beck contains the same element is not clear.

2 Weced port. Wacet in Domesday; Wechet in thirteenth century. This is probably one of the early names ending in $\operatorname{Cet}(=\mathrm{Coed}=$ wood), to which reference has already been made. *Guocet (*Vocetum, cf. Vocetius Mons. Holder, Sprachschatz, cf. note on Dunfoeder), would mean underwood.

3 Stane. Mr. Plummer (Anglo-Saxon Chronicle) has identified this with Folkestone, but the latter was called at the time of Domesday, and probably from its origin, Fulchestan. There are several places called Stone in Kent, but two, as suggested in the sixteenth century (Lambarde's Kent, p. 205), seem to offer possible sites-one is in the island of Oxney, near Appledore, which the Danes had been accustomed to use as a port, and the other on the Watling Street, two miles west of Faversham and eleven from Canterbury. The old ordnance map says of the latter, "in ruin." As the Durolevo of the Itinerary of Antonine was about twelve miles west of Canterbury, the latter Stone may mark the site. Stane is the dative (locative) singular, and may indicate a great rock or a ruin, or milestone. Nennius (Mon. Germ. Hist., Chronica iii, p. 187) calls the third battle between Vortemir and the Saxons that iuxta lapidem tituli qui est super ripam Gallici maris, which "inscribed stone" may refer to Folkestone. Stone on Watling Street was accessible from the Swale by a tidal stream, and Sandwich could be readily reached therefrom. Sand-zic, as already pointed out, involves, like Gypeswic, Northwic, Greenzic, the 
wich, made a raid upon Ipswich (Gypeswic), and thereupon we have the record of the slaying of Brihtnoth, alderman, at Maldon (Mceldon), ${ }^{1}$ Essex. Then, adds the Chronicle, owing to the terrors infused by the descents of the Danes upon the coast, the - English began the practice of buying off the foe by the payment of large sums of money- $£_{10,000}$ in this instance. King Ethelred gathered, in $99^{2}$, a great fleet together at London to crush the enemy, but owing to the treachery of one of his officers, as the Chronicle tells us, his attempt was defeated with great slaughter of his men.

The Danes now attacked the north-east coast, destroying the stronghold of Bamborough (Babbanburh), and devastating from the estuary of the Humber (Humbran muthe) the territories of Lindsay (Lindesige) and Northumberland. The next year (994) is marked by the arrival at London of Anlaf (King of Norway), and Sweyn (Swegen), King of Denmark, with 490 ships, but they could not capture the place, receiving, as the Chronicle says, more hurt than they rendered. In revenge they ravaged Essex, Kent, Sussex, and Hampshire, and King Æthelred had to come to terms with them, giving hostages-Anlaf being conducted to the king, who was then at Andover (to Andeferan), ${ }^{2}$ with great ceremony.

Under 995, we have the selection of Alfric at Amesbury (on

Scandinavian $v i k=$ bay. Gypes-wic involves also probably a personal name in the genitive, although the river is called (? evolved) "Gypping ".

1 Mældun (in Domesday, Melduna) is now Maldon. The Mal has a Celtic appearance ("bald", "treeless") and the Dun may be either the Saxon "Down" or the Celtic Dunon, a "stronghold". Hrofe ceastre; note that Bede's Hrofes is not maintained, cnstom being stronger than his etymological guess.

2 Andefer-an. This is Andover. It preserves a later form of the Early British $D u b r=$ water, river. The presence of this name, as well as Michel-dever (that is, "great water"), and Cen, or Can-dover in Hampshire, shows that Celtic influences survived the Conquest here. In a charter of Cod. Dip. 534, there is a Cen-defrion in Devon. The latter element is the plnal of Defr, earlier Dubr, cf. Caldour, earlier form Kaledofr, Mon. Ann. of Teviotdale. 
Ambresbyri), ${ }^{1}$ Bishop of Wiltshire (that is, Ramsbury), as Archbishop of Canterbury.

The year 997 is marked by the arrival of the enemy at the mouth of the Severn (Safern Muthan), whence they harried Devon, Wales, and Cornwall. Then, after again ravaging Watchet, they went round the Land's End (Penwiht Steort) ${ }^{2}$ to the mouth of the Tamar (Tamer Muthan) and proceeded as far as Hlidaford, ${ }^{3}$ burning and slaying wherever they went, Ordulfes Minster at Tavistock (Tefinge stoc) ${ }^{4}$ being given to the flames by them.

The next year (998), the enemy proceeded eastward to the

1 Ambres-byri. This is now Amesbury, and the tradition connecting it with Aurelins Ambrosius may have a foundation in fact. Ambrosius is a name derived from the Greek, but it had got into currency among the Latins at an early date. Asclepiodotus is a similar latinized name. Æthelinga-dene has not been identified. It would now be something like Aylden or Aylingden. It would not give, as has been suggested, Alton (Hants), of which the early form (Cod. Dip. 314) is Evweltun, that is, Spring-ton $(E a-$-well $=$ river source).

2 Penwihtsteort. This appears in Simeon of Durham as Penwithsteort. Steort is an English word meaning "tail", as in the bird Redstart. It is applied to a prominent headland, as "Start Point". Penwith, the Cornish name of the district, came to be applied to the Land's End. Tol Pedn Penwith is another point near. The meaning of with or guith is not clear. It could hardly be Cornish Gwedh, Welsh Gwodd, meaning "woods", for no woods conld well grow there. There is, however, no nearer term, and the Welsh Penzedic seems to be of similar import = wooded point. The name of Land's End in the Welsh Triads is Penbryn Penwaeth, and also Penzedic yng Nghernize (Myrv. Arch.).

${ }^{3}$ Hlidaforda is now Lydford, Devon, and the stream is called the Lid. Numerous Celtic river-names have the prefix Lit (? stem leto-s = broad, Welsh Llêd : and Ganlish Litanos in Litanobriga = "Broadburg, = Bradbury), as in Lit-ana and Olitana in Cart. Sax., which seem to be involved in the Leden-ford of the same charter; Leadon is the form preserved of the latter in English-speaking regions.

- Tefingestoc. This shows that the termination ing was applied to river-names with the same signification as the genitive case. Tavy is now the river-name. To judge from the analogy of Welsh Tave (silent) which is traced (Pedersen, Gramm. 37) to *Tausos, the earliest form was probably *Tausobios which occurs in Ptolemy in the form Toisobios as a river-name. 
mouth of the Frome (From-muthan), whence they raided Dorset on all sides. They proceeded next to the Isle of Wight (Wihtland), Hampshire, and Sussex, and in the next year (999) they came round into the Thames (into Temese), and went up the Medway to Rochester (Hrofeceastre). Here they encountered the Kentish host, which they defeated and put to flight.

King Ethelred proceeded in 1000 into Cumberland (Cumerland) and ravaged nearly the whole country, and afterwards came to Chester (Legceastre), but failing to get in there, made a raid upon the Isle of Man (Manige).

In roor, according to the Chronicle, the Scandinavian pirates brought great trouble on England, burning and harrying everywhere. On one expedition they encountered the men of Hampshire at Ethelingadene, and inflicted defeat upon them, slaying Æthelweard, the King's High-reeve, Leofric at Whit Church (at Hwitciricean), ${ }^{1}$ Godwin at Worthy (Worthige), and other notables, they themselves also suffering serious loss.

Pallig (a Danish earl, according to Mr. Plummer), having deserted King Æthelred, from whom he had received many benefits, burned Teignton (Drews Teignton) and many other good "homes" (háma) in Devonshire. Then, proceeding to Exmouth (Exanmuthan), he made an expedition to Pinho (Peonho)," Devon, where he defeated and put to flight King Athelred's forces, burning the "homes" at Pinho and Clist-ton (Glis-tun).3 Pallig then went to the Isle of Wight, whence he

1 Hzitciricean is Whitchurch (Hants) and Worthige is probably one of the places of this name near Winchester.

2 Peonnho is now Pinho, near Exeter. The Old Cornish form of Penn (= "head") was later Pedn. The early British form would be Pend, corresponding with the early Irish Cend. Pend would naturally become Penn, but in Cornish, and possibly in South British generally, the termination $n d$ instead of becoming $n n$ became at some time $d n$, and this possibly accounts for the Saxon pronunciation Peon instead of Pen, which is found elsewhere. The ho is hoh $=$ head-land.

s Glistun, of which there is the variant Clistun, is one of the "Clysts" on a river of that name not far from Pinho. Clyst is Celtic, since it appears in the Liber Landavensis. Its meaning is obscure. 
burned Bishops Waltham, Hampshire (Wealtham), ${ }^{1}$ and other hamlets (Cotlifa). Nothing, says the Chronicle, could withstand the enemy on sea or land, and in 1002 the king was obliged to buy them off once more by a payment $\left(£_{24}, 000\right)$.

In this year (1002), Ymma Elfgiva, daughter of Duke Richard of Normandy, came to England, and in the following year, 1003, the Reeve Hugo appointed by her took Exeter by storm and destroyed the defences (burh) there.

Sweyn (Swegen) entered Wilton in the same year and destroyed the stronghold, then proceeding thence to Salisbury (to Searbyrig) went afterwards to his ships. In 1004 Sweyn destroyed the stronghold at Norwich, and three weeks after came to Thetford (Theodforda), which he plundered and burned. As he was about to proceed to his ships on the morrow, he was encountered by Ulfcytel, ${ }^{2}$ an East Anglian notable, who inflicted serious loss upon Sweyn's army, although he was not able to prevent them getting to their ships.

In 1005 the Danish fleet went to Denmark, but in the following year came to Sandwich (Sandwic) and ravaged the country on every side. In mid-winter they went through Hampshire and Berkshire (Bearruc-scire) to Reading, and thence to Wallingford (Wealinga-forda) ${ }^{3}$ and Cholsey (Ceolesige), and along Æscesdun to Cwicelmes-hlæw. The king's forces assembled at the Kennet (at Cynetan) or at Kintbury, to give them battle, but were defeated and put to flight. The king and his council then agreed to pay tribute to the enemy and to victual them

1 Wealtham is Bishops Waltham, Hants.

2 Ulf-cytel, who was probably Alderman of East Anglia and a son-in-law of the king, is singled out for merited praise. A series of place-names a few miles east of Bungay perpetuate apparently his name. There is here a number of parishes, their centre being "the Moat Minster" (which possibly goes back to St. Felix), denominated each by a saint's name, followed by the word Ilketshall. This is in Domesday Ilchesteshala for Ulf-ketels-heala, heall meaning mansion.

3 Wealingaford preserves the name of an old ford over the Thames probably used by the Romano-British (Wealas). Ascesdun is Ashdown, Berks., noted for several encounters there with the Danes. 
throughout the English nation, the tribute paid in the year roo7

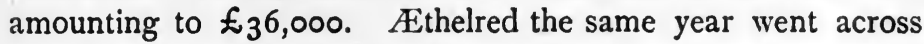
the Thames into Shropshire (Scrobbesbyrg). ${ }^{1}$

A great fleet got together by Æthelred became at length useless through incapacity, and when Thurkell's army came to Sandwich they were able to proceed unmolested to Canterbury, where the people of East Kent bought peace at the cost of $£_{3,000}$. The stronghold at London was again attacked by the enemy, but without success, and after mid-winter the latter proceeded through Chiltern to Oxford, which they burned. They then crossed the Thames at Staines (at Stane) and wintered in Kent, repairing their ships.

In roro they ravaged East Anglia and got dominion over it, and even made expeditions among the fen lands. Thence they proceeded westwards into Oxfordshire and Buckinghamshire, passing along the Ouse (Usa) until they came to Bedford (Bedeforde), and so to Tempsford (Temesan forda). The same year they burned Northampton (Hamtun) and then went over the Thames to Wessex, and so to Canning Marsh (with CaneganMersces). ${ }^{2}$

In ror I they had overrun the greater part of the country, and

1 Scrobbesbyrig would seem to involve a personal name in the genitive, but the term may be, like Hrofesceaster, a degraded form of some native designation. We have in an original charter of 901 (Cart. Sax.), "in civitate Scrobbensis," which is the earliest mention of the place, and suggests that the name was then something like Scrobba. The Welsh name Pengwern would mean either " chief signal station" (grvern = mast) or "head of the swamp" (grwern-og = "boggy"), or " head of the Alders" (Gwern = Alders). Amwythig, the Welsh name of the district, wonld mean "surrounded with woods", so that Scrobba may be an attempted translation = "scrub".

2 Caningan Marsces is said by Mr. Plummer to be "Canning fen" in Somerset. I have not found it on the Ordnance map. Cannington Hundred occurs, and there is a Caningis (Wilts.) in the British Museum Charter Rolls. In the Codex Dipl. 1193 we have a Canninga mare which may be the same place. Medewægan = Medway. Wag or Waga appears in the names of several rivers; as in the "Wye" and Weymouth, Dorset, and Weybridge. Its meaning and origin are obscure. 
capturing Canterbury, made prisoner Ælfheah, the Archbishop, whom they afterwards (IOI2) slew.

In ror 3 Sweyn came again to Sandwich and proceeded thence to East Anglia and to the Humber, and up the Trent to Gainsborough (Gegnes burh). Then all the people of Northumbria and Lindsey and the "five boroughs", and finally all the army north of Watling Street (Waclingastrat), and all the people held Sweyn for full king, and Ethelred went at length to Normandy. Sweyn died in IOr 4, and King Æthelred, having returned, tried to win back the country.

From Ior 4, when King Æthelred returned from the Continent, until his death at London in ror 5 , he was in continuous warfare with Cnut. Eadmund Etheling (known afterwards as "Ironside") was chosen king, and succeeded to a distracted kingdom. He had to withstand Cnut's attack on London, to which the latter constructed a dyke so as to get his ships above the bridge. Eadmund held his own, however, and proceeding into Wessex, fought the enemy at Pen (at Peonnan), ${ }^{1}$ near Gillingham (Gillinga-ham), and shortly afterwards another battle at Sherston (Sceorstane), Wilts. Then, gathering his forces for the third time, he proceeded to London, and thence north of the Thames, and so out through Clayhanger (Clceighangra). ${ }^{3}$ Then returning across the river by Brentford

1 At Peonnan. This is evidently the same as at Peonnum, the more correct form, in the Chronicle under 656, and is generally identified with Pen-selwood, Somerset. The latter appears in Domesday as Penna. Peonn-um is the locative plural, representing doubtless the Cornish Pennou = "heads", "hills". Gillinga-ham is Gillingham, Dorset, about four miles to the south-east of Pen-selwood. For the latter word see a previous note.

2 Sceorstane (Sherstone, Wilts.) was evidently some standing stone with a sharp edge. Scear-Seax, which means also "sharpstone" literally, is used for "razor".

3 Claig-hangra. Hangra or Angra is a frequent element in placenames, bnt it is not found in any explanatory text, although of frequent occurrence in land boundaries. Toller-Bosworth, A.-S. Dict., makes it a meadow, but this is an unsupported guess. From its application it seems 
(Bragentforda), ${ }^{2}$ he had another successful engagement with the enemy, putting them to flight.

After another vain attempt upon London, the enemy's fleet proceeded up the Orwell (Arwa) into Mercia, plundering and destroying everywhere. Eadmund then attacked the enemy in Kent and drove them into Sheppey (Sceap-ige). He then had a meeting with the treacherous Eadric, Alderman, at Aylesford (Egelesforda), ${ }^{2}$ Kent.

The enemy were now ravaging in Essex and Mercia, and Eadmund, having collected all the English he could gather, followed the foe up and overtook them in Essex, at Ashingdon (Assandun), ${ }^{3}$ near the Crouch, where Cnut won the victory, Eadric, according to the Chronicle, having treacherously begun the flight with the Magesatas." Eadmund went to Gloucester-

to mean the slope, or inclination of a hill; ct. Stone-henge (Stan-hange) $=$ "sloping stones". It is generally associated with woods, indicating trees on a hill-side, e. g. Haslehangra, Esshangra, Thornhangra, Birchanger (cf. Eschongas, Cod. Dip. 1067). Here it means "Clay Slope". Clayhanger is in Essex (there is also another in Devon and one in Staffordshire). Angra in Domesday is the early form of Ongar. Hunger-hill in Somerset is another deformation, and Rishangles, near Thorndon, Suffolk, is, the Rector, the Rev. H. A. Harris, tells me, Ris-angra in Domesday. Here the Ris represents Hrisc = "rush", the meaning of the whole being "Rushy Slope". A similar degenerate form, pointed out to me by the Rev. W. R. Harrisson, occurs in the Taxatio form Shelfangel for Shelfanger.

1 Bragentforda, near Brentford, Middlesex, preserves one of those early British river-names ending in ent or -ant, possibly participial in origin. This may, like Deva, Camel, \&c., involve the name of a Celtic deity, e. g. Brigant, surviving in St. Bridget.

2 Egeles-forda, now Aylesford, Kent, is an instance of the association with a ford of a personal name, e. g., Agelaf, in the genitive case. The latter being probably for Ecglaf, that is, "a survival of the sword," or one whose kin were cat off.

${ }^{3}$ Assandun has by attraction, not by philological law, become Ashingdon. Assa is probably a shortened form of some such name as Asabeorht (Searle's Onomasticon). Florence of Worcester, the Mediaeval Chronicler, made the word Mons Asini, "the hill of the ass"!

- Magesatas. These were a people of Hereford, probably employed 
shire (Gleau-ceastrescire), where at Olan-î́ge, ${ }^{1}$ near Deerhurst (Deorhyrst), he and Cnut became friends, and the kingdom was divided between them; Eadmund obtained Wessex as his share, while Cnut got Mercia, including London, where he wintered. Then in the same year (ror6), Eadmund died and was buried at Glastonbury (Glestinga byri), and Cnut became monarch of all the English race. The exactions of tribute became even heavier, $£_{72,000}$ having been paid in 1018, not counting the payment of $£_{10,500}$ by the citizens of London. The next year the Chronicle records Cnut's visit to Denmark, whence he returned in the following year (1020). In this year there was a great assembly at Cirencester (at Cyren-ceastre), ${ }^{2}$ and Cnut assisted at the hallowing of the Minster at Ashingdon (Assandun), to commemorate, no doubt, his victory there. Simeon of Durham, under ror 8 , tells us of a battle at Carrum (identified by Mr. Skene as Carham, near Coldstream), in which Malcolm, King of Scotland, and Owen the Bald, King of the Luetensium (men of Carlisle, according to some, or of Strath Clyde, according to others), ${ }^{3}$ won a victory over the Northumbrians.

In ro23 King Cnut gave permission at St. Paul's Minster in London to have the body of Ælfheah taken up. In the presence of the king, archbishop, and bishops, it was put on ship-board

here as mercenaries. In an original charter in the British Museum (Facsimiles) Yarkhill (Geardcylle) is in Magon-Setum, that is, in the land of the Magon-satas. Magon looks like the British Magos = plain, the whole term thus meaning settlers on the plain.

1 Olanîge was probably Alney Island some six miles south of Deerhurst, but not near enough to satisfy Mr. Plummer. In a charter ascribed to 744 (Cart. Sax. i, p. 242) Olan occurs as a river-name, but it seems to be the same as Olitane in the same charter, and perhaps as Leden in the Ledenford in the same charter.

2 Cyrenceaster, Cirencester, contains the ancient Romano-British Corinium, possibly derived from a river Corin, now represented by the Churn, and by the Cern in Cern-ey.

3 Luentinum, cf. Ptolemy's Luentinon, a town in Demetia = South Wales, and cf. the river Lune, Londes-dale, and the Celtic stem Louno = mud, and Welsh Lludedic glossed "Coenosus". 
and taken over the Thames to Southwark (Suthgeweorke), ${ }^{1}$ and thence to Canterbury. In 1025 Cnut was in Denmark again and fighting with the Swedes. In 1028 he took possession of Norway, and returned in the following year to England. In I03 I he went to Scotland and received, according to the Chronicle, the submission of King Malcolm, and of two other kings, Mælbæth and Iehmarc.

In ro33 the Chronicle records the death at Kempsey (Kemesegia, says Florence of Worcester) of Leofric, Bishop of Worcester, and his burial at Worcester (Wigra ceastre). In the next year Ethelric (variant Ælfric), Bishop of Worcester, died and was buried at Ramsey (Rames-ige), ${ }^{2}$ Hunts. The Chronicle records under ro34 the death of King Cnut at Shaftesbury (Sceaftesbyri), his burial at Winchester, and the election of Harold as king. In 1037 Æfic, the Dean, died and was buried at Evesham (on Heofeshamme), ${ }^{3}$ and the Chronicle records under ro39 the death of Bishop Byrhtmær and his burial at Lichfield (Licetfelda).4 King Harold died at Oxford (Oxnaforda) in 1040 and was buried at Westminster; and Harda-Cnut was brought from Bruges to succeed him. He landed at Sandwich and was welcomed by English and Danes, but he died at Lambeth (Lambhythe) $^{5}$ in 1042. He was succeeded by Eadward, who

1 Suth-geweorke, Sonthwark, is the fortified place ("work") on the sonth of the Thames.

2 Rames-ige, Ramsey Abbey, Hunts. Ram would be probably for Hram = Hraben (raven), a man's name, but it appears earlier as Rumesige, see note, p. 277. Mr. Plummer is my anthority for making this place to be Ramsey, Hunts.

3 Eofes-hamme, now Evesham, takes its name according to an ancient legend, from a certain Eofa. The latter part of the word is hamm, a piece of land, especially by a river.

- Licetfelda, Lichfield, has been already dealt with. As an instance of another transition stage between $\mathrm{Le}[\mathrm{c}]$ to-cetum, Cair Luit coyt, and Licet-feld, attention may be drawn to the form in the Welsh Triads "Caer Ligidit" (Myrv. Arch.) for earlier Licitit : Licet is clearly for Litcet.

s Lambhythe. This is evidentiy a late form, in which the Anglo-Saxon Lam (= loam) had degenerated to Lamb. In 1088 it was Lamhytha 
was crowned at Winchester in 1043. He married Earl Godwin's daughter, Eadgythe, in 1043.

In 1046 Earl Sweyn, son of Godwin, made an expedition into Wales, and Griffin (Gryffith = earlier Grip-iud), the king of the North Welsh, gave him hostages. On his way back he sent for the Abbess of Leominster (Leomynstre), ${ }^{1}$ and keeping her for a while, then let her go. In 1047 the orator, Bishop Lyfing, who had three bishoprics (Devon, Cornwall, and Worcester), died.

In 1046 Thanet and Essex were ravaged by Northmen, who went thence to Bruges, and in 1049 the Emperor attacked and brought to submission Baldwin of Bruges, because he had destroyed the Emperor's Palant ${ }^{2}$ at Nymegen $^{3}$ (Neomagan) in Gelderland. In the same year there was an earthquake at Droitwich $(W i c)$, in Worcestershire, and at Derby (Deorby). In 1049 King Edward gathered a great fleet at Sandwich, and

(B.M. Charters and Rolls). Cf. Lamseathas = Loampits (Cod. Dip. 570). For parallelism of the idea, compare Cealchythe $=$ chalk-harbour, now Chelsea.

1 Leominster is puzzling. The form here given is later than the Leofminster of Domesday, which suggests an earlier Leofan-Minster, Leofa being a shortened form, which actually occurs, cf. Leofdag, or Leofric, a common personal name. The legend about Leo $=$ Lion is a monkish invention.

2Palant. This is usually assumed, as by Mr. Plummer, to be "Palace", but, as Prof. Kluge has shown (Deutsches Etym. Wörterbuch sub Pfalz), it has quite a different origin. The Old High German Pfalanza (which gives Pfalz) corresponds with the Old Saxon Palencea. This cannot come from the Latin Palatium, but rests on a Middle-Latin Palantium = "wall", or "stockade", "contextus ac series palorum." The word had been adopted in Germany in the beginning of the eighth century, and when palaces came to be built there later, was identified with the latter. The word still survives in English nse-as in " the Palant" at Chichesteralthough it is not noted in the Nerw English Dictionary. A word of similar origin-Palancata - is given by Ducange as meaning "Palisade" from palis = pale, a stake.

${ }^{3}$ Neymegen or Nijmegen is the modern form of Novio-mag-um, the new-[settlement on the] plain, as opposed to Seno magnum, an older settlement. 
Earl Sweyn, having come with seven ships to Bosham (Bosenham), ${ }^{1}$ went and submitted to the king, but he was opposed by Harold and Beorn. Sweyn returned to Bosham, but Godwin and Beorn went to Pevensey (Pevene sea, Pefenasae, but these are later forms than that in Domesday, viz.: Pevenesel, a manifestly Celtic word).

Sweyn came to Pevensey and asked Beorn, with foul intent, to accompany him to the king at Sandwich. Sweyn bound him and took him on board ship and carried him to Darenta Mutha, ${ }^{2}$ where he killed him and buried him deep. But his body was ultimately brought to Winchester.

It was told King Edward that Osgod Clopa (i.e. ?"the lame"), who had been outlawed, was with a fleet at Wulpe (Ulpe) in Flanders, and the king sent for his ships that were lying at Northmouth (North Mutha), ${ }^{3}$ in order to attack him, but Osgod with some ships escaped, while the other ships went to the Naze (Eadolfesncesse) ${ }^{4}$ in Essex, where they did much harm.

Sweyn, the murderer of Beorn, is recorded as having lost about this time (1050) two of his ships, which were captured

1 Bosenham, now Bosham, near Chichester, is where the Irish Missionary Dicuil-one of Fursey's companions-had a small monastery, as Bede tells us (H.E. iv. 13). Bosa, who gave his name to the place, was probably one of the monks there, and possibly the same Bosa who was Archbishop of York (ibid., iv. 12).

2 Darenta-mutha, in other MSS. Derta Mutha and Axa Mutha. Mr. Plnmmer identifies this with Dartmouth, but there is no evidence that the Dart was ever called the Darent. The river Darent or Derwent, which ran into the Thames below Dartford (i.e. Darentford, Derentefort in the twelfth century), is more probably the river intended.

s North-mutha, according to Mr. Plummer (Sax. Chron.), is the northern mouth of the Kentish Stour.

4 Eadolfesnas, according to the same anthority, is the Naze in Essex, but as one of the MSS. says it was in Sussex it may be the Nasse (Dungeness) referred to later. The former hypothesis is the more probable, as the Soke of Eadwulfenese contained, according to Mr. J. H. Round (Feudal England, p. 107), Walton-on-the-Naze. 
by the men of Hastings (Hastinga Ceastre) ${ }^{1}$ and taken to the king at Sandwich (Sandwic). In the same year (1050) the Chronicle records that thirty-six ships came from Ireland to the Usk (Wylisce Axa), ${ }^{2}$ and did much damage thereabout with the aid of Gryfin, the Welsh king. Ealdred, Bishop of Worcester, attempted with a small force to withstand them, but was defeated. In the same year are recorded the deaths of Oswig, Abbot of Thorney (Thornege), Cambridgeshire, and of Sigward, Abbot of Abingdon (Abbandun). King Eadward's favour towards the Normans (called French in the Chronicle) is shown by his appointing one of them, Robert (Rodberd), Archbishop of Canterbury, and by his allowing them to build castles in various parts of his dominions. In I $_{5} \mathrm{I}$ Robert, having obtained his pallium at Rome, returned to England, where he used his influence with King Eadward to have Earl Godwin and his sons expelled the kingdom. The immediate reason for their exile was the conduct of Godwin towards Eustace, who was Count of Boulogne and brother-in-law of King Eadward. This Eustace, having, on his return from a visit to the King, entered Dover

1 Hastinga Ceastre. The application of "Chester" to Hastings does not indicate that it was ever a Roman stronghold. The English had adopted the word early, and applied it to fortified places generally. Hastingas is the name of the district, or rather the people of the district, in the Chronicle under A.D. Iorr. Hasten, the Danish chief, who made settlements in the estuary of the Thames in the end of the ninth century, may well have given origin to the name, Hastingas = descendants of Hasten.

2 Wylisce Axa. This is the Welsh Ax, or the Usk, and indicates the common source of the river-names $A x$ and $U_{s k}$, that is, Esc or Uisc = water, still surviving in Irish with that meaning, and preserved in Whisk-ey. Its earliest Romano-British form is Isc-a. It does not seem to find a representation in Welsh place-names except in Usk, but is frequent in such connexion in Ireland and Scotland: cf. the rivers Esk in the latter country and such componnds there as Desk-ford, where the first element contains probably $D a E s k$ (= "two waters") or Duhb-esk= Blackwater. Cf. the Finisk (= Fionn-Uisg $=$ Whitewater $)$ falling into the Blackwater near Cappoquin. This is called the "Phoenix", like the Park in Dublin of the same name and origin. 
(Dofra-n $)^{1}$ with his Norman followers fully armed, acted towards the citizens in a high-handed manner, with the result that a conflict ensued in which some twenty English and an equal number of Normans were slain. The king, on hearing of the matter from Eustace, was very angry with the people of Dover, and ordered Godwin to attack them. But Godwin was no friend to the Normans, and refused to do so. The king then called to him at Gloucester (Gleawe ceastre) all his notables for counsel. Now at this time the Normans (Welisce men) ${ }^{2}$ built a castle in Herefordshire (Hereford scire) in a region belonging to Earl Sweyn (Swegen), where they wrought much harm upon the king's men. Thereupon, the Chronicle states, Earl Godwin and his sons Sweyn and Harold came to Beverston (Byferestan), ${ }^{3}$

1 Dofra = Dover. This is the form which the Dubris of the Antonine Itinerary (ad Portum Dubris) had taken at this time. Dubris is a locative plural, the early nominative singular being $D u b r o \cdot n=$ water. A place called originally Dubrum in the Seine-et-Marne district is now Douvres, precisely the French word for the modern Dover. The "b" seems to have become " $f$ " or " $v$ " in English under Celtic influence. Dofras, the English plural form, appears in a twelfth-century charter (Cart. Sax. i. I 30 ). The British plural form, Dofron, appears in Wan-dofron (Cod. Dip. 593) now Wendover; and in Cen-defrion (ibid. 534, an original charter) the name of a stream near Zele monachorum, Devon.

2 Welisc men means here men speaking a neo-Latin tongue, that is, French-speaking Normans. The early application of "Welsh" exclusively to those who spoke Latin or neo-Latin has been already referred to.

3 Byferestan = Beverston, Gloncestershire. The Rev. C. S. Taylor (Bristol and Glouc. Arch. Trans. xix. 80) shows the suitable character of the site, which was close to the Fosse-way. In the MS. D the place of meeting is called Langatreo, that is, "tall tree". Longtree Hundred in Gloucestershire preserves the name. Many place-names end in trêon, which Dr. Henry Sweet says is an Anglian word, as opposed to Beam, but treozw occurs in exclusively Saxon districts. Most of the elements compounded with tréow are personal names, both male and female, as Ealdulfes trkow (Cod. Dip. 1298), Wynburge treove (ibid. 514), and we have also such forms as Hundrede treow (ibid. 709), indicating that these "trees" were the meeting-places of the Hundreds. Cofan-treo,= Coventry, referred to below, may contain the genitive (weak declension) of Cofa $=$ a chamber, or of Cofa, a man's name, probably the latter. 
Gloucestershire, to offer their help to the king against the Normans. The latter, however, forestalled them with the king, persuading him that Godwin had evil designs against him. After some futile attempts at reconciliation, Godwin and his sons were exiled, Godwin with three of his sons going to Bruges (Bricge) and Harold to Ireland. The MS. D adds that Godwin went first to Thorney (Thornege, an island off the coast of Sussex and Hants), and that Harold went to Bristol (Bricg Stowe), ${ }^{1}$ King Eadward having in vain attempted, by sending after him Ealdred, Bishop of London, to intercept him. Sailing out of Avonmouth (Afene-mutha $)^{2}$ in the face of bad weather, Harold reached Ireland. King Eadward sent his wife, who was Godwin's daughter, away to Wherwell (Hwarwella- $n)^{3}$ in Hampshire, to the Abbess there.

At this juncture William (Willelm), afterwards "the Conqueror", accompanied by a great host of Normans (Franciscra manna gen. pl.), paid a visit to King Eadward, and in this year ( 1052 ) another William (Norman by his name) was made Bishop of London.

In the same year Griffin, the Welsh (Wylisca) king, harried

1 Bricgstowe. This seems to be the first mention of Bristol in the Chronicle. Bricg = Bridge, but Stowe was generally applied to places where either things for sale were stowed or where the relics of a saint were preserved, e.g. Ceap-stowe, Chepstowe; Hibaldestowe, Lincoln, St. Alban's Stowe, \&c. Plegstow (now Plaistow) = theatre. The twelfthcentury form, Bristou (B. M. Chart. and Rolls), which is probably as early as that of the scribe of the Chronicle, suggests that Bricg may not be the element involved. Irish influences, suggested by the chapel of St. Brandan, giving name to "Brandon Hill" (see William of Worcester's Itinerary), would suggest a reminiscence of St. Bridget, whose name is preserved in Bridstow, Herefordshire, and in St. Bride's, Monmonthshire. Bristollum appears before the end of the twelfth century (B.M. Chart. and Rolls).

${ }^{2}$ Afene-mutha = Avon-mouth.

3 Hwar-wella-n = Wherwell, Hants; Hover = a basin, and may indicate the shape of the cavity in which the stream welled forth, or a drinking vessel may have been placed at it. 
Herefordshire, and came near Leominster (Leo mynstre), where he defeated the combined forces of the natives and the Normans (Frencisce men). In this year Godwin set out from Bruges and came to Dungeness (Nesse)," "which is south of Romney (Rumen-ea)," and being warned that the king's ships were gone out from Sandwich after him, he put into Pevensey (Pefenesea). Thence, after another visit to Bruges, he came to the Isle of Wight, where he imposed tribute, and finally to Portland (Portlande), ${ }^{3}$ which he ravaged. Harold returned at this time with nine ships from Ireland, and came to Porlock (Portloca), whence, after ravaging the country, he joined his father at Pevensey. (MS. C says Harold came first to the mouth of the Severn (Safern Muthan) near the bounds of the Sumersatas and Devonshire.) Then they both proceeded to Dungeness, whence after taking possession of all the ships they could find in Romney (Rumenea), Hythe, and Folkestone (Folcesstane), and alluring to him all the Kent folk and the boatmen of Hastings (Hasting-a), they went to Dover (Dofra-n) and thence to Sandwich, Northmouth, and London. Some of the ships ravaged Sheppey (Scapige) and Milton (Middeltun), which

${ }^{1}$ Leominster. This has been already dealt with. The early Domesday form excludes association with Leo $=$ Lion, with which the legend referred to by Mr. Plummer (Sax. Chron. ii. 226) couples the name.

2 Nesse, from being south of Rumen-ea, is Dungeness. The whole region seems to have been called Deinge, giving its name also to Dengemersh, later Donemers. Rumen-ea is the river of Rumen, a word which enters also into Romen-hale, Romenal, applied to old Romney and Romney Marsh. The oldest English form seems to be preserved in a contemporary charter dated A.D. 697, namely, Rumining-seta, south of the river called Liminaea. Seta is the genitive plural of ge-Set $=\mathrm{d} w e l l i n g$. The whole would mean "the dwellings of the people of Rumin". Its connexion with "Roman" may seem far-fetched, but the whole region is full of Roman associations. There is against this the fact that the 0 of Rom would not naturally become $u$ in English, but we have instances of the survival of the Latin 0 in Port from Portus and Porta, \&c.

3 Portland and Porlock have been already explained. The occurrence of the full form Folce-stane here is additional evidence why the Stan mentioned under 993 should not be identified with Folkestone. 
belonged to the king. King Eadward was finally forced to come to terms with Godwin, on learning which Archbishop Robert and the Normans (Frenchmen) took horse and escaped, some going west to Pentecostes Castel, ${ }^{1}$ some north to Rodbertes Castel, while the Archbishop proceeded to Eadulfes neese and thence over sea. Stigand succeeded him as Archbishop.

Under 1053 the Chronicle records that Hris (Rhys), the Welsh king's brother, was slain and his head brought to Gloucester, and that Wulfsige, Bishop of Lichfield (Licetfelda), Godwine, Abbot of Winchcomb (Wincel-Cumba), and Egelward, Abbot of Glastonbury (Glastinga-byrig), died, and also that Earl Godwin passed away at Winchester. The MS. C says

1 Pentecostes Castel. Because Florence of Worcester says that Osbern (who was the son of Richard, the son of Scrob) was called Pentecost, Mr. Plummer, following Freeman, argues that this is "Richard's Castle", some four miles sonth of Ludlow, and that the "certain castle in Herefordshire", which the Chronicle says was built by the Frenchmen (Welisce menn) in 1048, is the same. Osbern Fitz-Richard holds, in Domesday, Tenbury, Clifton, and other places on the Teme and neighbourhood. It is natural that "Richard's Castle" would take in his son's, Pentecost's, occupation the name of the new possessor, but why the older name should become the permanent one is not clear. In any case it is difficult to see the aim of the pre-Conquest Normans in occupying this region, where the Chronicle makes them numerous, except they were imported by Eadward to defend the Welsh border. The ruins of the Castle, which was built on a British earth-work, are still visible (Clark's Med. Military Architect. ii, p. 40r). Mr. J. H. Round (Feudal England, 320 et seq.) deals fully with "Richard's Castle", and shows (as against Freeman in Norm. Conq. ii. 607) that Osbern, son of Richard, and Osbern Pentecost, were different persons, and that "Pentecost's Castle" was probably at Ewyas Harold. Scrob (Scrápi is a Scandinavian nickname), the ancestor of Pentecost, might furnish a ready origin for the Civitas Scrobbensis (Shrewsbury) of the Charter, but the date of the latter (90I) is too early. Rodbert's Castle was north of London, and has been identified with Rayleigh, Essex, on what grounds I know not. The use of "castle" in place-names was not infrequent before the Conquest. Cestell Merit occurs in an original charter (Cart. Sax. iii. 473) of A. D. 967. In boundaries we have "on the Cistel" (ibid. 84), "on the Cæstallo" (ibid. 338). Chislet (Cistelet in the Charter), Kent, is very probably a Roman Casteletum, now represented on the Continent as "Chalet". 
that Leofwine, Abbot of Coventry (Cofan-treo), succeeded to the bishopric of Lichfield, and records the slaughter of many English by the Welsh at Westbury (Wast byrig), ${ }^{1}$ Gloucester.

Under 1055 we have the account of an expedition under Earl Siward of Yorkshire into Scotland, where, in a battle there, was great slaughter on both sides, King Macbeth, the hero of Shakespeare's play, escaping. Under the same year is recorded the hallowing of the minster at Evesham (Eofeshamme) and the death of Osgod Clapa.

In 1055 we have the record of the death of Earl Siward and of his burial in the minster at Galmanho, ${ }^{2}$ which he himself caused to be built. The Earl Elfgar-son of Leofric, Earl of Mercia-having been outlawed, went to Ireland, whence with eighteen ships in addition to his own he proceeded to Wales (Brytland) and joined his forces to those of King Griffin. Marching to Hereford (Hereford Port) they put the English there to flight, and burned the town and St. Ethelbryhte's minster there. Harold, gathering a great force, came to Gloucester, where, after having gone a little way into Wales, he had a dyke dug around the town (Port). Hearing that peace was possible, Harold proceeded to Bylgeslege, ${ }^{3}$ where he

1 Wast byrig = Westbury, Gloucester. "Westburg" on Trym appears in a charter dated $793-796$ (B. M. Chart. and Rolls).

2 Galman-ho. Ingram (Two Saxon Chronicles, p. 243) says: "It appears from a MS. quoted by Leland that Bootham Bar, York, was formerly called Galman-hithe"; and Mr. Plummer says Galmanho was a suburb of York. The Culdees were in York for some time (Reeves, Culdees), and we may have here a reminiscence of some Colman belonging to the community. Ganton (Yorks.) was called in II 28 Galmetona (B.M. Chart. and Rolls).

3 Bylgeslege. Mr. Plummer identifies this, without giving reasons, with Billingsley, Shropshire. The process of change is not clear. LEt Byligesdyna, in a charter dated late tenth century, has become Bildeston, so one would expect, not Billingsley, but Bilsley. Byligan fen (Cart. Sax. iii. $5^{87}$ ) which was near Pershore, is another instance of the use of the word Bylig. The genitive in es suggests a personal name, but, pace Mr. Stevenson, there are instances of the use of the genitive of inanimate things in place-names, and this may be Bylig = "leather bag", but generally 
and Ælfgar were made friends. His possessions were restored to the latter, whose shipmen went on to Chester (Legeceastre) to await their pay, which he had promised them. The death of Tremerin (it seems a Welsh form of Transmarinus), the Welsh (Wylisca) bishop, is recorded under this year.

Under the following year, 1056, is recorded the death of Athelstan, Bishop of Hereford, who had built the minster. He was succeeded by Leofgar, who is said to have preserved his moustache during his priesthood until he was made Bishop. Then putting aside his spiritual weapons, he took the field against Griffin, the Welsh king, by whom he and the priests with him were slain. Peace was at length concluded between Griffin and Harold after much slaughter of the English. In this year the death is recorded of Earl Odda and his burial at Pershore (Perscora). ${ }^{1}$

The records in the Saxon Chronicle between ${ }^{0} 0_{5} 6$ and the Norman Conquest in 1066 are marked by few important incidents. Under 1058 we have the statement that Elfgar, who perbaps "swelling", "bulging". Bolgros, Hereford, the Welsh equivalent of Byligan fen, has been translated into the English "Belly-moor". The British Bolg = bag, belly, appears in many place-names, e.g. the Scotch Blabolg, representing the Blatobulgium of the Itinerary, and in numerous Dunbolgs. The word is European, Dante using a form of it for designating regions. Florio, Ital. Dict. I611 ed., says Bolgia is "a gulfe-hole", but cf. the name of Arthur's Sword in Geoffrey of Monmouth, Caleturwlch = Caledfwlch (Irish Caladbolg; see Strachan's Early Welsh, Manchester, 1909), " hard in making notches", or "hard carver", Irish bolg being thus equivalent to Welsh bwlch, English Corfe, a pass, derived from Carve.

1 Per-scora. This, on the analogy of Land-scome (= a division of land), would mean a portion of land for growing pears. Per-e = Pear. Brisnodes Land-share (Cod. Dip. 706), Hebelmes Landschere (ibid. 419), Landschar dic, Landscorford, seem to show that the idea of allotment is involved. The singular ledges at Worth Maltravers, Dorset, are called there "Lanchers", undoubtedly the same word. In the chapel at Deerhurst, assumed to be dedicated by Earl Odda in 1056, an inscribed stone was found which was removed to the Ashmolean Museum at Oxford in 1675. It begins in Latin, "Duke Odda ordered this royal hall to be built and dedicated to the Holy Trinity for the soul of his brother Elfric," \&c. 
had succeeded his father Leofric, Earl of Mercia, was driven into exile, but that he was restored by the aid of Griffin, the Welsh king. Ealdred, Archbishop of York, after having consecrated the Minster at Gloucester to the praise of God and St. Peter, proceeded on a pilgrimage to Jerusalem, where he made costly offerings at the tomb of our Lord. Having returned to England he went to Rome after his pallium in ro6r. In the same year we have the record of the appointment at Windsor (at Windelsoran) ${ }^{1}$ of Ethelsige to the Abbacy of St. Augustine's, Canterbury. In 1062 William, Duke of Normandy (William the Conqueror), subdues Maine (Cynomannia). ${ }^{2}$ Harold and his brother Tostig made a military and naval expedition into South Wales (Brytland), which he reduced to obedience after burning Rhudlan (Rudelan), and Griffin the king was slain by his own men. Harold brought Griffin's head to King Eadward, who bestowed the land on Griffin's two brothers, Blæthgent and Rigwatlan. ${ }^{3}$

1 Windles-ôra is made up seemingly of a personal name in the genitive case, and ör $a=\mathrm{a}$ bank or shore. Windles-ham and Windles-cumb, early forms of place-names in Surrey and Devon respectively, contain the same personal designation.

2 Cynomannia represents the region occupied by the Cenomanni of the Gallican Notitia, now preserved in "Maine" and "Le Mans" in France. Cenomani, with one $n$, is the source of Maine according to M. Thomas, Nouveaux Essais.

${ }^{3}$ It is somewhat singular that we should find South Wales here designated Brytland. Wealas, which had been used in the early part of the Chronicle for British, meaning those who were Latinized, came, as we see under A.D. 915 and 918, to be used specifically of the Cornish. Hence, possibly, the reversion here to the terms Bryttas and Brytland. It may be that the Chronicler was aware that the Bryttas here were the Cymry (i.e. Combroges) from the North, and not the Wealas of South Britain. As a further proof of the knowledge of the Chronicler in Welsh matters, note how he gives to the donble $l$ of Rigzuallan the approximate Welsh sound $t l$, Ri.grwatlan. Bledgint appears as a personal name in the Liber Landavensis, p. 32. Bled $=$ wolf (modern Welsh Blaidd) is a common element in British names (as its equivalent is in Tentonic nomenclature), e.g. Bledic, Bledgur. The modern equivalent of Bledgint seems to be Blethyn, a person of this name being Bishop of Llandaff in 1755 . The 
In 1065 Harold ordered buildings to be put up at Portskewett (Portascihth) ${ }^{1}$ in South Wales (Brytland), and many things to be collected there with the aim of making it a hunting-lodge for the king. Cradoc, son of Griffin, fell, however, upon the builders and carried away the property stowed there. Tostig was at this time exiled by the Northumbrians, and Morker chosen in his stead. Tostig appeared later at Britford (at Brytan fordan $)^{2}$ with the king, but notwithstanding Harold's

-gent in Blethgent probably means "born"; compare northern Welsh Gened = birth. A Riguallan appears as a person of high position in the Lib. Land., p. 261. The usual form is Ri-uallaun, the former element representing Welsh Rhy = king (Goidelic $R i$, genitive $R i g$ ), and the latter the Vallaun-ius of the Caerleon inscription which appears later as welyn in Llevelyn. The llaun in ve-llauno-dunum, Cassi-ve-llaunus, \&c., and in the Breton forms cat-unallon, Hael-unalon is traced by Pedersen (Gramm. 837 ) to a word meaning "rich": cf. Old Norse Laun = reward, and Welsh go-lud = riches, the ve in vellaun representing the Welsh go for giu.

1 Portascihth. This appears in the Liber Landavensis as Porthisceuin, according to the Editors, p. 336. This would prompt one to regard the latter element as ceven (modern Welsh $C e f n$ ) $=$ ridge, and the whole as "the Port below the ridge", bnt there seems to be only one other instance in the Lib. Landav. where the word appears, and there it is Cemyn (p. 134), "yr hir cemyn." The earliest form of the Cévennes Kemmenon (Strabo, 2. 5. 28), which became Cevenna in Caesar (B. G. 7. 8.2) contains the stem Kemn = ridge, and according to Pedersen (V.Gramm. §99) is an instance of the existence of an aspirated $m$ in Gaulish. An unexplained word Cecyn seems to be used throughout for "ridge" in the Lib. Land. Except there is more evidence forthcoming than the Editors give, the identification of Porthisceuin with Portskewett must be regarded as doubtful. Another fact renders the identification still more hazardous. At p. 234 of the Lib. Land. there is a grant of Yscuit Cyst to Llandaff, and in a marginal gloss (given at p. 342) it is said, in common with Castel conscuit (Caldicot Castle) and Trig Peren (cf. Pernan Cross), to be near Marthern. It seems clear, therefore, we have in I'scuit Cyst the origin of Portskewett, and, if Cyst be the hill behind the port, Yscuit Cyst is the "shoulder of the Cyst": cf. Diuscuid ir alt, which appears at p. 226, meaning "to the shoulder of the alt, i. e. cliff".

${ }^{2}$ Brytanforda (Britford, south of Salisbury) is evidently an old word going back to the time when the Saxons were pushing the Bryttas westward of Wiltshire. It means the ford of the Britons, just as Walingeford 
intervention, was obliged to take refuge in Flanders (Baldwine's land), where at St. Omer (St. Audomar) he settled for the winter. King Eadward came at mid-winter (1065) to Westminster, and caused the minster, which he had built, to be consecrated on Innocents' Day, "to the praise of God and St. Peter, and all God's Saints." He died a few days after (on the eve of the Epiphany) and was buried in the same minster, Harold succeeding him on the throne. Tostig now returned from Flanders, and proceeding into Northumberland, was driven thence into Scotland by Morker. Harold, King of Norway, having arrived in the Tyne (1066) with a great fleet, Tostig joined forces with him, and they proceeded up the Ouse (Usa) towards York. Morker, on hearing of this, proceeded to intercept him, but was defeated after much loss. Harold, who had come northwards to Tadcaster (Tada, an instance of shortening in place-names), on hearing of the arrival of his namesake, the Norwegian king, encountered him and Tostig at Stamford Bridge (Stanford Brycg), where he inflicted on them a decisive defeat, Harold Harfager and Tostig being slain. Then came William of Normandy to Pevensey on Michaelmas Eve, and proceeding to Hastings (Hastinga Port) constructed a stronghold there. Harold, on hearing this, came against him at the "hoar apple tree", but, attacked by William before he could arrange his forces, was defeated and killed." William proceeded to Westminster, where he was crowned by Archbishop Ealdred, who had intended to proclaim Eadgar, but had submitted to

(Wallingford) probably meant the ford of the Wealas; cf. "Saxons Lode" on the Severn, "Frank-fort" in Germany.

1 J. H. Round (Feudal England, pp. 333 et seq.) deals with the site of the battle and with Freeman's adoption, on Orderic's sole authority, of "Senlac" as the place of the fight. Mr. Round argues that the name, which appears also in France as "Senlecque", is not English, and that, as Orderic wrote two generations after the battle, it is not to be given a place in history. It is well to note, however, that the name Santlache occnrs in a grant to Battle Abbey (Chron. Monast. de Bello, p. 20), and the term seems English $=$ Sandbrook, the latter element being probably -lacu, which gives latch, letch in place-names. The later form is Sandlake : see Index. 
William at Beorh-ham-stead. ' William was not, however, received at first everywhere as king. $\mathrm{He}$ appointed a certain Robert as Earl of Northumberland, but the people arose against him and slew him and nine hundred of his followers. Eadgar with all the Northumbrians proceeded then (1068) to York, and the townsfolk made peace with him, but William came with his hosts, attacked and ravaged the place, so that Eadgar had to fly to Scotland. In the following year, 1069, a great fleet under Sweyn's sons came from Denmark and proceeding up the Humber to York, aided by Eadgar and the Northumbrians, captured the castle and pillaged the place. Notwithstanding William's entry into the shire, the Danes remained all the winter between the Ouse and Trent. Harold's sons also came in the meantime from Ireland and entered the mouth of the $\mathrm{Taw}^{2}$ (Tawmuth) in Devon, but after ravaging the neighbourhood were obliged to return. Gytha, Harold's mother, with many honourable women, retired to Flatholm (Bradan Reolice ${ }^{3}$ ), whence, after a time, she proceeded to St. Omer (St. Audomar) in France.

MS. E of the Chronicle (which was compiled at Peterborough) continues in a doleful tone the narrative of events to the year I I54, recording under that year the death of King Stephen, and his burial at Faversham ${ }^{4}$ (Fauresfeld). There are some

1 Beorh-ham-stead. This has been identified with Berstead, Kent, but the latter place is given as Ber hamstede in a charter ascribed to 1005 (Cod. Dip.). It would seem that the first element is either Beorg $=$ hill, or Beorc = birch, and that Berkhamstead is intended, which in the twelfth century was Berchamstead (B. M. Charters and Rolls).

2 Taw. This name, which means in modern Welsh "silent", is, as already said (p. $282 \mathrm{n}$.), traced by Pedersen to an original *Tausos, in which the diphthong $a u(=a w)$ before $s$ lost its diphthongal character. Ptolemy's Tobios ( $=$ ? Towy) may represent an earlier stage, the $b=v$; cf. Breton, Tevel ("silent"), earlier Taguel.

3 Bradan relice. This has been dealt with under A. D. 918.

- Faversham was Fefres-ham in 811 (B.M. Charters and Rolls), and Febresham in 858 (ibid.). In Domesday it was Faversham. The first element is a personal name in the genitive, but there seems to be no 
place-names mentioned in this portion, but none of importance. Under 1087 we have mention of Berkeley (Beorclea) ${ }^{1}$ and the Castle of Tonbridge (Tonbrucge), and in rogr occurs "Lothian" (into Lothene), ${ }^{2}$ which is declared to be in England, and into which King Malcolm of Scotland led his troops. The hallowing of the minster at Battle (Bataille) is recorded under ro94. In rog5 we have an account of an expedition made by William against the Welsh, who had destroyed the Castle of Montgomery (Muntgumni; in Domesday it is Muntgumeri) and slain the garrison. The king's troops proceeded as far as Snowdon (Snawdun: in Welsh Mynydd Eryri), which they reached on All Saints' Day, but, the enemy having retired into their fastnesses, the king had to return.

In 1098 a prodigy is recorded at Finchamstead, Berks., where a fountain of blood was seen, and in the same year Earl Hugh is stated to have been slain by foreign Wikings (Utwikingan) in Anglesey (Angles ege). In 1110 , the Chronicle tells us, Henry I spent Easter at Marlborough (Marle-beorg). ${ }^{3}$ In a scrap of another MS. (H), there is an account (under III 4 ?) of a grant by Henry of the Earldom of Northampton Shire (Northham tun Scire) to David of Scotland, who was the queen's brother, and also grants of Abbacies at Ramsey (Ramesige), Thorney (Thornige), and Cerne Abbas (Cernel). The same MS. records also the death of the Abbot Nigel at Burton-on-Trent

similar Saxon designation. It may possibly be a case of the survival of the Latin Faber, = Smith, in a thoroughly Latinized district such as Kent must have been.

1 Beorc-lea contains Beorc, = birch, and leah, in its original signification of wood.

2 Lothene, = Lothian, has already been discussed. Freeman contends (Norman Conquest, vol. I, note B) that Lothian was given up to Scotland after, and as a result of, the battle of Carham (see back). The territory coverea by the name is vague. It probably extended south of the Tweed, and thus confirms the text.

3 Marl-beorg, = Marlborough, shows that beorg ( $=$ hill) becomes, as elsewhere in the South, borough. The Marl is obscure. The Domesday form is Marleberg. 
(Byrtun), and the burning of Chichester (Cicestre) and its Minster. At Pentecost, the MS. continues, King Henry was at St. Albans (St. Albanestorve), from whence he led an expedition into Wales, where he built castles, and the Welsh kings submitted to him. Returning to Winchester he bestowed, among dignities to other clerics, the Abbacy of Muchelney (Myclanyge) on the monk Ealdulf. MS. E tells us that in October, III4, King Henry was at Rowner (Rugenore: in Domesday it is Ruenore) in Hants, and that he kept, in III6, Christmas at St. Albans, and Easter at Odeham (Wudiham), Hants. In II 21 he spent Christmas at Brampton (Bramtun), Hunts, and in 1123 the same festival at Dunstable (Dunestaple), and went thence to Woodstock (Wudestoke). In the latter year he appointed a canon of St. Osyth's (Cicc: in Domesday, Cice), Essex, archbishop. In 1124 Ralph Basset and the king's thanes held a meeting at Hundcot (Hundehoge : in Domesday it is Hunecote), in Leicestershire (Lethecastrescire: cf. the Domesday form Ledecestre). In I 125 John Bishop of Lothian (Lothene) is mentioned. In $113^{2}$ the Prior of St. Neots (St. Neod) is named, and in 1135 is recorded the death of King Henry, and his burial at Reading (Redinge), Stephen of Blois succeeding to the throne. His first act was to take possession of the castles of those nobles who were disaffected, among these are named the castles of Rockingham (Rogingham), Cottingham (Cotingham), Easton (Estun), Irthlingborough (Hyrtlingberi), Stanwick (Stanewig), and Aldwyncle (Aldewingle), all in Northants. The defeat of David, King of Scotland, at the battle of "the Standard" is recorded under I I 38 , and Stephen's death under I I 54 .

The consideration of later records containing place-names is not worth pursuing, as the forms therein presented vary but little from those now in use, and the new terms introduced by the Continental monastic orders, such as Beaulieu, Rievaulx, Jervaulx, \&c., explain themselves. 


\section{N D E X}

Aballaba (Avalana, ? Papcastle), 99, 100, IOI, II $5,272$.

Abbandinn (Abingdon), 40, $277 n$., 279, 292.

Abbercurnig (Abercorn), 186.

Abbots Anne (Domesday Anne), $144 n$.

Aben, the river, 219.

Aber, meaning of, $186 n$.

Abercorn. See Abbercurnig.

Aberdeen. See Dëvana.

Abergavenny. See Gobannio.

A ber-guilly, $250 n$.

Abingdon. See Abbandun.

Abon (? Sea Mills), Abone, Abona

(river Avon), 22, 23 k., 112 , I I 3 ., $25^{2}$.

$A b$-os (or Aboub-os), the river, 98.

Abravann-os river-month, 93, 95 .

Ac beara, $24 \mathrm{I} n$.

Acemannes Ceastre, 278. See Bathan ceaster.

Aclea, Acley (Ockley), 196, 197 n., 242.

Aclea (Aycliffe), $234 n$.

Ac-leag (Oakley), 215.

Acmoda (Abudes Islands $=\mathrm{Heb}$ rides), 90.

Ad Ansam (? Stratford), I 10, I I $1 ~ n$. Ad Baruae, 18I.

Ad Lapidem (Stoneham), I83.

Ad Murum (Walton), royal vill called, 178 .

Ad Pontem (? E. Stoke-on-Trent), Iog.

Ad-Tanatos (Thanet), 9I. See also Tenid.

Adamnan's monastery at Hii, I91.

Adel, $169 n$.

Adescancaster. See Exanceastre.

"Adgefrin," the royal vill called, I68.

Adour, the, II4.

Adredes-eya, Andredes-eme, 203, 206. Acglea. See Aclea and Iglea.
Edwines clif ("Eldunum near Melrose") now Eildon, Eildon hills), 196.

Aedan, King, I62.

Egelbeorht (Egelbiryth), a Frankish Bishop, 175 .

Egelesbyrig, Agelesburg (Aylesbury), $147,267$.

Egelesthrep (Agelesforda, Aylesford), 139, 140, 141, 287.

Eldenham (Aldenham), 218.

Elfetee (El-vet, Elfetu, Elmet), 196.

Elfheah (Archbishop), slain, 286; his body taken up, 288.

Elfric selected Archbishop of Canterbury, 281 .

Eschongas, 287 . See also Hangra.

Ésica (Great Chesters), 99, 1 I 5.

Esphangra, 287.

Et-Treocum (Utrecht), I90 $\boldsymbol{n}$.

Ethelingadene, 283.

Ethelingaeg (Athelney), 253.

Ethelred crowned at Kingston, 279 ; goes to Normandy, 286; at war with Cnut, 286.

Ethelric, Bishop of Worcester, buried at Ramsey, 289.

Ethelstan's grants of lands, 162; death of king, 273.

Ethelwold made Bishop of Winchester and rebuilds Ely, 277; "father of monks," 280.

Aetins, the third Consulate of, 127 .

Afallen (Avallon), 198.

Afene-mutha (Avonmouth), 294.

Agelberct (Agelbeorht), Bishop, 182.

Ageloco (Littleborough), 108, 109 $n$., 172. See also Segeloci, and Tiouulfingacæstir.

"Agricola, a Pelagian," 124.

- aha, names ending in, 68.

Aibouda (? Uist), $9^{2}$.

Aiboudai, the, 92 . 
Ail-Cluade. See Nemthur.

Ailcluit (Alclut, Dumbarton, DunBrettan), 84, I 52 n., I 53.

"Ail-dun," I $96 n$.

"Aircol, son of Trephun," 56 .

Airer-Gaedhel (Argyll), 84.

Akeburg, I 7 I.

Ake-mann Cester (Bath), 4I. See Bathan ceaster.

Akemann Street, $4 \mathrm{I}$.

Alauna, Alaun-os (Alnwick, Alne, Alum), 97, 99, 203.

Alauna Silva, 96.

Alaun-os (? Axe), the river, 96.

Alba, extent of, 88.

Alban (Scotland), 9, 76, 92.

Alban, martyrdom of St., 35, 60, $69,70$.

Albans, St. (St. Albanestowe). See Verulamium.

Albion (Albiona), 88. See also Alviōn.

Alcester. See Alne-Chester.

Alclet (Halc-let, Auckland), 234 ., 237.

Alcluith (Petram Cluithe). See Ail Cluade, Ailcluit, and Alt Clyde.

Alcuin, $124 n$.

Aldborough. See Isourion.

Aldervingle (Aldwyncle), 304.

Aldhelm, I66.

Aler (in Alercumb), 207.

Alfred's Description of Europe, 225.

Alh-mund, $21 \%$.

Alione (Alone), III, II6.

Allectus, 62, 64, 65, 66, 67.

Aller. See Alre.

Allerdale (Alner-dale), 273.

Alne. See Alauna.

Alne-Chester (Alcester), 203.

Alner-dale. See Allerdale.

Alney Island. See Olan-îge.

Alnwick. See Alauna.

Alre (Aller), 255.

Alt Clyde, 245.

Alum. See Alauna.

Alviōn (Albion), 92.

Ambiani (Amiens), 79 .

Amboglanis. See Ambo-Glanna.

Ambo-Glanna (Burdoswald. ? Gaba Glanda), IOI, II 5 .
Ambresbyri (Amesbury), 282.

Ambrones, 208.

Ambrosius Aurelianus, I 22, I49.

Ambrosius (the Myrdin of Geoffrey of Monmouth), I 36, I $37 n$.

Amesbury. See Ambresbyri.

Amiens. See Ambiani and Embenum.

Amreythig (Shrewsbury), $285 n$.

Anava (Noe), the river, II 7 .

Anavio (? Brough), Anavione, rog, I16, II7.

Ancalites, 10.

Ancaster. See Causennis.

Andeferan (An-dever, Andover, Anton-dover), 97, 144n., 28I.

Ande-gav-ia (Angers, Anjou), rog $n$. Anderitos (Anderida, Andredes

Wald, Andereton, Anderitum), II 3. See also Andredes-Cester.

Andover. See Andeferan.

Andred (Andredesleage), the forest of, $143,195,218,258$.

Andredes Cester (? Pevensey, Pevenisel), Anderida, $143 n$.

Andredes-eme. See Adredes-eya.

Andredes Wald. See Anderitos.

Andret, I43n.

Andros (Adros), 90.

Aneurin, poems of, 154 .

Angen-geot-ing, 214 .

Angen-lab-es hamm, 214.

Angers. See Ande-gav-ia.

Angles, 128.

Angles-ey (Angles ege), 229 n., 303. See also Mona.

Angra and Hanger in place-names, $214,286 n$.

Angra (Ongar), $287 n$.

Anlaf besieged by Eadmund, at Leicester, 274; arrival at London, $28 \mathrm{I}$.

Annan, the river, 95 .

Annport, I $44 n$.

Anse, II I $n$.

Anstige (Anstey), 2 I I $n$.

Antivestaion. See Belerion.

Antona, the river, 22, Ir 7 Note $F$, I $44 n$.

Antondover. See Andeferan.

Anthun, 56.

"-apa," names ending in, 68, 69 . 
Apostle's Oak (the) on Abberley Hill, 168.

Appenzell, 190.

Apuldran (Apul-dore, Appledore), $187 n, 258$.

Aquantania, $4 \mathrm{I}$.

Aquis (Buxton), II 6.

Aquis Solis. See Bathan ceaster.

-ära $\bar{a}$, in river-names, $187 n$.

Arbeia (? South Shields), II4.

Arcencale (Ercal), $266 n$.

Arcunia, 266.

Arcuulf, Bishop, Igr.

Areconio, Ariconium (Deanery of Erchenfield), I07n., 112, I $39 n$., $266 n$.

Aregenua. See Arguenon.

Argento varia (Horburg), I5I $n$., $252 n$.

Arguenon (Aregenua), the river, I55n.

Argyll. See Airer-Gaedhel,

Armagh, Book of, $128 n$., I29n.

Armorica (Brittany), 9, 6r, $122 n$. ; emigration to, I54; state of, before sixth century, I54; Celtic names in, before and after immigration of British, I55; Gaulish words in, in fifth century, $156 n$.; British words imported into, 157 , 256.

Aro Sætna, 222.

Arran, I 7 I $n$.

Arras, 12.

Artbrannan, 50.

Arthur, King, place-names in con. nexion with legendary, 149; his victories, I 49.

Arthuret, 84. See Westmoreland.

Artois, 12.

Arviragus, $137 n$.

Arwa (Orwell), the river, 287 .

Arx, the Citadel of Vortigern, beside the river Teibi, $176 n$.

"Arx Cynuit", $253 n$.

Arx-Decant-orum, Arx Deganhui, (Deganwy), 94, 239.

Ascan-mynster (Axminster), 196.

Asclepiodotus, the Praetorian Prefect, $62,64,66$.

Ashbourne, $187 n$.

Ashdown. See Assandun.
Ashingdon. See Assandun.

Ash-over (Asher) $210 n$.

Assandun, Escesdun, Escesburh

(Ashingdon, Ashdown), ${ }^{24} 6 n$., $284,287,288$.

Atclete. See Etclete.

Ath (Adwy = ford). See Path.

Athelney. See Kthelingaeg.

Atholl. See Fotla.

A[d]trebates, the, 9, 12.

Atrebatioi, the, $\mathrm{IO}_{3}, 104$.

Atrebatum (Silchester), 9.

Attacotts (Atecotts, Atticotts, Attacotti), $6 \mathrm{I} n ., 78,79,8 \mathrm{r}$; harass Britons, I19n.

Auckland. See Alclet and Etclete.

Augustine, St., arrival of, I48; meeting-place with the British Bishops, 164.

"Angustine's Oak," 164; ?near Cricklade, $167 ; 202$.

Auray (Herio-s), the river, $155 n$.

"A ust Cliff," 203.

Anst on Severn, 167 .

Aust Passage, I $13 n$.

Austien (Austin, "Austins rick," Penryn Awstin), 202; ?"Augustine's Oak," "Austin's Well," "Aust Cliff," 202, 203.

Avalana. See Aballaba.

Avannus, 95.

Avon. See Abon.

Avonmouth. See Afene-mutha. $A x a$ (Axe, Exa), the, 96, 199.

Axeloduno (Axelodunum, Uxelludamo, ? Ellenborough or Hexham), 99, I00, IOI, II $5,174 n$.

Axium, the, 96.

Axminster. See Ascan-mynster.

Aycliffe. See Aclea.

Aylesbury. See Ægelesburg.

Aylesford. See Agelsthrep.

$\Lambda$ ynburg, 235.

Baccan-Celde, $226 n$.

Badbury. See Baddan-byrig.

Baddan-byrig (? Vindo-gladia, Badbury), 16, II 3, 26r.

Badecan - Wiella (Badecanzwiellan, Bakewell), 147, 268.

Badonic Mount. See Caer Badon.

Bænesingtun (Benson), 147 . 
Bagillt, 46.

Bakewell. See Badecanziellan.

Baldwines Healh, 2 I 7.

Balsboro. See Balteresberghe.

Balteresberghe (Balsboro, Baltonesboro), 201.

Bamborough. See Bebbanburh, Dinguoaroy.

Bampton, I 75 .

Ban-Chor (Bangor, Bancornaburg, Bangor-is-coed), I $30 n_{\text {. ; meaning }}$ of, 167; "Bangor" applied to Glastonbury, $167 n$.; Bangors in Wales, in Brittany, and in Scotland, $167 n$.

Bancornaburg. See Ban-Chor.

Bangor. See Ban-Chor.

Bangor Wydrin in Afallen (Avalon), 198.

Banna, 99, 100, 101.

Bannagher, $167 n$.

Bannatia, Ior.

Bannavem (Bannaventa, Bannavento, Bennavento), 33, 34, 106, 1 $07 n$., I09, I IO, I $29 n$., I $30 n$. See also Isannavantia.

"Bannavem Taberniæ," (Nentre, Nentria or Ventre), I $29 n$.

Banno-vallum, $72 n$.

Banuwille (Banwell), 249.

Bapchild (Baccan-Celde), $226 n$.

Barbury Camp. See Beranburg.

Bardaneu (Bardanege, Bardney), I74.

Bards, the, 54 .

Baregain, 272. See also Burrens.

Bare-oak-shire, II.

Barganes lapidum, "Sheep-fold[s] of Stone[s]," 28.

Barham. See Bioraham.

Barking. See Bercingon.

Barnbougle, 86.

Barwick-in-Elmet, I jon.

Basincge (Basing-stoke, Basingwerk), 2 I 2.

Basings (Basengum), 247.

Bassas, the river, I50, I52.

Bataille (Battle), 303.

Batch (Bach), 230.

Bat-chet (Bathgate), $86 n$., I8I $n$.

Bath. See Bathan ceaster.

Batham Gate, 117.
Bathan ceaster (Baðum, Ealdanbyrig, Hydata Therma, Aquis Solis, Bath), 9, 104, I13, I48; hot baths at, I64n., 262, 278.

Bathgate. See Bat-chet.

Battersea involves "Beadu-rich," $245 n$.

Battle. See Bataille.

Battle of Stamford Bridge (Stanfora $B r y(g)$, 301.

Bdora, I I6, 239 n. See also Dore.

Beadorices Uurthe (St. Edmundsbury), $245 n$.

Beamfleot (Ben-fleet), 208, $258,259$.

Beandune, battle of, 175 .

Beane, the river. See Beneficcan.

Beardanig (Beardan-eu, Beardanige), I94.

Bearruc-scire (Berkshire), 10, 284.

Bebban-burh (Bebbanbyrig, Babbanburh, Bamborough, Dinguoaroy), I46, I5I $n ., 269,281$. See also Durnono-varia, Argento varia.

Beber (in Beverley), 208.

Bech (Batch, Bach), 230.

Bedanforda (Bedcanforda, Bedeanford, Bekeford, Bydanford Bedeforde, Bedford), 147, 266, 285.

Beddan-haam, 2 I 3.

Bede-hus (Bettws), $227 n$.

Bed-ern, $227 n$.

Bedford. See Bedanforda.

Bedwig, I42.

Bedwin. See Biedan Heafde.

Beeston. See Bovio.

Befer pyttas, 204.

Beferith, I I.

Beggares-thorne, 204.

"Beggary-island," 205, $236 n$.

Bekeria (=parva Ybernia), Beceriu, Bickery, Bickworthy, 205.

Belerion (Bolěrion Antivestaion). See Penwiht Steort.

Belgae, 8, 9, 10, 104.

Belgium, 6I.

Belisama, estuary of the, 93,95 .

Bellum Cochboy, I74n. See also Maserfelth.

"Belly-moor." See Bolgros.

"Benavent" (in Catalonia), 33.

"Benaventa" (S. of Astorga), 33 . 
Bendchor, $167 n$.

Beneficcan (Beane), the river, 263.

Benesingtun (Benson), 196.

Beneventa, $129 n$.

"Beneventana Civitas," 34.

"Beneventenreut" (in Germany), 33.

"Beneventum" (now "Benevento", in S. Italy), 33.

Ben-fleet. See Beamfleot.

S. Benignus (Beonna), I98.

Benson. See Benesingtun.

Benwell Hill. See Conderco.

Beonna. See S. Benignus.

Beorclea (Berkeley), 303.

Beorg-ford (Berg-ford, Burford), $195,210$.

Beorh-ham-stead (Berkhamstead, Berchamstead), 302. See also Berstead.

Beowi, I42.

Beowulf, poem of, 130, I31, 142.

Beranburg (Beran burh, Barbury Camp), 146 ; battle of, 160 .

Bercingon (Barking), $2 \mathrm{I} 4$.

Berct, the Northumbrian leader, $\mathrm{I} 85$.

Berctfrid fights Picts, 192.

Berct-hun, Abbot, 188.

-bere or -bera in place-names, $24 \mathrm{I} n$. Bere Forest, $24 \mathrm{I} \boldsymbol{n}$.

Bere-weg, 2I 4.

-berga in place-names, $24 \mathrm{I} n$.

Bergiona (Iberion), 88.

Bergos (Berehu, Burhou), $88 n$.

Berigon, $88 n$.

Berkeley. See Beorclea.

Berkhamstead. See Beorh-hamstead.

Berkshire. See Bearruc-scire.

Bernicii, 26, 28.

Bernwood Forest. See Byrnervudu.

Berricen, $88 n$.

Berstead, 302.

Berwickshire. See Prendergast.

Betendune. See Vetadun.

Bettws (Bedhus), $227 n$.

Beverley. See Beber, and In-deraunda.

Beverston. See Byferestan.

Bibracte (Antun), II.

Bibr-ax (Beuvray), I I.

Bibroci, the, 10.

Bickery. See Bekeria.
Bickworthy. See Bekeria.

Bieda, son of Port, I 44 .

Biedan Heafde (? Bedwin, Bedewind), I 23 12., 2 I 7.

Billinga byrig, 2 I5.

Billingahoth, 237 .

Billingsley. See Bylgeslege.

Bilmiga, 222.

Binchester. See Vinovia.

Bindon, 175 .

Bioraham (? Barham), 2 I9.

Birchanger, $287 n$.

Birch-over (Bircher), 208, $210 n$.

Birdoswald, Ior.

Birinus, I 75 .

Birrens Camps (Burrins Camps), 28, $2721 \%$.

Biscopes unic (Bishop's dwelling), 215.

Bishop Felix (Dunwich), 173 .

Bishopricks in $73 \mathrm{I}, 193$.

Bishops Waltham. See Wealtham.

Bittern, Hants. See Clausentum and "Butter = Bittern".

Bitton. See Trajectus.

Bitnriges (Bourges), Britons received by the Emperor in, 160 .

Blabo, Blabolg, $106 n$.

Bladney. See Bledenhithe.

Blaecca of Lincoln, baptism of, 171.

Blrethgent, brother of Griffin, the Welsh king, 299.

Blato-bulgio (Blatobulgium), 105 , I06 n., $298 n$.

Bledenithe (Bledone, Bleadon, Bladney), 200.

Bledgint, 299 n.

Bledone (Bleadon), 200.

Blestio (Monmouth), I 12.

Bobing-seata, 219.

Bodan (in Bothamley, Ramsbotham, \&c.), 207.

Boderia, Bodotria Estuary (Firth of Forth), 44, 45, 97, $15^{2}$.

Bodfari. See Varis.

Bodmin manumissions, the, 162 .

Bodotria. See Boderia.

Boece $=$ beech (in Buckhurst), 207.

Boguelt. See Boullaion.

Boisil, Bishop of the Hwiccas, 184 .

Bolerion. See Belerion. 
Bolgros ("Belly-moor "), : $298 n$. See also bwlch.

Bollan-ea, 215.

Bomio (? Cowbridge), I $12,129 n$.

Boniface (Winifrith), educated at Adescancastre, martyred at Doccum, I90 $n$.

Bonny, the river, ${ }^{1} 5^{2}$.

Bononia. See Gesoriacum.

Bon-us (Bede-hus, Bed-ern), $227 \boldsymbol{n}$.

Bootham Bar. See Galman-hithe.

Borcovicio, II 5 .

"Boresti," 47.

Boructuari, 189 .

Bosenham (Bosan-hamm, Bosham), 182, 291.

Bosham. See Bosenham.

Bosley Minn, I $58 n$.

-bost, shortened form of Buistad-r, 229.

Boston (Lincs.). See Icanho.

Bothamley, Ramsbotham. See Bodan.

Botulf, St., I $76 n ., 278$.

"Bouden Hill" (Badon Mount). See Caer Badon.

Boudicca, Queen, 34, 36.

Boullaion (? Builth, Boguelt, Buelt), ro3.

Boulogne. See Gesoriacum.

Bonrges. See Bituriges.

Bovio (Beeston, Buistane), I03, ro6.

Bowes, 106.

Bown-hill (Badon hill). See Caer Badon.

Bowne, barony of, I $53 n$.

Bowness (Cumberland), 54.

Braboniaco (? Kirkby Thore), I05 n., I14. See also Ravonia.

Bradan forda be Afne (Bradford-onAvon), 175 .

Bradan Relice (Steapan Relice, Flatholm, Echni), 266, 302.

Bradene (Bredon), 193, $262 n$.

Bradford-on-Avon. See Bradan forda be Afne.

Bradwell, $276 n$.

Bragentforda (Brentford), 25, 26, $214,287$.

Braintree, IIr.

Bramtun (Brampton), 304.
Brancaster, Branchester. See Branoduno.

Branch Huish (Hîwisc), 206.

Brancminstre (Branuc minstre, i.e. of S. Branoc, =S. Brandan), 206.

Brandon. See Bravonio and Brannogenium.

Brandon Hill, 294n. See also p. 206. Brandon, St., memorials of, 206, $294 n$.

Brannogenion (Bravinnio, ? Brandon), 102, 103.

Branoduno, Branodunum (Brancaster, Branchester), 98, I I 3 .

" Branok hyalf hiwisce," 206.

Branuc Dunhead (Downhead), 206.

Braunton, Devon, 206.

Bravinnio. See Brannogenion.

Bravonio (Brandon), 105 n., I I 2.

Bre, in place-names, $105 n$., 193 .

Brecenan Mere, 264.

Brecknock. See Bricheniauc.

Bredon. See Bradene and Briudun.

Bregedes-were, 202.

Breguntford (Brentford). See Bra. gentforda.

Bremenio (Bremenium, Bremenion, Riechester), 53, 99, 105.

Bremes byrig (Bromesberrow), $262 n_{.}, 263$.

Bremesgraf (Bromesgrove), $262 n$.

Bremetannaco, I05 $n$. , Bremetonaci, Bremetonacum, Bresnetenace Veteranorum (Ribchester), IO2, III, II6.

"Brent," 26.

Brente (Brent Knoll), 199.

"Brente" hill, 26, 199.

Brentford. See Bragentforda.

Breten-land, $\mathbf{I}_{42} n$.

Breton's lands, the, I $62 n$.

Brettanoi, 75 .

Bretwalda, 239.

Bricg Stowe (Bristol), 294.

Bricge (Bridgenorth), 260 n., 263.

Bricheniauc (Brecknock), $259 n$.

Bridgenorth. See Bricge.

Bridstow, $294 n$.

Briga (Brig, Brig-s), 28.

Brigantes, the, 25, 26; State of, 30 ; $49,50,94$, IOI, IO2. 
"Brigden," early Brigo-duno-n, $193 n$.

Brige (Brigae), I I 3 .

Brigit and Brigantia, 94 .

Brigo-duno-n. See "Brigden".

"Briguntford." See Bragentforda.

Brisnodes Land-share, $298 n$.

Bristol. See Bricg Stowe.

Britain, Provinces of, 71 .

Britanni, 89.

Britannia, Brìttŏnes, Britanni, 88, 89 .

Britannia Minor, ${ }_{5} 6 n$.

Britannia Prima (Province of Britain), 71.

Britannia Secunda (Province of Britain), 71.

Britford, $25 n$.

British, cities of, $16_{5} n$.

British troops in Gaul, 158.

Britons, 84 ; on the Loire, I60 $n_{\text {. ; }}$ nnder Riothimus cross into Gaul, I 59.

Brittany. See Armorica and Lidwiccium.

Brĭttǒnes, 89.

Briudun (Bredon, Breodun), monastery of, 193. See also Bradene.

Briun (Brue), the river, 199.

Brixton Deverill, $253 n$.

Brocava, Brocavo (near Brougham Castle), 105 n., 108, I09 $n$.

Brochyl, 216.

Brockley Hill. See Sulloniacis and "Tunsteall, the old".

Brocoliti. See Procolitia.

Broco-mago, I 15.

Brog in place-names, $105 n$. (Brogzaos=Breton name for England. Bro-cavo, Bro-vonacis, \&c., possibly involve $\mathrm{Bro}$ ).

Bromesberrow. See Bremes byrig.

Bromesgrove. See Bremesgraf.

Bromfield. See Bruningafeld.

Brom-geheg, $2 \mathrm{I} 7$.

Broom, Loch. See Volas bay.

Brough. See Anavio, Crococalana and Verteris.

Brougham Castle, I08.

Brovonacis (Kirkby Thore), 106. Brunanburh, 161, 270, 27 I, 273. Brue. See Briuu.

Bruningafeld (Brunefeld, Brune,
Brunanwerc, Weondune, Bromfield), $271,272,273$.

Brut of Layamon, the, $137 n$.

Brytaen Vechan, ${ }_{5} 6 n$.

Brytan fordan (Britford), 300.

Brythons, 9.

Brytland (Wales), 297, 300.

Buckfast. See Faestin.

Buckhurst. See Boece.

Budecalech (Bodecaleie, Butley), 20r, 202.

Buelt (Boguelt, Builth), 29, 103, $248 n$. See Boullaion.

"Bugga," pet appellation of St. Eadburga, I $33 n$.

Buistane. See Bovio.

Bulcan pytte, 2 I 7 .

Bullaeum, 29.

Bun-an-Taberna, I $29 n$.

Bunchrew, I $30 n$.

Bun-doran, Bun-an-dall, rзon.

Bunker (Bunker Hill, Golf bunkers), 230.

Burdoswald. See Ambo-Glanna.

Burehn. See Bergos.

Burford. See Beorg-ford.

Burganes Lapidum, $272 n$.

Burgh and Burgh Castle, 98. See Garianno.

"burgs, the five," freed by Eadmund, 274.

Burgundians sent into Britain, 53.

Burgundiones, the, 27.

-burh in place-names, $24 \mathrm{I} n$.

Burhou. See Bergos.

Burrens (Burians, Birrens, Burwens, Borwen = Cumulus), 28, $272 n$.

Burrins Camps. See Birrens Camps. Burrio (? Usk), I I 2. See also Dinbirrion and Wylisce Axa.

Burrium, 29.

Burton-on-Trent. See Byrtun.

Bustadar, $228 n$., $229 n$.

Butley. See Budecalech.

"Butter" (= Bittern), I 2 I.

Buttington, $259 n$.

Buttingtontump, $259 n$.

Buxton. See Aquis.

bwlch, $298 n$.

Bydanford. See Bedanforda.

Byferestan (Beverston), 293. 
Bylgeslege (? Billingsley), 297.

Byrgelsun (burying-places), 215 .

Byrhtmær, Bishop, buried at Lichfield, 289.

Byrnewudu (Bernwood Forest), $26 \%$.

Byrtun (Burton-on-Trent), 304 .

Cadbury (Camelot), 20, 2 I.

Cadegyr (Categern), I 39 n., I 40.

Cader, 16.

Cæanganoi, 24. See also "Deceangli ".

Caedualla, king of Grvenedd, I73, 183.

Caelf-loca-a (Challock), 2 I I $n$.

Caer Badon (Mons Badonicus, Bown Hill), I 22 , I $23,148 n$., I 49, I $50 n$., I 5 I, 153 .

Caer Esca (Exeter), $252 n$.

Cære. See Hæfe and Cære.

Caer Guiragon. See Caerwrangon.

Caer-Gworthigirn (? Tintern, Dinthigirn, Dindeyrn), I $76 n$.

Caerleon (Mon.), (" Camp of the Legions," Isca), 54, 7 I I I 2.

"Caer Ligidit" (Lichfield), $289 n$. Caerluel (Carlisle). See Lugnvallo. Caer Pheris (Durnfries), I 20, 189.

Caer Seiont. See Segontium.

Caer Vudei, $148 n$.

Caer Went. See Venta Silurum.

Caerwrangon (Caer Guiragon, Worcester), $\mathbf{1}_{5} n$. See Wigornia.

Caesaromago, I08, I I0, II I $n$.

Caestri-unara (Caestruuara), 215, $220 n$.

Cafortun (Caverton), $211 n$.

Cairbre Righfada. See Reuda.

Cair Ceri. See Cirenceastre.

"Cair Glovi." See Gleawan Ceaster.

Cair Granth (Grant Chester), $25 \mathrm{I} n$.

Cair Lerion, $265 n$.

Cair Luit Coyt, $18 \mathrm{I}$.

Cair Pensa vel Coyt, $254 n$.

Cairn-Ryan. 94.

Cairuisc. See Exanceastre.

Caistor. See Venta Icinorum.

Cait (Caithness), 76, 77 .

Calacume(Kalagon), IOI; Casterton on Lune, IO2; ? Overtown on Lune, III.
Caladbolg, $106 n$.

Calat-ria (Kalentyre, Callender), 46.

Calat-ros, 46.

Calcaria (Tadcaster), 106, $30 \mathrm{r}$.

Calder, the river, $144 n$.

Caldour (Caledofre), the river, $144 n$.

"Caledo," 45.

Caledofre. See Caldour.

Caledon, wood of. See Celidon.

Caledonia, 45.

Caledonians, 65 .

Calgacos, 83 .

Callender. See Calat-ria.

Calleva Atrebatum (or Galleva, Silchester), 9, 47,64n., 103, II0, II 2 II 3 .

Calne, 277 n., 279.

Calne, the river (Scotland), $259 n$.

Calo-dunum, $277 n$.

Cal-ston hill, $277 n$.

Camalduno, 90.

Camboduno. See Campodunum.

Camborico, 108.

Cambridge. See Grantabrycge.

Cambus, 213.

Cam-dwr, $150 n$.

"Camel," river involving, 2 I, I4I.

Cameleac, Bishop, 266.

Camelot, 20, 2 I.

Camguili, the river, $250 \mathrm{n}$.

Cam-las, I $49 n$.

"Camlet way," 2 I.

Camp-town, I $70 n$.

Campodonum (Donafeld, Slack), 106, $169 n$.

Campus Lapideus, 88.

Camulodunum (Camuloduno, Colonia, Colneceastre, Colchester), 13, 19, 20, 21, 35, 36, 102, 103, 108, I10, 267.

Canary Islands (Makaroi nēsoi), 9I, 92.

Candida Casa (Whitehorn in Galloway), $124 n$.

Candover, $144 n$., $28 \mathrm{I} n$.

Canegan-Mersces (Canning Marsh, Cannington Hundred, Caningis, Canninga mare), 285 .

Canning Marsh. See Canegan. Mersces.

Canonio (? Kelvedon), I Io, I Ir $n$.

Canterbury. See Durobernia. 
Cantio-n. See Cantium.

Cantium (Cantio-n), 9.

Cantref Orddwyf (Hundred of the Ordovi), 32, 102.

Cantuc-uudu (Quantocks), 199.

Cantwarena. See Warena.

Canubio (Conway river), Io2.

Car (Kjarr) in northern placenames, 231.

Caratacus, 29, 144 n.

Carausius, 59, 60, 62-6, 68, 69, 119 .

Carbantorigon (Carbantium), 99.

Cari stream, the, 205.

Carling-ford, $229 n$.

Carlisle. See Lnguvallium.

Carlisle, Old, 53 .

Carlued. See luguvallo.

Carmarthen. See Maridunon.

Carnarvon, 10.

Carrawburgh. See Procolitia.

Carron River, 46.

Carron-Water, $186 n$.

Carrum (Carham), 288.

Carrum (Charmouth), 239, 240.

Cartismandua (Cartimandua), 30, $107 n$.

Carventana Arx, 33 .

Carvoran, II 5.

Cary. See Kari.

Cassi, the, 10.

Cassiterides, the, 90.

Castellum Menapiorum, 67.

Casterton, 102. See also Calacum. castle in place-names, 296.

Castle Hill. See Margiduno.

Castle-ford (Yorks.). See Ceasterforda.

Castleford. See Legeolio.

Castor. See Castre.

Castor on the Nene. See Durobrivas.

Castra Exploratormm, 105.

Castre (Castor), 278.

Cataracta (Cataractone, Katouraktonion, Cataractoni, Catterick), 101, 102, 105, 106, 108, 169.

Categirn (Cadegyr), death of, 139, 140.

Cathir, 16.

Catraeth. See Galt-reath. Cat-scaul, battle of, I74 $n$.

Catterick. See Cataracta.
Catu in Celtic names, $139 n$.

Catu-Vellauni (Katvellaunoi), 103.

Cat-walader, $139 n$.

Causennis (? Ancaster), 108, rog $n$.

Caverton. See Cafortun.

Ce, 76.

Cealchyth. See Celchyth.

Cealf-loca (Challock), $197 n$.

Ceangi. See Deceangli.

Ceap-stowe (Chepstowe), 208, $294 n$.

Ceasterforda (Castle-ford, Yorks.), $275 n$.

Ceaster setna, $220 n$.

Ceastrum ( $=$ York), 196. See also Eburäcum.

Ceddren (Cheddar), 206.

Ceitern (Kernes), I39 $n$.

Celchyth(Cealchyth,Chelsea), $157 n$., 196, 197, 219.

Celidon (Caledon, Celyddon), the wood of, $45,150,152,1_{53}$. See also Dun-chailden.

Celtae, 9 .

Cemyn, 300.

Cenapa, $176 n$.

Cenepes-moor, $176 n$.

Cend, $86 n$.

Cen-defrion, 28 I $n$.

Cen or Can-dover, $281 n$.

Cenimagni (Ceno-manni), 10.

Centinces treow, 214 .

Ceoftefine, 181 $n$.

Ceolesige (Cholsey), 284.

Ceollach (Kelly), Bishop, 178.

Ceorlingcburh (Charlbury), $179 n$.

Ceortes-igge (Chertsey), 183n.; canons expelled from, 278 .

Cerdic. See Cerdices-ora.

Cerdices-ford, 144, 145 .

Cerdices-leaga, 145.

Cerdices-ora (Cerdic, Certic), $143 n$., I44.

Ceretic (Corotic), $144 n$.

Cerne Abbas. See Cernel.

Cernel (Cerne Abbas), 303.

Certic. See Cerdices-ora.

Cestell Merit, $296 n$.

- Cet in place-names, $181 n$. See Letocetum.

Ceto-bricca, $86 n$., 181 $n$.

Cett as tumulus, $18 \mathrm{r} n$.

Cett, Bosco de, $181 n$. 
Cettingaham, 238.

Challock. See Cealf-loca.

Char-ford, I $44 n$.

Charing. See Ciornincge.

Charing Cross, 219.

Charlbury. See Ceorlingcburh.

Charmouth. See Carrum.

Charterhouse-on-Mendip, 24.

Charters, 213.

Chartulary of Redon, names in, I6 $n$.

Charudes, Heretha-land, the country of the, $223 n$.

Chatti (now Hesse), the, Io $n$.

Cheddar. See Ceddren.

Chelmsford, 108.

Chelsea. See Celchyth.

Chentis-beria (Kentisbury), $24 \mathrm{I} n$.

Chepstow. See Streguil.

Cherchehulle. See Cyric-burh.

Cheriton, 90.

Chertsey. See Ceortes-îge.

Chester. See Deva and Legeceastre.

Chesterholm. See Vindolana.

Chester-le-Street. See Incuneningum.

Chesters. See Scythles cester.

Chet $=$ Keith in place-names, $86 n$., I 8 I $n$.

Chett, Forest of, $165 n, 181 n$.

Chetwood, $16_{5} n$., I $81 \mathrm{I} n$.

Chevenage, Cefn, ${ }_{1}{ }^{8} n$.

Chichester. See Regno.

Chichestra. See Regno.

Child-rey. See Cilla-rith.

Chiltern. See Ciltinne.

Chippenham. See Cippanham.

Chirchind, 52.

Chirk (Cyric-burh), $263 n$.

Chiulas. See Cyulas.

Chochilaicus (Hygelac), I 3 I.

Chollerford, I I5. See Cilum.

Chollerton, I I $5,235 n$.

Cholsey. See Ceolesige.

Christchurch. See Tweoxn-eam.

Christian-Mal-ford $(=$ Cristemal $=$ "Christs Cross"), 203.

"Christs Cross." "See ChristianMal-ford.

Churchill. See Cyric-burh.

Churn, the river. See Corinnium.

Chute (Chet), Forrest, $165 n$., I8I $n$.
Cicc (Cice, Chich, St. Osyth), 179 n., 304 .

Cicht, 74 .

"Cideston" (Tideston), Wells, $249 n$.

Cilla-rith (Child-rey), I I I $n$.

Ciltern Sætna, 22 I.

Ciltinne (Chiltern), $216,285$.

"Cilurn," the river, I15.

Cilurnum (Celunno), I I $5,235 n$.

Cinges-tune (Kingston), 279.

Ciornincge (Charing), 219.

Cippanham (Chippenham), 252.

Circinn. See Cirig.

Cirenceastre (Cair Ceri, Corinion (? Cironizum), Durocornovium, Cyren-ceastre, Cirencester), 103, II 2, I 47, I 48, I 75, 252 n., 288.

Cirig (Circinn), 52, 76, 77 .

Cironium. See Cirenceastre.

Cironizm Dobunorum, $252 n$.

Cissa (son of Elle), I $42 n$. See also Cissecester (Chichester), Cissan beorh.

Cissan beorh, $142 n$.

Cissecester (Chichester), I $42 n$. See also Regno.

Cithlescester. See Scythles cester. City of the Legion. SeeUrbs Legionis. Ciulae. See Cyulas.

Clackmannan (Manau), $67,100$.

Claighangra (Clayhanger), 286, $287 n$.

Clanoventa. See Glannibanta.

Claudian the poet quoted, 80 .

Clausentum (? Bittern), 53, 54, 64 n., IIO.

Clayhanger. See Claighangra.

Cledemuthan (Clede-mouth), $26 \%$. See also Dou Clediv.

Clevo. See Gleawan Ceaster.

Clewer. See Clif wara.

Clif wara (Clewer), 217.

Cliffe at Hoo, 194.

Clist-ton. See Glis-tun.

Cloister words from Greek, $172 n$.

Closeworth. See Cloveshou.

Clota et Bodotria. See Boderia.

Cloveshou (Cloveshōh, Clofeshos), 194, $216,238$.

Cloves-wurthe (Cloves-uude, Closeworth), I $94 n$. 
Clûd (rock), 212.

Clyde, the. See Klōta.

Clyde-Forth wall, 49, 5 I.

Clysts, the, $283 n$.

Cnobhere, $176 n$.

Cnobheresburg. See Garianno.

Cnofwealh (Cnobwalch), i $76 n$.

Cnut, attack on London, 286 ; Cnut and Eadmund divide kingdom between them, 288; Cnut sole monarch, 288; he receives submission of King Malcolm, 289; dies at Shaftesbury and is buried at Winchester, 289.

Cobre, 237. (? Cover-ham.)

Coccio (? Wigan), III.

Cocidius (=Mars), 116 .

Cockermouth. See Glannibanta.

Cock shot (Cock shade), 2 I 3 .

Cocuneda (Coquet), 99, 100.

"Coel, King," 62.

Cofa, 210.

Cofan-treo (Coventry), 297.

Cogidubn-i, $110 n$.

Coit maur. See Seal-zuyda.

Colanica. See Kolanika.

Colchester. See Camulodunum.

Coldingham, $179 n$.

Colen-ea (Colne), 2 I 8.

Coleshill. See Counsylht.

Coligny, inscriptions at, 87 .

Colling (Cooling), 215.

Colman, Bishop of Lindisfarne, I 80.

Colne, the river, $218,258$.

Colneceastre. See Camulodunum.

Colonia. See Camulodunum.

Coludi urbs (Coludes-burh), I $79 n$.

Columba, 49.

Columcelli, 190.

Combretonio, IIO, III.

Combroges. See Cymry.

Comich (Combwich), $253 n$.

Compendio (Compiègne), I 82.

Concangios. See Deceangli.

Concha-ceastre, 179n. See also Incuneningum.

Conchenn, (Conchend, Cyngen, Doghead, Ugam Cuna-Cena), $55,68$.

Conchess, name of St. Patrick's mother, 73.
Condate (Northwich), 102, 103, I06 n., I I I. See also Kind Street.

Condé. See Cundoth.

Conder, the river, $144 n$.

Conderco $($ Condecor $=$ Benwell Hill $)$, 115.

Congangios. See Deceangli.

Congavata. See Incuneningum.

Congresbury. See Cungres-beria.

Conovio (Conway), I II.

Conway river. See Canubio.

Cooling Castle, 217 . See Culinga.

Coonore, $143 n$.

Coquet, the river, $100,116$.

Corbridge. See Corstopitum.

Corda, 99.

Corfe, $298 n$.

Corfes Geat (Corfe Castle), $276 n$., 278.

Corin (Churn), the river, $288 n$.

Corinium, $288 n$.

Corio (=Irish Cuire, host), I55n.

See also Tri-corii, Petru corii.

Coriosolites, the, $155 n$.

Corio-sopites, $155 n$.

Corio-vallum (Heer-le), I $55 n$.

Corn in "Abercorn", $186 n$.

Cornish compared with Breton placenames, $155^{-62}$.

Cornovii, the, I $12 n$.

Corotic. See Ceretic.

Corsept, $155 n$.

Corstopitum (Corbridge), 100, 105 , I5 $n$.

Coscaer, $158 n$.

Cotingham (Cottingham), 304.

Council of Arles, British Bishops at the, 70 .

Counsylbt (Coleshill), 24, 46 .

Count of the Saxon Shore, 79.

Coventry. See Cofan-treo.

Cowbridge. See Bomio.

Crailing. See Traver-er-lin.

Crann, $86 n$.

Cray, the river. See Crecga.

Crayford. See Crecganford.

Crecca-gelade (Cricklade), 261 .

Crecga, the (Cray), I 4I.

Crecganford (Crayford), I4I.

Crediton (? Cridian-tun), removal of Bishop Leofric's See from, I $3^{1} n$., $277 n$. 
Credy, the river, 277 .

Creech, 39 .

Creech-hill. See Crich hulle.

Creech Michael. See Crycbeorh.

Criccyl, $265 n$.

Crich hulle (Creech-hill), 199.

Crick-howel, $39 n$.

Cricklade. See Crecca-gelade.

Cridian-tun (Crediton), $277 n$.

Cristemal. See Christian-Mal-ford.

Crococalana (? Brough), 109, I 10.

Croes-oswald (Oswestre). See Maserfelth.

Croyland. See Crúland.

Cruc (=tumulus), 204. See Pucel. ancyrca.

Cructan. See Crycbeorh.

Crutimther, I $2 \mathrm{I}$.

Cruk-ceri (Crukeri), $252 n$.

Crúland (Croyland), i $78 n$.

Crummock brook, 273 .

Cruthenech. See Cruthni.

Cruthni (or Cruthenech), 74, 75; sons of, 76, 83. (Cf. Ogain inscription, Luguqritt, where gritt $=$ cruth.)

Crycbeorh (Cructan, Creech Michael), 39 .

Cuichelm, King of Wessex, 175 .

Cuit, the syllable, 85 .

Cul-chet (Culquith), $86 n$.

Culinga (Cooling Castle), 217.

Culquith. See Cul-chet.

Cumber, meaning of, $186 u$.

Cumberland (Cumerland), III ; an English possession, 273; ravaged by Eadmund, 274, and by Æthelred, 283.

Cumbroges (Combroges, Cymry), 26, $136 n$., $299 n$.

Cumenesora, $142 n$.

Cumrew, III.

Cuncha-Chester. See Incuneningum.

Cundoth (Condé), 256.

"Cunedda and his sons" arrive in Wales from Strathclyde, $136 n$.

$\mathrm{Cn}$-neit, 82.

Cunet-io(Cunetione, Kennet), 1 I, 1 I 3 .

Cungres-beria (Cungersbury, Cungresbyri, Congresbury), 24I $n$., 249.
Cuno-in Celtic personal names, 55 .

Cunobellinos, 12 , 19.

Cunoglas, 68. Cf. Glasi-Cunas.

Cunugl (Cunugl-ae, Knoyle), $258 n$.

Cununga-Chester. See Incuneningum.

Cursitter, $227 n$.

Cuthbert of Lindisfarne, his consecration, 184 ; at Cloveshou Synod, 194, 195.

Cn-Ulaid, 82.

Crvat-brycge, 260. See also Quat.

Czueorn Cleofie, 204.

Cwicelmes-hlæw, 284 .

Cyddzufr, $\mathrm{I} 50 \mathrm{n}$.

Cymbeline (Shakespeare's), 66.

Cymedes halh, 216.

Cymen (son of Elle), I42. See also Cymenesora, Cymenes-denu, Cumenesora.

Cymenes-denu, I 42 n., 217.

Cymenes-ora, $\mathrm{I}_{4} 2$ n., 143 .

Cymry. See Cumbroges.

"Cynebellinga-gemære," 12.

Cynegils, King of Wessex, 175 .

Cynemæres ford (Kempsford), 238 .

Cynetan (Kennet), 284.

Cyngen, 55. See also Conchenn.

Cynibre (Kinver), $216,260 n$.

Cynlas (a Welsh brook), $150 \mathrm{n}$.

Cynomannia $\quad$ (Cenomani=Maine), $299 n$.

Cynnit, 253.

Cyren-ceastre. See Cirenceastre.

Cyric-burh (? Cherchehulle, Churchill), $263 n ., 264$.

Cyulas (Ciulae, Chiulas $=1$ long ships), 122, 127 $n$.

Dacore (Dacre, Dacara), $187,269 n$. Dacre, 269. See Eamotum.

Dægstan. See Egesan-stan.

dal ( = valley), 23.

Dael (in Doverdale), 208.

-dæl (= portion), 23.

Darenta Mutha. See Darent.

Dagenham. See Deccan-haam.

Dal-chet (Dalkeith), $86 n$.

Dalreudini, 84 .

Dalriada, 84.

Damnonioi (Dumnonii), the, $3^{\mathrm{I}}$, 99, 104. 
Damnonion (Devonian), promontory, the, Okrion, 94,96 .

Danai, the, 189.

Danes, 224 , bought off for $£ 10,000$, 281; destroy Bamborough, 28I ; fleet ravages country about Sandwich, $284 ; t_{3} 6,000$ tribute paid to, 285. See also Northmen, coming of, 223 et seq.

Danihel, Bishop in the Isle of Wight, 166.

Dano (Doncaster), 108, 109 n., I10, 114.

Dante, a resemblance of the trilogy of, $188 n$.

Dante and bolgia, $298 n$.

Daoulas, I 59 n.

Darent (Darenta Mutha, Derwent), 141, 291. See also Dercentio.

Da Usque (Desk), I 501 .

"Daventry," 34, 106, 109; suggested home of St. Patrick, I $29 n$.

Dawlish. See Dwf[n]las.

Dawston in Liddesdale, $\mathrm{I}_{3}$.

Decantai. See Dekantai.

Deccan-haam (Dagenham), 214.

Deccetes, 94 .

"Deceangli" (Decea, Deceang, Deceangl, De Ceangos, Ceangi Congangios, Tegingel), 20, 24, 95, $114,188 n$.

Decuari. See Petouaria.

Deda, Abbot of Peartaneu, 17 .

Dee, the river, 95 .

Defnascire (Devonshire), 279.

Deganwy. See Arx-Decant-orum.

Deira (Deri), 28; conversion of, I69, I 88.

Dekantai, the, 94, 100, 101 .

Delgovicia, 105.

Démètai (Demetae, Deomidum, Dimet $=$ Dyfed $=$ South Wales), 29, 103, $248 n$., 266.

Denbigh. See Roweynauc.

Dene (Dean, East and West), $24 \%$.

Denge marsh, 216.

Denisesburna (Denises-burn), Rowley Water, 173,174 .

Deo Arciacon, inscription to, $107 n$.

Deomidum. See Demetia.

Deoraby (Derby, North Weorthig), 265,274 ; earthquake at, 290.
Deorham (Dyrham, Dereham), I47, I $54,167,238$.

Deorhyrst (Deerhurst), 288.

Deorstrete, Derestrete, $28 n$.

Derby. See Deoraby.

Dereham. See Deorham.

Deri. See Deira.

Deruvian (Devinianus), $197,198$.

Derv, meaning of, I $87 n$.

Derventio (Derventione, Derventioni, Dorvantizm, Darent, Derwent), I01, 105, 114, I16, I39, 14I, I86, I87 $\pi$., 291.

Derven-tum (Drev-ant), 187 .

Dervo (Der), $187 n$.

Derwent. See Derventio and Darent.

Derwentwater, I 86.

Desk, Desk-ford, I 50 n., $292 n$.

"Destruction of Britain, The" (Gildas), I 2 I.

Denddwr ( $=$ two waters), $150 n$.

Deva (Chester), 26, 95, 102, 103, I06, 11 I. See also Legeceastre.

Deva, the river (Aberdeen), 93, 95, 97 , 101 .

Dêvana (? Aberdeen), Ior.

Devilis, $150 n$., $174 n$. See also Dubglas.

Devil's Water (Dovols $f_{1}$ ), $150 n$., $174 n$.

Devonian. See Damnonion.

Devonshire. See Defnascire.

Dewlis, 150 n., 205.

Dicalydones, 79, 81, 92.

Dice (Diss), $242 n$.

Dictensian Nervii, II 4 .

Dictim, I14.

Dicul, Presbyter, 17$\rceil, 182$.

Diep (Dieppe), $173 n$.

dikes, the, 262.

Dimchurch, 2 I 3.

Dimet. See Démētai.

Dimet son of Maxim, 56 .

Din-birrion, 29, 112.

Din-Gerein (? Dinnurrin, Garrans), 192.

Dinguoaroy. See Bebban-burh.

Dinnurrin, $192 n$. See also DinGerein.

Din-orwig (Dinorddwig), 32, 102.

"Din-sol," name for St. Michael's Mount, $192 n$. 
Dinthigirn (Dindeyrn, Tintern), $176 n$.

diocese (Parochia), 249.

Dioceses, division of, 166 .

Diss. See Dice.

Dissington, 163 .

Ditcheate (Ditch-gate), 202.

Diuma (Dioma), 178 .

Dobounnoi, the, $\mathrm{O}_{3}, \mathrm{IO}_{4}$.

Doccum, $190 n$.

Dofisc, $150 n$.

Dofra-n, Dubris, Dofras, Douvres (Dover), 107, 108 n., 113, 293, 295.

Domesday" Illega", 254 n.

Domesday "selvra" (Monk-silver), 254 n.

Dommoc (Domnoc, Domuce), Dunwich, 173, 238; its meaning, I $73 n$.

Domnechenif. See Donecheniu.

Domneva. See Eormenburg.

"Domnonia," 160.

Domuce (Dunwich). See Dommoc. Don, the, $\log n$.

Donafeld. See Campodonum.

Doncaster. See Dano.

Donecheniu (Domnechenif), $253 n$.

Donemouth (Yarrow), 236. See also Dõunon and Ingyruum.

Dor, 117,274 . See also Bdora.

Dorchester (Oxon). See Dorcicceastre.

Dorchester. See Durnonovaria and Dorn-zwara Ceaster.

Dorcic-ceastre (Dorces-ceastre, Dorchester, Oxford), 175, 277. See also Durcinate.

Dore, II 7, 239.

Dorments, i $58 n$.

Dornsata. See Thornsata.

Dorn-zvara Ceaster, Dornwarana Ceaster (Anglo-Saxon Dorchester), I $38 n$., $25^{2} n$. See also Durnonovaria.

Dorset. See Durotriges.

Dorwit-ceastre. See Duro-bernia.

Dou Clediv (Dun-gleddy), $267 n$.

Douglas (the river) in the Lennox, $15^{2}$.

Doulting (Dulut-ing) stream, the, 199.
Dõumna (Dumna), 104.

Dounon gulf (? mouth of the Tees), 98. See also Done-mouth $=$ Yarrow.

Dourdu, I $59 n$.

Dover. See Dofra-n.

Doverdale. See Dael.

Dovey. See Toibi.

Dovols $f$. See Devil's Water.

Dowles, the river (Dowlais), I $50 n$.

Dragon of the British, $137 n_{.}$; the purple Dragon, the Roman Imperial Standard, I37 $n$.; Pendragon, I 37 n.; "Rouge Dragon," I37n.; "raise the Dragoun," I37n.

Drev-ant. See Derven-tum.

Drews Teignton, 283 .

Droitwich. See Salt wic.

Druidism, 76, I 35 .

Drumpellier. See Dunpeleder.

Drutingstræt, 38, 42. See also Durobernia.

Dvorico, $107 n$.

Dubgaill, 224, 24I $n$.

Dub-geinti, $24 \mathrm{I} n$.

Dubglas (Du-las, Duglas, Devilis), I 49, I 5 O, I 5 I , I 53 , I 59 n., I 74 n.

Dubris. See Dofra-n.

Duēcalèdonian Sea, the, 92.

Duin Necthan (Dunnichen, Dunnechtyn, Dunnichen Moss $=$ Nechtanesmere), $\mathrm{r}_{5} n$. See also Linn Garan.

Du-las. See Dubglas.

Dumbarton. See Ailcluit.

Dumfries. See Caer Pheris.

Dumna. See Dỡmna.

Dumnonii, the. See Damnonioi.

Dun-bulg, I06 $n$.

Dun-Brettan. See Ailclnit.

Duncan. See Duno-Catus.

Duncansby Head. See Virvédrum promontory.

Dunchad, Abbot, 192. See also Duno-Catus.

Dun-Chailden (Dunkeld), 45, 153.

Dunestaple (Dunstable), 304.

Dunfoeder (? Fothurdun), 269.

Dun-fries. See Caer Pheris.

Dungeness. See Nasse.

Dun-gleddy. See Dou Clediv.

Duningcland, 219. 
Dunion (? Muridunum, Ridumo = ? Sidmouth or Seaton), I04.

Dunipace, $\mathbf{r} 52$.

Dunkeld. See Dun-Chailden.

Dunmay, 52.

Dunmyat (Dalmyot), 52.

Dunnet Head. See Tarvedum, the promontory of.

Dunnichen, Dunnechtyn. See Duin Necthan.

Dunnichen Moss. See Duin Necthan.

Duno-Catus (Duncan), ' the fortress warrior': derivative Mac Dhuncadh = MacConkey or Maconochie), $139 n ., 192 n$.

Dunpeleder (Drumpellier), $86 n$.

Dun-rechet (? Dunragit), $124 n$. See also Reget.

Dunstable. See Durocobrivis.

Dunstan, Abbot of Glrestingaberig, 274; banished by Eadwig, 277; made Bishop of Worcester by Edgar, and Archbishop, 277 ; his death, 280.

Dun-unalhi Pincerni, 215.

Dunuuallan, 2 I 5 .

Dunwal-ing daenn, 288.

Dunwich. See Dommoc.

Durcinate, $175 n$.

Durham, Cuthbert's body removed to, 186 .

Durlstone Head, $157 n$.

Durngueis (Durngueir, Thornsata, Dornsata), 138 n., 25 I.

Durnono-varia, Durno-varia, Dornwara Ceaster (Dorchester), II3, I 38 n., I 51 n., 251 n., 252.

Durno-varia, involves varia $=$ theatre, $25 \mathrm{I} n$.

Dur-o (Duron), 187n.

Duro-bernia (Duro-vernum, Darvernon, Duroaverus, Cantwaraburg, Dorwit-ceastre, Canterbury), 38, 103, 106, 107 n., 187 n., 242.

Durobrivas (? Castor on the Nene), 108.

Dnro-brivis (Rochester), Hrofibrevi, Hrofesbreta, Hrofes-castir), 37, $38,106,107,256,280$.

Durocobrivis (Dunstable), 106, 107 n., 109, I 10.
Durocornovio. See Cirenceaster.

Durocornovium. See Corinion.

Durolevo(?near Sittingbourne), 106, $107 n$., $280 n$.

Duroli (Duroliponte, ? Godman. chester), $108 n$.

Durolito (? Writola-burna), Writtle, IIO, III, $2 I_{4}$.

Durotriges, the (Dor-sata), 104, $138 n$.

Durovernum (Canterbury). See Duro-bernia.

Dux Britanniarum, I I4.

Dwf[n]las (Dawlish), 150 n., $159 n$.

Dyfed. See Dēmètai.

Dyrham. See Deorham.

$\bar{e} a=$ river, in river and place-names, $68,179 n$.

Eadburga, St., $133 n$.

Eadesbyrig (Eddisbury), 263 n., 264.

Eadmund Etheling, succeeds Ethelstan in 940, 273; overruns Northumberland, 274 ; besieges Anlaf at Leicester, 274; ravages Cumberland, and leases it to King of Scots, 274 ; stabbed at Pncklechurch in 946,274 .

Eadmund Ætheling (known as "Ironside"), chosen king in 10r6, 286; fights at Pen and Sherston, 286 ; attacks enemy in Kent, 287 ; is defeated at Ashingdon, 287 ; divides kingdom with Cnut, 288 ; dies, and is buried at Glastonbury, 288.

Eadolfesnesse (Eadulfes nase, the Naze), 291, 296.

Eadred, succeeds Eadmund Ætheling in 946,274 ; reduces Northumbrians to obedience, 274; ravages Northumberland, 274; forces slaughtered at Ceasterforda, .275; imprisons Archbishop Wulstan, 275; slanghter at Theotford, 276 ; dies at $\mathrm{Frome}$, and is buried at Ealdminster, 277 .

Eadward, succeeds Cnut in $\mathrm{rO}_{2}$, 289; his favour to Normans, 292; comes to Westminster and has the Minster consecrated (1065), 30I ; 
his death, and burial in the Minster, 301 .

Eadward, succeeds Eadgar in 975, 278; he is slain at Corfe Castle and buried first at Wareham, 278.

Eadwig, succeeds Eadred in 957 and banishes Dunstan, 277 .

Eadwin, King of Northumbrians, baptism of, 168.

Ea-land, 68.

Ealdminster (Oldminster), 277 .

Eamotum (? Emmet or Dacre), 269, 273.

Earldom of Northampton Shire granted to David of Scotland, $3 \circ 3$.

Earnes-Scaga (Herneshaw), 188.

East Anglia, ravaged by Danes, 285 .

East Saxons (Essex), I 29.

Easton. See Estun.

East-ryge (Eastrgena, Eastrége, Eastry), $178 n$., I $79 n$., 219.

Ea-ton, 68.

Eatumberg (? Emborough, Eteneberga), 206.

Ebbsfleet, I33. See Eopwines flebt.

Ebchester. See Vindomora.

Ebriācus (now Yvré-le-Polin), 7I $n$. Eburācum (Eburaco, Eborakon, Eoforwic Ceastre, York), 37, 7 I, IOI, 102, 106, 108, II0, I I $2,237,243$, 244.

Eburiācus (now Evry near Melun), 71 . Eburo-Caslum, 7 I $n ., 99 n$.

Eburodunum (now Yverdon), 7I $n$.

$\mathrm{Eb}$ (ur)oudouron (now Ivorne), $7 \mathrm{I} n$.

Eburomagus, $7 \mathrm{I} n$.

Ëbürŏs (= Yew), ךI $n$.

Ecbryhtes-stan, 253.

Eceni. See Venta-Icenorum.

Ecgberct, Father, 185, 189, 193.

Echni, island of, 266.

Eddesbury. See Eadesbyrig.

Eden, the river, $95,120 n$.

Edinburgh. See Mount Agned.

Edington. See Ethandun.

Edisc (in Hídes-Edisc), 208.

Edisc-ueard, 208.

Effe-cestre, $276 n$.

Egelis Brich (=Varia Capella), 208.

Egesan-stan(Dægstan), Dægsa-stan, 162,163 .

Egisauuda (Fearfulwood), $209 n$.
Egonesham (Eynsham), 147.

Eildon. See Eldunum.

$e l$, meaning of Welsh, I $70 n$.

Eldunum, near Melrose (Eildon), $196 n$.

Eleuther (Eleutherus), 57. See also Lucius.

Elfetu. See Elfetee and Elmet.

Elge (Ely). See Elig, Eligabirig.

Elgovai. See Selgovai.

Elig, Eligabirig (Ely), 179 n., 277.

Eliseg (Elised, Elized), 55, 56, 248.

Elleanboro, 206.

Ellenborough. See Axeloduno.

Ellendun (Wroughton), $239 n$.

Elleti, the field of, 136 .

Ellos, the, a headwater, 97.

Elmed Sætna, 220.

Elmet (Elvet, Elvael), I43n., I 70, $196 n$. See also AElfetee.

Elvael, I 70 n. See Elmet.

El-vet. See Elmet.

Embenum (Amiens), 256 .

Emborough. See Eatumberg.

Emmet, 269 n. See Eamotum.

"Emricor va" (Chepstow), 34. See also Streguil.

Engla-felda, $246 n$. See also Tegeingl.

Engle, East, 222.

Eofeshamme (Evesham), 289, 297.

Eoforwic Ceastre. See Eburācum.

Eogan, 96.

Eohinga burh, 2I 5 .

Eoprvines fleot, Eobbes-fleet, Ebbesfleet, $\mathrm{I} 33 n$.

Eormenburg (Domneva), his brothers slain, $179 n$.

Epiakon (Epiacon), IOI, 102, II4.

Epidioi, the, 100.

Epidion Promontory, the (Mull of Cantire), 92.

Episford (Rithergabail), I 39, 140.

Epistola of Gildas, the, $123 n$.

Erchenfield. See Areconio.

Eriu (Erinn), 73.

Erlamstret (=Verlam-stret), 4I.

Essex, ravaged by Northmen, $290 n$.

Estun (Easton), 304.

Esugen-us, 96.

Etclete (Atclete, Auckland), 234, 237. 
Eteneberga. See Eatumberg.

Ethandun (Edington, Wilts.), $255 n$.

Etive, Loch, 93.

$e u$, the termination, $179 n$.

Enfania (Isle of Man). See Monapia.

Enre, the river, 7 r.

Eustace, Count of Boulogne, 292.

Evania (Isle of Man). See Monapia.

Evernili Patria, 73.

Evesham. See Eofeshamme.

Evigantes. See Jugantes.

Ewelm (river spring), 212.

Ezeyas. See Gervis.

"Ewyas, Earl of Erging and," I $39 n$.

Ewyas Harold, $296 n$.

Exa. See Axa.

Exanceastre (Isca Dumnuniorum, Adescancastre, Cairuisc, Exeter), I04, II3, I3I n., I90 n., 252, 254 ; taken by storm, 284 .

Exanmuthan (Iska-mouth, Exmouth), 96, 283 .

Exe, the. See Exanmuthan.

Exeter. See Exanceastre.

Exoche, the promontory, 98 .

exploratores, the (scouts), $106 n$.

$e y$, the Norse, $197 n$.

Eynsham. See Egonesham.

Faddiley (not Fethanleag), ${ }_{4} 8$.

Færpinga (Fearfinga), 222.

Faestin (in Buckfast), 208.

Fagan (Phaganus, Dyfan), 197, I98.

Fano-Cocidi. See Tunnocelo.

Fara, $170 n$.

fari in Lindesfarona, $180 n$.

Faringdon. See "Farndun in Mercia".

"Farndun in Mercia" (Faringdon), 268.

Farne Island (Holy Island), $171 n$., $184,186$.

Farnham. See Fearnhamme.

Faroe (Shetland Islands), 224.

Fauresfeld (Fefres-ham, Faversham), 302.

Faversham. See Fauresfeld.

Fearfulwood. See Egisauuda.
Fearnhamme (Farnham), 258.

Felbrig. See Thelbrig.

Felix, Bishop, from Burgundy, I76; death of (Bishop of Dunwich), 178.

"Fell," in North of England, $196 n$.

Fenglesham. See Thenglesham.

Fenny Stratford. See Magiovinto.

Fergunea (Hercynia silva), 2 I $2 n$.

Ferramere (Meare), 198.

Ferrex and Porrex, 66.

Fethanleag (not Faddiley), I48.

Fethar (Fothar =? Fiodh-thir), 77 .

Fetter (in Fetteresso), 77.

Fib (=Fife), $76,77,83$.

Fidach, 76 .

"Fif and Fothrif," 77 .

Finan, Bishop, I78.

Finchale. See Pincanheal and Fink-halh.

Finchamstead, 303.

Find Geinti, $24 \mathrm{I} n$.

Fine, Loch. See Lemannonion bay.

Finedon. See Thindon.

"Fin-Gall" (Norsemen), 224. See also Northmen.

Finglas, $150 n$. See also Glas.

Finhaven. See Fothenaven.

Finisk (Phoenix), $292 n$.

Fink-halh (Fink-halgh, Fink-halugh, Finchale), 233n., 234n. See also Pincanheal.

Finnsburg, Battle of, I3I.

Firgen (Firolandes, Firgenlandes, Fergen-berig), 2 I $2 n$. See also

Firle beacon.

Flatholm. See Bradan Relice.

Flavia (Province of Britain), $7 \mathrm{r}$.

Flod, 195.

Flynnon Gwas Patrig, $82 n$.

"Fobbinges," I $78 n$.

Fogo in place-names, 244.

Foithre, $270 n$.

Folcesstane $=$ Folkestone. See Ful. chestan.

Foodra (Peel of Further), $270 n$.

Forays (Forres), 47.

-ford, compounds with, $242 n$.

Foreign Wikings (Utwikingan) in

Anglesey (Angles Ege), 303.

Forres. See Forays.

Fors (= foss), 231 . 
Forsca burna, 218.

Fortenses, the, $276 n$.

Forth, Firth of. See Boderia estuary. Fortrenn, 76, 77, 84, 245, $246 n$.

Fosse-way, the, $293 n$.

Fothenaven, $7 \%$.

Fother. See Fethar.

Fotla 76,77 .

Foubister, $227 n$.

Fowey. See Kenion, the.

Frankish Bishop, a (ÆEgelbeorht), 175.

Franks, 6r.

Frauu (Främa, From - muthan, Frome), the river, 204, $25 \mathrm{I} n$., 277, 283. But cf. Pedersen $\$ 303$.

Fresia (Friesland), rgo.

Fresicummare (Frisian Sea), 120.

Frisians, Fresones, 120, 13 1, 189n. See also Dun-fries (Dumfries).

Frocester, 123.

Frome. See Fraun.

From-muthan. See Frauu.

Fulchestan (Folkestone), I42, 280n., 295.

Fulham. See Fullanham.

Fullanhamm (Fulham), $255,256$.

Fulney, 68.

Funt, Funtan, in place-names (as in Havant, Fovant, \&c.) borrowed from Latin, through British, I I8. Cf. Cornish Funten.

Furness. See Futher-ness.

Fursey, a Religious, $176, x_{77}, 182$.

Futerna (Whiterne), $124 n$.

Futher-ness, 78, $270 n$.

Fynten Goys, ${ }_{5} 8 n$.

Gaast (morass), I 2 I.

Gaba Glanda, I I5.

gabail, r4r.

Gabrant(ó)vikoi, Gulf-port of the (Humber-month), 98, 102, 274.

Gabrosente (Gabro-senti, Gabrocentes, ? Gateshead), 94, I 6.

Gaedhill and Gaill, Wars of, 230.

Gaelic. See Goidelic.

Gafol, 231 n.

Gafulford (Galford), $23^{8}$.

Gainford-on-Tees. See Gegenorda.
Gainsborough. See Gegnes burh.

Gala Water in Wedale, the, 152.

Galava, 1 II.

Galgacos. See Calgacos.

Gallemborne (Walbrook), 67.

Galleva. See Calleva.

Galli, 9.

Galloway. See Novantoi.

Galmanho (Galmanhithe, Bootham Bar), 297.

Galmetona (Ganton), 297.

Galt (=cliff), 229n. $G$ inorganic, cf. Ord and Gorrd: Pedersen \$ 302.

Galt (=Hog), $229 n$.

Galt-hanin, 46.

Gal[t]klint Wood, $4^{6}$.

Galt-reath (Catraeth), 46.

Galt-res, 46.

"Galt-weid" (Galt-way), 46.

Gamber, the river, 98, $268 n$.

Gamel, 23 r.

Ganganoi (Kaianganoi), 95.

Ganton. See Galmetona.

Garianno (Gariennos mouth, Gariannum, Cnobheresburg, Burgh Castle), $83 n ., 98,113,176,177 n$.

Garmani, I89.

Garrans. See Din-Gerein.

Gate (in the sense of way), $23 \mathrm{I}$.

Gateshead. See Gabrosente.

Gavylton (Yeovilton), r4I.

-ge termination = gau (?), I 79 .

Geardcylle (Yarkhill), $288 n$.

Gedtas (Jutes), I 3 I $n$.

Ged-burgh (Geddeworth, Jedburgh), $179 n$., $276 n$.

Geddeworth. See Jedburgh.

Geddingas (Yedding), 2 I9.

Gegen - forda (Gainford - on - Tees), 238.

Gegnes burh (Gainsborough), 286.

Gegunis. See Gewis.

Gelade, 189, 26 I $n$.

gelât, place-names ending in let, 189 .

Gemapia, 69.

Gemi $\delta_{0}=$ Gemȳthe- = mouth, 202.

Gemythe. See Gemiðo.

Genava (Geneva), 155 n.

Genealogies, Imperial Succession in Welsh, $5^{8 .}$

Genevieve, St., persuaded to dedicate berself to God, 125 . 
Genlade (Genlada, Yenlet), the river, $120,189,238 n$.

Genunian territory, 49, 50.

Geoffrey of Monmouth, 65 .

Geona Cohort, 49, 50.

Geoða (Ithan-ceaster), $276 n$.

Gerent, Gerontius (Wala-king), 192.

German, St., Bishop of Auxerre, visits Britain, 7o; Bede's account of "Hallelujah Victory" taken from Life of St. German, I $9 n$., $125,126,127$.

Gerontius. See Gerent.

Gesoriacum, origin of name, $6_{3}, 6_{4}$. Gestrio, 208.

Gewis (Gegunis, Gimoys, Iwys, Ewyas, Gewissi, Gunnnesse, Gunnis), 137, I $3^{8}$ n., 139 n., 183.

"Gewissi." See Gewis.

Gifla (? Ivel or Givell), I 4I n., 221. Gil (= narrow valley), 23 I.

Gildas, his work, "The Destruction of Britain," 121, 122; his "Epistola", I23 1., 1 28, I 35 ; "Life of Gildas," I 53.

Gilling. See Ingetlingum.

Gillinga-ham (Gillingham), 286.

Giolla, the use of, $82 n$.

Gisl, as a prefix, 195, 200.

Gizuys. See Gewis.

Givel, 141, $221 n$.

Gla-morgan, $138 n$.

Glun, Glann, 16, I I I $n$.

Glannibanta (Glannibenta, Clanoventa $=$ ? Cockermouth), 34, I I I, II 6.

Glas, a common river designation, $149 n$.

Glascoed (Lasket), I 81 $\boldsymbol{n}$.

Glas-Naoidhen. See Glas-Nevin.

Glas-Nevin (Glas-Naoidhen), I $50 n$.

Glastenic (Glæstingaberig, Glastinga-byrig, Glastingabyrg, Glastonbury), 60, 127 n.; "Glastimber of the Goidels," I 30 n., $147 n$., 153; the Minster built (? repaired) by Ina, 184 ; Note on, 197 ; names in doubtful Charters, 198 et seq.; grant to church of Blessed Mary and St. Patrick, 199; grant of
Ineswytrin, 200; St. Dunstan, Abbot, 274; Glastenic, native name, $275 n$.; Eadmund buried at, 288, 296.

Glastingabyrg. See Glastenic.

Glastonbury. See Glastenic.

Glazebrook, $150 n$.

Gleawan Ceaster ("Cair Glovi," Clevo, Clev-um, Glevum, Gloecester, Gloucester), I I 2, I47.

Glegrvisic (Gleguissing), I 36 n., $138 n$., 248.

Glein, the river, 149.

Glen, the river, $15^{2}, 168$.

Glend, 16.

Glessariae, 90.

Glevum. See Gleawan Ceaster.

Glis-tun (Clist-ton), $2 \mathrm{~S}_{3}$.

Glossaries, 207 et seq.

Glou, $112 n$.

Gloucester. See Gleawan Ceaster.

Glynn, 16.

Gobannio (Abergavenny), II 2.

Gobban, Presbyter, 177 .

Godenice (Godney), 206.

Godmanchester. See Duroliponte.

Godney. See Godenia.

Gododin (Guotodin), "Manaw of the Gododen," I00, 188n. See also Otadinoi.

Godwin and his sons exiled, 294, Godwin dies at Winchester, 296.

Gofer, meaning of, $186 n$.

Goibniu, 112 n. See Gobannio.

Goidels, 9 ; origin of name, 63 ; Goidelic (Gaelic), place-names in Scotland, 83,121 .

Gold-cliff, 47 .

Gore, 214.

Gospatric, "writ" of, 273.

Got. See Cait.

Gottes-scalc, $83 n$.

Gower, I $24 \boldsymbol{n}$.

"Grain" in Northumberland, $229 \boldsymbol{n}$.

"Grampian" Hills, 47.

Granta, the river, $25 \mathrm{I} n$.

Grantabrycge (Grantan brycge, Cambridge), $108 n$., 250, $25 \mathrm{I}, 267$.

Grant Chester. See Cair Granth.

Granpian Mount, 47.

Great Chesterford, I08 $n$.

Great Chesters. See Essica. 
Greenzic, 280 n.

Gregory the Great, St. , quoted, $126 n$.

Grendel, a demon called, I 3 I $n$.

Grendelesmere (Wiltshire), I 3 I $n$.

Grendles bec, Grindelespytt (Worcestershire), I 3 I $n$.

Griffin, Welsh king, 290, 294, 299.

Griffins in the Tudor arms, $137 n$.

Grindelespytt. See Grendles bec.

Gryffith. See Griffin.

Guare (Guare Miracle, Welsh Chware), $251 n$.

Guasmoric (Gwysmeuric, Gwys Veuruc), I37n., I $38 n$. See also Westymar.

Guened (Venedotia, now Gwynedd), I $35,136 n$.

"Guent," 32.

Guent, 259 .

Guentonia, $24^{8} n$.

Guern in Guern-s-ey, I 7 I $n$.

Guilou (Wiley), the river, $22 \mathrm{I} n$., 250. See also Wiltun.

Guinn liguiauc (Gwent loog), $259 n$. Cf. Irish Imliuch (Emly), and Amlwch.

Guinnion, the Castle of, $\mathrm{I}_{50}$, $\mathbf{I}_{52}$.

Guital (? Vitalis), 56.

Gulb (= beak), I $89 n$.

Gumeninga hergae (? Harrow-onthe-Hill), $209,216$.

Gunnis, Guunnesse. See Gervis.

guocob, in place-names, $244 n$.

Guorthigern, I $27 n$., I 28, 134-7. See Vortigern, the Irish form of the name used by Gildas and Bede.

Guorthemir, son of Gnorthigirn, $13^{8}, 139$.

Guortigirniaun, $248 n$.

Guotodin. See Gododin.

Guthlac, St., I94.

Gwas, the use of, $82 n$.

Greek (=Wick), I66n.

Grenedd (Gweneth, N. Wales), 32, I73 n., 248.

Gweneth. See Gwenedd.

Gwent loog. See Guinn lignianc.

Gwern-og. See Vern-um.

Gwerthyr, 84.

Gwic-Wern, $16_{5} n$.

Gwig, I65n.

Gwynedd. See Gwenedd.
Gruyr y Gogledd, I $5^{2}$.

Groysmeuric (Gwys Veuruc), I $37 n$.

Gypeswic (Ipswich), 280 n., 281 .

Gyrvii, the, $I_{7} 8$.

Gyrwa, North and Suth, 220.

"Gyrwa river," I $78 n$.

Gyrwe, a Teutonic tribe (?), I $78 n$.

"Gyrwe-fenn," I $78 n$.

Gytha, Harold's mother, retires to Flatholm, 302.

Hadley. See Headlega.

Hadrian's wall, 49.

Hæfe and Cære, between (Avon and

Carron, the rivers), $19^{2}$.

Haerg. See Gumeninga hergae.

Hæsel-hyrst gate, 218 .

Hastinga Ceastre (Hastings), 292, 295.

Hastinga Port, $30 \mathrm{I}$.

Haethfelth (? Hatfield chase), battle of, I73. See Meicen, battle of.

Hafing seota. See Hrempinguuic.

Hafren (Severn), 24. Initial $S$ becomes $H$ in British c. 300 A. D.: Pedersen $\S 303$.

hage (hedge, wood, enclosure), 2 I $2 n$.

Hagustaldesham (Hexham), 99, I I5; meaning of, I74n., I $84 n$. See also Axeloduno.

Halc (Healh), 180 $n$.

Halc-let, $234 n$.

Halech, 234.

Halha, 234 .

Halidene. See Hefenfelth.

Halignesse beorge, 214.

" Hallelujah victory," I I9, I 26, I 27.

Hallington. See Hefenfelth.

Halngh-ton (Haughton, Halech), $234 n$.

Hām (home), 213 . See also Hamm.

Hamble. See Homel-ea.

$H a m m$ (land drained by dykes),

213. See Ricinga-haam, \&c.

Hamtun (Hamtune-Southampton, Northampton), 240, 264, 266, 285.

Hanc-hemstede, $2 \mathrm{I}_{4}$.

Hanger, 214.

Hangra in place-names, $286 n$.

Hanratty. See St. Indracht. 
Harbour, $155 n$.

Harda-Cnut succeeds Harold ; dies at Lambeth, 289.

Hardwick, $166 n$.

Harehoch, $235 n$.

Harehouden (Harden), $235 n$.

Harold sncceeds Cnut as King in 1034, 289; dies at Oxford (IO40) and is buried at Westminster, 289.

Harold at Bylgeslege, 297 ; invades South Wales in 1062, 299 ; succeeds King Eadward in 1066, 301 .

Harraton, $235 n$.

Harrow. See Gumeninga hergae.

Hartbonrne. See Heorat burna.

Hartleford. See Ioratla-forda.

Hartlepool. See Herut-eu.

Harudes, $223 n$.

Hasel-over (Hasler), 208, $210 \mathrm{n}$.

Haslehangra, $287 n$.

Hasler. See Hasel-over.

Hastings. See Hastinga Ceastre.

Hatfield Chase. See Haethfelth.

Haughton. See Halugh-ton.

Hang-r (Donners hangk), $23 \mathrm{I}$.

Hawrds. See Hörðar.

Hayes. See Linga Hase.

Headlega (Hadley), 257.

Heahhaam (Higham), 215.

Hearrahalch, 235 .

"Heathen," meaning of, $240 \mathrm{n}$., $24 \mathrm{I} n$.

Hebelmes Landschere, $298 n$.

Hebrides. See Acmoda.

Hedene (Hide-clothed), 212.

"Heer-le" (Corio-vallum), I 56 n.

Hefenfelth (Halidene, Hallington), I $74 n$.

Hegestaldes setl, 204.

Hei-weg, 214.

Helena (wife of Constantius), $6 \mathbf{2}$.

Hemgisl, Abbot, 198.

Hendrica, 221, 222.

Hengest (stallion), and Hengist, 132.

Hengestdun (Hingston Down), 240.

Hengestes-ige (Hinksey), 132.

Hengestes-ricg (Henstridge), 132.

Hengist arrives in Britain, $127 n$. $128 n$; name mentioned in Beowulf, I 31, I 32 n., I33, I 39 .
Henry I, spends Easter at Marlborough in 1110,303 .

Henstridge. See Hengestes-ricg.

Heofeshamme. See Eofeshamme.

Heorat burna (Hartbonrne), 218.

Heorotforda (Hertford), 263.

Herberct, Presbyter, of St. Herbert's Isle, Derwentwater, 186.

Herculis, promontory of, 94 .

Herefinna, $22 \mathrm{I}$.

Hereford Port (Hereford), 297.

Herepath, Io $n$., $155 n$.

Heretha-land (Hörðar, Hawrds, Charudes, Harudes), $223 n$.

Herio-s. See Auray.

Heriri, montes'(Snowdon), I 36, 239, 303 .

Herneshaw. See Earnes-Scaga.

Hertford. See Heorotforda.

Herut-eu (Herot-ēa, Hartlepool), $179 n$., 180.

Hesket (Hesketh), $86 n$.

Hesse, ro.

Henuald (Black and White) Presbyters, 190.

Hew Goose (Uch coed), $158 n$.

Hexham. See Hagustaldesham and Axeloduno.

Hibaldestowe, $294 n$.

"Hiberni," forms of, 72 .

Hicca, 221.

Hídes-Edisc. See Edisc.

High Cross. See Venonio.

High Riechester. See Bremenio.

High Tor, 2 I 2.

Higham. See Heahhaam.

Hii (Hy, Iona), 1 46, $178,185 n$., 19o, $191,193,225,236$.

Hii Columcelli (I Cohumbe Cille), $190,236$.

Himeid, King of Dyfed (Demetia), 248. See also Maes-yvet.

Hincmar, Archbishop, $245 n$.

Hingston Down. See Hengestdun.

Hinksey. See Hengestes-ige.

Hin-Locrinus (Locrinus, Lloegr), I 98.

Historia Britonum, ${ }_{5}$.

Hjallt-land (Shetland), $225 n$.

Hjalpands-ey (Shapinsay), $225 \mathrm{n}$.

Hlid (Lydd), $216,235 n$.

Hlidaford (Lydford), 282. 
hlinc (slope), $2 \mathrm{I}_{4}$.

Hlud, Monastery of, 235.

Hocneratun (Hokenarton, Hook Norton), $265 n$.

$H \bar{h}$ (promontory), $194 n$.

Hokenarton. See Hocneratun.

Holegn (in Holenhyrst), 207.

Holenhyrst. See Holegn.

Holm, 23 r.

Holm-ryge, I $78 n$.

Holy Island. See Farne Islands.

Holy Places, a work on the, presented to King Aldfrid by Adamnan, 191.

Holy well. See Tegingel.

Homel-ea (Hamble), the river, $2 \mathrm{I}$, I $45 n$., I $72 n$.

Honeffe, 69.

"Honey Child" in Romney Marsh, $226 n$.

Honorius, Archbishop of Canterbury, I 78 .

Hook Norton, See Hocneratun.

Hope (= a bay and river valley), 23 I.

Horburg. See Argento Varia.

Horca or Orca (Okrion-point), the Lizard, 89, 96.

Hornblawerton (Hornblotton), 207.

Horncastle, 102.

Hörðar (Hawrds, Charudes, Harudes), $223 n$.

Horsa arrives in Britain, 127n., I $28 n$., I $3 \mathrm{I}, 132 n$., I 33 ; his death, I 39, I 40.

Horsafald (Horsfall), 132.

Horsaleah (Horsley), I32.

Horsfall. See Horsafald.

Horsham, r32.

Horsley. See Horsaleah.

Horstead, I 40.

Howth Hill, $229 n$.

Hremping-uuic (Hafing seota), 2 I9.

Hreod-ham, 217.

Hreopa-dun (Hreopedune, Repton), $196 n ., 250$.

"Hreth" Goths, 223.

Hreutford (Hreodford-Redford or Redbridge), I $72 n$., I 83 .

Hris (Rhys), slain, 296.

Hrither (= cattle), $208 n$., 216.

Hroching (Rocking), 2 I 8.

Hrofes-castir, Hrofes-breta, Hrofi- brevi (Rochester). See Durobrevis.

Hrother, $183 n$.

Hudan-flebt, I32, I33n., 215.

Hugabeorg, 214.

Hughes, Professor $\mathrm{M}^{\mathrm{c}}$ Kenny, and the landing-place of Augustine, I35.

Huic, $16_{5} n$. See also Hwicna.

Huicceundu, $16_{5} n$.

Huiccii (Huich), 164, 216.

Huiccii, territory of, 166 .

Humbran mūthe (Humber estuary), 281.

Humir, the, 98 .

Hunapa, 69.

Hundehoge (Hunecote, Hundcot), 304.

Hïnengräber, $82 n$.

Hunger-hill, $287 n$.

Hunni, 189.

Hunno (Onno), II5.

Hūnōz, $82 n$.

Huntandun (Huntingdon), 267 .

Husmerae, province of, 216.

Hussa, son of Ida, founder of the kingdom of Bernicia, 163 .

Hwarwella-n (Wherwell), 294.

Hweallæge (Whalley), 237.

Hwiccas, 184. See also Huiccii.

Hwicna biscop, $164 n$.

Hwicna Gemare, $164 n$.

Hwinca, 221.

Hivitan Wylles geat (Whitewell's gate), $274,275 n$.

Hritciricean (Whitchurch), I03, 283.

Hwitern, 235.

Hroyte Celdan, $226 n$.

Hy (Iona). See Hii.

Hybernia, go.

Hydata Therma. See BathanCeastre.

Hygelac. See Chochilaicus.

Hyppeles Fleote (near Sandwich), 134.

Hyrtlingberi (Irthlingborough), 304.

Hywel Dda, $267 n$.

Iarn (or Iron) language, $75 n$.

Iberran, IOI. 
Iberion, 88.

Ican, I $76 n$. See also Iceni.

Icanho (Boston), 176 .

Iceland discovered, 225 .

Icenan, the river, $108 n$. See also Itchington.

Icenhildeweg, ron.

Icenhylt (Icknield), 12,13 .

Iceni, the, 12, 20, I $76 n$.

Icht, see of. See Muir-n-Icht.

Icinos (? Ickworth), I08.

Ickham. See Ioccham.

Icknield. See Icenhylt.

Ickworth. See Icinos.

I Columba Cille. See Hii.

Iction. See Ition.

Ictis, 89.

Ida, founder of the kingdom of Bernicia, 163 .

Idla. See Yddil.

Iēna, the (Wigton-bay), 93, 95 .

Ierne (Iverna), 89.

$i g=i s l a n d$, I $79 n$.

Iglea (Acglea, Aiglea). See Aclea.

Ikenoi, the, 103 .

Ila, the river, $9 \%$.

Ilchester. See Irel-Chester.

Ilegh (South-leigh), $254 n$.

"Iley Oak," 254 n.

Ilketshall (Ulf-ketels-heall), ${ }_{28} n$.

Ilkley. See Olicana.

Imperial Succession in Welsh Genealogies, 58 .

Inber Domnann, 99.

Incuneningum (Congavata, KunkaCester, Concha-ceastre, CunangaChester, Chester-le-Street), II 5 , II 6, I $79 n$., I 88.

In-dera-uuda (Beverley), I 88.

Indracht, St. (Hanratty), 206.

Ine, King of Wessex, 194.

Ineswytrin (Glastonbury), 200. See also Glastenic.

In Feppingum, I78.

Ingetlingum (Gilling), I 78 .

Ingo-mar. See Ivarr.

In gyrutm (Yarrow), 178 n., 191. See also Donemouth.

Inhrypun (Ripon), I9I. See also Ripar.

Inisboufind, 180 .
Inis Metgoit. See Lindisfarn.

Inis Patraicc (Peel), 236.

inis Prydain (Welsh name for Great

Britain), 74.

Inlet (Yenlade), 121, 189.

Inscribed stone at Deerhurst, $298 n$.

Inscriptions at Coligny, 87 .

Inscriptions at Rom, 87.

Inscriptions at Todi, 87 .

"Insi-Gall," $27 n$.

In Undalum (Oundle), I 91.

Inver, meaning of, $186 n$.

Ioccham (Ickham), 2 I 8.

Iona. See Hii.

Ioratla-forda (Hartleford), 218.

Ipswich. See Gypeswic.

Ircingafelda (Erchenfield). See Areconio.

Ireland. See "Iuuerna ".

Ireland, Ecgfrid invades, $184,185$.

Irin. See Iuuerna.

Iris (Irin). See Iuuerna.

Irish sources in Nennius, $128 n$.; hermits in Iceland, 225; among Norse settlers in Iceland, $225 n$.; pilgrims land in Cornwall, 257 .

Irruaith, $223 n$.

Irthlingborough. See Hyrtlingberi. Isannantia. See Isannavantia.

Isannavantia (Isannantia), Iog. See also Bannaventa and Bannavento.

Isarn, $75 n$.

Isbister, $227 n$.

Isca. See Caerleon.

Isca Dumnuniorum. See Exanceastre.

Isenan æwelm, 215.

Iska (Exeter). See Exanceastre.

Iska-mouth. See Exanmuthan.

Iskalis, 9 n., I04.

Isoutrion (Isubrigantum, Isurium, Aldborough), 101, 102, 105, 106, 108.

Isubrigantum. See Isourion.

Isurium. See Isourion.

Itchington, $108 n$.

Ithtige, I I I $n$.

Ition (Ikion, Iction), 74, 90.

Itios river-mouth, the (? the Sound of Sleat), 92, 93 .

Ituna, the river, $93,95,120 n$.

Indan-byrig (Iuthan birig), I 79 n.; 
Wulstan imprisoned in, 275, $276 n$. See Geoda, Ythanceaster. "Inuerna" (Hiberni, Iverna, Ivernia, Evernili Patria, Eriu, Erinn, Iwerddon, Ireland), 72 n., 73, 89. Ivarr (Ingo-mar), $245 n$.

Ivel, I4I, $221 n$.

Ivel-Chester (Ilchester), I4I, 22 I $n$. Iverna, Ivernia. See Iuuerna.

Ivorne. See $\mathrm{Eb}$ (ur)odouron.

Iwerddon. See Iuuerna.

Iwys. See Gewis.

Jackments, ${ }^{58 n}$.

Jarls, flight of the, $224 n$.

Jedburgh. See Ged-burgh.

Jemeppe, 69.

Joseph of Arimathea, 197.

Judoc, St. (Jud-gual, Just), 261 $n$.

Jud-gual. See St. Judoc.

Jugantes (Evigantes), State of the, 30.

Jutes, the, I 28, I 3 I $n$., I 40.

Tuthan-birig. See Iudanbyrig.

Kaer Septon. See Sceftesburg.

Kaer vudei (? Woodchester), I $23 n$.

Kaianganoi, promontory of the, 93 .

Kaianganoi (Ganganoi), 95 .

Kaili-os, the mouth of the (? Port Gordon), 97 .

Kainos Limēen (? Portsmouth), 97. See also Portesmutha.

Kairlium, 153. See Chester and Dumbarton.

Kalagon. See Calacum.

Kaledofr. See Cen-defrion.

Kaledonian forest, the, I00. See also Caledonia.

Kalédonioi, the, 100, 101. See also Caledonia.

Kalentyre. See Calat-ria.

Kamoulodounon. See Camulodunum.

Kantioi (Kent), I03, I04.

Kantion, Noukantion, the promontory (Kent), ? Beachy Head, 89, 97 .

Kari (Cary), 20I.

Karnơnakai. See Kerōnes.

Karnönes. See Kerōnes.

Karreg Tylhvaen, $157 n$.

Kassiterides (tin-islands), 89.

Kassiteros. See Kattileros.
Katouraktonion. See Cataracta.

Kattiteros (Kassiteros), 89.

Katvellaunoi, the. See Catu-Vellauni.

"Keiths," in Scotland, $86 n$., I8I $n$. Kelda ( $=$ a well), $226 n$.

Kelly. See Ceollach.

Kelvedon. See Canonio.

Kemesegia (Kempsey), 289.

Kempsey. See Kemesegia.

Kempsford. See Cynemæres ford.

Ken, the prefix, $86 n$.

Kenchester (Hereford), 54. See also Magnis.

Kenetbury (Kintbury), I I, 284.

Keneth, King of Scotland, 206.

Keniōn, the (? Fowey), 96.

Kennet. See Cunetio.

Kenstey, Bishop of Dinnurrin, I92 $n$. Kent, evidence of Jutish place-names in, $226 n$. ; peace bought in East Kent for $£_{3}, 000,285$.

Kent. See Kantioi.

Kentisbury. See Chentis-beria.

Kenver, 216.

$\operatorname{Ker}$ (=horn), the root, $183 n$.

"Kernes and Gallowglasses," (Shakespeare), I $39 n$.

Kernwy, 203.

Kerones, the (Krēones, Karnones, Karnonakai), 100.

Kerriemuir, 270.

Kesteven. See Ket-stefena.

Ket-stefena (Kesteven), 18I $n$.

Keynor, I $43 n$.

Kidderminster, $5_{5} \mathrm{n}$. (cf. also Welsh Cyt-tir $=$ a common).

Kiddermore Green, $I_{5} 0 n$.

Kil-, in place-names, 190.

Kilda, St., $226 n$.

Kilpatrick, 190.

Kimble, I 2.

Kimbolton, 12.

Kind-street, 102, 106 n., 107 $n$.

King Lear (Shakespeare), 66.

Kingston. See Cinges-tune.

Kinnaird's Head, 97.

Kinross. See "Fif and Fothrif".

Kintbury. See Kenetbury.

"Kinver." See Cynibre.

Kirkby Thore. See Braboniaco.

Kirkintulloch, $\mathbf{5}^{2}$. 
"Kirkja," use of word by Norsemen, 226.

Kirknewton, carved sarcophagus at, 168.

Kirtlington. See Kyrtlingtun.

Kits Cotty-house, 140.

Kjarr, 23 I.

Klett-r, I6.

K'lota (Clyde), 92.

Knoyle. See Cunugl.

Kolanika (Colanica), 99.

Korio, 99.

Koritavo (Koritanoi), the, 103.

Kornavioi, the, 100, 101, 103.

Kreōnes. See Kerönes.

"Kunka-Cester." See Congavata.

Kyrtlingtun (Kirtlington), 279.

Laam (in Lamhythe, Lampyttas), 208.

Lackford, $108 n$.

Lactodoro (Lacto-duro, Lactodrodo, Lacto-dorum, Tofeceaster, Towcester), 106, 107 n., I09, 266, 267.

Laech. See ledh.

Lagecio. See Legeolio.

Lagny. See Latiniacum.

"Lakehead" (Penne locos), $109 n$.

Lamb-ay, $229 n$.

Lambeth. See Lambhythe.

Lambhythe, Lamhytha (Lambeth), 289. See also Lamseathas and Laam.

Lampyttas (loam-pits), 208.

Lamseathas (Loampits), 290 $n$. See also Lambhythe.

"Lanchers" at Worth Maltravers, $298 n$.

Lanchester (Durbam), 53 .

Lanchester north of Binchester, II 4 .

Lanchester on the Lune, II4.

Lancing, I $42 n$., I $43 n$. See also Wlencing.

Landford. See Leonaford.

Landnáma Bóc, $225 n$.

Landschar dic, $298 n$.

Landscor-ford, $298 n$.

Land-scoru, $298 n$.

Land's End. See Penwiht Steort, Penbryn Penzwath.

Langatreo (Longtree H.), $293 n$.

Lange berga, $24 \mathrm{I} n$.
Lantocal (Lantocai), 198, 201.

Larkbear. See Laurocabera.

Lasket in Cumberland, I 81 $\boldsymbol{n}$.

Lasket grove, I8I $n$.

Lastingaeu (Lastingham), I79, I80.

Lastingham. See Lastingaeu.

Latch, $23 \mathrm{I}$.

Latin words borrowed from, II 8.

Latiniacum (Lagny), 177 .

Laurocabera (Larkbear), 24112.

Lausiac of Palladius quoted, $172 n$.

Lavatres, Lavatris, Levatris, I06, I08, I09 n., II 4 .

Lavingtunes dices, 2 I 4.

Layer Marney. See Legra marany.

Lea, the river. See Lygan.

Leach, $23 \mathrm{I}$.

lead, $82 n$.

leáh in place-names, $145 n$., $177 n$.

Lech, 23 I.

Le(c)to-cet-um. See [L]Eto-cetum.

Ledecestre. See Ligera Ceastre.

Leden-ford (Leadon), 20I, $282 \mathrm{n}$.

Leeds. See Loidis.

Leek, 23 I.

Legeceastre (Lega Ceaster, Legceastre, Ligcester, Urbe Legionis, Carlegion, Chester), 150, I5I; battle of Chester (616), and slaughtering of monks, 168 ; West Chester, 1 $73 n$., 259, 262, 277 , 283,298 . See also Deva.

Legecio. See Legeolio.

Legeolio (Lagecio, Castleford), I08, IO9 $n$., II 0 .

I egions in Britain, II 7 .

Legra (Legra marany, Layer Marney), $26_{5} n$. See also Ratae.

Leicester. See Ligera Ceastre.

Leighton Buzzard. See Lygtun.

Lein-ster, $229 n$.

Leith (Lode), I 20.

Leixlip, $229 n$.

Lemanis (Lemannis, Limen - ea, Lympne, Liminge, Limen wero), 90, I08, I13, $214,215,218,219$.

Lemannonion bay (? Loch Fine or Loch Linhe), 92, 100.

Len-borough. See Lygeanburg.

Leofric, Bishop of Worcester, death of, 289. 
Leomynstre, Leofminster (Leominster), 290, 295 .

Leonaford (? Landford), 249.

- let and gelât (a junction of roads), place-names ending in, 189.

Letch, in place-names, 231 .

Letewic (Lledewic), I $59 n$.

Letervicion, $159 n$.

Lethecastrescire. See Ligera Ceastre.

[L]Eto - cet - um (Le(c) to - cet - um, Luit-coet, Litcidfeld, Lyccidfelth, Llwoyd coed, Licetfelda, Lichfield), 38, 106, 18 I $n$., 194, 296.

Leucaro (? Loghor), I I 2.

Levatris. See Lavatres.

Liber Vitae, the, 200.

Licetfelda. See [L]Eto-cet-um.

Lichfield. See $[L]$ Eto-cet-um.

Licitit. See Caer Ligidit.

Lid, the stream, $282 n$.

Lidwiccium (Brittany), 256. See also Armorica.

Ligera Ceastre (Ligora, Ligaraceaster, Letheccestrescire, Leicester), $264,274,304$. See also Ratae.

Ligualid. See Lugu-vallium.

Ligures, the, 88 .

Limen-ea. See Lemanis.

Limenemouth, 258.

Limen wero. See Lemanis.

Limfin (lime heap), 212.

Liminge. See Lemanis.

"Limit," the (N. Wall), 105, $106 n$.

Limnus. See Lemanis.

Lincoln. See Lindocolina.

Lind (Llynn), I6, I 70 n.

Lind-Cylne in Kent, I $7 \mathrm{I} n ., 275 n$.

Lindes farona, 220.1

Lindesige (Lindesse, Lindsay), 240 , $28 \mathrm{I}$.

Lindis, the river, I 7 I $n$.

Lindisfari distinct from Lindisfarne, $193 n$.

Lindisfarn (Medcaut, Inis Metgoit, Lindisfarena éé), meaning of name, I $70 n$., I 1 I $n$.; assigned to Aedan by Oswald, I 74, I78; Cuthbert's body removed to, 186,196 ; attack on the Church, 236.

Lindissi (Lindissa, "Lindis-farorum "), 1 70 $n$.

Lindocolina (Lindon, Lindo, Lin- dum, Lind-Cylene, Lincoln), 16, 99, 103, 108, 109, I10, I71, 274, $275 n$.

Lindsay. See Lindesige.

Linga Hase (Hayes), 219.

Linhalec, $159 n$.

Linhe, Loch. See Lemannonion bay. Also Longos, the river.

Linn. See Lind.

Linn Garan, $185 n$.

Linnuis, 150.

Litau, I 59 n.

Litchfield in Hants. See Lydeschulv.

Litherland, $209 n$.

Littleborough. See Ageloco.

Litus Fresicum (Frisian Shore), 120.

Livermere, $209 n$.

Liverpool, $209 n$.

Livius Gallus, 67 .

Liwellid. See Lugu-vallium.

Lizard, the. See Horca.

Llanaledh (St. Germains), $279 n$.

Llancarvan, 34, $129 n$. [In Life of S. Finnian "Garbayn, alio nomine Nont" is mentioned along with a civitas Melboc. Carvan is the same name as the Ogam Carbagni.] Llandaff, Book of, names in, I6I $n$. Lledewic. See Letewic.

Llewelyn, I $2 n$. See Lugu-Vallium. Lloegr. See Loegria.

Llwyd coed. See Luit Coyt.

Llỳn. See Lind.

loca (in Pynloke, \&c.), $197 n$.

Lochie, Loch, 92.

Lochlannach (men from fiords), $24 \mathrm{I} n$.

Locrinus, 198.

"Loddera-wyllon," 204.

"lodes" on the Severn, 120, I89.

Lodonia. See Lothene.

Lœek-r, 23 I .

Loegria (Loycr), 198, 259 n.

Loghor. See Lucaro.

Loidis (Leeds), royal vill in region of, 170 .

Loingseach (Lynch), I $22 n$.

Londinium (London, Londinio, Londonion, Lunden byrg), $35,36,78$, 79, 103, 106, 107, 108, 109, 110, I 4I, 242. 
Longae Naves, $122 n$.

Longeas, $122 n$.

Longmind, $158 n$.

Longo-vicio (Longo-vico), II 4 .

Longos, the river, 92.

Lossiemouth. See Loxa, the.

Lothene (Lothian), I 70 n., 303, 304.

Lothian. See Lothene.

Loucopibia, 99.

Loutentinon. See Luetensium.

Lougoi, the, 100, I0r.

Louth, $170,235 n$.

Lowdham, 235.

Lowther, the, rogn.

Loxa, the (Lossiemouth), 97.

Loycr. See Loegria.

Loyt Coyt. See [L]etocetum.

Luce-bay and river, 94 .

Lucius and Eleutherus, fable of, 197.

Lucotion, 99.

Lud-cerce, $235 n$.

Luddesdown, $235 n$.

L.uel, $187 n$.

Luetensium (Luentinum, Luentinon), 103, 288.

Lugu-dun-um, $13 n$.

Luguvallizem, Lugu-vallum (CaerLigualid, Liwellid, Carlued, Luguvallo, Lugubalia, Carlisle), 1 2, 1 3, 71, 106, 108, 1 37 n., 186, $187 n$.

Luit-coet. See $[L]$ Eto-cet-rum.

Lunden byrg. See Londinium.

Lune, the, I02, III $12 ., 115$.

Lusebyrge, 218.

Lyccidfelth. See $[L]$ Eto-cet-um.

Lydd. See Hlid.

Lydeschulv (Litchfield in Hants), $181 n$.

Lydford. See Hlidaford.

Lydney, 20.

Lygan (Lea), the river, 260, 263.

Lygeanburg (Len-borough), $14 \%$.

Lygtun (Leighton Buzzard), 26.

Lympne. See Lemanis.

Lynch. See Loingseach.

Lynn. See Lind.

Ma and Maes, $166 n$.

MacAlpin, King Kenneth, 84 .
Macbeth, King, 297.

MacConkey or Maconochie, $192 \mathrm{n}$.

Mac Dhuncadh (MacConkey or Maconochie), $192 n$.

MacNachten. See Nechtan.

Maeatae. See Maiatai.

Mædham (Medeham), 215.

Mrgla, son of Port, 144 .

Mael, the use of, $82 n$.

Mældun (Melduna, Maldon), 263, $281 n$.

"Maelmin" (Melmin, Melmun), the royal vill, 168 .

Mael-ros (Melrose), 168 n., 190.

Maen, II $2 n$.

Manige (Isle of Man). See Monapia.

Maercrædes-burn, I43.

Marle-beorg (Marlborough), $3 \circ 3$.

Maes-Aleth, I 36.

Maes Garmon, 127.

Maes-yvet (Maes Hyveidd, Old Radnor), 248.

Magen. See Magnis.

Magenasæete. See Magonsete.

Mageo. See Mayo.

Magesatas (Magon-Setum), 287 n., 288.

Magesitania, 166.

Magh-girginn. See Cirig.

Magio-vinto (Magiovento, Magiovinio, Fenny Stratford), Io6, 107 n., 109, I 10.

Mag-ith, II $n$.

Maglone, II 4 .

Magnis (Magen, Maen, ? Kenchester, or Carvoran), II 2 , II 5. Cf. Magos.

Magnum Monasterium, $124 n$. See Whitehorn.

Magonsete (Magenasæete), 166.

Magos, II $2 n$.

Maia, 100, 101.

Maiatai (Maeatae), the, 52, 100, IOI, I63.

Maine. See Cynomannia.

Mailros, 184.

Maio, ror.

Mais, ror.

Malahide Bay, 99.

Malaios (? Mull), 92.

Maldon. See Mældun.

"Maleventum," 33, 34 . 
Mamble, Momela, Mamele, $268 n$. Mameceaster. See Mancunio.

Mam-ilet, Mam-heilad, Mam-hilad, $268 n$.

Mamncio. See Mancunio.

Man, Isle of. See Monapia.

Manand (Manann), in Campo, 6o, $67,192 n$.

Manapia (? on the Wexford Coast), 68. See also Monapia.

manau Guodoton (Manaw of the Gododin or Votadinoi), 60, 67 .

Mancetter. See Manduesedo.

Manchester. See Mancunio.

Mancunio (Mancunium, Mameceaster, Manchester), 26, 102, 106, I I I, 268.

Mandu in personal names, $107 n$.

Manduesedo (Mancetter), I06, 107n.

Manna (Isle of Man). See Monapia.

Map, Walter, 65 .

Maple-durham, $187 n$.

Maran, the river. See Memeran.

Mara-scalc (now Marshall), $83 n$.

Margiduno (Castle Hill), I09, I 10.

Maridunon (Maridunum, Mnriduno, Carmarthen), 29, 103, 104, I1 2, II 3 .

Marlborough, II3.

Marshall. See Mara-scalc.

Marten. See Meretune.

Martenesie, 206.

Martin, St., episcopal See and Church of, $124 n_{\text {.-; }}$ oratory of, 215 .

Mascusius, " High Admiral," 206.

Maserfelth (? Oswestry, Croes-oswald, Bellum Cochboy, "Waneloc,"? Wenloc), I 74 n.

Mathnedoi, Count of Poher, 160.

Maxim Guletec, 56.

Maxima Caesariensis (Province of Britain), 7 I.

"Mayo of the Saxons," I80.

Meanuari (Meanwara), East and West Meon and Meonstoke, I82.

Mearcfleot, 2 I 7 .

Meare. See Ferramere.

Meave, Queen (Mab, Medb., Medvii in Ogam). See Pit Meave.

Medcaut. See Lindisfarn.

Medeshamsted (Medeshamstede, Me- des-wæl, Peterboro), I 76 n., 177, 244, 277; relics transferred to, 278.

Medewægan (Medway), $285 n$.

Mediolano (Mediolanion, ? Whitchurch), 102, 103, 106, 107 ., III.

meends, in place-names, $158 n$.

Megas Limēn (? Poole Harbour), 96.

Meguuines paeth, 2 I 4 .

Meicen, battle of, $173 n$.

Melandra Castle, I 16.

Melduna. See Mældun.

Melrose. See Mael-ros.

Melvas, King, I53.

Memeran (Maran), the river, 263.

Menapia, Menapioi (in the Low Conntries), 60, 67, 90. See also Monapia.

Mendip. See Munidop.

Menevia (St. Davids), 67. See also Monapia.

menez, mene, menedh, I $58 n$.

Meoles at Shrewsbury, 23I.

Meols ( Mel-r), 231.

Meosgelegeo, 216.

Merantun, 195.

Meresig (Mereseg, Mersea), 260.

Meretune (Marten), $246 n$.

Merlin. See Myrdin.

Merscuuare, 215; (Merscware) of Romney (Romenal), the, 2 I5, 240.

Mertai, the. See Smertai.

Messappia, early name of Milan, 69. Metaris estuary, the ("the Wash"), 98.

Menric (Marius), $137 n$. See also Gwysmeuric.

Mevania, name given by Bede to Man and Anglesea, 67. See also Manapia.

Miathi, battle of the. See Maiatai. Michel-dever, Mitchel-Dever, I44n., $281 n$.

Mictis (? Vectis), 90.

Middeltuna (Middeltune, Milton), 258 ; Canons expelled from, 278 , 295.

Middlebie Kirk, I05.

Milton. See Middeltuna.

Milton Abbas, relics at, $162 n$. 
Minard, I59n., $168 n$.

Mindton, $158 n$.

"Minister," St. Mildred's, I34.

Minton, I $58 n$.

Mintridge, ${ }_{5} 8 \boldsymbol{n}$.

Mirmantum. See Segontium.

mistletoe, 2 I I.

"Moat Minster, the," 284 ".

Moelfre, $193 n$.

Moerheb, now Morfe, Murief, Moref, now Moray. Reget another name for Murief, I I 4, I $24 n ., 216,260 n$. See also Morbio.

Mog-Nét, $185 n$.

Mona (Anglesea), 10, 30, 42, 90, 92 . Monaoida. See Monapia.

Monapia (Menavia, Manáoida, Evania, Manna, Eufania, Manige, Isle of Man), 67, 68, 90, 92, 235, 283 . See also Mevania.

Monk-silver. See selvra in Domesday.

Monmonth. See Blestio.

Mons Vo-Cetius, $86 n$.

Montes Ereri, or Heriri = Eryri (Snowdon), 136, 239.

Montgomery. See Muntgumeri.

Moravia, $260 n$.

Moray. See Moerheb, Morbio.

Moray Firth, the. See Varar Estuary.

Morbio, II4, I24n., $260 n$.

Morecambe Bay. See Morikambe.

Moresby. See Congavata.

Morfe. See Moerheb.

Moridunum (Seaton), 96.

Morikambē (Morecambe), 93, 95.

Morini, the, 90.

Mound Agned (Edinburgh), 151, 152.

Mount Paladur (Shaftesbury), $257 n$.

Moy-rath (Magoratum), ${ }_{26} n$.

Muchelney. See Myclanyge.

Muir-n-Icht (sea of Icht), $74 n$.

Mull. See Malaios.

Mull of Cantire. See Epidion Promontory, the.

Munet, $158 n$.

Munidop (Mendip, Mened-ipp), 24, 202, 206.

Mun-ster, 229 .

Munt Sorel (Mount Sorrel), preserves name of Soar-zuelle, $26_{4} n$., $26_{5} n$.
Muntgumeri (Montgomery), 303 .

Muriduno. See Maridunon.

Murief. See Moerheb.

Mutu-Antonis, I $44 n$.

Myclanyge (Muchelney), 304.

Myrcna landes, 220.

Myrdin (Merlin), $\mathbf{1}^{6}$.

Nabar-os river, the (Loch Naver), 93 .

Nachedethorne Hundred, $246 n$.

Nasse (Dungeness), 295.

Naiton. See Nechtan.

Nanione (Navione), II6.

Nantes, Chronicle of, 160, 161.

Nantgallim, 67 .

Natanleaga, 144.

Natan-leod, a British king, 144.

Naver, Loch. See Nabar-os river.

Navimagio. See Noiomagos.

Naze, the. See Eadolfesnasse.

Neath. See Nido and Rosneath.

Nechtan (Naiton), King of Picts, conversion of, 192 .

Nechtan, survival of name in MacNachten or McNaughten, $18_{5} \boldsymbol{n}$.

Nechtanesmere (Dunnichen Moss), $185 n$.

Nemeto, Nemeton. See Nimet.

Nemthur, Nen-thur (Ail-Cluade Dumbarton; Alcluith, Petram Cluithe, Nemeton, Nemeto-dorum, 129n., 130 n., 202.

Nen, the river, $22,176 n$.

Nennius, Irish originals in, $128 n$., 130 ; sources of Historia, $\mathbf{I}^{2} \mathbf{n}$.

Nentre, Nentria. See Nemthur, and "Bannavem Taberniæ".

Neod, St. (St. Neots), Annals or, 223 n., $250,304$.

Neomagan (Nymegen, Neymegen, Novio-mag-um), $290 \mathrm{n}$.

Nerigon, $88 n$.

Newcastle. See Ponte Aelii.

Newmarket, $108 n$.

Newry, 7 I.

Nidd (Nith), the river, 94, 95, 120. See also Novios.

Nido (? Neath), I I 2, $120 n$. See also Roseneath.

"Niduarian Picts," the, I 20.

Nimet, (Nemeto-briga, Nemetacum Atrebatum, Nemeto-daron, Ny- 
mede), 20r, 203. [This may be, like Frome, an instance of the retention of an unaspirated $m$; but see Pedersen § 303.]

Ninian, St., I 23 n., I $24 n$.

Nith, the river. See Nidd.

Nodons, Celtic God, 20.

Noe, the river, II 7 .

Noiomagos (Navimagio), Porchester, I04.

Non-Aryan people in Britain, 82; words common to Celtic and German, $82 n$.

Nôr (the Nore), $227,23 \mathrm{I}$.

Normans (Welisce men) build castle in Herefordshire, 293.

Norse elements in place-names, 227 , et seq.

Norse influence on language, 223.

Norsemen, cause of emigration, 224.

Norse names in Isle of Man, $229 n$.

Norse personal names, 227 et seq.

Northampton. See Hamtun.

North Foreland, the, I $27 n$.

Northham-tun Scire (Northampton Shire), 303 .

North-hill, preserves in second syllable Ivel or Gevil, I4I, $221 n$.

Northmen, coming of the, 223 et seq.

North Mutha (Northmonth), 29r.

North Weorthig. See Deoraby.

Northwich. See Condate.

Norwich. See Venta Icenorum.

"Noss," the. See Verubium Promontory.

Nottingham. See Snotingaham.

Novantai, Novantoi (Galloway), peninsula of the, 92, 93, 94, 99; conquest of, by Oswy, 120.

Noviomago (? Woodcot), ıо6.

Novio-mag-um. See Neomagan.

Novios (Novia, Novitia), the river, $93,94,95$, I $20 n$. See also Nidd.

Nox gaga, 22 .

Numerus Petueriensis, 102.

Nymede. See Nimet.

Nymegen. See Neomagan.

Nynias, Bishop. See St. Ninian.

Nyniga, St. See St. Ninian.

Oakengates. See Uxacona.

Oakhampton. See Occemund.
Oak-over (Oaker), 2 Ion.

Occemund (? Oakhampton), 207.

Ochthē Hypsēlè, 97.

Ockley. See Aclea.

Odda, Earl, his death, and burial at

Pershore, 298.

Odeham. See Wudiham.

Odencolc (Odyngalc), I 57 n., 203.

Odyn, 203.

Ofer in place-names, 2 ron.

Ogams (inscribed stones), $82,136 n$.

Oht gaga, 221.

Ohthere, Scandinavian traveller, 225.

Okelon promontory, the (Spurnhead), 98.

Okment (Uchmynydd), I 58 n., 207.

Okrion-point (Horca), the Lizard, $89,96$.

Oktapitaron, the promontory (St.

David's Head), 93, 96.

Olaf Feilan, $228 n$.

Olan (Olitane), the river, 20 .

Olan-îge (? Alney Island), 288.

Old Patrick. See Sen Patraic.

Oldminster. See Ealdminster.

Old yo (river), 202. .

Olenaco, i 6.

Olerica, ror.

Olicana (? Ilkley), Ior, I02, I 16.

Ondemone, 75 .

Oney (Onny), river, 187 $n$., 216.

Ongar. See Angra.

Onnan duun (? Onibury), 2 I 6.

Onnan-forda, 216.

Onno. See Hunno.

Orc in Orcades, $225 n$.

Orca. See Horca.

Orcada promontory, the, I04.

Orcades (Orkneys), 90.

Ordovices (Ordovikes), the, 29, 32, I02.

Ordulfes Minster at Tavistock, 282.

Orkas, the promontory of. See Tarved-um.

Orkneys, 224.

Orne (Olina), the river, $\mathbf{I}_{55} \boldsymbol{n}$.

Orrea, Ior.

Orwell. See Arwa.

Osgod Clopa, 29 I.

Oss, 23 r.

Ossismi, 90. 
Oswald, King, I 73 ; slain at Maserfelth, I74.

Oswestry. See Maserfelth.

Osyth, St. See Cicc.

Otadinoi (Otodinoi, Votadinoi), the, 25 n., 67, 99, 100, 101, 188.

Oteppe, 69 .

Otford. See Ottanford.

Othona, Ythanceaster, $179 n ., 276 n$. See 113 .

Ottanford (Otford), 196.

Oundle. See Undela.

Ouralanion (Virulamion), 103.

Ouse. See Usa.

Overtown. See Calacum.

Ozven ( = Eogan = Esugenus), 96 .

Oxnaforda (Oxford), 264.

$\mathrm{Pa}$ - (the prefix), $86 n$.

Pabo (Pappo) Post Priten, 57, 59.

paddock. See Pearroc.

Padstow (Petrockstow), 279.

Pægna, $177 n$.

Pægnalaech (? Finchale), $177,234 n$.

Paghal, Pagula. See Paull.

Paghenale (Pankale, Pannel), $234 n$.

Pal- (the prefix), $86 n$.

Palant (Pfalanza, Pfalz, Palantium) at Nymegen, 290; "the Palant" at Chichester, $290 \mathrm{n}$.

Palfrey. See Paravereda.

Palladius, $123 n$.; and Pelagianism, 125; his mission to the Scots, $129 n$.

Pallig, Earl, burns Teignton (Dreres Teignton), 283.

Pallins-burn, 169.

Palme Castre, $137 n$.

Panfield, $276 n$.

Panhale, Pannel. See Paghenale.

Pant, the river (? Indan-byrigon), $179 n$., $276 n$.

"Papa," use of word by Norsemen, 226.

Papa and Pfaffe, 24I $n$. [A borrowed form Popa occurs in Irish : Pedersen, V. Gramm. § 314.]

Papafjördr, $226 n$.

Papa Isle, $226 n$.

Papa Stour, $226 n$.

Papa Stronsay, $226 n$.
Papa Westray, $226 n$.

Papcastle. See Aballaba.

Pap-ey, $226 n$.

Paravereda (Palfrey), $106 n$.

(P)areimorica, 61. See Armorica, Letewic.

Paris, a district round Horncastle, 102.

Parisii (Paris), 125.

Parisoi, the, 102.

Park. See Pearroc.

Parnbougal, 86.

Parret. See Pedredi-strem.

Parthenay, Partanew, I 7 In., I $74 n$. See also Peartaneu.

Partney. See Peartaneu.

Pascent, 56, 59.

Passanhamm (Passenham), 267.

path, 18, $85 n$.

Pathenebergh'e (Pathene, Pathena), 205, 206. See also Peatanige.

Patney. See Peatanige.

"Patricesham" (Petersham), $246 n$. See Beadricesige.

Patrick, St., I24n.; his birthplace, 129 ".

Paul Aurelian, r6o.

Paulinus, appointed Bishop of Northumbrians, 168 ; made Bishop of Rochester, I 71 ; baptisms of, 172 ; sails to Kent, $\mathbf{I} 73$.

Paull (Paghal, Pagula), $177 n$.

Panlus Diaconus, 80.

Pawlet. See Pouelt.

Peac-lond (Peak), 268.

Peadan-Stigele, 217.

Peanfahel (? Pennaevalli), 72, 85.

Pearroc (paddock, park), 208.

Peartaneu (Peortan-ea, Partney), I $71 n$, I $72 n$.

Peartinga-wyrth (? Petworth), I $72 n$.

Peatanige (Patney), 205.

Pebble, $86 n$.

Pechts, 74.

Pec Sætna, 220.

Peddar's Way, the, $108 n$.

Pedigrees, British, 54.

Pedn (Penn), 175 n., $283 n$.

Pedridan (Pedredi-strem, Parret), the river, 175, 176, 201 .

Peebles, $86 n$.

Peel. See Inis Patraicc. 
Pefenesea (Pevensey), 295.

"Pelagius Britto," puts forth his doctrine, 123.

Pelagianism, corruption of British churches by, I 24, 125.

Pelydur, $87 n$.

Pemberton, $193 n$.

Pembrey, $193 n$.

Pen. See Peonnun.

Pen, the prefix, $86 n$.

Penbre, $193 n$.

Penbryn Penwaeth, Penwedic yng Ngherniw (Land's End in Welsh Triads), $282 n$.

Pencaitland. See Pen-cet-let.

Pencalmer, $86 n$.

Penceat (Pænge, Penge) Wood in Battersea, $182 n$.

Pen-cet-let, $86 n$.

Pen-cric. See Pennocrucium.

Pen-crik (? one of the Somerset "Creeches"), 20r.

Pend- (Pedn in late Cornish), $175 n$.

Penda of Mercia, 173 .

Pender-law, $86 n$.

Pend-lachna, $86 n$.

Pen-dragon, I $37 n$.

Pendrid-an, the river, $176 n$.

Pen-en-vern, I $59 n$.

Penge, Pænge, wood. See Penceat.

Pengelly (Penguilly), $158 n$.

Pengerd (Pennard), I 59 n., I99.

Pengzuern, $285 n$.

Pen-hwyl-koet (? Exeter), $254 n$.

Pen-in-inver, $86 n$.

"Penk," 39.

Penk-ridge. See Pen-cric.

"Pennaevalli." See Peanfahel.

Pennard. See Pengerd.

Penne-locos ("Lakehead"), 39, $109 n$.

Pennocrucium (Pennocrucio, Pencric, Penk-ridge), 38, 39, ro6, Io7 $n$.

Penns, the. See (Peonnum $=$ Penselwood).

Penrith, Old, 53.

Penryn Awstin, 202.

Pen-savel-coit, $254 n$.

Penta (Pant), the river, I80.

Pentecostes Castel, 296.
Pentelow, $276 n$.

Pent-land Firth, 74.

"Pentland Hills," 74.

Penwiht Steort (Penbryn, Penwaeth, and Penwidic yng Ngherniw, Land's End in Welsh Triads, Antivestaion or Bolerion, Land's End), 89, 96, 282.

Penwith, $282 n$.

Peoht-as, 74.

Peon Mynet, I57 n.

Peōnho (Pednho, Pinho), 283.

Peonnum (Peannan, Penselwood, Pen-savel-coit, Penns), battle at the, I 75, 254 n., 286.

Pepper, 193 n.

Pepper-harrow, Peper-harow, $209 n$.

"Peretur"(Pryderi), 57.

Perhamstede, 215.

Perigord. See Petrn-corii.

Perronne (Perrona), I 77 .

Perscora (Pershore), 298.

Pershore. See Perscora.

Personal names, shortening of, $\mathbf{I} 33$.

Perth, $86 n$.

Pet or Pit, the prefix, 85 .

Peterboro. See Medeshamstede.

Petersham involves "Beadu-rich," $245 n$.

Pelouaria, Petuaria (? Decuaria), IO2, II 4 .

Petrianis, II5.

Petrockstow. See Padstow.

Petru-corii (Perigord), 36, I55 $n$.

Petueriensis, II 5.

Petworth. See Peartinga-wyrth.

Pevene sea (Pevensey, Pevenisel), 29 I.

Pevenissel (Pevensey), $143 n$., I $70 n$. Phaganus. See Fagan.

Phoenix. See Finisk.

Pict, history of the name, 73 et seq.

Pictavi or Pictones, 74.

"Picti," 73.

Pictish " Brughs" or Barrows, 224.

Pictish language, the, 76 .

Picts, Scotland occupied by, 9, 84, $7^{2}$; variants of the word, $7^{2}, 73$; Romano-Britons plagued by, 7880,81 ; in Ireland, 83,85 ; harass Britons, I19, I 20, I 26, I 28, I35 ; receive Bishops in Galloway, 184 . 
Pil- (the prefix), $86 n$.

Pincanheal (Winchanheal, Wincahala, Finchale, Fink-halh, Pægnalaech, Wincle), 233, $234 n$.

"Pincr misser" (? Pincerna mensarius), 57.

Pinho. See Peonho.

Pinnatis, 101.

Pirates, Saxon and Frankish, I 9.

Pit Meave, 86.

Pit or Pet, the prefix. See Pet.

Pixies, 74.

Plain anGuare (Cornwall), $138 n$.

Plaistow. See Plegstow.

"Play," $85 n$.

Pleghelmestun, 214.

Plegstow (Plaistow), $294 n$.

Plenderleith (Premderleith, Prandergaist), I2I $n$. See also Pranderwyndes.

"Plight," $85 n$.

Plou-gonfelyn, $12 n$.

Po- (the prefix), $86 n$.

Poets, early Welsh, 15 I.

Poffil, $86 n$.

Poitiers, $74 n$.

Poitou, $74 n$.

Pol- (the prefix), $86 n$.

Poleglass, $86 n$.

Poll Waøan, 273.

Po-mer-ania, $6 r$.

Pomona, $228 n$.

Ponte Aelii (Newcastle), II5.

Pontesbury. See Posentes byrg.

Pontibus (Staines), Iro.

Pon-tri-las, $159 n$.

Pontulas, I 59 n.

Pool, the prefix, $86 n$.

Poole. See Megas Limèn.

Pope Caelestine sends Palladius to Scots, $129 n$.

"Popeselle" or "Popesalle", 226.

Poppel, $86 n$.

Porcensetene. See Wreocensetna, Westerna.

Porchester. See Noiomagos.

Porlock. See Port locan.

Port (Portland), Athelhelm defeated by Danes, 240 ; ravaged by Wicing ships, 280 ; ravaged by Godwin, 295.
Portascihth, "(Porthisceuin, Portskewett), 300 .

Port comes to Portes-mutha, I44.

Portesmutha (Portsmonth), $142 n$, 144. See also Kainos Limén.

Port Gordon, 97.

Portland. See Port.

Port locan, Port-loc (Porlock), 266, 280 n., 295.

Portskewett. See Portascihth.

Portus Itius, 74.

Porz is quin (Port-below-the-ridge), I 59 n.

Poscetene tune, 184 .

Posentes byrg (Pontesbury), 183, 184.

Pou (= Pagus), 199 .

Pouelt (Pawlet), 199.

Poull-pry (Polpry), $158 n$.

Pow- (the prefix), $86 n$.

Powis. See Poyzuis.

Poywis (Powis), 239.

Praesidium, II 4 .

Praetor, 57. See Peretur.

Prandergaist, $121 n$.

Pranderwyndes, $121 \boldsymbol{n}$.

Prasutagus, King, 34.

Premder (Premter), $121 n$.

Premderleitb, $12 \mathrm{I} n$.

Prenbougal, 86.

Prendergast (Berwickshire), I2I.

Prenn, 86 n.

Prenwensete, $86 n$.

Preosteselwe (? Priestleigh), 203.

"Pretannic Ocean," 96.

Pretorio, 105.

Priestleigh. See Preosteselwe.

Prifeta, 195, 2 10.

Primside. See Prenwensete.

Prior of St. Samson sends relics to Ethelstan, 162.

Privet. See Pryfetes floda.

Procolitia (Brocoliti, Carrawburgh), ror, II 5 .

Protector (Protec.), 57.

Provinces of Britain, $7 \mathbf{~}$.

Pryd, 74.

Prydain, inis Prydain, Inis Prydain, $74,75,89$.

Pryderi. See Peretur.

Prydyn (or Priten), 74.

Pryfetes floda (Privet, Prifet), 195. 
Pryved, Kerrig y, $195 n$.

Psalter of the tenth century at Salisbury, 162.

Pterōton Stratópedon, Iог.

Pucelancyrca (at Puclan Cyrcan, Pucklechurch), 203, 204, 274, $275 n$.

Pucklechurch. See Pucelancyrca.

Pukelonde, 205.

Pur-beck, 280.

Pusting uuerae, 218.

Puttan Ealh, 217.

Pwll, the prefix, $86 n$.

Pyle, 54.

Pynloke, I97 $n$.

Qrtania, Qrtaniko-s, 75.

Quantccks. See Cantuc-uudu.

Quat and Quatford, $260 n$.

Quemer-ford, $155 n$.

Quimper, $155 n$.

Rachry, or Rathlin Island. See Ricina.

Raculfs-ceastre. See Racuulfe.

Racuulfe (Recuulf, Regulbium, Reculver), 37, II 3, I $27 n$., I $75 n$., I89, 2 I3.

Rac-ynys, I $89 n$.

Radnor, Old. See Maes-yvet.

Ramesige, Ramsey, Hunts., 289, $3 \circ 3$.

Ramsbury, 282.

Ramsey. See Ramesige.

Ratae, Ratas, Ratis (Leicester), 96, I03, I09, IIo, 265 n. See Ratumagos and Moyrath.

Rates-burgh. See Ritupia.

Rathlin. See Ricina.

Rato, 96.

Ratostabios, the river, 94,96 .

Ratu-magos (Rouen), 96, $265 n$.

Ratupis. See Ritupice.

Ravonia, IOI, II4.

Rayleigh, $296 n$.

Readan-Solo, 216.

Readingum (Redingas), $246,304$.

Reatir. See Rhee.

Rechra. See Ricina.

Rechriu. See Ricina.

Reculver. See Racuulfe.

Redan solo, 216.
Redbridge. See Hreutford.

Redford. See Hrentford.

Redon, Chartulary of, 161 $n$.

Redones, the, $155 n$.

Redwald, king of East Angles, I 72.

"Reged" (Reget, Murief= Moray), I $24 n$. See also Moerheb.

Regensburg. See Regina.

Regina (Regensburg), I ron.

Regno, Regnum (Chichester), IIo, 143,182 n., 219.

Règnoi, the, 104.

Regulbi, Regulbium. See Racuulfe: also Gulb.

Reið Gotar, $223 n$.

Remi, I 2.

Rendlaesham, 180.

Reptaceaster. See Ritupia.

Repton. See Hreopa-dun.

Rerigonian (Rerigonium, Rerigonion) bay, (? Lough Ryan), 92, $94,99$.

Reuda (Cairbre Righfada, or Riada), 84 .

Rhaiadr. See Rhee.

Rhee (Rith, Reatir, Rhaiadr), I40 1. , I 7 I $n$.; a general name for stream, I 7 I $n$.

"Rhines," the, 200.

Rhizw-las, Rye-lass, I 7 I $n$.

Rhone, La Crau du, 88.

Rhyd Orddwy, 32, 102.

Rhyfoniog (Roweynauc, Rienuch), 239.

Rhys. See Hris.

Ribchester. See Bremetannaco.

"Richard's Castle," $296 n$.

Rich borough. See Ritupia.

Ricina (? Rachry, Rachrie, Rechra, Rechriu, or Rathlin Island), 90, $189 n$., 236.

Ricinga-haam, 214 .

Ridumo. See Dunion.

Riechester. See Bremenium.

Rienuch. See Rhyfoniog.

Rigodounon, IOI, IO2.

Rigwatlan, brother of Griffin the Welsh King, 299.

Rihala (Ryhall), 278.

Rind-burna, 216.

Rinderpool, 208.

"Rinns of Galloway," I 24 n. 
Riothimus, King, 159.

Ripar, Ripum (=Crags), I9I $n$.

Ripon. See Inhrypum and Ripar.

Ripon Minster, pillage of, 274 .

Ripp, 215.

Ris-angra (Rishangles), 287.

Rishangles. See Ris-angra.

Rith. See Rhee.

Rithergabail. See Episford.

Ritupia (Repta caester, Routoupiai, Ratupis, Ritupium, Ritubiportus, Ritupis, Ratesburgh, Rich borough), 37, 78, 79, 103, 104, 105, 106, $107 n_{\text {., }} 113,127 n_{\text {., }}$ 134.

Ritupium. See Ritupia.

River-names, form taken by, $187 n$.

Robroit. See Tribruit.

Rochester. See Duro-brivis.

Rock. See Clud.

Rocking. See Hrocking.

Rockingham. See Rogingham.

Roden, the river, 103, 106, $107 \mathrm{n}$.

Rodbertes Castel, 296. See also Rayleigh.

Rofes-ceastre, $175 n$.

Rogingham (Rockingham), 304 .

Rom, inscriptions at, 87 .

Roman Imperial Standard, the, $137 n$.

Roman legions leave Britain, 81, II 7.

Romney (Romenal), 215.

Rosnat or Alba, 1 24n. [Nat is involved in Irish personal names $=$ ? Netta in Ogams = Champion.]

Roseneath (Ros-nevet), I $24 n$., $125 n$.

Ros-nevet. See Roseneath.

Ros-uc-chet, $86 n$.

Rotherfield, $183 n$.

Rotherhithe, $183 n$.

Rotherwick, I $66 n$.

Rothket, 86.

"Rouge Dragon," the title of Tudor Pursuivant, $137 n$.

Round, Mr. J. H. and "Richard's Castle," 296.

"Route, the" (Co. Antrim), 84, I62.

Routoupiai. See Ritupia.

Roweynauc. See Rhyfoniog.

Rowley Water. See Denises-burna.
Rowner. See Rugenore.

Royd and Roothings, $23 \mathrm{I}$.

$\mathrm{Ru}$ (= point), in West Scotland placenames, $189 n$.

Rudelan (Rhudlan), 299.

Rugen. See Rugini.

Rugenore (Ruenore, Rowner), 304. Rugii, the continental, $178 n$., $2 \perp 9$.

Rugini (Rugen), I89.

Ruim, $277 n$.

Ruleystal, I73n.

Rumcofan (Runcofa, Runcorn), $263 n$., 264 .

Rumen-ea (Romney), 295.

Rumesige, Ramsey, 277 n., 278.

Rumining Seta, 214.

Runcorn. See Rumcofan.

Ruoihm. See Tanet.

Rutchester. See Vindobala.

Rutherford, $183 n$.

Rutonio, I03. See Roden.

Ryan, Longh. See Rerigonian bay.

Rye-lass. See Rhizu-las.

Ryhall. See Rihala.

Saball. See Saul.

Sabrina (Severn), the, 24, 94, 96, 199.

Sængelwicos, 215.

Sail-wood. See Selwood.

St. Abb's Head, I $79 n$.

St. Albans. See Verulamium.

St. Boisil (St. Boswell's-on-the Tweed), 184 .

St. Brandan, influence of, in West England shown by place-names, 206, $294 n$.

St. Davids. See Menevia.

St. David's Head. See Oktapitaron.

St. Edmundsbury. See Beadorices Uurthe.

St. Germains. See Llanaledh.

St. Herbert's Isle in Derwentwater, 186.

St. Just. See Judoc, St.

St. Malo, I6o.

St. Michael's Mount. See “Dinsol ".

St. Michael's Tor, 130 n., 202.

St. Neots. See Neod, St.

St. Peter's Chapel in Bradwell (St. 
Peter ad murum, Capella de la Val), I79n., $276 n$.

St. Petroces Stow (Petrocys Stowe), ravaging of, 279.

St. Samson, 260.

Sal-gewearp. See Salunerp.

Salinai, 103.

Salisbury. See Searobyrg.

Salt wic (Droitwich), 216.

Saltwich, $166 n$.

Saltwood Castle, r43 $n$.

Saluuerp (Salwarpe), 2 I 6.

Samaro-briva, $256 n$.

Sandbach. See Sandbec.

Sandbec (Sandbach), 230.

Sand tun, 2 I 5.

Sandwic (Sandwich, Sand-vik), 24I, 280 n., 292.

Santlache. See Senlac.

Sarisbury. See Searobyrg.

Sarre. See Sorram.

Sarum, a ghost word, $146 n$.

Sarva. See Soar.

Saudonio, I02.

Saul (Saball=Stabulum), $129 n$, $236 n$.

Saxon house, arrangement of, 195 .

Saxon's-lode, I89.

"Saxon Shore, Count of the," 6r, I I3, 1 I 9.

Saxons, infest coasts of SE. Britain, 6 I, 78, 8I, I I 9 n., I 26.

Saxons, Old, I89.

Scapige (Sheppey), 295.

Scaga, 2 I 7.

Scandias. See Skētis.

Scandinavia, words borrowed from, 230.

Scealces burna, 2 I 5 .

Sceap-ige (Sheppey), 239, 287.

Sceftesburg, Kaer Septon, Sceptonia, Shafton (Shaftesbury), 257. See also Mount Paladur.

Sceobyrig (Shoebury), 259.

Sceorstan (Sherston), 286.

Scergeate (Scrget), $262 n ., 263$.

Schechalzean. See Schiehallion.

Schiehallion (Schechalzean, Sithchaillinn), I53.

Scilly Isles, the, 3 I.

Sciraburnan. See Sherborne.

Scobbanwirth, 201.
Scotia, name applied to Ireland, after 844 became designation of Scotland, 84, I84.

Scotland. See Alban.

Scots, a tribe, pass from Ireland into Alban (Scotland), 9 ; attack Britons, 6I ; devastate country near frontier, 78, 79; invade Britain, $80,8 \mathrm{r}$; harass Britons, I I9, 1 28, 1 35 ; Goidels in N. Britain in prehistoric times, 83 .

Screafleah (Shrawley), 2 I 2.

Scrob, ancestor of Pentecost, $296 n$.

Scrobbesbyrg (Shrewsbury), Welsh Pengwern, in civitate Scrobbensis, 285. See also Amwythig.

Scydescestre. See Scythles cester.

Scythles cester (Scydescestre,Cithlescester, ?Chesters), I I 5, 233, $234 n$., $235 n$.

Sealterna Steallas, 2 I9.

Sea Mills. See Abone.

Searis-bury. See Searobyrg.

Searobyrg (Searo-burh, Sorbiodunum, Searis-bury, Saris-bury, Salisbury), I I $3,146,160,284$.

Seaton. See Dunion.

Seccandun (Seckington), ${ }_{9} 6 n$.

Seckington. See Seccandun.

Segeduno (Serduno), II 5.

Segeloci, 108, $\operatorname{109} n$. , I 10 . See also Ageloco.

Segontiaci, the, Io.

Segontium (Mirmanton, Caer Seoint, Segontio), 10, 72, 95, 102, III.

Seine. See Sigene.

"Seint" or "Seoint", the river, 72 , I I $n$.

"Sieintes," the river Seint, I I I.

Selaes-eu (Seoles-igge, Selsey), $182 n$., I $83,277 n$.; See of, transferred to Chichester, 279.

Seleberhtes Cert, 219.

Seletun (Silton), 196.

Selgovoi (Selgovai, Elgovai), the, 25,99 , IOI, I 88.

Selsey. See Selaes-eu.

Selwood (Seal-wyda, Seluuda, Coit maur, Sail-wood), $253,254$.

Sempingaham (Sempringham, Shimpling), $24^{2}$.

Sena, 90. 
Senescalc (now Seneschal), $83 n$. "Senlac" (Senlecque, Santlache, Sandlake), zor.

Seno-magum, $290 n$.

Sen Patraic (Old Patrick), 198.

Seoles-igge. See Selaes-en, Selsey.

Seotu, 2 I I.

Serduno. See Segeduno.

Serguil (Servilius), 57.

Set and Sætr, 231.

Setantioi, the, 93, 95 .

Seteia, estuary of the, 93,95 .

Severn, the. See Sabrina.

Sexena, East, South and West, 222.

Sextae, 114 . See also Eburācum.

Shaftesbury. See Scefteshurg.

Shakespeare's indebtedness to Geoffrey of Monmouth, 66.

Shapinsay. See Hjalpands-ey.

Sheaf river, the, II 7 .

Shelfangel (Shelfanger), 287 .

Sheppey. See Sceap-ige.

Sherborne. See Sciraburnan.

Sherston. See Sceorstan.

Shetland. See Hjallt-land. See also Hjalpands-ey and Shapinsay.

Shimpling. See Sempingaham.

Shoebury. See Sceobyrig.

Shoreham, 104.

Shrawley. See Screafleah.

Shrewsbury. See Scrobbesbyrg.

Shuthelve Hill, 202.

Siambis et Axantos (Ushant), 90.

Sicila (or Sicilia), 52.

Sidemann, Bishop of Devonshire (Defnascire), interred at Abingdon, 279.

Sidumanios, 98 .

Sidmouth. See Dunion.

Sigeberht, 172 .

Sigene (Seine), 256 .

Siger, the, 200.

Silchester. See Calleva.

Silton. See Seletun.

Silura island, $3 \mathrm{I}, 9 \mathrm{I}$.

Silures, the, 29, 30, 90, 103 .

Sinder ford, 204.

Sith-Chaillinn, 153.

Sittingbourne, 106.

Sitomago, 98 , I I0, III $n$.

Siward, death of Earl, 297; his burial at Galmanho, 297.
Skeirs and Skerries, $228 n$.

Sketis (? Scandias), 104.

Skibber (Ysgubor), $237 n$.

Skye, Isle of, 236 .

Slack. See Campodunum.

"Sla-mannan," Ioo.

Slaughterford. See Sloh-treo.

Sleaford. See Sliowaford.

Sleat, Sound of. See Itios rivermouth.

Sliowaford (Sleaford, Tench-riverford), $242 n$.

Slohtranford. See Sloh-treo.

Sloh-treo (Slohtranford, Slaughterford), 2 ro $n$.

Smertai, the, I00, Jor.

Sme-ster, $159 n$.

Smestow, I $59 \boldsymbol{n}$.

Snad (Snæd, a piece of a wood), 218.

"Snargate," 226 n., 232.

Snawdun (Mynydd Eryri, Snowdon), $136,239,303$.

Snottingaham (Tig grocobauc, Nottingham), 244, 274.

Soar (Sarva), the stream, $26_{4} n$. See also Soar-welle.

Soar-welle, Sorewella, 26jn. Cf. Mount Sorell.

Soccabyrig (? Sockbridge, Ockley), I $96 n$.

Sockbridge. See Soccabyrig.

Sockburn on the Tees, $196 n$. See also Soccabyrig.

Sodor and Man. See Sudr-eyjar.

Sole, in place-names, 213 .

Solway Firth, the, 99, I 20 n., I 88. See also Selgovai.

Sombreffe, 69.

Sondrvic (Sandwich), 240.

Sorbio-dunum. See Searobyrg.

Sorlinga (les Sorlingues), 32.

Sorram (Sarre, Serra, Searre), Kent, $265 n$.

South Saxons (Sussex), 129.

Southampton. See Hamtun.

Southampton, pillaging of, 279 .

South-hill, preserves in second syllable Ivel or Givel, I4I, 221.

South-leigh. See Ilegh.

South Shields. See Arbeia.

Southwark. See Suthgeweorke. 
Soweie (Sow-ige, Sū-ige, Sug-ige= Sow island, now Zoy), 201.

Spalda (Spalding), 220.

Speen. See Spinis.

Spey, the. See Tuésis, the.

Spinis (Speen), I I, I I2, II 3 .

Spinney, II $n$.

Springhead. See Vagniacis.

Spurn-head. See Okelon promontory.

Stabulum. See Saul.

Stadment, $\mathrm{I}_{5}^{8} n$.

Stath, I 43 .

Staines. See Pontibus.

Stamford. See Stanford, Steanford.

"Standard, the," battle of, 304 .

Stane, arrival of 390 ships at, 280 ; identified with Folkestone, $280 \mathrm{n}$.; (?) Stone near Faversham, $280 n$.

Stane (Staines), 285.

Stanewig (Stanwick), 304.

Stanford and S. Brycg (Stamford Bridge), 105, 274, 301,304 .

Stan-hange (Stone-henge), $287 n$.

"Start Point," 208, 282 n.

"Stater," 57.

-Stay, in place-names, 2 I r.

Steanford (Stamford), I 35, 267.

Steort (in Start-point), 208.

Stephen, death of King, and his burial at Faversham, 302 .

Stergavale (Stergaule), I59 $n$. Cf. Streguil.

Stigand, Archbishop, 296.

Stilicho (Minister of Honorius), 80.

Stirling, Carse of. See Trywerid.

Stoke on Trent. See Ad Pontem.

Stone in Oxney, $280 n$.

Stone of Inscription (Lapis tituli), I 39, I $^{2}$.

Stone near Faversham (? Stane), $280 n$.

Stoneham. See Ad Lapidem.

Stone-henge. See Stan-hange.

Stour. See Stur.

Stourbridge, I $59 n$.

"Stours," the, I $50 n$.

Stracled Walas (Strath-Clyde Welsh), 250, 268.

Strang-ford, $229 n$.

Stratford, Suffolk. See Ad Ansam.
Strathclyde, $136 n$. See also Stracled Walas.

Streanaeshalch (Whitby), I86.

Streguil (Straguil, Striguil, Estrighoiel, Storguyl, Ystreigyl, Chepstow), 34, I59 n., 208, 294.

Streon, I80 n.

Stret, 207.

Stret leg, 2 I 4.

Studfall (Stốdfald), 132, 208.

Stuf, leader of West Saxons, 145, I 46.

Stukkia river-mouth, 93, 96.

Stur (Stour), 2 I6.

Sturemouth (Essex), ${ }_{25} 6$.

Sturia (Sturry), 2I 3 .

Sualua (Swale), baptisms in river, I69; meaning of, 169 $n$.

Successa (Sussex), 2 I9.

Sudberi (Sudbury), 237.

Sudr-eyjar (Sodor and Man), 224.

Sū-ige (Sug-ige). See Sorveie.

Suithhelming daenn, 218.

Sulh (Sulh-lung, Sulung), $209 n$.

"Sulleye." See Sully.

Sulloniacis (? Brockley Hill), I06, $107 n$.

Sully (Sylye, Sulleye), 3r, 32 .

Sulmonnes burg, 2 I 8.

Sumor lida, 247.

Sumursæte (Sumersatas), 253, 295.

Surrey. See Sath-ryge.

Sussex, conversion of, $182 n$.

Susura, 3I.

Suthgerveorke (Southwark), 289.

Suth-ryge, Suthrigna-lande (Surrey), $178 n$.

Swale. See Sualua.

Swanage. See Srvanarvic.

Swanazwic (Swanage), $25^{2}$.

Sweord ora (Sueordleag, Sweordestan), 22 I.

Sweyn (Swegen), King of Denmark, arrives in London in 994, 28I ; enters Wilton (1003), 284; destroys stronghold at Norwich and burns Thetford, 284 ; held for full King, 286; his death, 286.

Sweyn, son of Godwin, 290.

Swindale beck, the, $106 n$.

Sylye. See Sully.

Sylva Caledonia, 90. 
Tabernae, $130 n$.

Tada (Tadcaster, Calcaria), 106, 30 . Taddenes scylfe (Tanshelf), 274, $275 n$.

Tameseforda (Temesanforda, Tempsford), 267,285 .

Taff, the river, 96 .

Tain, 97.

Taizaloi, the, $47,97,101$.

Taliessin, poems of, I 54 .

Tam in river names, $194 n$.

Tamar, the. See Tamar-os.

Tamar-os (Tamer Muthan, Tamar), the, 96 , 104.

Tamanweorde Tamwurth 266, 267, 274.

Tame (Thame), 278.

Tamer (Tame), the river, $\mathbf{1 8 2}$.

Tamer Muthan. See Tamar-os.

Tămèses (Tamèsa, the Thames), Io, $98,103$.

Tamia, Ior.

Tamworth. See Tamanweorde.

Tan (Tam) and its cognates, 194n., $275 n$.

Tanet. See Tenid.

Tannetum (Tannois), I $28 n$.

Tannois. See Tannetum.

Tanshelf. See Taddenes scylfe.

Tantun (Taunton), 194.

Tarn, $23^{2}$.

Tarnock Common (Tornoch). See Termic.

Tarvaidunos. See Tarved-um.

Tarv-anna (Thérou-anne), 93.

Tarved-um (Tarvaidunos or Orkas), the promontory of, 93,97 .

Tarvosedo-n, 93 .

Tatan Edisc, 2 I 7 .

Tattenhall. See Teotan-healh.

Taum. See Tava.

Taunton. See Tantun.

Tava estuary, the ("Tawi", Tavaus, Firth of Tay), 44, 45, 97 .

Tavaus. See Tava estuary.

Tavistock. See Tefinge stoc.

Tavy, the river, $282 n$.

Tawe, the, 96 .

"Tawi," the, 45.

Tawmuth (Taw), 302.

Tay, Firth of. See Tava estuary.
Tees, the. See Dounon gulf.

Tefeged (Teviot), 144.

Tefinge stoc (Tavistock), 282.

Tegingel, Tegeingl (Englefield, now Holywell), $24,96$.

Teifi, the, 96 .

Teignton. See Drews Teignton.

Tempsford. See Tameseforda.

Tenet, Tenetland. See Tenid.

Tenid (Rnoihm, Ru-oichim, Tenet, Tenitland, Thanet), 49, 91, 127, 134, 2I3, 243, 278; ravaged by Northmen, 290. [Tannouet, a Breton place-name, is given by Pedersen (V. Gramm. \& 38) as from $\operatorname{Tann}=$ oak.]

Tennyson on "Brunanburh", 2

Teotan-healh (Tattenhall), 262.

Terente (Trent). See Treanta.

Termic (Ternuc, Tarnock, Torric), 200.

Tern, the, I 8.

Ternuc. See Termic.

Terp (Thorp, trep, threp), I40, 209.

Territorial names, ancient, 220 et seq.

Terventum (Trivento), $33 n$.

Test [Tersten in Thorp, Diplom. 250], the. See Trisanton, the.

Teutonic tribes in Britain, date of, I $27,130$.

Teviot. See Tefeged.

Tey, 232.

$T h=F$ in early English, $233 n$. (Thelbrig now Felbrig, \&c.).

Thame. See Tame.

Thames, the. See Tăměses, the.

Thanet. See Tenid.

Thelbrig (Felbrig), $233 n$.

Thelwall (Thelwæle), 268.

Thenglesham (Fenglesham), $233 n$.

Theodforda, Theotford (Thetford), 244, 276.

theodweg, $2 I_{4}$.

Theo'-braut (=Highroad), 244.

Thérou-anne. See Tarv-anna.

Thetford. See Theodforda.

Thindon (Finedon), $233 n$.

Thornege (Thorney), an island off coast of Sussex and Hants, 294.

Thorney. See Thornige. 
Thornhangra, $287 n$.

Thornige (Thorney Abbey), I 76 n., 292,303 . See also Torneia.

Thornsata. See Durngueis.

Thorp. See Terp.

Thryduulf's monastery in Elmet, I 70. See also Barwick-in-Elmet and Elvael.

Thule, 90, 92 .

Thyfel (= thicket), $20 \%$.

Tideston. See Cideston.

Tidulfes treow, 218.

Tig guocobauc. See Snottingaham.

Tilaburg (Tilbury), I80.

Tilehurst, 2 I I.

Tina, the (? the Tyne at Tyningham), 97 .

Tintern. See Caer-Guorthigirn.

Tiouulfingacæstir (? Littleborough), 172.

Tobi-os, river, 94, 96 .

Toccan-sceaga, 216.

Todi, inscriptions at, 87 .

Tofeceastre (Towcester). See Lactodoro.

Toibi, the, 96 .

Toisobi-os, the, 93, 96.

Tol Pedn Penzwith, $282 n$.

Toman-worthig. See Tamanzeorde.

Tonbridge. See Tonbrucge.

Tonbrucge (Tonbridge), 303 .

Tonsuring, Roman mode of, 19 r.

Torksey. See Turicesiege.

Torneia (Thorn-ige), 218.

Torric. See Termic.

Touerobi-os river, 93,96 .

Touesis. See Tuěsis.

Towcester. See Lactodoro.

Towy, the, 96 .

Trahannon, 22.

Trah-treuroit. See Tribruit.

Trail-flat. See Trav-er-flat.

Trajectum. See Viltaburg.

Trajectus (?Bitton), I I 2, I I 3 .

Trannant. See Trev-er-nant.

Traquhair. See Treve-coer.

Trarmenez, $158 n$.

Tratheu. See Tribruit.

Trav-er-flat (Trail-flat), $87 n$.

Trav-er-len (Crailing), $87 n$.

Treanta (Treonta, Trent), 22, I 72 , 25I, 268.
Tremerin, Welsh bishop, death of 298.

Trent. See Treanta.

Treonta. See Treanta.

trēow, place-names ending in, 293.

Trephun, 56.

Treve-coer (Traquhar), $87 n$.

Trev-er-nant (Trannant), $87 n$.

Treves. See Trevirī.

Treviri (Treves), 79, 127 .

Triath (Trethan), $88 n$.

Triberg, 99 .

Triboci, 36 .

Tribruit (Tratheu, Trah-treueroit, Robroit), the river, $\mathrm{I}_{5} \mathrm{I}, \mathbf{I}_{5} 2$.

Tricassi (Tricassini, Troyes), 36, 125.

Tri-castini, 36 .

Tri-cori, 36 .

Trimontium (? Triberg), 99, $109 n$.

Trinovantes, the, 10, 35, 36, 103, Io7 $n$.

Tripont-io, Tripontium (Three Bridges), Iog n., I Io.

Trisanton, Trisantona, the (? the Test), 22, 96, II 8 .

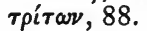

Trivento. See Terventum.

Trucculensis Portus, 44, 47, ror.

Trumher, Bishop, 178 .

Trumwine, Bishop, 186.

Tucincg-næs, 217.

Tuěsis, Touesis, Tuessis, estuary, the (? the Spey), 97, 101.

Tuican hom (Twickenham), 214.

tumulus. See Cett.

Tunnocelo (? Fano-Cocidi), roo, ror, I 6 .

"Tunsteall, the old," on Brockley Hill, $107 n$.

Turca-denu, 218.

Turca, the river, 218. See also Trurch.

Turcesig (Turicesiege, Torksey), 172 n., 250.

"Turnant brook," 36 .

Tuun, 209.

Troyes. See Tricassi.

Trywerid (Carse of Stirling), I 52.

Treoxn-eam (Christchurch), $26 \mathrm{r}$.

Twickenham. See Tuican hom.

Twrch, the river, 218 . 
Trurch Trwyth, story o 218.

Tyne, the. See Tina.

Tyne-Bowness Wall, 53.

Tythica Valley, the, 120.

Tywyn, 59.

Ugrulentum, ror.

Uinuaed, the river (? Broad Aire), 175.

uisc, in place-names, $252 n$.

Uist. See Aibouda.

Ulfcytel, an East Anglian notable, 284.

Ulf-ketels-heala. See Ilketshall.

Ulla-pool, 93.

Ul-ster, $229 n$.

Ultingford, $262 n$.

Undela (Oundale, Oundle), 23, 277.

Unecunga, 222.

Urbs Ebrauc (York), 244.

Urbs Legionis (Chester), I50, I5I, I53. See also Deva.

Urioconio (Viroconium, Wroxeter), 103, I06, I07 $n$., I12, I18.

Usa (Wusan, Wusa, Ouse), 262, 285.

Ushant. See Siambis et Axantos.

Usk. See Wylisce Axa.

Uthr, legendary father of Arthur, $137 n$.

Utrecht (Æt-Treocum), I90 $n$.

Utwikingan (Wikings), 303.

Uuduceaster (Woodchester), ${ }_{4} 8 n$.

Uuenrisc, the river, 218.

Unestburg, 219.

Unic-ing sceadan, 2 Io.

Uuidmundes felt (field), 2I4.

Uuidringa-muth (Wittering), I $43 n$.

Uuiela. See Willa.

"Uuigunennan," [Child's] Wickham, $165 n$.

Unisleag (Wisley), $2 \mathrm{I} 6$.

Uxacona (? Oakengates), 106, $107 n$.

Uxela, Uxella, Uxellon, 99, I04.

Uxella, the river, 94,96 .

Uxella Domnoniōn, 96 .

Uxellodamo (? Ellenborough or Hexham). See Axeloduno.

Vacomagi, IOI, $107 n$.

Vaetlinga-castir. See Verlamacastir.
Vagniacis (Vagnacis, ? Springhead), ro6, $107 n$.

Vakomagoi, the, I0I, 107.

Vallaun-ius of Caerleon, 300.

Valle Crucis, 55 .

Vallium, $72 n$.

Vandals, 53.

Vandogara (Vindogaro), 99.

Varar Estuary, the (Moray Firth), $97,100$.

Varis (? Bodfari), II I.

Vecta, Vectis (Isle of Wight), $6_{4}$, 90 ; conversion of, $182,283$.

Vedra, the (Wearmouth), 97, 98.

Venatores Bannies[es], I0I.

Venedotia (North Wales), I35.

Venedotians (Northern Welsh), 67 .

Venic-0, 101.

Venicones, Vernikomes, I01.

Venonio (High Cross), 106, 109, IIO.

Venonis, $\operatorname{10} n$.

"Venta," the meaning of (in Venta Silnrum, Venta Belgarum, Venta Icenorum), 32 et seq.

Venta Belgarum (Winchester), 9, I04, $110, I_{3}, 277$.

Venta Icenorum (Caistor, near Norwich), I3, 110, 130, 176n.

Venta Silurum (Caer Went), 31, I I 2, II $3 n$.

Ventre. See "Bannavem Taberniæ".

"Venunia," 50. See Vinonia.

Venunian Territory. See Genunian Territory.

Verada (Vereda), Castle-steads, I06, II4.

Verdouble. See Verno-dubrum.

Verdun. See Viro-dun-um.

Vereda. See Verada.

Vergivios Ocean, the, 88 n., 93, 94.

Verlamacestir (Vaetlingacestir), 39 .

Verlucione (Wans), II3.

Vernemeto (Verometo, Willoughby), I09, I IO.

Vernikömes. See Venicōnes.

Verno-dubrum (Verdouble), $187 n$.

Vern-um (Gwern-og), 187n.

Veroconinm (Wroxeter), II 2. 
Verometo. See Vernemeto.

Verteris (Brough Castle), 84, 106, 108, 114.

Verturiones, 79, 81, 84 .

Verubium promontory, the (? the Noss), 97.

Verulamium (Verolami, Verolamio, St. Albans), 35, 36, 39, 40, 4I, 60, 70, 106, 109, 110, I25.

Vetadun (Betendune, Yatadini, Watton), I88.

"Vicus emptorins," I66 $n$.

Vidu (in Viducasses), 77.

Viktoria, 99.

Vilbrord, Igo.

Villa Faustini (? Woolpit), 108.

Viltaburg (Trajectum), I90.

Vindobala (Vindovala,?Rutchester), II 5 .

Vindo-bona (Vienna), I6.

Vindogara bay, 92.

Vindogaro. See Vandogara.

Vindogladia (Badbury Rings), 16, II 3,261 .

Vindolana (= Chesterholm), II 5 .

Vindomi, I I 3 .

Vindomora (Ebchester), I05.

Vinonia (Vinovia, Vinovion, Binchester), 50, IOI, I02, 105.

Viroconium. See Urioconio.

Viro-dun-um, 116.

Virokonion. See Urioconio.

Viromandui, $\operatorname{I0} 7 n$.

Virosido, I I6.

Viro-viacum (Werwick), i 6.

Virulamion. See Verulamium.

Virvedrum promontory, the (? Dun. cansby Head), 97.

Vituduro ("Winterthur"), 40, 4I.

Viurae-muda (Wearmouth), I $78 n$., I9I.

Volas bay (Loch Broom), 93.

Voliba, 104.

Vor-tigern, I 22, I 28, I34-7. [Vortigurn, in Irish Ogams, later Fortchernn. See Guorthigern. The use of the Irish form by Gildas and Bede suggests that Vortigern was a Goidel.]

Votadini, Votadinoi. See Otadinoi.
Wadbeorge (Woad-hill), 2 I 7 .

Wade. See Wath.

Waclingastrat, 286. See Werlam. Wandofron (Wendoura, Wendover), I $44 n$.

Warham. See Werham.

Warincgwica (Wæringwicum Warwick), I6 6 n., $263 n$., 264.

Wærlame, the river, 40.

Wæst byrig (Westbury), slaughter by Welsh at, 297 .

Wætling or Wæcling. See Werlam.

Wætlingacæster, 40, 41.

Wafyr (Waver), the river, 272, 273.

Waga (in Medway, Weymouth), $2 I 2$.

Wagele, 177.

Wala-King (King of the Welsh), 192.

Walalege (? Whalley), 237.

Wales. See Brytland.

Wal(1)brook, 67 .

Wallingford, $25 n$.

Walton. See Ad Murum.

Walton-on-the-Naze, 29 I $n$.

Wamberge. See Wanborough (Wilts).

Wanborough (Surrey), Wenebergia, $194 n$.

Wanborough (Wilts), Wemberge, Wamberge, I $48 n$., I $94 n$.

"Waneloc" (? Wenloc), I 74n. See also Maserfelth.

Wanley, H., Sec. of S.P.C.K., $249 n$.

Wans (late name borrowed from Wansdyke). See Verlucione.

Wansdyke. See Woddesbeorg.

Wantsumu, the river, $134 n$.

Wapen-take, 232.

Warborough. See Weardbyrig.

Warena (Cantwarena), 213, 222, $25^{2} n$.

"Warne, the," I I $n$.

Warwick. See Warincgwica.

Wase, Wasan, 208.

"Wash, the." See Metaris Estuary.

Watchet. See Weced.

Waterford, $229 n$.

Waterloo, I $77 n$.

Wath, Wade (a ford), 232.

Watton. See Vetadun.

Waveney, the, 98 . 
Waver, the river. See Wafyr.

Waylet (Norden's Essex $=$ Crosroads). See -let.

Weala-ford, 39 .

Wealas. See Welsh.

Wealh, use of, 142 .

Wealinga-forda (Wallingford), 284.

Weall-wala. See Wyrtwala.

Wealtham (Bishops Waltham), 284.

Weardbyrig (Weardburh, Warborough), $263 n$., 264.

Wearmouth. See Viurae-1nuda.

Weced-port (Wacet, Watchet) ravaged, $266,280$.

Wedale, 152 .

Wedmore, 255 .

Weekborough, 24I.

Welland. See Weolud.

Wells. See "Cideston".

Welsh (Wealas), 26.

Wemberge. See Wanborough.

Wembury, 24I $n$.

Wendover. See Wandofron.

Wendwr ( $=$ white water), $150 n$.

Wenebergia. See Wanborough (Surrey).

Wen-frut ( $=$ white stream), $150 \mathrm{n}$.

Well-las (Gwyn- or Gwen-glas), $149 n$.

Wenloc. See "Waneloc".

Wenrisc (Windrush), the river, I $78 n$.

"Wents," the four, I $34 n$. and 32 .

Wen(t)sum, the, $135 n$.

Weolud (Welland), $266 n ., 267$.

Weondune, 271. See also Bribningafield.

Werham (Warham, Wareham), inscriptions at, 161 ; a stronghold of Northmen, 161; Beorhtric buried at, $196 ; 25 \mathrm{I}, 278$.

Werid (= Forth), 45, 152 .

Werlam (Watling), 40.

Wertermore (? Kerriemuir), 270.

Werwick. See Viro-viacum.

Westan-ëa, 213 .

"Westburg" on Trym, $297 n$.

Westbury. See Wast byrig.

Westerna (Porcensetene), 220.

Westmoreland, Westmering, Westmoringeland, $84,137 n_{\text {., }} 138 n$., 186 n., 278.

West Saxons (Wessex), r 29.
Westymar I $37 n$. See Westmoreland.

Wexford, $229 n$.

Whalley. See Walalege.

Wherwell. See Hwarwella-n.

Whitby. See Streanaeshalch.

Whitchurch. See Hzwitciricean.

Whitehorn. See Candida Casa and Rosnat or Alba and Magnum Monasterium.

Whitern, 120.

Whitewell's gate. See Hwitan Wylles geat.

Whitham. See Witham.

Whitsunbrook. See Wixenabroc. Whychervode. (Whucchewode), $165 n$. Wibbandun, 146.

Wîc (Droitwich), earthquake at, 290. $w i c=v i k=b a y, 24 \mathrm{I} n$.

wic $=$ Lat. vicus $=\mathrm{dwelling}$, market, 166. [Cornish Guicgur = market man, inerchant.]

Wicganbeorg, 240, $24 \mathrm{I} n$.

Wicgestan, 221 .

Wich, $166 n$.

Wichama, 216.

Wicing in place-names, 2 ro.

Wickham (Child's). See "Uuiguuennan".

Wicklow, $229 n$.

Widerigga, 22 I n., 222.

Widford, 108.

Widma (Withma, Witham), the river, $17 \mathrm{I} n$., I $74 n$.

Wîdsîth (Wide-wandered), poem of, I3I.

Wigan. See Coccio.

"Wigbeorths corner." See Witbrichteserna.

Wigborough (Wincheberie), $24 \mathrm{I} n$.

Wigera, meaning of, $\mathrm{I}_{4} n$.

Wigera-ceaster, Worcester, $164 n$.$166 n$.; Wigornia, origin of name, I $64 n$.; Wigera, meaning of, $\mathrm{I}_{4} n$.; Wirecestre, $165 n$. ; Caerwrangon, $165 n$.; metropolis of Hwiccia or Magesitania, 166.

Wigesta (? Wigerna), 22 r.

Wight, Isle of. See Vecta.

Wigingamere, 267.

Wigornia, $165 n$. See Wigera-ceaster.

Wigton-bay. See Iéna, the. 
Wiht-gaga, I $45 n$.

Wihtgar, leader of West Saxons, 145,146 .

"Wihtgara," 145 n., $22 \mathrm{r}$.

"Wihtgarabyrg." See Wiht garægbyrg.

Wiht garæsbyrg (Wihtgarabyrg), 145 ; no survival of in Carisbrook, $145 n$., 146 .

Wihtland (Isle of Wight). See Vecta.

Wikings (Utwikingan), in Anglesey, 303 .

Wilbaldes-febt, I32.

Wiley. See Guilou.

Wilfrid, consecration of, 182 .

Wilig. See Willa.

Willa, East and West (Wilig, Uuiela), 221 I $n .222$. [Wilga Hundred, Domesday, may be district meant.]

William of Normandy pays a visit to King Eadward (IO52), 294; subdues Maine, 299; comes to Pevensey and Hastings, 30r ; crowned at Westminster, 3 or.

Willoughby. See Vernemeto.

Wiltenburg, $190 n$.

Wiltun (Wilton, Wil-tun, Wiltunscir, Wiltescir, Wiltshire), Elfred defeated by Danes at, 250 ; Sweyn destroys stronghold, 284 .

Wimborne. See Winburna.

$W i n$ in place-names, $194 n$.

Winburna (Winburnan, Wimborne), 194, 247, 26r.

Wincanheal. See Pincanheal.

Wincel-Cumba (Winchcomb), 296.

Winchcomb. See Wincel-Cumba.

Wincheberie. See Wigborough.

Winchester. See Venia Belgarum.

Winchester, Canons expelled from, 278.

Wincle (? Winescol) in Cheshire, 234 .

Windermere. See Wonwaldremer.

Windelsoran (cf. Windles-ham, Windlescumb, Windsor), 299.

Windrush, the river, I $78 n$.

Winescol. See Wincle.

Winfrith, Winfrod, I $50 n$., I $75 n$., $194 n$.
"Winheath by Winwood," $27 \mathrm{I}$.

Winifrith. See Boniface.

Winster, the river, $150 n$., I $75 n$., 218.

Wintanceastre (Winchester), I96, 243. See also Venta Belgarum.

Wintonia (not Winchester), Guentonia, 248.

Winwaloe, St., I60.

Winwidfeld. See Uinuaed.

Wippedsfleet, I42.

Wirhealum (Wirheall, Wirral), 23I, 259.

Wirral. See Wirhealum.

Wirtgernesburg. See Bradan forda be Afne.

Wisley. See Uuisleag.

Wisseorum, Octavius dux (Geoffrey), I $39 n$.

Witbrichtesherna (Wigbeorthscorner), $276 n$.

Witch-Elm (Wice), 2 I I $n$.

Witham, the river. See Widma.

Witham (Whitham, Essex), 263.

Withering-sett, $22 \mathrm{I}$.

Withma. See Widma.

Wittering (Uuidringa-muth), I $43 n$.

Wizvarawic, $16_{5} n$. [If the locality suited it would mean "the market of the men of Wye, in Kent."]

Wixenabroc (Whitsunbrook), $220 n$.

Wixna (Wicsetna), East and West, 220.

Wlanc-heard, $142 n$.

Wlencing (son of Ælle), I42.

Wlfpeta (=Wolfpit), 108.

Woad-hill. See Wadbeorge.

Wocen Sætna, 220. See Wreocensetna.

Woddesbeorg, Woddesbeorh, ? Woodchester, Uuduceaster, I 23, I48. I 49, I 54, I $94 n$.

Woden, I3r.

Wodnesfield, 264.

Wolfpit. See Wlfpeta.

Wonwaldremer (Winandermere, Windermere), 235.

Wood of Celidon, the. See Celidon.

Woodchester. See Woddesbeorg.

Woodcot. See Noviomago.

Woodstock. See Wudestoke.

Wookey Hole, $244 n$.

Woolpit. See Villa Faustini. 
Worcester. See Wigera-ceaster.

Worcestershire. See Wigera-ceaster.

Words borrowed from Scandinavia, 230.

Worgret, Abbot, 200.

Worthige (Worthy), 283.

"Wrekin, the," I07 $n$.

Wreocensetna, 220.

Wring, the river, 203.

Wringford, 203.

Wrington, 203.

Writtle. See Durolito.

Writola-burna. See Durolito.

Wroughton. See Ellendun.

Wroxeter. See Urioconio.

Wudefine (wood-heaps), 2 I 2.

Wudestoke (Woodstock), 304.

Wudigan gæte, $234 n$.

Wudiham (Odeham), 304 .

Wulfmær, the minter, $276 n$.

Wulfstan, Scandinavian traveller, 225.

Wulstan, death of Abp., 277.

Wusan (Ouse), the. See Usa.

Wygel, 213.

Wygemore, $165 n$.

Wygewode, $165 n$.

Wyle-cop, 213.

Wylisce Axa (Usk), 292.

-Wyndes, 121.

Wyre forest, $165 n$.

Wyrtgeorn, I 39. See Vortigern.

Wyrtrum, 204.

Wyrtwala (Weall-wala, Wyrtrum), 204.
Yare, the river, $98,177$.

Yarkhill. See Geardcylle.

Yarrow. See In gyruum.

Yatadini. See Vetadun.

Ybernia, parva. See Bikeria.

Yddil (Idla), the river, I $\mathbf{7 2}$.

Yedding. See Geddingas.

Yenlet. See Genlade.

Yo, the old,=river. Cf. Alda Tersten: Thorp, Diplom. 250.

Yeo, 209.

Yeovilton, 14I.

"Yevering Bell," I68.

Ymma AElfgiva comes to England, 284.

Ynis Prydain, 89.

Ynsgitrin (Glastonbury), 198.

York. See Eburācum.

York, the Emperor Septimius Severus dies at, 52 ; a colony, 114 .

Ypples fleet, I33. See Hyppeles fleote and Yprvines fleot.

Ypruines fleot, 132; not an early form of Ebbs-fleet, I33, I 34, 140.

Yric made King of Northumbrians, 274 ; forsaken, 275 .

Ysgubor. See Skibber.

Ythanceastir (Othona, St. Peter's Chapel at Bradwell), I $79 n ., 276 n$.

Yttingaforda, 262.

Yverdon. See Eburodunum.

Yvré-le-Polin. See Ebriācus.

-Zell, 190.

Zoy. See Soweie. 
OXFORD: HORACE HART
PRINTER TO THE UNIVERSITY 



THIS BOOK IS DUE ON THE IAST DATE STAMPED BELOW

AN INITIAL FINE OF 25 CENTS WILL BE ASSESSED FOR FAILURE TO RETURN THIS BOOK ON THE DATE DUE. THE PENALTY INCREASE TO 50 CENTS ON THE FOURTH DAY AND TO \$1.00 ON THE SEVENTH DAY OVERDUE.

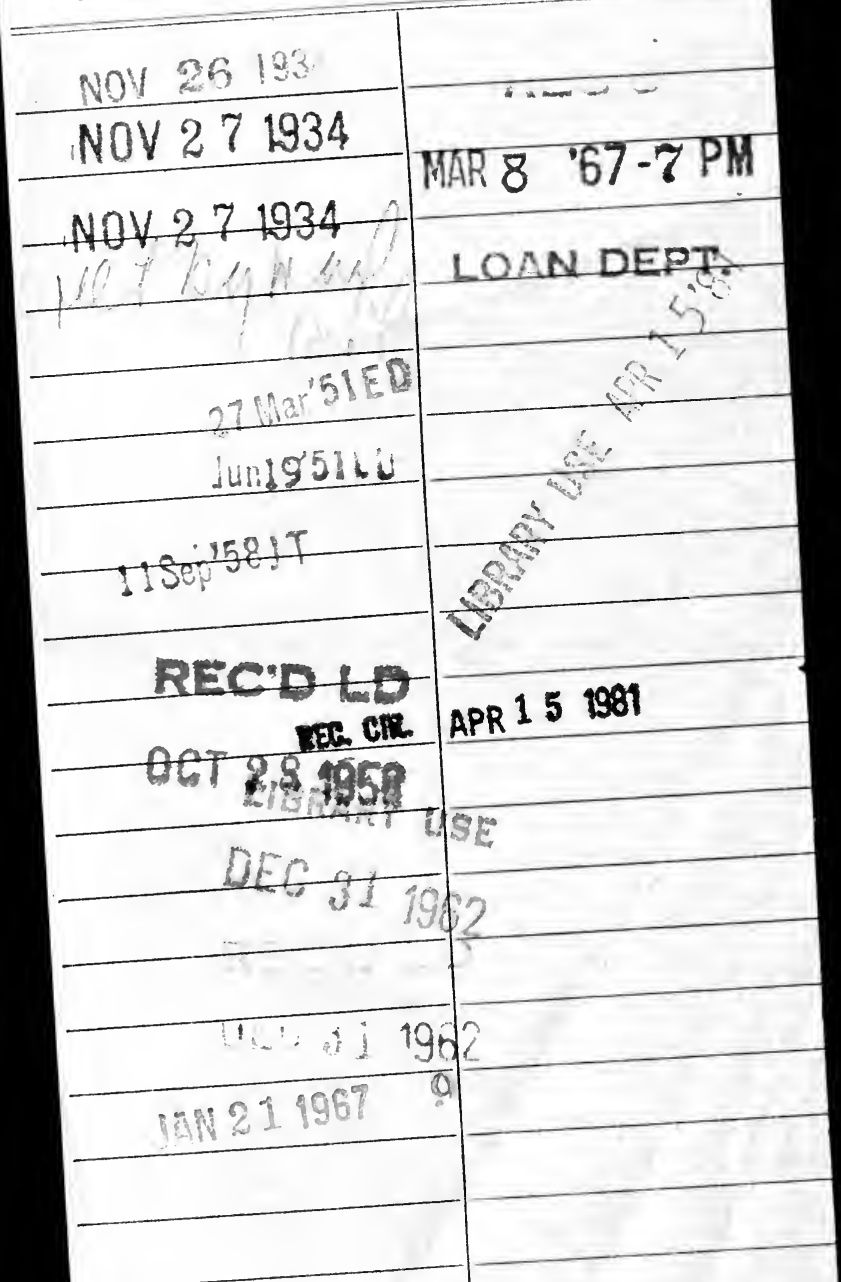




$$
\text { จ. } 12080
$$

UNIVERSITY OF CALIFORNIA LIBRARY 
